\title{
Tekstovi o glazbi hrvatskih autora na latinskom jeziku od 1701. do 1760. godine u sjevernoj Hrvatskoj
}

\section{Knešaurek Carić, Jelena}

\section{Doctoral thesis / Disertacija}

2021

Degree Grantor / Ustanova koja je dodijelila akademski / stručni stupanj: University of Zagreb, Faculty of Humanities and Social Sciences / Sveučilište u Zagrebu, Filozofski fakultet

https://doi.org/10.17234/diss.2021.7034

Permanent link / Trajna poveznica: https:/urn.nsk.hr/urn:nbn:hr:131:840707

Rights / Prava: In copyright/Zaštićeno autorskim pravom.

Download date / Datum preuzimanja: 2023-04-26

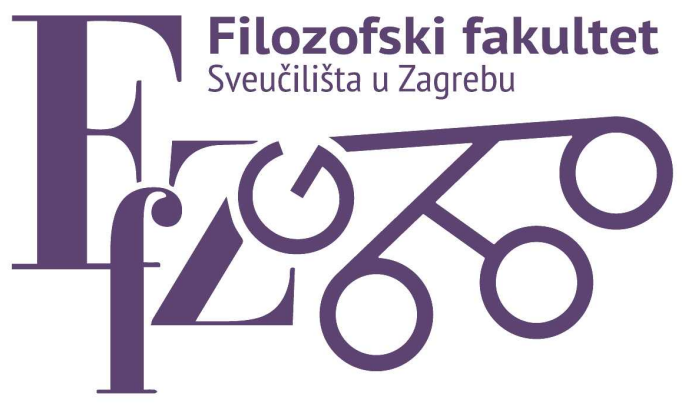

Repository / Repozitorij:

ODRAZ - open repository of the University of Zagreb Faculty of Humanities and Social Sciences
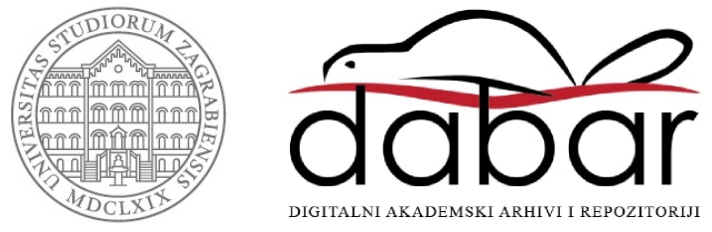


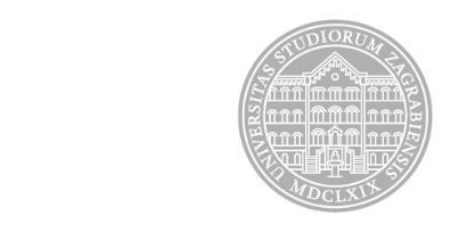

Sveučilište u Zagrebu

FILOZOFSKI FAKULTET

JELENA KNEŠAUREK CARIĆ

\section{TEKSTOVI O GLAZBI HRVATSKIH AUTORA NA LATINSKOM JEZIKU \\ OD 1701. DO 1760. GODINE U SJEVERNOJ HRVATSKOJ: IZMEĐU TEORIJE i PRAKSE}

DOKTORSKI RAD

ZAGREB, 2021. 


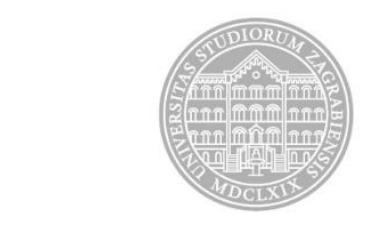

Sveučilište u Zagrebu

FILOZOFSKI FAKULTET

JELENA KNEŠAUREK CARIĆ

\title{
TEKSTOVI O GLAZBI HRVATSKIH AUTORA NA LATINSKOM JEZIKU \\ OD 1701. DO 1760. GODINE U SJEVERNOJ HRVATSKOJ: IZMEĐU TEORIJE i PRAKSE
}

\author{
DOKTORSKI RAD
}

\author{
Mentori: \\ Akademik Nikša Gligo \\ Red. prof. dr. sc. Nenad Ivić
}

Zagreb, 2021. 


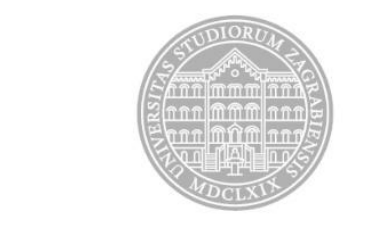

University of Zagreb

FACULTY OF HUMANITIES AND SOCIAL SCIENCES

\author{
JELENA KNEŠAUREK CARIĆ
}

\title{
MUSIC TREATISES WRITTEN IN LATIN IN THE NORTHERN CROATIA FROM 1701. - 1760: BETWEEN THEORY AND PRACTICE
}

DOCTORAL THESIS

\author{
Supervisors \\ Academician Nikša Gligo \\ Professor Nenad Ivić
}

Zagreb, 2021. 


\section{BIOGRAFIJA MENTORA}

\section{Akademik Nikša Gligo (kratka biografija)}

Nikša Gligo srednje opće (klasično) i glazbeno obrazovanje završio je u Splitu, komparativnu književnost i engleski jezik i književnosti diplomirao je 1969. na Filozofskom fakultetu Sveučilišta u Zagrebu, a muzikologiju na Filozofskome fakultet Sveučilišta u Ljubljani 1973. godine. Iz muzikologije je magistrirao na Muzičkoj akademiji u Zagrebu 1981., a doktorat iz muzikologije obranio je 1984. na Filozofskom fakultetu Sveučilišta u Ljubljani.

Usavršavao se na Odjelu za muzikologiju Filozofskog fakulteta Sveučilišta u Kölnu (stipendija DAAD-a 1972./73.), u Salzburgu (Salzburg Seminar in American Studies: American 20th Century Music, 1976.), u Berlinu (stipendija DAAD-a: znanstveni program, 1983./84.), u Freiburgu i.B. (stipendija Zaklade Alexander von Humboldt, 1985./86. i 1993./94.).

Na Odjelu za muzikologiju Muzičke akademije Sveučilišta u Zagrebu predaje u zvanju redovnog profesora od 1998. Do 2021. godine.

Član je Hrvatske akademije znanosti i umjetnosti od 2006. godine.

\section{Knjige:}

Gligo, Nikša. Vrijeme glazbe. Zagreb: Studentski centar, 1977. 111 str.

Gligo, Nikša. Varijacije razvojnog kontinuiteta: Skladatelj Natko Devčić. Zagreb: MIC KDZ, 1985. 208 str. s tablicama i notnim primjerima.

Gligo, Nikša. Problemi Nove glazbe 20. stoljeća: Teorijske osnove i kriteriji vrednovanja, Zagreb: MIC KDZ, 1987. 285 str. s tablicama i notnim primjerima.

Gligo, Nikša. Pojmovni vodič kroz glazbu 20. stoljeća s uputama za pravilnu uporabu pojmova, Zagreb: MIC KDZ: MH, 1996. XXXV + 377 str. s ilustracijama i notnim primjerima.

Gligo, Nikša. Zvuk - znak - glazba. Rasprave oko glazbene semiografije. Zagreb: MIC KDZ, 1999. 248 str. s notnim primjerima.

Mnogi prinosi u časopisima i zbornicima i zemlji i inozemstvu.

Potpuni pregled bibliografije dostupan je na stranici Hrvatske akademije znanosti i umjetnosti. 


\section{BIOGRAFIJA MENTORA}

Red. prof. dr. sc. Nenad Ivić (kratka biografija)

Nenad Ivić rođen je 1956. godine u Zagrebu. Školovan je u Zagrebu. Na Filozofskom fakultetu 1979. godine završava studij francuskog jezika i književnosti, španjolskog jezika i komparativne književnosti. Od 1981. radi kao asistent na Katedri za francusku književnost Filozofskog fakulteta u Zagrebu, 1989. postaje docent a 1996. izvanredni profesor. Doktorirao je 1988. godine s temom o odnosima starofrancuske književne proze i latinske historiografije XII. i XIII. stoljeća. 1986. i 1987. godine usavršavao se kao stipendist Fulbrightove zaklade na Odjelu za romanske jezike i književnost University of California, Berkeley. 1990. i 1991. boravi kao pozvani istraživač na Institut d'études classiques et médiévales Univerziteta u Montréalu. 1995. i 1996. kao Fulbright Fellow djeluje na Department of History, Princeton University. 2002. izabran je za redovitog profesora, 13.2.2007. za redovitog profesora u trajnom zvanju. Predstojnik je Katedre za francusku književnost.

Knjige:

Ivić, Nenad. Domišljanje prošlosti. Kako je trinaestostoljetni splitski arhiđakon Toma napravio svoju Salonitansku historiju. Zagreb : Zavod za znanost o književnosti, 2001. str. 221, bibliografija, summary, kazala.

Ivić, Nenad. Textus. Istraživanja o Amijanu Marcelinu, Zagreb : MH, 2001. str. 293, bibliografija, kazala, bilješka o piscu.

Ivić, N. 2009: Napulj i druga imaginarna mjesta, Zagreb: Gordogan, , str. 461, kazalo, bilješka o piscu.

Ivić, N. 2012: Augurium. Gustav Mahler: pustolovina neodgovornog nosača, Gordogan, Zagreb, str. 201, bilješka, kazalo, bilješka o piscu.

Ivić, Nenad. Grč Sirene. Stihovi u Gordoganu 2003-2013. Zagreb: Gordogan, 2014. str. 153 (str. 9-74 monografija; str. 79-150 prepjevi; str. 151-153 zaključak) ISBN 978-953-99744-57.

Ivić, Nenad. Građanski rat riječi. Povijest i književnost. Zagreb: Sandorf-Mizantrop, 2021. (u tisku). 


\section{ZAHVALE}

Po konačnom završetku disertacije čiju sam realizaciju zbog poslova kojima se bavim i obiteljskih obaveza dugo priželjkivala, želim zahvaliti onima koji su, svatko na svoj način, doprinijeli njezinom nastanku.

Zahvaljujem profesoru Zlatku Šešelju od kojeg sam imala čast i veselje učiti latinski i koji nas je svojim sjajnim predavanjima, nevjerojatnom širinom znanja i posvećenošću poslu naučio pozorno promatrati svijet oko sebe te nastojati razumjeti sve što čitamo, gledamo i doživljavamo.

Zahvaljujem svojim vrsnim profesorima na Odsjeku za muzikologiju Muzičke akademije u Zagrebu od kojih sam učila kako slušati glazbu i o njoj govoriti/pisati, ali i o važnosti kontinuiranog uvida u dosege drugih, muzikologiji srodnih znanosti, a posebno dr. sc. Evi Sedak koja, nažalost, više nije među nama, dr. sc. Enniju Stipčeviću te mom komentoru akademiku Nikši Gligu.

Akademiku Nikši Gligu zahvaljujem na stotinama sati nezaboravnih predavanja četvrtkom na studiju i poslijediplomskom studiju muzikologije. Ta su predavanja, širinom uvida u predmet o kojem se govori i kritičkim stavom u analizi partitura i tekstova, oblikovala moju želju za znanstvenim bavljenjem muzikologijom. Nikša Gligo je profesor koji svojim studentima i sugovornicima nesebično nudi svoje golemo znanje, ali je također, iznimno pozoran slušač. Iskreno mu zahvaljujem na pomoći pri dovršavanju disertacije.

Profesora dr. sc. Nenada Ivića najprije sam upoznala kroz njegove tekstove o splitskom arhiđakonu Tomi i o rimskom povjesničaru Amijanu Marcelinu, a potom sam dobila priliku slušati ga na predavanjima doktorskog studija. Njegova erudicija i neumorna pozornost prema najmanjem detalju te otvorenost za raspravu omogućili su mi da definiram smjer istraživanja. Zahvaljujem mu od sveg srca što mi je pristao biti komentor, što me pratio i podržavao u znanstvenom istraživanju i bodrio kad mi se činilo da neću pronaći vrijeme za dovršetak rada. Bez njegove ustrajne profesionalne i prijateljske podrške, bilo bi mi znatno teže dovršiti ovaj rad.

Hvala mojoj obitelji i prijateljima koji su me na razne načine poticali da ne posustanem. Neizmjernu zahvalnost dugujem osobama s kojima dijelim svakodnevicu, mojoj djeci i suprugu. Hvala vam, Barbara i Roko, što ste najbolja djeca na svijetu, što ste me naučili 
strpljivosti i tome da u životu za sve postoji određeno vrijeme. Hvala Ti, Hrvoje, što si vjerovao u mene i što si, zajedno s Barbarom i Rokom, bio strpljiv i pomogao mi da dovršim ovaj posao. 


\section{SAŽETAK}

Tekstovi čija je glavna tema glazba, bilo kao musica theorica, bilo kao musica practica, objavljeni u Zagrebu i Beču od 1701. do 1760. pisani su latinskim jezikom i obuhvaćaju dva temeljna oblika glazbenog diskursa. Jedan se bavi glazbom u pedagoškom smislu (musica practica) i nalazimo ga u priručnicima za poduku gregorijanskoga pjevanja Tome Kovačevića Brevis cantus gregoriani notitia (Beč, 1701.) i Mihaela Šiloboda-Bolšića Fundamentum cantus gregoriani seu choralis (Zagreb, 1760). Drugi promiče glazbu kao vid jačanja pobožnosti i vjerskog obrazovanja, alat u reguliranju osjećaja i ponašanja pojedinca te izravnu poveznicu s Bogom, na tragu srednjovjekovne musica theorica. Takav je diskurs prisutan u predgovorima najznamenitijem glazbenom pothvatu prve polovice 18. stoljeća u sjevernoj Hrvatskoj - zborniku Cithara octochorda. Kritičkom analizom diskursa željelo se propitati dosadašnji epitet anakrone glazbene djelatnosti koju je hrvatska glazbena historiografija pripisivala glazbenoj praksi u sjevernoj Hrvatskoj u prvih 60 godina 18. stoljeća. Potom se nastojao definirati okvir glazbenoteorijskog znanja te način promišljanja glazbe kao etičke i praktične djelatnosti. Glazbenoteorijski okvir u smislu korpusa znanja analiziran je na temelju izravnih ili neizravnih aluzija na izvore (probati auctores) među kojima je, uz opće reference na antičke autoritete Platona i Cicerona, najviše onih iz susjedne Italije. Način predstavljanja znanja analiziran je u kontekstu ideje dominantnih epistemologija 16., 17. i 18. stoljeća kako ih definira Michel Foucault. Pritom je potvrđena teza o koegzistiranju izrazito disparatnih modela glazbenoteorijskih diskursa, na što je upozorio Carl Dahlhaus. Usporedna analiza s tekstovima objavljivanima u susjednim zemljama pokazala je da se ne radi o anakronom, već isključivo o stilski ograničenom tipu glazbenoteorijskog diskursa koji dominira katoličkom obnovom u svim katoličkim zemljama Europe. U takvom se diskursu ravnopravno isprepliću srednjovjekovni temelji glazbene teorije (sustav heksakorda, abeceda, solmizacija, ključevi, nazivi tonusa) te renesansni elementi u metrici (podjela note brevis, ritmiziranje napjeva prema pjesničkoj metrici, a ne akcenatskim obilježjima uglazbljenog teksta) i modalnom sustavu (heksakordalni modalni sustav koji rabi starogrčku terminologiju). Estetika je u diskursu, ne i u samim napjevima, svedena na etičku ulogu glazbe u životu pojedinca, njezinu iscjeliteljsku i soteriološku moć budući da, kao izravna fizička manifestacija metafizičkog, vlada mikrokozmosom. Time postaje i važnim sredstvom u procesu katoličke obnove koja tijekom prve polovice 18. stoljeća u nekim elementima postaje kompatibilnom s prosvjetiteljskim apsolutizmom Habsburške monarhije. 
Ključne riječi: Diksurs o glazbi, 18. stoljeće, cantus gregorianus, musica theorica, musica practica, katolička obnova, neolatinizam. 


\section{EXTENDED SUMMARY}

Adhering to the contention of Leo Treitler that history is made up of a totality of records that include knowledge of history and that music, as well as writing about it, are in interaction with the society and culture of its time, then definitely, when presenting cultural achievements in northern Croatia during the $18^{\text {th }} \mathrm{c}$., texts on music in Latin script should also be included. This is primarily because they represent the only preserved sources of the formalised and official discourse on music and thus enable research not only from their theoretical precepts of projected music practice, but also of the patterns of cultural and social life of northern Croatia connected to it right before Josephinism.

Since in former musicological research they have been left without an in-depth analysis of thought on the music they were promoting, they need to be read in order to better comprehend its role in the daily routine of an average man (evenly in urban and rural regions) who, most frequently came into contact with it in the context of church ceremonies. At the same time, one should be aware that this is church liturgical and paraliturgical music, not folk or artistic music. In that sense, this dissertation pursues a detailed analysis of the introductions of all the three editions of the proceedings Cithara Octochorda (Vienna 1701 and 1723; Zagreb 1757), of the manual by Mihael Šilobod Bolšić Fundamentum cantus gregoriani seu choralis (Zagreb, 1760) and, to the extent of partially available content, of the manual by Tomo Kovačević Brevis cantus gregoriani notitia (Vienna, 1701).

The texts whose main theme was music, whether as musica theorica or as musica practica, published in Zagreb and Vienna from 1701 to 1760 were written in Latin script and encompassed two fundamental forms of music discourse. One deals with music in a pedagogical sense (musica practica) and we find it in manuals for teaching Gregorian chant of Tomo Kovačević Brevis cantus gregoriani notitia (Vienna, 1701) and Mihael ŠilobodBolšić Fundamentum cantus gregoriani seu choralis (Zagreb, 1760). The other promotes music as an aspect for strengthening one's devotion to God, a tool in regulating the emotions and behaviour of the individual and a direct connection with God, on the trace of the mediaeval musica theorica. Such a discourse is present in the prefaces of the most significant musical venture of the first half of the $18^{\text {th }} \mathrm{c}$. in northern Croatia-proceedings Cithara octochorda.

The first chapter titled "Historical and geographical positioning" presents an historicogeographical frame in which the mentioned texts have been written, as well as the general 
social and cultural climate in which their authors have worked. Likewise, the first chapter defines the terminology of the specific period, that, in Croatian lands, according to the former learnings and research of the author, unequivocally is defined as "Catholic restoration". The second chapter analyses past research that is directly or indirectly connected to our theme: describes Croatian sources that are the immediate subject matter of this dissertation, the research of the Gregorian chant in Europe and the place that belonged to domestic sources in local music historiography until this research.

The third chapter of the dissertation initiates a critical analysis of the discourse of the texts we have been writing about, thus challenging the present epithet of anachronistic music activity that Croatian music historiography accredited to music practice in northern Croatia in the first 60 years of the $18^{\text {th }} \mathrm{c}$. The third chapter defines the frame of the music theory knowledge and the manner of appraising music as an ethical and practical activity. The music theory frame in the sense of corpus of knowledge is analysed based on the definition of the manner of writing texts offered by St. Bonaventure, to be more precise, within the procedure of compilation (compilatio) that is the fundamental manner in which church writers compile their tractates. The analysis is conducted by revealing direct or indirect allusions to authors and their works (probati auctores) among which most are, along general references to antic authorities such as Plato and Cicero, from neighbouring Italy.

The manner of presenting knowledge is analysed in the fourth chapter in the context of the idea of dominant epistemologies of the 16th, 17th and 18th c. as defined by Michel Foucault. In so doing, the argument on the coexistence of disparate models of music theory discourses has been confirmed which was indicated by Carl Dahlhaus. A comparative analysis of the texts published in the neighbouring countries has shown that it is not an anachronistic, but solely stylistically limited type of music theory discourse that, in manuals accepts the contemporary manner of expressing knowledge that is distinguished by order, regardless whether it is shown in a table, sequence or mnemonic verses and exists in all European Catholic countries.

The fifth chapter discusses the similarities (similitudo) as the fundamental manner for connecting words and things that Michel Foucault attributed to episteme. The analysis of the introductions of proceedings Cithara octochorda comparative to a certain model, the proceedings Lyra coelestis published in Trnava in 1695, demonstrates a similitudo in the discourse on music even in the post-Renaissance period, but also denotes its significance in 
the discourse shaped in patristics and the Middle Ages. In addition, by investigating the general places such as affected modesty, utilitas and pietas, a strong influence of antic rhetoric theory is pointed out.

In the final sixth chapter, the relationship between musica theorica, as a speculative discourse on music and musica practica, as a didactical discourse that finds its foundations in manuals that emerged in the period of the Carolingian state is being analysed. In the didactical discourse there is an equal intertwining of the medieval fundamentals of music theory (the hexachord system, alphabet, solmisation, keys, names of modes) and Renaissance elements in metre (division of brevis, rhythmisation of chants according to poetical metre and not by accentuated markings in the text set to music) and the modal system (hexachord modal system that uses old-Greek terminology). Aesthetics on the other hand in the discussions on music, and not in the chants themselves, is reduced to an ethical role of music in the life of an individual, its healing and soteriological power, since, as a direct physical manifestation of the metaphysical, it rules the microcosmos. Accordingly it became a significant means in the process of catholic restoration that during the first half of the $18^{\text {th }} \mathrm{c}$. in some elements became compatible with the enlightening absolutism of the Habsburg Monarchy that was strongly tied to the Catholic Church.

\section{Key words:}

Discourse about music, 18th century, cantus gregorianus, musica theorica, musica practica, Catholic renewal, neolatinism. 


\section{SADRŽAJ:}

UVOD 1

PRVO POGLAVLJE: POVIJESNO I ZEMLJOPISNO SITUIRANJE 24

1.1. Habsburška monarhija u 18. stoljeću 27

1.2. Dugi srednji vijek, barok ili predmoderno doba? Prosvijećeni apsolutizam ili racionalizam? Katolička obnova ili novovjekovni katolicizam? 30

1.3. Zagrebačka biskupija i Zagreb u prvih 60 godina 18. stoljeća 33

1.4. Mjesto glazbe u liturgiji i u sustavu obrazovanja 37

DRUGO POGLAVLJE: IZVORI I STANJE ISTRAŽIVANJA 45

2.1. Izvori 45

2.2. Gregorijansko pjevanje u 17. i 18. stoljeću u Europi 52

2.3. Opstanak musica theorica 58

2.4. Cantus gregorianus i pučke nabožne popijevke u Hrvatskoj u 17. i 18. stoljeću: domaća glazbena historiografija o monodijskom pjevanju u baroku

2.5. Historijsko i teorijsko mišljenje o glazbi u prvoj polovici 18. stoljeća u sjevernoj Hrvatskoj: stanje istraživanja 73

TREĆE POGLAVLJE: DISKURS I COMPILATIO

3.1. Glazbenoteorijski neolatinistički diskurs u 18. stoljeću:

slučaj „gregorijansko pjevanje““

3.2. Arhiv glazbenoteorijskog diskursa

96

3.3. Quadruplex est modus faciendi librum

3.4. Ex probatis Athoribus composita

ČETVRTO POGLAVLJE: DISKURS II REGULATIO 
4.3. ... et brevi, ac facili dialogica methodo in lucem expositum 142

$\begin{array}{lr}\text { 4.4. Tablice i stihovi } & 150\end{array}$

PETO POGLAVLJE: DISKURS III SIMILITUDO MATER VERITATIS 171

$\begin{array}{ll}\text { 5.1. Praefatio libri } & 176\end{array}$

5.1.1. Retorika katoličke obnove 183

5.2. Loci communes 191

5.2.1. Posveta (dedicatio) 192

5.2.2. Afektirana skromnost 194

5.2.3. Utilitas 196

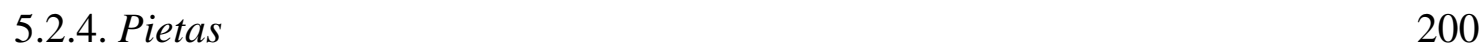

5.3. Similitudo mater veritatis 203

ŠESTO POGLAVLJE: MUSICA THEORICA - MUSICA PRACTICA 213

6.1. Teorija glazbe: historija kao definicija 213

6.2. Odjeci antike - musica theorica ili musica speculativa 219

6.3. Estetika kao dio musica theorica? 236

6.4. Musica practica 241

6.4.1. Tonus, modus, vox 242

6.4.2. Nota 244

$\begin{array}{ll}\text { ZAKLJUČAK } & 248\end{array}$

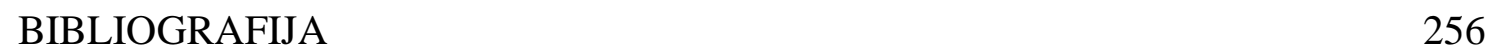

$\begin{array}{ll}\text { PRILOG } 1 & 275\end{array}$

$\begin{array}{ll}\text { PRILOG } 2 & 284\end{array}$ 


\section{Kratice}

BC - Brevis cantus gregoriani notitia:

CE - Il Cantore ecclesiastico, 1733.

CM - Cartella musicale del canto figurato, fermo e contrapunto, 1614.

CO (I, II, III) - Cithara octochorda, 1701., 1723., 1757.

Compendiosa - Compendiosa in cantum gregorianum seu choralem. // Psalterio-Antiphonale. Beč, 1742.

FCG - Fundamentum cantus gregoriani seu choralis. Zagreb,1760.

LC - Lyra Coelestis. Trnava, 1695.

PA - Psalterio-Antiphonale. Beč, 1742.

PL - Patrologia cursus completus, series latina. // uredio J. P. Migne, 221 sv. Paris: Garnier, 1844-1904.

SEMS - Scriptores ecclesiastici de musica sacra potissimum, 3 sv. // uredio Martin Gerbert. St. Blaise: Typis San-Blasianis, 1784.; pretisak Hildesheim: Olms, 1963.

TML - Thesaurus musicarum latinarum. URL: https://chmtl.indiana.edu/tml/ 


\section{POPIS SLIKA}

S1. 1 Karta Europe sredinom 18. stoljeća

S1. 2 Herrad iz Landsberga: Hortus deliciarum, pl. XI. 12. st.

S1. 3 Manus communis Guidonis Aretini iz Pslaterio-Antiphonale. Beč, 1742. Str. 109.

S1. 4 Libellus cantus mensurabilis secundum Johannem de Muris, Case MS 54.1, fol. 43r-49v. Str. 124.

S1. 5 Šilobod-Bolšić, Mihael. Fundamentum cantus gregoriani seu choralis. Zagreb. 1760. Str. 153.

S1. 6 Tettamanzi, Fabrizio. Breve metodo per apprendere fondatamente e con facilità il canto fermo. Milano: 1756. Str. 154.

Sl. 7 „Tabelle von den Vocibus musicalibus Guidonis Aretini“, Anon. 17. st. Str. 156.

S1. 8 prikaz autentičnih i plagalnih tonusa iz priručnika Šiloboda-Bolšića Fundamentum cantus gregoriani seu choralis. Zagreb: L\&G, 2009. Str. 161.

S1. 9 Prikaz niza tonova prema Pitagorinom nauku. Str. 164.

S1. 10 transkripcija tablice simbola tonusa objavljene u Fundamentum cantus gregoriani seu choralis Mihaela Šiloboda-Bolšića. Str. 165.

S1. 11 Tettamanzi, Fabrizio. Breve metodo per apprendere fondatamente e con facilità il canto fermo. Milano: 1756. str. 16. Str. 165.

Sl. 12 usporedna tablica naziva tonova prema grčkim slovima i Guidovim solmizacijskim slogovima iz priručnika Il Cantore Ecclesiastico Giuseppea Frezza Dalle Grotte.

Padova,1733. Str. 166.

Sl. 13 Mramorni stup i stup od opeke s urezanim pravilima glazbene teorije. Samber, Johann Baptist. Elucidatio musicae choralis. Salzburg, 1710. Str. 226.

Sl. 14 Ulomak iz četvrtog poglavlja o porijeklu glazbe iz Samber, Johann Baptist. Elucidatio musicae choralis. Salzburg, 1710. Str. 227.

Sl. 15 Šilobod-Bolšić, Mihael. Fundamentum cantus gregoriani seu choralis ... Prikaz prva četiri tonusa nazvana prema grčkim rednim brojevima. Str. 232. 
Sl. 16 Notni primjer Uskrsne antifone iz Psalterija-Antifonala, Beč, 1742. Str. 246.

S1. 17 Notni primjer iz Šilobod-Bolšić, Mihael. Fundamentum cantus gregoriani seu choralis ... Zagreb, 1760. Str. 13. 


\section{UVOD}

Pristajući uz tvrdnju Lea Treitlera da povijest čini ukupnost zapisa koji uključuju znanje o prošlosti $^{1}$ te da je glazba kao i pisanje o njoj u interakciji s društvom i kulturom svoga vremena, svakako bi, pri predočavanju kulturnih dosega u sjevernoj Hrvatskoj tijekom 18. stoljeća, valjalo uključiti i tekstove o glazbi pisane latinskim jezikom. Ponajprije stoga što oni predstavljaju jedine sačuvane izvore formaliziranog i službenog diskursa o glazbi te time omogućuju istraživanje ne samo iz njihovih teorijskih postavki projiciranu glazbenu praksu, već i s njom povezanih obrazaca kulturnog i društvenog života sjeverne Hrvatske u razdoblju neposredno prije jozefinizma. Budući da smo u dosadašnjim muzikološkim istraživanjima ostali bez pomnije analize mišljenja o glazbi što ga promiču, valja ih pročitati kako bismo bolje shvatili njezinu ulogu u svakodnevici prosječnoga čovjeka (u urbanim i u ruralnim sredinama podjednako), koji s njom u dodir dolazi najčešće u kontekstu crkvenih obreda. Pritom, dakako, treba biti svjestan da je riječ o crkvenoj liturgijskoj i paraliturgijskoj glazbi, a ne onoj koju se naziva pučkom ili umjetničkom. U tom smislu ova se disertacija bavi detaljnom analizom uvodnika svih triju izdanja zbornika Cithara Octochorda (Beč 1701. i 1723., Zagreb 1757.), priručnikom Mihaela Šiloboda Bolšića Fundamentum cantus gregoriani seu choralis (Zagreb, 1760.) te, u mjeri u kojoj to dopušta parcijalno dostupan sadržaj, priručnikom Tome Kovačevića Brevis cantus gregoriani notitia (Beč, 1701.). Uz dosad provedena istraživanja glazbene teorije i prakse ${ }^{2}$, vjerujemo da će analiza latinističkog korpusa tekstova o glazbi u sjevernoj Hrvatskoj u prvoj polovici 18. stoljeća doprinijeti potpunijoj slici teorijske i estetičke premise poželjne glazbene prakse toga vremena, odnosno onakve kakvom je, kao jedinu moguću ili dopuštenu, vide kaptolski kanonici kantori (ili pojci $)^{3}$ kao vrhovni autoriteti te kantori pojedinih crkava kao njezini svakodnevni provoditelji.

Diskurs (o glazbi) promatran kao „sustav koji strukturira način na koji percipiramo stvarnost ${ }^{\star 4}$ obuhvaćao je u prvoj polovici 18. stoljeća u Hrvatskoj glazbenu teoriju koja je uz normativne propise uključivala i makar vrlo kratke rasprave o porijeklu glazbe, njezinim

\footnotetext{
${ }^{1}$ Treitler, Leo. The Historiography of Music: Issues of Past and Present. // Rethinking Music / uredili Nicholas Cook; Mark Everist. Oxford: Oxford University Press, 1999. Str. 356-377.

${ }^{2}$ Popis najvažnije literature koja se bavi poviješću glazbe u sjevernoj Hrvatskoj u razdoblju 17. i 18. stoljeća dostupan je u drugom poglavlju koje se bavi stanjem istraživanja.

${ }^{3}$ Čazmanski je Kaptol imao dvanaest kanonika. Prvi je po časti bio kanonik prepošt ili prepozit, za njim slijedi kanonik lektor, a treći po redu bio je kanonik kantor ili kanonik pojac koji je imao svoga zamjenika, kanonika podkantora ili podpojca. Usp. Horvat, Rudolf. Prošlost grada Zagreba. Zagreb: AC, 1992. Str. 44.

${ }^{4}$ Mills, Sara. Michel Foucault. London \& New York: Routledge, 2003. Str. 11.
} 
moralnim aspektima, kurativnim moćima te estetici. Ti su spisi do duboko u 18. stoljeće tradirali razne modele pisanja o glazbi preuzete iz tradicije antike, srednjega vijeka i renesanse kao što su forma platonističkog dijaloga paideutičkog karaktera (npr. Juraj Alberti: Dialogo per imparare con brevita il canto figurato, 1619., Mihael Šilobod Bolšić:

Fundamentum cantus gregoriani seu choralis, 1760.), renesansni tip predgovora glazbenim izdanjima “ad lectorem" (Cithara Octochorda I, II, i III) koji porijeklo vuče iz rimske retorike $^{5}$ te raspravu o glazbi kao o dijelu matematičkih, astronomskih, medicinskih ili fizikalnih spisa. Takvi su npr. tekstovi liječnika i polihistora Gjure Baglivija De anatome, morsu et effectibus tarantulae, $1699 .^{6}$, te uglednog profesora fizike na sveučilištu u Pešti Josipa Franje Domina Sono campanarum fulmine promoveri potius..., iz 1786. godine.

Ovo je istraživanje vremenski ograničeno na prvih šezdeset godina 18. stoljeća s obzirom na godine izdanja spomenutih priručnika koje se protežu od 1701. do 1760. godine, a geografski na sjevernu Hrvatsku, prije svega na Zagreb i Zagrebačku biskupiju te se, s obzirom na dostupne izvore, zanima prvim i drugim modelom pisanja o glazbi. U njima nas prvenstveno zanima način mišljenja o glazbi, percepcija njezine uloge i njezinih moći u ljudskom životu te načini na koje glazba i pisanje o njoj zrcali aktualnu kulturnu sliku zemlje. Priručnici Šiloboda - Bolšića i Tome Kovačevića u kršćanskom ideologijom strogo odmjerenom opsegu, opisuju glazbenu teoriju i dotiču temu postanka glazbe, dok predgovori zbornicima Cithara octochorda zrcale u katoličkoj teologiji fundirano kozmološko objašnjenje svijeta u kojem svaka pojavnost, pa i ona glazbena, postoji isključivo kao volja i odraz svemogućega Boga. Nastojat ćemo pokazati da svi spomenuti tekstovi, zastirući se velom diskursa naslijeđenog iz kasnog srednjeg vijeka i renesanse, ipak zrcale svijest o suvremenim problemima crkve i crkvene glazbe, preuzimajući u praksi modele nastale u krilu široko postavljene katoličke obnove potaknute suparničkom ideologijom protestantizma koji se, zbog složenih povijesnih i

\footnotetext{
${ }^{5}$ Kao uzor predgovorima kojima su započinjali gotovo svi literarni uradci u renesansi i baroku, služila je, kao i u mnogočemu drugome, latinska proza i tipovi predgovora koje je ona njegovala osobito u tzv. aurea aetas. Jezične formule iskazivanja zahvalnosti i časti, izrazi (lažne) skromnosti, opća mjesta (loci communes) i druge stilske figure nasljedovane su naročito iz Ciceronova opusa koji je bio standard svakog jezičnog obrazovanja. $\mathrm{O}$ predgovorima u latinskoj prozi postoji sjajna studija objavljena u seriji Acta Universitatis Stockholmiensis: Janson, Tore. Latin Prose Prefaces. Studies in Literary Conventions. Stockholm; Göteborg; Uppsala: Almquist \& Wiksell, 1963.

${ }^{6}$ Recentno istraživanje o Bagliviju u sklopu projekta glazba i migracije proveo je akademik Stanislav Tuksar. O tome vidi članak Tuksar, Stanislav. „Quid agat musica in tarantis \& in aliis morbis“ - Ideas on Music Therapy in Dissertatio VI (1695) by Giorgio Baglivi.// Music Migration in the Early Modern Age: Centres and Peripheries - People, Works, Styles, Paths of Dissemination and Influence /uredile Jolanta Guzy-Pasiak i Aneta Markuszewska. Varšava: Liber Pro Arte, 2016. Str. 281-297.
} 
političkih okolnosti, nije snažnije afirmirao u hrvatskim zemljama kojima je vladala austrijska i ugarska kruna.

Tekstovi kojima se zanima ovaj rad jesu: predgovori zborniku Cithara octochorda čije je prvo izdanje objavljeno 1701. u Beču, drugo 1723. također u Beču, a treće 1757. godine u Zagrebu te priručnici o umijeću gregorijanskog pjevanja Brevis cantus gregoriani notitia (Beč, 1701.) Tome Kovačevića i Fundamentum cantus gregoriani seu choralis Mihaela Šiloboda Bolšića objavljen u Zagrebu 1760. godine. Priručnik Brevis cantus gregoriani notitia Tome Kovačevića jedini ne posjedujemo u originalu te se njegova analiza temelji na podacima dostupnim u diplomskom radu Martina Mihokovića. Naime, na temelju fotokopije snimke prijepisa što ga je načinio Inocencije Auer 1738. u slovenskom franjevačkom samostanu u Novom Mestu, a koju je ,Žganec (Vinko, op. a.) privatnom vezom bio dobio 1950. iz franjevačkog samostana u Novom Mestu“"7 o tom je djelu diplomski rad na Katoličkom bogoslovnom fakultetu izradio Martin Mihoković. ${ }^{8}$ Vrlo je vjerojatno, sudeći po sadržaju dostupnom iz treće ruke, da je ta skromna knjižica s osnovnim uputama za čitanje nota te podacima o modusima, ritmu, mjeri, intoniranju psalama i solmizaciji bila namijenjena lokalnoj upotrebi, baš kao i ostali spomenuti izvori.

Svi nabrojani tekstovi do sada su u domaćoj glazbenoj historiografiji ${ }^{9}$ spominjani u kontekstu održavanja linearnog tijeka hrvatske povijesti glazbe koji se (i) na tom mjestu nezgodno prekidao. Neke od njih nije dosad se uopće percipiralo kao izvore za povijest glazbe ${ }^{10}$. Takav je linearni tijek, naslijeđen od, u nas sve do druge polovice 70-ih godina najutjecajnije histioriografske škole, one njemačke, predstavljao pozitivnu premisu svakog pisanja glazbene historiografije usprkos otporu postojećeg (dostupnog) materijala ${ }^{11}$. Odsustvo primarnih

\footnotetext{
${ }^{7}$ v. bilj. 11. na str. 208. u Županović, Lovro. Hrvatski glazbeni zbornik Cithara octochorda iz XVIII. stoljeća i njegovo značenje za (domaću) glazbenu kulturu onoga doba i danas. // Cithara octochorda. Zagreb 1757. Komentari i studije / uredili Milan Moguš i Lovro Županović. Zagreb: HAZU, Insititut za crkvenu glazbu „Albe Vidaković“" KBF Sveučilišta u Zagrebu, Društvo hrvatskih crkvenih glazbenika, 1998. Str. 203-219.

${ }^{8}$ Mikrofilm teksta prema kojem je Mihoković izradio diplomski rad bila je dostupna još u vrijeme pisanja teksta Lovre Županovića objavljenog u Komentarima i studijama o zborniku Cithara octochorda 1998. kada je tajnik Instituta za crkvenu glazbu „Albe Vidaković“ gosp. Josip Korpar „u Vidakovićevoj ostavštini (koja se danas čuva u tom Institutu) pronašao fotokopije prijepisa toga djelca ...“. Usp. bilj. 6

${ }^{9}$ Pri tome mislimo na povijesti hrvatske glazbe koje imaju pretenziju sveobuhvatnog prikaza hrvatske glazbene kulture koje su redom objavili Božidar Širola, Josip Andreis, Stanislav Tuksar i Ennio Stipčević. Oni su predmetom analize poglavlja koje se bavi stanjem istraživanja. Njima valja pribrojiti i zbornik Glazbeni barok $u$ Hrvatskoj / uredio Ennio Stipčević. Osor: OGV, 1989.

${ }^{10}$ To je slučaj s vrlo zanimljivim uvodnicima objavljenima u sva tri zbornika Cithara octochorda. Naime, čak i u značajnom pothvatu koji je 1998. poduzela HAZU u suradnji s Institutom za crkvenu glazbu „Albe Vidaković“ $i$ Hrvatskim društvom crkvenih glazbenika priredivši četvrto, suvremeno izdanje CO te poseban zbornik Komentara i studija, nitko od pozvanih autora nije se bavio mišljenjem o glazbi kakvo nam nude ti uvodnici.

${ }^{11}$ Kada su materijalije i popisane, kao u slučaju samostana koje su obrađivali brojni domaći muzikolozi Zdravko Blažeković, Miho Demović, Vedrana Juričić, Vjera Katalinić, Ennio Stipčević, Ladislav Šaban, Stanislav Tuksar
} 
muzikoloških izvora (partitura) potkopavalo je, i još uvijek potkopava, tradicionalnu historiografsku shemu autor - djelo i uvjetovalo, s jedne strane nemogućnost linearnog prikaza razvoja umjetničke glazbe, a s druge uključivanje navedenih priručnika i drugog glazbenog materijala poput crkvenih kantuala u historiografiju, kako bi se ispunila poglavlja o glazbenom baroku u sjevernoj Hrvatskoj. Opisana situacija, međutim, karakteristična je ne samo za hrvatsku muzikologiju, već i za muzikološka istraživanja u mnogim drugim zemljama, o čemu svjedoči zamah u istraživanju povijesti teorije koja se počinje proučavati ne više samo kao dokaz za napredak, već i kao tekst sam (glazbenoteorijski, ali i literarni) čime se dopušta istovremenost polivalentnih glazbenoteorijskih mišljenja, kao i modela njihova oblikovanja. Naročito slabo istražene su veze retorike i glazbene teorije u najširem smislu riječi, odnosno utjecaj gramatičkog i retoričkog obrazovanja na govor o glazbi. Ronald Woodley, istražujući utjecaj procvata retorike u drugoj polovici 15. stoljeća na jezik i stil Johannesa Tinctorisa, jednog od najutjecajnijih i najuglednijih glazbenih teoretičara renesanse uopće čiji su tekstovi korišteni kao liber textualis u samostanima i na sveučilištima, upozorava upravo na gore spomenuti problem:

„Jer, naši instinkti prema srednjovjekovnoj i renesansnoj glazbenoj teoriji u cijelosti su bili instinkti znatiželjnog predatora: tekstovi su odabirani i secirani zbog specifičnih tehničkih ili notacijskih pojedinosti kako bismo potvrdili vlastite interese; drugdje se pak marljivo traže one dragocjene reference na stvarne polifone skladbe ili skladatelje za koje se nadamo da će pripomoći uspostavljanju kronologije ili prijenosa ili specifičnog dokaza za izvedbu na određenoj lokaciji u određeno vrijeme i tako još jednom obraniti našu katkad naivnu pozitivističku arugumentaciju.“12

Tekstovi kojima se bavi ovaj rad nude teorijsku (Kovačević i Bolšić) ili moralnu (Cithara Octochorda I, II i III) uputu za crkvenu glazbenu praksu, svjedočeći tako o njezinom

\footnotetext{
Tatjana Devčić Stefanović i drugi, ostale su najvećim dijelom bez prikladne analize. Katalozi muzikalija dostupni su u tiskanim verzijama na poveznici http://hmd-music.org/indices-collectiorum-musicarumtabulariorumque-in-croatia-catalogues-2/ te u digitaliziranoj verziji na poveznici

http://dizbi.hazu.hr/?object=list\&find=inventarne+knjige\&mr[94689]=a. Nažalost, znatan broj knjižnica i samostana u Hrvatskoj, koji obiluju građom za istraživanje povijesti hrvatske glazbe, ostao je do danas neistražen.

${ }^{12}$ Woodley, Robert. Renaissance music theory as literature: on reading the Proportionale Musices of Iohannes Tinctoris. // Renaissance Studies, 1/2 (1987.), str. 209-220. „For our instincts towards medieval and Renaissance music theory have been on the whole curiously predatory instincts: the texts are culled and dissected for specific technical or notational points in order to validate our own interests; or else those precious references to real pieces of polyphonic music or composers are assiduously sought out, which we hope will assist in establishing chronology, or transmission, or specific evidence for performance at a particular location at a particular time, and hence, once again, to vindicate our sometimes naively positivistic argumentation."
} 
kontinuitetu i pružajući uvid u glazbeni aspekt katoličke obnove u perifernim dijelovima Habsburške monarhije. Ne treba zaboraviti da je upravo Katolička crkva, kao presudan partner u mnogim političkim i društvenim pitanjima unutar Habsburške monarhije ${ }^{13}$ kojoj pripadaju i hrvatske zemlje, nositeljica i promicateljica dominantne estetike, ne samo u glazbenom, već i u svem ostalom umjetničkom djelovanju ${ }^{14}$. Razdoblje između završetka Tridentskog koncila i jozefinizma, doba je u kojem provođenje koncilskih odluka značajno oblikuje brojne aspekte društvenog i kulturnog života svih katoličkih zemalja te na osobit način pokazuje crkvenu posttridentsku politiku kao kohezijski faktor u područjima nekoherentne svjetovne vlasti. Područje današnje Republike Hrvatske, tada razjedinjene između Habsburške monarhije, Venecije i Osmanskoga carstva u tome nije izuzetak. Opsežna istraživanja provedena u nas povodom 450. obljetnica završetka Tridentskoga koncila ukazuju na potrebu revalorizacije društvenih, kulturnih i umjetničkih dosega naših zemalja u razdoblju katoličke obnove, te na problem periodizacije koja ionako predstavlja možda najkrhkiju i najkompleksniju potku povijesnih, pa onda i glazbenopovijesnih diskursa. ${ }^{15}$

Svu složenost periodizacije zrcale nazivi ovog razdoblja koje se u domaćoj kulturnoj povijesti proteže od Karlovačkog mira do početka biskupovanja Maksimilijana Vrhovca (1788.). To se razdoblje u povijesti glazbe naziva barokom i (ranim) klasicizmom ${ }^{16}$, a u povijesti književnosti klasicizmom i prosvjetiteljstvom ${ }^{17}$. Terminološka zbrka kao posljedica suživota raznih stilova dodatno otežava odabir epiteta kojima bi se obuhvatilo sve spomenute tekstove. Nemogućnost homogenizacije supostojećih umjetničkih ostvarenja u jedan pravac/stil/ideju te njihova navodna nekompatibilnost s prevladavajućim pravcem/stilom u Europi učinila ih je

\footnotetext{
${ }^{13}$ O snažnim vezama između dinastije Habsburgovaca i Katoličke crkve pisali su mnogi povjesničari. Usp. Evans, Robert J.W. Das Werden der Habsburger Monarchie 1550-1700. Gesellschaft, Kultur, Institutionen. Forschungen zur Geschichte des Donauraumes 6. Wien: Böhlau Verlag, 1986.; Coreth, Anna. Pietas Austriaca. s. 1. Purdue University Press, 2001.; Ewans, J. R. W.; Thomas, T. V. (ur.). Crown, Church and Estates. Central European Politics in the Sixteenth and Seventeenth Centuries. New York: St Martin's Press, 1991. Winkelbauer, Thomas. Ständefreiheit und Fürstenmacht. Länder und Untertanen des Hauses Habsburg im konfessionellen Zeitalter (2 sv.). Wien: Ueberreuter, 2003.

${ }^{14}$ Pretežna tematika slikarstva 17. i 18. stoljeća, primjerice, također se kreće u okviru biblijskih pripovijesti i antičke mitologije koja čini legitimni dio (post)skolastičkog obrazovanja.

${ }^{15}$ Tridentska baština. Katolička obnova i konfesionalizacija u hrvatskim zemljama / uredile Zrinka Blažević; Lahorka Plejić Poje. Zagreb: FFDI: KBF: MH, 2016.

${ }^{16}$ Barok u glazbi razvijenih zemalja iznimno je divergentan i obuhvaća dugo razdoblje od početka 17. stoljeća kojim dominira ranobarokna monodija pa sve do sredine 18. stoljeća čijom prvom polovicom vladaju raskošni instrumentalni i vokalnoinstrumentalni oblici kojima supostoje tehnike monodije uz pratnju i visoko razvedene polifonije.

${ }^{17}$ Usp. Frangeš, Ivo. Povijest hrvatske književnosti. Zagreb: NZMH; Ljubljana: Cankarjeva založba, 1987.; Jelčić, Dubravko. Povijest hrvatske književnosti: tisućljeće od Baščanske ploče do postmoderne. Zagreb: Naklada P.I.P. Pavičić 2004. 2; Ježić, Slavko. Hrvatska književnost od početaka do danas 1100.-1941. Zagreb, 1944.; i Novak, Slobodan Prosperov. Povijest hrvatske književnosti od Bašćanske ploče do danas. Zagreb: Golden marketing, 2003.
} 
neprikladnima u nastojanju da se hrvatsku kulturu uklopi u ideju napretka kao jedinu prihvatljivu. Usprkos tome, ili upravo stoga što ne pripadaju (ni)jednom stilskom pravcu, već baštine elemente usko profilirane estetike crkvene glazbe temeljene na jednoglasju gregorijanskoga pjevanja, zanimljivo je u njima istražiti ono što su naslijedili od proteklog te ono što dijele sa suvremenim dobom.

Svi spomenuti izvori pisani su latinskim jezikom što ih u kontekstu stvaranja nacionalne kulturne povijesti često svrstava u kategoriju „drugog reda“ u odnosu na ma kakav tekst koji je pisan vernakularom ${ }^{18}$. Iako je latinski stoljećima predstavljao konstantu kako u znanosti tako i u umjetnosti, dominirajući nad hrvatskim narječjima da bi potom s njima supostojao sve do pred kraj 19. stoljeća $^{19}$, devetnaestostoljetno uvjerenje o narodnom jeziku kao dokazu nacionalne pripadnosti, bez obzira na studije koje pobijaju tezu o jeziku kao nužnoj premisi za razvoj nacionalne svijesti ${ }^{20}$, još uvijek svrstava latinističku literaturu na drugo mjesto.

Glazbenoteorijski tekstovi iz razdoblja renesanse do sada su bili predmetom interesa studije Stanislava Tuksara Hrvatski renesansni teoretičari glazbe ${ }^{21}$, a isti se autor bavio i rječnicima baroknoga razdoblja kao izvorima za glazbenu terminologiju ${ }^{22}$. Glazbenoteorijski tekstovi objavljeni u 18. stoljeću u hrvatskoj glazbenoj historiografiji evidentirani su kao neistraženi sekundarni izvori za povijest glazbe. ${ }^{23}$

Priručnici i uvodnici kojima se bavi ova disertacija edukativnog su i prosvjetiteljskog karaktera te ne pripadaju korpusu ,najsjajnijeg razdoblja“ ${ }^{24}$ hrvatskog novovjekovnoga latinizma. Donose upute za praksu i to onu umjetnički ograničenu (gregorijansko pjevanje i na njemu utemeljene jednostavne oblike), a ne glazbena djela koja korespondiraju ondašnjoj glazbenoj praksi razvijenih središta u kojima se izvode instrumentalna i vokalno instrumentalna djela kao što su trio sonate, suite, velebne mise, oratoriji i opere. U nedostatku

\footnotetext{
${ }^{18}$ usp. npr. Povijest hrvatske književnosti u sedam knjiga. Goldstein, Slavko (ur.). Zagreb: Liber: Mladost, $1974-$ 1978. sv. 3.

${ }^{19}$ Tako Darko Novaković upozorava: „Narodno-latinska dvojezičnost nije, dakle, nikakva posebnost hrvatske književnosti. Ono što jest hrvatska posebnost trajnost je te pojave, koja obilježava ne samo hrvatsku književnost nego i cjelinu hrvatske kulture.“ u: Novaković, Darko (prir.). Hrvatski latinisti. Razdoblje humanizma. Zagreb: Erasmus, 1997. Str. 6.

${ }^{20}$ Usp. Hobsbawm, Eric. Nations and Nationalism Since 1780: programme - Myth - Reality. Oxford: Oyford University Press, $1992^{2}$. (hrv. izd. Nacije i nacionalizam. Zagreb: Novi Liber, 1993.)

${ }^{21}$ Tuksar, Stanislav. Hrvatski renesansni teoretičari glazbe. Zagreb: JAZU, 1978.

${ }^{21}$ Tuksar, Stanislav. Hrvatska glazbena terminologija u razdoblju baroka. Nazivlje glazbala i instrumentalne glazbe u tiskanim rječnicima od 1649. do 1742. godine. Zagreb: HMD: MIC KDZ, 1992.

${ }^{23}$ Usp. Katalinić, Vjera. Pregled izvora o glazbenoj kulturi baroknog razdoblja na tlu SR Hrvatske. // Glazbeni barok u Hrvatskoj / uredio Ennio Stipčević. Osor: Osorske glazbene večeri, 1989. Str. 20-47.

${ }^{24} \mathrm{O}$ tome vidi u Novaković, Darko. Op. cit. Str. 7.
} 
kvalitetnijeg i muzikologiji zanimljivijeg materijala, dakle glazbenih partitura složenijih formi i skladateljskih tehnika, kojima je na sjeveru oskudijevalo 18. stoljeće sve do samog svoga kraja, zaslužili su zajedno s (franjevačkim) kantualima potpoglavlja u nacionalnim glazbenim historiografijama. Znatan dio znanstvenoistraživačkoga rada Ladislav Šaban, Zdravko Blažeković, Vjera Katalinić i Ennio Stipčević posvetili su glazbenim izvorima nastalim u anonimnosti katoličkih redova. Njihov je muzikološki rad tijekom posljednjih šezdesetak godina rezultirao nizom znanstvenih studija o baroknoj glazbi u Hrvatskoj, osobito onoj isključivo vezanoj uz liturgiju koja je dominirala sjevernim hrvatskim zemljama. Potaknut brojnim poduzetim istraživanjima, Stipčević je prije nešto više od dva desetljeća napisao i sintetsku povijest hrvatske glazbe do 20. stoljeća u kojoj su mnogi dotad nepoznati ili zanemareni izvori stavljeni u kontekst onodobnih političkih, gospodarskih i kulturnih prilika. Imenujući očito slabe glazbene prilike prividnim zatišjem, Stipčević se detaljnije bavi franjevačkim kantualima i isusovačkim pjesmaricama dok zbornik Cithara octochorda smatra najavom posustajanja „njegovanja crkvene popijevke, kao da su čak tri izdanja tog opsežnog kantuala ispunila htijenja prethodnih naraštaja“‘25. Nasuprot tome, priručnik Fundamentum cantus gregoriani seu choralis Mihaela Šiloboda Bolšića iz 1760. najavljuje, čini se, intenzivniji rad na polju glazbene teorije: „U skladu s organiziranim i marljivim prepisivačkim radom, u hrvatskim su se samostanima, počam od druge polovice 18. st., počeli prepisivati i prevoditi i razni glazbenoteorijski spisi, udžbenici o teoriji, harmoniji, osnovama kompozicije. Potreba za poznavanjem glazbene teorije bila je velika, bio je to osnovni preduvjet širenja glazbenih znanja“ ${ }^{626}$. Prijevod tog prvog priručnika za glazbenu teoriju koji je objavljen u Hrvatskoj (podsjetimo, Dialogo per imparare con brevita il canto figurato Jurja Albertija tiskan je u Veneciji 1619., dok je tekst Tome Kovačevića Brevis cantus gregoriani notitia, prema informaciji iz prijepisa koji datira iz 1738., tiskan u Beču 1701.) i uvodnu studiju napravila je autorica ove disertacije, dok je priručnik Tome Kovačevića do danas ostao predmetom interesa samo jedne studije: diplomskoga rada Martina Mihokovića obranjenoga na Katoličkom bogoslovnom fakultetu 1970. godine ${ }^{27}$.

\footnotetext{
${ }^{25}$ Stipčević, Ennio: Hrvatska glazba, Povijest hrvatske glazbe do 20. stoljeća, Zagreb: Školska knjiga, 1997. Str.124.;

${ }^{26}$ Ibid., str. 127.

${ }^{27}$ Albertijem se najopsežnije pozabavio Josip Andreis u opširnome članku objavljenom o 350. obljetnici tiskanja toga priručnika. Usp. Andreis, Josip. Albertijev „Dijalog““. O 350-godišnjici objavljivanja. // Arti musices, 1 (1969), str. 91-104.; Stipčević, Ennio. Andreisova glazbena historiografija o „renesansi“ i ,baroku“ u hrvatskoj glazbi. // Arti musices 40/1-2 (2009), str. 89-98. Pomnija analiza teksta bit će objavljena u članku Jelene Knešaurek Carić „Giovanni Alberti's „Dialogo“ (1619)“ u monografiji Companion to Ivan Lukačić koja se planira objaviti u lipnju 2021. godine.
} 
Sa zbornikom Cithara Octochorda situacija je nešto drugačija: uz faksimilno izdanje trećeg izdanja zbornika objavljenog u Zagrebu 1757. objavljen je i poseban zbornik radova o pojedinačnim muzikološkim, etnomuzikološkim, povijesnim, jezikoslovnim, likovnim i drugim fenomenima koji se nude istraživačima crkvenih kantuala ${ }^{28}$, kao i doktorska disertacija fra Izaka Špralje u kojoj su pomno analizirani glazbeni oblici gregorijanskog i himničkog pjevanja objavljeni u sva tri izdanja zbornika. ${ }^{29}$ Ono što je dosad ostalo neistraženo jesu uvodni tekstovi (u Komentarima i studijama slobodno ih je preveo isusovac Predrag Belić) koji tumače razloge nastanka zbornika te inzistiraju na važnosti etičkog i estetičkog u glazbi, što podupiru citatima antičkih pjesnika i pisaca. Istovremeno ističu njezinu ulogu u intenzivnom nastojanju crkve da religiozna tematika postane bliskom puku i da pjevanje, do tada prepušteno klericima i profesionalnim koralistima, postane navikom puka i tako doprinese širenju i popularnosti liturgijske i paraliturgijske prakse ${ }^{30}$. Osim toga, prebirući po antičkim i ranokršćanskim legendama, uvodni tekst drugom i trećem izdanju zbornika nudi se čitatelju kao kratka sinteza neoplatonističke misli o glazbi kao odrazu harmonije svemira i svijeta, ali i renesansne sklonosti tumačenju svijeta kroz sličnosti: nudi, dakle, odjeke tada napuštene discipline teorije glazbe kao dijela matematičkih znanosti kvadrivija. Ona je, međutim, lišena znanstvene intencije zbog čega se ne poziva niti aludira niti na jedan Platonov tekst. Harmonija svemira i svijeta, Boga i čovjeka, neba i zemlje ispripovijedana je kroz velik broj raznovrsnih pripovijesti od kojih mnoge pripadaju antičkoj baštini, dok se manji broj odnosi na Starozavjetne i Novozavjetne parabole.

\section{Hipoteza i ciljevi istraživanja}

Ovaj će se rad, kroz analizu spomenutih izvora o glazbi pokušati odmaknuti od uvriježenih zaključaka o stagnaciji, anakronizmu ili, u najboljem slučaju, promjeni kvalitete - zaključaka koji pokušavaju prikriti nelagodu zbog nepostojanja materijala koji bi mogao ravnopravno sudjelovati u tradicionalnim europskim glazbenim historiografijama baroka i dokazivati našu pripadnost europskom krugu naroda kroz praksu takozvanih razvijenih glazbenih formi. Uvidom u postojeće baze podataka o teorijskim djelima u 18. stoljeću i usporednom analizom

\footnotetext{
${ }^{28}$ Usp. bilj. 7.

${ }^{29}$ Špralja, Izak. Cithara Octochorda. Glazbeni zbornik Zagrebačke crkve iz 18. stoljeća (Beč 1701. i 1723.; Zagreb 1757.) s posebnim osvrtom na glazbene oblike pokazatelje glazbenih razdoblja. Zagreb: Hrvatsko društvo crkvenih glazbenika, 1998.

${ }^{30}$ Usp. PRILOG 1: „Et quod plus est, tam turpis acedia, tam vitiosa authoritas invaluit apud te o Nobilis Familia, quod nec ad Ecclesiam Parochialem Diebus Festis venire velis, sed cum scandalo aliorum domi tuae incurie delitescis...", uvod, nepag. (I što je gore, kod tebe je, plemenita obitelji, prevladao tako ružan nemar, tako poročan stav, da ne želiš ni za blagdane ići u župnu crkvu, nego se na sablazan drugih bezbrižno kriješ kod kuće. prev. J. K. C.)
} 
sa srodnim djelima objavljenima u razvijenijim i bogatijim sredinama, nastojat će upozoriti na višeslojnost suvremenosti i, sukladno tome, aktualnosti koje se mogu istraživati i izvan najeksponiranijeg, najrazvijenijeg (u smislu u kojem razvoj razumije 19. stoljeće, kao neprestana mijena koja implicira poboljšanje ili barem novost u odnosu na ono prošlo) i umjetnički najuspjelijeg korpusa umjetničkih djela.

Premda iz današnje historiografske perspektive gotovo paradoksalan i, kako je lucidno prije više od pola stoljeća primijetio Edward Carr, „ne previše dubokouman aforizam“ Rankea iz ranih tridesetih godina 19. stoljeća ,wie es eigentlich gewesen“331, postao je egidom mnogih generacija povjesničara do duboko u drugu polovicu 20. stoljeća. Poslije desetljećâ povijesnih istraživanja od analista naovamo koja su uspješno protresla empirizam i pozitivizam stare historiografske škole, svakom bi istraživaču trebalo biti jasno da se ništa ne može prikazati „kako je uistinu bilo“. Novi su historiografski zahtjevi u središte zanimanja povijesnog istraživanja postavili periferiju, dugotrajnost i ustrajnost opstanka određenih pojava, beznačajnost u suprotnosti s prethodnim insistiranjem na velikim i važnim događajima $i$ kulturnim, društvenim i političkim središtima. Na tragu spomenutih promjena u političkoj i društvenoj historiografiji, svijest o potrebi za periodizacijom drugačijom od one koja je funkcionalna u susjednim društvima značajno je porasla proteklih desetljeća i u hrvatskoj muzikologiji te su intenzivirana istraživanja koja se tiču do tada marginaliziranih tema povijesti glazbe poput glazbene teorije, pedagogije i lokalnih glazbenika izvođača ${ }^{32}$. U proteklih se nekoliko desetljeća intenziviralo istraživanje posttridentske katoličke kulture, ne samo u Hrvatskoj već i u svijetu, kao i istraživanje rjeđe spominjanih tema u povijestima crkvene glazbe, kao što je npr. cantus fractus. Potreba za tumačenjem umjetničkih fenomena u razdoblju između Tridentskog koncila i francuske revolucije kojima ne pristaje tradicionalna nomenklatura baroka (i klasicizma) potaknula je istraživače na korištenje spoznaja nove historiografije i svih njezinih inačica okupljenih pod zajedničkim nazivnikom nova kulturna historija ${ }^{33}$. Snažan poticaj novom promišljanju umjetničkim izričajem vrlo

\footnotetext{
${ }^{31}$ Carr, Edward Callet. Što je povijest?. Zagreb: Srednja Europa, 2004. Str. 6.

${ }^{32}$ Takva su istraživanja povijesti odozdo u smislu proučavanja dotad slabo vidljivih ili čak nevidljivih dionika glazbene povijesti promovirale i velike muzikološke škole u Njemačkoj, Francuskoj i Sjedinjenim Američkim Državama, što je rezultiralo velikim brojem radova o dotad zapostavljenim temama kao što su žene skladateljice, povijest crkvene glazbe, povijest popularnih glazbenih žanrova, itd.

${ }^{33}$ Nova kulturna historija naziv je novih tendencija u proučavanju kulturnih praksi. Ujedno je to i naziv priručnika Lynn Hunt koja objašnjava promjenu paradigme u historiografiji koja se od socijalne povijesti usmjerava prema interdisciplinarnoj kulturalnoj povijesti u kojoj ekonomija i politika, ako već nisu podređene kulturi, onda su shvaćene kao njezin dio ili čak njome uvjetovane. Prema Hunt, takva, interdisciplinarna proučavnja određene teme, omogućuju koheziju nalaza kroz interpretaciju. Usp. Hunt, Lynn. Nova kulturna historija. Zagreb: Naklada Ljevak, 2001.
} 
heterogenih razdoblja kao što je to nesumnjivo bio barok, svakako su bila epistemološka istraživanja Michela Foucaulta, a naročito ona objavljena u djelu Riječi i stvari. Arheologija humanističkih znanosti. ${ }^{34}$ Uza sve spomenuto, sama ideja istraživanja teksta o glazbi (a ne glazbe kao teksta) kao glazbenoteorijskog, muzikološkog, ali i literarnog pothvata koji svjedoči o društvenim i kulturnim praksama nekog razdoblja, pothvata koji valja i kontekstualno, a ne samo glazbenoteorijski analizirati, u svjetskoj je muzikološkoj praksi također relativno nova. U kontekstu srednjovjekovnih autora (koji su uvelike temeljni izvor i za naše pisce), Woodley sjajno opisuje problem:

„Srednjovjekovni je autor s vremenom sveden na poziciju tihog suučesnika u postupku jednostavne verifikacije. Ovo je, dakako, u određenoj mjeri karikaturalni prikaz, no problem je vrlo stvaran. Postoji neobičan otpor prema obraćanju pažnje na literarni kontekst u kojem je srednjovjekovna glazbena teorija - ili barem njezin veći dio - zamišljena i napisana: očigledno „površinsko značenje“ (kako god tko protumačio ovu frazu) je shvaćeno zdravo za gotovo; obrazovni i intelektualni temelji pisca često se ignoriraju; sami tekstovi su rijetko, ako ikada podvrgnuti pomnoj stilističkoj kritici ili analizi.“35

Na tragu spomenutih historiografskih i epistemoloških uvida, zadatak će ovoga rada biti tekstove o glazbi hrvatskih autora objavljene na latinskom jeziku pomno opisati, smjestiti u europski kontekst uspoređujući ih sa srodnim glazbenoteorijskim radovima te analizirati slojeve utjecaja kako izrijekom spomenutih filozofa i glazbenih teoretičara, tako i onih čiji su stavovi samo naznačeni. Važno je pritom imati na umu iznimnu složenost epistemologijâ koje se u teoriji susreću i isprepliću tijekom cijelog razdoblja baroka supostavljajući filozofijsku tradiciju antike, srednjega vijeka, renesanse i suvremene filozofije prirode te etičke norme (neo)platonizma zaogrnute ruhom patristike. Promatrani uz pomoć teorije epistemâ Michela Foucaulta Kovačevićev Brevis cantus gregoriani notitia i Bolšićev Fundamentum cantus gregoriani seu choralis, kao i uvodni tekstovi svih triju izdanja zbornika Cithara Octochorda predstavljaju križanje dvaju glavnih tipova prikaza znanja: onoga koji se temelji na

\footnotetext{
${ }^{34}$ Foucault, Michel. Les mot set les choses. Une archéologie des sciences humaines. Paris: Editions Gallimard, 1966. (Riječi i stvari. Arheologija humanističkih znanosti. prev. Srđan Rahelić. Zagreb: Golden marketing, 2002.)

${ }^{35}$ Woodley, Robert. op. cit. str. 210.: „The medieval author becomes at times reduced to the position of silent accomplice to an act of simple verification. This is, of course, to caricature the picture somewhat, but the problem is a very real one. There has been an extraordinary reluctance to attend to the literary context in which medieval music theory - or much of it - was conceived and written: the apparent 'surface meaning' (however one interprets the phrase) is taken pretty well at face value; the educational and intellectual background of the author is often ignored; and the texts themselves are rarely if ever subjected to detailed stylistic criticism or analysis."
} 
ulančavanju sličnosti - epistema renesanse prema Michelu Foucaultu ${ }^{36}$ - čiji je vjerojatno najpoznatiji primjer knjiga isusovca Athanasiusa Kirchera Musurgia universalis objavljena 1650. godine ${ }^{37}$, te onoga koji reflektira racionalizam i empirizam kao komplementarne moduse organizacije i objašnjenja materijala, a prisutan je, na primjer, u djelu Harmonie universelle Marina Mersennea iz $1636^{38}$. Premda, kao jedan od najopsežnijih i najvažnijih za povijest europske glazbe, neusporediv s istraživanim tekstovima lokalnoga dometa, najiscrpniji traktat o glazbi koji promišlja i vlastitu metodologiju a ujedno vremenski najbliži domaćim izvorima jest Der vollkommene Capellmeister iz 1739. ${ }^{39}$ Johanna Matthesona.

Neizbježan je, međutim, kao referentni prikaz glazbenoteorijskog sustava koji, suvremen našim izvorima, postulira četiri područja unutar kojih i s kojima glazba uspostavlja odnose: priroda, moral, retorika i matematika. Na taj način definira i četiri osnovne funkcije glazbe te implicira odnosna područja interesa: akustiku (priroda), afekt i stil (moral, odnosno psihologija glazbe), performativne i gramatičke aspekte skladanja (retorika) i normativnu teoriju glazbe (matematika) ${ }^{40}$, od kojih su svi u određenoj mjeri prisutni i u domaćih autora. Spomenuti je sustav od kraja 18. stoljeća postupno uzmicao te ustupao mjesto onome što se danas smatra „klasičnom“ ili „,normativnom“ glazbenom teorijom koja s većinom predmodernih fundamentalnih glazbenih tema poput akustike, matematike, retorike ili etike ima vrlo malo dodirnih točaka. Naime, glazbena praksa i na njoj utemeljena glazbena teorija koja je zaživjela s poimanjem glazbenog djela kao objekta, a njegovog autora kao subjekta, tonalitetom kao neupitnom zadanošću na području akustike te harmonijskim principom skladanja što favorizira jedan, najčešće najviši glas, do te je mjere stekla status „vječne istine“ ili „dogme“ da je „kao rezultat, glazbeno-teorijski diskurs postao u velikoj mjeri glazbenoegzegetski u sadržaju. Samo-stabilizirajući, potkrepljujući efekt međuovisnih premisa onemogućuje temeljite revizije, velika otkrića ili čak slučajne prodore. “41 Potrebna je, čini se,

\footnotetext{
${ }^{36}$ Usp. Foucault, Michel. op. cit. str. 35 - 64.

${ }^{37}$ Athanasii Kircheri Fuldensis E Soc. Iesu Presbyteri Musurgia Universalis sive Ars Magna consoni et dissoni in x libros digesta. ... Romae, Ex Typographia Haeredum Francisci Corbelletti. Anno Iubilaei. MDCL.

${ }^{38}$ Harmonie Universelle, contenant la Theorie et la Pratique de la Musique, où il est traité de la Nature des Sons, \& des Mouvemens, des Consonances, des Dissonances, des Genres, des Modes, de la Composition, de la Voix, des Chants, \& de toutes sortes d'Instruments Harmoniques. Par F. Marin Mersenne de l'Ordre des Minimes. A Paris, Chez Sebastien Craimoisy, Imprimeur ordinaire du Roy, ruë S. Iacques, aux Cicognes. MDCIIIVI. Avec Privilège du Roy, \& Approbation des Docteurs.

${ }^{39}$ Der vollkommene Capellmeister, Das ist Gründliche Anzeige aller derjenigen Sachen, die einer wissen, können, und vollkommen inne haben muß, der einer Capelle mit Ehren und Nutzen vorstehen will: Zum Versuch entworffen von Mattheson. Hamburg, 1739.

${ }^{40}$ Usp. Blasius, Leslie. Mapping the terrain. // The Cambridge History of Western Music Theory / uredio Thomas Christensen. Cambridge: Cambridge University Press, 2002. Str. 27-45.

${ }^{41}$ Gjerdingen, Robert. An Experimental Music Theory? // Rethinking Music / uredili Nicholas Cook i Mark Everist. Cambridge: Cambridge University Press 2010. ${ }^{3}$ Str. 162.: "The self-stabilizing, corroborating effect of interdependent premisses precludes fundamental revisions, major discoveries, or even accidental breakthroughs.“
} 
stanovita desakralizacija sakralnog u baroknoj glazbi kako bi analiza prestala neosviješteno ponavljati implicitne zasade analiziranih tekstova.

U spomenutom su kontekstu istraživanja glazbenoteorijskih traktata ranijih razdoblja ostala predmetom interesa prilično zatvorene skupine muzikologa medievista ili onih koji su se od druge polovice prošloga stoljeća počeli zanimati takozvanom povijesno osviještenom interpretacijom rane glazbe.

Promjena paradigme u znanosti o književnosti i u historiografiji, a tek potom (od osamdesetih godina dvadesetoga stoljeća) i u muzikologiji omogućila je da se, nakon što su strukturalizam i semiotika proširili pojam teksta „na takve sveobuhvatne fenomene kao što su „kultura“, „,jezik“, ,ideologija“42, na popisu mogućih tema nađu i dotada marginalizirana ostvarenja glazbene prakse promatrana iz različitih kutova povijesti odozdo, mikropovijesti, strukturalizma, hermeneutike, semiotike glazbe, feminističke i postfeminističke teorije, psihologije glazbe, povijesti recepcije i mnogih drugih, te da se muzikolozi pozabave glazbenim djelom kao tekstom, ali i da kritički promisle lingvističke, historiografske i filozofske probleme u diskursu o glazbi. Spomenuta je praksa omogućila i da ,predmet više [ne bude] neka supstancijalna stvarnost, nego svojevrsno križište kodova i odnosa“, odnosno da objektom postaje „ono što mi interpretiramo u svojstvu objekta“443. Tako je predmetom muzikoloških istraživanja postao i sam muzikološki diskurs u svim svojim inačicama (teorijsko-analitičkim, interpretacijskim, historiografskim), shvaćen između ostaloga i kao jezik koji se „mora razumjeti ne samo kao sredstvo informiranja, čak niti kao pitanje stila, već prije svega kao društvena aktivnost, kao sila koja spaja ili razdvaja pojedince, koja stvara mogućnosti za identifikacije i koja prenosi vrijednosti i ideale, fantaziju i želju“444.

Premda se muzikologija uspostavila kao humanistička disciplina koja kudikamo šire zahvaća u fenomen glazbe i glazbenoga od glazbene teorije te potonju koristi kao jedan od alata za

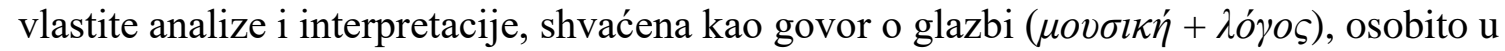
razdoblju do 19. stoljeća u kojem su i muzikologija i teorija imale prostrano i šaroliko polje proučavanja, posve je legitimno pojam teorija glazbe koristiti kao nadpojam golemom

\footnotetext{
${ }^{42}$ Užarević, Josip. 1995. Znanost o književnosti i teorija interpretacije. // Trag i razlika. Čitanja suvremene književne teorije / uredili Nenad Ivić, Vladimir Biti i Josip Užarević. Zagreb: Naklada MD / HUGHZ. Str. 13. ${ }^{43}$ Ibid., str. 13-14.

${ }^{44}$ Korsyn, Kevin. Decentering music. Oxford: Oxford University Press, 2005. Str. 34.: ,[language] must be understood not merely as a vehicle for information, nor even as matter of style, but primarily as a social activity, as a force that joins individuals or divides them, that creates possibilities for identifications, and transmits values and ideals, fantasy and desire.“
} 
fundusu raznovrsnih i raznolikih tekstova o glazbi nastalih u razdoblju prije no što je oblikovana znanost o glazbi - Musikwissenschaft.

Uz to, valja napomenuti da je muzika pojam koji u hrvatskom, kao i u mnogim drugim jezicima, nasljeduje latinski pojam musica i sve ono što je on tijekom povijesti obuhvaćao, te da je u standardnim rječnicima suvremenog hrvatskog jezika identificiran kao sinonim za

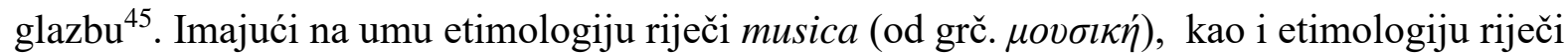

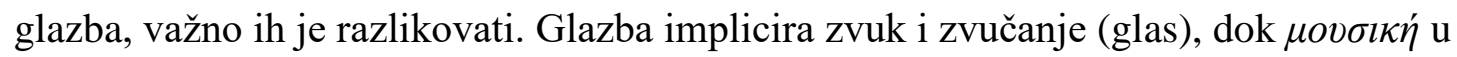
izvornom značenju implicira sinkretički umjetnički doživljaj u kojem su deklamacija kao pjevani govor i pokret podjednako važni kao i instrumentalna pratnja ${ }^{46}$. Musica, kao latinska inačica grčke riječi, uz neosporni zvučeći aspekt koji proizlazi iz matematičkih i fizikalnih zakona, najprije pretpostavlja spekulativnu matematičku disciplinu kvadrivija. Zbog spomenutih nemalih razlika važno ih je pažljivo upotrebljavati i ne nužno tretirati kao sinonime.

U kontekstu povijesti teorije glazbe, čime se ova disertacija u ograničenom tematskom i vremenskom okviru bavi, teorijom glazbe legitimno je nazivati svaki tekst (ili njegov dio) koji se odnosi na musica theorica u smislu matematičke znanosti kvadrivija, ali i svaki koji propisuje, propitkuje ili opravdava praksu, odnosno procese kojima je posljedica zvuk i zvučanje. Glazba, glazbino i glazbeno značenjski pokrivaju polje zvukovnoga i zvučnoga, svih teorijskih, poetičkih i estetičkih premisa koje im prethode te zaključaka koji se na njima temelje. Riječ muzika čini se primjerenijom pri prevođenju i tumačenju teksta koji se odnosi na predmodernu filozofiju glazbe, odnosno na mišljenje koje muziku smatra dijelom prirodnih znanosti - filozofije prirode i tretira je kao dio promišljanja odnosa transcendentalnog i fizičkog. Zanimljivost hibridnih diskursa o muzici/glazbi proizlazi upravo iz činjenice da o njoj govore i tumače je iz obje perspektive, a odlika je mnogih kasnosrednjovjekovnih i ranonovovjekovnih tekstova, kao i izvora analiziranih u ovome radu. Teorija glazbe koja se danas prije svega odnosi na normativne propise zapisivanja, čitanja, interpretiranja i skladanja

\footnotetext{
${ }^{45}$ Hrvatski jezični portal donosi sljedeću definiciju riječi muzika: „umjetnost izražavanja tonovima, glasovima i šumovima (atonalna muzika; dodekafonska muzika; filmska muzika; tonalna muzika); glazba“ dostupno na: http://hjp.znanje.hr/index.php?show=search, pristup 06.08.2019. Etimologiju pojma vezuje uz grčki izvorni oblik mousikē tekhne i temeljno značenje ,umijeće muza“, usp. ibid. Isti izvor pojam glazba opisuje identičnom definicijom, a kao sinonim navodi riječ muzika. Umijeće Muza ne može se, dakako, u cijelosti izjednačiti s umjetnošću izražavanja tonovima, glasovima i šumovima, budući da ono obuhvaća sinkretičku umjetnost koja je uz glazbu (pjevanu i sviranu) obuhvaćala i pjesništvo (lirsko i epsko) te ples. Istu definiciju nudi i Anić upućujući na latinski, odnosno grčki izvor. Usp. Anić, Vladimir. Veliki rječnik hrvatskoga jezika. Zagreb: Novi liber, 2003.

${ }^{46} \mathrm{O}$ muzici u antičkoj Grčkoj i svemu što je podrazumijevala kao sveprisutna umjetnička praksa usp. Barbarić, Damir (2012). Mousike i ethos u Grka. // Treći program Hrvatskoga radija 80. str. 135-143.
} 
glazbe, poslužit će kao krovni pojam za sve tekstove koji se bave promišljanjem glazbe njezine filozofije, povijesti, etike, estetike i teorije u užem smislu u razdoblju do 19. stoljeća (notacije, ljestvičnih sustava, trajanja, ritmike, itd.). ${ }^{47}$

Shvaćena kao diskurzivna formacija koja diskurs oblikuje kao „znanje“, teorija glazbe postala je zanimljivom istraživačima te je, pošto se uvažilo činjenicu da se ,vrlo divergentni koncepti glazbene teorije mogu često naći isprepleteni jedan s drugima u istoj povijesnoj kulturi, unutar opusa jednog autora, a ponekad čak i unutar istoga djela“"48, postala predmetom proučavanja i u svojim povijesno manje atraktivnim ostvarenjima o čemu svjedoči osnivanje subspecijaliziranih društava poput Američkog društva za glazbenu teoriju (American Society for Music Theory) ili golemi izdavački poduhvat Državnog instituta za glazbeno istraživanje iz Berlina koji je u petnaest tomova objavio Povijest teorije glazbe ${ }^{49}$ kao i sve veći broj istraživačkih projekata usmjerenih na povijest teorije glazbe.

Upravo svojoj gusto i od najrazličitijih autora ispisanoj povijesti, teorija glazbe duguje nemoć pred uobličavanjem vlastite definicije, a onda i vlastite (pri)povijesti. Već je Carl Dahlhaus upozorio na nemogućnost pisanja povijesti teorije glazbe kao discipline čiji se predmet istraživanja stubokom mijenjao tijekom vremena ${ }^{50}$, a Thomas Christensen koji je na Cambridgeu istoj toj teoriji pokušao pristupiti iz mnogih očišta, uvodnim tekstom u velikom zborniku što ga jedinstvenim čini upravo pluralnost pristupa, priznaje golemi opseg teškoća koje nosi ideja pisanja jedne jedinstvene povijesti teorije glazbe bilo kao epistemologije, bilo kao normativne upute za skladanje, bilo kao analitičkog alata u hermeneutici glazbe.

Osim kao teorijom glazbe u užem smislu riječi, dakle kao skupom normativnih pravila, ovo će se istraživanje baviti načinom na koji je glazba kao praksa, ograničena izvorima na gregorijansko pjevanje i duhovnu vokalnu monodiju, transformirana u diskurs. Naime,

\footnotetext{
${ }^{47}$ Ovdje smo kratko ukazali na terminološki problem odnosa - preklapanja i razlikovanja značenjskog polja riječi muzika i glazba, dok se teorijom glazbe iz povijesne perspektive kao mrežom iznimno raznorodnih tekstova bavi Šesto poglavlje koje promišlja sadržajna polja musica theorica i musica practica i njihov suodnos u kontekstu analiziranih priručnika.

48 "Widely diverging conceptions of music theory can often be found jostling with one another in the same historical culture, within the oeuvre of the same writer, and occasionally even in the same publication." Christensen, Thomas. Music Theory in Clio's Mirror. // Music in the Mirror: Reflections on the History of Music Theory and Literature for the Twenty-First Century / uredili Andreas Giger i Thomas J. Mathiesen. Lincoln \& London: University of Nebraska Press, 2002. Str. 1.

${ }^{49}$ Usp. Geschichte der Musiktheorie / Uredio Frieder Zaminer, 15 sv. Darmstadt: Wissenschaftliche Buchgesellschaft, 1990. Osim toga i Riemann, Hugo. Geschichte der Musiktheorie im 9.-19. Jahrhundert. Hildesheim - Zurich - New York: Georg Olms Verlag, 1990.

${ }^{50}$ Usp. Dahlhaus, Carl. Was heisst „Geschichte der Musiktheorie?“. // Ideen zu einer Geschichte der Musiktheorie GMth 1 / uredio Frieder Zaminer. Darmstadt: WBG, 1985. Str. 8 - 39.
} 
usprkos činjenici da su glazbena djela događaji u vremenu koji sami za sebe tijekom vlastitoga odvijanja ne zahtijevaju prevođenje u jezik da bi se realizirali, značenje svih događaja „ovisi o strukturiranju diskurzivnog polja“"51. To diskurzivno polje - mišljenje i govor o glazbi - nudi u analiziranim tekstovima supostavljanje barem dviju ontologija glazbe, odnosno dva različita načina artikuliranja prirode glazbe kao predmeta istraživanja. Pri tome, a to je osobito važno u našem slučaju, valja imati na umu da svako mišljenje o glazbi u temelju predstavlja „pokušaj da se glazbu proglasi i kontrolira kao svoje vlasništvo“52.

Ontologije koje prožimaju teorijski i historiografski diskurs o glazbi sve do pred kraj 18. stoljeća jesu platonizmom nadahnuta ontologija koja pita: „Postoji li glazba bez obzira na postojanje ili nepostojanje intervencije ljudskog djelovanja kako bi je se postvarilo?“53 te promišljanje glazbe kao znanosti. Štoviše, ,izjave o sposobnosti glazbe da bude znanost - da osigura način spoznaje - često predstavljaju najranije tragove glazbene ontologije. ... Važno je da glazba predstavlja sredstvo koje nam pomaže spoznati." ${ }^{\text {54 }}$ Ono što nam pomaže spoznati razlikuje se, dakako, od kulturnog konteksta u koji je to znanje uronjeno, od episteme (da se poslužimo Foucaultovim terminom) u kojoj nastaje i djeluje.

Pitanja koja se tekstovima kao strukturiranim diskurzivnim poljima, odnosno kao verbalnim manifestacijama postojeće glazbene prakse postavljaju u ovome radu jesu:

- Koji su načini oblikovanja diskursa prisutni u tekstovima hrvatskih pisaca?

- Na kojim filozofskim i glazbenoteorijskim izvorima crpe domaći autori? Čije tekstove poznaju, interpretiraju i interpoliraju u vlastiti?

- Koje se epistemologije dodiruju, isprepliću ili izmjenjuju u teorijama glazbe 18. stoljeća u Hrvatskoj?

- Kakav jezik i koju terminologiju koriste tekstovi koji o njemu govore?

- Kakvo znanje o glazbi nude te kako se ponuđeno znanje oblikuje?

- Kakvu etiku i estetiku podrazumijevaju?

\footnotetext{
${ }^{51}$ Laclau, Ernesto; Mouffe, Chantal. Hegemony and Socijalist Strategy: Towards a Radical Democratic Politics. London: Verso, 1985. Str. 108. (prema Korsyn, Kevin. Decentering Music: a Critique of Contemporary Musical Research. Oxford: Oxford University Press, 2003. Str. 8.)

${ }^{52}$ Bohlman, Philip V. Ontologies of Music. // Rethinking Music / uredili Nicholas Cook i Mark Everist. Oxford: Oxford University Press, $2010 .^{3}$ Str. 17.: ,an attempt to claim and control music as one's own.“

${ }^{53}$ Ibid., str. 22.: „Does music exist anyway, with or without the intervention of human actions to bring about its reification?"

${ }^{54}$ Ibid., str. 24.: "Pronouncements about music's capacity to be a science - to provide a way of knowing - are often the earliest traces of music's ontologies. ... What is important is that music is a vehicle to help us know."
} 
- Predstavljaju li istraživani izvori uistinu anakronizam i „,nužno zlo“ kakvima ih predstavljaju postojeće nacionalne povijesti glazbe ili je slične tekstove i uz njih vezane prakse moguće pronaći i u drugim, razvijenijim sredinama? Drugim riječima, radi li se doista samo o rezultatu ,periferije“ koja nema snage za dosege „,središta“ ili o praksi koja opstaje široko rasprostranjena kao jedan od mnogih oblika baroknog muziciranja?

- Je li se teorija, etika i estetika glazbe kakve se promoviraju doista zrcale u praksi ili predstavljaju pokušaj obuzdavanja prakse koja je izmaknula (crkvenoj?) kontroli?

\section{Metodologija/korišteni znanstveni koncepti}

Smatramo da su navedena pitanja nužna ukoliko želimo, kao što je prema Habermasu htio Foucault, ,prekinuti s globalnim pisanjem povijesti“655 (pa makar u skromnom tematskom, vremenskom i geografskom opsegu kojim se bavi ovaj rad) te ako smatramo da se ,povijest u jednini mora (se) rastvoriti, doduše ne u mnogostrukost narativnih povijesti, ali u pluralizam diskurzivnih otoka koji bez pravila izranjaju i opet tonu““56.

Fokus je, dakle, uglavnom na znanju i to na znanju kao diskursu. Diskursu se zatim pristupa na dva načina: formalno kao tekstu te empirijski kao društvenoj vezi (lien social), pojmu što ga u svojim radovima uvode Marcel Mauss, Émile Durkheim i Lévi-Strauss „koji društvenu vezu definiraju kao 'svijet simboličkih odnosa koji nadilaze individuu'“657. Pritom je svijet simboličkih odnosa u našem slučaju svijet u kojem se odnosi definiraju na dva temeljna načina koja rastvaraju ideju znanja utemeljenu na devetnaestostoljetnim postavkama pozitivnoga uma. Prvi je način sličnost na temelju dviju figura koje spominje Foucault, a to su analogija kojom ,se sve figure svijeta mogu međusobno približiti“58 i simpatija koja ,potiče kretanje stvari u svijetu i izaziva približavanje najudaljenijih stvari“c59. Drugi je način specifičan za razdoblje 17. i 18. stoljeća (u glazbi za razdoblje baroka i pretklasicizma), a ostvaruje se kroz formiranje velikih sustava i poredaka znanja te se vjerojatno najjasnije

\footnotetext{
${ }^{55}$ Habermas, Jürgen. Filozofski diskurs moderne. Dvanaest predavanja. Zagreb: Globus, 1988. Str. 238.

56 Ibid.

${ }^{57}$ Le Bihan, Anne. Discours et lien social. URL: http://www.champlacanienfrance.net/IMG/pdf/Le_Bihan.pdf (05.06.2013.). Str. 56.

${ }^{58}$ Foucault, Michel. Op. cit. Str. 40.

${ }^{59}$ Ibid. Str. 42.
} 
očituje u posezanju za sistematskim raspoređivanjem građe u tablicama - čega nisu lišeni niti naši izvori - te sklapanju rječnika i enciklopedija.

Preuzimanje Foucaultovih pozicija u periodizaciji, odnosno priklanjanje teoriji epistema nauštrb klasične historiografske razdiobe, upućuje i na mogućnost definiranja diskursa kao sustava znanja koje konstruira, pa onda i čini realnim predmete znanja koje zatim i predstavlja. Upravo je stoga moguće, zbog međusobnog odvajanja pojedinih epistema i razbijanja lažno postavljene prezentacije znanja kao kumulativne cjeline, ukazivanjem na diskontinuitete u povijesti ideja doći do zaključka da disperziranost prezentacija znanja rezultira time da korpusi znanja u modernom dobu postaju znanostima ${ }^{60}$ iz čijih diskursa kao „svijeta simboličkih odnosa“ zatim promatramo i predznanstveno ili kvazi znanstveno znanje.

Naime, već pri letimičnoj analizi tekstova kojima će se disertacija baviti, vidljivo je opiranje većini uvriježenih historiografskih, glazbenoteorijskih i estetičkih osobina koje se pridaju razdoblju u kojem su tekstovi nastali - visokom baroku. Postupno stjecanje primata instrumentalne glazbe, skladanje prema uzusima Affektenlehre, teatralnost, monumentalnost vokalno - instrumentalnih djela, virtuoznost kao glavna odlika solističkih dionica bilo vokalnih bilo instrumentalnih ili programnost u glazbi (tzv. glazbeno slikanje) ne nalazimo niti u jednome od njih, što je razumljivo ako neprestano imamo na umu njihovu funkciju. Propedeutika gregorijanike s nakanom snažnijeg uključivanja vjernika i popunjavanja praznina na korovima na kojima je kronično nedostajalo iole školovanih pjevača gotovo da i nema dodirnih točaka s gore spomenutim idealima barokne glazbe. No, nelagodu koju stvara svaki opus koji iskače iz kolosijeka pravocrtne povijesti koja se temelji na relativno ujednačenom smjenjivanju stilski homogenih razdoblja, moguće je pretvoriti u ugodu istraživanja ukoliko razmišljamo o razdobljima kao multiplicitetima: ,[...] Dok god ustrajemo na suprotstavljanju povijesti i strukture, ustrajemo u uvjerenju da subjekti mogu sakupljati, izgrađivati i ujedinjavati materiju. Ali ovo više nije istina ako razmišljamo o 'epohama' ili

\footnotetext{
${ }^{60}$ Skokoviti prikaz povijesti razvoja ideja Foucault određuje konceptom epistemološkog reza koji „uvodi Gaston Bachelard i opisuje skok od predznanstvenog svijeta ideja prema znanstvenom svijetu; ovaj skok uključuje radikalni prekid s čitavim obrascem i referentnim okvirom predznanstvenih (ideoloških) pojmova, i konstrukciju novog obrasca (problematike)“., u: Althusser, Louis; Balibar, Etienne. Kako čitati Kapital. Zagreb: Centar za kulturnu djelatnost SSO, 1975. Str. 347.
} 
povijesnim formacijama kao multiplicitetima. Oni izmiču vladavini subjekta kao i carstvu strukture. “61

Razdoblje baroka u povijesti glazbe koje se proteže od početka 17. pa sve do sredine 18 . stoljeća obuhvaća djela čija stilska heterogenost nedvojbeno ukazuje na poteškoće pri upotrebi jednog krovnog pojma za cijeli spomenuti period ${ }^{62}$. Barok donosi preokret i u filozofiji glazbe s obzirom da se ona i teorijski počinje promišljati kao umjetnost za sebe, lišena nužnosti društvene funkcije u najširem smislu, osobito unutar stila nazvanog seconda prattica i njemu usporednog razvoja instrumentalne glazbe. I dok je renesansa revitalizirala starogrčku teoriju glazbe pa tijekom 16. i 17. stoljeća u Italiji svjedočimo pravoj „maniji za glazbenom teorijom “63 koja je rezultirala brojnim traktatima koji problematiziraju kako musica theorica, tako i musica practica, krajem 17. stoljeća glazbena je teorija svedena prije svega na uputu za praksu: „S jedne strane, postupno je silazila sa svojih boetijskih visina putem snažnog rasta musica practica kao discipline. ... S druge strane, za mnoge s vremenom prihvaćene probleme s kojima se teorija glazbe povijesno identificirala, kao što je mjerenje i vrednovanje konsonance, sada su postale nadležne discipline u okviru prirodnih znanosti... 'Glazbenu teoriju' prema modelu tradicionalnih kanona nastavila je njegovati nekolicina znanstvenika tijekom prosvjetiteljstva. No, u većini, bilo koja rasprava koja je u naslovu koristila sintagmu „teorija glazbe“ predstavljala je ograničenu i prilično osiromašenu sliku nekad plemenite discipline $[\ldots]^{\text {"64 }} \mathrm{U}$ tom smislu, makar izrijekom ne spominju riječ theoria kao uostalom ni većina traktata koje danas svrstavamo u grupu glazbenoteorijskih djela, tekstovi kojima će se disertacija baviti odgovaraju tom konglomeratu najrazličitijih ideja pod nazivom glazbena teorija kakvim ga opisuje i Thomas Christensen u uvodu knjizi The Cambridge History of Western Music Theory.

U sjevernoj Hrvatskoj krajem 17. i u prvoj polovici 18. stoljeća u tekstovima o glazbi moguće je uočiti pretapanje obilježja koje Foucault u djelu Riječi $i$ stvari. Arheologija znanja pridaje epistemama renesanse i klasicizma, a koje proizlazi iz činjenice da je u nas u spomenutom

\footnotetext{
${ }^{61}$ Deleuze, Gilles. Foucault. Minneapolis, London: The University of Minnesota Press, 1988. Str. 14.

${ }^{62}$ Kritički pregled upotrebe termina barok u povijesti glazbe nude npr. Wellek René. Concepts of Criticism. New Haven, Conn.: Yale University Press, 1963. zatim Palisca, Claude V.. Baroque as a Music-Critical Term, // French Musical Thought 1600-1800 / uredile Georgia Cowart i Ann Arbor. Michigan: UMI Research Press, 1989. Str. 7-21.

${ }^{63}$ Citat Knuda Jeppesena u: Palisca, Claude V.. Humanism in Italian Renaissance Musical Thought. New Haven \& London: Yale University Press, 1985. Str. 8.

${ }^{64}$ Christensen, Thomas. Introduction. // The Cambridge History of Western Music Theory / uredio Thomas Christensen. Cambridge: Cambridge University Press, 2002. Str. 8.
} 
razdoblju skolastički tip obrazovanja još uvijek dominantan, unatoč nastojanjima oko reforme školstva koje provodi Bečki dvor. To je pretapanje stvorilo hibridne tvorevine koje se, oslanjajući se i dalje na božansko porijeklo glazbe, kolebaju između estetike koja je u cijelosti podređena etici kršćanstva i estetike utemeljene na retorici. Glazba je, čak i u svojim „suvremenim“ ili „baroknim“ inačicama, sve do druge polovice 18. stoljeća funkcionirala ponajviše kao pokazatelj političke i moralne moći crkve kao dominantne društvene institucije u zemlji, suzivši tako vlastito polje djelovanja u odnosu na tripartitnu ideju Boetijevog pojma musica (musica mundana kao glazba sfera te njoj inferiorne musica humana i musica instrumentalis), na koju se u teorijskom diskursu još uvijek obilno naslanjala.

Osim toga, jednostavni liturgijski glazbeni oblici nudili su se kao relativno lako dostupan način borbe protiv reformacijskih pokreta, odnosno borbe za snažniji utjecaj katolicizma u društvu. Takozvana druga protureformacija ${ }^{65}$, koju katolička historiografija radije naziva katoličkom obnovom, koristila se glazbenim sredstvima svojih suparnika u reformiranim crkvama: kontrafakturom i četveroglasnom harmonizacijom korala uz pranju orgulja na način na koji je to radio protestantizam. Vidljivo je to u četveroglasnoj skladbi Te Deum pridodanoj Šilobodovom priručniku o gregorijanskome pjevanju (sic!), a osobito u trima izdanjima zbornika Cithara Octochorda koji predstavljaju sintezu gregorijanskoga naslijeđa s onim narodnim. Praksa višeglasja, premda očigledno prisutna u liturgijskome pjevanju, nije spomenuta niti na jednome mjestu u priručnicima Kovačevića i Šiloboda Bolšića, dok je postupak kontrafakture iskazan uputom iznad svake pojedine tako oblikovane popijevke u zborniku CO.

Sukladno prethodno formuliranim pitanjima, nastojat ćemo pojasniti fenomen opstanka gregorijanskoga pjevanja u prvoj polovici 18. stoljeća u kontekstu katoličke obnove, korala koji se izvodio u raznim oblicima usporedno uz druge glazbene prakse, od kojih su mnoge nastale upravo pod njegovim izravnim utjecajem ili pak njegovom modifikacijom. Glavni interes ovoga rada jest analiza diskursa o gregorijanskom pjevanju u obliku glazbenoteorijskih priručnika i uvodnika glazbenim zbornicima u spomenutom razdoblju i njegove glazbene,

\footnotetext{
${ }^{65}$ usp. Kriegseisen, Wojciech. Between State and Church. Confessional Relations from Reformatio to Enlightenment: Poland-Lithuania-Germany-Netherlands. Frankfurt: New York: Peter Lang, 2016. Str. 534-535. Kriegseisen razdoblje od 1648. do 1768. naziva drugom protureformacijom u kontekstu jačanja utjecaja Katoličke crkve i sve snažnijih veza svjetovne i crkvene vlasti što je rezultiralo i intenzivnijom promocijom katolicizma, odnosno ograničavanjem prava ostalih konfesija. Usporedba s Habsburškom monarhijom moguća je, izgleda, na razini implementiranja katolicizma i njegovih postulata kao idejnoga temelja školstva u jednoj i u drugoj zemlji.
} 
epistemološke i socijalne uvjetovanosti i implikacije. Nastojanjem iznalaženja odgovora na ranije postavljena pitanja, taj će se govor o glazbi analizirati kao:

1. „anakronizam“ baroknoga razdoblja u svjetlu opće povijesne i kulturne situacije u sjevernim hrvatskim zemljama od kraja 17. do u drugu polovicu 18. stoljeća te u kontekstu dosadašnjih domaćih muzikoloških studija kao i međunarodnih glazbenih historiografija, kako bi se uvidom u postojanje velikog broja sličnih izvora i u drugim europskim zemljama, ukazalo na isključivanje koje pozitivistička muzikologija podrazumijeva u slučajevima koji ne odgovaraju ideji linearnoga razvoja. Ujedno će se time ukazati i na aktualnost naših izvora u kontekstu identičnih glazbenoliturgijskih praksi diljem Europe (Prvo poglavlje: Povijesno i zemljopisno situiranje i Drugo poglavlje: Izvori i stanje istraživanja).

2. govor koji oblikuje glazbu kao predmet znanja i svijet simboličkih odnosa unutar glazbenog; govor koji povezuje, pa makar labavo, nekada razdvojena diskurzivna područja musica theorica i musica practica s naglaskom na promjeni fokusa (i razlozima i oblicima te promjene) teorijskih tekstova, od onih kojima dominira filozofsko ontološka problematika muzike do praksom i pedagogijom motiviranih priručnika. Pritom će se raspraviti praksa kompilacije i interpoliranja tekstova u vremenskom rasponu od antike do baroka kao jezična praksa predmodernog doba par excellence, neprispodobiva s postmodernističkom teorijom intertekstualnosti koja se referira prije svega na umjetnost književnosti, naročito romana (Treće poglavlje: Diksurs I. Compilatio);

3. nositelj obilježjâ srednjovjekovne i renesanse, pretklasične episteme na način na koji je definira Michel Foucault, osobito pak u odnosu na prikaz znanja kao ulančavanja sličnosti te znanja i diskursa o njemu kao isprepletanju raznih vrsta usporedbe, fenomena koji se iščitavaju u muzičkoteorijskim tekstovima na razini muzičkog etosa (Četvrto poglavlje: Diskurs II. Regulatio i Peto poglavlje: Diskurs III. Similitudo, usporedbi na temelju sličnosti kao osnovnom modusu obrazloženja glazbe kao istovremeno fizičkog i metafizičkog fenomena).

4. sredstvo i razlog opstanka kasnosrednjovjekovnih teorijskih i terminoloških temelja muzike u vremenu u kojem nastaje sve dublji rez u duboko i čvrsto ukorijenjenom poimanju sadržaja teorije muzike. Pritom se misli prije svega na međuodnos musica theorica koja se oblikovala kao filozofija muzike i zauzela svoje mjesto $\mathrm{u}$ 
matematičkim vještinama kvadrivija i musica practica koja se oblikovala kao teorijska uputa za izvođenje (i skladanje) glazbe. Diskurs o gregorijanskome pjevanju ukazuje na postupno odumiranje ontološki i matematički-fizikalno utemeljene teorije koja prepušta mjesto teoriji za praksu. Musica practica je, od 17. stoljeća nadalje, od složene mješavine starogrčkih, srednjovjekovnih i renesansnih postavki namijenjenih prije svega podučavanju jednoglasnoga gregorijanskog pjevanja i vokalne polifonije, postupno usmjerila svoj interes prema emancipaciji disonance u smislu u kojem je određuju pravila vertikalnog podupiranja glavne melodije, dakle suvremeno shvaćenoj harmoniji, postupnom potiskivanju crkvenih modusa u korist dur i mol tonaliteta, emancipaciji glazbe od teksta i konačno defunkcionalizaciji glazbenih vrsta. Razlika između predmodernog i modernog shvaćanja muzike/glazbe jasno je podvučena korištenjem termina muzika umjesto glazba svaki puta kada se raspravlja o predmodernim tekstovima (odnosno njihovim dijelovima) koji se bave muzikom kao matematičkom i fizikalnom disciplinom te sredstvom etičkoga odgoja. Pojam glazba koristi se u svim ostalim slučajevima, kao standardnom hrvatskom jeziku primjeren prijevod latinskog pojma musica u značenju koje stječe afirmacijom moderne estetike od kraja 18. stoljeća (Četvrto poglavlje te Šesto poglavlje: musica theorica i musica practica).

5. legitimni nositelj etičkih i iz njih proizašlih estetičkih premisa (antičke) teorije etosa prilagođene kršćanskoj ideologiji te kao takav uspostavljen kao regulacijski mehanizam napora uljuđivanja i edukativne prakse posttridentske Crkve. Gregorijansko pjevanje i njegova neprestana reafirmacija pritom se pokazuje kao kulturni, društveni i politički fenomen koji se shvaća kao sredstvo produžene protureformacije, ali i prosvjetiteljskih elemenata obrazovnih nastojanja Habsburške monarhije te važan element u procesu reintegriranja katoličke crkve razdirane reformatorskim pokretima (Šesto poglavlje, potpoglavlje o estetici kao etici).

Uza sve spomenuto, glazbenoteorijski traktati o cantus gregorianus nose u sebi rudimente glazbenoteorijske historiografije, ali ne i povijesti glazbe kao razvoja skladateljskih oblika! Jedina historijska tema koju dotiču jest ona koja se vezuje uz postanak glazbe, protumačen antropološki i teološki. Korištenjem raznih izvora, od Boetija preko Guida iz Arezza pa sve do suvremenog Johanna Baptista Sambera, implicitno prikazuju historijski razvoj teorije glazbe redovito upućujući na objasnidbene sheme koje su se nasljeđivale i mijenjale usprkos ahistorijski zamišljenom opstanku muzičkoga pamćenja. Historiografske prakse koje su 
gregorijansko pjevanje i uz njega vezane muzičkoteorijske traktate nastale nakon zamaha vokalne polifonije sustavno ignorirale, upravo zbog gregorijanskom pjevanju inherentne (premda lažne) ahistoričnosti, znatno su doprinijele ideji razdoblja dekadencije koja se i danas vrlo često prenosi kad se govori i piše o gregorijanskome pjevanju od 16. stoljeća pa do njegove restauracije u 19. stoljeću. Njegova dekadentnost koja se za historičare gregorijanike očituje u priklanjanju estetici renesansne deklamatorike i kasnije ranobarokne melodije, ne čini ga, međutim, manje vrijednom i važnom glazbenom praksom u u to doba. Gregorijansko pjevanje (cantus planus, cantus gregorianus, cantus firmus) je u 17. i 18. stoljeću, kao što ćemo pokazati upućujući na množinu posvećenih mu tekstova i priručnika, ključna forma liturgijske glazbe i kao takav iznimno sredstvo evangelizacije te važan alat u pastoralu. Glazba kao praksa utemeljena u metafizičkom promišljanju muzike kao kvadrivijske discipline posjeduje i snažnu soteriološku funkciju objašnjenu još u sv. Augustina.

Posebnost i ograničenost glazbenoteorijskog govora koji isključuje fenomene kao što su polifonija, vertikalni slog i glazbeni oblik (glazba kao djelo!), u razdoblju u kojem buja praksa utemeljena na upravo spomenutim fenomenima, uskraćuju ovakvim izvorima mjesto u nizu značajnih postignuća u povijesti glazbe. Ovaj je rad, uvjetovan sadržajem analiziranih izvora, usredotočen na samo jedan aspekt muzičkog života, onaj koji se smatra manje vrijednim te je u dosadašnjim muzikološkim istraživanjima interpretiran kao nevelik ${ }^{66}$, „,prividno zatišje“667,

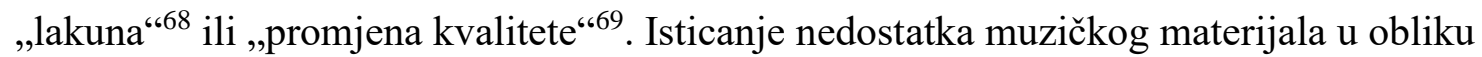
glazbenih djela, ali i sekundarnih dokaza o kontinuiranom izvođenju ili skladanju glazbe prešutno implicira glazbu isključivo kao umjetnička djela skladatelja koja žanrom, skladateljskim tehnikama i estetičkim postulatima komplementiraju s umjetničkim tendencijama prisutnima u kudikamo većim i razvijenijim glazbenim središtima. Stoga tek druga polovica 18. stoljeća u sjevernoj Hrvatskoj zavređuje pomniju pažnju hrvatske muzikologije. Slijedom toga, Varaždinski skladateljski krug ${ }^{70}$, ali i glazbenici koji su samo porijeklom, no ne i djelovanjem vezani uz Hrvatsku, čine temelj za historiografski opis

\footnotetext{
${ }^{66}$ Josip Andreis tako piše da ,[D]oprinos sjeverne Hrvatske u XVIII. stoljeću nije velik. Osim nekoliko teoretskih radova i zbornika crkvenih pjesama i napjeva, moći ćemo spomenuti svega nekoliko imena." Usp. Andreis, Josip. Povijest glazbe. Povijest hrvatske glazbe, knj. 4. Zagreb: Liber Mladost. 1974. Str. 158. ${ }^{67}$ Usp. Stipčević, Ennio. Op. cit. 1997.

${ }^{68}$ Usp. Tuksar, Stanislav. Kratka povijest hrvatske glazbe. Zagreb: MH, 2000.

${ }^{69}$ Usp. Stipčević, Ennio. Glazbeni barok u Hrvatskoj, uvodna razmatranja. // Glazbeni barok u Hrvatskoj. / uredio Ennio Stipčević. Osor: Osorske glazbene večeri, 1989. Str. 7-19.

${ }^{70}$ Varaždinski skladateljski krug čine trojica skladatelja: Jan Krtitel Vanhal, Ivan Werner i Leopold Ebner. O njihovom je umjetničkom djelovanju opsežniju studiju uz tisak sačuvanih djela objavio Lovro Županović u četvrtom svesku niza „Spomenici hrvatske glazbene prošlosti“ pod naslovom Varaždinski skladateljski krug $s$ kraja XVIII stoljeća, Zagreb: DHS (danas HDS). 1973.
} 
osamnaestostoljetnih postignuća u glazbenom životu. ${ }^{71}$ Iznimka je, donekle, franjevački barok što ga je sustavno istraživao i analizirao Ennio Stipčević ${ }^{72}$ : naime, crkvena glazba monodijskog tipa ili pak jednostavni polifoni oblici skladaju se kontinuirano u krugu muzički obrazovanih klerika. Tim ostvarenjima pripadaju brojni kantuali, pjesmarice, pasionali i ostala duhovna glazba nastala za potrebe liturgijske i paraliturgijske prakse. Riječ je prije svega o franjevačkoj ostavštini, ali i o liturgijskim knjigama zagrebačke katedrale ${ }^{73}$ koje predstavljaju velik, do sada parcijalno istražen korpus duhovne glazbe koji svjedoči o specifičnostima kako franjevačkog baroka, tako i zagrebačkog obreda. Takva se glazba u cijelosti, i teorijski i estetički, jasno može vezati uz glazbenoteorijske postavke ovdje proučavanih tekstova, kao i etička i estetička tumačenja koja ti tekstovi nude. U tom smislu teorija i praksa pokazuju se međusobno komplementarnima. Uvidom u tekstove koji čine jedino glazbenoteorijsko svjedočenje iz tog razdoblja te usporedbom s tekstovima koji im prethode, a koji su bili dostupni našim autorima, razmotrit će se opravdanost ranijih interpretacija i ponuditi analiza glazbenoteorijskog, povijesnog, društvenog i kulturnog okvira kojeg nude kao tekst, odnosno kao (latinskim) jezikom posredovano uobličavanje jednoga dijela muzičke stvarnosti.

\footnotetext{
${ }^{71}$ To je slučaj s nizom skladatelja čije se porijeklo vezuje uz Hrvatsku, no koji su se školovali i djelovali izvan naše zemlje. Opravdanost uvrštavanja njihovih imena i djela u nacionalne glazbene historiografije stoga je u najmanju ruku dubiozna, budući da osim mjestom rođenja i/ili porijeklom ni na koji način nisu oblikovali hrvatski kulturni prostor ili iz njega crpili tijekom odrastanja i školovanja. To su npr. Amando Ivančić, Stjepan Spadina i Ivan Mane Jarnović. Činjenica da su Josip Andreis, Lovro Županović i Ennio Stipčević u svojim sintezama opusu Ivana Jarnovića posvetili više stranica nego tekstovima i zbornicima koji su tema ovog rada, te da je ugledna hrvatska muzikologinja Vjera Katalinić znatan dio svog znanstvenog rada posvetila biografiji i opusu ovog skladatelja, izvrsno ocrtava znanstvene kriterije koji su dominirali (i dominiraju) domaćom muzikološkom historiografskom praksom. O tim kriterijima, kao i o promjeni paradigme u europskoj i američkoj historijskoj muzikologiji raspravljaju mnoga suvremena djela koja se bave teorijom historiografije, od kojih se neka nalaze u popisu literature (npr. Lynn Hunt, Edward Carr, itd.).

${ }^{72}$ Popis najvažnijih tekstova Ennija Stipčevića o franjevačkom baroku nalazi se u bibliografiji.

${ }^{73}$ usp. Stipčević, Ennio. Hrvatska glazba. Povijest hrvatske glazbe do 20. stoljeća. Zagreb: ŠK, pogl. 4.
} 


\section{PRVO POGLAVLJE: POVIJESNO I ZEMLJOPISNO SITUIRANJE}

„Ipak, ako ljudi u ono doba postupno i jesu počeli gledati na habsburške teritorije kao na jedinstvenu državu zvanu Austrija, ta državnost gotovo da i nije imala uporište u institucijskim realnostima. Naviknuti na institucionalnu i administrativnu homogenost današnjih teritorijalnih nacionalnih jedinica, možda bismo mogli doći u iskušenje da i habsburške teritorije sa zemljopisnih karata iz 1700-ih smatramo koherentnom cjelinom. Ta bi pretpostavka bila pogrešna. Karakter i razmjeri vlasti Habsburgovaca bitno su se razlikovali od jednog do drugog mjesta unutar granica njihovih zemalja.“74

Usprkos znatnoj količini objavljenih studija o političkim, gospodarskim, društvenim, kulturnim, religijskim i svim drugim fenomenima koji su ispunili osamnaesto stoljeće diljem zapadne Europe, ono još uvijek predstavlja iznimno dinamično polje istraživanja u humanističkim znanostima. Osamnaesto stoljeće u historiografiji najčešće se prikazuje kao predmoderno doba koje odlučno raskida s društvenom praksom koju determinira religija, a ne znanost. Promjena u prikazu koji osvješćuje perzistentnost srednjovjekovnih društvenih i političkih modela posljedica je svijesti o određenoj razini kulturne homogenosti koja $u$ zapadnoj Europi ne posustaje padom Carigrada niti velikim otkrićima ${ }^{75}$. Naprotiv, ta je homogenost uočljiva sve do pred sam kraj 18. stoljeća, a određuju je još uvijek postojeći feudalni političko-gospodarski sustav te dominacija crkve u području obrazovanja i kulture. Tijekom brojnih istraživanja pokazala se dovoljno snažnom da omogući historiografima koji su se željeli odmaknuti od uvriježene razvojne sheme historijskoga pozitivizma, razumijevanje razdoblja kraja 18. stoljeća svojevrsnim kontinuitetom nazvanim „dugi srednji vijek" ${ }^{\text {“76 }}$. Taj dugi srednji vijek kako ga je zamislio i objasnio Jacques le Goff nesumnjivo predstavlja plodonosnu ideju za proučavanje društvenih odnosa u smislu rastakanja dotrajale feudalne sheme, no podjednako je važan u kontekstu proučavanja kulture i kulturnih praksi:

\footnotetext{
${ }^{74}$ Judson, Pieter M. Povijest Habsburškog carstva. Zagreb: Sandorf, 2018. Str. 33.

${ }^{75}$ Za svijest o mogućnostima drugačijeg razumijevanja i tumačenja 18. stoljeća, izvan granica uhodanih prosvjetiteljskih okvira, prije svega su zaslužni analisti, a za naš slučaj osobito Jacques le Goff kao pripadnik treće generacije ove historiografske škole.

${ }^{76}$ Pojam uvodi Jacques Le Goff u predgovoru zbirci tekstova Jacques Le Goff, Jacques. Un long Moyen Âge. Paris: Pluriel, 2010.
} 
„Ista ovisnost o ruralnoj ekonomiji koja počiva na gladi, ista slabost strojeva, isti život u gradu u kojem buržoazija još nije stekla moć, ista snažna prisutnost Crkve, isti feudalni mentaliteti i još uvijek vrlo jak utjecaj vjerovanja u čuda, iste skolastičke metode $u$ poučavanju na sveučilišu i isti monarhistički rituali produžuju srednji vijek. Dakle, vjerujem u dugi srednji vijek, jer renesansu ne vidim kao raskid. Srednji je vijek više puta svjedočio renesansama: karolinška u 9. stoljeću, osobito ona u 12. te ona u 15. i 16. stoljeću odgovaraju tome modelu. ... Srednji se vijek smjestio unutar spore mutacije koja se odnedavno razborito naziva 'kasnom antikom' radije nego rani srednji vijek (ovaj počinje kasnije, oko 7. i 8. stoljeća), i revolucije na kraju 18. stoljeća, premda, s obzirom da povijest uvijek čuva kontinuitet u određenoj mjeri, njegovi djelići preživljavaju i tijekom 19. stoljeća.“77

Gospodarski, društveni i kulturni uvjeti u kojima su se nalazili mnogi krajevi Europe udaljeni od bogatih gradova, središnjih osi iz kojih su proizlazile silnice svih umjetnosti i umijeća, bili su sve do kraja 18. stoljeća uvelike nalik onima otprije više stotina godina, a siromaštvo stanovništva i posvemašnja slaba obrazovanost širokih slojeva osnaživala je perpetuiranje naslijeđenih obrazaca i otežavala prodiranje novih praksi. U Hrvatskoj su geopolitičku situaciju dodatno otežavali netom završeni višedesetljetni ratovi s Turcima i rascjepkanost teritorija koji je bio pod vladavinom dviju država - Austrougarske monarhije i Venecije (Dubrovnik je, premda samostalan politički entitet koji bira vlastitoga kneza, obnovivši ugovor iz 1358. godine priznavao vrhovnu vlast Ugarske krune, a njegovu je samostalnost 1808. godine dokinuo general Marmont).

Mnoštvo termina kojima se historiografija služi pri pokušaju da iz perspektive ove ili one teme opiše značajke toga doba, možda najizravnije svjedoči teškoćama s kojima se susreće

\footnotetext{
${ }^{77}$ „La même dépendance d'une économie rurale à la merci des famines, la même faiblesse des machines, la même vie urbaine où la bourgeoisie ne parvenait pas à saisir le pouvoir, la même forte présence de l'Église, les mêmes mentalités „féodales" et l'impact toujours fort de la croyance au miracle, les méthodes toujours scolastiques de l'enseignement universitaire, les mêmes rites monarchiques prolongent le Moyen Âge. Je crois donc en un long Moyen Âge, car je ne vois pas la rupture de la Renaissance. Le Moyen Âge a connu plusieurs renaissances, la carolingienne du IXe siècle, celle surtout du XIIe siècle, et celle des XVe - XVIe siècles s'inscrit dans ce modèle. ... Le Moyen Âge se situe entre une lente mutation, qu'on appelle judicieusement depuis quelque temps „Antiquité tardive“ plutot que Haut Moyen Âge (celui-ci commence plus tard, vers le VIIe VIIIe siècle), et une revolution à la fin du XVIIIe siècle, bien que l'histoire conservant toujours une part de continuité, des lambeaux de Moyen Âge survivent pendant le XIXe siècle." u: Le Goff, Jacques. Un long Moyen Âge. Paris: Tallandier Editions/Pluriel, 2010. Str. 13.
} 
svaki proučavatelj 18. stoljeća koji je voljan uhvatiti se ukoštac s problematikom periodizacije. S obzirom na velik broj naziva koji se odnose na političko i društveno uređenje te upućuju na:

- postupno oblikovanje novog i drugačijeg načina društvenog uređenja i svakodnevnice bliže suvremenom poimanju stvarnosti: predmoderno doba (pojam se najčešće odnosi na dugačko razdoblje od otkrića Amerika krajem 15. pa sve do kraja 18. stoljeća)

- novu snagu Katoličke crkve u promicanju vlastitih ideja: katolička obnova

- nastavak borbe Katoličke crkve protiv jačanja utjecaja novih reformacijskih crkvi koje su se širile diljem Europe: druga protureformacija

- uviđanje potrebe za obrazovanjem svih društvenih slojeva: prosvjetiteljstvo

- potrebu da svi podanici, a ne samo tanki sloj povlaštenih, trebaju što bolje služiti idejama koje provodi monarhija: prosvijećeni apsolutizam,

jasno je da jednoznačno imenovanje prostora i vremena o kojem govorimo nije moguće. Potrebno se, dakle, prikloniti onome što je specifično za područje kojim se bavimo (tematski i geografski) te po provedenoj pomnoj analizi vidjeti kojem od nabrojanih stilskih i periodizacijskih koncepata (ili većem broju njih) ga se može pripisati i je li to uopće nužno za njegovo razumijevanje. 


\section{EUROPA U 18. STOLJEĆU}

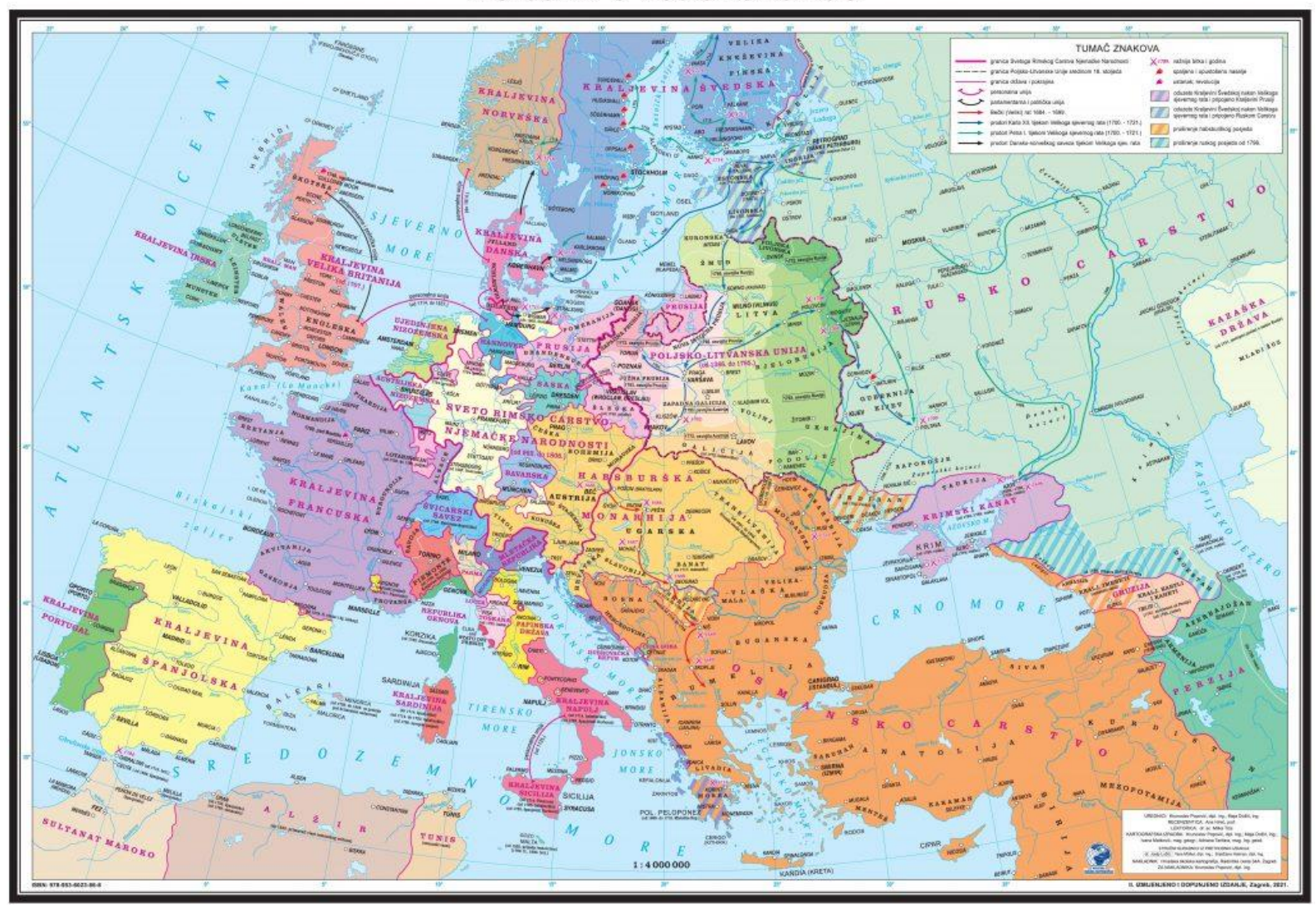

Sl. 1 Karta Europe sredinom 18. stoljeća; Izvor: https://hsk.com.hr/povijesne-karte/zidnekarte/europa-sredinom-18-stoljeca/

\subsection{Habsburška Monarhija u 18. stoljeću}

Pojam Europe u 18. stoljeću jedva da ima veze s današnjim poimanjem Europe u okviru zemljopisnih, političkih, društvenih i kulturnih granica. Europa 18. stoljeća obuhvaćala je iznimno jaku Habsburšku Monarhiju, Sveto Rimsko Carstvo (Njemačku), Francusku te ostale države čiji je ustroj više ili manje bio utemeljen na feudalnom sustavu. Habsburška Monarhija, kojoj je pripadala i Hrvatska, obuhvaćala je posjede koji su se protezali od „današnjeg grada Innsbrucka na zapadu do Lavova na istoku, od Milana i Firence na Apeninskom poluotoku do Antwerpena na Sjevernom moru i Cluja na Karpatima, od Praga u Bohemiji, pa sve do Vukovara i, niže na jugu, Beograda. Habsburgovci su posjedovali teritorije koji se danas nalaze u dvanaest različitih europskih država i na kojima su krajem osamnaestog stoljeća živjeli govornici jezika danas poznatih kao češki, flamanski, francuski, hrvatski, jidiš, ladinski, mađarski, njemački, poljski, rumunjski, slovački, slovenski, srpski, 
talijanski i ukrajinski. Ta se raznolikost protezala i na religijsku praksu. “78 Osim toga, jezična i vjerska raznolikost bila je tipična za sve veće države u Europi u ranom novovjekovlju, prije svega zbog načina stjecanja posjeda. „Europske dinastijske države, ..., nisu počivale na jedinstvenim administrativnim institucijama niti jedinstvenim kulturnim praksama (na primjer upotrebi zajedničkog jezika), a sasvim sigurno ni na ikakvom osjećaju zajedničkog identiteta

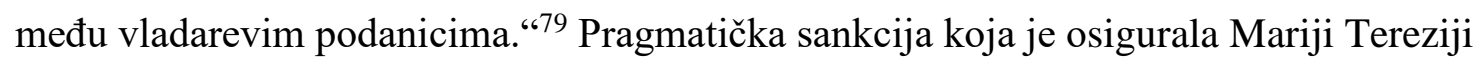
krunidbu, ujedno je omogućila snažne administrativne reforme čiji je cilj bio administrativna i institucionalna homogenizacija brojnih teritorija. Odmah po završetku Rata za austrijsko naslijeđe započeo je niz reformi koje je inicirala carica Marija Terezija, a nastavio se tijekom vladavine cara Josipa II. i cara Leopolda II. „Svi troje imali su temeljne zajedničke dugoročne ciljeve: stabilizirati državne financije oporezivanjem plemstva; podići produktivnost seoskih proizvođača slabljenjem - ili ukidanjem - feudalnih odnosa; potaknuti širenje domaćih industrijskih, trgovinskih, putnih i komunikacijskih mreža; smanjiti regionalna cehovska ograničenja manufakturne proizvodnje; poticati moralno i praktično obrazovanje svojih podanika; i reformirati Katoličku crkvu stavljanjem vjerskih poslova pod državnu kontrolu. “60 Premda je neosporna njihova sklonost prosvjetiteljstvu kao skupu intelektualnih mreža i kulturnih pokreta diljem Europe u kasnom sedamnaestom i u osamnaestom stoljeću, koje su veličale razvoj znanja i poticale njegovu primjenu u društvenim institucijama i političkim strukturama radi unapređivanja životnih prilika, u isto su vrijeme ,religijska i moralna pitanja i dalje ostajala u srži prosvjetiteljskih interesa. ... ipak su i dalje priznavali temeljnu vrijednost religije u društvu. “81 Prosvjetiteljstvo, dakle, suprotno uvriježenim floskulama u brojnim povijesnim priručnicima, ne podrazumijeva isključivanje crkvenoga utjecaja na društvo i potiranje religijskog osjećaja u državnih podanika. Upravo iz snažne povezanosti s (Katoličkom) crkvom, a na temelju ideje općeg širenja temeljnog obrazovanja, proizlazi i revitalizacija tradicionalnih crkvenih vjerskih praksi i njihova prilagodba velikom broju vjernika - ideja na temelju koje su nastali i ovdje proučavani priručnici i zbornici crkvenih popijevki.

Opseg promjena koje su zahvaćale u društvo kao cjelinu tijekom 18. stoljeća, prema sudu povjesničara toliko je velik da se, analizirajući dinamiku i rezultate tih promjena, posljednja njegova desetljeća s pravom mogu označiti kao prijelom koji za sobom ostavlja ono što Le

\footnotetext{
${ }^{78}$ Judson, Pieter M. Op. cit. Str. 33-34.

${ }^{79}$ Ibid.

${ }^{80}$ Ibid. Str. 42.

${ }^{81}$ Ibid. Str. 43.
} 
Goff naziva dugim srednjim vijekom i pritom otvara vrata novim i dotad nezamislivim mogućnostima gospodarskog, političkog i kulturnog razvoja koje će se ostvarivati tijekom 19. stoljeća. Te su se promjene u hrvatskim zemljama značajnije počele provoditi tek od kraja 18. stoljeća. Vrijeme do posljednje trećine 18. stoljeća, vrijeme je velikog općeg siromaštva i niske razine obrazovanja. Popis stanovništva iz 1770. godine što ga je provodila carska vojska, a kako bi se izbjegao utjecaj, odnosno iskrivljavanje informacija lokalnog plemstva ili crkvenih službenika, analizirao je četrnaest različitih tema vezanih uz svakodnevicu „,uključujući zdravlje i higijenu, obrazovanost, vjersku pobožnost, imovinsko stanje i opće raspoloženje javnosti. “82 On nam oslikava stanje kojim se dijelom može obrazložiti i kulturna politika crkve u hrvatskim zemljama tijekom 18. stoljeća. Emancipiranje građana i seljaka za što je nužno bilo obrazovanje, imalo je za cilj reduciranje utjecaja lokalnog plemstva. „Vojno istraživanje provedeno 1770-1777. neprestano je skretalo pozornost na seljačku nepismenost kao važan uzrok siromaštva i socijalne bijede. Krivnja za nepismenost pak pripisivala se lokalnim vlastima koje zanemaruju škole te nedovoljnom broju ili nepodnošljivoj preopterećenosti učitelja. ${ }^{\text {“83 }}$ Obrazovna politika usmjerila se prije svega na osnovno obrazovanje najnižih klasa, dok je više obrazovanje i dalje prepušteno crkvi i crkvenim redovima do njihova ukidanja.

Dakako, većina učitelja i dalje su bili lokalni svećenici, a, kako nas upozorava Judson ,/N/i drugdje u Europi situacija nije bila bitno drukčija, jer su lokalni svećenici bili jedine osobe s makar najpovršnijim obrazovanjem“. ${ }^{84}$ S obzirom na spomenuto, jasno je da se u hrvatskim zemljama nije radilo, niti se moglo raditi o raskošnom baroknom protureformacijskom katolicizmu. Osim u nepostojanju uvjeta za provođenje vizualno i auditivno bogate liturgijske prakse zbog općeg siromaštva, nedostatka ljudstva i, posljedično, izostanka elementarnog instrumentarija za iole pompozniju liturgiju, razloge dominacije jednostavnog pučkog oblika pobožnosti kojem pripada i glazbena praksa prilagođena najširim slojevima, utemeljena kako na gregorijanskom pjevanju tako i na pučkom glazbenom naslijeđu, treba tražiti u vjerskoj praksi katolicizma koji se „tijekom osamnaestog stoljeća proširio i u Ugarskoj i Austriji. Takav katolicizam naglašavao je jednostavne, skromne i pobožne vrline u svakodnevnom životu, a izbjegavao je emocionalna pretjerivanja barokne ritualne prakse. Tijekom vladavine Marije Terezije brojni katolički mislioci, dužnosnici i crkveni redovi podržavali su sve snažnije uplitanje vlasti u crkvenu politiku. Zato je utjecaj Crkve na javno obrazovanje u

\footnotetext{
${ }^{82}$ Ibid. Str. 51.

${ }^{83}$ Ibid. Str. 53.

${ }^{84}$ Ibid. Str. 54.
} 
velikoj mjeri ovisio o stavovima lokalnih svećenika koji su se i sami na nekoj osnovnoj razini mogli zanimati za ovaj ili onaj trend $u$ humanističkim znanostima ili za prosvjetiteljske stavove prema obrazovanju općenito. “65

Trend interveniranja državne uprave u crkveni ustroj te inzistiranje na zaposjedanju brojnih, dotad isključivo crkvenoj ingerenciji podložnih prava, doveo je u drugoj polovici 18. stoljeća do značajnih promjena u odnosima crkvene i državne uprave, koje su se, dakako, odražavale i na obrazovanje. Zrinka Novak u tekstu Crkva i vjerske prilike u zborniku posvećenom hrvatskoj povijesti 18. stoljeća, naziva ga u podnaslovu stoljećem radikalnih reformi. ${ }^{86}$ Uistinu, ukoliko se osvrnemo na političke mjere koje je poduzimala Marija Terezija, a potom i Josip II, Crkva se našla u položaju koji je konačno potvrdio svjetovnu prevlast nad onom crkvenom, barem u Habsburškoj monarhiji. „Vladar je, prema novim odredbama, imao pravo nadzora u Crkvi, sazivanja crkvenih sabora, imenovanja biskupa (koje je potvrđivao papa), pravo smanjivanja broja redovnika kao i reguliranja samostanskih pravila te pravo raspolaganja crkvenom imovinom. U tom je smislu Marija Terezija, ponajprije preustrojem školskoga sustava, ostvarila preduvjet za snažniji državni nadzor nad crkvenim učilištima i zavodima. Isusovci su izgubili prevlast na Bečkom sveučilištu te je otvoren pristup profesorima iz inozemstva, a u uporabu su uvedeni školski priručnici u jansenističkome duhu. Zabranjeno je osnivanje novih samostana i povećanje crkvenoga posjeda, a ograničen je i broj svetkovina i procesija. U svojim pohodima ad limina biskupi su bili podvrgnuti strogom nadzoru, a morali su polagati i zakletvu vjernosti vladaru. Na taj su način svećenici odgajani da postanu odani državni činovnici. “87

\subsection{Dugi srednji vijek, barok ili predmoderno doba? Prosvijećeni apsolutizam ili racionalizam? Katolička obnova ili novovjekovni katolicizam?}

„Pensare la storia e certamente periodizzarla“ (Benedetto Croce)

Mnoštvo odrednica koje se pridjevaju 18. stoljeću prije francuske revolucije kako bi se što bolje opisale dominantna mu obilježja, govori ne samo o namjeri pisca i njegovoj

\footnotetext{
${ }^{85}$ Ibid. Str. 55.

${ }^{86}$ Novak, Zrinka. Crkva i vjerske prilike. // U potrazi za mirom i blagostanjem. Hrvatske zemlje u 18. stoljeću / uredila Lovorka Čoralić. Zagreb: MH, 2013. Str. 169-194.

${ }^{87}$ Ibid. Str. 169-170.
} 
istraživačkoj poziciji, kako smo već upozorili u prvome dijelu teksta, već i o kulturološkoj definiciji znanja, njegovog religijskog ili pozitivnog temelja. U hrvatskoj historiografiji i književnoj povijesti prva polovica 18. stoljeća najčešće se naziva razdobljem protureformacije i katoličke obnove. Još krajem 20. stoljeća uočen je antagonizam pojmova od kojih prvi implicira aktivnu borbu protiv reformacije smatrajući osnivanje isusovačkog reda conditio sine qua non za istu, dok potonji inzistira na unutarinstitucionalnoj reformi crkve potaknutoj Koncilom u Tridentu. Hubert Jedin, ključni njemački crkveni povjesničar koji se uz opću povijest crkve osobito bavio Tridentskim koncilom, posve svjestan različitosti koje u sebi nose pojmovi „katolička reforma“ i ,protureformacija“ te na kulturnoumjetničkom planu suprotstavljeni pojmovi „katolička obnova“ i „,barokni katolicizam“, zbog važnosti koncila u Tridentu predlaže jedinstveni novi naziv ,tridentsko doba“. Koncil u Tridentu u crkvenoj se povijesti smatra ,epohalnim događajem novovjekovlja ili razdjelnicom predmodernog i modernog vremena“ ${ }^{\text {(88 }}$ pa je razumljivo da društvo impregnirano kršćanskom idejom kao idealom baštini brojne posljedica toga događaja, napose u području kulture koje se evangelizatorski karakter koncila možda najviše dotaknuo. Prijedlog Huberta Jedina prihvatili su donekle i domaći znanstvenici objavivši 2016. godine zbornik radova sa znanstvenog skupa čija je tema bila upravo tridentska baština u najširem smislu riječi, a u kojem se analizira razdoblje od druge polovice 16. do kraja 18. stoljeća u Hrvatskoj. ${ }^{89}$

Pokušavajući nadići nužnost veze protureformacije i osnivanja isusovačkoga reda na kojoj insistira Hubert Jedin, John W. O' Malley, američki povjesničar i isusovac uvodi novi pojam, relativno neutralan s obzirom na odnos protestantizma i katolicizma, imenujući razdoblje od Velike shizme Zapadne Crkve i Stogodišnjeg rata do Francuske revolucije ranonovovjekovnim katolicizmom. Pod njime uključuje ,sve ljude, institucije, te kulturne i religijske manifestacije koje su prije 1517. bile kršćanske, a poslije 1517. nisu bile protestantske“ te u njega uključuje ,i crkvu i, kako kažu, religiju, i nauk i pobožne prakse, župu i bratovštinu, princa i siromaha, zakone i umjetnost, svećenstvo i laike“ “. 90

\footnotetext{
${ }^{88}$ Musa, Ivica. Tridentski sabor - koncil nad koncilima?. // Tridentska baština. Katolička obnova $i$ konfesionalizacija u hrvatskim zemljama. MH-KBF-FFDI, Zagreb 2016. Str. 17-30.

${ }^{89}$ Usp. Tridentska baština. Katolička obnova i konfesionalizacija u hrvatskim zemljama. // uredile Zrinka Blažević i Lahorka Plejić Poje. Zagreb: Matica Hrvatska, Katolički Bogoslovni Fakultet u Zagrebu, Filozofski fakultet Družbe Isusove u Zagrebu, 2016.

${ }^{90} \mathrm{O}^{\prime}$ Malley, John W. Was Ignatius Loyola a church reformer? How to look at Early Modern Catholicism. // The Catholic Historical Review 77(1991), str. 71-87.
} 
S obzirom na učestalost odabira pojma katolička obnova u recentnijoj domaćoj znanstvenoj produkciji koja je poduzela nova istraživanja utjecaja (vremenski i prostorno) odluka donesenih na Tridentskom koncilu ${ }^{91}$ te na činjenicu da su tekstovi kojima se ovdje bavimo proizvod kršćanskih pisaca, štoviše klerika kojima je provođenje obnoviteljskog pastorala bila dužnost, smatramo primjerenim glazbenoteorijska djela i zbornike nastale od početka 18. stoljeća pa sve do šezdesetih godina kada je objavljen Fundamentum Mihaela ŠilobodaBolšića uključiti u navedeni pojam.

Glavne smjernice katoličke obnove relevantne (barem djelimice) za sve tipove umjetničkih praksi u hrvatskom kontekstu sažeo Ivo Frangeš u Povijesti hrvatske književnosti:

„Predvođena isusovcima, katolička je obnova - naoko - počinjala iznova: u biti, ona je sačuvala sve stečevine renesanse, tako da se barok na nju izravno nastavlja, ističući prije svega ulogu crkve i njezina naučavanja. Posebno je u toj koncepciji izražena golema distanca između svemoćnog, pravednog ali strogog božanstva i njegova malog, preuzetnog i nesmotrenog stvorenja koje, uzvisujući svoje beznačajno micanje na dostojanstvo povijesti, zaboravlja da je prah i sjena, pulvis et umbra. Stoga i umjetnost, ako ima nekog smisla, mora čovjeka podsjećati na to i pripravljati ga za sud posljednji. Posve jasno, time se opravdavala $i$ vergilijevska epska vizija života, koja je i teološka i teleološka, potvrđujući da je povijesno zbivanje progressus ad finitum. “92

Shvaćena izvan strogo teoloških okvira kao način djelovanja crkve u društvu, katolička obnova obuhvaća ne samo snažniju afirmaciju katolicizma u odnosu na druge vjere putem agilnijega pastorala, već i na dokidanje u puku rasprostranjenih paraliturgijskih pobožnosti koje je Tridentski koncil smatrao nedopustivima. Za to je, dakako, bila nužna sustavna edukacija ne samo vjernika, već i klerika čijem se školovanju počela posvećivati sve veća pozornost. ${ }^{93}$ Potrebno je podsjetiti se da katolička obnova u sjevernoj, panonskoj Hrvatskoj djeluje u kontekstu prosvijećenog apsolutizma Habsburške monarhije koji iz temelja protresa uhodane prakse i uvodi niz novina vezanih uz obrazovanje širih slojeva društva. Lokalni odgovori u književnosti na spomenutu politiku, od kojih je najznamenitiji Reljkovićev „Satir

\footnotetext{
${ }^{91}$ Teodora Shek Brnardić umjesto pojma katoličke obnove koristi pojam katoličkoga prosvjetiteljstva i tridentskoga katolicizma u kontekstu istraživanja obrazovanja na primjeru Adama Baltazara Krčelića. Usp. Shek, Brnardić, Teodora. Svijet Baltazara Adama Krčelića : obrazovanje na razmeđu tridentskoga katolicizma $i$ katoličkoga prosvjetiteljstva. Zagreb: Hrvatski institut za povijest, 2009.

${ }^{92}$ Frangeš, Ivo. Op. cit. Str. 87-88.

${ }^{93}$ Petrić, Hrvoje. O katoličkoj obnovi i obrazovanju na prostorima Senjske, Modruške i Zagrebačke biskupije u 17. stoljeću. // Podravina, 4/8 (2005), str. 147-166.
} 
iliti divji čovik“ iz 1762. najčešće se nazivaju racionalizmom, no „neograničeno prosvjetiteljsko pouzdanje u moć praktičnog i moralnog odgoja“994 dopušta uočavanje ideja koje promiče prosvijećeni apsolutizam Habsburgovaca. Slično pouzdanje u praktični i moralno odgoj koje izvire iz književnih djela uočljivo je i u neolatinističkim tekstovima o glazbi.

Problem periodizacijski i stilski teško odredivog razdoblja nije povlastica isključivo glazbe, već se pojavljuje i u povijesti hrvatske književnosti. S obzirom na razumijevanje književnosti 18. stoljeća kao literature, dakle svega napisanog ${ }^{95}$, o čemu svjedoče i teme Danâ hvarskog kazališta, dugovječnog domaćeg znanstvenog skupa posvećenog hrvatskoj književnosti, i teorija glazbe ili tekstovi koji se glazbe na bilo koji način dotiču, našli su svoje mjesto na spomenutim skupovima pa se periodizacijska problematika u književnosti donekle može primijeniti i na njih. ${ }^{96} \mathrm{O}$ ideološkom pristupu 18. stoljeću kao stoljeću prosvjetiteljstva, bez kritičkog promišljanja pri posuđivanju pojma iz drugih europskih književnosti i bez pokušaja usitnjavanja i razlikovanja raznovrsnih stilskih procesa koji se u njemu javljaju piše Cvijeta Pavlović u tekstu Kako rasplesti klupko hrvatske književnosti XVIII. stoljeća nastalom povodom 40. obljetnice postojanja spomenutog skupa usmjerenoga na domaću književnu produkciju. ${ }^{97} \mathrm{U}$ tom tekstu ističe se problem razdoblja 18 . st. koje, što se periodizacije tiče, ne samo u Hrvatskoj, već i u drugim zapadnim znanostima o književnosti „,uvodi pomutnju i predstavlja paradoksalno sjecište, zamršeno klupko, vrtloženje različitih kriterija i oruđa znanosti o književnosti“. Tako povjesničari književnosti za 18. stoljeće najčešće rabe pojam prosvjetiteljstvo, ,,a pojavljuju se još i nazivi racionalizam, moralizam, često i u kombinaciji racionalizam i klasicizam. “98 U glazbi je situacija drugačija pa se, po uzoru na povijest umjetnosti, za dominantne stilske pravce u 18. stoljeću koriste pojmovi zrelog ili visokog baroka (do otprilike polovice stoljeća), rokokoa, pretklasicizma i klasicizma. Problem atribucije nastaje kad se pokušavaju definirati djela i tekstovi o glazbi koji se ne uklapaju u ideju razvoja i dominantnih skladateljskih formi iz aspekta razvojno usmjerene historiografije, poput tekstova koji su predmetom ovoga rada. Neke recentne povijesti glazbe, dotičući se problema periodizacije, naglašavaju složenost problema odabira kriterija (stilsko-estetički,

\footnotetext{
${ }^{94}$ Ibid. Str. 113.

${ }^{95}$ Usp. Peto poglavlje, bilj. 429.

${ }^{96}$ Usp. Dani hvarskog kazališta. Hrvatska književnost 18. stoljeća: tematski i žanrovski aspekti. // uredio Nikola Batušić [et al]. Zagreb: Split: HAZU: Književni krug Split, 1995.

${ }^{97}$ Pavlović, Cvijeta. Kako rasplesti klupko hrvatske književnosti XVIII. stoljeća. // Dani Hvarskoga kazališta. Četiri desetljeća Hvarskoga kazališta - dosezi i propusti u istraživanju hrvatske književnosti i hrvatskog kazališta, Zagreb: Split: HAZU: Književni krug Split, 2014. Str. 152 - 179.

${ }^{98}$ Ibid. Str. 157.
} 
formalni, ideološki, kronološki) te osobitu kompleksnost istog tog 18. stoljeća u kojem se, prema nazivlju korištenom u povijestima glazbe nižu, ali i miješaju spomenuti pravci te predlažu kronološki kriterij prezentirajući 18. stoljeće kao cjelinu bez pretenzije da na nju primijene jedinstvenu stilsko-estetičku odrednicu. ${ }^{99}$

\subsection{Zagrebačka biskupija i Zagreb u prvih 60 godina 18. stoljeća}

Svi izvori kojima se bavi ovaj rad vezuju se geografski uz prostor grada Zagreba i Zagrebačke biskupije (djelo Tome Kovačevića objavljeno je u Beču i za sada nismo pronašli sačuvani primjerak, no budući da je bio zagrebački kanonik, pretpostavit ćemo da je priručnik bio namijenjen i njegovoj matičnoj biskupiji), a šire uz prostor Kraljevine Hrvatske koju su činile tri županije - Varaždinska, Zagrebačka i Križevačka - i Slavonije koja je uz područje današnje Slavonije obuhvaćala i cijeli Srijem. One su pod civilnom upravom Hrvatskog sabora i bana, kao sastavni dio nasljednih Zemalja Krune svetog Stjepana ulazile u sastav Habsburške Monarhije kojoj je pripadala i Vojna Krajina, dio istarskog poluotoka (Pazinska knežija) te Međimurje uključeno od 1720. u Zaladsku županiju u sklopu koje se, pošto je oslobođena Karlovačkim mirom 1701., nalazila i Baranja. Južna Hrvatska pripadala je pretežno Mletačkoj Republici (Mletačka Istra, Mletačka Dalmacija i Mletačka Albanija), uz iznimku samostalne Dubrovačke republike i njoj pripadajućih područja. „Dok su prvu polovicu 18. stoljeća obilježavali protuosmanski ratovi, definiranje granica te jasno razgraničavanje civilnog od vojnog dijela hrvatskog prostora, druga se polovica s pravom može nazvati razdobljem reformi. ... S druge strane, u hrvatskim je zemljama pod mletačkom vlašću u zadnjem stoljeću postojanja Republike zamjetan kontinuitet u političkom, gospodarskom i društvenom životu. “ ${ }^{100}$ Budući da je naš predmet interesa prvih 60 godina 18 . stoljeća, u političkom smislu radi se o razdoblju koje prethodi reformama Marije Terezije i Josipa II, odnosno svjedoči njihovim počecima, te koje još uvijek u temelju zadržava institucije i prakse prethodnoga 17. stoljeća.

\footnotetext{
${ }^{99}$ Ideju o 18. stoljeću kao glazbeno-povijesnoj cjelini ponudio je prije više od tri desetljeća Carl Dahlhaus. Usp. Dahlhaus, Carl. The Eighteenth Century as a Music-Historical Epoch (prev. Ernest Harriss). // College Music Symposium, 26/1986, Str. 1-6. Usp. i The Cambridge History of Eighteenth-Century Music / uredio Simon P. Keefe. Cambridge: Cambridge University Press, 2011.

${ }^{100}$ Katušić, Maja. Pregled političkih zbivanja. // U potrazi za mirom i blagostanjem. Hrvatske zemlje u 18. stoljeću / uredila Lovorka Čoralić. Zagreb: MH, 2013. Str. 3-26.
} 
U kontekstu crkvene organizacije i njezinog teritorijalno-administrativnog ustroja, važno je podsjetiti da su na prostoru od sjevernog Jadrana pa do istočne granice s Osmanskim carstvom, od sredine 16. pa sve do kraja 17. stoljeća na području pod Habsburgovcima postojale samo dvije biskupije: Zagrebačka i Senjsko-modruška. Zagrebačka biskupija 1701. godine dobila je u nadležnost veliki dio središnje Slavonije koja je prije bila pod nadležnosti Pečujske biskupije, no područje između Petrove gore i Slunja pripojeno je Senjsko-modruškoj biskupiji. U drugoj polovici stoljeća izgubila je 16 župa u Prekomurju koje su pripale Szombateljskoj biskupiji, a 1800. desetak župa u slavonskoj Posavini u korist Đakovačkosrijemske biskupije. Tijekom razdoblja kojim se bavimo u ovoj disertaciji na biskupskoj stolici izmijenili su se mnogi biskupi s različitim idejama o vođenju biskupije i modusima njihova provođenja. ${ }^{101}$ Stjepan Seliščević (1694. - 1703.) bio je iznimno politički i društveno aktivan i prije no što je imenovan zagrebačkim biskupom, a tijekom biskupovanja djelovao je i kao banski namjesnik. Osim što je intenzivno nastojao oko uređenja zagrebačkih zidina i biskupskih rezidencija izvan Zagreba, Seliščević je 1695. donio prve konstitucije Metropolitanske knjižnice. Po Seliščevićevoj smrti biskup Martin Brajković (1703.-1708.) intenzivno se zalagao za uzdizanje Zagrebačke biskupije u rang nadbiskupije u čemu ga je podržavao papa Klement XI i Bečki dvor. Brajkovića je naslijedio bivši pavlinski prior iz Remeta Mirko Esterházy (1708.-1722.) koji je zapamćen kao veliki darovatelj crkava na području Zagrebačke biskupije. Njegov nasljednik, biskup Juraj Branjug (1723.-1748.) „osobite je zasluge imao u graditeljstvu na području Zagrebačke biskupije pa ga se u literaturi naziva i „biskup graditelj“. Kroničar Zagrebačke crkve Baltazar Adam Krčečić u svojemu djelu Annuae hvali biskupa Branjuga kao velikoga naručitelja kiparskih djela, oltara i skulptura te liturgijskoga pribora za crkve.“102 Franju Klobusiczkog zagrebačkim je biskupom imenovala carica Marija Terezija i, premda je na toj dužnosti ostao samo tri godine (1748.1751.), uspostavio je duhovni stol, odnosno konzistorij kanonika koji mu je pomagao u vođenju svih duhovnih i administrativnih poslova biskupije. Pošto je otišao na funkciju kaločko - bačkoga biskupa, u zagrebačkoj biskupskoj stolici naslijedio ga je Franjo Thauszy (1751.-1769.) koji je osobito brinuo o slavonskome dijelu svoje biskupije osnovavši konzistorij za ispomoć u poslovima i sjemenište za odgoj klera u Požegi. Ujedno je zatražio

\footnotetext{
101 Temeljni uvid za ovu temu pruža priručnik Zagrebački biskupi i nadbiskupi / uredio Juraj Batelja ... [et al.] Zagreb: S̆K, 1995.

${ }^{102}$ Novak, Zrinka. Op. cit. Str. 173.
} 
od isusovaca, čiju je pedagošku djelatnost iznimno poticao i pomagao, da u istome gradu osnuju visoko učilište.

Rast gradova i jačanje uloge njegovih stanovnika slijedom potiskivanja Osmanskog carstva te upravnog, vjerskog i gospodarskog preustroja oslobođenog prostora koji je sada pripadao Habsburškoj monarhiji također je važan element obnoviteljske atmosfere, premda je stanovništvo sjeverne Hrvatske u 18. stoljeću i dalje dominantno ruralno. Mijenjaju se funkcionalne i društvene osobitosti urbanih sredina, a grad Zagreb pripada gradovima koji se kontinuirano razvijaju uslijed jedinstvenog državnog sustava te doživljava duboke strukturne i funkcionalne promjene, prije svega prema baroknim građevinskim uzusima. Zamah u razvoju grada očituje se u snažnom proširenju grada izvan gradskih zidina, osobito u Donjem gradu „koji u posljednjim desetljećima 18. stoljeća po broju kuća već nadmašuje povijesnu gornjogradsku jezgru“103, premda je grad očuvao glavno srednjovjekovno obilježje podijeljenost na Gradec i Kaptol. „Nadalje, s razvojem državnoga upravnog aparata, pojačanom ulogom županijskih središta, Zagreb postaje primamljivo odredište za naseljavanje plemstva, koje je do tog vremena najvećim dijelom bilo vezano uz ladanjske vile i posjede. Upravo će podizanje plemićkih palača dati snažan barokni pečat Gornjem gradu. Sličnu prostornu preobrazbu možemo pratiti i na Kaptolu, gdje će barokne kanoničke kurije i novi biskupski dvor promijeniti dotadašnju vizuru biskupskoga grada.“104

Grad Zagreb u 18. stoljeću grad je mnogih obrtnika koji zapošljavaju više od polovice ukupnog stanovništva, a postupno se razvija i manufaktura sukna, svile i papira, dok zbog razvoja uprave buja činovništvo. Sve to upućuje na sliku nešto drugačiju od onih koja je do sada dominiralo u udžbenicima povijesti, u kojima je 18. stoljeće na sjeveru prikazivano prije svega kao stoljeće rascjepkanosti teritorija i velikoga siromaštva što je uzrokovalo društvenu i kulturnu stagnaciju. Nova istraživanja, međutim, približavaju sjevernu Hrvatsku slici 18. stoljeća kao razdoblja postupnoga napretka, razvoja, bujanja stanovništva, rasta standarda te pluralnosti stilova u umjetnostima. S druge strane, snaga promjena koje su zahvatile crkveni, politički i društveni život sjeverne Hrvatske, ne smije zavarati svojom silinom: diskurs koji i dalje dominira obrazovanjem i društvenim uzusima pripada katoličkoj crkvi, osobito pak redovima: franjevcima i isusovcima te pavlinima.

\footnotetext{
${ }^{103}$ Benyovsky Latin, Irena; Vitek, Darko. Gradovi // U potrazi za mirom i blagostanjem. Hrvatske zemlje u 18. stoljeću/ uredila Lovorka Čoralić. MH: Zagreb. 2013. Str. 69.

104 Ibid. Str. 70.
} 
Dakle, usprkos utemeljenoj povjesničarskoj percepciji prve polovice 18. stoljeća kao posebno teškog razdoblja zbog višedesetljetne razjedinjenosti teritorija i teških gospodarskih posljedica turskih osvajanja, općeg siromaštva naroda i još uvijek snažno ukorijenjenog feudalnog sustava koji ustrajava i onemogućava snažniji rast građanstva, obnoviteljsko ili „obnovno“ katoličanstvo na temelju zasada Tridentskoga koncila poslije mira u Srijemskim Karlovcima 1699., vidljivo je u arhitekturi, plastici i općenito crkvenoj umjetnosti, čemu korespondiraju i nastojanja oko obnavljanja glazbenih znanja. Bez obzira što neki autori, primjerice Zrinka Novak, obnoviteljski posttridentski duh djelovanja pripisuju tek njihovim nasljednicima: Franji Klobusiczkom (1748.-1751.), Franji Thauszyju (1751.-1769.) i Josipu Galjufu (1772.1786. ${ }^{105}$, aktivno nastojanje oko provođenja rekatolizacije društva vidljivo je od samog početka 18. stoljeća u sve intenzivnijem objavljivanju raznih liturgijskih priručnika, nabožne literature namijenjene najširim slojevima, ali i prvih ozbiljnijih historiografskih naslova te nastojanju oko atraktivnosti crkvenih prostora što se provodi paralelno s revitalizacijom liturgije.

\subsection{Mjesto glazbe u liturgiji i u sustavu obrazovanja}

„Sve do razvoja ranonovovjekovnih, protomodernih državnih sustava - a na području hrvatskih zemalja taj je proces bio najintenzivniji u drugoj polovici 18. i početkom 19. stoljeća - vodeću ulogu u obrazovanju igrala je Katolička crkva.“106

Školstvo u prvoj polovici 18. stoljeća još uvijek se snažno oslanja na pedagoške okvire srednjega vijeka oblikovane kroz sustav septem artes liberales (trivium: gramatika, logika i retorika; quadrivium: aritmetika, astronomija, glazba, geometrija). U tom sustavu glazba kao dio kvadrivija prije svega se smatra matematičkom disciplinom, dok se njezine etičke funkcije oslanjaju na Platonovo i Aristotelovo učenje o djelovanju glazbe na dušu, odnosno njezin dio koji se odnosi na karakter. Novum u obrazovanju i dalje dominantno namijenjenom muškarcima, još od renesanse predstavlja niz praktičnih znanja i umijeća nužnih budućim državnim činovnicima, trgovcima, ali i glazbenicima koji su i dalje u najvećoj mjeri crkveni službenici, no brojni pripadaju i laicima.

\footnotetext{
${ }^{105}$ Usp. Novak, Zrinka. Op. cit.

${ }^{106}$ Horbec, Ivana; Matasović, Maja; Švoger, Vlasta. Od protomodernizacije do modernizacije školstva u Hrvatskoj: zakonodavni okvir. Zagreb: Hrvatski institut za povijest, 2017. Str. 9.
} 
Dominacija Katoličke crkve vidljiva je, očekivano, i u zapisima o glazbi i muziciranju koje se sve do druge polovice 18. stoljeća vrlo često vezuje uz liturgijske i paraliturgijske obrede. Glazbena poduka za Katoličku crkvu bila je vrlo važna zbog činjenice da se temeljni vjerski čin - sveta misa - pjevao. Budući da je misa svečani čin, pjevanje se smatralo njezinim integralnim dijelom nastavljajući time sinagogalnu praksu. Pjevan je promjenjivi (Proprium missae) i nepromjenjivi dio mise (Ordinarium missae) koji sadrži dijelove Kyrie, Gloria, Credo, Sanctus i Agnus Dei. Tiha misa (missa lecta) jest kasnija inačica povijesno starije pjevane mise. Ovisno o stupnju svečanosti u Katoličkoj crkvi pjevana misa služi se na različite načine: kao jednostavna pjevana misa bez asistiranja ministranata (missa cantata), kao svečana misa uz asistenciju (missa solemnis) i kao pontifikalna misa koju služi biskup uz velik broj asistenata ministranata (missa pontificalis).

U prvoj polovici 18. stoljeća glazbenom praksom u katoličkim crkvama, pa i u razvijenijim sredinama, još su uvijek dominirali koralisti koji su izvodili napjeve gregorijanskoga repertoara te, u slučaju vještijih i obrazovanijih pjevača i figuralno pjevanje koje je u papinskim dokumentima načelno odbijano kao neprimjereno radi nerazumljivosti teksta ${ }^{107}$, no brojni kantuali svjedoče o njegovom kontinuiranom prisustvu u glazbenom dijelu liturgije. Temelj glazbenog obrazovanja činila je usmena poduka kapelnika uz pomoć nekog od dostupnih priručnika. Kapelnik je bio učitelj i voditelj zbora, ujedno i orguljaš, dok su temelj glazbene literature, barem sudeći po dostupnoj ostavštini crkvenih arhiva, rukopisni i tiskani kantuali i pasije. S obzirom da se potreba za pjevačima često nije uspijevala riješiti angažiranjem sjemeništaraca i svećenstva, sve su češće podučavani i angažirani laici. Paraliturgijsku i svjetovnu glazbu vezanu uz razne javne svečanosti i procesije najčešće su izvodili isti ti glazbenici - laici. Naime, slobodni kraljevski grad Gradec bio je patron župe sv. Marka što je crkvene namještenike činilo u isto vrijeme i gradskim službenicima. Gradski orguljaš (dakle, orguljaš u crkvi sv. Marka Evanđeliste) imao je plaću u novcu i u naturi, najčešće u vinu i žitu, dok su koralisti bili plaćeni znatno manje. Među koralistima najcjenjeniji je bio prvi koralist koji je imao ulogu učitelja pjevanja i dužnost brige o repertoaru. ${ }^{108}$ Također, posao koralista često se prenosio obiteljski s oca na sina. Što se

\footnotetext{
${ }^{107} \mathrm{O}$ papinskim dokumentima i insistiranju na gregorijanici te odbacivanju figuralnog pjevanja, polifonije $\mathrm{i}$ instrumentalne pratnje uz iznimku orgulja, pišemo u poglavlju o gregorijanici kao kulturnoj praksi. Temeljna literatura o crkvenim propisima vezanima uz glazbu u liturgiji jest Hayburn, Robert F.. Papal Legislation on Sacred Music, 95 A. D. to 1977 A. D. Collegville, Minessotta: Liturgical Press, 1979.

${ }^{108}$ Dio teksta koji se odnosi na Gradec i tamošnju glazbenu praksu dugujem istraživanju Zdravka Blažekovića objavljenom u članku Blažeković, Zdravko. Bilješke o glazbenicima na zagrebačkom Griču u 18. stoljeću. // Glazbeni barok u Hrvatskoj / uredio Ennio Stipčević. Osor: Osorske glazbene večeri, 1989. Str. 114 -129.
} 
repertoara tiče, o njemu nam govore sačuvani rukopisi i tiskovine, a odnose se mahom na liturgijske priručnike u kojima je zapisana glazba te pjesmarice koje su se počele intenzivnije objavljivati od 17. stoljeća. ${ }^{109} \mathrm{U}$ svjetlu katoličke obnove i nastojanja da vjerske dogme dopru do što širih slojeva društva, postojala je i sve snažnija intencija uključivanja vjernika u pjevani dio liturgije.

Značajnu ulogu u objavljivanju liturgijskih priručnika i nabožne literature, u vrijeme kada se diljem (franjevačkih) samostana još uvijek intenzivno prepisivalo postojeće kantuale, $u$ Zagrebu je obnovljena stara biskupska tiskara koju je oživila jedna od najznačajnijih osobnosti toga vremena, svećenik i znanstvenik Pavao Ritter Vitezović. On je od 1690. do požara 1706. godine u Zagrebu vodio tiskaru u kojoj je tiskao raznovrsnu literaturu prije svega namijenjenu narodu, ali i vlastita djela na latinskom i hrvatskom. Međutim, za opsežnije znanstvene pothvate, prije svega povijesno zemljopisne tematike, nije dobivao potporu dvorske gospode, plemića, crkvenih dostojanstvenika niti bogatih građana. ${ }^{110} \mathrm{U}$ pismu banskome namjesniku grofu Petru Kegleviću iz 1710. godine Vitezović spominje i djela koja je objavio u svojoj tiskari:

„U njoj štampane su knjige za školsku mladež ovoga naroda tako korisne kao i potrebite, onda Kronika hrvatska, zatim latinska kronika s naslovom Plorantis Croatiae; nadalje Prodromus in Croatiam redivivam, mnoge molitvene knjižice, hrvatski kalendari za više godine, Priričnik (Proverbiorum sententiarum libellus); suviše Artikuli kraljevine Slavonije (Articuli Regni Slavoniae), Stemmatographia Regni Illyrici, Propovjedi Šimunićeve (Conciones Simunicianae) i još druge stvari, koje su, nekad nečuvene, domovinu dovoljno rasvijetlile.“111 Uz svjetovno svećenstvo i katolički su redovi obnoviteljski djelovali u smislu opismenjavanja naroda, ali i insistiranja na glazbenom elementu liturgije, a često su djelovali i u sinergiji s kaptolskim župama, osiguravajući im svojim školskim sustavom i zakladama potreban broj glazbenika.

\footnotetext{
${ }^{109}$ Usp. Katalinić, Vjera. Pregled izvora o glazbenoj kulturi baroknog razdoblja na tlu SR Hrvatske. // Glazbeni barok u Hrvatskoj / uredio Ennio Stipčević, Osor: Osorske glazbene večeri, 1989. Str. 20 - 47.

${ }^{110}$ Aktivnom prosvjećivanju pismenih slojeva svakako je znatno doprinijela tiskara Pavla Rittera Vitezovića čija nesretna sudbina nipošto ne umanjuje veliku vrijednost koju je imala za Zagreb. Opširnije o Vitezovićevom djelovanju vidi kod Bratulić, Josip. Pavao Ritter Vitezović, utemeljitelj Hrvatske zemaljske tiskare u Zagrebu. // Senjski zbornik, 22 (1995), str.179-186.

111 cit. prema Klaić, Vjekoslav. Obrana Pavla Rittera Vitezovića od god. 1710. // Građa za povijest književnosti Hrvatske, Zagreb: Tisak Dioničke tiskare, 1915. Str. 375-394. Usp. i Klaić, Vjekoslav. Život i djela Pavla Rittera Vitezovića. Zagreb: MH, 1914.
} 
Franjevci, kao jedan od najplodonosnijih redova u smislu kontinuiranog djelovanja među narodom te osmišljavanja i provođenja obrazovanja kako članova vlastitih redovničkih zajednica, tako i naroda koji im je povjeren, doživjeli su već krajem 16. st. odumiranje većine svojih samostana. „Koncem 16. st. svedena je (Banska Hrvatska koja je imala 27 samostana prije turskog prodiranja u Bansku Hrvatsku, op. a.), na šest kuća i trideset članova. U hrvatskome dijelu Ugarske provincije stanje je bilo još teže. Prije turskoga nadiranja Provincija je brojila 50 samostana, a početkom 17. st. ima samo sedam; od toga broja dva su samostana u hrvatskome dijelu Provincije. No, jedno vrijeme nije bilo nikoga ni u ta dva samostana, Zagrebu (1590.-1607.) i Varaždinu (1568.-1617.).“112

No, u 17. stoljeću, osobito u njegovoj drugoj polovici, franjevci su osnažili na zagrebačkom području. „Pokretač obnove je Franjo Drašković (1637). Ponovno je uveo franjevce u Zagreb, Koprivnicu, Varaždin, Remetinec, Križevce, Ivanić i Krapinu. U Zagrebu je 1613. osnovao višu bogoslovnu školu, a nešto kasnije i školu filozofije. Njegov rad je nastavio Timotej Međurečki (1610.-1678.), osnivač i prvi provincijal Provincije Sv. Ladislava sa sjedištem u Zagrebu, gdje je od 1670. djelovala prva visoka bogoslovna škola s fakultetskom nastavnom osnovom u sjevernoj Hrvatskoj.“113

Premda su franjevci autori sačuvanih djela katoličke nabožne književnosti koju pišu u duhu posttridentske obnove, njihovi napori u očuvanju i širenju elementarnog glazbenog obrazovanja vidljivi su u popisima inventara njihovih knjižnica. ${ }^{114}$ Glazbeni život prema dostupnim podacima, odvijao se na razini jednostavne, ali harmonizirane gregorijanike. Na temelju egzempcije $\mathrm{e}^{115}$ franjevci su 1702. u Beču tiskali vlastiti obrednik Ordo agendorum et cantandorum in actibus processionalibus ${ }^{116}$, dok ih je ,u slavljenu mise obvezivao Rimski obrednik. U dijeljenju sakramenata slijedili su obrednike Zagrebačke biskupije, i to do 1729. obrenik Ostrogonske nadbiskupije, a kasnije Branjugov Rituale Zagrabiense. "117 Većina misa bila je tiha, čak i nedjeljom: ,pjevalo se samo pod jednom misom svake nedjelje. Teško je

\footnotetext{
${ }^{112}$ Hoško, Franjo Emanuel. Franjevci i poslanje Crkve u kontinentalnoj Hrvatskoj. Zagreb: Kršćanska sadašnjost, 2001. Str. 26-27.

113 Ibid. Str. 27.

${ }^{114}$ Usp. Katalinić, Vjera. Op. cit.

${ }^{115}$ Egzempcija (izuzeće) jest stari institut Kanonskoga prava koji podrazumijeva izuzetost redovničkih zajednica iz vlasti mjesnih ordinarija, a kako bi se očuvala autentičnost posvećenoga života te veća djelotvornost u apostolatu. Do II. vatikanskog koncila egzempcija se smatrala regularnim pravom svake redovničke zajednice. ${ }^{116}$ Cijeli naziv obrednika glasi ORDO / AGENDORUM ET/ CANTANDORUM / IN / ACTIBUS

PROCESSIO- / NALIBUS. / Pro F. F. Franciscanis Regu- / laris opservantiae in Venerabili Provin- / cia Sancti Ladislai in Sclavonia, / DEO famulantibus. / Viennae impressus, Typis Leopoldi Voigt, Anno salutis 1702.

${ }^{117}$ Hoško, Emanuel. Op. cit. Str. 107.
} 
danas reći tko je pjevao nepromjenjive pjevne dijelove mise na način gregorijanskoga korala, ali su sačuvane harmonizacije takvih napjeva za mnoge samostane Provincije sv. Ladislava. Samostanske zajednice, pogotovo one u kojima su bili studenti bogoslovlja, često su u nedjelje pjevale večernju ili povečerje, štoviše i male časove.“118

Zagreb, Varaždin i Čakovec posjeduju glazbene zbornike s harmonizacijama koje je ispisao Konrad Potočnik ${ }^{119}$, ali i druge muzikalije koje upućuju na visoku razinu jedinstvenosti glazbenog izričaja u katoličkim crkvama, bilo nadbiskupijskim, bilo redovničkim, uz izuzetak isusovaca koji su prakticirali i tipične barokne oblike poput oratorija i misterija.

Franjevački samostani u Varaždinu, Osijeku i Našicama posjeduju primjerke priručnika za učenje gregorijanskoga pjevanja: Il cantore ecclesiastico (Crkveni pojac) objavljeno u Padovi 1698. (treće izdanje 1733.) Giuseppea Frezza Dalle Grotte i Breve metodo per apprendere fondatamente e con facilita' il canto fermo (Kratka metoda za temeljno i lako učenje gregorijanskoga pjevanja) franjevca Fabrizija Tettamanzija, objavljenog u Milanu 1756. koji će nam poslužiti kao komparativni predlošci u analizi naših izvora te mogući izvori za djela Šiloboda Bolšića i Tome Kovačevića. ${ }^{120}$

Isusovačka glazbena praksa u odnosu na sve ostale crkvene redove, pa i na svjetovno svećenstvo, najprije bi se mogla imenovati aktualnom u smislu pristajanja uz suvremene skladateljske i izvodilačke trendove. Međutim, svi dostupni podaci o muziciranju u isusovačkim kolegijima i crkvama ostali su u sekundarnom obliku te do danas ne raspolažemo partiturama koje su isusovci koristili za svečane oratorije i glazbene priredbe, kao niti literaturom kojom su se koristili pri poduci. Marijan Steiner razlikuje četiri aspekta isusovačkog bavljenja glazbom: poduka glazbe u kolegijima, praksa glazbenog oratorija,

\footnotetext{
118 Ibid. Str. 87.

${ }^{119}$ O njima su pisali: Širola, Božidar. Crkvena glazba u Hrvatskoj. // Croatia sacra, 11-12 (1943). Str. 310-311; Dugan, Franjo. O našem glazbenom prilogu s. Crisiense Majus, vulgo S. Joannis dictum. // Sv. Cecilija, 1917. Str. 9-20.; Mantuani, Josip. Dva glazbena rukopisa iz franjevačkog samostana u Varaždinu. // Sv. Cecilija, 1924 Str. $1-5$.

${ }^{120}$ Radi se o priručnicima tiskanima od kraja 17. pa sve do sredine 18. stoljeća koji se najčešće nalaze u hrvatskim samostanskim knjižnicama franjevačkog reda, budući da su im franjevci autori: Tettamanzi, Fabrizio Breve metodo per fondatamente e con facilità apprendere il canto fermo. Milano: Agnelli, 1686. (Priručnik je tiskan više puta, a zadnje izdanje, koliko je nama poznato datira iz 1756.); Frezza dalle Grotte, Giuseppe. Il Cantore ecclesiastico. per istruzione de' Religiosi Minori Conventuali, e benefizio comune di tutti gli Ecclesiastici. Padova: Nella stamperia del seminario Giovanni Manfrè, 1733. (djelo je tiskano više puta od 1698.). Oba priručnika se bave isključivo praktičnim uputama za kantora i nimalo se ne osvrću na spekulativni aspekt teorije glazbe. Tettamanzija čuvaju knjižnice u Baču, Našicama i Slavonskoj Požegi, a Frezza Della Grotte se nalazi u Baču, Makarskoj, Našicama i Sinju. Uz ove priručnike u Osijeku se nalazi i priručnik tiskan u Rimu u 17. stoljeću De Martinis, Joannes Baptist. Clavis cantus ecclesiastici seu modus intonandi et cantandi. Roma: Nicolo Angelo Tinassi, 1661. Usp. popis u Katalinić, Vjera. Op. cit.
} 
distribucija katekizama i ostalih liturgijskih knjiga koje sadrže nabožne popijevke te glazba u isusovačkim crkvama tijekom velikih svečanosti. Na temelju dostupnih arhivskih dokumenata $^{121}$ zna se da su organizirali bogato opremljene glazbene priredbe u skladu s onodobnom glazbenom modom te da su obrazovali pjevače i instrumentaliste za te potrebe, ali isto tako da su i unajmljivali potrebne glazbenike kad im ovi u Zagrebu nisu bili dostupni:

„Općenito, može se reći da su isusovci uveli dotad neuobičajenu monumentalnost i sjaj u liturgijsku i svjetovnu glazbu u Hrvatskoj. Crkvene svečanosti, procesije, trionfi (...), kazališna djeli i alegorijska prikazanja sadržavala su značajne glazbene dijelove u kojima je s vremenom sudjelovao sve veći broj izvođača i publike." ${ }^{\text {122 }}$

Svjedočanstva o izvođenju simfonija i postojanju orkestra te čak pedesetijednoj partituri simfonija, potvrđuju isusovce kao donositelje i promicatelje aktualne glazbene prakse i izvan strogih okvira gregorijanike i nabožnih jednoglasnih pučkih pjesama. No, budući da se ovaj radi bavi izvorima koji podučavaju jednoglasje ili ga promiču kao idealnu liturgijsku praksu, na ovom je mjestu važno istaknuti isusovačku podršku koralistima na Gradecu, usprkos činjenici da se isusovački red upravo po pitanju glazbe razlikuje od svih prethodno uspostavljenih redova: isusovačke konstitucije ne propisuju zbor u kojem se pjeva brevijar i zajednički sudjeluje u ostalim obredima. ${ }^{123}$ Razlog tome Ignacijevi su postulati za maksimalnom mobilnošću i uključenošću u potrebe zajednice što bi sudjelovanje u nizu pjevanih dnevnih molitvenih obaveza znatno otežavalo. ${ }^{124}$

Kao što smo spomenuli, svijest o potrebi za koralistima postojala je i sustavno je podržavana o čemu svjedoči školovanje i uzdržavanje trojice koralista za župu sv. Marka u sklopu Sjemeništa Sv. Josipa za siromašne đake (Seminarium Sancti Iosephi studiosorum pauperum) što su ga isusovci osnovali u Zagrebu. Oko te su se odluke zbog nepovoljnih financijskih okolnosti i nevoljkosti gradske uprave da riješi pitanje ostavštine Ivana Krušelja, gradskog odvjetnika koji je oporučno odredio da se sav njegov imetak upotrijebi za osnivanje internata. „Konačno su se općina i kolegij tako nagodili da je sjemenište preuzelo dužnost hraniti tri

\footnotetext{
${ }^{121}$ Za Zagreb, Rijeku i Varaždin dostupne su Litterae annuae, a za Zagreb i Rijeku također i Historiae u rukopisu.

${ }^{122}$ Steiner, Marijan; Županović, Lovro. The Jesuit Contribution to Croatian Musical Culture, with Particular Emphasis on the 17th and 18th Centuries. // Jesuits Among the Croats. / uredio Valentin Pozaić. Zagreb: Filozofski i teološki institut, S. J.; Beč: Hrvatski povijesni institut, 2000. Str. 459.

${ }^{123}$ Usp. Constitutiones Societatis Jesus, p. VI, c. III, n. 4. URL: https://archive.org/details/constitutionesso00jesuuoft (05.01.2020.)

${ }^{124}$ Usp. Monumenta Ignatiana. Fontes narrativi II. Romae, 1951. Str. 337.
} 
pjevača za župu sv. Marka, kojoj je patron bila gradska općina ... U zavodu su živjela dva kapelana, 24 gojenca (uključivši pjevače i glazbenike) i četvorica iz konvikta. “125

Insistiranje općine Gradec na što većem broju uzdržavanih glazbenika - ,(s) vremenom je općina povisila svoje zahtjeve i g. 1644. tražila da u sjemeništu budu četiri pjevača i jedan orguljaš za crkvu sv. Marka ..."126 - ukazuje na iznimnu važnost koralista i glazbenog dijela liturgije. Petnaest godina poslije Mijo Škrlec osnovao je ,,prvu zakladu za pjevače i glazbenike crkve sv. Katarine“ ostavivši regentu Sjemeništa sv. Josipa o. Jurju Habdeliću svoju kuriju i ostali imetak, ,a u tu svrhu da oci Družbe Isusove na veću slavu Božju i na pobudu bogoljubnog puka od prihoda spomenutih nekretnina uzdržavaju toliko glazbenika za crkvu sv. Katarine koliko ih budu lako mogli uzdržavati. ... Broj pitomaca ove zaklade bio je malen, rijetko je iznosio tri ili četiri, ili čak više. “127 Nestalnost prihoda od imanja i nekretnina uvjetovala je ograničenost broja uzdržavanih glazbenika, premda je zaklada postojala sve do 1913. godine. Ipak, usprkos očitom siromaštvu zajednice koje često određuje položaj glazbe u društvu, kontinuirana nastojanja oko dostojanstvene, glazbom ispunjene liturgije, pokazuju svijest o njezinoj važnosti u motiviranju vjernika za aktivno sudjelovanje u crkvenim obredima. Tako je 1667. značajni podupiratelj brojnih umjetničkih aktivnosti, protonotar kraljevine Hrvatse Ivan Zakmardi od Diankovca istavio Sjemeništu nekretnine „da se uzdržava toliko đaka koliko se po sudu isusovaca može. Zakladnik je želio također uveličati bogoslužje u crkvi sv. Katarine uzdržavanjem pjevača u sjemeništu, pa su isusovci namijenili prihod od 2000 forinti za uzdržavanje dvaju pjevača.“ Potom je 1682. ,/Z/a uzdržavanje pjevača i glazbenika crkve sv. Katarine u Sjemeništu sv. Josipa rektor zagrebačkog kolegija Ivan Despotović s odobrenjem provincijala Adama Aboedta odredio (je) prihod glavnice od 6000 forinti ..." 128

Uz franjevce koji su se isticali brigom o pastoralu naroda širom zemlje, isusovci su, sve do ukinuća reda 1773. bili najvažniji provoditelji sustavnog višeg obrazovanja u Hrvatskoj. Ratio studiorum iz 1599. ostao je sve do ukinuća reda predložak za oblikovanje programa i nastave, predložak koji ipak nije ostajao imun na suvremene umjetničke prakse. Inzistiranje na gramatici i retorici kao dominantnim predmetima, bojažljivo i sporo pristajanje na uvođenje novih i potrebnih predmeta, bilo je predmetom snažne kritike njihova obrazovnog programa

\footnotetext{
${ }^{125}$ Vanino, Miroslav. Isusovci i hrvatski narod, sv. I. Zagreb: GZH, 1969. Str. 230.

126 Ibid. Str. 228.

${ }^{127}$ Ibid. Str. 236.

${ }^{128}$ Ibid. Str. 237.
} 
koja se to više čula kako je državni aparat rastao. Premda su u hrvatskoj povijesti glazbe isusovačka postignuća tijekom baroka, na temelju sekundarnih izvora, evidentirana kao vrlo suvremena i atraktivna, sačuvanih notnih materijala, nažalost, nema. Isto tako, preostaje istražiti sadržaj njihovih knjižnica koji bi omogućio uvid u autore iz kojih su crpili svoja glazbena znanja. Spomenuta dominacija antičke literature i patristike kao temelja edukacije, objašnjava, pak, niz metafora kojima se služi diskurs o glazbi.

Poduka glazbe odvijala se u Hrvatskoj, osim u crkvenim školama i redovničkim konviktima, u tzv. narodnim, odnosno župnim školama u kojima je učitelj gramatike (trogodišnjega obrazovnog programa) vrlo često bio i lokalni orguljaš i voditelj zbora. Stoga je i ta, uvjetno rečeno svjetovna poduka, bila snažno vezana uz crkvenu glazbenu praksu. Uz župne škole, najznačajnije su bile škole već spomenutih franjevaca i isusovaca, ali i pavlina te klarisa $\mathrm{i}$ uršulinki za djevojčice i djevojke.

Jasno je, s obzirom da je učenje glazbe u svim oblicima bilo snažno vezano uz Katoličku crkvu, da je liturgijska i paraliturgijska glazba i u 18. stoljeću predstavljala dominantni glazbeni izričaj. U slučaju Hrvatske u kojoj su i bogatije crkve oskudijevale glazbenicima i pjevačima, crkveno jednoglasje ili pak skromno višeglasje te nabožne pučke pjesme ostaju jedini ili gotovo jedini izvor glazbenog iskustva za veliku većinu stanovništva. Uzimajući u obzir baroknu glazbenu praksu bogatih gradova i sredina diljem Europe ,istina je da se mnoga kretanja i estetske orijentacije u hrvatskome glazbenom životu 17. i prve polovice 18. stoljeća ne podudaraju vremenski ni sadržajno sa zbivanjima u većini ostalih evropskih zemalja“, te se glazbena koja se izvodila i skladala u spomenutom razdoblju katoličke obnove odvijala ,ispod jasno vidljivih znakova i tragova što ih ostavljaju izuzetne skladateljske ličnosti, virtuozni interpreti i veličanstveni glazbeni spektakli“،. To, međutim, kao što ćemo pokazati u disertaciji, ne znači da je takva praksa predstavljala izuzetak ili da je značila anakronu praksu u odnosu na ostale, veće i bogatije sredine. Naime, orguljanje crkvenog kantora i pjevanje zbora napjeva iz kantuala, glazbena teorija omeđena Guidovim heksakordima, solmizacijom, osnovnim notnim trajanjima, crkvenim ljestvicama i intoniranjem psalama, predstavljala je, ne samo u sjevernim hrvatskim zemljama, već i u brojnim europskim zemljama, redovnu i legitimnu glazbenu praksu. 


\section{DRUGO POGLAVLJE: IZVORI I STANJE ISTRAŽIVANJA}

„Quid est cantus? Peritia musicae, artis, inflexio vocis et modulatio.“

Anonimus, 3. st. ${ }^{129}$

\subsection{Izvori}

Pijev, pjevanje i napjev (cantus) kao vještina glazbe ${ }^{130}$, sposobnost muziciranja i glazba sama, kao znanje stečeno učenjem i iskustvom, poput vještine obrtnika ili vojnika (peritia), kao postvarenje umijeća (ars) kojim se ljudski glas uznosi ili spušta (inflexio) i modulira, uspostavlja okvir unutar kojeg se kreće istraživanje tekstova o gregorijanskom pjevanju, posvećenih glazbi kao pjevanju i to onome koje opisuju i opasuju liturgijski i paraliturgijski obredi. Upravo je cantus poistovjećen s musica i vice versa tema tekstova raznovrsne intencije i provenijencije koji su objavljeni u Zagrebu i Beču u razdoblju između 1701. i 1760. godine. I upravo ih ograničenost muziciranja na pijev čini koherentnim skupom izvora za poimanje glazbe kao takve, ako ne u praksi koja dopušta i upotrebu instrumenata, a ono u njezinu razumijevanju i podučavanju. Prema imenu autora i lokacijama pronađenih kopija tekstova te iskazima samih autora u predgovorima, namijenjeni su zagrebačkoj sredini koja je potaknula njihov nastanak ${ }^{131}$, ali potencijalno i svim sličnim mjestima ondašnjeg Austrougarskog carstva koja su se zbog oskudijevanja u ljudstvu i materijalnome morala ograničiti na jednostavnu vokalnu glazbu uz eventualno prisutne orgulje.

Jedini za koji to ne možemo s velikom sigurnošću utvrditi jest priručnik Brevis cantus gregoriani notitia (Beč, 1701.) Tome Kovačevića kojeg posjedujemo isključivo u parcijalnom obliku kopije snimke prijepisa što ga je načinio Inocencije Auer 1738. u slovenskom

\footnotetext{
${ }^{129}$ Wagner, Peter. Un piccolo trattato sul canto ecclesiastico in un manoscritto del secolo x-xi // Rassegna Gregoriana 3 (1904), str. 481. (prema Citation and Authority in Medieval and Renaissance Musical Culture. Learning from the Learned / uredile Suzannah Clarke; Elizabeth Eva Leach. Woodbridge: The Boydell Press, 2005.)

${ }^{130} \mathrm{U}$ uvodu smo upozorili na problematičnost prevođenja pojma musica hrvatskim pojmom glazba, zbog niza isključivo teorijskih konotacija koje pojam musica u određenim razdobljima nosi, a koje se ne odnose nužno na samo zvučanje koje pojam glazba implicira.

${ }^{131}$ Vidljivo je to iz predgovora svih triju izdanja CO, kao i knjizi Šiloboda Bolšića. Mecene i cenzori zagrebački su svećenici koji provode politiku katoličke obnove priklanjajući se dijelom i metodologiji koju je tijekom zauzimanja religijskog prostora Europe provodio protestantizam.
} 
franjevačkom samostanu u Novom Mestu. ${ }^{132}$ Vjerojatno je, međutim, da je ta skromna knjižica s osnovnim uputama za čitanje nota te podacima o modusima, ritmu, mjeri, intoniranju psalama i solmizaciji ipak bila namijenjena lokalnoj upotrebi. Naime, Beč je obilovao kako teorijskim, tako i praktičnim mogućnostima za razvijenu glazbenu izvedbu liturgije i malo je vjerojatno da je ovakav priručnik u sjedištu Habsburške monarhije klericima (i sjemeništarcima) uopće bio potreban.

Izvori - tekstovi kojima se bavi ovaj rad u pokušaju ocrtavanja ideje glazbe i glazbenoga u zagrebačkoj sredini u prvih šezdeset godina 18. stoljeća jesu: Brevis cantus gregoriani notitia Tome Kovačevića tiskan u Beču 1701., uvodnici zborniku Cithara octochorda čije je prvo izdanje objavljeno 1701. u Beču, drugo 1727. također u Beču, a treće 1757. godine u Zagrebu te priručnik o umijeću gregorijanskoga pjevanja Mihaela Šiloboda Bolšića Fundamentum cantus gregoriani seu choralis objavljen u Zagrebu 1760. godine. Uz spomenute izvore o glazbi na latinskom jeziku, postoji još i kratki tekst s nalovom Musica u rukopisnom rječniku Adama Patačića koji se čuva u Kalocsi. Riječ je o rječniku koji svojim konceptom više odgovara enciklopedijskom rječniku, budući da je oblikovan u trinaest tematskih cjelina s brojnim podcjelinama. Tim se rječnikom, s obzirom da se radi o rukopisnoj ostavštini i leksikografskoj građi ovdje nismo bavili. Još jedan rukopisni rječnik, onaj Pavla Rittera Vitezovića, Lexicon Latino-Illyricum, 1700.-1709. (rukopis se čuva u Nacionalnoj i sveučilišnoj biblioteci, sign. MR 112; presliku rukopisa objavio je ArTresor, Zagreb, 2000.) konzultiran je kao izvor za razumijevanje latinskih pojmova vezanih uz glazbu početkom 18. stoljeća.

Spomenuti priručnici, kao i Cithara Octochorda, pod pojmom musica podrazumijevaju pojam cantus, odnosno jednoglasno pjevanje. Kovačevićev i Šilobod-Bolšićev manual nastali su kao uputa u osnove teorije nužne za ispravno pjevanje gregorijanskih napjeva, i posljedično, poboljšanja glazbenoga dijela liturgije - mise, časoslova, procesija i posebnih svečnosti, dok uvodnici zbornicima CO funkcioniraju kao etičko-estetička uputnica u svrhovitost glazbe, točnije crkvene duhovne monodije. Jasno iskazano ograničenje na vokalnu liturgijsku glazbu koja u 18. stoljeću u sjevernoj Hrvatskoj još uvijek podrazumijeva gregorijansko pjevanje kao

\footnotetext{
${ }^{132}$ Usp. Županović, Lovro. Hrvatski glazbeni zbornik Cithara Octochorda iz XVIII. stoljeća i njegovo značenje za (domaću) glazbenu kulturu onoga doba i danas. // Cithara Octochorda, Zagreb 1757., Komentari i studije / uredili Milan Moguš i Lovro Županović. HAZU, Zagreb, 1998. Str. 209. Snimku koju navodi Županović u tekstu uvidom u Vidakovićevu ostavštinu koju danas čuva Institut za crkvenu glazbu „Albe Vidaković“ u Zagrebu, nisam uspjela pronaći. Isto tako, ljubaznošću fra Felicijana Peveca, pregledala sam knjižnicu franjevačkog samostana u Novome Mestu, no prijepisu Inocencija Auera nisam uspjela ući u trag.
} 
temelj muziciranja za vrijeme obreda, ovaj je rad usmjerilo na istraživanje načina njegova ustrajavanja ${ }^{133}$ te fenomen izjednačavanja gregorijanskoga pjevanja s glazbom uopće u prvoj polovici 18. stoljeća. Upravo taj fenomen, anakron ako ga promatramo iz aspekta razvoja glazbenih oblika kako ih percipira tradicionalna historiografija, čini razliku između bogatijih i siromašnijih sredina. Gregorijansko pjevanje, naime, supostoji s visokobaroknim formama mise, oratorija, instrumentalne glazbe i opere u svim sredinama Europe u kojima katolička crkva čini važan element društvenog ustroja. To je slučaj u Habsburškoj monarhiji, ali i u Italiji, južnoj Njemačkoj, Španjolskoj i Francuskoj. Međutim, potreban je oprez: kada diskurs o glazbi izjednačava gregorijansko pjevanje s muziciranjem uopće te ignorira praksu koja koristi višeglasje i/ili instrumentarij, odnosno kad glazbeno iskustvo u cjelini svodi na vokalnu jednoglasnu glazbu izvođenu zborski i njoj pridaje ulogu moralnoga korektora, riječ je o pokušaju ovladavanja neglazbenoga glazbenim.

Gregorijansko pjevanje kao temelj glazbene poduke u spomenutim izvorima (ali i u većini napisanih traktata koji se bave glazbenom praksom sve do 16. stoljeća) uvjetuje snažno oslanjanje na estetiku koja se prije svega bavi međuodnosom tona i riječi te etiku koja, nasljedujući stavove antičkih uzora dotjeranih za potrebe kršćanstva još u vrijeme crkvenih otaca, ima iznimno važnu ulogu: glazba bez riječi i glazba lišena unaprijed jasno definirane etičke dimenzije posve je irelevantna te se o njoj ne govori.

Svi proučavani tekstovi spominjući (ars) musica podrazumijevaju pojam cantus i to cantus ecclesiasticus, crkveno pjevanje. Ono je, uz gdjegdje izrečenu svijest o postojanju druge i drugačije (vokalne) glazbe ${ }^{134}$, ideal muziciranja koji propagiraju, ono što žele podučiti neuke, ono što žele proširiti urbi et orbi, ono čime svako ljudsko biće snaži vlastitu pietas, praktičnu pobožnost koja jest osobni čin, no ujedno i čin vidljiv ostatku zajednice, pobožnost koja prema znamenitoj sintagmi quis cantat bis orat ${ }^{135}$ vjerojatnijim čini konačni spas. Osim toga,

\footnotetext{
${ }^{133} \mathrm{O}$ oblicima koji figuriraju kao gregorijanski, a odmiču se od propisanih napjeva rimskoga misala pisao je fra Izak Špralja u studiji Povijesna situiranost gregorijanskoga pjevanja u vrijeme pojave Citharae octochordae i njegova primjena posebice u trećem izdanju toga zbornika. // Cithara octochorda: Komentari $i$ studije / uredili Milan Moguš i Lovro Županović. Zagreb: HAZU: Institut za crkvenu glazbeu Albe Vidakovićc KBF Sveučilišta u Zagrebu: Hrvatsko društvo crkvenih glazbenika, 1998. Str. 221-250.

${ }^{134}$ Samo Šilobod Bolšić navodi cantus figuralis kao opoziciju cantus gregorianus. Zbornici Cithara Octochorda ne spominju izrijekom niti jednu vrstu pjevanja. Instrumentalna glazba, premda prisutna i u Zagrebu o čemu svjedoči instrumentarij samostana klarisa, izvještaji o priredbama koje su priređivali isusovci, itd., ne spominje se uopće kao alternativa vokalnoj s obzirom da su početkom 18. stoljeća, i u glazbenicima i glazbom kudikamo bogatijim sredinama, glazba i poezija smatrane nerazdvojnima. O odnosu glazbe i poezije u kontekstu gregorijanskoga pjevanja govori se u poglavlju o retorici gregorijanike.

135 Izreka pogrešno pripisana Aureliju Augustinu, često se navodi i u obliku qui bene cantat, bis orat. Zapravo se radi o parafrazi Psalama koji pozivaju na slavlje Jahve ne samo molitvom, već i glazbom. Psalam 33, 2-3:
} 
cantus ecclesiasticus nipošto nije jednoznačan: diči se mnogim obilježjima prevedenim u jednako brojna imena, a zajednička im je briga za jasnoću ispjevanog teksta. On je choralis, planus, Gregorianus, firmus: „Znaj da je vokalna glazba još podijeljena na koralnu i figuralnu. ... Ipak, pravilnije s običava reći cantus Gregorianus, ... Zbog toga što se sastojao od najjednostavnijih nota neki ga zovu planus. Talijani ga pak zovu firmus ..." ${ }^{\text {136 }}$. Opsežni i brojni priručnici iz gregorijanike nastali tijekom 17. i 18. stoljeća u velikim kulturama Europe izvrsno svjedoče nepokolebljivost kojom ga je Crkva njegovala dopuštajući mu modifikacije sukladne ukusu vremena.

\section{Fundamentum cantus gregoriani seu choralis Mihaela Šiloboda Bolšića i Brevis cantus} gregoriani notitia Tome Kovačevića didaktički su priručnici izrijekom nastali kako bi se budućim koralistima (sjemeništarcima, bogoslovima ili unajmljenim pjevačima laicima) olakšalo učenje gregorijanskoga pjevanja i posljedično, poboljšao glazbeni dio liturgije. Zbornik Cithara Octochorda, uz sačuvane liturgijske knjige, tiskane ili rukopisne kantuale ${ }^{137}$, bilježi napjeve koji se izvode tijekom obreda i gregorijanske su provenijencije, ali i one što potječu iz narodne baštine te su, tekstualno prilagođeni, uvedeni u liturgijsku praksu. Njegova je, nikad dovoljno istaknuta dragocjenost, u cjelovitosti koju nastoji podastrijeti: „Liturgijskoglazbeni zbornik CO, kao izdanje Zagrebačke prvostolne crkve, objelodanjen [je] s nakanom da donese cjelokupni liturgijski program ... U ovom glazbenom zborniku predstavljeno je gotovo cjelokupno monofonijsko liturgijsko glazbeno stvaralaštvo zapadnog obreda od njegovih (sačuvanih) početaka do glazbenog baroka.“... Spomenuto bogatstvo gregorijanskog i himničkog porijekla objelodanjeno je u glazbenom zborniku CO tek u 18. stoljeću. Možda baš ta datost može protumačiti i opravdati činjenicu da se nitko od naših muzikologa nije pozabavio analizom glazbenih oblika koji se nalaze u ovom zborniku. ... Tako je, s obzirom na glazbeni sadržaj u cjelini, a time i značenje u njemu objelodanjenih

\footnotetext{
„Slavite Jahvu na harfi, na liri od deset žica veličajte njega! Pjesmu novu zapjevajte njemu i glazbala skladna popratite poklicima." URL: http://www.hbk.hr/biblija/sz/ps.htm\#ps141 (14.11.2019.).

136 Šilobod - Bolšić, Mihael. Fundamentum cantus gregoriani seu choralis. prir. i prev. Jelena Knešaurek Carić. Zagreb: L\&G, 2009. Str. 56-57: „Scias etenim vocalem musicam adhuc subdividi in choralem et figuralem. ... Potiori tamen iure dici consuevit cantus Gregorianus, ... Quia vero simplicibus notis constaret, a quibusdam nuncupatur planus, $a b$ Italis vero firmus ob stabilem temporis mensuram in notis servandam, ...".

${ }^{137}$ U Zagrebu je sačuvan samo jedan kantual iz 18. st. i to Cantuale processionum, tiskan u Beču 1751., dok su iz 17. st. sačuvani rukopisni kantuali Cantuale Ecclesiae Cathedralis Zagrabiensis MR 7 i Cantuale Ecclesiae Cathedralis Zagrabiensis MR 108, Hymnuale Ecclesiae Cathedralis Zagrabiensis MR 4, Fragmentum antiphonarii MR 179 i Liber antiphonarius MR 181. Osim toga, s kraja 17. st. sačuvani su i pasionali Kristofora Peršića Passionale Croaticum iz 1683. i Passionale latino-croaticum koji nije precizno datiran te pjesmarica Laus Dei iz 1749. Za cjeloviti popis vidi: Katalinić, Vjera. Pregled izvora o glazbenoj kulturi baroknog razdoblja na tlu SR Hrvatske. // Glazbeni barok u Hrvatskoj. Zbornik radova sa simpozija održanog u Osoru 1986. godine / Ennio Stipčević (ur.). Osor: Osorske glazbene večeri, 1989. Str. 20-47.
} 
glazbenih oblika za povijest crkvene glazbe Zagrebačke crkve (i šire), ovaj zbornik ostao nezapažen. “138

Dvadesetak godina poslije objave pretiska trećeg izdanja $\mathrm{CO}$ ovaj se rad zanima drugim slojem: načinom na koji tekst(ovi) objavljen(i) kao predgovor(i) - praefatio - zborniku u sva tri izdanja tumače fenomenološke, glazbenoteorijske, ontološke, etičke i estetičke aspekte glazbe same. Anakronizam o kojem govori Špralja i u ovom je slučaju, čini se, najizgledniji uzrok slabog zanimanja struke za spomenute teme.

Ne smijemo zaboraviti činjenicu da su svi izvori kojima se bavi ova disertacija pisani latinskim jezikom, a neolatinistička baština nerijetko je slabije vrednovana u odnosu na literarnu ostavštinu na vernakularu. ${ }^{139}$ Spomenutoj situaciji usprkos, svijest o postojanju i ulozi nemalog neolatinističkog korpusa u sveukupnoj povijesti polako je rasla tijekom proteklih desetljeća, osobito pak od šezdesetih godina prošloga stoljeća kada Vladimir Vratović i Veljko Gortan započinju sustavno bavljenje hrvatskim novovjekovnim latinizmom, što ga zatim nastavljaju Darko Novaković, Mirko Tomasović, Neven Jovanović, Irena Bratičević i drugi. ${ }^{140}$ U Hrvatskoj su istraživanja spomenutoga repertoara tekstova usmjerena prije svega na književnost u razdoblju humanizma i to iz razloga izvrsnosti. Tako će Darko Novaković u uvodu knjizi koja donosi najvažnija djela hrvatskih latinista utvrditi: „Iako je

\footnotetext{
138 Špralja, Izak. Cithara Octochorda ..., doktorski rad. Zagreb: Hrvatsko društvo crkvenih glazbenika, 1998. Str. 11-12.

${ }^{139}$ Koncepcijski različite povijesti nacionalne književnosti kao što su radovi Ive Frangeša (Povijest hrvatske književnosti. Zagreb: NZMH; Ljubljana: Cankarjeva založba, 1987.) Dubravka Jelčića (Povijest hrvatske književnosti: tisućljeće od Baščanske ploče do postmoderne. Zagreb: Naklada P.I.P. Pavičić 2004. ${ }^{2}$ ), Slavka Ježića (Hrvatska književnost od početaka do danas 1100.-1941. Zagreb, 1944.) i Slobodana Prosperova Novaka (Povijest hrvatske književnosti od Bašćanske ploče do danas. Zagreb: Golden marketing, 2003.) neolatinizmom se bave gotovo usputno. Pet stoljeća hrvatske književnosti posvećuje im 2. i 3. knjigu: Gortan, Veljko; Vratović, Vladimir. Hrvatski latinisti: Croatici auctores qui latine scripserunt. Zagreb: MH: Zora, 1969.-1970. Skup Dani Hvarskog kazališta posvećuje hrvatskom latinizmu 18. stoljeća nešto više prostora, ali i dalje je taj korpus u očitom nesrazmjeru s djelima pisaca hrvatskog jezičnog izraza. O nesrazmjeru između kapitalnog popisa Šime Jurića (Iugoslaviae scriptores Latini recentioris aetatis, Zagreb 1968-1971, Additamentum Zagreb 1982. dostupno na opak.crolib.hr/liste/045/ koji je još i danas polazna točka za istraživanje hrvatskog latinizma i kasnijim prikazima latinističkog dijela hrvatske književnosti v. Jovanović, Neven. Pred jednom zbirkom hrvatskih latinista. // Perivoj od slave: Zbornik Dunje Fališevac / uredio Tomislav Bogdan ... [et al.]. Zagreb: FF press, 2012. Str. 143-153.

${ }^{140}$ Usp. Gortan, Veljko; Vratović, Vladimir. Op. cit.; Vratović, Vladimir. Hrvatski latinizam i rimska književnost. Zagreb: Nakladni zavod MH, 1989. Novaković, Darko. Hrvatski latinisti: razdoblje humanizma. Zagreb: Erasmus naklada,1997. Vratović, Vladimir. Ogledi o hrvatskoj književnosti latinskoga izraza. Zagreb: Biakova, 2012. Hrvatskim latinizmom bave se Irena Bratičević (usp. https://www.bib.irb.hr/pregled/znanstvenici/262736), Vladimir Rezar (usp. https://www.bib.irb.hr/pregled/znanstvenici/219810) i Neven Jovanović (usp. https://www.bib.irb.hr/pregled/znanstvenici/211662).
} 
gotovo u svakom stoljeću hrvatskoga latinizma bilo i važnih djela i važnih autora, nema sumnje da njegovo najsjajnije razdoblje valja vidjeti u dvama stoljećima humanizma.“141

Uz navedene izvore, postoji i spomenuta rukopisna leksikografska ostavština koja se bavi temom glazbe, a koja do sada nije analizirana. Premda je nećemo uključiti u ovo istraživanje koje se bavi modelima diskursa o glazbi, a ne glazbenom leksikografijom, ukratko ćemo prikazati njezine autore i djela sâma. S obzirom da donose glazbenu latinističku i i ilirsku terminologiju u 18. stoljeću, neka buduća istraživanja će, nadamo se, uz pomoć riječi koje dvojica hrvatskih intelektualaca koriste (ili barem poznaju), a koje se odnose na glazbu, moći djelomice rasvijetliti glazbenu praksu viših slojeva hrvatskog društva. Ova ostavština uključuje Lexicon Latino - Illyricum Pavla Rittera Vitezovića te Dictionarium latinoillyricum et germanicum Adama Patačića.

Hrvatski književnik, povjesničar, jezikoslovac, pjesnik hrvatskih i latinskih stihova, tiskar i nakladnik Pavao Ritter Vitezović (Senj 1652. - Beč, 1713.), prema dostupnoj literaturi, slovio je za najučenijega čovjeka u Hrvatskoj svoga vremena. ${ }^{142}$ Diplomat koji je obavljao dužnosti banskoga i saborskoga predstavnika na bečkome dvoru od 1681. do 1687. i kapetana u hrvatskoj pukovniji Petra Ricciardija, postao je 1691. ličko - krbavski podžupan. Po povratku u Hrvatsku nastanio se u Zagrebu gdje je na biskupskome dvoru otkrio već skoro zaboravljenu tiskaru. „Uz biskupovu suglasnost, Vitezović je tiskaru prenio u Vlašku ulicu i osposobio je za rad. Odlukom Hrvatskoga sabora 1964. godine predana mu je na upravljanje kao javna tiskara. Od 1965. godine tiskao je u njoj povijesna, književna i jezikoslovna djela, prigodnice, molitvenike, kalendare i proglase te oživio kulturnu sliku Zagreba. Vitezovićeva je kuća 1706. potpuno izgorjela, a tiskara je teško oštećena. Ostavši bez ičega, obratio se caru Leopoldu I. koji mu je odobrio zakup imanja Šćitarjevo i skrbništvo nad duševno bolesnim zagrebačkim kanonikom grofom Ivanom Jonatom Ivanovićem. Tomu su se žestoko usprotivili turopoljsko plemstvo, Kaptol i Sabor te brojni utjecajni pojedinci, pa je Vitezović morao napustiti Zagreb i potražiti utočište u Beču. Po smaknuću Petra Zrinskoga i Frana Krste Frankopana u hrvatskome javnom mišljenju i u saboru stvorio se negativan odnos prema Austriji te su potaknute rasprave o Vitezovićevoj odanosti hrvatskoj domovini. Njemu, kao

\footnotetext{
${ }^{141}$ Novaković, Darko. Op. cit. Str. 7.

${ }^{142}$ Usp. Klaić, Vjekoslav. Život i djelo Pavla Rittera Vitezovića 1652.-1713. Zagreb, 1914. Bratulić, Josip. Pavao Ritter Vitezović utemeljitelj Hrvatske zemaljske tiskare u Zagrebu. // Senjski zbornik 22, 1995. Str. 179-186. Lisac, Josip. Pavao Ritter Vitezović kao leksikograf. // Prikazi i osvrti. Rasprave Instituta za hrvatski jezik $i$ jezikoslovlje. Knj. 36/2, 2010. str. 385-470. O Vitezovićevoj protonacionalnoj koncepciji v. Blažević, Zrinka. Vitezovićeva Hrvatska između stvarnosti i utopije. Ideološka koncepcija u djelima postkarlovačkog ciklusa Pavla Rittera Vitezovića (1652.-1713.). Zagreb: Barbat, 2002.
} 
legitimistu i dvorskomu savjetniku, bila je dužnost iz arhiva i knjižnica u Hrvatskoj i Slavoniji izdvojiti građu koja pripada kraljevskomu tisku te ga se zbog toga optuživalo kako radi protiv hrvatskih interesa, a u korist bečkoga dvora. Pavao Ritter Vitezović umro je 20. siječnja 1713. godine u bečkome svratištu Zlatni medvjed u velikoj oskudici i bijedi. “" ${ }^{143}$ Vrlo je vjerojatno kako su teške okolnosti posljednjih godina Vitezovićeva života razlog zbog kojega nikada nije tiskan njegov najveći jezikoslovni poduhvat Lexicon Latino - Illyricum. Rječnik Pavla Rittera Vitezovića Lexicon Latino - Illyricum čuva se u Metropolitanskoj knjižnici u Zagrebu pod signaturom MR 112. Riječ je o svesku veličine 21 x $16 \mathrm{~cm}$ od 572 uvezana lista od kojih je 566 listova paginirano. Rječnik je uredio Bojan Marotti koji je u suradnji sa Zrinkom Meštrović i Nadom Vajs koje su Rječnik kritički pročitale i upisale, 2000. uredio preslik rukopisa, a 2010. i prijepis i obradu Rječnika. Opsežno djelo u prijepisu obuhvaća 1057 paginiranih stranica nakon čega slijede supplementa, dodatni kratki tematski rječnici. ${ }^{144}$

Još jedan opsežan, no formalno i sadržajno posve drugačije koncipiran rječnik jest onaj Adama Patačića (Kaštel kraj Karlovca, 18. 02. 1716. - Kalocsa, Madžarska, 19. 07. 1784.), hrvatskog velikaša i leksikografa, nadbiskupa u Kalocsi i predsjednika Kraljevskoga vijeća budimskoga sveučilišta. U hrvatskim se glazbenim historiografijama spominje jer je na svom dvoru u Velikom Varadinu (danas u Rumunjskoj) uzdržavao stalni zbor i orkestar na kojem je kao maestro di cappella djelovao i Michael Haydn (1760. - 1765.), a naslijedio ga je Carl Ditters von Dittersdorf (1765-69). Tada je ansambl povećan na tridesetičetiri glazbenika, a prema Dittersdorfovim prijedlozima sagrađeno je i malo kazalište, u kojem je skladatelj organizirao i za koje je pisao glazbeno-scenske predstave. Zbog dvorskih spletki Patačić je 1769. smanjio ansambl i otpustio većinu glazbenika. Za Dittersdorfov oratorij Isak, lik otkupitelja (Isacco, figura del redentore), Patačić je sastavio libreto prema Metastasijevu predlošku, no libreto je danas izgubljen. Njegov Dictionarium latino-illyricum et germanicum ostao je u rukopisu i čuva se u Kalocsi, a zanimljiv je zbog koncepta kojim se odmiče od klasičnog rječnika i priklanja enciklopedijskom načinu izlaganja materijala. Patačić je Rječnik oblikovao kao niz od trinaest tematskih područja i više potpodručja s dosta enciklopedijskoga tumačenja na latinskom jeziku. S obzirom na opseg građe i činjenicu da ne postoji niti kritički

\footnotetext{
${ }^{143}$ Tekst objavljen povodom obilježavanja 300. obljetnice smrti P. Rittera Vitezovića u Katalogu NSK. URL: http://www.nsk.hr/obljetnica-rodenja-pavla-rittera-vitezovica/ (17.04.2019.).

${ }^{144}$ Ti dodani tematski rječnici obuhvaćaju: Lexicon Nominum propriorum et Festorum apud Illyrios celebriorum, Nominum Illyricorum Interpretatio; Nomina Sacrae Scripturae interpretata, Lexicon Verborum et Nominum Infantilium, Nominum Illyricorum Interpretatio, Nomenclatura Planetarum qua Poetice et qua Astronomice apud Illyrios nuncupatur, Item Deorum et Heroum apud Poetas celebratorum.
} 
prijepis teksta, analiza ovog Patačićevog Rječnika zahtijeva temeljit i multidisciplinaran istraživački rad. ${ }^{145}$

\subsection{Gregorijansko pjevanje u 17. i 18. stoljeću u Europi}

Gregorijansko pjevanje posebna je vrsta glazbe koja izvire iz liturgije, u njoj se oblikuje i izvodi te iscrpljuje svoju soteriološku, etičku i estetičku ulogu. Kao takvo predmet je posebnih muzikoloških studija stručnjaka koji se bave gregorijanskim pjevanjem i uza nj vezanom teorijom. Ta su istraživanja, što se periodizacijskog kriterija tiče, ograničena srednjim vijekom kako ga poima tradicionalna historiografija, dakle, od 5.-15. stoljeća, odnosno do razdoblja koje se prema talijanskim duhovnim postignućima naziva renesansom.

Razdoblje po završetku Tridentskog koncila pa sve do benediktinske reforme gotovo se bez iznimke naziva razdobljem dekadencije gregorijanskoga pjevanja u priručnicima povijesti glazbe. Ipak, suprotno uvriježenim mišljenjima koja ponavljaju gotovo svi glazbeni historičari, 17. i 18. stoljeće nisu stoljeća zatišja u produkciji jednoglasne crkvene glazbe ${ }^{146}$ usprkos činjenici da se čak i u najvećim monografijama posvećenima gregorijanskom pjevanju ovo razdoblje gotovo redovito preskače. Uzroke ne treba tražiti isključivo u slaboj obaviještenosti istraživača o rukopisnim i tiskanim kantualima ovoga razdoblja, premda vrlo skroman broj radova posvećenih stoljećima koja slijede Tridentskom koncilu, a prethode velikoj benediktinskoj reformi gregorijanskog pjevanja s kraja 19. st. ${ }^{147}$ sasvim sigurno doprinose općoj slici lakune. Oni, vrlo vjerojatno, počivaju i na nekritički prihvaćenom stavu naslijeđenom od protagonista benediktinske reforme prema kojemu svi gregorijanski napjevi koji reflektiraju utjecaj u renesansi nanovo otkrivene i slavljene antičke metrike ne zavređuju naziv gregorijanskoga pjevanja. ${ }^{148}$ David Hiley, primjerice, u svom opsežnom priručniku

\footnotetext{
145 usp. URL: http://www.enciklopedija.hr/natuknica.aspx?id=46960 (12.11.2019.)

${ }^{146}$ Karp, Theodore. An Introduction to the Post-Tridentine Mass-Proper. Middleton, Wisconsin: American Institute of Musicology, 2005. osobito Poglavlje 2 „A Checklist of Printed Graduals ca. 1590-1890“ i Poglavlje 11 „A Retrospective glance at the Eighteenth Century“.

$147 \mathrm{O}$ radu benediktinaca u opatiji Solèsmes na reformi gregorijanskoga pjevanja v. Combe, Dom Pierre. Histoire de la restauration du chant grégorien d'après des documents inédits. Abbaye Saint Pierre Solèsmes, 1968.

${ }^{148} \mathrm{Ne}$ možemo u ovoj disertaciji ulaziti u raspravu o (ne)ispravnosti ovoga stava. Činjenica jest, međutim, da je su se crkveni napjevi nastavili prepisivati i modificirati sukladno ukusu vremena te da je izum tiska, sasvim sigurno, baš kao i u književnosti, iz temelja izmijenio percepciju pjevane riječi te umanjio važnost dotad nezamjenjive improvizacije pri izvedbi. O intervencijama priređivača v. npr. Gillion, Marianne. Editorial endeavours: plainchant revision in early modern Italian printed graduals. // Plainsong and Medieval Music, 29,1, str. 51-80. URL: https://www.cambridge.org/core/services/aop-cambridge-
} 
Western Plainchant ${ }^{149}$ pretposljednje poglavlje posvećuje reformama gregorijanskoga pjevanja, ali se vremenski zadržava na razdoblju neposredno po završetku Tridentskog koncila. To kratko poglavlje jedino je mjesto gdje se posttridentske reforme i opstanak gregorijanike do velike reforme u 19. i 20. st. uopće spominju, ali ne i analiziraju. Razlog ignoriranja oblika gregorijanskoga pjevanja kakav promiče Editio Medicaea (1614.-1615.) za Hileyja je jasan i opravdan: ne radi se o srednjovjekovnoj inačici, već o reformiranim oblicima koji se priklanjaju estetici svoga vremena, prije svega ranobarokne monodije, ignorirajući srednjovjekovnu estetiku. „U glazbi uopće, razumljivost teksta bila je važna. Izdano je važno upozorenje da provincijske sinode trebaju uspostaviti glazbenu praksu poštujući lokalnu tradiciju i okolnosti. “ ${ }^{150}$ Govoreći o Anerijevoj i Sorianovoj reviziji tradicionalnog repertoara, ne može se zaobići činjenica da je repertoar osuvremenjen na način da godi uhu naviklom na deklamaciju teksta i jasno definirane moduse. Ono što je imalo najznačajnije posljedice, smatra Hiley, jest činjenica da je otvoren put zadiranju u repertoar.

Suprotno općeprihvaćenom i ponavljanom mišljenju o teškim političkim, gospodarskim i socijalnim, pa onda i kulturnim prilikama kao isključivim generatorima ovakve, skromne glazbene prakse u Hrvatskoj, svjetska istraživanja podastiru kudikamo složenije razloge. Uvažavajući neospornu činjenicu ekonomske prihvatljivosti monofonije uz orgulje ili bez njih u manjim i gospodarski slabije razvijenim sredinama, ne treba ipak zaboraviti na važnost ideologije koja dominira ne samo društvom u hrvatskim zemljama, već u svim zemljama u kojima postoji snažna veza svjetovne vlasti s katoličkom crkvom. U tom smislu, važno je spomenuti rezultate sve opsežnijih istraživanja sličnih fenomena u neizmjerno bogatijim sredinama poput Francuske, Španjolske, Njemačke i Austrije. Premda ne osobito brojna, posvjedočila su da su sve spomenute zemlje tijekom 17. i 18. stoljeća, tiskale velik broj kantuala i priručnika crkvenog pjevanja. ${ }^{151}$ Riječ je, dakako, o dosada slabo istraženom fenomenu katoličke obnove koji svoje ideje i načine njihova provođenja vrlo dobro otkriva upravo na području glazbe, točnije jednostavnijih formi vokalne crkvene glazbe temeljene na gregorijanskome pjevanju. U tom svjetlu, a u smislu pokušaja prevrednovanja razloga

core/content/view/C2D40C11E7BAA45E0BDB2D717340F654/S0961137120000066a.pdf/div-class-titleeditorial-endeavours-plainchant-revision-in-early-modern-italian-printed-graduals-div.pdf

${ }^{149}$ Usp. Hiley, David. Western Plainchant. A Handbook. Oxford: Clarendon Press, 1993., osobito str. 615-618.

${ }^{150}$ Ibid. Str. 614.: „In all music, intelligibility of the text was important. An important provision was made that provincial synods should establish musical practice with respect to local traditions and circumstances." Hiley s jedne strane ističe kako je svaki kantor mogao bez velikih poteškoća nastaviti svoj posao na temelju novih rimskih izdanja revidiranih tekstova i melodija, a s druge žali zbog potpunoga prekida s tradicijom i rezignirano odbacuje mogućnost analize melodija sačuvanih u kantualima 17., 18. i prve polovice 19. stoljeća kao gregorijanskih. V. o tome podrobnije na str. 57. Disertacije.

${ }^{151}$ Usp. bilj. 9. 
nastanka ovih priručnika i ,anakronističkog“ sadržaja što ga nude, ovaj će rad nastojati objasniti fenomen opstanka gregorijanskoga pjevanja, odnosno njegovih reformiranih inačica nazvanih istim ili drugačijim imenom, te diskursa o gregorijanskom pjevanju koji takvo pjevanje izjednačava s glazbom općenito u prvoj polovici 18. stoljeća. Pritom će se koristiti spoznajama iz povijesti, crkvene povijesti, povijesti školstva te filozofije, psihologije i sociologije glazbe, a u teorijskome okviru kulturne povijesti koja je i potaknula i omogućila ovakav tip multidisciplinarnog istraživanja. Kulturni krug unutar kojeg spomenuti diskurs vrijedi kao jedini ispravan, krug je čiji govor o glazbi počiva na naslijeđu patristike i srednjega vijeka, isprepliće povijest glazbe, etiku, estetiku, glazbenu teoriju i praksu (gregorijaniku). Osim toga, glazbu beziznimno vezuje uz tekst i njemu je potčinjava te se, ignorirajući suvremene i ne tako suvremene (npr. vokalna polifonija) glazbene prakse, oslanja na monofoniju i vjeruje u neupitnu moć njezina etičkoga djelovanja. Pritom ne inzistira na čistoći i izvornosti, kako se često pogrešno vjeruje, već pristaje uz melodiku blisku narodu kako bi mu približio i istaknuo važnost tekstovne poruke, očitujući na taj način svijest o suvremenim glazbenim potrebama.

Promatrani iz aspekta razvoja glazbenih oblika kako ih percipira tradicionalna historiografija, gregorijansko pjevanje kao glazbeni oblik u 18. stoljeću, jednako kao i vokalna monofonija himničkoga tipa, uistinu se doimaju irelevantnim glazbenim praksama: niti jedna temeljna studija opće povijesti glazbe ili povijesti glazbe 17. i 18. stoljeća ${ }^{152}$ ne spominje niti gregorijansko pjevanje niti crkvene glazbene oblike utemeljene na njemu, kao ni teorijske tekstove o njemu u ovom povijesnom razdoblju. Iznimku donekle predstavlja suvremeno izdanje The Cambridge History od Eighteenth-Century Music iz 2011. u kojem je cijelo prvo poglavlje posvećeno crkvenoj, katoličkoj i protestantskoj glazbi razlikujući ove dvije prakse i registrirajući još uvijek snažan utjecaj tradicionalne liturgijske glazbe utemeljene na gregorijanskom pjevanju kakvim ga definira posttridentska praksa. ${ }^{153}$ Svijesti o važnosti velikih skladateljskih imena pridodana je i svijest o važnosti okruženja u kojem glazba nastaje, sklada se i izvodi, koju je u istom tom 18. stoljeću istaknuo jedan od prvih velikih

\footnotetext{
${ }^{152}$ Usp. npr. The Oxford History of Western Music. Sv. II, The Seventeenth and Eighteenth Centuries / uredio Richard Taruskin. Oxford: New York: 2005. Grout, Donald Jay; Burkholder, J. Peter; Palisca, Claude V. A History of Western Music. NY: W. W. Norton \& co. 2006. ${ }^{7}$; The Cambridge History of Eighteenth-Century Music / uredio Simon P. Keefe Cambridge: Cambridge University Press, 2011.

${ }^{153}$ Usp. The Cambridge History of Eighteenth-Century Music. Str. 27-180. Poglavlja posvećena crkvenoj glazbi razdvojena su po načelu kršćanske denominacije -katoličanstvo, luteranstvo, protestantizam- i zemljopisnom određenju kako slijedi (poglavlje 1. nosi naziv The Musical Map of Europe i prethodi prvome dijelu knjige): 2. Catholic Church Music in Italy, and Spanish and Portuguese Empires; 3. Catholic Sacred Music in Austria; 4. Catholic Church Music in France; 5. Lutheran Church Music; 6. Protestant Church Music in England and America.
} 
povjesničara glazbe Charles Burney: „Svakako, dostignuća pojedinaca bila su važna; no, jednako je značajno bilo i okruženje u kojem su djelovali. Kao što je Charles Burney napisao: 'Glazba, baš kao i vegetacija, različito cvate u različitim klimama; i u proporciji s kulturom i poticajem koji prima.'“154 Ipak, niti uvodni tekst knjizi, niti pojedinačna poglavlja koja obrađuju katoličku crkvenu glazbu u Italiji, Španjolskoj, Portugalu, Austriji i Francuskoj ne dotiču se najrasprostranjenijeg tipa crkvenog muziciranja - liturgijskog gregorijanskog pjevanja usklađenog s ukusom 18. stoljeća, kakvo svjedoče brojni objavljeni zbornici napjeva diljem spomenutih zemalja i koje podučavaju priručnici o čijim domaćim inačicama raspravljamo u ovome radu. Dapače, u suprotnosti s najavljenom sviješću o različitim kontekstima koji potiču i raznolikost praksi, ograničavaju se isključivo na poznata skladateljska imena zaposlena kod bogatih biskupa i jednako poznate skladatelje koji su djelovali na raznim europskim dvorovima onoga vremena što, uz iznimku funkcije glazbenog djela, predstavlja u stvari vrlo sličan okvir za djelovanje. ${ }^{155}$

U The New Oxford History of Music izdana 1975. u 11 svezaka, u petom svesku posvećenom razdoblju baroka, a vremenski omeđenom 1630. i 1750. godinom, analiziraju se opera i crkvena glazba kao dva žanra (svodeći svo bogatstvo formi crkvene glazbe pod jedan zajednički nazivnik) koja dominiraju ovim razdobljem. U sklopu potonje, unatoč razvedenom prikazu glavnih oblika prema kriteriju geografskih/nacionalnih posebnosti ${ }^{156}$, gregorijansko pjevanje svoje je skromno mjesto pronašao tek u poglavlju o francuskoj glazbi. I dok u Njemačkoj i Austriji supostoji s visokobaroknim formama mise, oratorija, instrumentalne glazbe i vrlo razvijene tradicije duhovnih kantata i oratorija, o čemu svjedoče brojni objavljeni priručnici za njegovu poduku, u Francuskoj ga štiti chapelle royale u kojoj čini važan temelj ne samo spomenutih velikih moteta i duhovnih koncerata, već i jednostavnih duhovnih napjeva zvanih cantiques spirituels. Snažna tradicija gregorijanskog pjevanja, kasno prihvaćanje prakse bassa continua i favoriziranje velikog moteta transformiranog u duhovni koncert, sačuvali su važnost i dostojanstvo le chant gregorien također sve do pred kraj 18. stoljeća. U Francuskoj su se, međutim, razvila i dva osobita tipa gregorijanskoga pjevanja od kojih se raniji naziva le plainchant musical i gotovo je u cijelosti vezan uz djelovanje

\footnotetext{
${ }^{154}$ Ibid. „Certainly the achievements of individuals were important; but equally significant were the environments in which they worked. As Charles Burney wrote: 'Music, indeed like vegetation, flourishes differently in different climates; and in proportion to the culture and encouragement it receives." "“ ${ }^{155}$ Usp. Rose, Stephen. The Musical Map of Europe. op. cit. str. 7-25. i dalje poglavlja navedena u bilj. 24. ${ }^{156}$ V. The New Oxford History of Music. V. sv. Opera and Church Music / uredili Nigel Fortune; Lewis, Anthony. London: Oxford University Press, 1975.
} 
uglednog orguljaša i kantora Guillaumea Gabriela Niversa (1632-1714). Nivers je priredio niz graduala za potrebe samostana časnih sestara franjevačkog, augustinskog i benediktinskog reda, ali i nemali broj antifonala, procesionala, pasija i lamentacija. Premda je „kao što je pokazao u svojoj Raspravi o gregorijanskom pjevanju - bio kudikamo svjesniji povijesnog puta gregorijanskog pjevanja od prosječnog suvremenika“157, vrlo je slobodno koristio moduse i tonove (koristi fis, cis i gis) kojima stvara polustepene ukrase u melodici, inače strane gregorijanskom pjevanju, no melodije općenito zadržava strogima i više deklamatornima no pjevajućima. „Premda zadržava gregorijanske tekstove, modalnost njegovih melodija vrlo se često razlikuje od onih iz gregorijanskoga repertoara." ${ }^{158} \mathrm{Uz}$ Niversa i njegov model monofonije, u Francuskoj je od kraja 17. do sredine 19. stoljeća cvala, dosad relativno slabo istražena, praksa neogalikanskoga pjevanja. Slično kao i u hrvatskim izvorima, radi se o djelomičnoj intervenciji u rimski obrednik, s ciljem očuvanja određene razine neovisnosti liturgije od modela koji propisuje rimski obrednik. ${ }^{159}$

Prva velika inicijativa za reformiranje gregorijanskoga pjevanja, ujedno i najpoznatija u glazbenoj i općoj historiografiji, provedena je kao nuspojava odredbi velikog Tridentskog koncila, održanog s namjerom da pokuša povratiti poljuljani ugled katoličke crkve te odgovoriti na izazove koje je na terenu postavljao protestantizam na čiji uspjeh, čini se, Rim nije bio spreman. Najvažnije odredbe koncila vezane uz reformu crkvene glazbe donosi dragocjeni pregled papinskih dokumenata koji se odnose na glazbu autora Roberta F. Hayburna Papal legislation on sacred music, 95 A.D. to 1977 A.D. ${ }^{160}$ Bez obzira na njihovu relativnu brojnost, moglo bi ih se svesti na zahtjev za uzvišenom i dostojanstvenom melodijom, lišavanjem napjeva bespotrebnih ukrasa te nadasve brigu oko razumljivosti teksta.

Tridentsku reformu gregorijanskoga pjevanja i val intervencija u tradicionalno crkveno pjevanje koje je potaknula, sažeto je prikazao David Hiley u spomenutom priručniku o gregorijanici. „Sljedeća velika reforma gregorijanskoga repertoara dogodila se kao posljedica Tridentskog koncila i može se promatrati kao dio protureformacije. Ovo opsežno

\footnotetext{
157 „Nivers was unquestionably a highly learned man, and - as demonstrated in his Dissertation sur le chant gregorien - far more aware of the historical panorama of Gregorian chant than his average contemporary.", u: Karp, Theodore. Op. cit. Sv. 1, str. 207.

158 Ibid.

${ }^{159}$ Budući da je motiv sličan, baš kao i postupci, komparativna analiza neogalikanskog obreda i zagrebačkog obreda (koji je ukinut 1797. odlukom Maksimilijana Vrhovca) sasvim bi sigurno donijela zanimljive rezultate. Neogalikansko pjevanje od službenog gregorijanskoga pjevanja može se razlikovati na jedan od sljedeća tri načina: 1) razlikuje se melodija i tekst; 2) poznatome tekstu pripisuje se nova melodija; 3) poznatoj melodiji dodaje se nabožni tekst koji nije službeno potvrđen od Rimske crkve.
}

${ }^{160}$ Usp. Hayburn, Robert F. Op. cit. 
propitkivanje rimskog gregorijanskoga repertoara bilo je, međutim, samo početak niza preinaka repertoara u drugim zemljama, osobito u Francuskoj gdje je tzv. 'neogalikansko pjevanje' nastalo kao zamjena za srednjovjekovne ili novije rimske melodije.“161

Objašnjavajući prirodu zahvata u melodiku, ritmiku i agogiku srednjovjekovnih napjeva, zaključuje:

„Drastična narav revizije Anerija i Soriana ne smije biti podcijenjena. Bila je to cjelovita preinaka repertoara sukladno estetičkim principima humanističkoga doba, a proveli su je skladatelji čiju je glazbenu senzibilnost oblikovala polifona crkvena glazba Palestrine i njegovih suvremenika. ... Kameni - temeljci revizije bili su modernizacija tonalnosti i preraspodjela tonova tako da ispravno odražavaju pravila deklamacije, na način da nenaglašeni slogovi nemaju više tonova od naglašenih.“"162

No ne treba se zavaravati pompoznošću korištenog vokabulara u opisu revizije, odnosno spomenutom drastičnošću intervencija, barem što se tiče teksta: , Novi Rimski brevijar i misal Pija V (...) ni na koji način nisu značili drastičnu reviziju tradicionalnih tekstova, i prosječni kasnosrednjovjekovni kantor smatrao bi ih prilično uobičajenima. “163

Ipak, jednom kada se započelo s preinakama postojećeg repertoara pod egidom pročišćavanja i uređivanja, a s ciljem veće razumljivosti teksta, kraj intervencijama nije se nazirao tijekom sljedeća dva stoljeća: ${ }^{164}$ „No, sjeme književne i glazbene pobune protiv srednjovjekovnog naslijeđa posijano je, i tijekom sljedeća dva stoljeća pojavio se velik broj posve novih knjiga u kojima su tekstovi i melodije bili revidirani ili u cijelosti zamijenjeni novima. “165 Uz velik broj kantuala objavljenih u Italiji i Španjolskoj, ,nove su kantuale osobito energično

\footnotetext{
${ }^{161}$ Hiley David. Op. cit. Str. 609.: „The next major reform of the chant repertory took place in the aftermath of the Council of Trent and can be regarded as part of the Counter-Reformation. This radical overhaul of the Roman chant repertory was but the beginning of a series of recastings of the repertory in other lands, particularly in France, where so-called 'neo-Gallican' chant was written as a substitute for the medieval or the newer Roman melodies."

162 Ibid. Str. 616.: „The drastic nature of the Anerio-Soriano revision cannot be understated. It was a complete recasting of the repertory according to the aesthetic principles of the humanist age, carried out by composers whose musical sensibilities were formed by the polyphonic church music of Palestrina and his contemporaries. ... The corner-stones of the revision were modernization of the tonality and rearrangement of the notes to reflect correct declamatory principles, so that unaccented syllables should not have more notes than accented ones." ${ }^{163}$ Ibid. Str. 618.: „The new Roman breviary and missal od Pius V (...) were by no means drastic revisions of the traditional texts, and would have been found quite normal by the average late-medieval cantor."

${ }^{164}$ Hiley govori o dva stoljeća objavljivanja novih kantuala, međutim, sve do reforme gregorijanskoga pjevanja po uzoru na srednjovjekovno u drugoj polovici 19. st. radilo se u stvari o preinakama starog repertoara prema vladajućem glazbenom ukusu.

${ }^{165}$ Ibid.: „But the seeds of literary and musical revolt against the medieval heritage were sown, and the next two centuries were to see large numbers of quite new books where texts and melodies were revised or completely replaced.“
} 
sastavljali u Francuskoj ... Mnoge druge crkvene knjige iz osamnaestog i ranog devetnaestog stoljeća, osobito one objavljene u Njemačkoj, također su svjedoci pokušaja reforme gregorijanskoga pjevanja u skladu sa suvremenim ukusom. Kao primjer mogu poslužiti one koje je sastavio Reiner Kirchrad u Bonnu (Theatrum musicae choralis, Köln, 1782.) i Caspar Ett u Münchenu (Cantica sacra iz 1827., s orguljskom pratnjom).“166

Revitalizacija gregorijanskoga pjevanja kojeg je crkva nastojala provesti kroz priručnike izdavane tijekom i neposredno nakon Tridentskog koncila, vidljiva je, osim u velikom broju tiskanih kantuala, i u porastu broja priručnika o takvom pjevanju ne samo u manjim sredinama, već i u gradovima s iznimno dobro razvijenim glazbenim životom poput Leipziga, Münchena, zatim Pariza, Beča i ostalih u kojima se tiskao velik broj takvih djela. „Suvremena djela koja nude raspravu o gregorijanskom pjevanju ili upute (sc. za pjevanje, op. a.), temeljna su za razumijevanje onovremenih stavova.“167

\subsection{Opstanak musica theorica}

O šarolikosti stavova iskazanih u takvim djelima, ali i o čvrstoj ukorijenjenosti u tradiciju glazbene teorije te insistiranju na srednjovjekovnoj baštini svjedoče brojni primjeri, pa i oni najpoznatiji u bogatoj povijesti teorije glazbe. Johanna Matthesona (1681. - 1764.), njemačkog teoretičara iz Hamburga čiji je opus i danas nezaobilazna povijesna činjenica $u$ svim glazbenim historiografijama, neposredno po objavljivanju njegova znamenitog djela Das neu-eröffnete Orchestre (1713.) na muzikološki dvoboj izazvao je Johann Heinrich Buttstet (1666. - 1727.), pristalica teološko-teorijskog sistema Andreasa Werckmeistera, koji je između 1715. i 1717. u Leipzigu objavio djelo Ut, mi, sol, re, fa, la, tota musica et harmonia aeterna; oder Neu-eröffnetes, altes, wahres, eintziges und ewiges Fundamentum musices, entgegen gesetzt dem neu-eröffneten Orchestre. U njemu se bori za povratak crkvenim modusima i Guidovom sistemu solmizacije kakav, pokazat ćemo u sljedećim poglavljima, promoviraju hrvatski teoretičari, kao i njihovi talijanski kolege franjevci. Johann Baptist Samber (1654. - 1717.), orguljaš i pedagog, objavio je nekoliko priručnika namijenjenih prije

\footnotetext{
${ }^{166}$ Ibid. Str. 618, 620.: „The making of new chant-books was particularly energetic in France ... Numerous other books of the eighteenth and early nineteenth centuries, especially those published in Germany, are likewise witness to attempts to reform plainchante in accordance with contemporary taste. Those produced by Reiner Kirchrad in Bonn (Theatrum musicae choralis, Cologne, 1782) and Caspar Ett in Munich (Cantica sacra, 1827, with organ accompaniment) are examples.“

${ }^{167}$ Ibid. Str. 621.: „Contemporary works which offer discussion of or instruction in plainchant are essential for an understanding of the attitudes current in those times."
} 
svega orguljašima, ali i skladateljima. Posljednje njegovo djelo tiče se muzičke prakse katoličke crkve, odnosno musica choralis kako je pisac naziva, a citira ga i Mihael Šilobod Bolšić. Djelo je objavljeno u Salzburgu 1710. pod naslovom Elucidatio musicae choralis; Das ist, Gründlich und wahre Erläuterung oder Unterweisung, wie die edle und uralte Choral-Music fundamentaliter nach denen wolgegründten Reglen mit leichter Mühe möge erlehrnt werden ...

Meinrad Spiess (1683. - 1761.) predstavljao je snažnu konzervativnu glazbenu struju u Njemačkoj 18. stoljeća. Usprkos progresivnim teorijama koje su zastupali Johann David Heinichen (1683. - 1729.) i Johann Mattheson, Spiess je predstavnik iznimno velikog broja tradicionalista koji su, poput Johanna Josepha Fuxa dva desetljeća ranije, nastojali oko očuvanja crkvenih modusa i gregorijanskoga pjevanja te i dalje inzistirali na važnosti matematičkog i fizikalnog aspekta muzičke teorije. Njegovo je djelo Tractatus musicus compositorio-practicus; Das ist Musicalischer Tractat, in welchem alle gute und sichere Fundamenta zur musicalischen Komposition aus denen alt- und neusten besten Autoribus herausgezogen, zusammen getragen, gegen einander erhalten, erkläret, und mit unterseltzem Exemplen dermassen klar und deutlich erläutert werden ... objavljeno 1745. i, kao i većina njemačkih traktata iz 18. stoljeća, uz spomenuto pristajanje uz tradicionalnu muzičku praksu, donosi zanimljivu mješavinu neolatinizma i njemačkog jezika. Uz jasno naznačen praktičan karakter djela, veliku pažnju pridaje muzičkoj teoriji vezanoj uz matematičke i fizikalne zakone te etičku funkciju glazbe utemeljenu u antičkoj filozofiji i kršćanskoj teologiji. Podjednako konzervativnim pokazao se i Francesco Antonio Vallotti (1697. - 1780.) koji je razvio opsežan glazbenoteorijski sustav oslanjajući se prije svega na matematičko (numeričko) tumačenje glazbe: čak je i konzervativnog Fuxa smatrao suviše naprednim zbog prihvaćanja renesansnih modusa. ${ }^{168} \mathrm{U}$ rukopisu su ostala tri sveska Vallottijevih istraživanja, od kojih se Trattato dei tuoni modali, si ecclesiastici corali, che musicali ed armoniali. I: Compendio storico de'tuoni modali della musica greca, del canto ecclesiastico, del canto figurato e della moderna musica; II: Trattato de'tuoni modali, in cui si tratta dei dodici tuoni

\footnotetext{
$168 \mathrm{O}$ renesansnim modusima u odnosu na srednjovjekovne i njihovoj uvjetovanosti monodijskom, odnosno polifonom kompozicijskom praksom v. Powers, Harold S. Tonal Types and Modal Categories in Renaissance Polyphony. // Journal of the American Musicological Society. 34/3, 1981, str. 428-470./ URL: http://links.jstor.org/sici?sici=0003-0139\%28198123\%2934\%3A3\%3C428\%3ATTAMCI\%3E2.0.CO\%3B2-T
} 
ecclesiastici e corali iz 1733. - 1735. osobito bavi jednoglasnim crkvenim pjevanjem i tonusima. 169

Svi nabrojani tekstovi, njihov opseg i važnost koju su imali u vrijeme svoga nastanka, kao i posvjedočeni ugled njihovih autora ukazuju na mogućnost razumijevanja domaćih izvora kao aktualnih i suvremenih, a njihovih pisaca kao teoretičara svjesnih aktualnih potreba i glazbenih kretanja u okvirima crkvene glazbe.

Ulogu i praktičnost primjene musica choralis kao sredstva za širenje vjerskih istina izvrsno je razumio i iskoristio protestantizam ${ }^{170}$. Upravo je koral, odnosno njegova harmonizirana inačica s tekstom na narodnom (njemačkom) jeziku bila simbolom demokratizacije crkve i liturgije, a simplifikacija meloritamskog obrasca po uzoru na pučke melodije te korištenje vernakulara umjesto latinskog jezika bili su jedno od najvažnijih oružja u borbi protiv katoličanstva $^{171}$. Snažna protureformacija koja je uslijedila tijekom prve polovice 17. stoljeća nije odmah prepoznala značaj ovog luteranskog poduhvata. Ipak, kako se protestantizam širio Europom, katolička je crkva uvidjela plodove korištenja narodu bliskih melodija te narodnoga jezika kao modusa približavanja crkvenih dogmi širim slojevima. To je osobito vidljivo u Habsburškoj monarhiji u kojoj, sve do ukidanja crkvenih redova i aboliranja ,prijestupnika“ u vjerskim pitanjima 1780., još od cara Ferdinanda traje poseban oblik protureformacijskog djelovanja, odnosno katoličke obnove. U hrvatskim su krajevima postupno preuzimane melodije narodnih pjesama kojima je pridodavan nabožan tekst na latinskom ili vernakularu i vice versa: gregorijanskim se melodijama potpisivao tekst nabožnog karaktera što je oboje izvrsno dokumentirano u zborniku Cithara Octochorda. ${ }^{172}$ Stoga, nakon stoljeća

\footnotetext{
${ }^{169}$ Vallottijeva su djela, osim Della scienza teorica e practica della moderna musica koje je objavljeno u Padovi 1779., ostala u rukopisu sve do sredine 20. stoljeća unatoč činjenici da su ga suvremenici iznimno cijenili. O njemu je iscrpno pisao Giulio Cattin koji je uredio zbornik Francescantonio Vallotti nel Il centenario della morte (1780-1980): Biografia, catalogo tematico delle opere e contributi critici. Padova: Messaggero, 1981. ${ }^{170}$ Andreas Werckmeister čiji je traktat Musicalische Temperatur objavljen u Frankfurtu na Majni 1691. zbog površnog čitanja i pogrešnog razumijevanja, sveden na manifest unificiranja polustepena i temperiranja ljestvice, bio je iznimno pobožan orguljaš čija je muzička teorija snažno usidrena u onu srednjovjekovnu, ali i u skolastičku filozofiju. Upravo zbog insistiranja na kombiniranju mističkih i metafizičkih spekulacija o matematičkoj prirodi glazbe kao produktu Božjeg uređenja svijeta, prilagodio je metafiziku i etiku protestanstkog korala praksi dvaju najčešće korištenih modusa - dorskog i jonskog kao ekvivalenta dura i mola. O Werckmeisteru su pisali brojni muzikolozi. Najiscrpnija je svakako disertacija Ursule Hermann Andreas Werckmeister (1645-1706) obranjena na Sveučilištu u Halleu 1950. te članak Dammann, Rolf. Zur Musiklehre des Andreas Werckmeister. // Archiv für Musikwissenschaft, 11/3 (1954): 206-237 (prema Dammschroder, David; Williams, David Russel. Music Theory from Zarlino to Schenker. A Bibliography and guide. New York: Pendragon Press, 1990. Str. 383.)

${ }^{171}$ Usp. Jedin, Hubert. Velika povijest crkve V: Crkva u doba apsolutizma i prosvjetiteljstva. Zagreb: KS, 1978. ${ }^{172}$ Usp. Gavazzi, Milovan; Bezić, Jerko. Elementi narodnoga melosa u zborniku Cithara octochorda. // Cithara octochorda. Zagreb, 1757. 2. sv. Komentari i studije. / uredili Milan Moguš i Lovro Županović. Zagreb: HAZU: Institut za crkvenu glazbu „Albe Vidaković“ KBF Sveučilišta u Zagrebu: Hrvatsko društvo crkvenih glazbenika, 1998. Str. 261-280.
} 
iskorištavanja ,izvornog“ oblika crkvenog pjevanja kao podloge sve razvijenoj polifoniji, vokalna monodija ponovno postaje poželjnim oblikom muziciranja i značajnim sredstvom vjerske propagande, a kontrafaktura omiljeni postupak u približavanju gregorijanske melodije narodnom nabožnom tekstu i prilagođavanju biblijskih tekstova puku poznatim i bliskim melodijama.

Dakle, usprkos općem istjerivanju iz službene glazbene historiografije, gregorijansko pjevanje i na njemu utemeljena duhovna monofonija, opstaje tijekom cijelog 17. i 18. stoljeća u svim sredinama Europe u kojima katolička crkva čini važan element društvenog ustroja. To je slučaj u Habsburškoj monarhiji, ali i u Italiji, južnoj Njemačkoj, Španjolskoj i Francuskoj. ${ }^{173}$

Barem su tri moguća razloga sustavnom ignoriranju bogate gregorijanske (ili dekadentne gregorijanske) produkcije tijekom baroknog razdoblja. Prvi je pluralnost stilova u baroku koji je, kao malo koje drugo stilsko razdoblje obilovao raznolikim glazbenim praksama. Ta se pluralnost najjasnije zrcali upravo u crkvenoj glazbi složenoj od niza tematski povezanih, a izričajem udaljenih glazbenih vrsta. Od gregorijanskoga pjevanja, preko nabožnih jednoglasnih napjeva pučkoga porijekla, do četveroglasno obrađenih gregorijanskih napjeva uz orgulje ili bez njih, od virtuoznih polifonih skladbi, veličanstvenih oratorija i crkvenih kantata, preko instrumentalne glazbe za tipke do zahtjevnih crkvenih trio sonata, crkvena glazba obuhvaća gotovo sve postojeće glazbene oblike, osim opere. Upravo zbog iznimne umjetničke privlačnosti potonjih, jednoglasno pjevanje ostaje po strani. Drugi razlog nalazimo u pozitivističkoj historiografskoj logici nužnosti prikaza razvoja u koji se naoko statična gregorijanika, čiji izričaj ima vrlo ograničenu mogućnost diferencijacije u odnosu na višeglasna djela, bilo vokalna bilo instrumentalna, ne uklapa. Treći i možda najvažniji razlog jest afirmacija estetičkih principa formalizma i transcendentalizma u ranom 19. stoljeću koji smatraju da „su sadržaj i značenje glazbe sadržani unutar ili obuhvaćeni isključivo svojim glazbenim elementima, svojim notama i svim njihovim značajkama i obrascima, kao suprotnost ideji da značenje proizlazi iz bilo kakve reference izvanjske glazbi (doktrina mimesisa), odnosa prema slušatelju (doktrina katarze), ili iz glazbine povezanosti s običnim svijetom konkretnih značenja““174, ma što ta konkretna značenja značila. Pretendirajući tako na

\footnotetext{
${ }^{173} \mathrm{O}$ njegovoj nesmanjenoj važnosti govore i veliki traktati posvećeni isključivo gregorijanskom pjevanju, objavljivani u kasnom baroku u Italiji, Francuskoj, Njemačkoj i Španjolskoj. Bogatstvo graduala objavljenih tiskom izvrsno ilustrira drugo poglavlje „A Checklist of Printed Graduals ca 1590-1890“ u knjizi Theodorea Karpa An Introduction to the Post-Tridentine Mass Proper: Text (Musicological Studies and Documents). Middleton, Wisconsin: American Institute of Musicology. Str. 11-78.

${ }^{174}$ Goehr, Lydia. Writing Music History. // History and Theory, 31 (1992), str. 182-199. URL:

https://www.jstor.org/stable/2505596 (14.11.2018.). Str. 191: ,'Formalism' - understood as the doctrine that
} 
cjelovitost prikaza razvoja glazbe kao autonomne umjetnosti, i najveći su povijesni prikazi, kao što smo vidjeli, nužno zaobišli mnoge prakse. Među onim prešućenima, najčešće se nalazi upravo gregorijansko pjevanje i nabožna pučka pjesma. ${ }^{175}$ Suprotno od ideala formalizma, ne samo gregorijansko pjevanje, nego i sva barokna glazba, snažno su vezani uz Državu i Crkvu servisirajući prije svega njihove ceremonijalne i obredne potrebe: „Smatrana je (sc. glazba) dijelom društvenoga svijeta čijoj je dobrobiti pridonosila svojim sudjelovanjem u vjerskim, političkim i privatnim ritualima. Smatrana je vrijednom zahvaljujući svojoj ovisnosti o neglazbenim institucijama, o svijetu prirode i o jeziku i jezičnim umjetnostima. “176 No, i u kasnijim razdobljima u kojima je, barem u historiografiji i estetici nastojala steći samostalnost uz pomoć ideje autonomije glazbenoga djela ,[G]lazba utjelovljuje svoju povijesnost kada kroz svoje institucije, funkcije, tradicije i okolnosti izvedbe i prijenosa, svoje tehnologije, $\mathrm{i}$ odnose s drugim umjetnostima, propisuje ili zrcali društvene i kulturne obrasce te prevladavajuće ideologije koje konstituiraju povijesne kontekste njezina nastanka.“177

music's content and meaning are contained within or comprised by its musical element salone, its notes and all their propoerties and patterings, as opposed to the idea that meaning arises out of any sorto f reference outside the music itself (e.g. the doctrine od mimesis), out of rhe relation to a listener (e.g. rhe doctrine of catharsis), or out of music's 'connection to the ordinary world of concrete significance."

${ }^{175}$ O problemu ignoriranja „,nenaprednih“ crkvenih oblika u povijesti glazbe, kao i teškoćama koje se pojavljuju pri pokušaju njihova integriranja u prikaz glazbenog života u18. stoljeću usp. Lutteken, Laurenz. Konfession und Säkularisation. Zu den Schwierigkeiten der Musikgeschichtsschreibung mit der Kirchenmusik des 18.

Jahrhunderts. // Musik aus Klostern Alpenraums / uredili Peter Lang; Giulio Castellani. Peter Lang AG: 2010.

176 Treitler, Leo. The Historiography of Music: Issues of Past and Present. // Rethinking Music / uredili Nicholas Cook; Mark Everist. Oxford: Oxford University Press, 1999. Str. 356-377. Str. 372.: „It was regarded as part of the social world, to whose welfare it contributed through its participation in religious, political, and domestic rituals. It was considered significant by virtue of its dependence on non-musical institutions, on the natural world, and on lanuage and the language arts."

${ }^{177}$ Ibid. Str. 366.: „Music embodies its historicity when, through its institutions, its functions, its traditions and conditions of performance and transmission, its technologies, its relationships with the other arts, it enacts or mirrors the societal and cultural patterns and practices and the prevailing ideologies that constitute the historical contexts of its creation." 


\subsection{Cantus gregorianus i pučke nabožne popijevke u Hrvatskoj u 17. i 18. stoljeću: domaća glazbena historiografija o monodijskom pjevanju u baroku}

Rečena raširenost prakse cantus gregorianus u Europi te snažna promocija crkvenoga pjevanja u sklopu katoličke obnove diljem staroga kontinenta nije zaobišla niti hrvatske zemlje. Cilj priručnikâ Tome Kovačevića i Mihaela Šiloboda-Bolšića jest što ispravnija izvedba gregorijanskoga pjevanja, odnosno monodijskog pjevanja srodnog gregorijanskome i nastalog po uzoru na nj. Svrha pjevanja i sudjelovanja u pjevanim dijelovima mise tema su pak uvodnika svih triju (osobito drugog i trećeg) izdanja Cithara Octochorda. Svi ovi tekstovi našli su mjesto u povijesnim prikazima hrvatske glazbe, najčešće samo kao kratka informacija o autoru, vremenu nastanka i sadržaju. Iznimka je treće izdanje Cithara Octochorda koje je pretiskano, a njegov je sadržaj analiziran u drugom svesku nazvanom Komentari $i$ studije. ${ }^{178} \mathrm{I}$ tom prigodom, međutim, nisu analizirani uvodni tekstovi kao izvori informacija o načinu promišljanja glazbe u prvoj polovici 18. stoljeća.

U knjizi muzikologa Ennija Stipčevića Hrvatska glazba, općem prikazu povijesti hrvatske glazbe do 20. stoljeća, 18. stoljeće nazvano je prividnim zatišjem. ${ }^{179}$ Naslov svjedoči odmak od dotada uvriježenoga stava o 18. stoljeću u sjevernoj Hrvatskoj, kao o razdoblju u kojem je doprinos domaćih umjetnika glazbenoj umjetnosti bio gotovo nepostojeći, uz iznimku takozvanog Varaždinskog skladateljskog kruga krajem stoljeća. Taj se odmak ogleda dakako u pridjevu ,prividno“ koji daje naslutiti postojanje barem nekakve glazbe unatoč zatišju koje dominira zamišljenom zvučnom slikom razdoblja, prije svega zbog nepostojanja materijalnih dokaza u obliku sačuvanih partitura. Te bi partiture trebale posvjedočiti ono što autor naziva „profesionalizam i zastupljenost svjetovne glazbe“ ${ }^{\text {(180 }}$, osobito u prvoj polovici stoljeća kada su „,razvijena glazbena žarišta bila (su) smještena u većim gradskim sredinama, ponajviše katedralama s duljom i življom glazbenom tradicijom. Na prijelazu iz 17. u 18. st. u nizu manjih mjesta, koja su povezivala hrvatski sjever i jug, glazbenim su zbivanjima upravljali skromniji glazbenici, najčešće redovnici““181.

\footnotetext{
${ }^{178}$ Cithara Octochorda, Zagreb 1757. sv. 1, Komentari i studije sv. 2 / uredili Milan Moguš i Lovro Županović. Zagreb: HAZU: Institut za crkvenu glazbu Albe Vidakovićc "KBF Sveučilišta u Zagrebu: Hrvatsko društvo crkvenih glazbenika, 1998.

${ }^{179}$ Usp. Stipčević, Ennio. Op. cit. (1997).

${ }^{180}$ Ibid. Str. 121.

${ }^{181}$ Ibid.
} 
Nastavak je to situacije u glazbenoj kulturi 17. stoljeća u Hrvatskoj kada su „u drugoj polovici dominirale anonimne glazbene tvorevine, zabilježene uglavnom u rukopisnim muzikalijama i glazbeno liturgijskim priručnicima. Kontinuitet pojedinih glazbenih oblika i disperzivnost nekih skladateljskih postupaka pružaju sliku o naglašenim težnjama za međusobnom povezanošću glazbenih regionalnih prostora u Hrvatskoj. Zbog te naglašene težnje za očuvanjem zajedničkih tradicionalnih vrednota u hrvatskoj glazbenoj kulturi 17. stoljeća, neke su suvremene tendencije i inovacije bile prihvaćane s rezervom. “182 I premda o naglašenoj težnji za međusobnom povezanošću glazbenih regionalnih prostora možemo govoriti samo u kontekstu crkvene glazbe, težnji koja je nesumnjivo postojala barem na sjeveru Hrvatske, suvremene tendencije i inovacije nisu ignorirane isključivo zbog spomenutih nastojanja oko konzerviranja situacije. One su bile rezervirane za prostore u kojima su se mogle ostvariti, što hrvatska sredina teško da je bila u vremenu koje je slijedilo nakon iscrpljujućih ratova s Osmanskim carstvom. Nepostojanje kritične mase glazbenika - skladatelja i reproduktivaca, uvjetovalo je koncentriranje muzičkih postignuća u okviru crkvenih krugova čime je sadržaj tih postignuća bio strogo ograničen svojom funkcijom i/ili unaprijed zadanom estetikom.

Hrvatska muzikologija u analizi 17. i 18. stoljeća kao važan dio glazbene prakse spominje niz liturgijskih knjiga ispunjenih gregorijanskim napjevima, priručnike za učenje gregorijanskog pjevanja, mnoge pjesmarice franjevačkih i isusovačkih autora te nadasve zbornike: Pavlinski zbornik iz 1644. i zbornik Cithara Octochorda iz 1701., 1723. i 1757. godine. Čini to u nedostatku zanimljivijeg i europskim dosezima sukladnijeg notnog materijala, žaleći za „pravom“ glazbom i domaćim skladateljima koji bi bili na razini svojih njemačkih ili talijanskih kolega: „Ovdje nisu postojali preduvjeti za nastanak glazbenih velikana.“ Tako Josip Andreis u svojoj Povijesti hrvatske glazbe piše: ,doprinos sjeverne Hrvatske u XVIII. stoljeću nije velik... Pokazala se potreba za sastavljanjem i objavljivanjem teoretskih priručnika, pjesmarica, zbornika i drugih liturgijskih knjiga s odgovarajućim napjevima. Tako je već 1701. zagrebački kanonik Toma Kovačević objavio u Beču knjižicu Brevis cantus gregoriani notitia. Znatno kasnije 1760. pojavio se u Zagrebu Fundamentum cantus gregoriani seu choralis Mihajla Šiloboda Bolšića... “183. Uz još nekolicinu stranica o zborniku Cithara octochorda i njegovom glazbenom aspektu koji se odnosi prije svega na međusobni utjecaj pučke i liturgijske glazbe te Varaždinskom skladateljskom krugu, to je sve što Andreis kaže o glazbi u sjevernoj Hrvatskoj sve do Narodnog preporoda. Slične zaključke nalazimo i u

\footnotetext{
182 Stipčević, Ennio. Hrvatska glazbena kultura 17. stoljeća. Split: Književni krug Split. 1992. Str.141.

${ }^{183}$ Andreis, Josip. Op. cit. Str. 158.
} 
ostalim nacionalnim historiografijama koje ukupnost izvora koji se vezuju uz glazbenu praksu liturgijske i paraliturgijske (pučke) duhovne popijevke tretiraju kao svjedoke protureformacijskih težnji crkve: „Na glazbenom području gotovo isključivo crkvena odnosno religiozna tematika i posizanje za prodornijim metodama pri osvajanju i discipliniranju puka popijevkom, također upućuju na protureformaciju. “184, no zanemaruju detaljniju analizu izvora $^{185}$. Promjenom historiografske paradigme u Europi te postupnim sve potpunijim, iako do danas nedovoljnim uvidom u domaću baštinu, nedostatak i anakronizam s vremenom su postali promjena kvalitete pa se već od kraja osamdesetih godina uvriježila spoznaja da je „u onome što se donedavno smatralo regionalnom nezanimljivošću pohranjeno ustvari dosta autohtonih vrijednosti, utemeljenih i u kasnijim zbivanjima u hrvatskoj kulturi“186. Veliki pomak u istraživanju ovoga razdoblja dogodio se od kraja osamdesetih godina 20. st., otkada je Ennio Stipčević, najneumorniji hrvatski istraživač renesansne i barokne glazbe, neprestance nudio nove spoznaje revidirajući suptilno dotad iznesene zaključke te podsjećajući na složenost zahtjeva koji su glazbi bili namijenjeni, kao i onih koje je uspijevala ostvariti. Uz njega velik istraživački posao obavili su muzikolozi Ladislav Šaban (osobito se bavio crkvenom glazbom i orguljama), Zdravko Blažeković, Vjera Katalinić (koja je izradila niz kataloga crkvenih knjižnica diljem Hrvatske, a osobito se bavila skladateljima s kraja 18. st.), Gorana Doliner (na području glagoljaškoga pjevanja), Stanislav Tuksar i drugi. ${ }^{187}$

\footnotetext{
${ }^{184}$ Bilić, Franjo. Paraliturgijska glazba sjevernohrvatskog baroka - spona između pučkog i umjetničkog izraza. // Glazbena baština naroda i narodnosti Jugoslavije od 16. do 19. stoljeća I / uredio Srećko Lipovčan. Zagreb Varaždin: MIC, 1980. Str. 19.

${ }^{185}$ Usp. Županović, Lovro. Stoljeća hrvatske glazbe. Zagreb: Školska knjiga, 1980., kao i bogatu bibliografiju Ennija Stipčevića o tom razdoblju: Hrvatska glazba: Povijest hrvatske glazbe do 20. stoljeća. Zagreb: Školska knjiga, 1997.; Glazbeni barok u Hrvatskoj: Zbornik radova sa simpozija održanog u Osoru 1986. godine. // uredio Ennio Stipčević. Osor: Osorske glazbene večeri, 1989.; Idem. Andreisova glazbena historiografija o «renesansi» i «baroku» u hrvatskoj glazbi. Arti musices, 40/1-2, 2009. Str. 89-98.; Baroque Music in Eastern Europe. Music in Croatia. // A History of Baroque Music / uredio George J. Buelow. Bloomington \& Indianapolis: Indiana University Press, 2004. Str. 414-429 i 603-606.; Glazba i glazbenici XVII. stoljeća. // Hrvatska i Europa, kultura, znanost i umjetnost, sv. III. Barok i prosvjetiteljstvo (XVII-XVIII. stoljeće). I uredili Ivan Golub; Ivan Supičić. Zagreb: Školska knjiga, 2003, str. 717-725. (La musique et les musiciens au XVIIe siecle, Croatie. Le temps du Baroque et des Lumieres. Tresors d'art et de culture (XVIIe-XVIIIe siecles), sous le direction de Ivan Golub et Ivan Supičić. Zagreb - Reinnes: ŠK - PUR, 2011.; Counter-Reformation, Jesuits and Music Culture in Croatia of the 17th and 17th Centuries / Protureformacija, isusovci i glazbena kultura 17. i 18. stoljeća. // The Musical Baroque, Western Slavs, and the Spirit ot the European Cultural Communion / Glazbeni barok i zapadni Slaveni u kontekstu europskog kulturnog zajedništva. / uredio Stanislav Tuksar. Zagreb: HMDHAZU, 1993. Str. 85-90. i str. 235-240. Glazbeni barok u Hrvatskoj, uvodna razmatranja. // Glazbeni barok u Hrvatskoj. / uredio Ennio Stipčević. Osor: Osorske glazbene večeri, 1989. Str. 7-19.
}

186 Stipčević, Ennio. Op. cit. (1989.). Str. 7.

${ }^{187} \mathrm{O}$ tome više u popisu literature, osobito djela Ennija Stipčevića, Ladislava Šabana i Zdravka Blažekovića. 
Uz gregorijansko pjevanje, živa praksa obuhvaća i crkvene popijevke te nabožne napjeve paraliturgijske funkcije koji su tijekom 17. i 18. stoljeća odigrali „ulogu koja je znatno prelazila njihovu prvotnu crkvenu i duhovnu namjenu““. ${ }^{188}$ Ta je uloga usko vezana uz novu svijest o publici koja se postupno oblikuje ne samo u svjetovnom, već i u crkvenom kontekstu. Potaknuta važnom ulogom koju vjernici stječu u funkcioniranju glazbe kao dvosmjernog procesa, crkva pripušta kontrafakturu u svoje krilo ne kao povremenu iznimku, već kao pomno osmišljen način djelovanja. „Naime, crkveni raskol na početku 16. stoljeća, reformacija i srodni „heretički“ pokreti, pogodovali su osmišljavanju novih duhovnih poruka uz pomoć glazbe. Odjednom se pokazalo da novu duhovnu poruku mahom nepismeni puk lakše prihvaća u glazbenome ruhu, pogotovo ako su mu i tekstovna i glazbena poruka bliske. ... Kontrafaktura više nije slučajni plod povremenih, prigodnih crkvenih svetkovanja, nego postaje dugoročno osmišljena strategija u pridobivanju novih vjerskih istomišljenika. Nimalo slučajno, kad je došlo do isusovačkoga protureformacijskog udara, upotrijebljena su ista sredstva, ... Tako su različiti ideološki ključevi otvarali ista vrata manipulaciji kolektivnim sjećanjem.“189

U tekstu o „pisnima“ iz 17. i 18. stoljeća, Ennio Stipčević sugerira njihovu važnost u osvješćivanju nacionalnog elementa, a spomenutu crkvenu i duhovnu namjenu definira granicama „pastoralnih potreba i lokalnih namjena“190 triju svećeničkih redova koji su se najviše istaknuli promicanjem crkvene glazbe i kulture uopće: franjevaca, isusovaca i pavlina. No, unatoč neospornom doprinosu glazbenoj kulturi isusovaca i pavlina, franjevačka glazbena ostavština najopsežniji je i najkoherentniji ostatak glazbenog baroka u Hrvatskoj, i stoga što su isusovačka i pavlinska ostavština slijedom nemilih događaja dostupne samo kao sekundarni zapis o njihovu nekadašnjem postojanju. Upravo velik broj kantuala sa sačuvanim notnim zapisima koji potječu iz ostavštine franjevačkih samostana diljem Hrvatske uvjetovao je naziv „franjevački barok“ kojim se imenuje razdoblje druge polovice 17. i prve polovice 18. stoljeća, a u domaću muzikološku literaturu uveo ga je Ladislav Šaban osamdesetih godina prošloga stoljeća ${ }^{191}$. „Bilo je to doba kada su franjevci, više i marljivije od bilo kojega drugog

\footnotetext{
${ }^{188}$ Stipčević, Ennio. „Pisni duhovne“: o narodnim nabožnim popijevkama 18. stoljeća. // Glazba, tekst, kontekst Zagreb: Meandar, 2006. Str. 41.

${ }^{189}$ Stipčević, Ennio. Umjesto uvoda: Poesia per musica (uz jedno čitanje Žmegačeve knjige). Op. cit. str. 15.

${ }^{190}$ Stipčević, Ennio. „Pisni duhovne“: o narodnim nabožnim popijevkama 18. stoljeća. // op. cit. Str. 41.

${ }^{191}$ Usp. radove Ladislava Šabana: Glazba u franjevačkom samostanu u Varaždinu. // Varaždinski zbornik 11811981. / Andre Mohorovičić (ur.). Varaždin: JAZU, 1983. Str. 323-329.; Glazba u slavonskim samostanima u Lanosovićevo vrijeme. // Zbornik o Marijanu Lanosoviću. / Dragutin Tadijanović; Đuro Berber (ur.). Osijek: Zavod za znanstveni rad JAZU Osijek, 1985. Str. 113-121.; Ladislav Šaban - Zdravko Blažeković, Izvještaj o dvogodišnjem sređivanju triju glazbenih zbirki i o pregledu glazbenih rukopisa i knjiga u franjevačkim samostanima u Slavoniji i Srijemu, Arti musices, 11, 1980, 1 str. 47-101. Usp. i radove u citiranome zborniku
} 
reda, pisali i prepisivali glazbene rukopise. Njihovi brojni rukopisi ističu se postojanom i prepoznatljivom glazbenoestetskom okosnicom. U sjevernoj Hrvatskoj franjevačka je glazbena baština bila ne samo ono najstarije, nego i najvrednije iz razdoblja baroka. “192 Premda su i isusovci ostavili velik broj pjesmarica namijenjenih svim slojevima vjernika te su njegovali razvijenu glazbenu kulturu unutar svojih kolegija (o kojoj, kako smo već spomenuli, svjedoče samo posredni izvještaji, ali ne i sačuvani notni materijal) ${ }^{193}$, franjevačka ostavština, zbog znatnije geografske rasprostranjenosti reda i prisnijeg odnosa sa širim slojem stanovništva, dominira sačuvanim glazbenim rukopisima i knjigama, a franjevačkim se redovnicima pripisuje i uloga kopče između tada razjedinjenog sjevernog i južnog dijela zemlje. „Po ustroju svoga reda oni su bili najbliskiji puku, a nepretenciozne nabožne popijevke i skromna, gotovo asketska, instrumentalna svirka, imale su važnu ulogu u očuvanju drevnih autohtonih glazbenih vrednota. Tzv. ,franjevački barok“ jedna je od najznačajnijih glazbenih pojava u Hrvatskoj u 18. stoljeću, ... Taj glazbeni stil povezivao je u jedno Slavoniju, Hrvatsko zagorje, Dalmatinsku zagoru i sjeverozapadnu Bosnu tijekom gotovo cijelog 18. stoljeća. “194 I franjevci i isusovci, a uz njih i pavlini, njegovali su, dakako, duhovnu glazbu i to najčešće duhovnu monodiju i jednostavno višeglasje uz eventualnu pratnju orgulja i katkad manjeg instrumentalnog sastava. Takvu duhovnu glazbu, čini se, najjednostavnije je negativno definirati u odnosu na tipične barokne forme: premda nadilazi okvire strogo shvaćenog gregorijanskog pjevanja, ne pripada izričaju razvedene barokne monodije uz instrumentalnu pratnju (šifrirani bas), niti polifonim oblicima utemeljenima na cantus gregorianus i baštinjenima od renesanse (Palestrininog stila), a niti modelu

Glazbeni barok u Hrvatskoj. Zbornik radova sa simpozija održanog u Osoru 1986. godine/ uredio Ennio Stipčević. Osor: Osorske glazbene večeri, 1989. Soldo, Josip Ante. Glazbena ostavština 17. i 18. stoljeća u franjevačkim samostanima Splitske provincije. Str. 130-144.; Cvekan, Paškal. Franjevačko zakonodavstvo o pjevanju i orguljama u 17. i 18. stoljeću. Str. 145-154.

192 Stipčević, Ennio. Op. cit. (1997.). Str. 123.

${ }^{193}$ Miroslav Vanino, autor trosveščane monografije Isusovci i hrvatski narod prvi je pisao o isusovačkom kazalištu u članku Povijest kazališta isusovačke gimnazije u Zagrebu. // Hrvatska prosvjeta, III (1916.) Str. 132140. U monografiji objavljenoj nakon autorove smrti nalazi se relativno opsežan tekst o kazalištu u sklopu zagrebačkog kolegija, no niti na jednom mjestu ne spominje se glazba. Usp. Vanino, Miroslav. Isusovci $i$ hrvatski narod, sv. I. Zagreb: GZH, 1969. Str. 261-288. O isusovačkom kazalištu pisao je Ennio Stipčević u monografiji Hrvatska glazbena kultura 17. stoljeća, Split: Književni krug Split, 1992. O isusovačkom doprinosu hrvatskoj glazbenoj kulturi općenito v. Steiner, Marijan; Županović, Lovro. The Jesuit Contribution to Croatian Musical Culture, with Particular Emphasis on the 17th and 18th Centuries. // Jesuits Among the Croats. / uredio Valentin Pozaić. Zagreb: Filozofski i teološki institut, S. J.; Beč: Hrvatski povijesni institut, 2000. Str. 457-479.

${ }^{194}$ Stipčević, Ennio. Glazbeni barok u Hrvatskoj (uvodna razmatranja). // Glazbeni barok u Hrvatskoj. Zbornik radova sa simpozija održanog u Osoru 1986. godine. / uredio Ennio Stipčević. Osor: Osorske glazbene večeri, 1989. Str. 14. 
protestantskog višeglasnog korala uz pratnju orgulja. Njezin je skladateljski izričaj teško usporediv s razvijenim oblicima duhovne barokne glazbe: oratorijem, koncertantnim motetom, misom, psalmima i skladbama za solo glas uz instrumentalnu pratnju u Italiji, misama, motetima, polifonim psalmima, duhovnim koncertima i fauxbourdonom $\mathrm{u}$ Francuskoj, a cappella ili Lied misama, motetima, pasijama i oratorijima, koncertantnim kantatama i višeglasnim koralima u Njemačkoj i Austriji, premda svi oni, barem načelno, crpe iz gregorijanike koja se i dalje smatra izvornom kršćanskom glazbenom praksom. Franjevački barok i barokna crkvena glazba na sjeveru Hrvatske dostupna u pjesmaricama, kantualima i pasijama lokalna je verzija posttridentske reformirane gregorijanike u kojoj se miješaju izvorno gregorijansko pjevanje sa starim hrvatskim narodnim napjevima. Ona ne bježi od jednostavnog višeglasja, kao niti od utjecaja svjetovne, među narodom prisutne glazbe, no temelje crpi iz deklamatorne crkvene monodije. „U gregorijanici što su je prepisivali i prilagođavali novim potrebama vidljiv je, doduše, jasan utjecaj baroknoga duha, no značajno je da repertoar svojom jezičnom, glazbenom i motivičkom starinom vuče podrijetlo nerijetko čak iz srednjovjekovlja. “" ${ }^{195}$ Snaga srednjovjekovne tradicije iznimno je dobro vidljiva u tradiciji scenskog prikazivanja pasija koje su, dakako bile pjevane. Naime „Kristofor Peršić [je] u Passionale Croaticum Almae Ecclesiae Zagrabiensis 1683. godine prepisao muke koje se uvelike temelje na melodijskim predlošcima zagrebačkog Lectionariuma iz 14. stoljeća. Osim toga, Peršićev Passionale, kao i Passionale latino-croaticum anonimnoga skriptora iz istog vremena, utjecali su na Passionale Croaticum (iz 1736) Nikole Stanislava Pepelka i na konačnu tiskanu verziju zagrebačkih muka, koju je pod naslovom Muka i smert Kristuševa (Zagreb, 1764.) objavio Toma Zakarija Pervizović. ... u njima su (sc. pasionalima, op. a.) bile konačno utvrđene i određene koralne melodije koje su se održale u praksi sve do ukinuća zagrebačkog obreda krajem 18. stoljeća“"196. Osim neupitne uloge u približavanju puka crkvi, na gregorijanici utemeljena monodija, jednako kao i pučke pjesme pjevane u liturgijskim i paraliturgijskim prilikama, važne su, smatra Stipčević, i kao poveznica politički razjedinjenih dijelova zemlje. On smatra da je ,,crkvi najvažniji zadatak bio povezati na kulturnom planu u jedno ono što je političkom silom bilo razjedinjeno, da je duhovno jedinstvo virtualni nadomjestak za razjedinjene hrvatske zemlje, membra disiecta. Tako je izričajem jednostavan

\footnotetext{
${ }^{195}$ Ibid. Zanimljivo je uočiti kako povjesničari gregorijanskoga pjevanja pristajanje uz suvremenu baroknu estetiku vide kao dekadenciju, dok historiografi glazbe koji nastoje prikazati uklopljenost neke glazbene kulture u opći, zadani okvir glazbenostilskog razvoja, pozdravljaju sklonost suvremenoj melodijskoj estetici i gotovo s nelagodom spominju srednjovjekovne glazbene slojeve prisutne u osamnaestostoljetnim skladbama.

196 Stipčević, Ennio. Hrvatska glazba: Povijest hrvatske glazbe do 20. stoljeća. Zagreb: Školska knjiga, 1997.
} 
pučki sloj crkvene glazbe postao važniji svojim djelovanjem nego li djelom, značajniji zbog ispunjene crkvene i prosvjetiteljske zadaće nego li umjetničke, skladateljske izvornosti.“197

Važnost jednostavnosti crkvene glazbe potekle iz puka neosporna je u kontekstu skromnih uvjeta u kojima je, uz iznimku katedrale i crkvi vezanih uz samostane, crkva djelovala te u spomenutoj snazi srednjovjekovne tradicije. Nastojanje oko što snažnijeg uključivanja puka u liturgiju sa svrhom sustavne evangelizacije i sudjelovanje u pjevanom dijelu liturgije koji je najčešće jedini koji puk razumije, budući da je jezik obreda latinski, jedan je od temeljnih naputaka Tridentskoga koncila. No, ideja duhovnog jedinstva kao virtualnog nadomjestka za prostornu i političku razjedinjenost upitna je. ${ }^{198}$ Čini se da je prije katolička obnova, u smislu intenzivnog pastoralnog djelovanja u svim katoličkim zemljama, nego duhovno povezivanje politički razjedinjenih teritorija koje pretpostavlja svijest o jednoj, hrvatskoj naciji, bio zadatak Crkve i njezinih službenika. ${ }^{199} \mathrm{Uz}$ to, valja se prisjetiti da se pučki glazbeni sloj, odnosno repertoar, razlikuje na sjeveru i jugu zemlje te da je glavni kohezivni faktor $u$ glazbenom smislu bio rad redovnika - franjevaca, isusovaca, pavlina i uršulinki. Glazba koju su oni njegovali i promicali bila je osnova koju se nadograđivalo lokalnom glazbenom praksom. $^{200}$

U kojoj je mjeri spomenuti repertoar nužnost s obzirom na skučene materijalne prilike u kojima su se nalazile mnoge crkve i župe i nepostojanje kontinuiteta drugačije umjetničke prakse, a u kojoj ustrajavanje „na očuvanju tradicije i kontinuiteta“ kako bi se „pripremalo tlo za narodni preporod i veliku važnost glazbe u tom pokretu“²01 tek treba pokazati uvidom u

\footnotetext{
${ }^{197}$ Stipčević, Ennio. „Pisni duhovne“: o narodnim nabožnim popijevkama 18. stoljeća. // Glazba, tekst, kontekst. / Ennio Stipčević. Zagreb: Meandar, 2006. Str. 42. Upitno je može li se uopće pučko vrednovati iz aspekta umjetničke, skladateljske izvornosti i definirati ili barem uspoređivati s pojmom djelo, kada pučko samo po sebi anulira i umjetničko i osobu skladatelja.

${ }^{198} \mathrm{O}$ kulturnopolitičkom konceptu protoilirizma, odnosno ilirizma prije ilirizma raspravlja Zrinka Blažević u knjizi Ilirizam prije ilirizma. Zagreb: Goldenmarketing: Tehnička knjiga, 2008. definirajući pojam kulturološki i ideološki u prvome dijelu knjige te propitkujući i analizirajući njegova značenja na primjerima brojnih tekstova u drugome dijelu. U poglavlju „Reformnokatolički ilirizam“ obradila je ilirske koncepcije u djelima pisaca koji su djelovali u 17. stoljeću u dubrovačkom području (Dubrovnik, Mljet, Ston, Boka kotorska). Postojanje nacionalne svijesti u zajednici s Ugarskom raspravlja i analiza oslikanih prizora u refektoriju Ilirskoga kolegija u Bologni

${ }^{199}$ Tek je 1783. Josip II. izdao Gottesdienstordnung u kojem se propisuju pravila za održavanje liturgije u svim biskupijama Habsburške monarhije. Slijedom njegove odredbe, zagrebački je biskup Josip Galjuf (1772.-1786.) izdao prvu službenu hrvatsku pjesmaricu za sjeverne hrvatske zemlje Popevke pod szv. Massum y pred prodechtvom z litaniami, y molitvami koja je objavljena 1785., 1787. i 1789.

${ }^{200} \mathrm{Za}$ franjevački glazbeni barok na jugu zemlje v. npr. Stipčević, Ennio. Toma Babić i franjevački glazbeni barok // Zbornik o Tomi Babiću: zbornik radova sa znanstvenoga skupa "Fra Toma Babić i njegovo vrijeme" / uredio Alojz Jembrih, Alojz. Skradin-Visovac, 2001. Za franjevačku glazbenu praksu sjevernih zemalja usp. nosač zvuka Barokna glazba sjeverne Hrvatske : izbor pjesama iz zbirke "Franjevački pjevnici 18. stoljeća u Hrvatskoj" - "Cantilenae chorales pro conventu Warasdinensi". Zagreb: Cantus, 2013.

${ }^{201}$ Stipčević, Ennio. Op. cit. Str. 14-15.
} 
kontekst njihova nastajanja i eventualne druge sačuvane izvore koji bi upućivali na izraženu svijest o tradiciji, baštini, narodnom jeziku i nacionalnom identitetu.

Govoreći o duhovnoj glazbi prethodnog, 17. stoljeća, Ennio Stipčević ističe kako kantuali, liturgijski priručnici i pjesmarice ,nisu međusobno povezane prvenstveno sličnim glazbenim fundusom. Razlikuje ih pripadnost drugačijem socijalnom kontekstu, kao i različitim svećeničkim redovima i liturgijskim potrebama. Nešto ipak sve te duhovne skladbe već na prvi pogled sjedinjuje: gotovo su sve zapisane u rukopisnim glazbenim i liturgijskim knjigama. U odnosu na korpus duhovnih monodija i skladbi za male sastave koje su se sačuvale samo iz prve polovice 17. stoljeća, duhovnih skladbi zapisanih u kantualima, liturgijskim priručnicima i pjesmaricama ima mnogo više. “202 Te duhovne skladbe, vokalna liturgijska i paraliturgijska monodija i jednostavno višeglasje, tvore u sjevernoj Hrvatskoj poveznicu između cantus gregorianus i pučke duhovne pjesme. Za njihovo je širenje bila presudna posttridentska katolička obnova koju promiču crkveni redovi, osobito franjevci i pavlini koji snažno promoviraju gregorijansko pjevanje, te isusovci, protureformacijski red par excellence čiji credo glazbu doživljava suvišnom: praksom koja ometa drugo, korisnije djelovanje. ${ }^{203}$ Usprkos činjenici da su jedini red koji ne pjeva časoslov, isusovci su iznimno puno učinili za pučku crkvenu popijevku, nastojeći neprestance oko kodificiranja tih napjeva: „njihova nastojanja (franjevaca i isusovaca, op. a.) oko zapisivanja, prenošenja iz narodne i usmene u pismenu i čim više ujednačenu, instituticionaliziranu, glazbenu tradiciju bila su obilježena potiskivanjem iz kolektivnoga sjećanja „poganih“ i ,lascivnih“ tekstova ... te redizajniranjem tog sjećanja novim duhovnim sadržajima.“204 Teško je, u svjetlu korištenja gregorijanskoga pjevanja i duhovnih pjesama uopće kao alata barokne protureformacijske aktivnosti, precijeniti ulogu Bartula Kašića i njegova djela Ritual rimski istomačen slovinski (Rim 1640.) u integriranju gregorijanskog pjevanja u najšire društvene slojeve. Kašiću je kao osnovni predložak poslužio Rituale Romanum pape Pavla V. iz 1614., a „kao neposredni predložak iz kojega je Kašić prevodio i preuzimao notne zapise koralnog pjevanja poslužio je

\footnotetext{
${ }^{202}$ Stipčević, Ennio. Hrvatska glazbena kultura 17. stoljeća. Split: Književni krug Split. 1992. Str. 96.

${ }^{203}$ Pozaić, Valentin. Op. cit. Str. 457.: „The Constitutions of the Society of Jesus contain an innovation, according to which the Jesuits differ from all previous orders: there is no choir in which they pray (sing) the breviary and participate in other liturgical celebrations together."

Usp. I Const., p. VI, c. III, n. 4.: Quoniam occupationes, quae ad animarum auxilium assumuntur, magni momenti sunt, ac nostri Instituti proprias, et valde frequentes ; cumque alioqui nostra habitatio tam sit in hoc vel in illo loco incerta : non utentur nostri choro ad horas canonicas, vel missas, et alia officia decantanda : quandoquidem illis, quos ad ea audienda devotio moverit, abunde suppetet ubi sibi ipsis satisfaciant. Per nostros autem ea tractari convenit, quae nostrae vocationi ad Dei gloriam magis sunt consentanea. URL: https://ia600401.us.archive.org/23/items/constitutionesso00jesuuoft/constitutionesso00jesuuoft.pdf. (28.07.2019.)

${ }^{204}$ Stipčević, Ennio. (2006.). Str. 47.
} 
Rituale romanum Pauli V. Pont. Max. Jussu editum. Et Urbani VIII. auctoritate recognitum.

Editio Novissima, cum Accentibus, Parisiis, 1635. I on je, naime, bio napisan na hrvatskom jeziku. Kao takav, on je upravo najraniji kompletni ritual tiskan na jednom živom narodnom jeziku.“ ${ }^{205}$ Uz neospornu važnost za razvoj narodnoga jezika, Kašićev je Ritual najstarija tiskana hrvatska knjiga s tolikim brojem notnih zapisa gregorijanskih melodija i time važan izvor podataka za proučavanje širenja, integriranja i interferiranja gregorijanskoga pjevanja s narodnim melodijama.

Rukopisnim kantualima, liturgijskim priručnicima i pjesmaricama ponajviše franjevačke provenijencije obiluje cijelo 17. stoljeće, a isti se trend nastavlja i u prvoj polovici 18. stoljeća. „U tom kontekstu udomaćene i snažno prisutne prepisivačke tradicije iznikao je već u 17., a naročito u 18. stoljeću, čitav niz duhovnih i liturgijskih skladbi koje se malo ili neznatno razlikuju po melodijskoj strukturi, a koje pripadaju prepoznatljivom i koherentnom glazbenom korpusu. “206 Iz 18. stoljeća sačuvan je niz muzikalija na sjeveru Hrvatske, no do zadnje četvrtine stoljeća, tek nekolicina skladateljskih imena. Najstarije skladateljsko ime koje se vezuje za zagrebačku katedralu (kao i za zbornik Cithara Octochorda) jest ono Ivana Leopolda Šebelića, ${ }^{207}$ orguljaša zagrebačke stolne crkve, čija je misa Sacrum S. Ladislai Domini Ioannis Sebegglich zabilježena u dva franjevačka kantuala: Remetinečkom kantualu iz 1707. i Virovitičkom kantualu iz 1736. godine. ${ }^{208} \mathrm{U}$ nizu zagrebačkih katedralnih obrednih knjiga koje su upotrebljavali svećenici i/ili katedralni pjevači choristae, a koje su nastale i bile u upotrebi tijekom 17. stoljeća, ali i kasnije, najvjerojatnije do ukidanja zagrebačkog obreda, ističe se upravo nepropusnost za barokne inovacije: „Glazbenoliturgijski rukopisi iz 17. st. najvećim dijelom sadrže jednoglasne koralne melodije, samo mjestimice nailazimo na dvoglasje ili troglasje. Već u doba kasnoga srednjeg vijeka i renesanse glazba je bila uklopljena u bogoslužje tako da su se izmjenjivale jednoglasne koralne melodije i višeglasne skladbe, a upravo je maestro di cappella, zborovođa, bio glazbenik odgovoran za odabir skladbi, kojima je i sam mogao biti autor. Stoga je prodor baroknih inovacija prepoznatljiv ne

\footnotetext{
205 Stipčević, Ennio. Hrvatska glazbena kultura 17. stoljeća. Split: Književni krug Split. 1992. Str. 96. 206 Ibid.

${ }^{207}$ Šebelić (Sebegglich), Ivan Leopold, hrvatski orguljaš i skladatelj kao orguljaš zagrebačke katedrale zabilježen je 1710. i 1713., a postoje indicije da je na toj službi bio uposlen od 1702. do 1718. Usp. Šebelić, Ivan Leopold. Hrvatska enciklopedija, mrežno izdanje. Leksikografski zavod Miroslav Krleža, 2020. URL: http://www.enciklopedija.hr/Natuknica.aspx?ID=59402 (26.01.2020.)

${ }^{208}$ Usp. Šaban, Ladislav. Glazba u franjevačkom samostanu u Varaždinu. // Varaždinski zbornik 1181-1981. / uredio Andre Mohorovičić. Varaždin: JAZU, 1983. Str. 323-329. Stipčević o toj misi domeće: „No, bilo bi pogrešno u Šebelićevoj misi tražiti neku osobitu autorsku crtu po kojoj bi se ta skladba razlikovala od ostalih misa u kantualu. Naprotiv, sličnost svih misa u Remetinečkom kantualu značajna je ne samo za taj rukopis, nego i za većinu sjevernohrvatskih franjevačkih glazbenih rukopisnih zbornika misa i druge crkvene glazbe s početka 18. st." Stipčević, Ennio. (1997). Str. 123.
} 
u gregorijanskom pjevanju, već u autorskim skladbama, monodiji, komornom dvoglasju i troglasju, ili u višezbornim duhovnim skladbama. Novi stil očitovao se osobito u instrumentalnoj glazbi ..." ${ }^{609}$ Uz njih, prepisivale su se i tiskale pjesmarice i zbirke duhovnih tekstova koje su pisali franjevci i isusovci, a koje su se „oslanjale na prijemčljivost pjevanih, stihovanih poruka“. Te su poruke bile čitane i pamćene „ponajprije zahvaljujući svojoj glazbenoj dimenziji koja je bila sačinjena od jednostavne monodije bliske koralnom izričaju, onom koji je omogućio da se „nabožni tekstovi pokušaju približiti puku pomoću glazbe jednostavne pučke glazbe, nevelikih estetskih zahtijeva, čak bliske narodnome izričaju i folklornoj memoriji. “210 Zajednička namjera koju dijele gregorijansko pjevanje i nabožno liturgijsko i paraliturgijsko pjevanje utemeljeno na pučkim melodijama pastoralno je djelovanje, odnosno svjesnije sudjelovanje ljudi u liturgiji.

Ne samo graduali, antifonariji, himnali i procesionali, već i pasionali koji se ispisuju i prepisuju od 14. do kraja 18. stoljeća, čine važan dio glazbenog repertoara zagrebačke katedrale. Upravo su u pasionalima „,bile definitivno fiksirane određene koralne melodije, koje su se održale u praksi sve do ukinuća zagrebačkog obreda koncem 18. stoljeća“ “211 što znači da je, usprkos možebitnim povremenim proplamsajima suvremenih strujanja u načinu strukturiranja melodike, korištenju ljestvica ili ritmičkih fraza, gregorijanika ustrajno dominirala muzičkom praksom. Ne osporavajući ni na koji način praksu svjetovne glazbe dostupnu samo plemstvu, crkvena je glazba predstavljala dominantni način muziciranja. Utoliko je važnija bila kao katalizator suvremenih skladateljskih praksi kojima je crkvena glazba razvijenih sredina obilovala (prisjetimo se samo oratorija, misa, kantata, crkvenih sonata, simfonija, itd. skladanih u to vrijeme u Njemačkoj ili pak duhovnih skladbi s one strane Jadranskoga mora). Uzimajući u obzir repertoar sačuvan u liturgijskim knjigama sačuvanima u hrvatskim samostanima te prema teorijskim priručnicima koji se upravo na početku (Kovačević) i u sredini (Šilobod Bolšić) 18. stoljeća tiskaju, ali i prevode za potrebe hrvatske sredine, Stipčević ističe: „Valjalo je slušateljima - a to se ponajviše odnosilo na pučanstvo skupljeno u crkvi - pružiti glazbu koja će nositi razumljivu tekstovnu poruku i biti moderna, lijepa i autohtona. ... Neke glazbene inovacije - posebice na sjeveru gdje su se prostirale reliquiae hrvatske državnosti - sporo su prihvaćane zbog objektivnih okolnosti, ali i zbog svjesnog odustajanja od elitizma.“212 To je, uz tešku gospodarsku situaciju i

\footnotetext{
209 Stipčević Op. cit. Str. 98.

${ }^{210}$ Stipčević, Ennio. (2006). Str. 47.

${ }^{211}$ Stipčević, Ennio. (1997). Str. 98.

${ }^{212}$ Ibid. Str. 122.
} 
posvemašnje siromaštvo, svakako i posljedica snažnog obnoviteljskog djelovanja katoličke crkve koje se u perifernim sredinama carstva pretapalo s politikom prosvjetiteljstva i apsolutizma. „Glazbena djelatnost svećeničkih redova u prvoj polovici 18. st. kretala se u granicama lokalnih namjena i pastoralnih potreba. Premda su domaći svećenici bili lišeni mogućnosti da prate suvremene barokne tendencije, ipak su održavali kontinuitet u glazbenome životu, nastojeći ga širiti na cjelokupnome hrvatskom prostoru. “213

${ }^{213}$ Ibid. Str. 127. 


\subsection{Historijsko i teorijsko mišljenje o glazbi u prvoj polovici 18. stoljeća u sjevernoj Hrvatskoj: stanje istraživanja}

„Djelatnost Crkve bila je važna i zbog brige za školstvo. Glazba je, prema još u srednjem vijeku ustanovljenom programu, pripadala disciplinama quadriviuma, a učitelji u samostanskim školama nazvani su cantorima, scolasticusima ili ludimagisterima.“214

„U skladu s organiziranim i marljivim prepisivačkim radom, u hrvatskim su se samostanima, počam od druge polovice 18. st., počeli prepisivati i prevoditi i razni glazbenoteorijski spisi, udžbenici o teoriji, harmoniji, osnovama kompozicije. Potreba za poznavanjem glazbene teorije bila je velika, bio je to osnovni preduvjet širenja glazbenih znanja.“215

„Dva glazbeno-teoretska rada što su objavljena u ovom stoljeću pripadaju sjevernom dijelu zemlje, a rezultat su sve intenzivnijeg bavljenja glazbom svećenstva zagrebačke biskupije. Znači da im se sadržajnost kreće u okviru objašnjavanja tematike duhovnog karaktera, čime je u odnosu na 17. stoljeće postignuta i nehotična nadopuna sadržajne komponente.“216

Dva tipa znanstvenog bavljenja glazbom - glazbena historiografija i glazbena teorija ${ }^{217}$ osobito intenzivno promišljaju tekstove o glazbi nastale od kasne antike pa sve do kraja 18. stoljeća. ${ }^{218}$ I historiografija i glazbena teorija u njima ponajprije pronalaze dokaze za razvoj glazbene umjetnosti. No, differentia specifica tekstova o kojima ćemo raspravljati njihova je usredotočenost na glazbu kao ars odnosno $\tau \dot{\varepsilon} \chi v \eta$ u antičkom značenju umijeća korištenja stečenoga znanja, iz čega proizlazi heterogenost tema koje takvi tekstovi obuhvaćaju, kao i relativno površna obrađenost svake od njih. Usto, ona je, zamišljena kao uputa za praksu, gotovo u potpunosti lišena historijske svijesti te, dostigavši u nekoliko koraka razinu teorije

\footnotetext{
214 Stipčević, Ennio. (1997). Str. 87.

215 Ibid.

216 Županović, Lovro. (1980). Str. 121.

${ }^{217}$ Znanstvenost i normativnost teorije glazbe do sada su bile predmetom mnogih rasprava vođenih unutar muzikološke, ali i glazbenoteorijske struke. Tu je problematiku naročito dobro obradio Dahlhaus u svojoj kapitalnoj ediciji Geschichte der Musiktheorie, sv. 1. Problemom odnosa znanstvenosti i normativnosti u teoriji glazbe u tekstovima koji su predmet ovoga rada bavimo se kratko u šestom poglavlju disertacije.

${ }^{218}$ Granica povučena na kraju 18. stoljeća odnosi se na činjenicu da se u 19. stoljeću, kao i u drugim područjima, i u muzikologiji kao govoru i pismu o glazbi, jasnije i odlučnije razdvajaju dotad povezana područja opće glazbene teorije, estetike, historiografije i teorije skladanja zbog čega interes prema predmodernim tekstovima o glazbi počinje pripadati prije svega glazbenoj teoriji i estetici kao novoustanovljenoj disciplini, dok ih se historiografija dotiče samo ovlaš i, kao u domaćoj produkciji, u slučaju kad joj manjka ,pravog“ muzičkog materijala i skladateljskih imena.
} 
potrebnu za izvođenje glazbe kojom se bavi, ne promišlja njezine stupnjeve razvoja, niti se previše osvrće na paralelne glazbene sustave (npr. svjetovnu glazbu, višeglasnu glazbu, itd.). Teorija glazbe, povijest glazbe i glazbena praksa tri su dominantna, međusobno snažno isprepletena područja interesa muzikologije koja sukladno temeljnom interesnom području svakog pojedinog istraživanja oblikuje i njemu prikladnu metodologiju.

Tekstovi koji su predmetom interesa ove radnje pripadaju korpusu glazbenoteorijskih propedeutičkih tekstova te adhortativno konotiranih uvodnika zbirki čime se smještaju na fluidnu granicu normativne i znanstvene ${ }^{219}$ teorije i prakse dozvoljavajući tako pristup glazbi iz oba aspekta.

Tri izdanja zbornika Cithara octochorda (Beč 1701. i 1727. te Zagreb 1757.), Brevis cantus gregoriani notitia Tome Kovačevića (Beč, 1701.) te Fundamentum cantus gregoriani seu choralis Mihaela Šiloboda Bolšića (Zagreb, 1760.) nezaobilazni su factum djela o povijesti hrvatske glazbe, od Povijesti hrvatske glazbe Josipa Andreisa i Stoljeća hrvatske glazbe Lovre Županovića, pa sve do priručnika Hrvatska glazba. Povijest hrvatske glazbe do 20. stoljeća Ennija Stipčevića i Kratka povijest hrvatske glazbe Stanislava Tuksara. ${ }^{220}$

Priručnici o poduci glazbe i zbornik Cithara octochorda pisani latinskim jezikom privlače pozornost navedenih autora ponajprije kao jedini ili rijetki svjedoci postojanja glazbenoga života u Zagrebu tijekom prve polovice 18. stoljeća. Rukopisni rječnici Patačića i Vitezovića, pak, nisu zainteresirali niti jednog muzikologa. Sama činjenica da ta djela postoje i svjedoče postojanje ikakve glazbene prakse nipošto nije sinonim izvrsnosti ili umjetničke vrijednosti, već povijesne vrijednosti sui generis. Tekstovi o kojima je ovdje riječ spominjani su upravo na temelju pozitivističke ideje povijesne vrijednosti postojanja dokumenata kao svjedoka glazbenog života te su, uz nabožne paraliturgijske skladbe s tekstovima na hrvatskome jeziku, tvorili kratak, stidljivi odsječak povijesti hrvatske glazbe: onaj koji je trebao povezati slavnu renesansu i rani barok južnoga dijela zemlje s jednako tako važnom drugom polovicom 18. stoljeća u kojoj se dičimo „,varaždinskim skladateljskim krugom“221 ili pak glazbenicima koji,

\footnotetext{
${ }^{219}$ Pod znanstvenom teorijom ovdje mislimo na musica theorica, matematičko-fizikalno-filozofsku teoriju glazbe koja je bila dijelom kvadrivija. Pritom je filozofsko promišljanje glazbe - razmatranje njezinih etičkih funkcija najustrajniji ostatak toga golemog i iznimno složenog znanstvenog područja.

${ }^{220}$ V. Andreis, Josip. (1974); Županović, Lovro. (1980); Stipčević, Ennio. (1997); Tuksar, Stanislav. Kratka povijest hrvatske glazbe. Zagreb: MH, 2000.

${ }^{221}$ Lovro Županović u knjizi Stoljeća hrvatske glazbe na str. 98. povezuje Jana Krtitela Vanhala (1739.-1813.), Ivana Wernera (1752.-1786.) i Leopolda Ignacija Ebnera (1769.-1830.) sintagmom „Varaždinski skladateljski krug s kraja XVIII. stoljeća“. O njima piše: „Sačuvane skladbe što podupiru iznesene navode upućuju na spoznaju kako njihova tehnička, stilska, pa prema tome i ugođajna orijentacija potopuno izviru iz opće glazbene klime razdoblja, kome je jedno od značajnih središta bio i Beč. To drugim riječima znači da u tim djelima
} 
osim možebitnom genealogijom svoga prezimena ${ }^{222}$, ne predstavljaju dio uistinu življene glazbene kulture na ovim prostorima.

Hrvatskim se glazbenim piscima i teoretičarima u 17. i 18. st. sustavno bavio akademik Stanislav Tuksar. ${ }^{223}$ Sintezom njegovih istraživanja može se smatrati poglavlje u 3. svesku zbornika Hrvatska i Europa naslovljeno „Glazbeni pisci i teoretičari“ u kojem autor za razdoblje baroka i prosvjetiteljstva, odnosno 17. i 18. stoljeće, popisuje sve pisce koji se bave glazbom. Pritom, odmah na početku ističe kako ,ni među njima, jednako kao što je to bio slučaj u XVI. stoljeću, nema neke škole, ni misaonog kontinuiteta, oni tvore skupinu osobnosti, tema i tekstova koje ujedinjuje ipak činjenica da su po nekom od usvojenih kriterija pripadali hrvatskomu glazbenokulturnom krugu.“224 Također, vrijedi istaknuti da je Tuksar hrvatskim glazbenim piscima imenovao i „Hrvate i Talijane rođene $u$ hrvatskim povijesnim zemljama (Istra, Dalmacija) ili one koje je njihova djelatnost dovela u hrvatske krajeve na određeno vrijeme. “225

Pritom Tuksar predstavlja napise 1) ,autora djelatnih u hrvatskim zemljama“ u kojima izostavlja Tomu Kovačevića, a spominje Jurja Albertija, Mihaela Šiloboda-Bolšića, Alberta Fortisa, Josipa Franju Domina, Julija Bajamontija; zatim pod 2) napise autora djelatnih u inozemstvu, no i tu izostavlja Kovačevića i niže Jurja Križanića, Karla Ivanovića, Gjuru Baglivija, Gian Rinalda Carlija, Josipa Mihovila Stratica, Paola Serru; 3) glazbenu leksikografiju (Jakov Mikalja, Juraj Habdelić, Ardelio Della Bella, Ivan Belostenec, Andrija Jambrešić) i 4) nominalno poznate napise (Vinko Komnen, Gian Rinaldo Carli, Matteo Marchesini).

U leksikografiju nisu uvršteni rukopisni rječnici Adama Patačića niti Pavla Rittera Vitezovića, stoga što nisu tiskani. Djela koja nisu bila dostupna u tiskanom obliku (a pritom se ne radi o kantualima čija je praksa prepisivanja u skriptorijima živjela stoljećima), pretpostavlja se, nisu imala niti značajan utjecaj. Ova je premisa, međutim, upitna kada se istražuje mišljenje o

odzvanja glazba kakva se u to vrijeme stvarala pod snažnim utjecajem Mozarta i Haydna, što onda Varaždin (i taj dio Hrvatske) povezuje s Evropom u najplemenitijem značenju riječi. Po tome on u tim godinama svog umjetničkog uspona i na ovom glazbenom polju dosiže svoj potpuni vrhunac.“

${ }^{222}$ Mislimo ovdje prije svega na Ivana Manu Jarnovića i golem interes koji je pobudio u domaćim muzikološkim krugovima.

${ }^{223}$ Usp. npr. Tuksar, Stanislav. Hrvatski renesansni teoretičari glazbe. Zagreb: JAZU, 1978.; Hrvatska glazbena terminologija u razdoblju baroka: nazivlje glazbala i instrumentalne glazbe u tiskanim rječnicima između 1649. i 1742. godine. Zagreb: HMD; MIC KDZ, 1992. Misao o glazbi u autora podrijetlom iz hrvatskih povijesnih zemalja u tiskom objavljenim djelima 16. i 17. stoljeća. // Filozofska istraživanja, 142/36, 2016. Str. 273-286. ${ }^{224}$ Tuksar, Stanislav. Hrvatska i Europa // 3. sv. Barok i prosvjetiteljstvo / uredio Ivan Supičić. Zagreb: ŠK, 2003. Str. 735.

225 Ibid. 
glazbi u nekom razdoblju, budući da su autori oba rukopisna rječnika bili utjecajni članovi društva i pripadnici vrlo tankog obrazovanog sloja, kao, uostalom, i autori svih spomenutih tiskanih tekstova.

Za priručnik Mihaela Šiloboda-Bolšića navodi skraćeni naslov Fundamentum cantus gregoriani seu choralis pro captu tyronis discipuli te daje podatak o cijenjenosti ŠilobodaBolšića kao pisca priručnika iz aritmetike ne navodeći izvor za isto. Uz to autor navodi da je udžbenik namijenjen koralistima katedrale u Zagrebu što također nigdje nije eksplicitno napisano niti utvrđeno. Potom naslov prvoga poglavlja koji glasi „Dialogus I. De Authore musices, sive cantus“ prevodi „O autorima glazbe ili pjeva“ premda je riječ Authore u ablativu singulara. Radi se o sintagmi koja podrazumijeva izumitelja (inventor, no Šilobod nije vrstan latinist), a ne autore (auctores), odnosno skladatelje što je vidljivo iz sadržaja prvog poglavlja u kojem se raspravlja o postanku glazbe, odnosno o pitanju njezina ,izuma““. Tim je zanimljiviji njegov zaključak o ovom kratkom poglavlju koje poslije izvještaja o raznim verzijama nastanka glazbe nabraja samo nekolicinu autoru važnih teoretičara (ne i skladatelja!) pa je nejasno kakva bi to povijest glazbe bila. Tuksar tako piše: ,prvi dijalog, naslovljen „O autorima glazbe ili pjeva“ može se smatrati kronologijski prvim, rudimentarnim i vrlo konzervativnim, pregledom opće povijesti glazbe nastalim u sjevernoj Hrvatskoj.“ 226 Potom nastavlja sa zaključkom o uporabi ovoga priručnika koja je po njemu bila ,zapravo lokalnog dometa, iako su primjerci Fundamentuma... sačuvani u Beču, Bologni, Bressanoneu i Zagrebu.“'227

Identičnost teme koju proučavaju (gregorijansko pjevanje), jezika kojim pišu (latinski) i autoriteta na koje se pozivaju (antički pisci, antička mitologija, Biblija, kršćanski teoretičari glazbe) upućuje čini se, suprotno spomenutoj premisi o nepostojanju „škole“, na kompaktnost u mišljenju o glazbi omeđenom granicama koje su definirali skolastičko obrazovanje s jedne i projekt katoličke obnove s druge strane. Upravo na tu, kršćanskom ideologijom ograničenu cjelovitost, upućuje ovo istraživanje.

Toma Kovačević, autor najranijeg poznatog glazbenoteorijskog priručnika na sjeveru Hrvatske, bio je ugledni zagrebački kanonik, povjesničar, kantor (pojac) i kustos. U kanoničkim vizitacijama o Kovačevićevu vođenju župe svete Marije Magdalene u Ivancu kraj Varaždina, kanonik i varaždinski arhiđakon Simon Juda Židić zapisao je 1693.: „Župnik u

\footnotetext{
226 Ibid.

${ }^{227}$ Ibid. Str. 735.
} 
ovome mjestu (Ivanec) je časni svećenik Toma Kovačević u dobi od 29 godina, svećenik 3 godine, župnik na ovome mjestu pola godine, filozof i teolog školovan u Rimu. Čovjek vrlo učen (dobra znanja) i dobar pojac.“228 Već sljedeće godine Kovačević je ,po smrti Petra Brezarića postao kanonikom prvostolne crkve u Zagrebu, pa je tu čast obnašao gotovo trideset godina, sve do smrti svoje.“ O Kovačeviću kao povjesničaru pisao je Vjekoslav Klaić u članku „Tomo Kovačević, povjesničar hrvatski (1664-1724.)“: „Među povjesničare, koji su se potanje bavili historijom zagrebačke biskupije, njezinog kaptola i prvostolne crkve, ubrojiti nam je i Tomu Kovačevića, kanonika zagrebačkoga. (...) Napokon je Kovačević prinosio obilatu građu za monumentalno historijsko djelo o crkvenoj povjesnici čitavoga Ilirika s napisom „Illyricum sacrum“ (poglavito za V. svezak), pa je potom bio suradnik Filipa Riceputija i Danijela Farlata.“229 U Klaićevom članku nema spomena priručniku o gregorijanici, već se relativno detaljno razlaže Kovačevićeva biografija i historiografski rad. Kantorsku službi Kovačevićevu, čini se, nisu pratile sretne okolnosti. Dva spisa sačuvana i dostupna u Hrvatskom državnom arhivu svjedoče o njegovoj brizi za očuvanje svih pojedinosti crkvenoga obreda: „Aliqua de ritu proprio cathedralis ecclesiae Zagrabiensis“ koji je prepisivač prepisao iz Kovačevićeva izvornika te originalni rukopis „Directorium pro usu chori ecclesiae Zagrabiensis pro anno bissextili MDCCXX“ sačuvan u kodeksu II. A. 70., no niti kaptolski arhiv, niti Kovačevićeva ostavština ne čuvaju niti jedan primjerak njegove upute u gregorijansko pjevanje. Budući da, osim kao graditelj kantorske kurije, njegova kantorska dužnost nije spomenuta niti na nadgrobnoj ploči ${ }^{230}$, izgleda da se zbog ostalih brojnih poslova nije stizao pomnije baviti kantorskim dužnostima. O tom dijelu njegove karijere Klaić piše: „Tako je Kovačević negđe u drugoj polovici god. 1704. postao kantorom zagrebačkoga kaptola. Ali ga u novoj časti nije osobita sreća pratila. “231 Naime, veliki požar koji je poharao Zagreb 14. lipnja 1706. u cijelost je uništio kantorsku kuriju, no Kovačević je 1710. dovršio radove na novoj kuriji. Usto, u požaru je stradala i sjemenišna zgrada. „Trebalo je i nju obnoviti. Posao je taj bio povjeren Kovačeviću, koji je kroz dvije tri godine sjemeništem

\footnotetext{
${ }^{228}$ Klaić, Vjekoslav. Toma Kovačević, povjesničar hrvatski (1664.-1724.). // Bogoslovska smotra. Zagreb, 13/1925. br. 1, str. 69-91. Str. 71.: „Parochus in hoc loco (Ivancz) est venerabilis presbiter Thomas Kovachevich annorum aetatis 29, presbiterii 3, parochus in hoc loco anni medii, philosophus et theologus absolutus Romanus. Vir bonae scientiae et bonus cantor."

${ }^{229}$ Ibid. Str. 69.

${ }^{230}$ Natpis s nadgrobne ploče prenosi Ivan pl. Kukuljević u djelu Nadpisi sredovječni i novovjeki u Hrvatskoj $i$ Slavoniji. Zagreb, 1891. Str. 349. br. 1203.: „Reverendissimus dominus Thomas Kovachevich custos et canonicus senior cathedralis ecclesiae Zagrabiensis protonotarius apostolicus assiduus devotionis et decoris ecclesiarum promotor. Ministrorum sacrarii institutor. Poenitentiariae benefactor. Cantoralis residentiae pius fundator. Indefessus antiquitatum compilator. Aetatis suae anno 61. die 13. mensis Junii in Domino obiit. Saxo hoc tectus res urget. 1724.“

${ }^{231}$ Ibid. Str. 76.
} 
upravljao ...“232 Osim toga, zbog mnogih znanja i vještina koje je posjedovao „[V]eć od onoga časa, kad je Kovačević postao kantorom zagrebačkoga kaptola, mora se je sve više baviti javnim poslovima. Redovito ga je hrvatski sabor birao u komisiju, koja je imala izraditi naputke ili instrukcije za hrvatske nuncije. God. 1708. pače izabrao je kaptol njega i kanonika Antuna Vukmerovića za svoje ablegate na ugarskom saboru u Požunu.“

Brevis cantus gregoriani notitia pedagoški je intoniran traktat o gregorijanskome pjevanju autora Tome Kovačevića (1663.-1724.) tiskan u Beču 1701. godine, a sačuvan, nažalost, samo u kopijama prijepisa slovenskoga franjevca Inocentija Auera načinjenoga "ad simplicem usum” 1738. godine. Taj je prijepis iz franjevačkog samostana u Novom Mestu dobio 1950. Vinko Žganec te je "uspio da ga u JAZU presnime pa je nakon toga prijepis/izvornik vratio posuđivaču. Potom je snimljenu građu "na revers" posudio Vidaković, ali je nije dospio vratiti pa je komplet ostao (i danas se nalazi) u njegovoj ostavštini." 233 To, međutim, danas više nije točno. Žgančevih kopija prijepisa nema u Vidakovićevoj ostavštini, a jedini dokaz o njihovom postojanju diplomski je rad pokojnoga Martina Mihokovića koji je pisao o Tomi Kovačeviću na Institutu za crkvenu glazbu „Albe Vidaković“ KBF-a u Zagrebu. To je ujedno najopsežniji i sada jedini postojeći prikaz Kovačevićevog djela.

U razgovoru s fra Izakom Špraljom koji se osobito bavio ovom problematikom i pisao je relativno detaljno o Kovačeviću, doznala sam da se on služio ne snimkama, već diplomskim radom Martina Mihokovića u kojem su te snimke izložene parcijalno. ${ }^{234}$ Mihoković je imao u rukama fotografije koje je dao izraditi dr. Vinko Žganec 1950., jer, kako kaže u uvodu „Rukopis je prilično dobro sačuvan, kako ga fotografija pokazuje. Ja imam samo to. Prepisivačev posao čuvao se u Novom Mestu. Tamo ga je pronašao Dr. Vinko Žganec i dao ga fotokopirati. I ja sam tražio taj rukopis kod Franjevaca u Novom Mestu. No oni ga nisu

\footnotetext{
${ }^{232}$ Ibid. Str. 77. Na Kaptolu br. 8 stoji i danas kurija kantora Kovačevića na kojoj piše: „Haec domus cantoratus per Thomam Kovachevich prohonotarium apostolicum Cantorem et canonicum Zagrabiensem est a fundamento constructa. Successor tibi fundavi, dotemque locavi tu memor esto mei, carmina psalle Dei." (prema: Kukuljević, Ivan pl. Op. cit. str. 348, br. 1195.)

${ }^{233}$ Županović, Lovro. Hrvatski glazbeni zbornik Cithara Octochorda iz XVIII. stoljeća i njegovo značenje za (domaću) glazbenu kulturu onoga doba i danas. // Cithara octochorda, Zagreb 1757., sv. 2 Komentari $i$ studije / uredili Milan Moguš i Lovro Županović. Zagreb: HAZU: Institut za crkvenu glazbu Albe Vidaković“ KBF Sveučilišta u Zagrebu: Hrvatsko društvo crkvenih glazbenika, 1998. Str. 209.

234 Špralja je o Kovačeviću pisao u disertaciji Cithara octochorda. Glazbeni zbornik zagrebačke crkve iz 18. stoljeća (Beč 1701. i 1723.; Zagreb 1757.) s posebnim osvrtom na glazbene oblike pokazatelje glazbenih razdoblja. Zagreb: Hrvatsko društvo crkvenih glazbenika, 1998. te u članku Povijesna situiranost gregorijanskoga pjevanja u vrijeme pojave Citharae octochordae i njegova primjena posebice u trećem izdanju toga zbornika. // Cithara octochorda, Zagreb 1757., sv. 2 Komentari i studije / uredili Milan Moguš i Lovro Županović. Zagreb: HAZU: Institut za crkvenu glazbu Albe Vidakovićc“ KBF Sveučilišta u Zagrebu: Hrvatsko društvo crkvenih glazbenika, 1998. Str. 221-250.
} 
mogli pronaći, pa sam se za ovaj rad poslužio ovim fotokopijama“. ${ }^{235}$ Martin Mihoković relativno je detaljno izložio sadržaj knjižice: „Prvu glavu najprije ću doslovno prevesti i koliko je potrebno razložiti. Daljnje glave ne ću prevoditi, nego samo razgovijetno i kratko prikazati o čemu rade. Jasno, da ću to učiniti služeći se rječnikom samog autora: sve definicije, važnije pojmove i specifične nauke, pogotovo sve razlike, varijante i eventualne nedostatke ondašnjeg shvaćanja i znanja o gregorijanskom pjevanju iznijeti ću u tančine onako, kako ih nalazim u ovom rukopisu.“ Parcijalni prijevod što ga je izradio Mihoković i loše fotokopije Žgančevih fotokopija priložene uz diplomski rad, jedino su čime sam raspolagala pri izradi disertacije. Prema njegovom (djelomičnom) prijevodu, radila sam sadržajnu analizu djela što je svakako otegotna okolnost.

Iste godine kad i Brevis cantus gregoriani notitia u Beču je objavljeno prvo izdanje najpopularnijeg hrvatskog zbornika crkvenih pjesama u 18. stoljeću Cithara octochorda ${ }^{236}$. Upravo iz tog razloga Albe Vidaković koji se bavio Kovačevićem, smatrao je da bi ugledni zagrebački kanonik i kantor Kovačević mogao biti i priređivač odnosno urednik zbornika. O mogućim vezama tekstova koji su predmet ove disertacije članak je napisao fra Izak Špralja nastojeći prije svega rasvijetliti do sada neriješeno pitanje urednika svih triju izdanja CO. ${ }^{237}$

Toma Kovačević nesumnjivo je mnogo učinio za glazbu u zagrebačkoj biskupiji. Albe Vidaković u članku u Muzičkoj enciklopediji piše da je „bio 'odličan i ugledan pjevač' i nepokolebljiv čuvar ispravnog načina pjevanja kod bogoslužja“; da je „od 1704. do 1710. vršio (...) službu kanonika pojca (kantora), poučavao katedralne pjevače, sagradio kantorsku kuriju i osnovao kantorsku zakladu“. Stoga je vrlo vjerojatno da je upravo on ,priredio za tisak i dao složiti ne samo svoj priručnik, nego i prvo izdanje Cithare“ te ,da je njegov priručnik muzičke teorije trebao poslužiti pjevačima kao pomoć i uputa za što bolju praktičnu upotrebu same Cithare“. ${ }^{238}$ Izak Špralja, kratkom analizom sadržaja oba priručnika i

\footnotetext{
${ }^{235}$ Mihoković, Martin. Prikaz o djelu Tome Kovačevića „,Kratki nauk o gregorijanskom pjevanju“. Dipl. rad u strojopisu. Zagreb: ICG, 1970. Str. 1.

${ }^{236}$ Puni naslov prvog izdanja zbirke glasi CITHARA OCTOCHORDA SEU CANTUS SACRI LATINOSCLAVONICI,/ quos in Octo Partes, pro diversis Anni temporibus, distributos;Ut in Sclavoniae Populis Erga DEUM, Divosque AnIMos aCCenDat:/ Pia sua munificentia in lucem prodire jussit, REVERENDISSIMUS DOMINUS, DOMINUS JOANNES ZNIKA ${ }^{236}$, Almae \& Vetustissimae Cathedralis Ecclesiae Zagrabiensis Custos, \& Canonicus Senior; nec non Abbas Ecclesiae SS. Trinitatis de Petrovaradino./VIENNAE AUSTRIAE, Typis LEOPOLDI VOIGT, Universitatis Typ. U daljnjem tekstu Cithara Octochorda navodit će se skraćeno u obliku CO za zbornik općenito te CO I (prvo izdanje), CO II (drugo izdanje) i CO III (treće izdanje).

${ }^{237}$ Špralja, Izak. Pitanje urednika/priređivača glazbenog zbornika Cithara octochorda (CO). // Glazba i baština: zbornik u čast Lovri Županoviću. / uredio Ennio Stipčević. Šibenik: Gradska knjižnica „Juraj Šižgorićc“, 2002. Str. 259-270.

${ }^{238}$ Ibid. Str. 259.
} 
usporedbom s notografijom i sadržajem napjeva u CO, zaključuje: ,Što se tiče priručnika o gregorijanskom pjevanju T. Kovačevića (Beč, 1701.) i M. Šiloboda-Bolšića (Zagreb, 1760.) treba ustvrditi da nemaju neposredne veze s glazbenim zbornikom CO. U njima je očita nakana pisaca da izvrši naslovom postavljeni zadatak. (...) Eventualna povezanost između ovih priručnika i CO mogla bi biti zapažanja autora o intonaciji gregorijanskih napjeva za psalme općenito i u zagrebačkoj prvostolnoj crkvi (zagrebačke napjeve donosi CO I/II u dodatku), (...). Takva zapažanja gube na uvjerljivosti kad se, kako je istaknuto, uzme u obzir da T. Kovačević opširnije raspravlja o onim glazbenim oblicima koje CO ne donosi, ili donosi u zanemarivom broju; odnosno kad se uzme u obzir da M. Šilobod-Bolšić raspravlja o različitim notnim znakovima kojima se bilježi gregorijansko pjevanje, a ne osvrće se na način notnog zapisa gregorijanskih i himničkih oblika koji je primijenjen u glazbenom zborniku CO itd. “239

Uvodni tekst u prvom (Beč, 1701.) i drugom izdanju (Beč, 1723.) bitno se razlikuje, dok je u trećem izdanju (Zagreb, 1757.) pretiskan uvodnik drugoga izdanja. Uvodni tekstovi ovoga zbornika mješavina su estetičkog i etičkog promišljanja uloge glazbe u čovjekovom životu, u liturgijskim i paraliturgijskim prigodama. Do danas je njihov sadržaj ostao izvan područja zanimanja hrvatske muzikologije koja se bavi 18. stoljećem. Naime, 1998. godine HAZU je u suradnji s Institutom za crkvenu glazbu „Albe Vidaković“ i Hrvatskim društvom crkvenih glazbenika, pod uredničkim vodstvom Milana Moguša i Lovre Županovića, objavila kritičko izdanje CO III u dvije knjige: faksimilni pretisak trećeg izdanja u prvoj knjizi te Komentare $i$ studije u drugoj knjizi. Kako su se Citharom do tada bavili uglavnom povjesničari hrvatskoga jezika i književnosti, naglasak u Komentarima $i$ studijama stavljen je na glazbeni aspekt zbornika te su, shodno tome, komentare izrađivali uglavnom crkveni glazbenici i liturgičari. Studije pak analiziraju mjesto zbornika u kulturi onoga vremena (Lovro Županović), fenomen gregorijanskoga pjevanja i njegove primjene u zborniku (Izak Špralja), liturgijsko značenje CO (Vladimir Zagorac), elemente folklora (Milovan Gavazzi i Jerko Bezić), likovnu opremu (Anđelko Badurina) te kajkavske (Antun Šojat i Olga Šojat) i latinske pjesničke tekstove (Franjo Gruić) koji su ondje zapisani. No, unatoč priloženim prijevodima uvodnika svih triju izdanja CO, studija o njima kao o svjedocima govora o glazbi, ne postoji.

Sastavljači svih triju izdanja ostali su do danas nepoznati, premda se spekuliralo o raznim imenima, među kojima se nalazi i ono Tome Kovačevića, ali i autora drugog glazbeno-

\footnotetext{
${ }^{239}$ Ibid. Str. 268.
} 
teorijskog priručnika Mihaela Šiloboda Bolšića. Šilobod Bolšić je 1760. godine, nakon uspjeha aritmetičkog priručnika objavljenoga na hrvatskom jeziku te zanimljivoga djelca o Kabali pisanog latinskim, objavio djelo Fundamentum cantus gregoriani seu choralis ${ }^{240}$ kojim je zaslužio status autora najstarijeg sačuvanog glazbeno-teorijskog traktata u sjevernoj Hrvatskoj.

O njemu se pisalo prije svega kao o autoru prvog priručnika iz aritmetike na hrvatskom jeziku pa ga u kontekstu razvoja jezika spominje i Povijest hrvatske književnosti. ${ }^{241} \mathrm{O}$

Fundamentumu u kratkim crtama piše Izak Špralja u disertaciji objavljenoj pod naslovom Cithara Octochorda ${ }^{242}$ te ponovno u tekstu objavljenom u kritičkom izdanju CO 1998. godine. Kao tema diplomskog rada Šilobodov je priručnik proučavan dva puta: najprije ga je analizirala sestra Katarina Koprek na Institutu za crkvenu glazbu „Albe Vidaković“ u svom diplomskom radu koji je u skraćenom obliku objavila kao članak $2007 .{ }^{243}$, a zatim autorica ove disertacije koja je, saževši tekst diplomskoga rada, napisala i studiju o autoru i njegovom djelu u dvojezičnom, suvremenom izdanju tog prvog tiskanog priručnika za glazbu objavljenog u ediciji Latina \& Graeca. ${ }^{244}$

Uvodna studija dvojezičnog izdanja opisuje tekst, situira ga povijesno u kontekst glazbenog obrazovanja klerika te sumarno objašnjava glazbenoteorijske principe koji se ondje iznose bez komparativne analize sa sličnim suvremenim tekstovima. ${ }^{245}$ Koprek je, pak, Bolšićev priručnik usporedila sa znamenitim Augustinovim tekstom De Musica libri sex, ističući formalnu dispoziciju kao dominantni element usporedbe. ${ }^{246}$ Vjerujem da će ovaj rad pokazati

\footnotetext{
${ }^{240}$ Puni naslov Šilobodovog priručnika jest Fundamentum cantus gregoriani, seu choralis pro captu tyronis discipuli, ex probatis authoribus collectum, et brevi, ac facili dialogica methodo in lucem expositum opera, ac studio./ Admodum Reverendissimi Domini Michaelis Sillobod, parochi in Martinszka Vesz./Zagrabiae, Typis Cajetani Francisci Härl, Inclyti Regni Croatiae Typographi, 1760.
}

${ }^{241}$ Bogišić, Rafo. Književnost prosvjetiteljstva. // Od renesanse do prosvjetiteljstva, Povijest hrvatske književnosti 3 / uredili Marin Franičević; Franjo Švelec; Rafo Bogišić. Zagreb: Liber Mladost, 1974. Str. 309.: „Razvoju jezika i ujednačenju hrvatskoga školsko-prosvjetnog izražavanja pomogli su i razni udžbenici koji su se pojavili kao školska nužnost. Tako je 1758. u Zagrebu izašla na kajkavskom Aritmetika horvacka MIHAJLA ŠILOBADA BOLŠIĆA (,ne za vučene nego za priproste priprosto“).“

242 Špralja, Izak. Cithara Octochorda ... doktorski rad. Zagreb: Hrvatsko društvo crkvenih glazbenika, 1998. Str. 17-18.

${ }^{243}$ Koprek, Katarina. Gregorijanski manual Fundamentum cantus gregoriani seu choralis (1760.) Mihajla Šiloboda - Bolšića, u: Povijesni prilozi 33., 2007. Str. 311.-330.

244 Šilobod - Bolšić, Mihael. Fundamentum cantus gregoriani seu choralis. Jelena Knešaurek Carić (prir. i prev.). Zagreb: L\&G, 2009.

${ }^{245}$ Usp. bilj. 81.

${ }^{246}$ Koprek piše: „Čitavo je, naime, djelo, plod kulturne baštine i, na neki način, pojednostavljena sinteza starih glazbenih teoretičara, većinom filozofa i teologa: primjerice Platona, Plotina, Boetiusa, Tome Akvinskog, a nadasve Sv. Augustina. Naime, Augustinova se De Musica libri sex već po svojoj (dijaloškoj) formi, a onda i po 
nemogućnost usporedbe Augustinovog neoplatonistički formuliranog teksta koji se bavi prije svega ritmom i brojem te muzikom kao zemaljskim odrazom kretanja nebeskih tijela što su dominantne teme o kojima promišlja musica theorica u kasnoj antici i patristici, s manualom čija je glavna svrha poduka temeljnih glazbenoteorijskih elemenata nužnih za pjevačku praksu.

Propedeutički ton prisutan je u svim analiziranim tekstovima, kao osobina zajednička posttridentskoj katoličkoj obnovi i nastojanjima crkve oko restituiranja izvorne, odnosno najstarije poznate crkvene glazbe - gregorijanskoga pjevanja ${ }^{247}$. Edukativna intencija objavljenih tekstova inherentna je i prosvjetiteljskim nastojanjima Habsburške monarhije čija je politika prosvjećivanja nastojala obuhvatiti što veći broj podanika carstva. Snažni procvat poduke i uz nju velik broj edukativnih priručnika zajednička je karakteristika svih europskih kultura tijekom 18. stoljeća koja se vezuje uza sve predmete što su se podučavali u školama i na sveučilištu. U cilju svladavanja (Kovačević, Šilobod-Bolšić) ili pak promoviranja (Cithara octochorda I, II i III) bilo kojega umijeća ili vještine, priručnik, udžbenik ili rasprava prve polovice 18. stoljeća obuhvaća razne aspekte same ars - skicira njezinu povijest po ugledu na arhontologije, definira predmet interesa te ga raščlanjuje i prikazuje u mjeri koja se autoru čini prikladnom s obzirom na ciljanu čitalačku publiku. Ostvarena razina cjelovitosti prikaza shvaćena ne kao cjelina znanja o temi, već kao cjelina znanja potrebnih da bi se provodila praksa prokazuje autorovu razinu obrazovanja, društvenu ulogu i položaj, ideologiju kojoj se priklanja te narativne strategije koje preuzima i kombinira kako bi vazda suvremeni (moglo bi se čak reći ahistorični) sadržaj učinile privlačnim. Naime, 18. stoljeće u pisanju o glazbi predstavlja prekretnicu koja dominaciju diskursa orijentiranog prema dvije glavne teme: musica universalis i musica instrumentalis (a koja uključuje musica vocalis) potiskuje prema samostanskim školama i knjižnicama, oslobađajući prostor za praksu i promišljanje glazbe ponajprije iz aspekta skladanja (poietičke prakse) i izvedbe (instrumentalne ili vokalne ili instrumentalno-vokalne prakse), ali i iz aspekta estetike koja se u odnosu na predmet svoga izučavanja - umjetnost kao nesvrhovito djelovanje - formulira također tijekom druge

svojim teoretskim postavkama oslikala se u ovoj Šilobod-Bolšićevoj raspravi.“, Koprek, Katarina. Op. cit. Str. 313. U kojoj mjeri je ovo mišljenje upitno, pokazat će, vjerujem, ova radnja.

${ }^{247}$ Pitanje prisutnosti glazbe u liturgiji bilo je predmetom brojnih rasprava i službenih papinskih dokumenata još od pape Klementa (92/93-101.) pa sve do danas. Gregorijansko pjevanje u obliku u kojem se oblikovalo tijekom ranog srednjeg vijeka iz fuzije starorimskog i galikanskog pjevanja, kao ideal crkvenoga muziciranja ustanovljen je nakon Grgura I (590-604.), odnosno tijekom 7. stoljeća. Pošto su odbačene brojne legende vezane uz ovog papu po kojem je gregorijansko pjevanje dobilo ime danas se drži sigurnim samo da je proveo reforme crkvenoga pjevanja ustanovivši Gregorijanski sakramentarij, Gregorijanski antifonarij te časoslov. Usp. Hayburn, Robert F. Op. cit. 
polovice 18. stoljeća. U kulturno i materijalno bogatijim sredinama dolazi do značajnije diferencijacije diskursa o glazbi koji se od tada relativno kontinuirano može pratiti na odvojenim poljima glazbene historiografije, normativne teorije glazbe, teorije skladanja i nešto kasnije estetike glazbe.

Do druge polovice 18. stoljeća, paralelno uz traktate o teoriji glazbe koji opisuju razvojnu krivulju vokalne i instrumentalne glazbe - polifoniju, opstoje manuali koji proklamiraju cantus firmus (kao opozicija uvijek se navodi cantus figuratus) i monodiju kao jedini ispravni način muziciranja u crkvi. Većina traktata koji su zamišljeni kao udžbenici na sveučilištima ${ }^{248}$ ili namijenjeni kantorima na korovima crkava, bilo da raspravljaju o polifonom načinu skladanja, orguljanju, monodiji, tonusima ili modusima dijeli velik dio sadržaja: uključuje spomenute arhontologije kao preteče historiografije, rasprave o učinku glazbe na pojedinca, rasprave iz područja glazbene teorije (pitanja konsonance i disonance, matematičkih proporcija, itd.), probleme solmizacije i Guidove ruke i slično. Osim toga, navedeni traktati sadržajno pripadaju onome što Boetije u podjeli glazbe naziva musica quae in quibusdam constituta est instrumentis, koja ih ograničava u teorijskom aspektu, a potiče poietički i napose izvedbeni aspekt bavljenja glazbom. Toj skupini, koja obujmom nipošto nije zanemariva, pripadaju i priručnici koje su napisali Toma Kovačević i Mihael Šilobod Bolšić, ali i brojni slični tekstovi objavljivani opetovano i u ostalim zemljama Austrougarske, Njemačkoj, Francuskoj i Italiji.

Analizom izvora kojima se Brevis cantus gregoriani notita, sva tri izdanja Cithara octochorda i Fundamentum služe, te usporedbom sa sličnim suvremenim tiskovinama u srednjoj Europi, nastojat ćemo pokazati da glazbeni svjetonazor naših autora nije isključivo proizvod materijalno i kulturno osiromašene Hrvatske, već svjetonazor koji dijele i mnogi njihovi kolege u kudikamo bogatijim i kulturno razvijenijim sredinama Austrougarske i Italije. Osim toga, narativne strategije pedagoški intoniranog dijaloga baštinjenoga još od stare Grčke legitiman su dio episteme 18. stoljeća kao forma kojom se i dalje koriste čak i najveći umovi toga doba. Predgovori zbirkama koncipirani po uzoru na retorički idealan tip govora, kao i obilno korištene retoričke figure (naročito svi oblici metafore) koje zamah doživljavaju upravo u vrijeme baroka, učinit će, vjerujemo, spomenute tekstove kudikamo

\footnotetext{
${ }^{248}$ Nakon osnivanja sveučilišta i smanjivanja utjecaja samostanskih škola, osobito od 13. stoljeća nadalje, i poduka glazbe seli na sveučilišta. Radi se međutim najprije o teoriji kao dijelu kvadrivija, dakle o matematičkom i fizikalnom aspektu glazbe. Praksa se i dalje izučava prije svega u krilu crkvenih i samostanskih škola i korova gdje su kantorima povjereni budući klerici stjecali vještine praktičnog muziciranja i elementarne teorije dovoljne za uspješno interpretiranje napjeva iz kodeksa.
} 
suvremenijima no što ih se držalo do sada. Ono što je u njima osobito zanimljivo jest način na koji se na formalnoj, sadržajnoj i stilističkoj razini spajaju srednjovjekovna znanja, itekako prisutna u cjelokupnoj teoriji glazbe sve do trenutka prevlasti dur-mol sistema i monodije uz pratnju harmoniziranoga basa, dakle do druge polovice 18. stoljeća, s renesansnom zaokupljenošću antičkim autorima i baroknom sklonošću egzaltiranoj retorici. Osim toga, povijest gregorijanskoga pjevanja pripovijest je o žanru koji u glazbenoj praksi gubi svoje, dotada čvrsto uglavljeno mjesto upravo u trenutku izdisaja mentalnog krajolika koji se, $\mathrm{u}$ regionalnim i lokalnim inačicama, prostire od kasne antike pa sve do kraja 18. stoljeća.

Upravo u heterogenosti glazbenoga diskursa analiziranih tekstova u odnosu na modernističku podjelu glazbenopovijesnih i glazbenoteorijskih tekstova koja se formira krajem 18. stoljeća i zadržava sve do danas u pisanju o glazbi, a koja (heterogenost) se otkriva dotičući unutar jednog teksta povijesne, teorijske i etičke aspekte glazbenog (vokalnog) umijeća - ars nalazimo opravdanje za terminološku neodređenost naslova disertacije. Naslov Tekstovi o glazbi premda implicira nevoljkost za pomnijim određivanjem sadržaja, (npr.

glazbenoteorijski, glazbenoestetski, glazbenopovijesni tekstovi) nipošto ne bježi od potrebe za definicijom. No ta će se definicija tijekom istraživanja pokazati suviše složenom a da bi opterećivala naslov.

Tekstovi o glazbi nastali u razdoblju prve polovice 18. stoljeća u sjevernoj Hrvatskoj obuhvaćaju nekoliko, tijekom devetnaestoga stoljeća razdvojenih područja: normativnu glazbenu teoriju, znanstvenu glazbenu teoriju, povijest glazbe po uzoru na arhontologije, etiku glazbe u smislu promišljanja njezina utjecaja na vladanje čovjeka te estetički aspekt koji se beziznimno pokorava etičkome. Osim toga, uvodnici svih triju izdanja Cithara octochorda jasno definiraju vlastitu intenciju propagiranja gregorijanskoga pjevanja i monodije kao ideala crkvenoga muziciranja te precizno navode socijalne kategorije kojima je namijenjen. Ispreplićući mnoštvenost znanja koja se još uvijek ne propitkuju u smislu znanstvene provjerljivosti oni ravnopravno, uvjereni u istinitost sviju navoda, barataju legendama, antičkim mitovima, književnim djelima starorimskih autora, biblijskim citatima i glazbenoteorijskim postavkama provjerljivima u praksi. Takav tip diskursa proizišao je iz ponovne aktualnosti skolastičke filozofije i obrazovanja koja je zaživjela osnutkom isusovačkoga reda te se protiv reformacije pokušavala boriti obraćajući se autoritetu crkvenih otaca i jeziku Biblije. Vezan uz srednji vijek i ondašnje poimanje autoriteta čiji se iskazi ne provjeravaju, ili barem ne izlažu eksplicitnoj kritici, dominirao je europskom misli o glazbi 
sve do razdoblja prosvjetiteljstva, no ni potom nije posve iščezao. Preselio se iz glazbenoteorijskih i historiografskih djela u područje estetike glazbe.

S obzirom na spomenuto supostojanje raznovrsnih diskursa proizašlih iz skolastičkog sustava dopuštenih i poželjnih znanja te jasno iskazanu svijest o potrebi za korisnošću objavljenih tekstova, u analizi izvora oslanjamo se na dva rada Michela Foucaulta: razmišljanje o prosvjetiteljstvu (Aufklärung) u članku „Qu'est-ce que les Lumières?“ i teoriju epistemâ kakvu nudi u knjizi Les mots et les choses. ${ }^{249} \mathrm{U}$ članku u kojem, potaknut Kantovim odgovorom na isto pitanje, nastoji definirati temeljne odlike prosvjetiteljstva, osobito u odnosu na humanizme koji u svojoj brojnoj pojavnosti i samim time višeznačnosti, ne pružaju čvrst oslonac niti os za promišljanje, Foucault upozorava na tip filozofskog pitanja koje “ $u$ isto vrijeme problematizira odnos prema sadašnjosti, način povijesnog bivanja i uspostavljanje samoga sebe kao autonomnog subjekta“. ${ }^{250}$ Spomenuto čini razliku koja prosvjetiteljstvo presudno distancira od drugih tipova filozofskog promišljanja i čini ga stavom (attitude), filozofskim ethosom. Štoviše, moguće ga je definirati kroz ,princip kritike i stalnog stvaranja nas samih u našoj vlastitoj autonomiji“ kakav je prisutan u ,povijesnoj svijesti kakvu je Aufklärung imao sam o sebi“251. Analizirani iz ovog aspekta, tekstovi hrvatskih autora ne pripadaju prosvjetiteljstvu kakvim ga definira Foucault, već idealima katoličke obnove i ,prosvjetiteljstvu“ kakvo promovira i potiče Habsburški dvor. ${ }^{252}$

Pri analizi načina sklapanja teksta, obraćamo se modelima kompilacije i interpolacije kakve koriste srednjovjekovni pisci oblikujući tekst, s osobitim osvrtom na proces internalizacije teksta u odnosu na njegovo kreiranje te promjene koje se događaju kada se znanje više ne prenosi isključivo usmenim, već i pisanim putem.

Nadalje, valja upozoriti da se svrstavanje tekstova utemeljenih na mješavini antičkog, kasnoantičkog, srednjovjekovnog i renesansnog muzičkoteorijskoga naslijeđa te posttridentske prakse u ladice historicistički orijentirane muzikologije koja piše o glazbenim teoretičarima, povjesničarima, pedagozima ili estetičarima, pokazuje nedostatnim i neprikladnim s obzirom na snažnu međusobnu uvjetovanost teorijskog, povijesnog, etičkog i

\footnotetext{
${ }^{249}$ Foucault, Michel. Qu'est-ce que les Lumières?. Dits et Ecrits, tome IV. Paris: Gallimard, 1994. str. 562-578. URL: https://monoskop.org/File:Foucault_Michel_Dits_et_ecrits_4_1980-1988.pdf (02.02.2021.); Foucault, Michel. Les Mots et les choses. Paris: Gallimard, 1966. (Riječi i stvari (prev. Srđan Rahelić). Zagreb: Golden marketing, 2002.

${ }^{250}$ Foucault, Michel (1994.). str. 570.

251 Ibid.

${ }^{252}$ Usp. Beales, Derek. Enlightenment and Reform in Eighteenth-century Europe. London: New York: I. B.

Tauris, 2005. Poglavlje 3. „Christians and 'Philosophes': The Case of the Austrian Enlightenment.“
} 
pedagoškog aspekta muzike ${ }^{253}$. Nemogućnost njihova jasnog razdvajanja, kao i, ne samo historijski, već prije svega društveni kontekst koji motivira nastanak takvih tekstova, razlog je njihovoj sadržajnoj složenosti, usprkos formalnim ograničenjima koja indiciraju priručnici. Ta je složenost motiv za analizu naoko neukalupljivih traktata koji svojim sadržajem upućuju prema medievističkim i renesansnim tekovinama, dok oblikom, namjenom i, ponajviše vremenskim okvirom svoga nastanka pripadaju visokobaroknom, odnosno prosvjetiteljskom razdoblju europske kulturne povijesti.

${ }^{253}$ Takvi su tekstovi nalik kompendijima koji su kao sažeci raznovrsnih znanja tipični upravo za srednji vijek kojim u području obrazovanja i dalje dominiraju Kvintilijanovih sedam slobodnih umijeća (septem artes liberales). Najčešći tip kompendija ticao se retorike i gramatike, a obuhvaćao je tekstove kanonskih autora ili njihove dijelove koji su držani prikladnima za učenike, no zamiranjem viva voce metode u prenošenju liturgijske glazbene prakse, odnosno njezinoj sve većoj teorijskoj složenosti, javljaju se i na područuju glazbe. Rasprava o glazbi koja u skraćenom obliku povezuje teoriju (musica speculativa ili musica theorica) s praksom (musica vocalis ili musica instrumentalis, ie. musica humana) u okvirima koje zadaje propedeutička funkcija teksta proizvod je srednjega vijeka no opstaje tijekom cijelog 17. i duboko u 18. stoljeće. Osobito je uobičajen u glazbenom obrazovanju klerika ili laika korista posttridentskog razdoblja koje pokušava oživjeti praksu gregorijanskoga pjevanja potisnutu razvojem polifonije. 


\section{TREĆE POGLAVLJE: DISKURS I COMPILATIO}

„Aliquis scribit aliena, addendo, sed non de suo.“

sv. Bonaventura 254

„Mais pourquoi la musique devrait-elle faire l'objet d'une science, elle qui est le véhicule suprême et subtil de nos emotions?!“

Jean-Jacques Nattiez: Le discours sur la musique entre science et littérature ${ }^{255}$

Rečenica muzikologa i semiologa Jean-Jacquesa Nattieza izrečena na svečanoj dodjeli priznanja u Akademiji znanosti države Québec u Montrealu upozorava na nerazumijevanje potrebe za znanstvenim govorom o glazbi, za diskursom o glazbi, s kojom se muzikolozi neprestano susreću. Štoviše, veli on, ,još općenitije se diskurs o glazbi smatra beskorisnim, štoviše parazitskim: glazba je vrlo dobro sposobna samu sebe izraziti, može govoriti sama za

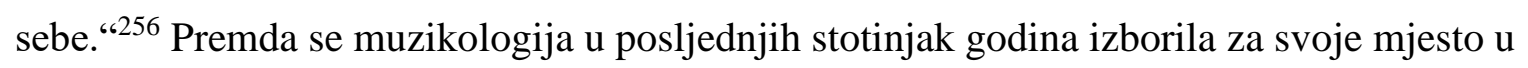
okviru humanističkih studija, znanstveni, pa i publicistički govor o glazbi nerijetko se i danas u glazbenoumjetničkim krugovima smatra suvišnim, rezultatom promišljanja onih koju glazbu nisu sposobni izvoditi pa onda o njoj govore i pišu. Glavni argument u apologiji muzikologije zamišljene kao discipline koja uz znanstveni oblikuje i kritički, publicistički i pedagoški diskurs o glazbi, oslanja se na analogiju, odnosno na praksu verbalizacije umjetničkih postupaka i ostvarenja u ostalim umjetničkim područjima: povijest umjetnosti kao znanstveni

\footnotetext{
${ }^{254}$ Usp. Sancti Bonaventurae Commentaria in quatuor libros Sententiarum magistri Petri Lombardi, Proemium in librum primum sententiarum, quaestio IV, sv. I. Firenze: Quaracchi,1882. Str. 14-15. URL:

https://archive.org/details/doctorisseraphic11bona (14.10.2019.) (prema Long, Micol. Autografia e epistolografia tra XI e XIII secolo. Milano: Ledizioni, 2014. str. 175. URL: https://books.openedition.org/ledizioni/409 (23.11.2019.)). Tekst pripada uvodu (Praefatio) Komentara: „Quadruplex est modus faciendi librum. Aliquis enim scribit aliena, nihil addendo vel mutando; et iste mere dicitur scriptor. Aliquis scribit aliena addendo, sed non de suo, et iste compilator dicitur. Aliquis scribit et aliena et sua, sed aliena tamquam principalia, et sua tamquam annexa ad evidentiam; et iste dicitur commentator non auctor. Aliquis scribit et sua et aliena, sed sua tamquam principalia, aliena tamquam annexa ad confirmationem et debet dici auctor."

${ }^{255}$ Nattiez, Jean-Jacques. Le discours sur la musique entre science et littérature. Allocution de remerciements prononcée lors de la remise de la médaille 2009 de l'Académie des lettres du Quebec. Montréal: 2009. str. 8. URL:

http://www.academiedeslettresduquebec.ca/system/ckeditor_assets/attachments/140/nattiez_medaille.pdf?14083 83286 (14.03.2018.).

${ }^{256}$ Ibid.: „Plus generalement, le discours sur la musique est percu comme inutile, voire parasitaire: la musique est bien cabale de s'exprimer elle-meme, elle peut se passer de commentaires.“
} 
diskurs o likovnim umjetnostima odavno je zauzela važno mjesto unutar humanističkih znanosti, a o važnosti i utjecaju povijesti i teorije književnosti izlišno je i govoriti - ona je ne samo generator novih spoznaja u znanosti o književnosti, već, osobito od druge polovice 20. stoljeća, iznimno utjecajna i u mnogim drugim humanističkim disciplinama kao kreator ili sukreator novih spoznajnih pravaca i metodologija. Glazba je, kao što znamo, u posebnom položaju zbog dvije osobitosti od kojih prvu dijeli s likovnim umjetnostima, dok joj druga osigurava jedinstvenost u odnosu na sve druge načine umjetničkog izražavanja. Prva se odnosi na činjenicu da, premda jezik često koristi kao podlogu za glazbena djela, njezin temeljni izričaj ne počiva na jeziku već na tonovima i ritmu kao temeljima glazbenog izražavanja, kao što i likovne umjetnosti u svome umjetničkom izričaju ne moraju koristiti jezik. Druga je osobina inherentno glazbena: glazbeno se djelo ostvaruje u vremenu zbog čega izmiče mogućnosti slušanja i promatranja, odnosno analiziranja na način na koji se analizi podaju sva umjetnička djela koja pripadaju tekstualnom i likovnom izražavanju ${ }^{257}$. Gotovo sav se Nattiezov govor fokusira na obranu časti muzikologije kao važne humanističke discipline koja govorom pojašnjava glazbu. Ta je obrana, međutim, suvišna ako se prisjetimo činjenice koju je definirao Louis Hjelmslev: svako ljudsko djelovanje koje ne uključuje jezik, u konačnici njime biva objašnjeno, pa tako ni glazba nije iznimka ${ }^{258}$.

Glazba kao zvučanje i glazba kao teorijski sustav u europskoj je civilizaciji od antičke Grčke predmet znanstvenih proučavanja i rasprava. Ona se, dakle, ne iscrpljuje u vlastitoj praksi, već kao i svaka druga ljudska djelatnost, zahtijeva verbalizaciju kako bismo mogli svladati njezine stvarateljske i izvedbene zakonitosti te je samima sebi i drugima pokušali objasniti. To je objašnjenje, kao što znamo, uvijek uvjetovano kulturnim kontekstom, odnosno društvenim, geografskim i povijesnim uvjetima u kojima djeluje onaj koji objašnjava, kao i kulturnim kontekstom onoga kome se objašnjava. Pitanjem kanadskog semiologa Jean-Jacquesa Nattieza o potrebi oznanstvenjivanja glazbe postavlja se inherentno i pitanje o uvjetima

\footnotetext{
${ }^{257}$ Ovdje se, dakako, misli na živu glazbenu izvedbu koja je uvijek neponovljiva, ne samo u odnosu na kontekst izvedbe (čak i ako su izvođači i slušatelji isti), već i zbog nemogućnosti ponavljanja identične izvedbe u tehničkom smislu sviranja ili pjevanja tonova i interpretacije. Moguća je, eventualno, usporedba s analizom filmske umjetnosti i glazbenih djela ukoliko se glazbeno djelo analizira isključivo na temelju neke snimke koju je moguće ponavljati. Tada je, i u jednom i u drugom slučaju, različit kontekst i istraživač. No, za razliku od filma koji se analizira na temelju snimke, glazbeno je djelo teško relevantno analizirati i interpretirati isključivo na temelju snimke. Ona (analiza) zahtijeva i partituru koja je podjednako temelj izvedbe - snimke, ali i njezine analize i interpretacije.

${ }^{258}$ Nattiez, Jean-Jacques. Op. cit. Str. 12.: „Le linguiste Louis Hjelmslev l'a souligné naguère: le langage verbal est toujours le système de signes que l'on utilise en dèrniere instance pour rendre compte de tous les autres systèmes de signes, y compris les signes non-linguistiques. La musique n'échappe pas à ce principe.“
} 
verbalizacije njezinih osobina i uvjeta njezina postojanja bilo kao procesa bilo kao djela, odnosno kao znanstvenog predmeta (l'objet d'une science).

Na početku poglavlja u kojem ćemo opisati diskurs neolatinističkih priručnika za učenje gregorijanskoga pjevanja u 18. stoljeću u Hrvatskoj i kantuala s napjevima koje trebaju izvoditi i kler i obredu prisustvujući vjernici, definirat ćemo pojam diskursa kako ga razumijemo u kontekstu govora o glazbi. ${ }^{259}$

Terminološka baza strukovnoga nazivlja Hrvatskog instituta za jezik i jezikoslovlje Struna diskurs definira kao „skup kulturno strukturiranih jezičnih reprezentacija i obrazaca za stvaranje značenja o nekome aspektu ljudske stvarnosti““. ${ }^{260} \mathrm{Na}$ temelju svijesti o kulturi kao pokretaču i okviru strukturiranja jezičnih reprezentacija i obrazaca, diskurs razumijemo kao tekstove ,„čiji složeni i relativno stabilni način strukturiranja posjeduje određenu vrijednost za neki kolektiv, tekstove koji su povezani zajedničkim uvjerenjem koje potiču i osnažuju, ukratko kao tekstove koji impliciraju pozicioniranje unutar diskurzivnog polja.“261 Pritom se analiza odnosi na francuski pojam Analyse du discours $(A D)$ uzimajući kao temelj Foucaultovu definiciju koja omogućava da istražujući ideju ili ideologiju analiziramo različite vrste žanrova, odnosno da tipologija teksta ne određuje a priori pojam diskursa. Ono što Michel Foucault u Arheologiji znanja naziva diskurzivnom formacijom u stvari se tiče odnosa skupa tekstova prema zajedničkome mjestu iskaza ili „točci porijekla iskazanog““262, a tim je tekstovima zajedničko to što „u društvenom prostoru definiraju određeni iskazivi identitet koji je i povijesno omeđiv.“ U našem je slučaju riječ o diskurzivnoj formaciji koja okuplja raznovrsne tekstove usmjerene na promicanje crkvene glazbe tijekom prvih šezdeset godina

\footnotetext{
${ }^{259}$ Odlomak o teoriji diskursa i diskurzivne formacije dugujem knjizi Foucault, Michel. Op. cit. i članku Maingueneau, Dominique. Analyse du discours et archive. // Semen (en ligne), 8/1993, mis en ligne le 12 juin 2007. URL: http://journals.openedition.org/semen/4069. (26.02.2020.)

${ }^{260}$ Usp. Diskurs. // Struna. Hrvatsko strukovno nazivlje. URL: http://struna.ihjj.hr/naziv/diskurs/25343/ (01.04.2018.)

${ }^{261}$ Maingueneau, Dominique. Op. cit. Str. 7.: „Il s'agit donc d'énoncés dont le mode de structuration complexe et relativement stable possède une valeur pour une collectivité, des textes associés à une conviction partagée, qu'ils suscitent et renforcent, en bref de textes qui impliquent un positionnement dans un champ discursif.“

${ }^{262}$ Ibid.: „Ce regroupement est corrélatif d'une certaine conception du "point d'origine" énonciatif. Celui-ci n'est pas considéré comme une forme de subjectivité, qu'il s'agissed'une conscience singulière ou collective, mais comme une place. Dire que l'énonciateur d'une formation discursive ne parle pas "en son nom", qu'il ne peut rapporter son dire à une subjectivité, c'est supposer qu'il assume le statut d'énonciateur que définit la formation discursive dans laquelle il se trouve pris.“
} 
18. stoljeća u sjevernim hrvatskim zemljama, ali, potencijalno, i u svim sličnim područjima Habsburškoga carstva. ${ }^{263}$

Pristup za koji se zalaže Foucault, Maingueneau naziva integrativnim: „Ovaj pristup koji bismo mogli okvalificirati kao integrativan, razumijeva diskurzivnu formaciju u složenosti globalizirajućeg funkcioniranja. Ondje gdje analitički pristup dezartikulira diskurs, integrativni nastoji artikulirati različite sastavnice diskurzivne formacije kroz četverostruku igru artikulacija: - onu intratekstualnih ulančenja, - onu različitih tekstova unutar iste diskurzivne formacije, - onu diskurzivne formacije u intertekstualnoj mreži i - onu diskurzivne formacije i njezina 'neverbalnog konteksta'‘. ${ }^{264}$

Procesi iskazivanja konstituiraju, međutim, i socijalne dispozitive koje treba promišljati kao takve: diskurzivna formacija, koju se nipošto ne misli izvan svijeta koji nastoji ,predstaviti“, ("représenter") sudjeluje u njegovoj igri moći ipak je ne razrješujući.

Budući da su novovjekovni latinistički pisci o glazbi u hrvatskim zemljama temeljno određeni pripadnošću Katoličkoj crkvi i to ne samo kao vjernici, već kao službenici te kao takvi ključni promicatelji njezine ideologije, $\mathrm{u}$ istraživanju tipa diskurzivne formacije koju oblikuju valja potražiti „neuralgične točke“ čije lociranje Maingueneau pripisuje realističkom pristupu analizi diskursa: „Realistički pristup jest iznad svega pristup istraživača koji se oslanjaju na psihoanalizu ili teoriju ideologije: analitičar mora upotrijebiti svo svoje umijeće kako bi u lancu iskaza locirao one neuralgične točke koje dopuštaju pristup onim snagama koje u isto vrijeme dozvoljavaju tekstu da se replicira u svojoj imaginarnoj koheziji i zabranjuju mu da

${ }^{263}$ AD podrazumijeva najrazličitije tipove tekstova koji, bez obzira na žanr, mogu tvoriti jedinstveni diskurs. Usp. Ibid.: „Ce ne sont pas les sermons en tant que sermons, les tracts politiques en tant que tracts politiques qui intéressent l'AD mais un ensemble de sermons ou de tracts en ce qu'ils définissent dans l'espace social une certaine identité énonciative historiquement circonscriptible. Le plus souvent une formation discursive ne correspond pas à un genre unique mais en associe plusieurs (tracts, manifestes, articles de journaux...).“

${ }^{264}$ Ibid. Str. 5: „Cette démarche que nous pourrions qualifier d'intégrative appréhende la formation discursive dans la complexité d'un fonctionnement globalisant. Là où la démarcheanalytique désarticule le discours, la démarche intégrative vise à articuler les diversescomposantes d'une formation discursive à travers un quadruple jeu d'articulations :

- celui des enchaînements intratextuels ;

- celui des divers textes à l'intérieur d'une même formation discursive ;

- celui de la formation discursive dans un réseau intertextuel ;

- celui de la formation discursive et de son "contexte non-verbal". 
ispravi sve svoje slabosti.“265 Pritom valja imati na umu da ,,[O]va mjesta iskaza pretpostavljaju institucije produkcije i difuzije specifičnog diskursa, dispozitive koji delimitiraju vježbu iskazne funkcije, status iskazitelja kao i onaj primatelja, te tipove sadržaja koji se može i mora izreći u takvom pozicioniranju. “266

Nadalje, zbog ,polisemije pojma 'diskurs' koju je nemoguće kontrolirati“ i široko postavljenog okvira diskurzivne formacije, Maingueneau nudi koncept arhiva koji je (ali ne i kakav!) koristio i Foucault povezujući ga s očuvanjem i memoriranjem tekstova: „On u njemu (arhivu, op. a.) vidi ono što za određeno društvo definira „opći sustav oblikovanja i transformacije iskaza“, ono što ,između tradicije i zaborava čini vidljivim i pravila prakse koja dopušta iskazima da se istovremeno supstituiraju i redovito modificiraju. “267

Maingueneau, međutim, arhiv razumije drugačije: ,arhiv nije 'element' iz kojeg izranjaju mnogostruke diskurzivne formacije, on se više odnosi na diskurzivne formacije, no shvaćene na specifičan način. ... [S]hvaćen kao "arhiv", zbir tekstova ne definira se samo kao odgovor na svežanj obvezujućih praksi već, također, dopušta legitimiranje određene govorne prakse za neku grupu. Proučavanje arhiva igra na taj način ulogu usporedivu s ulogom mita za primitivna društva. Za analitičara diskursa, kao i za mitologa radi se o razmatranju iskazivih pozicija koje povezuju tekstualno funkcioniranje s konstrukcijom identiteta u očuvanju zajednice.“268 Radi se, u stvari, o replikaciji de Saussureova dvojnoga koncepta vrsta odnosa u

\footnotetext{
${ }^{265}$ Ibid. Str. 8: „Les processus énonciatifs constituent en effet aussi des dispositifs sociaux, qu'il faut penser comme tels ; la formation discursive, loin d'être à l'extérieur d'un monde qu'elle se contenterait de "représenter" participe de son jeu des forces, sans pour autant s'y dissoudre. La démarche "réaliste" est surtout celle des chercheurs qui s'appuient sur la psychanalyse ou une théorie des idéologies : l'analyste doit user de tout son art pour repérer dans l'enchaînement des énoncés ces points névralgiques qui donnent accès aux forces qui à la fois permettent au texte de se replier sur sa cohésion imaginaire et lui interdisent de jamais colmater toutes ses failles."
}

${ }^{266}$ Ibid.: „Ces places d'énonciation supposent des institutions de production et de diffusion du discours spécifiques, des dispositifs qui délimitent l'exercice de la fonction énonciative, le statut des énonciateurs comme celui des destinataires, et les types de contenus que l'on peut et doit dire à partir d'un tel positionnement."

${ }^{267}$ Ibid. Str. 10: „Il y voit ce qui définit pour une société donnée "le système général de la formation et de la transformation des énoncés", ce qui "entre la tradition et l'oubli, fait apparaître les règles d'une pratique qui permet aux énoncés à la fois de subsister et de se modifier régulièrement"."

${ }^{268}$ Ibid.: Pour nous, en revanche, l'archive n'est pas "l'élément" dont émergent les multiples formations discursives, elle renvoie plutôt aux formations discursives, mais appréhendées demanière spécifique. ... Considéré comme "archive", un ensemble de textes ne se définit pas seulement comme la réponse à un faisceau de contraintes pratiques, il permet aussi de légitimer un certain exercice de la parole pour un groupe donné. L'étude de l'archive joue ainsi un rôle comparable à celle du mythe pour les sociétés primitives. Pour l'AD comme pour le mythologue il s'agit de considérer des positions énonciatives qui nouent un fonctionnement textuel à la construction de l'identité et à la préservation d'un groupe.“ 
jeziku koji mogu biti sintagmatski (in praesentia) i asocijativni (in absentia) te dvojnog koncepta jezične djelatnosti (langage) koja objedinjuje jezik kao apstraktni sustav (langue) i govor (parole).

Treba spomenuti još dvije važne odrednice analize diskursa u ovom istraživanju. Prva se odnosi na pristup analizi diskursa koji je pluridisciplinaran, a ne strogo lingvistički. Priklanja se, naime, kontekstualizmu, odnosno principima strategije kontekstualizma pri čemu je kontekst rezultat „mehanizma inferencije (međudjelovanja) između skupa lingvističkih elemenata i drugog nelingvističkog, omogućavajući interpretaciju iskaza i iznalaženje njegova smisla“. Druga je povezana s prvom i tiče se metodologije. S obzirom da se diskursu pristupa kao govornoj praksi koju čini lanac međusobno povezanih iskaza, a ta se govorna praksa analizira iz nekoliko aspekata: muzikologije i povijesti glazbene teorije, povijesti liturgijskih praksi i crkvenih institucija koje ih proizvode, filozofijskih i ideoloških postulata sustava obrazovanja u kojem se formirao oblikovatelj diskursa, ali i onog za koji svoj diskurs proizvodi, te društvenih i političkih uvjeta prostora i vremena u kojem je diskurs nastao, metoda koja se nameće kao jedina moguća jest metoda koja proizlazi iz same pluridisciplinarne analize izvora - metoda kao put analize: „Metoda se može oblikovati samo tijekom istraživanja; može se otkriti i oblikovati tek poslije, u času kada konac ponovno postaje nova točka polaska, ovoga puta opremljena metodom. Nietzsche je to znao: „metode dolaze na kraju“ (Antikrist). Vraćanje na početak nije začarani krug ako putovanje, kao što danas kaže riječ „trip“, označava iskustvo iz kojeg se izlazi promijenjen. “269

\footnotetext{
${ }^{269}$ Morin, Edgar. La méthode, 1 - La nature de la nature. Paris: Point seuils Essais, br. 123, 1977. Str. 22.
} 


\title{
3.1. Glazbenoteorijski neolatinistički diskurs u 18. stoljeću: slučaj ,gregorijansko pjevanje ${ }^{6}$
}

\begin{abstract}
„Mnogobrojne analize diskursa koje se provode u području lingvistike variraju u odnosu na discipline na koje se odnose, $\mathrm{u}$ odnosu na unutarnje tendencije tih disciplina te, također, $\mathrm{u}$ odnosu na tip diskurzivnih fenomena koji ih zanimaju. “270
\end{abstract}

Mainguenau u gornjem citatu upozorava na pluralnost analitičkog diskursa s obzirom na ciljane discipline. Ta je pluralnost itekako vidljiva unutar muzikološkoga diskursa koji se od znamenitog teksta Guida Adlera „Umfang, Methode und Ziel Musikwissenschafts“271 račva na historijski i sistematski dio. Teme koje su pripale historijskom dijelu (glazbena povijest zemalja, naroda, glazbenih oblika, skladatelja ...) u ovoj podjeli na kojoj i danas počiva velik dio muzikoloških istraživanja, zamišljene su da se istražuju dijakronijski, dok su ove druge, određene kao sistematske (odnose se prije svega na glazbenoteorijske teme i glazbenu pedagogiju), zamišljene kao više-manje statičan dijakronijski diskurs u kojem historijski aspekt nije presudan. Ipak, Adler je bio svjestan historijskog elementa sistematskih disciplina, odnosno svakog istraživanja uopće ${ }^{272}$, dok analitički diskurs muzikologije danas, nakon zahtjeva za kontekstualnim pristupom istraživanju, nastoji pomiriti njezin filološki aspekt s uvjetima koje postavljaju umjetnička djela.

Diskurs o gregorijanskom pjevanju kao o izvedbeno (monodija koju zbor izvodi unisono) i funkcionalno (crkvena glazba) određenom tipu glazbenog izričaja počinje u 9. stoljeću spisima Musica enchiriadis i Scolica enchiriadis i opstaje usporedo sa sve složenijom i rasprostranjenijom vokalnom polifonijom. U tom ga smislu donekle prati glazbena

\footnotetext{
${ }^{270}$ Mainguenau, Dominique. Op. cit. Str. 6.

${ }^{271}$ Adler, Guido. Umfang, Methode und Ziel der Musikwissenschaft. // Vierteljahrschrift für Musikwissenschaft, 1 (1885) 1. Str. 5-20.

${ }^{272}$ Adler istraživanje umjetničkog djela uspoređuje s paleološkim istraživanjima koja su krajem 18. stoljeća uspostavila u svijesti ne samo prirodnih znanosti, vremenske slojeve kojima pripadaju određene posebnosti: „Liegt ein Kunstwerk vor, so wird es vorerst paläologisch bestimmt werden.“, nav. čl. str. 6, i dalje: „“Den höchsten Rang nimmt 3) die Erforchung der kunstgesetze verschiedener Zeiten ein; diese ist der eigentliche Kernpunkt aller Musikhistorischen Arbeit.“ Ibid. Str. 9. Adler povijest razumije potpuno pozitivistički kao organski razvoj sve kvalitetnije materije od koje otpadaju periferni, nevažni elementi, a teoretičare kao one koji ne reflektiraju suvremenu praksu već je radije zauzdavaju: „Wie von der Anfänghen der einfachen Melodie ausgehend der Bau der Kunstwerke allmählich wächst, wie von den einfachsten Thesen ausgehend die in den Tonprodukten latenten Kunstnormen complicirt und complicirter werden, wie mit den entschwindenen Culturen die Tonsysteme vergehen, wie an das Glied sich nach und nach eine Kette von Zelle einschließt und so organisch wächst ..."
} 
historiografija koja o gregorijanskom pjevanju govori kao o temeljnom glazbenom izričaju do pojave polifonije, a potom se fokusira na razvoj polifonih oblika u kojima crkveno jednoglasje često funkcionira kao temelj kontrapunktski oblikovanih skladbi. U stvari, u priručnicima za povijest glazbe nakon spominjanja znamenitog osamnaestogodišnjeg Koncila u Tridentu (1545-1563.) i nastojanja oko implementacije na njemu donesenih odluka u kontekstu opće katoličke obnove, gregorijansko pjevanje se ne spominje sve do dviju velikih restauracija: one koju je u Njemačkoj, u Regensburgu, u posljednjoj trećini 19. stoljeća inicirao Cecilijanski pokret ${ }^{273}$ i kao temelj koristio tzv. Medičejsko izdanje (Editio Mediceae 1614-1615.) te znamenite benediktinske koju su potaknuli i desetljećima minuciozno provodili benediktinci u francuskoj opatiji Solèsmes u drugoj polovici 19. stoljeća želeći iznaći izvorni oblik gregorijanskoga pjevanja koje se prakticiralo prije renesansne reforme. ${ }^{274}$ Čak i relativno nedavno objavljeni, vrlo iscrpni i o novim historiografskim tendencijama temeljito informirani priručnici poput The Cambridge History of Western Music Theory ${ }^{275}$ ostavljaju dojam da je gregorijansko pjevanje kao diskurzivna (propedeutički tekstovi, kantuali popraćeni ekstenzivnim uvodima koji veličaju gregorijaniku, itd.) i glazbena praksa (pjevanje u zboru a cappella ili praćeno orguljama tijekom moljenja brevijara i slavljena mise) u cijelosti zamro između Editio Mediceae početkom 17. stoljeća i spomenutih devetnaestostoljetnih pokreta. Upravo je to razdoblje koje opća povijest glazbe opisuje kao

\footnotetext{
${ }^{273}$ O Cecilijanizmu v. Boisits, Barbara. Cäcilianismus. // Oesterreischisches Musiklexikon online. URL: //www.musiklexikon.ac.at/ml/musik_C/Caecilianismus.xml

${ }^{274} \mathrm{O}$ restauracijama gregorijanskog pjevanja informativno v. Hiley, David. Op. cit. Str. 624-627. O cecilijanskoj verziji: ,The editions of the Graduate (1871 and 1873) and Antiphonale (1878) published in Regensburg by the firm of Pustet were edited by Franz Xaver Haberl. The gradual was a faithful revival of the Medicaea, the antiphoner was based on the printed editions of Venice 1585 and Antwerp 1611.“I još: „In 1871 Pius IX declared the Regensburg editions to be the only versions officially recognized by the Roman Church, an astonishing monopoly enjoyed by Pustet for thirty years, and the first of its kind, for the Medicean gradual had never had this status." U naporima francuskih benediktinaca u pokušaju uspostave autentičnoga gregorijanskog pjevanja vjerojatno najvažniju ulogu igrali su Dom Jospeh Pothier („Already by 1867 Pothier felt able to write the first draft of a 'method', of the type which abounded at the time. And by 1868 a new gradual had also been prepared. These eventually became the Mélodies gregoriennes of 1880 and the Liber gradualis of 1883 . Meanwhile a litographed Processionale had been published in 1873.) i André Mocquereau („In 1875 Andre Mocquereau (1849-1930) joined the community. It was he who conceived the idea of the series of facsimiles Paleographie musicale, whose indisputable evidence should support Pothier's publications.") Papa Lav XIII povukao je monopol Pustet izdanja 1899., a isusovac Angelo de Santi, urednik Civiltà cattolica, oduševljen Pothierovim radom uveo je kroz Francuski seminar u Rimu, a postupno i u druge rimske zborove, uključujući i onaj u Sikstinskoj kapeli, benediktinske verzije antifonala, graduala i brevijara. Nasljednik Lava XIII, Pio X objavio je na blagdan sv. Cecilije 1903. znameniti motu proprio „Tra le sollecitudini“ kojim verzije iz Solèsmesa postaju i do danas ostaju službenim vatikanskim edicijama gregorijanskoga pjevanja.
}

275 The Cambridge History of Western Music Theory. / uredio Thomas Christensen. Cambridge: Cambridge University Press, 2008. Knjiga je u stvari zbornik radova brojnih znanstvenika koja pruža uvid u razvoj teorije glazbe kronološki obuhvaćajući teoriju glazbe od antičke Grčke do kraja 20. st., istovremeno nastojeći u tematskim blokovima prikazati sinkronijsku sliku razdoblja, jasno komunicirajući s čitateljem svijest autorâ i urednika o problematici razvojno usmjerene glazbenoteorijske historiografije. 
barok, pretklasiku i klasiku sa svom množinom i raznovrsnošću glazbenih oblika koji su tada nastajali i postupno se afirmirali tvoreći i danas važan dio repertoarnog kanona tzv. ozbiljne glazbe. Silne novine u glazbenim formama i izričaju i emancipacija glazbe od crkvenih i aristokratskih krugova u historiografiji su gotovo u cijelosti potisnuli, u praksi crkvene glazbe 17. i 18. stoljeća još uvijek vrlo važno gregorijansko pjevanje koje se, omeđeno granicama koje opasuje s jedne strane crkva u smislu religijske funkcionalnosti, a s druge glazbeni oblik jednoglasja, također mijenjalo. Suprotno dojmu koji pruža europska glazbena historiografija, i diskurs o gregorijanskom pjevanju itekako je živ i plodan zahvaljujući, dakako, činjenici da ono o čemu tekstovi govore postoji i dalje kao nezaobilazan glazbeni izričaj, premda svakako umanjene društvene važnosti. Tijekom cijelog 17. i 18. stoljeća tiska se velik broj priručnika koji podučavaju teoriju potrebnu za izvođenje ili skladanje koralnih melodija, kao i kantuala čiji je koral temeljni glazbeni oblik. ${ }^{276}$ Procvat gregorijanike, kao i teorije potrebne za ispravno izvođenje gregorijanskih napjeva, usko je vezan uz odluke donesene o poželjnom obliku liturgije na Koncilu u Tridentu. Uz izbjegavanje lascivnosti i izlišne svjetovnosti u izričaju, temeljna uputa Koncila, sukladno vladajućoj očaranosti antičkom kulturom i umjetnošću, jest razumljivost teksta. U tom smislu, kako smo istaknuli u uvodu, gregorijansko pjevanje i dalje je onaj koji oblikuje glazbu kao modus spoznaje i spasa, koji predstavlja svijet simboličkih odnosa unutar glazbenog i onaj koji povezuje, pa makar labavo, nekada razdvojena diskurzivna područja musica theorica i musica practica. S obzirom na istaknutu potrebu za uređivanjem i unificiranjem liturgije te, sukladno tome, na primjereno obrazovanje budućih svećenika, naglasak je na promjeni fokusa teorijskih tekstova od onih kojima dominira filozofsko ontološka problematika muzike do praksom i pedagogijom motiviranih priručnika. Niz objavljenih kantuala pritom svjedoči da se diskurzivno polje kojim se prostire govor o gregorijanskom pjevanju, proteže i na izvedbu čime poništava definiciju anakronog fenomena i potvrđuje ga kao jednu od postojećih i vrlo živih glazbenih praksi.

\footnotetext{
${ }^{276} \mathrm{Npr}$. Trattati italiani di canto fermo. URL: http://canto-fermo.univ-tours.fr/collections/show/3 (20.06.2020.) dostupan je popis pedeset i tri (!) priručnika za učenje koralnoga pjevanja objavljenih u Italiji tijekom 18. stoljeća, a svi su pisani talijanskim. Usp. i Bisaro, Xavier. Par-delà des monts: Les traités de „,canto fermo“. URL: https://www.cantus-scholarum.univ-tours.fr/publications/essais-et-notes-de-travail/canto-fermo/ (20.06.2020.) Obilje tiskanih i rukopisnih kantuala nalazimo tijekom prve polovice 18. stoljeća u Hrvatskoj. U sjevernim Hrvatskim zemljama od tiskovina najviše je sačuvanih primjeraka kantuala Ordo Agendorum et Cantandorum (Beč, 1702.). U Zagrebu se još čuva Cantuale processionum (Beč, 1751.) te PsalterioAntiphonale Romanum (Beč, 1742.) čiji je dio priručnik za učenje koralnog pjevanja Compendiosa in cantum gregorianum seu choralem. U Hrvatskoj je, također, prisutan i velik broj rukopisnih kantuala od kojih je većina onih koji su nastali sredinom 18. stoljeća prepisana u Veneciji: „Poznato je da su nastali (sc. kantuali, op. a.) po narudžbi provincijala Josipa Jankovića, koji je iz venecijanskog samostana S. Francesco della Vigna naručio 13 kantuala (sačuvano je 10 kompletnih i 3 knjige samo orguljske pratnje) za svaki samostan unutar provincije." (Katalinić, Vjera. Op. cit. Str. 25).
} 
U kontekstu novovjekovne latinističke glazbene teorije o gregorijanskom pjevanju (ona objavljena na drugim jezicima, osobito talijanskom, ali i njemačkom i francuskom služi u našem slučaju kao potencijalna komparativna građa za neolatinistički teorijski diskurs), diskurzivnu formaciju razumijemo kao skup tekstova koji se na određeni način odnose prema zajedničkoj točki iskaza - cantus gregorianus/cantus planus/cantus firmus - te oblikuju sadržajno jasno određeni glazbenoteorijski diskurs. ${ }^{277}$ Pritom je, s obzirom na godine objavljivanja analiziranih tekstova i društveni kontekst katoličke obnove, epoha o kojoj se govori razdoblje od kraja 17. stoljeća pa sve do reforme Maksimilijana Vrhovca krajem 18. stoljeća $^{278}$ koja prekida višestoljetnu praksu zagrebačkog obreda.

\subsection{Arhiv glazbenoteorijskog diskursa}

Ukoliko izvorište oblikovanja diskurzivnih formacija o muzici kao „opći sustav oblikovanja i transformacije iskaza ${ }^{\text {‘279 }}$ koji dopušta da se određeni iskazi supstituiraju i modificiraju, prema Maingueneauovom prijedlogu nazovemo arhivom, analizom ovoga u koji posežemo uočavamo da je bremenit srednjovjekovnom građom te stoga i duboko uronjen $u$ srednjovjekovni način mišljenja, ustroj njegovih jezičnih i perceptivnih shema i načine razmjene znanja. Taj zamišljeni arhiv znanja o glazbi taloži i miješa ideje i spoznaje potekle iz filozofskih sustava razvijenih u antičkoj Grčkoj (Platon, Aristotel i Aristid Kvintilijan) ${ }^{280}$,

\footnotetext{
${ }^{277}$ To, međutim, ne znači da postoji jedna izlazna točka ili jedno mjesto koje iskaz čini legitimnim. Štoviše, raznovrsnost žanrova doprinosi koherenciji diskurzivne formacije. Usp. Maingeneau, Dominique. Op. cit. Str. 67. „Cela ne signifie pas que pour chaque formation discursive il existerait une et une seule place d'énonciation légitime, puisqu'un ensemble d'énoncés rapportés à un même positionnement peut se distribuer sur une multiplicité de genres de discours. Mais à supposer que l'analyste se donne pour objet cette diversité il lui faut la penser comme telle: la diversité des genres d'une formation discursive, loin d'être un accident survenu a un noyeau de sens stable, contribue à définir son identité.“

278 Takozvani „Zagrebački obred“ o kojem pišu i Toma Kovačević i Mihael Šilobod-Bolšić, Vrhovac je ukinuo 1787. godine, iste godine kad je imenovan zagrebačkim biskupom. O povijesti zagrebačkog obreda v. Kniewald, Dragutin. Obred i obredne knjige zagrebačke stolne crkve 1094-1788. Zagreb, 1940. i od istog autora Himnodija zagrebačke stolne crkve. Zagreb, 1944. O suvremenom uvidu u razlike između starog zagrebačkog i rimskog obreda v. Šaško, Ivan. Biskup Kažotić, promicatelj knjige u Hrvata s posebnim naznakama iz povijesti liturgije. Croatica Christiana Periodica (CCP) 49 (2002), str. 59-68.; Šaško, Ivan. „Liturgijski identitet Sakramentara iz Zagreba. Istraživanje na temelju molitava korizmenoga vremena“. CCP, 55 (2005), str. 7-41.

279 Ibid.

${ }^{280}$ Temeljni izvori za oblikovanje ideja u glazbi bili su Platonovi spisi Država (osobito III. knjiga, 398c-401a, knj. V, 401d), Zakoni te osobito posljednji njegov dijalog Timej. (Navođenje mjesta u knjizi odgovara originalnom tekstu Zakona dostupnom na http://www.perseus.tufts.edu/hopper/text?doc=Perseus\%3atext\%3a1999.01.0165, odnosno Države dostupnom na http://www.perseus.tufts.edu/hopper/collection?collection=Perseus\%3Acorpus\%3Aperseus\%2Cwork\%2CPlato $\% 2 \mathrm{C} \% 20$ Republic, digitaliziranima prema kritičkom izdanju Platonis Opera. // uredio John Burnet. Oxford University Press, 1903. Aristotel je pak na opću teoriju obrazovanja i definiranje teorije i prakse utjecao
} 
Rimu (Marcijan Kapela) ${ }^{281}$ i općenito kasnoj antici (Plotin, sv. Augustin, Boetije) ${ }^{282}$

preuzimajući jedne i odbacujući druge pritom ih modificirajući sukladno kršćanskim

vrijednostima i praktičnoj potrebi svakodnevnog pjevanja brevijara i svete mise. Nasljedujući

(kasno)antičke pojmove, ali ne uvijek i njihovo značenjsko polje, glazbenoteorijska baština

srednjega vijeka koja obuhvaća pisce kao što su sv. Aurelije Augustin, Flavije Magno

Aurelije Kasiodor, Guido iz Arezza, Johannes de Muris, Izidor iz Seville, Johannes Tinctoris,

Johannes de Grocheo i mnogi drugi uvelike je prisutna i u glazbenoj teoriji 17. i 18. stoljeća

koja se odnosi na gregorijansko pjevanje. U odnosu na srednjovjekovni sustav modusa

ponajviše djelom Nikomahova etika. Što se glazbe tiče, Aristotel se njome kao važnim elementom u obrazovanju slobodnoga građanina, slijedeći tako Platona, bavi u osmoj knjizi Politike. O stavovima Platona i Aristotela o etičkoj ulozi glazbe podrobnije u poglavlju „Musica theorica“. Aristid Kvintilijan iz Smirne djelovao je između

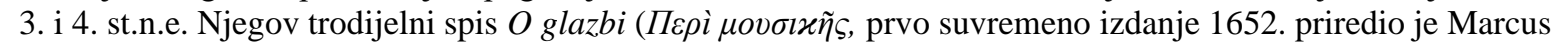
Meibomius, znameniti antikvar i knjižar) prema riječima suvremenog muzikologa Thedorea Karpa predstavlja jedan od najobuhvatnijih prikaza antičke teorije, estetike i ethosa u glazbi, kompilirajući vlastite poglede $\mathrm{s}$ idejama Aristoksena, Damona Atenjanina i Dionizija Halikarnašanina te Platona, Aristotela i pitagorejske tradicije. Od Aristida Kvintilijana mnoge ideje preuzima i Marcijan Kapela. Marcus Meibomius priredio je za uvid u antičku teoriju važno djelo Antiquae musicae auctores septem. Graece et latine. Marcus Meibomius restituit ac notis explicavit, Amstelodami: Ludovicum Elzevirum, 1652. URL:

https://books.google.be/books?vid=GENT900000090383\&printsec=frontcover\&hl=nl\#v=onepage\&q\&f=false (28.07.2020.). V. Marrou, Henri-Irénée. Mousikos aner. Grénoble: Didier \& Richard, 1938.; Idem. Histoire de l'éducation dans l'antiquité. Paris: Éditions du Seuils, 1948.

${ }^{281}$ Marcijan Kapela (Kartaga, 5. st. n. e.) autor je djela De nuptiis Philologiae et Mercurii pisanog pod snažnim utjecajem neoplatonizma u kojem definira raspodjelu umijeća (artes) na trivium i quadrivium, smještajući glazbu uz aritmetiku, geometriju i astronomiju u matematičke znanosti kvadrivija. O Marcijanu Kapeli i njegovom utjecaju na srednjovjekovnu znanost v. Stahl, William H. To a better Understanding of Martianus Capella // Speculum: 40/1, University of Chicago Press, 1965. Str. 102-115. URL:

https://www.jstor.org/stable/2856467?seq=1 (28.07.2020.) i monografiju Stahl, William H.; Johnson, Richard; Burge, Evan Laurie. Martianus Capella and the Seven Liberal Arts. sv. I: The Quadrivium of Martianus Capella. Columbia University Press: 1991. (reprint izdanja iz 1971.)

${ }^{282}$ Neoplatoničar Plotin bio je iznimno utjecajan u oblikovanju srednjovjekovne filozofije. U Eneadama ponavlja Platonov stav o sličnosti utjecaja aritmetike, geometrije, astronomije i glazbe na dušu. O sličnostima i razlikama u Platonovu i Plotinovu poimanju glazbe v. Tokić, Marko. Platon i Plotin o glazbi. // Filozofska istraživanja, 142/36, 2016. sv. 1, str. 193-202. Sv. Augustin i njegov spis De musica libri sex odigrao je važnu ulogu u oblikovanju musica theorica, pristajući uz (neo)platonizam i nudeći filozofsko opravdanje upotrebe glazbe u kršćanskim obredima. U konstituiranju srednjovjekovne theoria practica važni su njegovi stavovi o broju kao temelju za proučavanje glazbe te ritmu kao temelju glazbe i glazbenoga. No, njegov utjecaj i ugled u traktatima koji donose glazbena pravila za praksu, osobito tijekom 17. i 18. stoljeća gotovo je zanemariv. Boetije je kao kompilator antičkoga znanja o glazbi djelom De musica stekao nemjerljiv utjecaj i ugled, a njegove su teze o glazbi kao odrazu harmonije sfera, jednako kao i trodijelna podjela glazbe postali opće mjesto u povijesti teorije glazbe. Premda je musica theorica u smislu matematičko-filozofskih rasprava o glazbi poslije 16. stoljeća uživala sve manji ugled, Boetiija se citira i parafrazira u nizu rasprava sve do kraja 18. stoljeća, a iznimka nisu niti priručnici koje analiziramo u ovoj disertaciji. O Boetiju i njegovu filozofskom opusu te utjecaju u srednjem vijeku v. A Companion to Boethius in the Middle Ages. // uredili Kaylor, Noel Harold; Phillips, Edward Phillip. Leiden: Brill, 2012. Za temeljnu analizu Boetijeva utjecaja na filozofiju općenito te na glazbu, kao i na ulogu u povezivanju antičke i srednjovjekovne kulture v. bibliografiju Illoa Humphreya dostupnu na poveznici https://ubordeaux3.academia.edu/IlloHumphrey, pristup 23.08.2019. Za recepciju u ranom srednjem vijeku v. Bernhard, Michael. Rezeption der Institutio Musica des Boethius im frühen Mittelalter. Boèce ou la chaîne des savoirs. Actes du Colloque International de la Fondation Signer-Polignac, Paris, 1999. / uredio Alain Galonnier.

Louvain - Paris: Peeters, 2003. Str. 601-612. 
preuzet iz starogrčke teorije ${ }^{283}$ izmijenjen je višestoljetnom glazbenom praksom utemeljenom na heksakordalnom ljestvičnom nizu, a podjela vrijednosti dobe kao mjerne jedinice rezultat je polifone prakse koja se reflektirala i u ritmiziranju načelno neritmiziranog napjeva cantus planus. Upravo heksakordalni ljestvični sustav te podjela note brevis na semibrevis i minima osuvremenjuju srednjovjekovni temelj arhiva i ukazuju na sve snažniji utjecaj prakse na teorijski govor. Adriano Banchieri višestruko naveden kao izvor i autoritet i u Kovačevića i u Šiloboda-Bolšića pripada najvećim renesansnim i ranobaroknim autoritetima. Austrijska i južnonjemačka tradicionalna liturgijska praksa također je vrlo utjecajna, osobito djela Johanna Baptista Sambera, salcburškog orguljaša i teoretičara. Ipak, kontinuitet gregorijanike ne dopušta značajnije otklone u teoriji koja je, za razliku od svjetovne pa i polifone liturgijske glazbe, komplementarna s praksom upravo zbog zahtijevanog očuvanja čistoće gregorijanskoga pjevanja.

\footnotetext{
${ }^{283}$ Sustav starogrčkih modusa, odnosno princip podjele na četiri glavna i četiri sporedna, preuzeli su već prvi pisci priručnika za učenje pjevanja gregorijanskoga repertoara. Preuzeti su, međutim samo nazivi, dok je sama ljestvica prilagođena potrebama gregorijanike. Također, mijenja se i naziv te se ljestivčni nizovi protus, deuterus, tritus i tetrardus koji postoje u izvornom authenticus obliku i sporednom plagalis, nazivaju tonoi. Tonus će i u kasnijoj teoriji ostati najčešće upotrebljavan termin za ono što suvremena glazbena teorija naziva crkvenim modusima. O grčkoj muzičkoj teoriji v. Atkinson, Charles M. The Critical Nexus, Tone-System, Mode and Notation in Early Medieval Music. Oxford: Oxford University Press, 2008.; Nowacki, Edward. Greek and Latin Music Theory. Principles and Challenges. University of Rochester Press: 2020.; Mathiesen, Thomas J. Greek music theory. The Cambridge History of Western Music Theory. / uredio Thomas Christensen. Cambridge: Cambridge University Press, 2008. Str. 109-135. Bowler, Calvin M. The transmission of ancient music theory into the Middle Ages. The Cambridge History of Western Music Theory. / uredio Thomas Christensen. Cambridge: Cambridge University Press, 2008. Str. 136-167.
} 


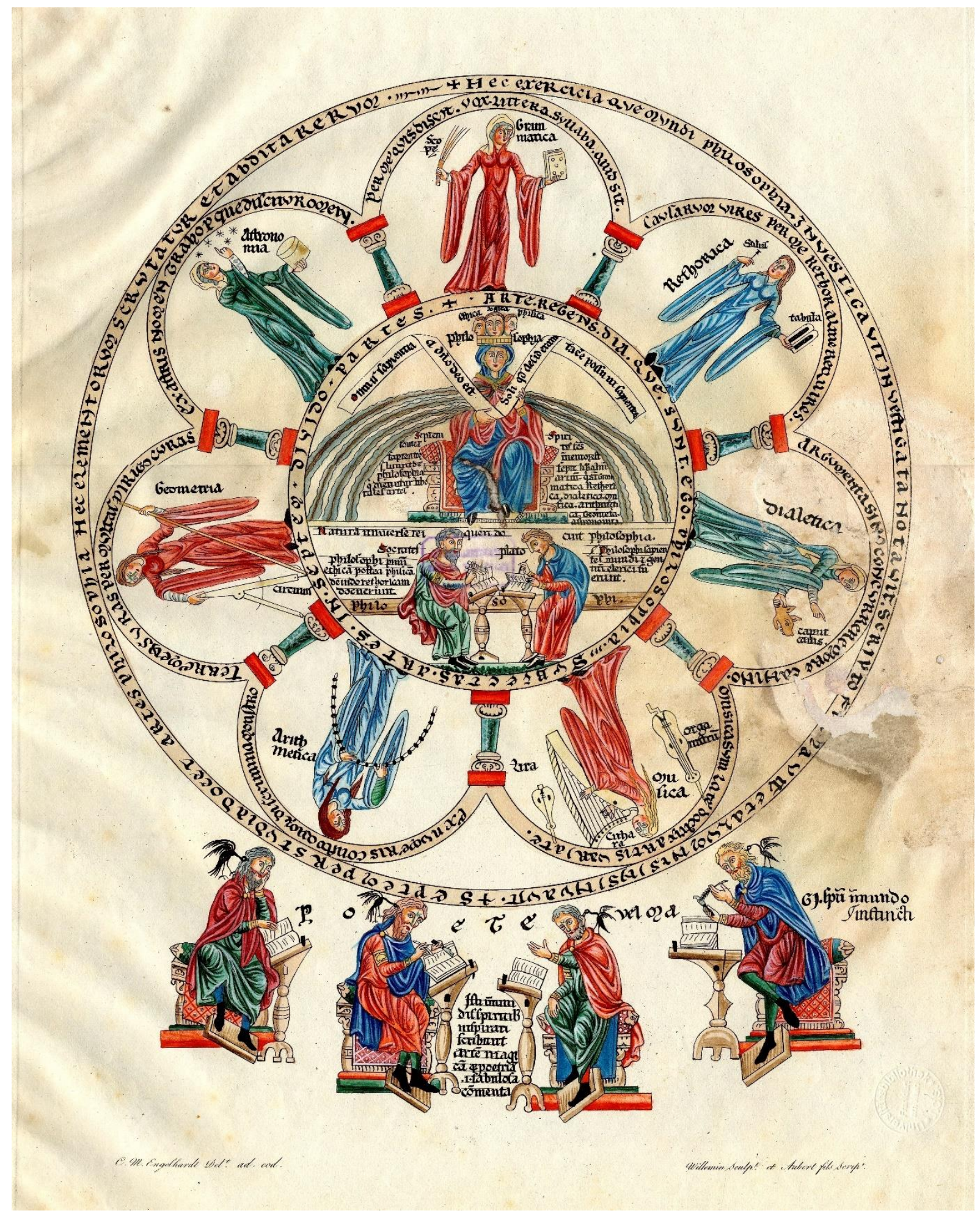

S1. 2 Herrad iz Landsberga (oko 1167. - 1185.) Hortus deliciarum, pl. XI. Filozofija i sedam slobodnih umijeća. Znameniti prikaz Filozofije koja raspodjeljuje sedam slobodnih umijeća i vlada nad njima. Glazba je već tada prikazana kao praksa, a ne kao matematička disciplina, premda im u sklopu kvadrivija pripada. Djevojka koja prikazuje glazbu drži citru, a okružena je lirom i vrstom viole da gamba, dok tekst kaže: „Musica sum late doctrix artis variate“. 
Vrlo često, kao što pokazuju i domaći neolatinisti, glazbenoteorijski diskurs o gregorijanskom pjevanju u ovome razdoblju $\mathrm{u}$ istom traktatu niže neoplatonističke uvide u glazbu kao teoriju (matematički modeli koji impliciraju harmonijski odnos makrokozmosa i mikrokozmosa, svemira i svijeta, neba i zemlje), etiku (glazba shvaćena kao mimeza svemirskoga sklada i posrednik u oblikovanju čovjekove duše) i praksu (profana, zvukovna rezonancija teorijske harmonije te praktični glazbenoteorijski elementi, ono što mi danas nazivamo solfeggio). Komplementarnost svih triju vrsta muzike koje je definirao Boetije ${ }^{284}$ - musica mundana ${ }^{285}$, musica humana, musica instrumentalis - za kršćanskog se mislioca na zemlji ostvaruje u gregorijanskom pjevanju, liturgijskoj monodiji čija je dužnost ostvariti sinergiju razumljivosti teksta i ljepote melodije što doprinosi zdravlju duše, a time i vječnom spasu, glavnoj svrsi čovjekova postojanja na zemlji.

Obilje glazbenih priručnika objavljenih tijekom 17. i 18. stoljeća koji nastoje čitatelju približiti sve aspekte njezine višestrukosti oslanja se, čini se, na reducirane verzije kasnoskolastičkih summae čiji su autori mahom uglednici glazbenoteorijske misli koji, sukladno srednjovjekovnoj praksi, relativno slobodno tretiraju tekst iz kojeg crpe vlastito znanje: prenose ga rijetko citirajući, češće parafrazirajući i uvijek prilagođavajući vlastitoj estetičkoj ideji. ${ }^{286}$ Kasnosrednjovjekovne glazbenoteorijske summae, od kojih su najpoznatije one Johannesa de Murisa (čije djelo, barem posredno poznaje i Šilobod-Bolšić), Waltera iz Odingtona, Marchetta iz Padove i Jakoba iz Liègea, primjeri su kompilacija i komentara obilja glazbenoteorijske građe iz koje svaki budući pisac može crpiti onu sukladnu temi kojom se bavi. To znači da je odabir sadržaja koji se prenosi i zastupljenost neke teme iz gore spomenutih vrsta musica sukladan namjeni priručnika i svjedoči o načitanosti autora, ali i o

\footnotetext{
${ }^{284}$ Teško je precijeniti utjecaj koji je Anicije Manlije Severin Boetije imao na kršćanske mislioce. Premda sam nije bio kršćanin, njegov je spis Consolatio philosophiae uvelike odredio smjer srednjovjekovne filozofije, baš kao što je i De institutione musica stoljećima predstavljala temelj obrazovanja u muzici kao dijelu kvadrivija te umnogome definirala razumijevanje platonističkih ideja kongruencije svemirskoga i zemaljskoga sklada. Podjela glazbe na tri vrste prenosila se ad infinitum, no postoje razne inačice. Mihael Šilobod-Bolšić prenosi podjelu na pet vrsta koju preuzima iz spisa Johanna Baptista Sambera Elucidatio musicae choralis iz 1710.

${ }^{285}$ Ta je podjela, premda sve rjeđe spominjana od 16. stoljeća nadalje, nalazila odjeke sve do kraja 18. stoljeća: „The idea of the harmony of the spheres, that heavenly bodies move in concord with each other, goes back in Western writings, at least to Plato, and remains a topos through the Latin classics (Ptolemy, Pliny, Cicero, Boethius) and their medieval readers into the scientific early modern world." $u$ : Naturalis concordia vocum cum planetis. Conceptualizing the Harmony of the Spheres in the Early Middle Ages // Citation and Authority in Medieval and Renaissance Musical Culture: Learning from the Learned / uredile Suzannah Clarke; Elizabeth Eva Leach. Woodbridge: Boydell Press, 2005. Str. 5.

${ }^{286}$ Musurgia universalis sive ars magna consoni et dissoni in x libros digesta Athanasiusa Kirchera objavljena u Rimu 1650. godine vjerojatno je najbolji primjeri pristajanja uz skolastički način podučavanja glazbe u 17. stoljeću. Usp. digitalizirano izdanje dostupno na URL:

https://books.google.hr/books?id=Fr1CAAAAcAAJ\&printsec=frontcover\&redir_esc=y\#v=onepage\&q\&f=false, (17.04.2018.)
} 
razini obrazovanja koja se očekuje od budućih čitatelja/učenika. Diskurs koji spaja „pravu““ spekulativnu teoriju s uputom za praksu nije novost posttridentskog vremena. Nalazimo ga već u slavnim anonimnim traktatima iz 9. st. (Musica enchiriadis ${ }^{287}$, Scholica enchiriadis de arte musica $^{288}$ ), a diljem srednjovjekovnih skriptorija, samostanskih i kaptolskih škola postaje vrlo čest od neizmjerno utjecajnih traktata Micrologus ${ }^{289}$ i Epistola Guidonis Michaeli monacho de ignoto cantu ${ }^{290}$ Guida iz Arezza u 11. stoljeću. Takav miješani teorijsko-praktični tip diskursa o glazbi postao je redovitom glazbenoteorijskom diskurzivnom praksom takozvane druge renesanse u 12. i 13. stoljeću kada se pišu i prepisuju brojni teorijskopraktični priručnici o glazbi, a proučavanje glazbe kao matematičke discipline u sklopu studium generale iz redovničkih i kaptolskih škola seli na sveučilišta. Afirmacija praktičnog diskursa odnosno teorije namijenjene izvođačima i skladateljima, tzv. musica practica, i usporedno slabljenje afiniteta prema raspravama o musica mundana, odnosno o harmoniji kao znanosti o proporcijama, u povijesti glazbene teorije potaknuto je iz tri smjera. Prvi je bilo otkriće i revitalizacija Aristotelove filozofije i njegova razumijevanja prakse ( $\pi \rho \alpha ́ \xi ı \varsigma)$ kao procesa koji propitkuje formalne uzroke neke pojave, odnosno prakse kao primijenjene teorije $(\theta \varepsilon \omega \rho i ́ \alpha)$ koja postavlja pitanja o njezinim ishodišnjim i krajnjim uzrocima. ${ }^{291}$ Drugi je poticaj

\footnotetext{
287 Scriptores ecclesiastici de musica sacra potissimum, 3 sv. / uredio Martin Gerbert. St. Blaise: Typis SanBlasianis, 1784; pretisak Hildesheim: Olms, 1963., 1:152-73. URL:

https://books.google.de/books?id=VdtWAAAAcAAJ\&printsec=frontcover\&hl=de\&source=gbs_atb\#v=onepag $\& \mathrm{q} \& \mathrm{f}=$ false $(17.04 .2018$.)

${ }^{288}$ Musica enchiriadis. URL: https://chmtl.indiana.edu/tml/9th-11th/MUSENCI (11.03.2019.) Suvremeno kritičko izdanje prema kojem je tekst digitaliziran jest Musica et scolica enchiriadis, una cum aliquibus tractatulis adjunctis: recensio nova post Gerbertinam altera ad fidem omnium codicum manuscriptorum, uredio Hans Schmid. Munchen: Bayerische Akademie der Wissenschaften, 1981. Scholica enchiriadis de arte musica. URL: https://chmtl.indiana.edu/tml/9th-11th/SCHEN (11.03.2019.). Digitalizirano prema Patrologia cursus completus, series latina. / uredio J. P. Migne, 221 vols. Paris: Garnier, 1844-1904. 132:981-1026.

${ }^{289}$ Gudiova je djela objavio u svome monumentalnom izdanju Martin Gerbert: Scriptores ecclesiastici de musica sacra potissimum, 3 sv. / uredio Martin Gerbert. St. Blaise: Typis San-Blasianis, 1784.; reprint Hildesheim: Olms, 1963), 2:2-24. Kritičko izdanje iz 1904. Guidonis Monachi Aretini Micrologus ad praestantiores codices mss. exactus cura et studio Ambrosii M. Amelli o. s. b., Romae: Desclée, Lefebvre et S. Edit. Pont.,1904. URL: https://www.scribd.com/doc/316059199/Guido-D-Arezzo-Micrologus-pdf . Kritička izdanja u Sjedinjenim Američkim Državama koja su postala temelj za daljnja proučavanja i prijevode priredio je Joseph Smit van Waesberghe, a objavio Američki institut za muzikologiju (v. http://corpusmusicae.com/csm/csm_cc003.htm). ${ }^{290}$ Patrologia cursus completus, series latina, ur. J. P. Migne, 221 sv. (Paris: Garnier, 1844-1904), 141:423-32. Guidov tekst na poveznici https://books.google.hr/books?id=gxgRAAAAYAAJ\&redir_esc=y. Recentno kritičko izdanje s prijevodom svih Guidu atriburianih tekstova osim traktata Micrologus priredila je Dolores Pesce, usp. Pesce, Dolores. Guido d'Arezzo's Regule rithmice, Prologus in antiphonarium, and Epistola ad michaelem: a critical text and translation, with an introduction, annotations, indices, and new manuscript inventories. Musicological Studies, sv. LXXIII. Ottawa, Canada: The Institute of Mediaeval Music, 1999. ${ }^{291}$ Inklinacija k Aristotelovskom poimanju mimeze kao prakse koja oponaša postojeću stvarnost, ali i oblikuje novu vidljiva je osobito od druge polovice 13. stoljeća u djelima teoretičara kao što je Johannes de Grocheo koji u spisu De musica obrađuje vrlo pomno musica instrumentalis što do tada nije bilo uobičajeno. Djelo dominikanca Hyeronimusa de Moravie Tractatus de musica primjer je insistiranja na zadržavanju Boetijevog neoplatonizma i monastičkom poimanju glazbe kao nesavršenog odraza nebeske harmonije. O sukobu Platonova poimanja mimeze i uloge glazbe kao poveznice transcendentalnog i zemaljskog i Aristotelove ideje o snažnoj ulozi glazbe u oblikovanju karaktera u djelima glazbenih teoretičara 13. stoljeća v. Mews, Constant J.
} 
proizašao iz činjenice da su gotovo svi srednjovjekovni pisci o glazbi bili svećenici koji su vrlo često obavljali dužnost kantora te su, uz provođenje svakodnevne glazbene prakse, imali obavezu glazbeno obrazovati svoju subraću. Uz to, svijest o soteriološkom i eshatološkom aspektu sudjelovanja u pjevanom dijelu liturgije koju je afirmirao još sv. Augustin, jačala je tijekom sljedećih stoljeća.

Tako nas Honorije iz Autuna (Honorius Augustodunensis, 1080 - 1154), teolog znamenit po jasnom, živom i pristupačnom stilu upozorava u alegorijskom tumačenju liturgije u spisu

\section{Gemma animae:}

„Cantores, qui choros regunt, sunt Apostoli, qui Ecclesias laudes Dei instruxerunt. Hi qui Graduale cantant, significant eos qui in activa vita Christo serviunt. In gradibus cantantes stabunt, quia iusti de virtute in virtutem in scala charitatis ibunt. Qui Alleluia cantant, designant eos qui in contemplativa vita Christum laudant. Hi cantantes altius consistunt; quia tales in celsitudine virtutum coelestia contemplando scandunt. “292

„Kantori koji vode zborove su apostoli koji podučavaju crkvene pohvalnice za Boga. Oni koji pjevaju gradual predstavljaju one koji služe Kristu u stvarnom životu. Na stubama će pjevači stajati, jer će pravednici od vrline do vrline hoditi po ljestvici ljubavi. Oni koji pjevaju Aleluja označavaju one koji hvale Krista u kontemplativnom životu. Oni koji pjevaju na većoj se visini nalaze; jer takvi se, razmatrajući vrline, penju do nebeskih tijela.“

U 16. stoljeću, potaknut novim valom neoplatonizma, glazbenoteorijski diskurs cvate crpeći iz nanovo otkrivene glazbene teorije antičke Grčke i Rima, osobito iz Platonova Timeja i

Questioning the Music of the Spheres in Thirteenth-Century Paris: Johannes de Grocheio and Jerome de Moravia. // Knowledge, Discipline and Power in the Middle Ages. Essays in Honour of David Luscomb / uredili Joseph Canning, Edmund King i Martial Staub. Leiden: Brill, 2011.

${ }^{292}$ Honorius Augostodunensis Gemma animae 1.16, „De cantoribus“. PL 172: 549 B-C. URL: https://www.documentacatholicaomnia.eu/04z/z_10801137_Honorius_Augustodunensis_Gemma_Animae MLT.pdf.html (26.05.2019.): „Hi qui Graduale cantant, significant eos qui in activa vita Christo serviunt. In gradibus cantantes stabunt, quia iusti de virtute in virtutem in scala charitatis ibunt. Qui Alleluia cantant, designant eos qui in contemplativa vita Christum laudant. Hi cantantes altius consistunt; quia tales in celsitudine virtutum coelestia contemplando scandunt. Sequentiam chori alternatim iubilabunt, quia frequentiae angelorum et hominum in domo Dei Dominum in saeculum saeculi laudabunt.“ Honorije je bio osobito važan kao evangelizator puka tijekom cijelog srednjeg vijeka. Njegov Elucidarium - „,summa totius theologiae“ - pronađen je u preko 300 rukopisa te preveden na a brzo pošto je napisana bila je i prevedena na srednjoengleski te provansalski. Podijeljen je u tri knjige kao katehetski priručnik za evangelizaciju puka pisan u formi dijaloga između učitelja i učenika. Prva knjiga nosi naslov De divinis rebus, druga De rebus ecclesiasticis, a treća De vita futura. Usp. Flint, Valerie I. J. The „Elucidarius“ of Honorius Augustodunensis and Reform in Late Eleventh Century England. // Revue Bénédictine, 85 (1975), str. 178-189. URL: https://www.brepolsonline.net/doi/epdf/10.1484/J.RB.4.00818 (31.01.2021.). Usp. i Gurevič, Aron. Problemi narodne kulture u srednjem veku. Beograd: Grafos, 1987. 
Plotinovih Eneada, tekstova koji su uvelike odredili i patrističko razumijevanje glazbe, osobito sv. Augustina kao najcitiranijeg autoriteta u tom području. Vrlo česta historiografska premisa o dominaciji musica theorica u 16. stoljeću donekle je razumljiva zbog eksplozije tekstova koji se bave isključivo fizikalnim, matematičkim i filozofskim aspektima glazbe zbog čega se uistinu čini da je glazbena praksa u teoriji posve zapostavljena. ${ }^{293}$ Valja se ipak podsjetiti da je upravo antička glazbena teorija bila temelj one patrističke i srednjovjekovne koja je glazbenu emanaciju harmonije čula upravo u gregorijanskom pjevanju.

Uvidom u digitalizirane zbirke glazbenoteorijskih priručnika objavljenih u Europi od 4. do 18. stoljeća jasno je da se i glazbena teorija koja daje uputu za praksu -npr. za pjevanje gregorijanskog i figuralnog pjevanja, upute za skladanje i izvođenje polifonih skladbi, itd. objavljivala vrlo često. ${ }^{294}$ Treći i vjerojatno najsnažniji poticaj procvatu neolatinističke glazbenoteorijske literature o gregorijanskom pjevanju u 17. i 18. stoljeću bile su odluke Koncila u Tridentu koji je naložio obnovu katolicizma u sklopu koje je i glazbi pripala važna i jasno definirana uloga, uz izostanak preciznih uputa za praksu. Ono što se ističe kao presudno u glazbenoj izvedbi jest razumljivost teksta (intelligibilitas). Dokumentima Tridentskog koncila sve su važnije odluke, u stvari, prepuštene lokalnim biskupima. ${ }^{295}$ Premda je oblik gregorijanskoga pjevanja koji promiču kantuali iz 17. i 18. stoljeća iz očišta reformatora s kraja 19. stoljeća, kao i suvremenih medievista, dekadentan zbog reforme u duhu humanističke estetike deklamacije i oslanjanja na antička metrička pravila, brojnim ga se priručnicima promicalo kao primjerenu liturgijsku glazbu ne samo u manjim sredinama, već i

\footnotetext{
${ }^{293}$ Knud Jeppesen pomamu za pisanjem spekulativnih glazbenoteorijskih traktata po uzoru na antičke pisce naziva „manijom za glazbenom teorijom“. Usp. Palisca, Claude. Humanism in Italian Renaissance Musical Thought. New Haven, CT: Yale University Press, 1985. Str. 8.

${ }^{294}$ Usp. citiranu zbirku Thesaurus musicarum latinarum nastalu kao rezultat projekta Sveučilišta u Indiani tijekom kojeg su digitalizirane stotine tekstova o glazbenoj teoriji na latinskom jeziku. Zbirka je dostupna na http://www.chmtl.indiana.edu/tml/.

295 usp. Declarationes Illust. Sac. Rom. Cardinalium Congregationis. Ipsis Sacrosancti / Oecumenici Concilii Tridentini canonibus et decretis insertas. Coloniae Agrippinae, 1619.: Sessio XVII, 18. jan. 1562. i Sessio XXIII, 15. jul 1563., Doctrina de Sacramento Ordinis, canon XII. URL: https://books.google.hr/books/about/Declarationes_Illust_Sac_Rom_Cardinalium.html?id=M1GK0PKtMoAC\&r edir_esc=y (24.07.2019.); Picone, Philippe. La question musicale au concile du Trente. // Le Jardin de Musique, V:2, 2008. Str. 49-60. URL:

https://www.academia.edu/6981419/_La_question_musicale_au_Concile_de_Trente_in_actes_du_colloque_Mus iques_et_r\%C3\%A9formes_religieuses_aux_XVIIe_et_XVIIIe_si\%C3\%A8cles_statuts_fonctions_pratiques_Le _Jardin_de_Musique_Paris_Universit\%C3\%A9 (30.09.2019.); Fellerer, K. G. \& Hadad, Moses. Church Music and the Council of Trent. The Musical Quarterly, 39:4, 1953. Str. 576-594. URL:

http://ww.jstor.org/stable/739857 (26.03.2016.)
} 
u velikim, bogatim gradovima u kojima je cvala barokna glazba u obilju svoje raznovrsnosti. $^{296}$

\subsection{Quadruplex est modus faciendi librum}

„Ad intelligentiam dictorum notandum, quod quadruplex est modus faciendi librum. Aliquis enim scribit aliena, nihil addendo vel mutando; et iste mere dicitur scriptor. Aliquis scribit aliena, addendo, sed non de suo; et iste compilator dicitur. Aliquis scribit et aliena et sua, sed aliena tamquam principalia, et sua tamquam annexa ad evidentiam; et iste dicitur commentator, non auctor. Aliquis scribit et sua et aliena, sed sua tanquam principalia, aliena tamquam annexa ad confimationem; et talis debet dici auctor. Talis fuit Magister, qui sententias suas ponit et Patrum sententiis confirmat. Unde vere debet dici auctor huius libri. “297

Sv. Bonaventura

„Za razumijevanje rečenoga valja napomenuti da je način stvaranja knjige četverostruk. Netko, naime, piše tuđe, ne dodajući ništa svoje niti što mijenjajući; za njega se kaže da je prepisivač. Netko piše i dodaje tuđe, ali ne vlastito. Taj se naziva kompilator. Netko piše i tuđi i vlastiti tekst, no tuđi kao glavni, a vlastiti kao jasno dodan. Taj se naziva komentator, a ne autor. Netko piše tuđe i vlastito, ali vlastito kao glavno, a tuđe kao dodano radi potvrde. Takav se treba nazivati autorom. Takav je bio Učitelj koji je izložio vlastite rečenice te ih potvrdio rečenicama Otaca. Dakle, valja ga uistinu nazvati autorom ove knjige.“

\footnotetext{
${ }^{296}$ Kao i Hrvatska i Mađarska ima bogatu i dugotrajnu tradiciju prepisivanja i objavljivanja crkvenih kantuala s gregorijanskim napjevima te relativno siromašnu baštinu barokne glazbene prakse. Institut za muzikologiju mađarske Akademije znanosti proveo je istraživanje posttridentskog tipa gregorijanskoga pjevanja u sklopu istraživačkog znanstvenoga projekta Post-Tridentine latin liturgical chant in Hungary. Detalji su dostupni na mrežnoj stranici http://zti.hu/index.php/en/early-music/research-projects/post-tridentine-chant.

297 Sancti Bonaventurae Commentaria in quatuor libros Sententiarum magistri Petri Lombardi, Proemium in librum primum sententiarum, quaestio IV, sv. I. Firenze: Quaracchi,1882. Str. 14-15. URL: https://archive.org/details/doctorisseraphic11bona (14.10.2019.) (prema Long, Micol. Autografia e epistolografia tra XI e XIII secolo. Milano: Ledizioni, 2014. str. 175. URL: https://books.openedition.org/ledizioni/409 (23.11.2019.)).
} 
Sveti Bonaventura sredinom 13. stoljeća u Komentaru četiriju knjiga sentencija Petra

Lombarda definira načine stvaranja knjige, kao i status pisca koji ih piše. Kompilator je onaj tko piše djelo uzimajući tuđi tekst i dodaje mu tekstove drugih pisaca od kojih niti jedan nije vlastiti, ,addendo, sed non de suo“. Komentatorom se naziva onaj tko „piše i tuđe i svoje, no tuđe kao glavno, a svoje kao očigledno dodano“. Bonaventura, dakle, komentatorima naziva sve one pisce koji uzimaju od drugih pisaca, no njihovom mišljenju o nekoj stvari dodaju i vlastito, pritom jasno odjeljujući jedno od drugoga. Četiri stoljeća poslije modus faciendi tekstova Mihaela Šiloboda-Bolšića i Tome Kovačevića, uvodnika CO, kao i priručnika pridodan Psalteriju-Antifonalu iz 1742. koji se koristio u zagrebačkoj katedrali još uvijek se može opisati Bonaventurinim riječima. Većim dijelom teksta Šiloboda-Bolšića i Kovačevića dominira način oblikovanja koji dominira i cijelim srednjovjekovljem, a Bonaventura ga naziva compilatio. I jedan i drugi nižu općepoznate činjenice naučene iz koje od spomenutih summae ili sličnih priručnika dostupnih im tijekom školovanja. Pritom slobodno citiraju i parafraziraju, najčešće po sjećanju, a za većinu podataka o kojima pišu ne navode izvor. Velik dio znanja koje prikazuju u tradiciji pisanja glazbenoteorijskih pedagoških priručnika predstavlja opća mjesta ( $(o ́ \pi o \iota)$ koja pripadaju korpusu zajedničkog, svima poznatog znanja. Razlog tome je uzajamnost i povratnost procesa čitanja i pisanja: srednjovjekovna pa i renesansna literatura oslanja se na kompilaciju i komentar (a kompilaciju se, s obzirom na kriterije odabira autor(a) tekst(ov)a ili njihovih ulomaka može shvatiti kao oblik komentara) kao na temeljni način oblikovanja teksta koji su proizašli iz višestoljetne prakse prepisivanja. Clotilde Dauphant nas upozorava:

"Ideja djela uspostavila se u srednjem vijeku bez čvrste granice između jedinstvenog teksta i skupine tekstova. Slika pčele koja slijeće na različito cvijeće kako bi proizvela med ili riznice koju slavi Brunetto Latini ${ }^{298}$ (...), potvrđuje vrijednost zanimanja za kompilaciju koju su u srednjem vijeku provodili prepisivači - urednici ili autori - prisvajači za koje se proces pisanja definirao kao « čitanje, odabir, uređivanje "299

\footnotetext{
${ }^{298}$ Radi se o enciklopedijskom traktatu Trésor firentinskoga pisca Brunetta Latinija napisanom između 1262. i 1266.

${ }^{299}$ „La notion d'œuvre s'établit au Moyen Âge sans frontière fixe entre le texte unique et le groupement de textes. L'image de l'abeille butinant différentes fleurs pour fabriquer son miel ou du trésor célébré par Brunetto Latini (...) valorisent l'intérêt de la compilation pratiquée au Moyen Âge par les scribes-éditeurs ou auteurs-pilleurs pour lesquels l'acte d'écriture se définit par "lire, extraire et ordonner “. L'encyclopédiste en est le meilleur exemple.“ Usp. Dauphant, Clotilde. La mise en recueil : diffusion \& réception des textes médiévaux.
} 
Stoga je, ne samo vrlo zahtjevno, već u mnogim slučajevima, pa i ovom, izlišno nastojati doprijeti do izvora svega izloženog u djelima koja se nastavljaju na gotovo devet stoljeća kontinuiranog pisanja - kompiliranja o poduci u pjevanju. Šilobod-Bolšić, kako ćemo pokazati u poglavlju o odnosu musica practica i musica theorica, raspored sadržaja djela i sâm sadržaj (premda ne i način prikaza) uvelike preuzima iz Samberovog spisa Elucidatio musicae choralis iz $1710 .{ }^{300}$, dok se Toma Kovačević vrlo vjerojatno nadahnuo nekim kraćim i jednostavnijim prikazom poduke gregorijanskoga pjevanja, sličnim onome što ga nalazimo u Psalteriju-Antifonalu iz 1742. Sudeći po odabiru tema koje prikazuju, lapidarnosti zaključaka i izostavljanju svega što bi moglo izaći iz okvira elementarnog, čini se da su se Kovačević i sastavljač bečkog kantuala i upute za pjevanje Compendiosa, nadahnjivali sličnim izvorom, vrlo vjerojatno djelom Cartella musicale del canto figurato, fermo e contrapunto Adriana Banchierija objavljenim u Veneciji 1614., pisca na kojeg se obojica pozivaju u svojim djelima.

Mihael Šilobod-Bolšić i Toma Kovačević jasno se pozivaju na autoritete temeljeći na njima vlastitu vjerodostojnost. Kovačevićeva Brevis cantus gregoriani notitia jest „ex probatis Authoribus composita“, a Fundamentum Šiloboda Bolšića je ex probatis authoribus collectum, sabran od prokušanih autora koje autor imenuje poslije u tekstu.

Namjera obojice pisaca već je i naslovima reducirana na kompilaciju kako je definira sv. Bonaventura, a koja, s druge strane, upozorava čitatelja na vrijednost djela koje potvrđuju upravo spomenuti ,probati authores“. Ipak, pokazat ćemo da i u jednom i u drugom tekstu postoje određeni elementi autorskog, izvornog dodatka zbog kojih se, barem djelomično, oba djela mogu smatrati i nekom vrstom komentara prema podjeli sv. Bonaventure.

\footnotetext{
// Acta fabula, sv. 12, br. 3. Poétiques médiévales : lire, inventer, composer, 2011. URL : http://www.fabula.org/acta/document6229.php1 (8.09.2017.)

${ }^{300}$ Samber, Johann Baptist. Elucidatio musicae choralis. Salzburg, 1710.
} 


\subsection{Ex probatis Athoribus composita}

Prepisivač Kovačevićeva djela na naslovnoj stranici bilježi „Brevis cantus gregoriani notitia ex probatis Authoribus composita et in lucem exposita a Thoma Kovachevich“. Martin Mihokovic ${ }^{301}$ piše da Toma Kovačević ili prepisivač nigdje ne navode imena ,prokušanih autora“"što nije točno te zaključuje da je ovakav naslov posljedica prepisivačeve želje za uvažavanjem njegova rada koji se temelji na znanju „odobrenih autora“ kako, prema Mihokovićevim riječima ,probati Authores“ prevodi Vinko Žganec:

„Koji su to „probati Authores“ ni pisac ni prepisivač nigdje ne kažu, a još se manje može znati, što je u tom kratkom nauku /noticiji/ možda piščeva vlastita, izvorna misao, a što je uzeto iz tudjih izvora. Upravo zato što se ti ,prokušani“ ili „odobreni“ pisci nikako ne spominju po imenu, imam dojam, da je to prepisivač možda dodao na svoju ruku, da bismo više cijenili njegovo prepisivanje tako solidnog djela.“302

\section{Retorička norma od antike poznaje argumentum ab auctoritate (također se naziva i} argumentum ad verecundiam, argumentum ad potentiam) koji se osobito često rabi $\mathrm{u}$ srednjem vijeku u svim vrstama spisa, a definirao ga je sv. Toma Akvinski u Summa theologiae. ${ }^{303}$ Ključno je, dakako, pozivanje na Sveto pismo te na crkvene naučitelje kao jamce ispravnog kršćanskog mišljenja o nekoj temi. Uz njih, auctoritas posjeduju i antički autori čiji su tekstovi prošli ispit primjerenosti i vjerodostojnosti u kontekstu kršćanske teologije. U slučaju teorije glazbe (ali i drugih znanja, osobito onih koja se vezuju uz filozofiju i teoriju jezika) to su ponajprije Pitagora, Platon i Aristotel, Ciceron i Kvintilijan te

\footnotetext{
${ }^{301}$ Svi navodi o priručniku Tome Kovačevića temelje se na diplomskom radu i njemu priloženim fotografijama Martina Mihokovića Prikaz o djelu Tome Kovačevića „,Kratki nauk o gregorijanskom pjevanju“. Zagreb: KBF, 1970. koji je imao u rukama fotokopije prijepisa iz 1738. koje je dao izraditi Vinko Žganec. Te su fotokopije, danas, nažalost, zagubljene, kao što je zagubljena i izvorna knjižica koju smo tražili u samostanu u Novome Mestu, no u knjižnici je nismo mogli pronaći.

302 Ibid., str. 3.

${ }^{303}$ Argumentum ab auctoritate definira sv. Toma kao infirmissimus, najslabiji argument afirmirajući tako razumsko zaključivanje utemeljeno na logici umjesto na autoritetu. Ipak, sv. Toma podsjeća da je važno znati izabrati autoritet kojem se obraćamo sukladno temi kojom se bavimo: Aristotela za prirodne znanosti, Galena i Hipokrata za medicinu, a Sveto pismo za pitanja teologije, ali ne i znanosti. Usp. M. l'abbé Drioux. La somme theologique de Saint-Thomas, latin-français en regard. Paris: EB, 1853. URL: https://books.google.com.bz/books?id=7RoVAAAAQAAJ\&printsec=frontcover\#v=onepage\&q\&f=false, (12.04.2020.). O ovom tipu argumenta rasprava ne jenjava stoljećima, čak ni po ukidanju retorike kao obaveznog predmeta u školama. U 19. stoljeću, primjerice, Arthur Schopenhauer raspravlja o njemu nazivajući ga argumentum ad verecundiam. Smatra ga prikladnim u slučaju kad je sugovornik slabije obrazovan te zbog toga poštuje autoritete bez propitkivanja teze. Usp. Schopenhaur, Arthur, Die Kunst recht zu behalten, Megaphon eBooks 2008. URL: http://www.wendelberger.com/downloads/Schopenhauer_DE.pdf (20.04.2020.)
} 
dakako, kasnoantički filozof Boetije. Niti jedan nama poznati spis o glazbi (ili o ma kojoj drugoj temi) od srednjega vijeka do sredine 18. stoljeća ne navodi u naslovu pisce od kojih autor djela preuzima podatke i mišljenje, već to čini u samom tekstu, budući da je praksa prepisivanja i kompiliranja stoljećima implicirala legalnost, dapače poželjnost preuzimanja tuđih tekstova ${ }^{304}$.

Slijedeći običaje stvaranja djela u obliku kompilacije, Toma Kovačević nam zapravo nudi cijeli niz autora iz čijih je djela crpio znanje i koje smatra jamcima istinitosti vlastitih riječi i pouzdanosti zaključaka koje iznosi. To su neizostavni Guido iz Arezza (između 990. i 1000. oko 1050.), potom slavni ranobarokni venecijanski skladatelj, orguljaš i teoretičar Adriano Banchieri (lat. Bancherius, 1565. - 1634.) čija su djela doživjela desetke tiskanih izdanja i bila iznimno utjecajna, osobito Cartella overo regole utilissime a quelli che desiderano imparare il Canto Figurato objavljena u Veneciji 1601. u formi dijaloga učitelja i učenika te trinaest godina mlađe djelo pisano pripovijednim stilom Cartella musicale nel canto figurato, fermo e contrapunto, Venecija, 1614. Potom su tu Franchino Gaffurio (lat. Gaffurius Franchinus, 1451. - 1522.) autor traktatā Theorica musicae (1492.) i Practica musicae (1496.), prema mnogim muzikolozima najiscrpnijih uvida u renesansnu glazbenu teoriju, kako onu filozofski orijentiranu, tako i praktičnu usmjerenu na skladanje i izvedbu te Pietro Aaron (lat. Petrus Aronus, oko 1489. - oko 1545). Uz njih navodi i Giovannija Battistu Chiudinija čije ime Mihoković navodi u obliku Ivan Krstitelj Chiodinus o kojem je, usprkos velikom broju raznovrsnih tiskanih radova, sačuvano relativno malo podataka. Toma Kovačević najvjerojatnije aludira na njegovo djelo Arte pratica latina et volgare di far contrapunto a mente, \& a penna, divisa in diece libretti, brevissimi, ordinatissimi et facilissimi. In Venetia, Appresso Ricciardo Amadino, $1610 .{ }^{305}$ D. Gregorius koji se navodi kao autoritet za temu

\footnotetext{
${ }^{304}$ Usp. Canfora, Luciano. Le copiste comme auteur (prev. Laurent Calvié i Gisle Cocco). Toulouse: Anacharsis, 2012. osobito str. 19-24.

${ }^{305}$ Giovanni Battista Chiodino (lat. Johannes Baptista Chiodinus) pisao je na latinskom i talijanskom jeziku i bio vrlo plodan autor koji je danas gotovo u potpunosti zaboravljen. Glazbom se bavio u spomenutom spisu Arte pratica latina et volgare di far contrapunto a mente, \& a penna, divisa in diece libretti, brevissimi, ordinatissimi et facilissimi. In Venetia, Appresso Ricciardo Amadino, 1610. URL: https://download.digitalesammlungen.de/pdf/15985259857282bsb10527103.pdf (12.04.2020.). Najznačajnije njegovo djelo jest astronomska rasprava Praxis sphaerica clarissima. De motibus, \& proprietatibus celorum, \& planetarum, tribus libris disposita, cum questionibus ad sententiam Scoti, ad libros metheorum Aristotelis. Cum duplo indice capitum, \& sententiarum. Per mag. Ioan. Baptistam Chiodinum minor. conuentual. .... - Venetiis : apud Ambrosium \& Bartholomeum Dei, fratres, 1615. URL: https://bibdig.museogalileo.it/Teca/Viewer?an=958438 (12.04.2020.). Objavio je i marijološko djelo Disputationes quinquagenta de nobilitate et salutis ... per mag. Jo. Bapt. Chiodinum, ... Venetiis, A. et B. Dei, 1614. koje navodi Kelso, Ruth, Doctrine of the Lady of the Renaissance, Urbana \& Chicago: University of Illinois Press, 1978. Još jedno njegovo djelo Diadema solemnitatum ac virtutum B/eatae/V/iriginis/ bez oznake mjesta i godine izdanja spominje franjevačka trosveščana enciklopedija Bibliotheca universa franciscana sive alumnorum trium ordinum s. p. $n$. Francisci ... Encyclopaedia ... in tres tomos distributa ..., Paderborn, 1733. Osobito je zanimljiva knjiga epigrama koju je
} 
rodova u gregorijanskom pjevanju, najvjerojatnije je Grgur Veliki (oko 540. - 604.) koji se, doduše rijetko, u određenim srednjovjekovnim izvorima naziva Gregorius Divinus.

Način oblikovanja teksta kao kompilacije u Kovačevića funkcionira tako da se, pošto se definira tema o kojoj se govori, navede autoritet čiji tekst(ovi) predstavljaju glavni izvor za pisca. Potom se sadržaj navodi bez označivanja citata, već se slobodno odabiru i parafraziraju dijelovi teksta prema potrebi i opsegu djela. Iznimku donekle predstavlja Guidova ruka koja je u prijepisu Inocencija Auera, kao i u većini glazbenoteorijskih traktata precrtana, a znakovi na njoj detaljno objašnjeni. Njezinu je važnost u povijesti predmoderne glazbene teorije nemoguće precijeniti: navode je podjednako često traktati koji obrazlažu gregorijansko pjevanje, kao i oni koji objašnjavaju pravila figuralnog ili menzuralnog pjevanja. Guidova ruka jest temelj za solfeđiranje napjeva: ocrtavajući po prstima ruke ton za tonom označen abecednim i solmizacijskim imenom, navodi heksakordalne nizove poredane na način na koji se heksakordi nižu i na crtovlju odozdo prema gore, od duboke (gravis), preko visoke (acuta) do najviše (superacuta) ljestvice. ${ }^{306}$

posvetio vjenčanju Marca Antonija Burghesija i Camille Orsina nazvana La nobilta Burghesia Romana, cantata e descritta in versi, \& prose in latino, \& in volgare idioma, In Macerata, nella stamperia di Martellini 1619.

${ }^{306}$ Guido iz Arezza nesumnjivo je najslavniji i najprepisivaniji autor srednjega vijeka što se tiče glazbene teorije koja se odnosi na praksu. On je za područje musica practica višestoljetni autoritet, baš kao što je za teme musica theorica Boetije. Sa sigurnošću mu se pripisuju četiri djela: Prologus in Antiphonarium, Epistola Guidonis Michaeli monacho de ignoto cantu directa, Micrologus i Regulae rhytmicae. Ipak, niti u jednom od spomenutih spisa ne nalazimo crtež ruke. Povjesničari su skloni zaključku da je ruka nastala vrlo brzo po Guidovoj smrti kao spretno mnemotehničko sredstvo njegovih, za izvođenje glazbe, kapitalnih pronalazaka. V. Reiseinwiever, Ana J. Gudio of Arezzo and his Influence on Music Learning. // Musical Offerings, 3/1, čl. 4, 2012. URL: https://digitalcommons.cedarville.edu/musicalofferings/vol3/iss1/4 (20.08.2019.). 


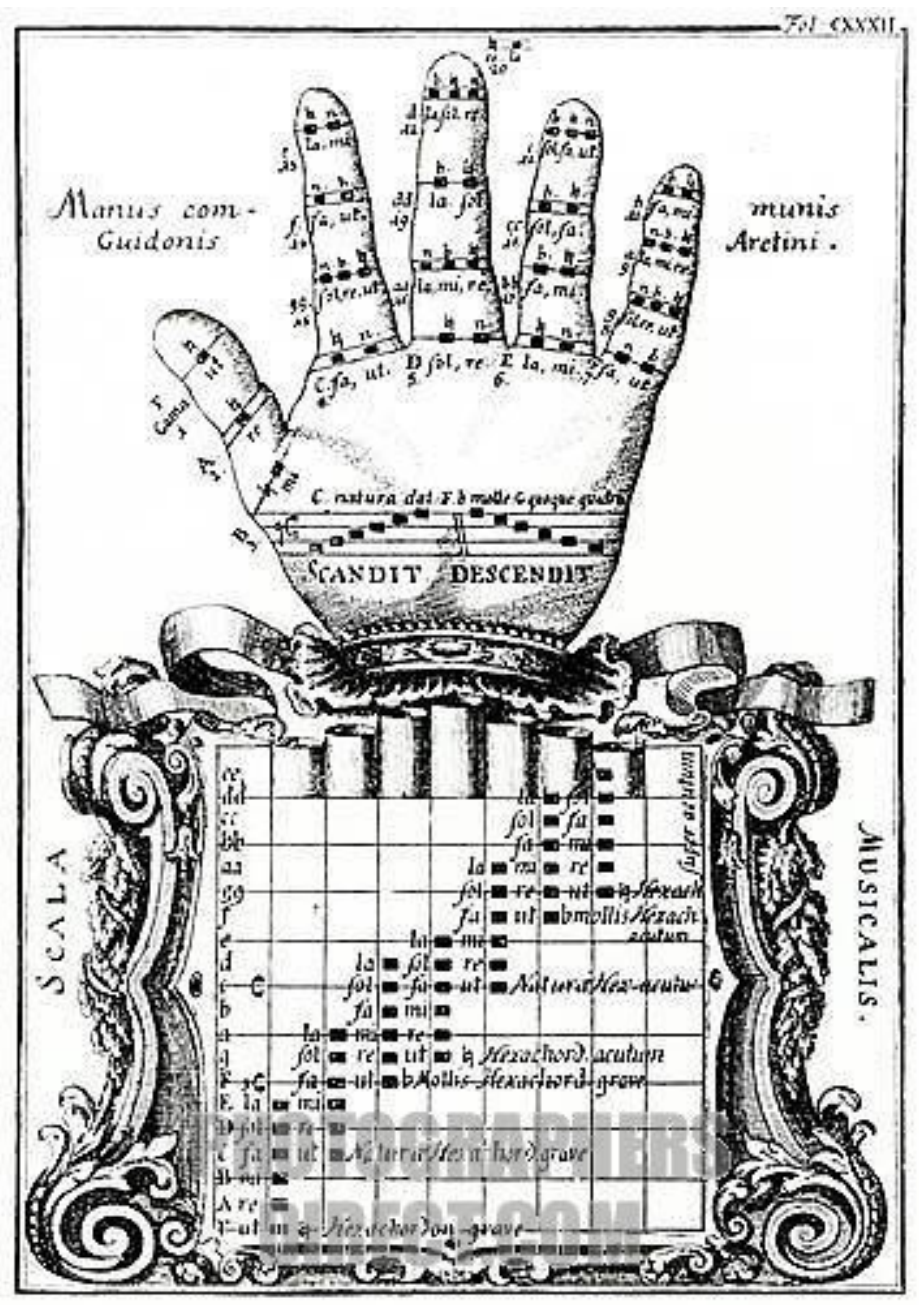

sl. 3 Manus communis Guidonis Aretini iz Pslaterio-Antiphonale. Beč, 1742. Čuva se u Riznici Zagrebačke katedrale.

Adriano Banchieri ${ }^{307}$ se također spominje već u prvom poglavlju o odnosu abecede i solmizacije, odnosno načinima imenovanja tonova u sustavu heksakorda:

„Ali zašto se uz jedno slovo vežu po dva ili tri sloga? Odgovara Bancherius: Ti se slogovi uzimaju i dvostruko i trostruko zato, što glasovi imaju različita imena s obzirom na prirodnost

\footnotetext{
${ }^{307}$ Usp. Banchieri, Adriano. Cartella musicale del canto figurato, fermo \& contrapunto ... Venetiis, 1614. URL: https://imslp.org/wiki/Cartella_musicale_(Banchieri\%2C_Adriano) (21.08.2019.). Str. 17-19. Idem.Cartella overo regole utilissime a quelli che desiderano imparare il Canto Figurato, Venetiis, 1601. oblikovana je kao „Dialogo del maestro \& Discepolo“. Adriano Banchieri bio je slavni skladatelj koji se u teoriji bavio najviše onim što je provodio u praksi: figuralnim pjevanjem i uputama za sviranje orgulja. Bio je iznimno utjecajan teoretičar prve polovice 17. stoljeća. O plodnosti njegova glazbenoteorijskog i skladateljskog rada izvrsno svjedoči naslovnica djela Cartellina musicale koja u izvornom obliku glasi: Cartellina musicale che in Documenti facili ridotti dall'antico allo Istile moderno introduce i Principianti a sicuro posesso del Canto Figurato: Opera trentesimaquinta del P. D. Adriano Banchieri Monaco Olivetano. Quarta impressione ... In Venetia, 1615. (bold J. K. C.)
} 
/= visinu?/ i s obzirom na oblike ključeva. Da se to bolje mogne razumjeti, treba znati, da je osnovica pjevanja jedna jedincata, i da je nadasve potrebna ruka /naime lijeva/ kojoj ovdje vidiš dodanu sliku. “308

Ivan Krstitelj Chiodinus, danas zaboravljeni astronom, teolog i marijolog, autoritet je za akustičku problematiku:

„Ovdje navodi Kovačević mišljenje autora Ivana Krst. Chiodinus koji veli, da je polustepen od la do fa /fictum/ polustepen veći, jer zauzima dva različita mjesta, /dvije korde/, razmak sekunde. ...“309, dok je Grgur Veliki (?) autoritet u području rodova gregorijanskoga pjevanja:

„Čita se u nekom originalu D. Gregorija, da u gregorijanskom pjevanju ima 5 redova ili radije rodova /genera/, od kojih se prvi naziva: odredjen /differens/a to je onda, kad je pjevanje autentično ili plagalno savršeno. ... “310

Pietro Aaron podupire tezu o unisonu - jednoglasju kao principu intervala, a ne samom intervalu: „mišljenje autora Petra Arona koji tvrdi da Unisonus - jednoglasje nije zapravo interval, nego prinicip konsonancije /intervala/ kao što jedinstvo /unitas/ nije broj, nego princip broja. “311 Nadalje, na njega se Kovačević poziva objašnjavajući razliku između autentičnih i plagalnih načina. Aaron, a po njemu i Kovačević, teološkim razlozima tumače hijerarhiju crkvenih načina insinuirajući da su autentični načini proizvod same Crkve kao duhovne institucije što im jamči božansko porijeklo ${ }^{312}$, dok su plagalni niža razina načina budući da su proizvod grešnog ljudskog bića:

\footnotetext{
${ }^{308}$ Ibid. Str. 6.

${ }^{309}$ Ibid. Str. 14. Usp. Arte pratica latina et volgare di far contrapunto a mente, \& a penna... Gio. Battista Chiodino autor., In Venetia, 1610. str. 7: Omnis modus intorquendi vocem habet semitonum, qui est medius tonus. Semitonus est duplex: maior, \& minor: Maior semper est in duabus cordis, \& locis, \& est mi fa, \& fa mi, la fa, \& fa la Minor est in eodem loco, \& corda, in befabemi dicitur mi\&fa, illa mutatio, \& distantia facit minorem semitonum, exemplum.“

${ }^{310}$ Ibid. O pojmu genus i problemu prikladnoga roda govori samo Kovačević, dok ga ostali izvori ne spominju. Kovačević prenosi gotovo doslovno tekst glazbenog teoretičara iz 14. stoljeća Johannesa Cicconije koji napjeve dijeli najprije prema redu (ordo), a potom četvrti red napjeva dijeli na pet rodova (genus): „Quartum autem accidens ordo est, qui in quinque ordinibus ordinatur, id est: differens, indifferens, metricus, prosaicus et comunis. ..." Ciconia, Johannes. Nova musica and De proportionibus. // kritičko izdanje i prijevod Oliver B. Ellsworth. Lincoln: London: University of Nebraska Press, 1993. Usp. Str. 366-368.

${ }^{311}$ Ibid. Str. 15. Pietro Aaron bio je vrlo poznat skladatelj, a uz to i teoretičar. Kovačević se osvrće na njegovo djelo o gregorijanskom pjevanju Aaron, Petrus. Libri tres de institutione harmonica, liber primus (izvor: Libri tres de institutione harmonica editi a Petro Aaron Florentino (Bononiae, In aedibus Benedicti Hectoris Bibliopolae Bononiensis, 1516; reprint ed. New York: Broude Bros. 1978.). URL: http://www.chmtl.indiana.edu/tml/16th/AARIH1 (10.08.2019.)

${ }^{312}$ Usp. Aaron, Petrus. Op. cit. pogl. XXVI „De tonis quattuor antiquis““.
} 
„Prema patru Aronu došlo je u običaj da se stvar koja zaslužuje pohvalu naziva da je autentica - prava, a budući da su neparni načini bili od Crkve odredjeni njoj na upotrebu, zato se smatraju vrijedniji od drugih i odličniji i prema tome nazivaju autentični. A plagalni, jer su pronadjeni od glazbenika, manje su u časti i ovisni od onih autentičnih.“313

Činjenica da svi tonusi, odnosno modusi kako ih naziva suvremena teorija ${ }^{314}$, potječu iz starogrčke teorije te da su nazivi ljestvica, kao i ideja autentičnosti i plagalnosti također preuzeti iz starogrčkog naslijeđa, ne zamara kompilatore kratkih priručnika, pa tako ni dobro obrazovanog Tomu Kovačevića. Izvor zabune je pogrešno čitanje Boetija u 9. stoljeću: Alia musica i Musica enchiriadis jednostavno prisvajaju imena koja Boetije daje osmotonskim ljestvicama i pridodaju ih starocrkvenim načinima koji se od grčkih razlikuju u rasporedu cijelih stepena i polustepena, smjeru kretanja ljestvičnog niza i (ne)funkcionalnosti pojedinih stupnjeva ljestvice. ${ }^{315}$ U sljedećim stoljećima, upravo zbog modus faciendum libri kojima dominira prijepis i kompilacija, ne propitkuje se više prvo čitanje/prepisivanje vrhunskog autoriteta za musica theorica koje je i samo postalo izvorom za daljnje propedeutičke traktate. Ovakva mjesta u tekstu dokazuju slabo poznavanje materije, a vjerojatno i latinskog jezika posljedice čega su vidljive još u 17. i u 18. stoljeću koje nastavlja praksu nekritičkog prepisivanja i kompiliranja barem onih dijelova teksta koji nisu presudni za sam tekst. Ovakva mjesta možemo u velikom broju pronaći u mnogim priručnicima za praksu, osobito u onima koje je lokalno svećenstvo priređivalo za svoje samostane i samostane svoje provincije. Redukcija materijala iz koje nerijetko proizlazi pogrešno baratanje podacima provodi se kako bi se što brže i jednostavnije ispunila svrha teksta te kako bi se sadržaj teksta maksimalno prilagodio ideologiji koju podupire autor. Ne smijemo zaboraviti da u 17. i prvoj polovici 18 . stoljeća odluke Tridentskog koncila i zahuktali pokret katoličke obnove proizišao iz njega uvelike određuju sadržaj i ton svih školskih udžbenika, pa tako i onih za pjevanje.

\footnotetext{
313 Ibid. Str. 22.

${ }^{314}$ Premda niti jedan antički, kasnoantički niti srednjovjekovni glazbenoteorijski traktat ne rabi riječ modus u označivanju ljestvica nazvanih prema starogrčkim terminima (rednim brojevima): protus, deuterus, tritus, tetrardus, a poslije dorski, frigijski, lidijski i miksolidijski, suvremena glazbena teorija kontinuirano rabi riječ modus kao izraz kojim označava crkvene ljestvice i općenito ljestvični poredak intervala koji naziva modalnost nasuprot tonalitetnosti. Stari Grci koristili su pojam tóvoৎ u mnogim značenjima. Usp. npr. Mathiesen, Thomas J. Op. cit. i u istom priručniku Cohen, David E. Notes, Scales and Modes in the Earlier Middle Ages. The Cambridge History of Western Music Theory. // uredio Thomas Christensen. Cambridge: Cambridge University Press, 2008. Str. 307-363. U srednjem se vijeku, dakako latiniziran u obliku tonus, koristio prije svega kao oznaka ljestvica. I Kovačević i Mihael Šilobod-Bolšić, kao i svi traktati koje koristimo u ovoj disertaciji kao komparativnu građu, bilo u smislu izvora za kompiliranje, bilo kao usporedna suvremena ostvarenja, koriste isključivo pojam tonus pri označivanju crkvenih ljestvica.

315 Za načine prijenosa starogrčke glazbene teorije u srednjovjekovnu te načine prilagodbe naslijeđenih obrazaca v. Cohen, David E. Op. cit.
} 
Još jedno veliko ime glazbene teorije, Gaffurio Franchino ${ }^{316}$ izvor je za deveto poglavlje Kovačevića djelca o tonusima u kojem ga parafrazira odmah na početku. No, miješa pojmove

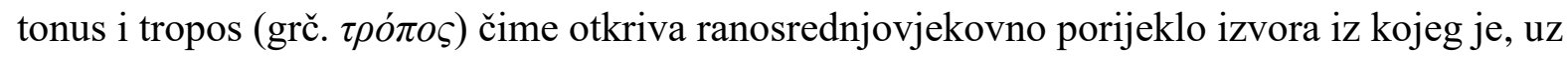
Gaffurija, učio o glazbi. Mihoković piše: „U broju 33. iznaša Kovačević najprije definiciju načina /tonus/ ili grčki tropus-a. Način je neko pravilo, koje se raspoznaje prema završetku i prema dizanju i spuštanju /tona, napjeva/, kako uči Franchinus prema Gvidonu.“317

Gaffurio, međutim, kaže:

„At octo ipsos modos quos et tonos vocant quasi ex tonis eorumque partibus scilicet semitonijs ductos: Alij tropos propter accidentalem vnius in alterum conuersionem toni vel semitonij intensione seu remissione deductam ... . “318 (bold J. K. C.)

\begin{abstract}
„A osam je samih modusa koje nazivaju i tonusi kao da su izvedeni iz tonova i njihovih dijelova, odnosno polutonova: drugi (ih nazivaju) tropi zbog slučajne konverzije u drugi (sc. trop) proširenjem ili izostavljanjem jednoga tona ili polutona ....“319
\end{abstract}

Brevis cantus gregoriani notitia, kratka bilješka o gregorijanskom pjevanju Tome

Kovačevića, bilježi elementarno znanje koje je pisac stekao, ali ga nije domislio već je „ex

\footnotetext{
${ }^{316}$ Franchino Gaffurio bio je znameniti talijanski glazbeni teoretičar i manje znameniti skladatelj (1451. 1522.). Studirao je latinsku književnost i glazbu u benediktinskom samostanu u Lodiju, a potom djelovao na dvoru Gonzaga u Mantovi te u Genovi, Napulju i Bergamu. U Milanu je kao maestro di cappella katedrale djelovao je trideset i osam godina, od 1484. Premda je mnogo skladao sukladno svome položaju, ostao je upamćen kao uspješniji teoretičar no skladatelj. Napisao je petnaestak glazbenoteorijskih traktata od kojih su i u njegovo vrijeme i danas najznačajnijima smatrani Theorica musicae, 1492. i Practica musicae (1496.) u kojima je u stvari kompilirao stečeno naslijeđe i tada osobito omiljene grčke teoretičare kao što su Aristid Kvintilijan, Kleonid i Plutarh te suvremena strujanja. usp. Blackburn, Bonnie J. Gaffurius Francinus. Grove Music Online. URL: https://doi.org/10.1093/gmo/9781561592630.article.10477 (13.07.2019.)
}

${ }^{317}$ Ibid. Str. 20. Franchino u Theorica musice kaže: „[Quid sit tonus. in marg.] Est enim tonus legitimum sesquioctauae dimensionis spacium duobus sonis circumscriptum.“ Usp. Gaffurio, Franchino. Theorica musice, liber primus. (digit. prema Theorica musice Franchini Gafuri Laudensis (Milan: Ioannes Petrus de Lomatio, 1492; reprint ed., New York: Broude Bros., 1967.) URL: http://www.chmtl.indiana.edu/tml/15th/GAFPM1 (13.07.2019.)

${ }^{318}$ usp. Gaffurio, Franchino. Practica musicae. (digit. prema Practica musice Franchini Gafori Laudensis (Milan: Ioannes Petrus de Lomatio, 1496; reprint ed., New York: Broude Bros., 1979.) http://www.chmtl.indiana.edu/tml/15th/GAFPM1 (13.07.2019.)

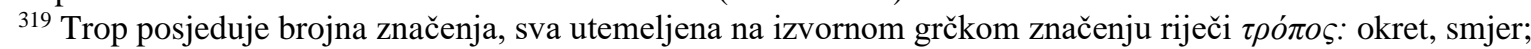

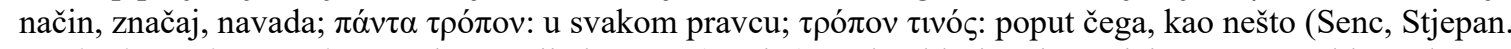
Grčko-hrvatski rječnik. Zagreb: Naprijed, 1988. (reprint). Dok u klasičnoj retorici označava otklon od uobičajenog značenja riječi pa se u trope ubraja metafora, metonimija, sinegdoha i alegorija. U povijesti glazbene teorije trop znači način u smislu ljestvice, okret i promjenu tog načina unutar neke melodije, a u sklopu liturgijske glazbe, i to je njegovo najčešće značenje, proširenje liturgijskog teksta, odnosno interpolacija u postojeći obredni obrazac. 
probatis Authoribus composita“. Eklatantan je primjer kompilacije koja se oslanja na srednjovjekovni način prenošenja znanja citirajući autoritete iz određenog područja koji u isto vrijeme potvrđuju istinitost tvrdnji i kompetencije pisca. Kovačevićevi su glavni izvori Adriano Banchieri, Pietro Aaron i Franchino Gaffurio, a teme kojima se najviše posvećuje obuhvaćaju ispravno intoniranje psalama, solfeđiranje napjeva i mutacije. Slično će o važnosti elemenata glazbene teorije suditi i mnogi njegovi suvremenici koji će se, ovisno o opsegu djela, također redovito usredotočiti na primjere iz prakse.

Opsežnije, vještije strukturirano, no sadržajem srodno djelo Fundamentum cantus gregoriani seu choralis Mihaela Šiloboda Bolšića također predstavlja redukciju dostupnog znanja primjerenu potrebama korskih pjevača. Kao što je Kovačević svjestan da je njegovo djelce primjereno opisati kao osnovno znanje (notitia) ${ }^{320}$, znanje ukratko (brevis) prikazano, tako i Šilobod-Bolšić zna da, bez obzira što se radi o vrlo dobro strukturiranom dijalogu između učitelja i učenika koji otkriva niz izvora na kojima se školovao pisac, njegov priručnik predstavlja samo temelj toga znanja - fundamentum. Radi se također o kompilaciji koja sažima osnovne elemente, temelj znanja o glazbi baštinjen od brojnih pisaca s kojima su se hrvatski svećenici susretali u raznim kompendijima tijekom svoga školovanja.

Probati authores Mihaela Šiloboda-Bolšića nisu, međutim, isti oni koje navodi Kovačević. Štoviše, Guido iz Arezza i Adriano Banchieri jedini su zajednički izvor našim piscima. I Šilobodovi pripadaju kanonu glazbene teorije antike i srednjega vijeka što osigurava točnost sadržaja koji prenosi: on se poziva na Platona, Boetija, Guida iz Arezza, Johannesa de Murisa, Adriana Banchierija te austrijskog orguljaša, teoretičara i učitelja glazbe Johanna Baptista Sambera. ${ }^{321}$ Uz to, Šilobod voli pokazati širinu vlastitog obrazovanja, pa u svoj tekst uvodi i Vergilija i Horacija. Ciceronova djela koja su, među ostalima, činila temelj skolastičkoga

\footnotetext{
${ }^{320}$ Usp. notitia, ae, $f$. u Lewis, Charlton T.; Short, Charles. A Latin Dictionary. URL: http://www.perseus.tufts.edu/hopper/text?doc=notitia\&fromdoc=Perseus\%3Atext\%3A1999.04.0059 (08.09.2019.) Jozo Marević u Latinsko-hrvatskom enciklopedijskom rječniku, Zagreb: MH, 2000. navodi sljedeća značenja: 1. poznanstvo, poznavanje, oglašenost, upoznatost; 2. znanje, poznavanje; 3. pojam, zamisao; 4. popis, kazalo, imenik.

${ }^{321}$ Johann Baptist Samber (Salzburg 1654. - 1717.) bio je glazbeni teoretičar, katedralni orguljaš poslije smrti Hansa Jacoba Reiffa i pedagog u katedralnoj kapeli. Objavio je tri djela Manductio ad organum 1704., Continuatio ad manductionem organicam 1707. te Elucidatio musicae choralis 1710. Ona svojim tematskim okvirom - polifonija, realizacija šifriranog basa, poduka u orguljanju i pjevanju gregorijanskih napjeva - opisuju glazbenu praksu u Austriji krajem 17. i početkom 18. stoljeća. Sva su djela pisana njemačkim jezikom i tiskana goticom uz česte interpolacije izraza na latinskom. Osobito mnogo latinskoga nalazimo u djelu Elucidatio musicae choralis iz 1710. koje je, kao što smo već naveli, bilo uzorom Mihaelu Šilobodu-Bolšiću. O Samberu još uvijek ne postoji opsežnija literatura. Za osnovne podatke v. Rausch, Alexander. Samber, Johann Baptist. // Oesterreichisches Musiklexikon online. URL: https://www.musiklexikon.ac.at/ml/musik_S/Samber_Johann.xml, (07.08.2020.)
} 
obrazovanja, tzv. humaniora, umnogome su oslonac u oblikovanju dijaloške poduke pjevanja. Ciceron i Platon, na kojega se prvi često poziva kao na uzor, uvelike oblikuju diskurs pisca, kršćanskog ciceronovca kakvog oblikuje renesansa: određuju etos u smislu djela i običaja te propisuju metodologiju. Pisac koji se poziva na spomenute autore školovan je čovjek koji poznaje temelje ne samo teorije muzike kakvima ih priznaje i stoljećima prenosi kršćanstvo, već i retorike i poetike. Ipak, premda je djelo objavio 1760. u jeku takozvanog prosvjetiteljskog apsolutizma, Šilobod-Bolšić po odabiru uzora u stvari je tradicionalniji od Tome Kovačevića koji je obrazovanje stekao krajem 17. stoljeća.

Platon je, uz Aristotela čiji utjecaj jača od 13. stoljeća, neupitni autoritet u filozofiji i pedagogiji srednjega vijeka i temelj patrističke baštine. Lucidna Gilsonova primjedba da u srednjem vijeku Platonovih djela gotovo da i nema, no platonizam je posvuda ${ }^{322}$, potvrda je gore spominjanog kompiliranja kao osnove prenošenja znanja, a posljedično i dokidanja mogućnosti za razvijanjem svijesti o autoru kao neoskrvnjivom autoritetu i provjeri vjerodostojnosti nekog teksta. Boetijeva glazbenoteorijska ostavština, s obzirom na golem utjecaj koji je imala u sljedećim stoljećima, predstavlja pak temelj u spekulativnoteorijskom promišljanju glazbe. No, valja imati na umu da bi isključivanje utjecaja Boetija na glazbenu praksu, ili barem diskurs o njoj, značilo jednostrano i plošno čitanje ovoga autora. De institutione musica libri quinque jest temelj za razumijevanje glazbe kao discipline u sustavu sedam slobodnih umijeća i glavni izvor za starogrčku teoriju glazbe koja je pak osnova za onu srednjovjekovnu. Iz nje su crpili pisci djela Alia musica, Musica enchiriadis i Scolica enchiriadis u 9. stoljeću, a na ovima pak njihovi nasljednici, pa i neizostavni Guido. ${ }^{323}$

Boetijev je traktat iznimno često citiran i(li) parafraziran kasnoantički tekst na kojem počivaju definicije intervala, konsonanci, disonanci, tonusa i drugih pojmova koji se iz čistog teorijskog područja protežu u ono praktično, kao što ćemo vidjeti i na primjeru ŠilobodaBolšića, premda je važnost Boetijeva djela kudikamo veća u spekulativnim razmatranjima muzike no u pedagoški intoniranim traktatima. Djela Guida iz Arezza, već smo istaknuli, još od 12. stoljeća temelj su i neizostavni dio svakog traktata koji objašnjava praksu. Aretinskog monaha i ruku koja mu se pripisuje (manus Guidonica) navode svi traktati posvećeni poduci praktičnog muziciranja. Ako ne donose grafički prikaz ruke (što je vrlo rijetko), objašnjavaju

\footnotetext{
322 „Platon lui-même est nulle part, mais le platonisme est partout; disons plutôt, il y a partout des platonismes.“ u Gilson, Étienne. La philosophie au moyen âge. Paris, 1944. Str. 268.

${ }^{323} \mathrm{O}$ načinu čitanja Boetija i općenito o preuzimanju starogrčke teorije i njezinoj prilagodbi gregorijanici u trima temeljnim traktatima karolinške renesanse (kojima pribrajamo i Hucbaldov tekst Musica iz prve polovice 10. stoljeća) v. Chailley, Jacques. Povijest glazbe srednjeg vijeka (prev. Jelena Knešaurek Carić). Zagreb: HMD. 2006.; Fuller, Sarah. Interpreting Hucbald on Mode. // Journal of Music Theory (52:1), 2008. Str. 13-40.
} 
je vrlo pomno, a njezina tvorca navode kao ključnog autora u oblikovanju znanja potrebnih za jednostavno solfeđiranje napjeva. Iznimka nisu ni hrvatski autori, kao ni priručnik Compendiosa pridodan Psalteriju-Antifonalu ili talijanski franjevci Fabrizio Tettamanzi i Giuseppe Frezza Dalle Grotte, pisci udžbenika koje u najvećem broju pronalazimo u hrvatskim franjevačkim samostanima. ${ }^{324}$ Vrlo velik ugled od polovice 14 . stoljeća uživa i Johannes de Muris, teoretičar čiju podjelu notnih vrijednosti navode nebrojena srednjovjekovna, renesansna i novovjekovna djela o glazbi. Sva tri citirana ili parafrazirana pisca o glazbi po zanimanju su svećenici pa i njihovi tekstovi, razumljivo, potvrđuju pristajanje uz kršćansko poimanje muzike. S obzirom na učestalost citata i parafraza ulomaka, djela Boetija, Guida iz Arezza i Johannesa de Murisa evidentno su dijelom školskoga kanona i o njihovim dostignućima uče svi klerici zaduženi za glazbenu praksu. ${ }^{325}$ Elementi spekulativne teorije naslijeđene iz antičkog poimanja muzike, kao što su utjecaj glazbe na karakter ljudskoga bića te, usporedno s time, osobine pojedinih tonusa koji potiču određeno raspoloženje i sposobni su, kratkoročno i dugoročno, oblikovati ljudske osjećaje, i dalje se prenose bez obzira na izostanak elaboracije temeljne ideje odraza metafizičkog u glazbi koja je generirala etičku teoriju muzike. Poznavanje djela Elucidatio musicae choralis Johanna Baptista Sambera, potvrda je suvremenosti Šiloboda-Bolšića i svjedoči njegovu upućenost u suvremena ostvarenja u glazbenoj pedagogiji - koliko god se ona odnosila na iz današnje perspektive nesuvremenu praksu - te aktualne načine poduke gregorijanskoga pjevanja.

Analiza teksta Šiloboda-Bolšića iz aspekta izvora i utjecaja koje spominje ili na njih aludira, što se Platona tiče, ukazuje na svjesno ili nesvjesno zanemarivanje onih elemenata Platonova učenja o glazbi koji se u povijestima filozofije i estetike glazbe najčešće spominju kao temelj ne samo filozofova učenja, već i stava o glazbi kreiranog u antici i prenesenog u kršćanstvo. Naime, niti na jednome mjestu u tekstu, baš kao ni u ostalim analiziranim tekstovima hrvatskih autora, ne spominju se Platonova promišljanja o glazbi na koje najčešće nailazimo u obilnoj literaturi o Platonovu odnosu prema glazbi: ulomci iz Države (II knjiga) i Zakona (II i

\footnotetext{
${ }^{324}$ V. str. 16. Prvog poglavlja disertacije - „Povijesni uvod“. Tettamanzi u Breve metodo per apprendere il canto fermo donosi sliku Guidove ruke već na 6. stranici prve knjige, dok je Frezza Dalle Grotte prikazuje odmah po završetku uvodnog teksta, prije upute čitatelju o podjeli djela (Divisione dell'opera) i to detaljniju verziju koja na dlanu prikazuje sustav heksakorda poredanih u crtovlju.

${ }^{325} \mathrm{O}$ školskom kanonu u prvoj polovici 18. stoljeća u Zagrebu te u kolegijima u Beču i Bologni u kojima su se školovali hrvatski svećenici opširno je pisala Teodora Shek Brnadić u knjizi Svijet Adama Baltazara Krčelića: obrazovanje na razmeđu tridentskoga katolicizma i katoličke obnove. Zagreb: Hrvatski institut za povijest, 2009. Za isusovački ratio studiorum i njegovu praksu u Zagrebu te glazbeni dio obrazovanja u isusovaca v. Vanino, Miroslav. Isusovci i hrvatski narod, 3 sv. Zagreb: FTIDI, 1987-2005. i Steiner, Marijan; Županović, Lovro. Op. cit. Vidi još i Religijske teme u glazbi / uredio Marijan Steiner. Zagreb: FTIDI, 2003. Za franjevački model obrazovanja Hoško, Emanuel Franjo. Franjevačke visoke škole u kontinentalnoj Hrvatskoj, Zagreb: KS, 2002.
} 
VII knjiga) koji se odnose na filozofovo učenje o važnosti glazbe u obrazovanju djece i čuvara države (grč. $\varphi v ́ \lambda \alpha \kappa \varepsilon \varsigma$ ), na njezin utjecaj na čovjekovu dušu te učenje o glazbi kao postvarenju matematičkih zakona i fizičkoj realizaciji harmonije sfera (Fedon i osobito Timej). ${ }^{326}$ Platon je u Šiloboda-Bolšića spomenut više puta, no prvenstveno kao uzor mudrosti općenito i autoritet u pedagogiji, pa tako i u onoj glazbenoj. Zbog toga reference na njegovo djelo nalazimo samo u uvodnom tekstu, dok se u dijalogu koji se bavi konkretnim uputama za pjevanje više ne spominje, čak niti u poglavlju o ljestvicama i njihovim karakteristikama te načinu na koji utječu na čovjeka. Čini se da Šilobodu Bolšiću podjednaku važnost u poduci o ispravnom načinu života i rasuđivanja ima i Ciceron. Naime, niz Ciceronovih misli iz spisa $O$ dužnostima (De officiis) za Bolšića čini temelj na kojem počiva razumijevanje ljudskih dužnosti i obaveza te modus prenošenja znanja. Ciceron je, uostalom, pisac kroz čije tekstove Šilobod-Bolšić dobiva uvid u Platonove misli.

Već ga cenzor u odobrenju djela za tisak (approbatio censoris) parafrazira koristeći slavnu, tisućama puta korištenu rečenicu: „... quod de Platone olim Poëta dixit, dicam ego de libro hoc: Hic unus instar est omnium."

„... ono što je o Platonu nekoć rekao pjesnik, ja ću reći o ovoj knjizi: ova jedna vrijedi kao i $\left.\mathrm{sve}^{\mathrm{cc}}\right){ }^{327}$

Poëta je, dakako, Ciceron, a ulomak iz djela Brut u originalu glasi: „... Legam, inquit, nihilo minus: Plato enim mihi unus instar est centum milium.“328

„... reći ću, veli, ništa manje od ovoga: Platon mi, naime, vrijedi više od stotinu tisuća (sc. drugih, op. J. K. C.).“

\footnotetext{
${ }^{326}$ Velik je broj tekstova posvećen Platonovom razumijevanju glazbe kao medija presudnog za oblikovanje čovjekova duha i duše, kao i njegovu utjecaju na druge autore. Usp. Pelosi, Francesco, Plato on Music, Body and Soul. Cambridge: Cambridge University Press, 2010.; Barbarić, Damir. Mousikē i ethos u Grka. // Treći program Hrvatskog radija (0353-94743) 80 (2012), str.135-143. URL: http://eprints.ifzg.hr/702/1/Mousike\%20i\%20ethos\%20u\%20Grka.pdf (27.02.2019.); Hankins, James. Plato in the Middle Ages. // Dictionary of the Middle Ages / uredio Joseph Reese Strayer. sv. IX, str. 694-704. New York: 1987. URL: https://www.scribd.com/doc/7878958/Hankins-Plato-in-the-Middle-Ages; Hankins, James, Plato in the Italian Renaissance, Leiden, NY, København, Köln: E. J. Brill, 1990.; Tokić, Marko Platon i Plotin o muzici. // Filozofska istraživanja 142, 36/2016, sv. 2. Str. 193-202. URL: https://hrcak.srce.hr/173350 (27.02.2019.)

${ }^{327}$ Šilobod Bolšić, Mihael. Op. cit. Str. 43.

${ }^{328}$ Usp. digitalizirano kritičko izdanje Ciceronovih djela M. Tullius Cicero. M. Tulli Ciceronis Rhetorica, Tomus II. A. S. Wilkins. Oxonii. e Typographeo Clarendoniano. 1911. Scriptorum Classicorum Bibliotheca Oxoniensis. URL: http://www.perseus.tufts.edu/hopper/text?doc=Cic.\%20Brut.\%2051.191\&lang=original (13.2.2019.)
} 
I u kolebanju i u malodušnosti zbog očekivanih kritika dežurnih Zoilâ, sukladno omiljenom toposu afektirane skromnosti ${ }^{329}$, naš se pisac poziva na opće dobro u svrhu kojega je pisan Fundamentum i na što smo svi pozvani misliti izvršavajući svoje dužnosti. Ponovno se obraća za pomoć Ciceronu koji i u sljedećem primjeru parafrazira Platona:

„eiusmodi Zoilos ${ }^{330}$, ego quoque, licet minimus, ut evitarem, scripturus, suspensam identidem tenui manum, atque etiam calamum abieci, abiectum tamen, suffragio gratiosi Moecenatis, ac patroni mei resumpsi, qui ex Platone monitum me esse volebat: Nos nobis natos non esse; sed ortus nostri partem patria, partem parentes, partem amici, partem denique posteri sibi vendicent.“

„Kako bih i ja, ma koliko neznatan, izbjegao takve Zoile, počesto sam, dok sam namjeravao pisati, zadržavao ruku kolebajući se, pa sam čak i odbacio pisaljku. Ipak, odbačenu sam je ponovno uzeo uz podršku ljubaznog Mecenata i mog pokrovitelja, koji me želio opomenuti prema Platonu: Nismo rođeni sami za sebe, nego u našem postojanju sudjeluju dijelom domovina, dijelom roditelji, dijelom prijatelji i napokon dijelom potomci.“331

Non nobis solum nati summus... jedna je od najčešće parafraziranih rečenica iz Ciceronova opusa i koristi se u brojnim tekstovima najrazličitijih tematika sve do sredine 19. stoljeća. Njezina popularnost ne jenjava do danas kada se najčešće navodi u popisima latinskih poslovica - sententiae. I ona potječe iz Ciceronova spisa $O$ dužnostima (De officiis) koji na tom mjestu, prema vlastitim riječima, parafrazira Platona iz njegova Pisma Arhitu "non nobis solum nati sumus ortusque nostri partem patria vindicat, partem amici" (De Officiis, 1:22). ${ }^{332}$

\footnotetext{
${ }^{329}$ Usp. Curtius, Ernest. Europska književnost i latinsko srednjovjekovlje. Zagreb: MH, 1998.

${ }^{330}$ Zoilo iz Amfipola, grčki gramatičar, filozof i retoričar. Osobito je bio poznat po svojim analizama Homerovog opusa, žestoko kritizirajući njegovo djelo u devet knjiga Protiv Homerova pjesništva. U antici stečena reputacija Homeromastix - bič Homerov, proširila se u srednji i novi vijek te je Zoilovo ime postalo sinonimom za nesmiljeni kriticizam, ironiju, a često i neutemeljen apriorni negativni sud o nekom djelu. Valja spomenuti da je i Platon u Državi kritizirao Homera ponajviše zbog načina na koji su u Ilijadi i Odiseji prikazivani grčki bogovi. Strepeći od mogućih Zoila, Šilobod-Bolšić se utječe Platonu ne znajući da su po pitanju Homera uvelike dijelili mišljenje. Homera je u antici u stvari rehabilitirao Aristotel u Poetici i danas izgubljenim djelom A pitanjima. Usp. Davison, J. A. The Homeric Question. // Companion to Homer / uredili A. J. B. Wace; F. H. Stubbings. London: Macmillan \& co. 1963.

331 Šilobod-Bolšić, Mihael. Op. cit. str. 46-47.

${ }^{332}$ Ciceron kaže sljedeće: „Sed quoniam, ut praeclare scriptum est a Platone, non nobis solum nati sumus ortusque nostri partem patria vindicat, partem amici, atque, ut placet Stoicis, quae in terris gignantur, ad usum hominum omnia creari, homines autem hominum causa esse generatos, ut ipsi inter se aliis alii prodesse possent, in hoc naturam debemus ducem sequi, communes utilitates in medium adferre, mutatione officiorum, dando
} 
Platonove riječi od pomoći su i u prosudbi čovjeka i njegova djela. Mi smo ono što govorimo i što činimo, veli Platon. Stoga, prema riječima i djelima valja suditi čovjeka, podsjeća nas Šilobod-Bolšić:

„Quod si me, qui vos ita alloquor, novisse cupitis, adite eundem divinum Platonem, libro de Legibus dicentem: nulla ex re magis hominem, quam ex verbis, quae loquitur, \& opere, quod facit cognosci.“

„Ako želite upoznati mene koji vam ovo govorim, latite se istog božanskog Platona koji u knjizi o Zakonima kaže: Niti iz jedne stvari čovjeka ne možemo bolje spoznati do iz riječi koje govori i djela koja čini. “333

Stoga, nastavlja Šilobod-Bolšić u kićenom stilu, ,[C] ]ognoscite ergo, me ex hoc opere ${ }^{334}$, quod totus vester ita esse voluerim, ut corpore etiam a vermibus absumpto, cor saltem meum, in animis vestris, vivum inventum iri confidam.“

,[U]poznajte, dakle, mene iz ovog djela jer sam želio u cijelosti postati vaš, pa se uzdam da će, ako tijelo i bude izgriženo crvima, barem moje srce biti nađeno kako živi u vašim dušama.“335 Fundamentum cantus gregoriani seu choralis reflektira, dakle, Šiloboda-Bolšića u potpunosti, štoviše, prenosi dalje njegovo srce koje je ovdje metafora za duh.

I u konkretnim stvarima, poput učenja novih vještina, Šilobod-Bolšić postojano se oslanja na Platona s čijim su zahtjevom u metodologiji poduke suglasni i Aristotel i Ciceron. Sva trojica, naime, zahtijevaju definiciju pojma koji se objašnjava kao početak svakog učenja, a rečenica ponovno potječe iz Ciceronova teksta $O$ dužnostima:

„Recte cupis id, quod a Platone, \& Aristotele prius traditum praecepit Cicero: Omnem institutionem, quae de re quacunque suscipitur, debere a definitione proficisci, ut intelligatur, quid sit id, de quo disseritur.“

accipiendo, tum artibus, tum opera, tum facultatibus devincire hominum inter homines societatem." Usp. Cicero. De Officiis, 1:22. URL: https://www.thelatinlibrary.com/cicero/off1.shtml (23.04.2020.)

\footnotetext{
333 Šilobod-Bolšić, Mihael. Ibid.

${ }^{334}$ Referenca na Evanđelje po Ivanu, 4: 2 ,ex hoc cognoscite spiritum Dei ...“

335 Šilobod-Bolšić, Mihael. Op. cit. str. 48-49.
} 
„Ispravno želiš saznati ono što je, otprije preneseno od Platona i Aristotela naložio i Ciceron: svaka pouka koja se bavi ma kojom stvari mora početi od definicije da bi se razumjelo što je to o čemu se raspravlja. “336

Napredujući kroz tekst koji od kratkog povijesnog prikaza nastanka i razvoja glazbe postaje niz objašnjenja temeljnih glazbenoteorijskih pojmova, Platon prestaje biti uporište i podrška te svoje mjesto ustupa glazbenim teoretičarima: najprije Boetiju, potom Guidu iz Arezza i Johannesu de Murisu, a na kraju i salcburškom orguljašu i teoretičaru Samberu. Boetije, apsolutni autoritet za područje musica theorica tijekom cijelog srednjeg vijeka i renesanse, sve snažnijim prodorom musica practica u pisanu riječ o glazbi, postupno gubi prvenstvo pred teoretičarima poput Guida iz Arezza, Johannesa de Murisa, Franchina Gaffurija i Gioseffea Zarlina. Ipak, Bolšić se na njega poziva pri definiranju umijeća pjevanja i intervala: „Est autem musica bene canendi scientia: bene autem canere (teste Boetio) est singulare donum, \& gratia omnipotentis Dei.“

„A glazba je umijeće dobrog pjevanja. Dakle, umjeti dobro pjevati (kako svjedoči Boetije) jest dar i milost svemogućeg Boga.“337

Moglo bi se pomisliti da je Šilobod-Bolšić, barem u ekscerptima iz kakve srednjovjekovne rukoveti tekstova o glazbi kakvi su kolali samostanima poznavao Boetijevo djelo. Možda i jest, pa je pogrešno zapamtio autora definicije. Ipak, to je malo vjerojatno, jer Šilobod-Bolšić radi ne samo faktičku, već i logičku pogrešku tvrdeći da je Boetije autor definicije dobrog pjevanja. Naime, Boetije se u De institutione musica ne poziva na kršćanskoga Boga. Za njega je neupitan autoritet Platon. ${ }^{338}$ Šilobod-Bolšić, usprkos uvriježenom postupku

\footnotetext{
${ }^{336}$ Ibid., str. 50-51; Radi se o parafrazi Ciceronove rečenice iz De Officiis, 1,1: „Omnis enim, quae a ratione suscipitur de aliqua re institutio, debet a definitione proficisci, ut intellegatur, quid sit id de quo disputetur.“ Riječ je o često korištenom i parafraziranom citatu u svim vrstama srednjovjekovnih i renesansnih tekstova, pa sve do 19. stoljeća. Usp. npr. spis De locis theologicis Melchiora Cana koji na samom početku djela koristi gotovo istu rečenicu: „Quod a Platone prius \& Aristotele traditum praecipit Cicero, omnem institutione, quae de re quacunque suscipitur, debere a definitione proficisci, ut intelligatur, quid sit id, de quo disseritur." usp. De locis theologicis, lib. primus, cap. ult. De locorum Theologicorum numero atque ordine; dostupno na poveznici https://books.google.hr/books?id=Z21GbpyUb24C\&printsec=frontcover\&redir_esc=y\#v=onepage\&q\&f=false, pristup 28.08.2020. Još usp. Commentarii Gasparis Laurentii in librum secundum Hermogenis de Inventione Partium orationis u udžbeniku iz retorike što se čuva u Austrijskoj nacionalnoj biblioteci Degli autori del ben parlare per secolari, e religiosi parte quarta, bez oznake mjesta i godine izdanja: „Hoc significatu dixit Cicero libro officiorum primo, Omnem institutionem quae de ratione suscipitur, debere a Definitione proficisci, ut intelligatur quid sit id de quo disceptatur.“, dostupno na poveznici

https://books.google.hr/books/about/Degli_autori_del_ben_parlare_per_secolar.html?id=CKDu5steX2EC\&redir _esc=y, pristup 28.08.2020.

${ }^{3} 37$ Ibid., str. 102-103.

${ }^{338}$ Usp. Boetii De institutione musica libri quinque, Gottfried Freidlein (prir.), Leipzig: B. G. Teubneri, 1867. dostupno na https://www.scribd.com/doc/262396235/Boethii-De-Institutione-Musica-Libri-Quinque, pristup
} 
kompilacije i interpolacije tuđih tekstova u vlastiti, čini se, nastoji prikiriti najvažniji izvor za svoje djelo. Naime, tek na jednome mjestu, u pripovijesti o spašavanju znanja o glazbi urezivanjem istoga na mramorni stup, spominje on salcburškoga orguljaša: ,Quae (ut refert Samber in elucidatione musicae choralis) hodiedum in Syria pro aeterna memoria, tanquam pretiosissimus thesaurus vigilantissime custoditur.“339

No, pomnim čitanjem Samberova teksta postaje jasno da je upravo Elucidatio glavni izvor za Fundamentum te da je i u slučaju o Boetiju i porijeklu muzike riječ o pogrešnom prepisivanju i/ili prevođenju definicije koju na samom početku svoga djela donosi Samber:

„Musica ist ein sonderbares Gnaden-Geschänkte und Gaabe des Allmächtigen Gottes. (Teste Boetio Romano) ist solche aus denen siben freuen Künsten die erste.“

Dakle, Samber kaže: „Muzika je posebno darovana milost i dar svemogućega Boga. (Po svjedočenju Boetijevom), kao takva je prva među sedam slobodnih umijeća.“340

Nije, dakle, Boetije taj koji definira muziku kao dar i milost svemogućega Boga, već Samber koji se na kasnoantičkoga filozofa poziva tek kako bi osnažio vlastitu tezu dajući joj prvenstvo među svim disciplinama trivija i kvadrivija. Kao što Šilobod-Bolšić površno čita Sambera, tako je i ovaj vrlo slobodan u interpretaciji Boetijeva teksta koji niti na jednome mjestu u svome djelu izričito ne tvrdi da muzici valja prepustiti tron u društvu preostalih umijeća kvadrivija kojima pripada. No, prvenstvo muzike može se smatrati implicitnim zbog isticanja njezine posebnosti u smislu etičkoga djelovanja: naime, muzika kao i ostale tri kvadrivijske vještine - aritmetika, geometrija i astronomija - istražuje istinu, ali nije povezana samo sa spekulacijom već i s moralom, stoga ništa nije poput nje prikladno ljudskome rodu i to ne samo u određenim poslovima i dobima, već u svima, jer ni sa čim se tako prirodno i spontano ne možemo povezati kao s radošću koja proizlazi iz slatkih napjeva:

„Unde fit, cum sint quattuor matheseos disciplinae, ceterae quidem in investigatione veritatis laborent, musica vero non modo speculationi verum etiam moralitati coniuncta sit. Nihil est

24.06.2017. Rasprave o Boetijevom shvaćanju kršćanstva vodile su se desetljećima uzimajući u obzir snažan utjecaj neoplatonizma i pitanje „pravovjernosti“ filozofovih stavova. Recentno istraživanje o Boetijevom shvaćanju Boga u De consolatione philosophiae, sumiralo je dosadašnje rasprave u preglednom prikazu Manczak, Tomasz. Dieu dans la Consolation de Philosophie // Phares XVIIb-03. Str. 59-73. URL: https://revuephares.com. (04.02.2021.)

339 v. bilj. 98.

${ }^{340}$ Elucidatio musicae choralis ... durch M. Joannem Baptistam Samber, Salzburg: Mayr, 1710., str. 1 (paginacija počinje na 14. stranici digitaliziranog dokumenta), dostupno na: https://books.google.hr/books/about/Elucidatio_musicae_choralis.html?id=7xxDAAAAcAAJ\&redir_esc=y, pristup 12.05.2017. Pri citiranju iz Samberovog traktata zadržan je originalni pravopis. 
enim tam proprium humanitatis, quam remitti dulcibus modis, adstringi contrariis, idque non sese in singulis vel studiis, vel aetatibus tenet, verum per cuncta diffunditur studia et infantes et iuvenes nec non etiam senes ita naturaliter affectu quodam spontaneo modis musicis adiunguntur, ut nulla omnino sit aetas quae a cantilenae dulcis delectatione coniuncta sit.“341

„Odatle proizlazi, budući da postoje četiri discipline mathesisa, od kojih druge nastoje oko iznalaženja istine, glazba uistinu nije povezana samo sa spekulacijom, već i s ćudoređem. Ništa, naime, nije toliko primjereno ljudskome rodu, koliko opustiti se uz pomoć slatkih modusa, a postati napet od onih suprotnih. I to se ne događa u pojedinačnim djelovanjima ili dobima, nego se razliježe kroz svo djelovanje, a djeca, mladi, pa čak i stariji tako su prirodno privučeni spontanim osjetom muzičkim modusima, da ne postoji niti jedno doba koje ne bi bilo privučeno radošću slatkoga napjeva.“

Ćudoređe povezano sa spekulacijom i iznimno prisutno u samo jednom od sedam slobodnih umijeća, dopušta Samberu zaključak da joj je Boetije, izuzimajući je iz ograničenosti spekulacije u traženju istine, dao prvenstvo koje joj, s obzirom na važnost moralnog aspekta djelovanja, valja pripasti.

Snagu glazbe, njezin silan i moćan utjecaj na ljudsko biće, ne razrađuju ni Kovačević ni Bolšić. Ne zanima ih, kao ni ostale suvremene im teorijske tekstove koje nalazimo u sjevernohrvatskim knjižnicama, promoviranje dobrobiti koje pjevanje ili slušanje pjeva nosi. One se same po sebi razumiju budući da ih je ljudima darovao Bog i stoga dostaje ukratko podsjetiti na njih, više u obranu teme teksta, no u svrhu uvjeravanja čitatelja u korisnost glazbe. O moćima koje glazba ima i imala je ne samo na ljudska bića, već i na junake grčkih mitova, naširoko će elaborirati pisac predgovora Cithara octochorda. Kovačevića, Bolšića, ali i Tettamanzija, Dalle Grotte, Sambera i anonimnog pisca priručnika Compendiosa zanima konkretna glazba, govor o njoj prije svega u smislu uputa koje će nevještom pjevaču pomoći da s lakoćom sudjeluje u liturgiji.

Šilobod-Bolšić još jednom navodi De institutione musica i to kao izvor za definiciju intervala:

„De intervallis, breviori temporis intervallo exercitationem habituri, etiam non rogatus intervallum definio: Quod sit (teste Boetio Romano lib. I. c. 8.) soni acuti, gravisque distantia:

\footnotetext{
${ }^{341}$ Usp. Boetii De institutione musica libri quinque. Gottfried Freidlein (prir.). Leipzig: B. G. Teubneri, 1867. dostupno na https://www.scribd.com/doc/262396235/Boethii-De-Institutione-Musica-Libri-Quinque, pristup 24.06.2017. str. 7-8.
} 
hoc est, si forte non itelligis: distantia vocis a voce penes ascensum, $\&$ descensum considerata: quam aliqui consonantiam vocant.“”

„Intervale ćemo vježbati u kraćem vremenskom razdoblju pa i bez pitanja definiram interval: to je udaljenost između dubokih i visokih tonova (tako kaže Boetije Rimljanin knjiga 1. c. 8). To je, ako slučajno ne razumiješ, razlika od tona do tona kod koje se podrazumijeva uzlaženje i silazeženje. Neki je nazivaju konsonancom.“342

Boetije uistinu tako i veli: „Intervallum vero est soni acuti gravisque distantia.“ No, konsonanca za Boetija nije isto što i interval: „Consonantia est acuti soni gravisque mixtura suaviter uniformiterque auribus accidens.“ (Boetii De institutione musica, I, 8.) ${ }^{343}$

Johannesa de Murisa, pak, naziva izumiteljem notnih znakova. ${ }^{344}$ Premda mnogi suvremeni izvori spominju Philippea de Vitryja u kontekstu prve poznate podjele notne vrijednosti longa i brevis na manje notne vrijednosti, Johannes de Muris izvršio je snažan utjecaj na praksu figuralne glazbe znamenitom podjelom notnih vrijednosti u djelu Libellus cantus mensurabilis (oko 1340.) prikazujući ih u tablici kakva se, poslije dakako grafički osuvremenjena, koristila stoljećima u poduci solfeggia.

\footnotetext{
342 Šilobod-Bolšić, Mihael. op. cit. str. 62-63.

${ }^{343}$ Više o korištenju sinonima i homonima te promjenama značenja pojedinih glazbenoteorijskih pojmova vidi u Šestom poglavlju.

${ }^{344}$ Znakovi koji su nastali na temelju dvodijelne podjele osnovnnog notnih znakova brevis na semibrevis, minima, semiminima, itd. te njihovo grupiranje u skupinu (tempus imperfectum je binarna mjera, dok je tempus perfectum trodijelna) nastali su zbog potreba polifone, ritmizirane figuralne glazbe cantus fractus. No, postupno su se počeli koristiti i u zapisivanju gregorijanskih napjeva.
} 


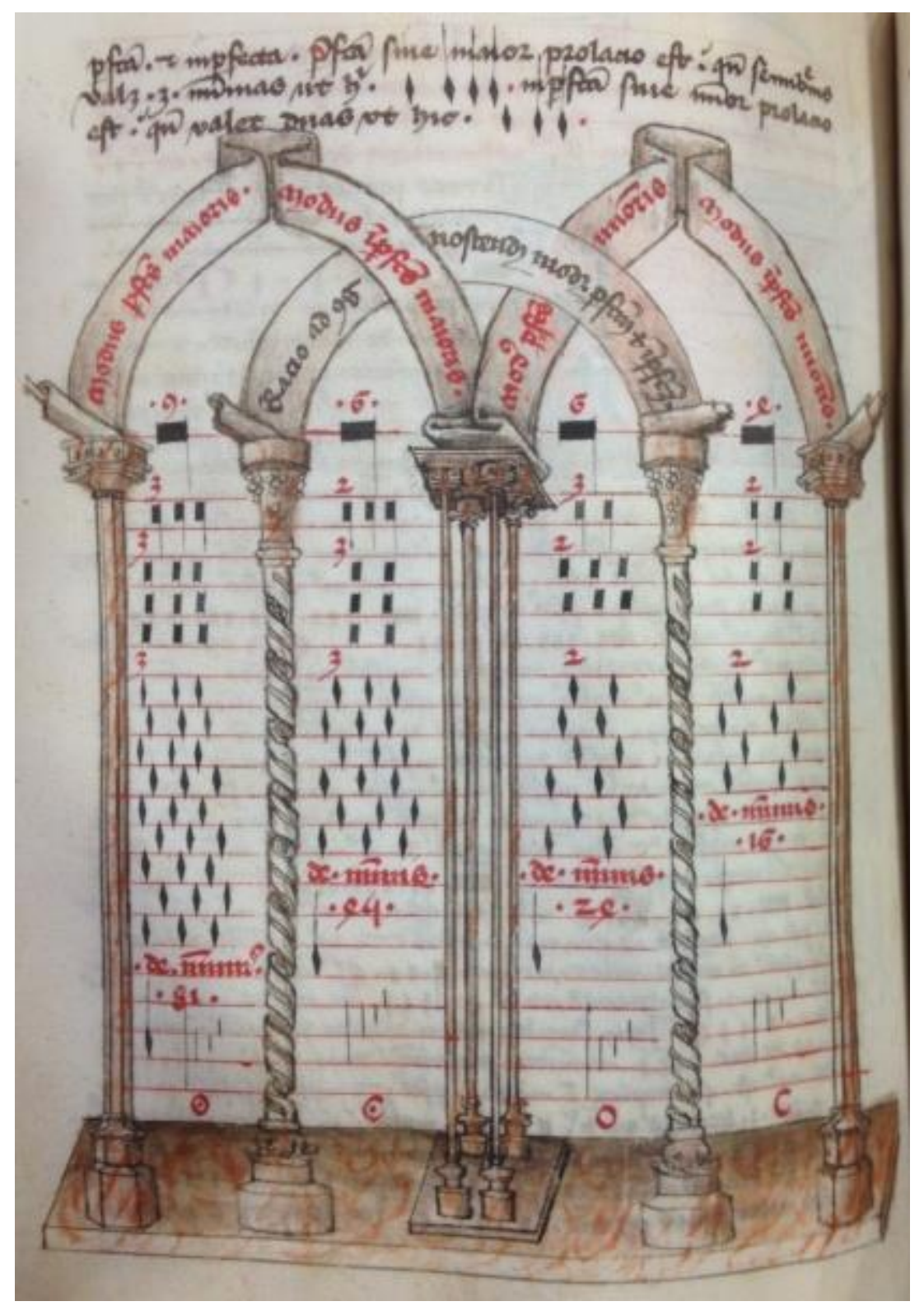

sl. 4 Libellus cantus mensurabilis secundum Johannem de Muris, Case MS 54.1, fol. 43r-49v

„Nequaquam amplius ita fiet. Nam Ioannes de Mours ${ }^{345}$, eximius quondam philosophus et mathematicus, alias ad canendum notas invenisse, nobisque tradidisse legitur.“

\footnotetext{
${ }^{345}$ Johannes de Muris (oko 1295. - oko 1350.), teoretičar glazbe, matematičar, astronom i reformator kalendara. Od 1321. do smrti predavao na Sorbonni. Teoretičar tada vladajućeg glazbenog stila Ars Nova, reformator notnoga pisma. Najznačajniji de Murisovi glazbenoteorijski traktati su Musica practica i Musica speculativa secundum Boethium (1323.), a uz njih i Libellus cantus mensurabilis (1340.) i Ars practica mensurabilis cantus. Značajno je i njegovo djelo koje se bavi reformom starog kalendara Epistola super reformatione antiqui kalendarii objavljeno 1317. godine.
} 
„Nipošto više neće biti tako. Naime, pripovijeda se da je Johannes de Muris, nekoć izvrstan matematičar i filozof, izumio druge oznake za pjevanje te da nam ih je prenio. ${ }^{\text {‘346 }}$

Tako veli Šilobod, no svjestan je da podatak o izumitelju mezuralne notacije nije sasvim siguran. On koristi riječ legitur - priča se, pripovijeda se. Legitur stvara odmak od sigurne konstatacije, osigurava piscu mogućnost ispravka ukoliko netko utvrdi drugačije. Ipak, izum menzuralne notacije uistinu se najčešće pripisuje Johannesu de Murisu čije je spomenuto djelo Libellus cantus mensurabilis (oko 1340.), ,najjasnija i najutjecajnija prezentacija novog menzuralnog sustava. Libellus je bila prepisivana, prevođena i obilno citirana sljedećih 150 godina te se koristila kao udžbenik u većini škola i sveučilišta tijekom cijelog srednjeg vijeka

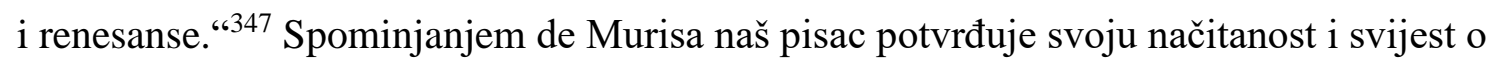
aktualnim zahtjevima za reformom gregorijanskoga pjevanja sukladnom estetici zamišljene antičke monodije s jedne i vokalne renesansne polifonije s druge strane. Također, zapisivanje koralnih melodija menzuralnom notacijom predstavlja odmak od tradicionalnog načina zapisa gregorijanskoga pjevanja kvadratnom koralnom notacijom koja je zamijenila neumatsku u 13. stoljeću. Koralni napjevi se, naime, od 13. stoljeća bilježe najčešće na crtovlju od četiri crte jednakim notnim vrijednostima - kvadratnim neumama. Menzuralnost u zapisu koralnih napjeva označava njihovu prilagodbu u praksi vrlo čestom figuralnom, odnosno polifonom pjevanju, ali i jednostavnim pučkim napjevima koji su bili ritmizirani. Na taj način ne samo da su se gregorijanske melodije prilagođavale posttridentskim reformama koje insistiraju na silabičnosti i deklamativnosti teksta, već je i zapis pratio stvarno stanje u praksi. De Muris je prvu, jednostavniju verziju menzuralne notacije predstavio 1321. u djelu Summa musice koji je danas poznat pod nazivom Notitia artis musice. U njemu je objasnio binarnu podjelu note longa na brevis i brevis na semibrevis. „No, pazio je da ne uvrijedi tradicionaliste.“ ${ }^{“ 348} \mathrm{I}$

\footnotetext{
${ }^{346}$ Šilbod-Bolšić, Mihael. op. cit. str. 62-63.

${ }^{347}$ Libellus cantus mensurabilis secundum Johannem de Muris, izvor: Scriptorum de musica medii aevi nova series a Gerbertina altera, 4 sv., ur. Edmond de Coussemaker (Paris: Durand, 1864-76; pretisak Hildesheim: Olms, 1963.), 3:46-58., dostupno na poveznici http://www.chmtl.indiana.edu/tml/14th/MURLIB, pristup 24.07.2018. „In his later treatise, Libellus cantus mensurabilis (c. 1340), he must have lost his fears of offending conservative theorists. It is the clearest and most influential presentation of the new mensural system. The Libellus was copied, translated, and quoted from extensively for the next hundred and fifty years, and used as a textbook in most schools and universities throughout the Middle Ages and Renaissance." Busse Berger, Anna Maria, The evolution of rhythmic notation, u Christensen, Thomas (2002). op. cit. str. 628-656.

${ }^{348}$ Ibid., str. 636. Busse Berger o njemu piše: „Des Murs was a prolific writer on music theory, and his many writings constitute a summa of medieval speculative and practical traditions. He was also the author of several astronomical and mathematical treatises. In his first treatise on mensural notation, Notitia artis musicae (1321), he introduces binary mensurations of the long, breve and semibreve. ... But he is careful not to offend traditionalists. He stresses the superiority of perfect mensuration and does not yet detail his new notational system."
} 
Šilobod-Bolšić se čuvao suviše smionih intervencija u poduci te se, prije no što je izložio mogućnost menzuralnog zapisa, jasno ogradio:

„Licet enim, ut priori sermone dixeram tibi, in solo cantu figurali servanda sit temporis mensura, ex qualitate notarum, \& signorum cognoscenda; est tamen etiam in cantu chorali aliqua differentia temporis ex diversitate notarum commensuranda.“

„Moguće je, kao što sam ti bio rekao u prethodnom razgovoru, u samom figuralnom pjevanju služiti se vremenskim oznakama poznatim iz osobina nota i znakova. Ipak, postoji čak i u koralnom pjevanju neka razlika u trajanju koja proizlazi iz različitosti nota.“349

Potom je izložio spomenutu, prvu verziju podjele longa-brevis-semibrevis:

„Si est caudata; tunc erit longa, \& vox infra illam diutius protrahetur. Si est sine dependente cauda, tunc erit brevis, \& vox nonnihil citius canetur. Si vero est angularis, tunc erit semibrevis, \& vox infra illam citissime absolvi debebit.“

„Ako ima rep tada će biti longa i glas se ispod nje duže zadrži. Ako je bez ovješenog repa tada se zove brevis i glas pjeva nešto hitrije. A ako je zaobljena tada će biti semibrevis i glas će se pod njom morati najbrže maknuti. “350

Glazbenoteorijski nauk Adriana Banchierija poznavao je ovaj marljivi župnik preko njegova već spominjanog djela Cartella Musica $(l e)^{351}$ kojem se utječe po pitanju glazbene abecede. Grci su za Bolšića ,prvi izumitelji pisma“ pa je logično da su i za note izumili posebna imena: „Scribit Banchieri in sua Cartella Musica quod Graeci, qui primi litterarum inventores, notas cantus per sex litteras G. A. B. C. D. E. canere solebant.“

„Banchieri u svome djelu Cartella Musica piše da su Grci kao prvi izumitelji pisma, običavali pjevati note napjeva prema šest slova G, A, B, C, D i E.“352

I odmah pridodaje vrlo popularan distih o solmizacijskim imenima tonova (koje autor distiha naziva modus!) koji možemo pronaći u nizu glazbenoteorijskih traktata u 17. i 18. stoljeću:

„Sex natura modis totum circumsonat orbem.

\footnotetext{
349 Šilobod-Bolšić, Mihael. Op. cit. str. 64-65.

${ }^{350}$ Ibid.

351 Šilobod-Bolšić pogrešno navodi ime djela u skraćenom obliku Cartella Musica. usp. bilj. 51.

352 Šilobod-Bolšić, Mihael. Op. cit. str. 66-67.
} 
Quos referunt: ut, re, mi, fa, sol, laque simul.“353

„Šest tonova iz prirode razliježe se po cijelome svijetu.

Njih zovu: ut, re, mi, fa, sol i zajedno s njima la.“354

Najmlađeg od svih spomenutih teoretičara, Johanna Baptista Sambera koji je pedesetak godina prije Šiloboda objavio vlastiti priručnik za gregorijansko pjevanje mješavinom njemačkog i latinskog i pisan goticom, navodi samo jednom, i to u pripovijesti o postanku glazbe. U odnosu na već spomenute filozofe i teoretičare koji su zaslužili višestruki spomen u knjizi, Samber je spomenut samo u prvom poglavlju u dijelu posvećenom prijenosu glazbenog znanja u vrijeme biblijskoga potopa:

„Inundantibus ergo super terram aquis diluvii destructa, ac dissipata est columna latericia, ac sola marmorea cum impressis musicae principiis, integra inventa est per Noe. Quae (ut refert Samber in elucidatione musicae choralis) ${ }^{355}$ hodiedum in Syria pro aeterna memoria, tanquam pretiosissimus thesaurus vigilantissime custoditur.“

„Vode potopa poplavile su zemlju, uništen je i raznesen stup od opeke, a samo je mramorni stup s urezanim glazbenim pravilima čitavog pronašao Noa. Taj se stup (kako kaže Samber u Prikazu koralne glazbe) i dan danas za vječan spomen brižljivo čuva u Siriji kao najvrednije blago.، $“ 356$

Šilobod uvelike preuzima Samberov način prikaza postanka glazbe i prijenosa znanja o njoj temeljeći pripovijest na Starom zavjetu, no postoje i značajne razlike u tumačenju njezina porijekla. ${ }^{357}$ Austrijski teoretičar ograđuje se od složenosti pitanja nastanka glazbe i njezina porijekla: „Quot capita, tot sententiae“ veli na početku poglavlja naslovljenog Von Erfindung und Ursprung der Music. U njemu niže razne mogućnosti, od zviždukanja, preko pjeva ptica, podrigivanja i grgljanja sve do bibanja vode i zvuka slapova rijeke. No, zaključuje Samber poglavlje, glazba nije izum Egipćana, Kaldejaca, Grka ili Židova, već je odmah po stvaranju

\footnotetext{
${ }^{353}$ Identičan distih, napisan prozno donosi tekst Stephana Vannea Recanetum de musica aurea. Rim, 1533. Tekst se nalazi u XII. poglavlju „De vocibus“. Ne znamo je li Šilobod-Bolšić poznavao baš ovaj tekst, no mnoge su rečenice prepisane ili parafrazirane. Vanneo je, ipak, kudikamo opširniji u obrazlaganju teme od našeg pisca. ${ }^{354}$ Ibid.

${ }^{357} \mathrm{O}$ (ne)postojanju historiografske svijesti i načinu prikazivanja povijesti glazbe u prvoj polovici 18. stoljeća v. Allen, Warren Dwight. Philosophies of Music History. A Study of General Histories of Music 1600-1960. Dover: Dover Publications, 1962.
} 
svijeta, prije izgona iz raja stvorena. Stoga nam Stari zavjet, misli Samber, daje pouzdanu pripovijest o njezinu postanku, odnosno pronalasku - jer ona je milost i dar svemogućega Boga, stoga je čovjek može samo otkriti, ne i izumiti -, nastanku instrumenata i njezinu širenju po svijetu o čemu nas podučava u poglavlju Von dem wahrhaften und ersten Erfinder der Music ( $O$ istinskom i prvom pronalazaču glazbe). Kao što detaljno navodi izvore za vlastito mišljenje o etimologiji riječi muzika, tako i o postanku glazbe detaljno popisuje na čijim je tekstovima učio. Athanasius Kircher, Zacharius Tevo, Andreas Ornitoparchus i Michael Reinspeck ${ }^{358}$ pouzdani su temelj za Sambera, a time i za našeg Šiloboda-Bolšića. No, dok Samber obrazlaže cijelu obiteljsku lozu Jubala i Tubala (Tubalkajina) ističući ih kao neupitne pronalazače glazbenoga znanja i glazbenih instrumenata, naš se pisac zadovoljava skraćenom verzijom prikaza potvrđujući Starozavjetnu pripovijest presudnom za poznavanje glazbe i njezinih pravila. Za Sambera nema sumnje: Bog je jedini pravi i prvi tvorac glazbe. To potvrđuju i nabrojani ugledni pisci u sljedećoj, nespretno konstruiranoj rečenici:

„Nego, smatram zajedno sa sljedećim uzornim i odličnim autorima i glazbenicima, kao što su Athanasius Kircher i Zacharius Tevus te Andreas Ornitoparchus, Michaele Rienspeck, koji za istinskog i prvog izumitelja plemenite glazbene umjetnosti pokazuju i govore da je prvi istinski izumitelj ove plemenite i radosne umjetnosti bio svevišnji glazbenik, sam BOG.“ 359

\footnotetext{
358 Athanasius Kircher najpoznatiji je u kvartetu teoretičara što ga spominje Samber. Musurgia universalis iz 1650. čudesno je djelo, mješavina spekulativne filozofije glazbe, ezoterije i praktičnih uputa koje do danas ne prestaje fascinirati istraživače, v. bilj. 35 u Uvodu. Zacharius Tevus najvjerojatnije je Magister Zacharia da Teramo (ca 1350. - 1415.), pjevač, skladatelj i papin sekretar, Andreas Ornithoparchus, učitelj koji se školovao diljem Njemačke, a osim u rodnoj zemlji djelovao i u Austriji, Češkoj i Mađarskoj pisac je vrlo popularnog renesansnog udžbenika Musicae activae Micrologus, tiskan u Leipzigu 1517. i nadahnut Guidovim traktatom iz 12. stoljeća. Obilno prevođen i nebrojeno puta dotiskan svjedočio je o potrebi za tekstovima koji se bave musica practica (activa) u vrijeme dominacije spekulativnih muzičkoteorijskih traktata. Napisao je, osim toga, diljem Europe vrlo popularnu gramatiku latinskoga jezika Enchiridion Latinae constructionis (1515.). Michael Reinspeck (Keinspeck, Künspeck) njemački je teoretičar iz druge polovice 15. stoljeća. Živio je i podučavao na sveučilištu u Baselu gdje je i objavio traktat Lilium musice plane Michaelis Künspeck Musici Alexandrini (1496.), tekst konceptom vrlo sličan Kovačevićevom i Bolšićevom. Keinspeckov se tekst oslanja na glazbenoteorijsku ostavštinu Huga Spechtsharta iz Reutlingena (1285. -1360.), to jest na njegov vrlo utjecajan traktat Flores musicae omnis cantus gregoriani iz 1332. Ono što ga izdvaja od većine renesansnih teoretičara jest odbacivanje Guidove ruke kao temeljne metode poduke i korištenje ljestvičnog prikaza tonova (scala) koji visinu tona imenuje dvojako: glazbenom abecedom (claves) i solmizacijom (voces). Digitalizirani original teksta dostupan na

https://books.google.hr/books?id=_LlUAAAAcAAJ\&printsec=frontcover\&source=gbs_book_other_versions_r \&redir_esc $=\mathrm{y} \# \mathrm{v}=$ onepage $\& \mathrm{q} \& \mathrm{f}=$ false, pristup 18.05.2020. $\mathrm{v}$. članak u NGROVED URL: https://www.oxfordmusiconline.com/grovemusic/view/10.1093/gmo/9781561592630.001.0001/omo9781561592630-e-0000014830?rskey=uhkxFe (17.05.2020.)
}

${ }^{359}$ Samber, Johann Baptist, op. cit., str. 3: „... sondern halte es mit denen nachstehenden vortrefflichen und excellenten Authoribus und Musicis, als mit R. D. P. Athanasio Kirchero, und Zachario Tevo, auch Andrea Ornitoparcho, Michaele Reinspeck, welche den wahrhafften und ersten Urheber der edlen Music-Kunst hervor 
Bog je, nastavlja u tekstu potom Samber, tvorac i svih ostalih znanja koja čovjek posjeduje i koja može, sukladno svojim sposobnostima, samo pronaći i otkriti. Uz očito nadahnuće (neo)platonizmom, implicitno se nadaje i zamišljeni idealni kontekst glazbe o kojoj se piše. Ona je Božji dar, stoga se ne može i ne smije koristiti u svrhe koje bi na bilo koji način remetile utvrđeni Božji poredak i narušavale stoljećima uhodane liturgijske obrasce što jamče ispravnost vjerskoga života. Ta idealna glazba koja utvrđuje, potvrđuje i prenosi ispravnu Božju poruku jest, dakako, gregorijansko pjevanje što ga je sam Duh sveti prenio Grguru Velikom.

Relativno je jasan slijed uzora kojima se utječu našu pisci i koji je moguće uspostaviti pomnom analizom dvaju priručnika. Bez obzira na razlike koje su značajne, jer ŠilobodBolšić jasno komunicira važnost glazbe same, metodologiju prijenosa znanja te njezino porijeklo i nastanak, dok Kovačević to ne čini, sličnosti su očite u odabiru prenesenog sadržaja. Iznalaženje autoriteta iz čijih tekstova crpe znanje, pisaca koji kao ,probati Authores“ jamče istinitost podataka dok ujedno pokazuju razinu obrazovanja naših svećenika, omogućuje, makar djelomice, razlaganje procesa kompilacije te upućuje, ne samo na izvore kojima se naši pisci koriste, nego i ocrtava kulturne okvire sredine u kojoj djeluju, njezine temeljne vrijednosti i ideje. Niz europskih pisaca čija su djela služila kao priručnici za poduku glazbe sjemeništarcima, studentima na sveučilištima i kapelnicima za poduku koralista svjetovnjaka u kasnijim stoljećima, stvaraju zajednički kulturni krug koji se prostire diljem zemalja čija je kulturna politika utemeljena na promicanju katoličke obnove inicirane Koncilom u Tridentu. Ti su kulturni okviri snažno određeni politikom katoličke obnove i vladara koji je podržavaju (kao što je slučaj s Habsburgovcima) te modelima obrazovanja i šireg pastorala koje nude novoosnovani redovi, ponajprije isusovci. Ipak, ne smijemo zanemariti njihovu čvrstu ukorijenjenost u srednjovjekovni skolastički sustav kojem je nesumnjivo najsnažniji pečat u poduci glazbe još u 12. stoljeću dao Guido iz Arezza, čiji neumanjeni utjecaj svjedoče i tekstovi Kovačevića i Šiloboda-Bolšića.

weisen/und sagen das der erste wahrhaffte Urheber gewesen sene diser edel und frölichsten Kunst der allerhöchste Musicus, GOTT selbsten.“ 


\section{ČETVRTO POGLAVLJE: DISKURS II REGULATIO}

\subsection{In choro almae cathedralis ecclesiae Zagrabiensis}

Kompilacija kao temeljni obrazac sklapanja novoga teksta, interpolacija kao mehanizam kojim se tekst puni argumentima i usporedba kao najčešća veza pojmova u 18. stoljeću postaje u glazbenoj teoriji osnova za klasificiranje znanja i regulaciju pravila - dopuštenog i nedopuštenog, valjanog i nevaljanog, onoga što se otklanja kao neprimjereno i onoga što se prešutno dopušta.

Prije no što opišemo regulacijske mehanizme u propedeutičkim priručnicima za pjevanje, ukratko ćemo se osvrnuti na kontekstualizaciju općih pravila u smislu lokalnih specifičnosti primjene predstavljenih uputa, odnosno specifičnosti koje oba udžbenika za pjevanje hrvatskih pisaca Tome Kovačevića i Mihaela Šiloboda-Bolšića čine proizvodom zagrebačkog kulturnog kruga 18. stoljeća. Osobitosti zagrebačke crkve omogućile su joj da poslije bule pape Pija V Quo primum tempore kojom 1570. propisuje da su sve crkve koje se ne mogu podičiti liturgijskom tradicijom starijom od dvjesto godina dužne uvesti na Tridentskom koncilu revidiran rimski misal i brevijar, sačuva vlastite obredne navike koje uključuju i u određenoj mjeri vlastiti glazbeni repertoar. ${ }^{360}$ Taj se repertoar ustalio i fiksirao u zborniku CO, a važnost njegova opstanka ističu predgovori svih triju izdanja insistirajući na spasonosnoj ulozi glazbe.

U prvome izdanju primjerena, crkvena glazba poništava sirensku zavodljivost otrovnih melodija i upućuje ljudske želje prema nebeskim otocima:

„... quod, cum venefica Sirenum carmina passim pudorem plurimorum in Syrtes illidant; ne suavi hoc toxico decepta incantentur animae, substituta Sacrorum hymnorum dulcedine, hominum affectus \& desideria sis ad fortunatas Coelorum insulas, elusa charybdi, pellecturus.“

„... budući da otrovne sirenske pjesme stidljivost mnogih posvuda zavode u Sirtu, kako duše ne bi bile začarane ovim slatkim otrovom, a pošto si im u zamjenu ponudio slast svetih

\footnotetext{
${ }^{360}$ Bula „Quo primum tempore“ dostupna je u sklopu Missale Romanum ex decreto SS. Concilii Tridentini restitutum summorum pontificum cura recognitum. Reimpressio editionis XXVIII. 2004.
} 
himana, upućivat ćeš ljudske čežnje i želje, izbjegavši Haribdu, prema sretnim nebeskim otocima.“

Jamči vezu s nebom, budući da će se zemaljskim pjevačima u zboru pridružiti nebeski stanovnici anđeli:

„Reipublicae siquidem laudes Dei canentium confoederati sese associant Angeli: queis, Ephramo teste, in deliciis est, eundem cum psallentibus Chorum instruere.“

„Zemaljskim će se pjevačima pohvalnica Bogu pridružiti anđeli kojima je, prema Efremovu svjedočanstvu, pravi užitak tvoriti jedan zbor s onima koji pjevaju psalme““

Na koncu, sjedinjuje ljudske duše sa samim Bogom:

,altius assurgit sacrae hymnodiae meritum: cuius voluntate cum ipso Deo coniungi animos, Strabo asseruit.“

„Još se više uzdiže zasluga svetog pjevanja, jer oduševljenje što ga ono stvara sjedinjuje ljudske duhove sa samim Bogom, kako je tvrdio Strabon. “361

To sveto pjevanje, međutim, nesumnjivo je pjevanje Zagrebačke crkve Svetog Kralja Stjepana, kako nas upozorava sam početak predgovora drugom i trećem izdanju, koja kao „Benigna, \& zelosa Mater Divi Stephani Regis Basilica Zagrabiensis, zelo zelata pro Domino DEO exercituum Filias suas esurientes pabulo verbi Divini implet, ut fidelis populus illo enutritus aeternam adipiscatur salutem, quo animarum lucrandarum zelo \& fervore mota...“ „,dobra i gorljiva majka revnuje gorljivo za Gospodina Boga vojskâ te hranom Riječi Božje napunja svoje gladne kćeri kako bi vjerni puk, njome nahranjen, postigao vječno spasenje.“362

Himne i duhovne popijevke koje donosi CO, a koje predstavljaju fiksiranje glazbenih običaja takozvanog Zagrebačkog obreda, nisu, međutim, namijenjene isključivo liturgiji u prvostolnici. Poziv na korištenje upućen je pastirima stada te se, sudeći po pozivu, odnosi na sve župe pod ingerencijom Zagrebačke biskupije:

\footnotetext{
361 „Praefatio libri“. Cithara octochorda seu cantus sacri Latino-Sclavonici quos in octo partes ... Viennae Austriae Typis Leopoldi Voigt, universitatis typ., MDCCI, str. XI. Usp. prijepis teksta i prijevod u Prilog 1 Disertaciji. Predgovor drugom i trećem izdanju iznosi više od desetak primjera čudesnog učinka glazbe na mitološke i povijesne velikane koje ćemo potanko iznijeti u Petom poglavlju u kojem se ispituju načini argumentacije koristi koje glazba pruža, a koji se temelje na vezi sličnosti.
}

${ }^{362}$ Usp. Prilog 2 Disertaciji. 
„Ast Zelosa Mater Divi Stephani Regis Basilica Zagrabiensis, Zelum vestro etiamnum constanti Zelo confirmari cupit o Pastores ovium Christianarum! Ut renovato utilissimo hoc opusculo, seu Cithara octochorda per secuturas annorum illiades, oves Christi ad ovile insatiabilis voluptatis, laudes DEI \& Divorum dulci modulamine personando allicere tota mentis vestrae industria non intermittatis in hymnis nempe \& canticis; ut ait Doctor gentium, Spiritialibus cantantes \& psallentes Domino.“

„Ali gorljiva majka - zagrebačka bazilika Svetog Stjepana Kralja -sada želi svoju predanost povećati i vašim žarom, Pastiri kršćanskog stada! Po novom izdanju ovog vrlo korisnog djelca, tj. Osmožične Citare, kroz sljedeće tisućljeće ne zanemarujte Kristove ovce svom dušom i svim nastojanjima privlačiti u ovčinjak neizrecive slasti i to himnima i popijevkama duhovnim, kako veli Učitelj naroda, pjevajući i psalmujući Gospodu.“363

Vještina intoniranja psalama vrlo je važan, uz tečno i točno čitanje notnog zapisa i mutiranje iz heksakorda u heksakord, možda i najvažniji cilj svih priručnika za gregorijansko pjevanje. Prisjetimo se samo omjera teorijskih uputa za upoznavanje nota, crtovlja, ključeva, intervala, tonusa, heksakorda, mutacija, itd. te uputa za intoniranje prema rasporedu brevijara $\mathrm{u}$ talijanskih autora Tettamanzija i Frezza Dalle Grotte. ${ }^{364}$ Intoniranje psalama na određene svetkovine, bilo da je riječ o velikim blagdanima kao što su Uskrs i Veliki tjedan koji mu prethodi, Božić, Tijelovo, Duhovi ili pak o svetkovinama svetaca, uz svetačke blagdane koji se slave, definira prepoznatljivost i osobitosti lokalne crkve.

Kovačević i Šilobod-Bolšić kompiliraju glazbenoteorijska znanja talijanskih i njemačkih teoretičara, no također i komentiraju otklone od naučenih i naslijeđenih obrazaca i uputa čime otkrivaju ne samo svrhu teksta kojeg su autori, već i lokalni kontekst kojem su namijenjeni. Time lokalnost o kojoj je riječ u ovom kratkom odlomku čini poveznicu između kompilacije i interpolacije kao metode oblikovanja teksta čime smo se bavili u trećem poglavlju i mehanizma regulacije naučenog što je tema ovoga poglavlja.

Za razliku od priručnika Compendiosa in cantum gregorianum seu choralem pridodanog Psalteriju-Antifonalu iz 1742. koji se koristio u zagrebačkoj prvostolnici i pripada istom vremenskom razdoblju, Brevis cantus gregoriani notitia i Fundamentum cantus gregoriani seu choralis pripadaju zagrebačkom kulturnom i glazbenom krugu. Jasno je to iz primjedbi o pjevačkoj praksi zbog kojih je ove pedagoški intonirane tekstove moguće djelomično opisati i

\footnotetext{
363 Ibid.

${ }^{364}$ Usp. u ovom poglavlju analizu sadržaja Tettamanzijeva priručnika.
} 
kao komentare, a ne isključivo kompilacije. Naime, Šilobod-Bolšić i Kovačević jasno iskazuju svijest o posebnostima zagrebačkog obreda ${ }^{365}$ koje se ogledaju u glazbenom elementu. Opisivanje specifičnosti u odnosu na pravila, nabrajanje elemenata koji odudaraju od tradicionalne upute za učenje gregorijanskoga pjevanja odnosi se na incipite psalama te na svetačka slavlja koja se razlikuju od biskupije do biskupije. Dijelovi teksta u kojem se i jedan i drugi pokazuju kao onaj tko ,scribit et aliena et sua, sed aliena tamquam principalia, et sua tamquam annexa ad evidentiam“ čini ih ne samo kompilatorima, već i komentatorima.

Toma Kovačević, koliko doznajemo prema Mihokovićevom čitanju teksta i taj dio komentira dosta šturo: „Gore navedene intonacije psalama vrijede u crkvama Rimskog obreda posvuda: samo na koru Almae Cathedralis Zagrebačke crkve u Kraljevstvu Hrvatske početak četvrtog i sedmog načina ima neku razliku. Četvrti način naime počinje obično na istoj noti na kojoj antifona svršava tj. Na E/teškom/ i to ovako: mi, sol, la. Sedmi pak počinje na D/oštrom/, ovako: sol, fa, sol, ostalo je kao i gore. Isto tako u drugom načinu razlikuje se na središnjoj noti, na medijaciji a isto i na finalnoj kako se može vidjeti na priloženom primjeru. “366

Šilobod-Bolšić nešto je elokventniji. Već u odobrenju cenzora, hvaleći knjigu cenzor Juraj Bistrički uživajući ugled dviju visokih crkvenih funkcija, one kanonika i dijecezanskog bilježnika (,canonicus Zagrabiensis, \& sacrae sedis dioecesanae Zagrabiensis notarius“) navodi kako je Šilobod-Bolšićev priručnik podjednako primjeren za učenje pjevanja u svrhu izvedbe koralnih napjeva sukladno rimskom obredu, ali i vrlo starom zagrebačkom obredu:

„Sive enim cantum choralem omnium ritus Romani ecclesiarum, sive chori nostri cathedralis ecclesiae Zagrabiensis antiquissimam canendi consuetudinem specte, ita haec attemperata praefert: ut nulli in aliquo deesse videatur.“367

„Naime, bilo da proučavaš koralni napjev svih crkava rimskog obreda, bilo vrlo star običaj pjevanja kora naše zagrebačke stolne crkve, ona to izlaže tako prikladno da zasigurno nikoga neće ni u čemu iznevjeriti.“

\footnotetext{
365 O specifičnostima zagrebačkog obreda čije se oblikovanje, odnosno redakcija pripisuje bl. Augustinu Kažotiću, te o modusima i opsegu promjena u odnosu na rimski obred, odnosno obredne knjige v. Šaško, Ivan. Biskup Kažotić, promicatelj knjige u Hrvata s posebnim naznakama iz povijesti liturgije. // Croatica Christiana Periodica (dalje CCP) 49, 2002. Str. 59-68.; Šaško, Ivan. Liturgijski identitet Sakramentara iz Zagreba. Istraživanje na temelju molitava korizmenoga vremena. // CCP, 55, 2005. Str. 7-41. O glazbenom djelovanju bl. Augustina Kažotića v. pregledni rad dosadašnjih istraživanja Tuksar, Stanislav. Augustin Kažotić, biskup zagrebački, sakralna glazba i liturgijsko pjevanje. // Arti musices, 50/1-2, 2019. Str. 9-19.

${ }^{366}$ Mihoković, Martin. Op. cit. Str. 26.

${ }^{367}$ Šilobod-Bolšić, Mihael. Op. cit. str. 42-43.
} 
U poglavlju o intonacijama „De intonationibus“ Šilobod-Bolšić daje i konkretne upute vezane uz zagrebački obred:

„Atque hae intonationes psalmorum per omnes passim ecclesias ritus Romani habentur. In choro tamen almae cathedralis ecclesiae Zagrabiensis in Regno Croatiae, circa tonum secundum, quartum, septimum, \& octavum invenitur quaedam discrepantia. Nam secundus circa medium, \& finem: quartus autem, septimus, \& octavus circa initium nonnihil mutantur: prout videre est in hisce exemplis.“

„A ovakve intonacije psalama postoje bez razlike u svim crkvama rimskog obreda. Ipak, na koru zagrebačke stolne crkve u Hrvatskom kraljevstvu oko drugog, četvrtog, sedmog i osmog tonusa nailazi se na određeni nesklad. Naime, drugi tonus se ponešto mijenja oko sredine i kraja, a četvrti, sedmi i osmi tonus oko početka kao što je moguće vidjeti u ovim primjerima.“368

I dalje nastavlja, u istom poglavlju:

„Prout autem idem psalmus, in choro Zagrabiensi per octavam paschatis canitur, non sumit initium ex quarto tono; sed (ut vides) ex septimo.“

„No, budući da se isti napjev pjeva i na zagrebačkom koru u Pashalnom tjednu, početak nije u četvrtom nego, kao što vidiš, u sedmom tonusu. “ 369

I jedan i drugi pisac, dakle, nude čitatelju opće upute za stjecanje vještine pjevanja koralnih melodija te specifičnosti vezane uz takozvani zagrebački obred. Budući da je Kovačević kanonik zagrebačkog kaptola, a Šilobod-Bolšić župnik u Martinskoj Vesi koja pripada stolnom kaptolu zagrebačkom, i jedan i drugi praksom su vezani uz običaje stolne crkve ili su toj praksi svjedočili tijekom nekog dijela svoga školovanja i djelovanja. Njihovi se priručnici, stoga, mogu koristiti u svim crkvama koje prakticiraju rimski obred, ali i u crkvama zagrebačke biskupije.

Cithara octochorda također je proizvod zagrebačkog kulturnog kruga. U prvome izdanju predgovor koji nam opisuje okolnosti nastanka mnogo je kraći u odnosu na drugo i treće izdanje te usredotočen ponajviše na iskazivanje hvale i pohvale meceni Ivanu Zniki. Stoga

\footnotetext{
${ }^{368}$ Riječ je osobitostima tzv. Zagrebačkog obreda, koji je, unatoč svim odredbama i nastojanjima Rima za posvemašnjom unifikacijom obreda, u liturgijskim knjigama i praksi sačuvan sve do reforme biskupa Maksimilijana Vrhovca koji ga je ukinuo 1887. godine. Ibid. str. 138-139.

${ }^{369}$ Ibid. str. 144-145.
} 
mnogo više doznajemo o njegovim građevinskim poduhvatima te inicijativama o ukrašavanju crkvi diljem Zagreba, kao i uvođenju mramornih kipova i oltarnih ograda što početkom 18. stoljeća predstavlja novost na sjeveru Hrvatske, no o samome zborniku. Drugo i treće izdanje donose kudikamo opsežniji predgovor koji obiluje toposima, metaforama i alegorijama formuliranima u antici i srednjem vijeku te neumorno prenošenima stoljećima. Taj predgovor, istovjetan u oba izdanja (1723. i 1757.), ističe zagrebački kaptol kao podupiratelja projekta izdavanja zbornika što i napjeve koji u njemu slijede svrstava u repertoar tipičan za zagrebački kulturni krug čije granice omeđuje utjecaj stolne crkve. Međutim, ograničiti uporabu ovoga zbornika na širu okolicu Zagreba bilo bi pogrešno, budući da ga nalazimo i u samostanima izvan Zagrebačke biskupije. ${ }^{370}$ Citara octochorda zbornik je koji je kodificirao glazbene specifičnosti zagrebačke liturgije, ali je istovremeno prikupio i predstavio sjevernohrvatsku kajkavsku glazbenu baštinu, kao i suvremeno skladane napjeve prema modi ondašnjega vremena. Pisac dušebrižnike, župnike i kantore u župnim crkvama, upućuje na neumorno korištenje ovih napjeva „kad već pjevanje ili vokalna glazba vlada nad svim moćima mikrokozma“:

„Dajte zato, dajte, dobri dušobrižnici, ne prestajte poticati svoj puk da pjevanjem slavi Boga i Svece. Deder, i udarajući u ovu Osmožičnu citaru, podbadajte narodnu dušu koju onečistiše grijesi. Deder, ovom Citarom odbijajte od svojega naroda zasjede paklenskih zloduha; budući da ona, često brže od svih prednosti navjestitelja Riječi Božje običava pobuđivati ljudske duše. Gorljiva majka zagrebačka Bazilika Svetog Stjepana Kralja prinijela je ove prve plodove sve na veću slavu Vrhovnoga Božanstva i na korist Crkve, kako bi ljudi, služeći se njima kod psalama i himana i duhovnih popijevaka u ime Gospoda našega Isusa Krista, mogli jednodušno hvaliti Dobrotu koja će se dolično ubuduće Hvaliti ovom Osmožičnom citarom, pa će čak i nepismeni župljani iz nje moći često pjevati.“

S obzirom na ograničeni broj uputa vezanih uz antiquissimam consuetudinem izvođenja napjeva u zagrebačkoj prvostolnici te na recentna liturgička istraživanja provedena na kodeksima koji su korišteni u srednjovjekovnoj zagrebačkoj biskupiji, čini se da je u muzikološkoj literaturi pojam zagrebačkog obreda, premda nesumnjivo dokaziv u smislu odstupanja od rimskoga oblika, napose u sakramentaru i obredima Velikoga tjedna, ponešto precijenjen. ${ }^{371}$ Naime, mnoga su katolička biskupska sjedišta njegovala vlastite posebnosti i,

\footnotetext{
${ }^{370}$ CO čuva se, primjerice, i u Franjevačkom samostanu sv. Križa u Osijeku. Usp. URL: https://www.europeana.eu/en/item/2023827/ECBC42E27C6048933064719EF01C34424CC48C60 (14.04.2020.) ${ }^{371}$ Usp. Šaško, Ivan. Op. cit.
} 
premda su načelno prihvaćala rimski obrednik, čuvala su vlastite običaje vezane uz čašćenja lokalnih svetaca. Osobito poslije završetka Tridentskoga koncila koji, je redefinirajući katoličku vjeru u teološkom i liturgijskom smislu jasno odredio duhovnu pouku (Catechismus Romanus, 1566.) i obrednike (Breviare Romanum, 1568. i Missale Romanum, 1570.), brojne su biskupije nastojale, ako već ne eksplicitno, onda barem implicitno, u sakramentaru zadržati najvažnije liturgičke posebnosti koje su bile bitne za uspješniju pastoralizaciju i odnose klera s narodom. ${ }^{372}$ Zagrebačka biskupija, kao i mnoge druge susjedne biskupije, u tom smislu nije predstavljala iznimku već je nastojala oko zadržavanja autohtonosti i određene slobode u provođenju koncilskih uputa što ih ističu i sami koncilski dokumenti. ${ }^{373}$ Kao što je iznalaženje izvora na temelju kojih kompiliraju vlastiti tekst važno kako bi se mogao razumjeti i opisati glazbeni, obrazovni i kulturni kontekst naših pisaca, tako su njihovi komentari na naučene i preuzete tekstove važan pokazatelj njihove pripadnosti kulturnom i društvenom okruženju zagrebačke katedrale te odgovor na potrebe zagrebačkih kapelnika, ali i brojnih župnika u okolici Zagreba koji su uz pastoralne obaveze imali dužnost izvršavati i one kapelničke. Svrha i cilj poduke koralnoga pjevanja otkriva se upravo u posljednjim poglavljima koji su svojevrsna kulminacija stečenoga znanja. Pravilno intoniranje psalama i lakoća u razaznavanju tonusa vještine su koje svaki koralist, bio on pripadnik klera ili pak plaćeni svjetovnjak, mora steći kako bi mogao sudjelovati u glazbenom dijelu liturgije. Izuzetke od propisanih pravila intoniranja psalama kojima se odlikuje lokalna liturgija valja istaknuti kako ne bi došlo do automatske primjene općeg stečenog znanja koje na dane određenih svetkovina valja modificirati prema lokalnim običajima. Međutim, liturgijske i glazbene posebnosti zagrebačkog obreda, kako je upozorio liturgičar Ivan Šaško ${ }^{374}$, treba promatrati interdisciplinarno, uvažavajući teološki i povijesnoliturgijski aspekt čime se postiže jasnija slika stvarne liturgijske prakse i njezina odnosa s rimskim obrednikom. Ipak, ostaje činjenica

\footnotetext{
${ }^{372}$ Usp. npr. Wright, Anthony David. Early Modern Papacy: From the Council of Trent to the French Revolution 1564 - 1789. London: Harlow: Essex: Longman, 2000. str. 167.: „Similarly, the popes faced pressure over the cult of specific saints, as Rome found in initial post-Conciliar revision of liturgical texts, wether the Martyrology or Breviary, for instance. ... The unachieved plans of Benedict XIVto reform the Roman Breviary were intended not least to counter liturgical peculiarities in places, such as some French dioceses, where local usage was informed by a sense of polemical confrontation with claims made over the centuries for papal authority." Osim toga, detaljnije o samom koncilu u Tridentu v. Jedin, Hubert. Velika povijest crkve, sv. 4.: Reformacija, katolička reforma, protureformacija (prev. Ivica Tomljenović). Zagreb: KS, 2004.; Franzen, August. Pregled povijesti crkve. Zagreb: KS, 1996.; Bedouelle, Guy. Povijest crkve. Zagreb: KS, 2004. Odluke koncila u prijevodu na engleski jezik dostupne su na https://history.hanover.edu/texts/trent.html, pristup. 08.10.2019.

${ }^{373}$ Usp. Crnčević, Ante. Concilium Tridentinum i liturgijska reforma. Prijekoncilska liturgijska nastojanja i recepcija poslijekoncilske obove. // Tridentska baština: katolička obnova i konfesionalizacija u hrvatskim zemljama. / uredile Zrinka Blažević; Lahorka Plejić Poje. MH: KBF: FFDI: Zagreb, 2016. str. 31-41.

${ }^{374}$ Ibid.
} 
da je Zagrebačka biskupija, dokazavši višestoljetnu autohtonost u obredniku, uspjela vrlo dugo sačuvati lokalne modifikacije rimskoga obreda, posebnost koja je vrlo vjerojatno generirala potrebu za proizvodnjom tekstova kakvi, u suprotnome, možda nikada ne bi bili napisani. ${ }^{375}$

\subsection{Klasifikacija i regulacija znanja}

Kompilacija ulomaka tekstova pisaca od 5. stoljeća prije Krista (Platon), preko zlatnog doba rimske književnosti (Ciceron), srednjovjekovnih propedeutičkih traktata (Guido iz Arezza) do ekstenzivnih teorijskih shema renesanse i ranog baroka (Pietro Aaron, Franchino Gaffurio, Adriano Banchieri) te zrelog baroka (Johann Baptist Samber), model je oblikovanja diskursa o glazbenoj praksi kakav funkcionira tijekom cijelog 17. stoljeća i počinje ozbiljnije uzmicati tek krajem idućega. Ne odriče se u potpunosti spekulativnog naslijeđa i humanističke tradicije u obrazovanju koja se ogleda ponajviše u utjecaju retoričkih pravila, no oni funkcioniraju više kao opravdanje za pisanje samoga teksta, nego kao njegov istinski temelj. Osnovu pedagoških priručnika (compendium), uputa (notitia), temelja (fundamentum) ili pravila (regulae) o pjevanju čine pregledno prikazani elementi glazbene teorije, onog njezinog dijela što danas pripada predmetu solfeggio. Ti su elementi najčešće pažljivo razvrstani, opisani i objašnjeni ne samo riječju već i glazbenim primjerima. Nastojat ćemo, stoga, u ovom dijelu poglavlja odgovoriti na pitanje o paradigmi kakvu analizirani priručnici glazbene teorije napisani za potrebe kantora i koralista, uspostavljaju i o svrsi kojoj teže. Pritom paradigmu razumijevamo na način na koji ju definira Thomas Kuhn, dakle kao skup primjera konsenzusom prihvaćen kao egzemplaran za određenu znanost koji omogućava ne samo primjenu ključnih teorija i zakona, nego i uočavanje veze na temelju sličnosti između različitih obrazaca i problema, te sukladno toj sličnosti sugerira analogno rješavanje istih. Kuhn se, dakle, nadovezuje na izvorno značenje pojma paradigma što znači obrazac i primjer (grč. $\pi \alpha \rho \alpha ́ \delta \varepsilon \imath \gamma \mu \alpha$ ). Pritom

\footnotetext{
${ }^{375}$ Kao izvor obrednih knjiga zagrebačkoga obreda utvrđene su knjige iz sjeverne Franačke prispjele najvjerojatnije preko ugarskih benediktinskih samostana. Razlike u liturgiji odnose se na raspored nekih molitava te na prisutnost narodnoga jezika u obredu. Nakon Tridentskoga koncila obred je zadržan, no liturgijske su se knjige zagrebačkog obreda sve manje prepisivale i tiskale zbog čega je, čini se opstao samo u prvostolnoj zagrebačkoj crkvi. Usp. Zagorac, Vladimir. Povijesno-liturgijski aspekt Pavlinskog zbornika. // Pavlinski zbornik 1644. II. Transkripcija i komentari / priredili i popratne studije napisali Koraljka Kos, Antun Šojat i Vladimir Zagorac. Zagreb: HAZU - Nakladni zavod Globus, 1991. i Livljanić, Katarina. Nepoznati rukopisni procesional u kontekstu procesionalnih obrednih priručnika zagrebačke stolnice s kraja 17. i prve polovice 18. stoljeća. Diplomski rad na Odsjeku za muzikologiju Muzičke akademije Sveučilišta u Zagrebu, sign. DR 1297,1989.
} 
korištenje njegove ideje paradigme ne implicira neupitnu znanstvenost glazbene teorije, opsežnu i složenu temu kojom se ovdje ne možemo baviti. ${ }^{376}$

U šestom poglavlju koje ispituje odnos musica theorica i musica practica u traktatima koji su se koristili u prvoj polovici 18. stoljeća u sjevernim hrvatskim zemljama te u predgovorima zbornicima CO, opisat ćemo konkretan muzičkospekulativni i glazbenoteorijski sadržaj koji se podastire čitateljima u usporedbi s traktatima-uzorima i suvremenim tekstovima ostalih teoretičara koje nalazimo u knjižnicama gradova sjeverne Hrvatske. U ovom poglavlju prikazat ćemo načine ustroja objasnidbenih obrazaca i primjera kakve nude glazbenoteorijski priručnici koje analiziramo, a tiču se onoga što Carl Dahlhaus naziva regulativnom teorijskom tradicijom, Leslie Blasius taksonomijama, a Michel Foucault klasičnom epistemom utemeljenom na odnosu prema mathesisu. ${ }^{377}$

Ta regulativna teorijska tradicija koja se odnosi na razdoblje 17. i 18. stoljeća pod raznim je nazivima prepoznata i definirana u dvjema već spomenutim povijestima teorije glazbe: Die Musiktheorie im 18. und 19. Jahrhundert. Erster Teil: Grundzüge einer Systematik Carla Dahlhausa (objavljena kao deseti svezak edicije Geschichte der Musiktheorie Državnog Instituta za glazbena istraživanja u Berlinu) $)^{378}$ te zborniku tekstova The Cambridge History of Western Music Theory koju je uredio Thomas Christensen. Podsjećajući da svaka kultura posjeduje vlastiti način predstavljanja onoga što čini njezinu glazbenu teoriju, područja istraživanja, pravila i odnose među tim područjima, pokušavajući pomiriti dijakronijski i sinkronijski aspekt, Blasius pojmom historijske kartografije definira tri povijesna razdoblja: „,prvo koje upravlja teorijom glazbe do 16. stoljeća, drugo koje upravlja teorijom 17. i 18. stoljeća i posljednje koje upravlja teorijom poslije obrata u 19. stoljeću“. ${ }^{379}$ Koristeći

\footnotetext{
${ }^{376}$ Stjepan Senc u Grčko-hrvatskom rječniku (Zagreb, 1988.) navodi značenja $\pi \alpha \rho \alpha ́ \delta \varepsilon 1 \gamma \mu \alpha$ : primjer, ugled, uzor, uzorak, opomena, dokaz. Za definiciju paradigme u teoriji znanosti usp. Kuhn, Thomas. Struktura znanstvenih revolucija (prev. Mirna Zelić). Zagreb: Jesenski \& Turk, 2013. str. 57.: „Temeljito povijesno istraživanje neke određene specijalnosti u nekom određenom vremenu iznosi na vidjelo skup kvazi-standardnih ilustracija (koje se ponavljaju) različitih teorija u njihovim pojmovnim, promatračkim i instrumentalnim primjenama. ... Proučavajući ih i služeći se njima u praksi, članovi odgovarajuće zajednice uče svoj zanat."

377 Usp. Dahlhaus, Carl. Die Musiktheorie im 18. und 19. Jahrhundert: I. Grundzüge einer Systematik. Darmstadt: Wissenschaftliche Buchgesellschaft. 1984. str. 1-13. Dahlhaus naziva teorijske modele „tradicijama“ i „paradigmama“; Blasius, Leslie. Op. cit. Str. 34 i dalje; Foucault, Michel. Les Mots et les choses. Paris: Gallimard, 1966. Str. 71: „Car le fondamental, pour l'épistémè classique, ce n'est ni le succès ou l'échec du mécanisme, ni le droit ou l'impossibilité de mathematiser la nature, mais bien un rapport à la mathesis qui jusqu'à la fin du XVIIIe siècle demeure constant et inaltéré. Ce rapport présente deux caractères essentiels. Le premier c'est que les relations entre les êtres seront bien pensées sous la forme de l'ordre et de la mesure, mais avec ce déséquilibre fondamental qu'on peut toujours ramener les problèmes de la mesure à ceux de l'ordre. De sorte que le rapport de toute connaissance à la mathesis se donne comme la possibilité d'établir entre les choses, même non mesurables, une succession ordonnée.“

${ }^{378}$ v. Drugo poglavlje, bilj. 73.

${ }^{379}$ usp. Blasius, Leslie. Op. cit.
} 
geografijsku terminologiju, kartografiju koja uređuje ili upravlja (govern) spekulativnim, preskriptivnim, pedagoškim i analitičkim diskursom o glazbi izjednačio je s kartama (mapama ili planovima) koje na određeni način raspoređuju i prikazuju sadržaj. Temeljna ideja trodijelne vremenske razdiobe u svakom slučaju vrlo je korisna za lakše obrazlaganje dominantnih diskurzivnih obrazaca u glazbenoj teoriji i u konačnici se oslanja na stariju Dahlhausovu ideju tripartitne podjele sveukupnog glazbenog teorijskog naslijeđa na tradicije i to na temelju istih vremenskih odrednica. ${ }^{380}$ Ono što je problematično u svakom pokušaju uspostavljanja historiografske kartografije, čega je Blasius svjestan, jest činjenica da su granice spomenutih diskursa i tradicija vrlo porozne, katkad posve zamagljene, a vrlo često i usporedno ocrtane pa i križane u jednom te istom traktatu.

Dvije tradicije prisutne prije analitičkog 19. stoljeća - spekulativnu i praktičnu - valja stoga konceptualno separirati, upozorava nas Dahlhaus, premda ih često možemo pronaći jednu uz drugu u istome tekstu. Prva posjeduje kudikamo veći autoritet od potonje sve do 15. i osobito 16. stoljeća, premda i jednu i drugu baštinimo iz antike. ${ }^{381}$

Ona praktična koja nas zanima u ovom poglavlju važnom postaje još od planskog širenja rimskog obreda tijekom karolinške obnove u 9. stoljeću i pojave prvih tekstova koji spekulativnu tradiciju uvjetovanu teološkim okvirima razlažu i simplificiraju kako bi je prilagodili onoj praktičnoj. Višestoljetna podređenost traktata koji raspravljaju o musica practica objašnjena znamenitim, već izlizanim distihom o kantoru koji ne poznaje muziku, ali pjeva i muzičaru koji je poznaje i stoga jedini smije nositi dično ime musicus $^{382}$ nestaje krajem 16. stoljeća kada u kvantitativnom smislu primat preuzimaju tekstovi posvećeni musica practica. „Zadatak teoretičara glazbe sada je bio zadatak praktičnog pedagoga: podučavati elemente glazbe kako bi ih mogli primijeniti budući izvođači ili skladatelji, istovremeno pomažući discipliniranje te prakse kroz uspostavu propisanih pravila. Time se uopće ne želi reći da je „spekulativno“ znanje o glazbi sada bilo posve podcijenjeno; ono je bilo cijenjeno, no uglavnom u opsegu u kojem je moglo koristiti musica practica. Pravi

\footnotetext{
${ }^{380}$ usp. Dahlhaus, Carl. Ibid. i Idem. Was heißt „Geschichte der Musiktheorie?“. // Ideen zu einer Geschichte der Musiktheorie. Einleitung in das Gesamtwerk. Geschichte der Musiktheorie. / uredio Frieder Zaminer. vol. I. Str. 39.

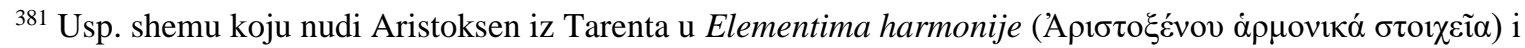
Elementima ritma ('A Aristid Kvintilijan u djelu De musica u Blasius, Leslie. Op. cit. Str. 28 i dalje.

${ }^{382}$ Riječ je o distihu iz prologa traktata Regulae rythmicae Guida iz Arezza koji glasi: „Musicorum et cantorum magna est distantia/Isti dicunt illi sciunt quae componit musica“. usp. Guidonis Aretini. Regulae rhythmicae. // Divitiae musicae artis A/IV / uredili Joseph Smits van Waesberghe; Eduard Vetter. Buren: Knuf, 1985. Str. 92133. URL: http://www.chmtl.indiana.edu/tml/9th-11th/GUIRR (02.10.2018.)
} 
musicus kasnog srednjeg vijeka bio je sada „cantor peritus et perfectus“ - pojac vješt i savršen. ${ }^{383}$

U svakom slučaju, predmoderno je doba i u govoru glazbi dalo prednost opisu glazbe koju se izvodilo i skladalo. Nije to značilo jednoznačno preuzimanje mjesta koje je dotad zauzimala musica speculativa, „trijumf usus nad ars. Prije se radilo o promjeni fokusa glazbene teorije i rekonfiguracije njezinih principa kako bi bolje prilagodili području musica instrumentalis.“384

Uz to, česte i značajne promjene u glazbenoj praksi i poetici zahtijevale su sve veću pozornost i napore teoretičara da sistematiziraju i urede parametre postojećeg muziciranja. U kontekstu gregorijanskoga pjevanja valjalo je odgovoriti na zahtjeve za ostvarenjem ciljeva katoličke obnove, što je značilo discipliniranje i uređivanje pravila muziciranja u sklopu liturgije prema vrlo općenitim naputcima Tridentskoga koncila.

Procvat raznovrsnih uputa za učenje konkretnog umijeća pjevanja, sviranja i skladanja tako se vremenski poklapa sa 17. i 18. stoljećem i u tom smislu tvori tradiciju kojom više ne dominira spekulativna rasprava koja metaforama i poredbama objašnjava srodnosti i veze svemira i muzike, muzike i duše, pjevanja i vječnoga spasa, već praktičan pregled, klasifikacija potrebnoga znanja kako bi se to pjevanje, sviranje i skladanje moglo i ostvariti. Nije, dakle, riječ o obratu i promjeni epistemološke opcije, već o postupnom jačanju i konačnoj kvantitativnoj prevlasti tekstova o praksi koji su je potom izdigli, ističući ipak i važnost njezine kompatibilnosti sa spekulativnim aspektom muzike. Musica practica kao diskurs o načinima fizičke realizacije metafizički zamišljene muzike koja počiva na brojčanim odnosima, i u svijesti Katoličke crkve koja je stoljećima ohrabrivala spekulativni tip diskursa, postaje službeno predmetom rasprave, poticanja poželjnih, a ograničavanja i dokidanja onih oblika koji se ne smatraju primjerenima liturgiji. Čini se da je procvat glazbene propedeutike posljedica nekoliko događaja i okolnosti: rastuće raznolikosti glazbenih praksi koje su još uvijek dominantno, ali ne isključivo vezane uz crkvu, Guttenbergova izuma koji je omogućio

\footnotetext{
${ }^{383}$ Christensen, Thomas. Op. cit. Str. 8: „The task of the music theorist was now that of the practical pedagogue: to teach the elements of music to be applied by the would-be performer or composer, while conversely helping to discipline that practice through the establishment of regulative rules. This is by no means to say that "speculative" knowledge of music was in complete disrepute; such knowledge was valued, but mainly to the extent that it could be of value to musica practica. The true musicus of the later Middle Ages was now the "cantor peritus et perfectus".

${ }^{384}$ Ibid.: „Rather, it was more a case of music theory being refocused, its principles reconfigured so as to accommodate better the domain of musica instrumentalis."
} 
veću dostupnost partitura i uvid u glazbene prakse međusobno udaljenih dijelova Europe ${ }^{385}$, projekta katoličke obnove te u austrougarskim zemljama afirmacije politike prosvijećenog apsolutizma, u čemu je crkva državi pružala znatnu potporu u vidu učiteljskog kadra.

Značajna je za praksu na našim prostorima i usporedba s kurikulumom takozvanih latinskih škola (njem. Lateinschule) koje su protestanti osnivali diljem Njemačke i u kojima je poduka iz latinskog predstavljala temelj obrazovanja, a glazba se podučavala omeđena estetikom gregorijanskoga pjevanja, ali harmoniziranog i ritmiziranog po ukusu protestantizma. Iz takve glazbene prakse i diskursa o njoj čini se da proizlazi i Samberov Elucidatio musicae choralis koji je temeljni izvor za Šilobod-Bolšićev Fundamentum. ${ }^{386}$

U opisanome kontekstu priručnici Kovačevića i Šiloboda-Bolšića, ali i kratka uputa Compendiosa pridodana Psalteriju-Antifonalu iz Riznice Zagrebačke katedrale, baš kao i sveprisutni franjevački priručnici za gregorijaniku, više se ne doimaju anakronim tekstovima iz rubnih dijelova golemoga carstva u kojima su nastali isključivo zbog učestale ratne opasnosti i siromaštva te ondje funkcioniraju kao temeljna glazbena literatura. Oni su, suprotno dosadašnjim premisama, primjeri uobičajene glazbene propedeutike kakvu u isto vrijeme pronalazimo u zemljama srednje i zapadne Europe (sjetimo se samo više desetaka talijanskih traktata o gregorijanskom pjevanju iz 18. stoljeća te golemih priručnika napisanih u Francuskoj neposredno prije revolucije ${ }^{387}$ ): sastavljeni na temelju niza prethodnih sličnih, opsežnijih i kudikamo slavnijih udžbenika iz glazbene prakse, kako bi pružili oslonac najraširenijem tipu muziciranja - onom liturgijskom.

Uz to, važan su alat u golemom zamahu obnove katoličke crkve koja dotiče sve zemlje s katoličkim stanovništvom.

Prostorno i vremensko mapiranje teorije glazbe o kojem smo govorili upućuje na potrebu pridavanja pažnje formi diskursa, ali i terminologiji pri opisivanju načina na koji se vrši regulacija prikaza znanja. Shemom se najčešće imenuje opći prikaz, odnosno sistematizacija cjelokupnog znanja o predmetu (u ovom slučaju teoriji glazbe) i njegovo raspoređivanje u

\footnotetext{
${ }^{385}$ Notografija se, doduše, usavršavala sporije no tisak teksta, a tiskanje nota bilo je i iznimno skupo, zbog čega je još krajem 18. stoljeća u Beču prepisivanje nota bilo redovna praksa usp. npr. Edge, Dexter. Viennese Music Copyists and the Transmission of Music. // Revue de Musicologie 84/2, 1998. Str. 298-304. Dostupno na https://jstor.org/stable/947381, pristup 02.10.2018.

386 usp. McCreles, Patrick. Music and Rhetoric. // The Cambridge History of Western Music Theory. / uredio Thomas Christensen. Cambridge: Cambridge University Press, 2008. Str. 847-879. Str. 856: „... in the German Lateinschule tradition, music theory had become virtually synonymous with a constricted notion of musica plana - one limited virtually to the teaching of musical notation and solmization."

${ }^{387}$ Npr. Nivers, Guillaume-Gabriel. Dissertation sur le chant grégorien. Paris, 1683.
} 
kategorije. Sheme kakve su ponudili Aristoksen iz Tarenta u 4. st. pr. Kr. i Aristid Kvintilijan koji je djelovao u 3. i 4. st. naše ere, u srednjem su vijeku imale utjecaja na velike spekulativne traktate, ali s obzirom na preuzimanje naslijeđenih obrazaca antike i redukciju glazbenoteorijskog sadržaja, sve do druge polovice 18. stoljeća ne postoji potreba za značajnom formalnom rekonfiguracijom naslijeđenih sistematizacija. ${ }^{388}$ Postojeće znanje dijeli se prema dvama kriterijima: funkcionalnom koji razdvaja spekulativno znanje sveučilišta od onog praktičnog, kantorskog znanja te glazbenoskladateljskom koji razdvaja dva temeljna područja musica plana (jednoglasna neritmizirana glazba) i musica mensurabilis (polifona glazba). Radi se o složenome mehanizmu čiji korijeni vremenski sežu u antiku, a formalno se, osim na glazbenu teoriju, oslanjaju i na gramatičke priručnike, naročito onaj Elija Donata napisan oko 350. koji je tijekom srednjega vijeka bio prepisivan nebrojeno puta, a po izumu tiska otisnut u više desetaka izdanja. ${ }^{389}$ Pod utjecajem retorike kao najvažnijeg predmeta u skolastici te gramatike s kojom je nužno povezana, paradigma koja se u retorici odnosi na dijelove govora upravlja konstituiranjem opće raspodjele sadržaja i glazbenoteorijskih priručnika, dok ona koja se u jezikoslovlju odnosi na podjelu vrsta riječi te sklonidbu promjenjivih vrsta riječi postaje važnim i korisnim modelom za teoriju glazbe. Teorija glazbe ugleda se u gramatiku oblikujući i propisujući načine korištenja svakog od osnovnih elemenata glazbenog zapisa: ključeva, nota, crtovlja i oznaka za trajanje te, na planu melodike, modusa i tonusa, incipita i mutacija.

Tekstovi koji su poslužili kao temelji na kojima naši pisci kompiliraju vlastite priručnike, uzorni su izvori podataka za dio teksta (govora) koji retorika naziva inventio dovršen konzultiranjem probati authores. Istovremeno su i uzor za dispositio građe i način njezina prikaza. Dva su osnovna modela glazbenoteorijskih traktata. Prvi model je prozni tekst u kojemu se izmjenjuje pripovijedanje i opis dopunjen glazbenim primjerima, kakav oblikuju Toma Kovačević i autor priručnika Compendiosa i kakav dominira glazbenoteorijskim traktatima kasnog srednjovjekovlja. Drugi model je pripovijedanje kakvo nalazimo u predgovorima zbirkama $\mathrm{CO}$, a od prvoga se razlikuje pristupom temi (opis funkcije glazbe $\mathrm{u}$

\footnotetext{
${ }^{388}$ Za kratki prikaz shema usp. Blaisus, Leslie. Op. cit. Za analizu Aristoksenova prikaza teorije glazbe, ostale njegove interese sačuvane u fragmentima, a koji dotiču meliku, epiku, ples i organologiju usp. Gibson, Sophie. Aristoxenus of Tarentum and the Birth of Musicology. NY \& London: Routledge, 2005.

${ }^{389} \mathrm{O}$ važnosti poduke gramatike uopće i posebno one Elija Donata kao temeljnog gramatičkog priručnika tijekom cijelog srednjeg vijeka i u renesansi v. Medieval Grammar and Rhetoric. Language Arts and Literary Theory AD 300-1475. / uredile Rita Copland; Ineke Sluiter. Oxford: Oxford University Press, 2012.
} 
društvu i u osobnom životu) te živošću postignutom brojnim mitološkim, biblijskim i povijesnim pripovijetkama i aluzijama na suvremeno stanje nizom retoričkih pitanja.

Mihael Šilobod-Bolšić, usprkos snažnom utjecaju Samberova djela u pogledu sadržaja, odlučuje se za treći model ${ }^{390}$, a to je dijalog učitelja i učenika što ga je srednji vijek naslijedio od Platona, a afirmirao u renesansi kao model par excellence za stjecanje znanja.

\section{3. ... et brevi, ac facili dialogica methodo in lucem expositum}

Uvidom u sve dostupne priručnike za učenje glazbe koje nalazimo u samostanima sjevernohrvatskih gradova, dakle i one talijanskih franjevaca Tettamanzija i Dalle Grotte, jedino Fundamentum Šiloboda-Bolšića koristi „kratku i laku metodu dijaloga“ kako bi izložio željeno gradivo. U kontekstu hrvatske glazbenoteorijske produkcije predstavlja tako jedinstveni primjer korištenja žanra koji 18. stoljeće baštini od antike i renesanse, u kojoj je bio jedan od omiljenih oblika poduke i rasprave. U tekstovima čiji je glavni ili jedan od ciljeva promocija kršćanstva, snažno ga je afirmirao sveprisutan i vrlo utjecajan katekizam Petra Kanizija ${ }^{391}$ također pisan u dijaloškoj formi.

Kratak uvod pretisku originala Šilobodova teksta koji je uz prijevod teksta 2016. ponudila Katarina Koprek, ne referirajući se uopće na sedam godina stariju postojeću studiju i prijevod $^{392}$, o dijaloškoj formi teksta iznosi sljedeća razmišljanja: da se „,današnjem čitatelju forma Šilobodove rasprave može činiti trivijalnom i arhaičkom“, ali da joj „,vrijedi ... posvetiti pozornost iz metodoloških pobuda.“ Ona joj se (sc. forma), naime, u kontekstu suvremene metodike muzičke nastave ${ }^{393}$,čini pedagoški zanimljivom“. Koprek dijalog shvaća kao nositelja dramatike „koji potiče na refleksiju i otvara prostor učenju“ čime se

\footnotetext{
390 Traktat i dijalog razdvojeni su kao dva heterogena načina obrazlaganja nekog sadržaja. Za definiciju traktata i dijaloga u latinističkoj literaturi usp. Powell, J. G. F. Dialogues and Treatises. A Companion to Latin Literature. str. 223-240. URL: https://doi.org/10.1002/9780470996683.ch17 (17.04.2020.)

${ }^{391}$ Radi se o najpoznatijem katoličkom katekizmu Summa doctrinae christianae isusovca i znamenitog njemačkog teologa svetog Petra Kanizija koji je u stoljeće i pol doživio preko četiristo izdanja. Summa doctrinae christianae verzija je za odrasle vjernike, dok je Catechismus catholicus priredio za djecu (dvadesetak stranica) $\mathrm{i}$ mladež (dvjestotinjak stranica teksta). Katekizam je pisan u dijaloškoj formi, premda nisu imenovani sudionici dijaloga, već se nižu pitanja i odgovori. Usp. Summa Doctrinae Christianae ex postrema cognitione doctoris Petri Canisii ... Antverpiae 1587. URL: https://books.google.hr/books?id=bvwTAAAAYAAJ\&redir_esc=y (13.05.2020.)

${ }^{392}$ Latina \& Graeca objavila je original teksta i prijevod uz uvodnu studiju autorice ove disertacije još 2009.

${ }^{393}$ Koprek u razmatranju dijaloške forma u Šilobodovom tekstu upućuje na udžbenik Požgaj, Joža. Metodika muzičke nastave. Zagreb: NZH, 1950.
} 
čitatelja potiče na sudjelovanje u razgovoru i čuva ,životnost ove rasprave“. Zaključuje, potom, da su uz filozofsko-teološke podjednako interesantne i ,glazbeno-pedagoškometodološke smjernice“ ovoga teksta koji je, zaključuje autorica „sinteza starih glazbenih teoretičara, većinom filozofa i teologa, kao npr. Platona, Plotina, Boetiusa, Tome Akvinskog, a napose Augustina. Naime, Augustinova se rasprava De musica libri sex već po svojoj (dijaloškoj) formi, a onda i po svojim teoretskim postavkama oslikala u ovoj Šilobodovoj raspravi. “394 O posljednjoj rečenici iz citata raspravljat ćemo u šestom poglavlju u kojem obrađujemo elemente musica practica koje kao nužno znanje nude analizirani tekstovi, posebno Bolšićev. Bolšić niti na jednome mjestu ne spominje Augustina, niti na njega aludira, a sadržaj kojim se bavi, kao i način oblikovanja dijaloga bitno se razlikuju od spekulativne Augustinove rasprave kojoj je glavna tema i temelj muzike kao dijela kvadrivija: numerus (broj).

Nadalje, promatrati dijalog, kao i bilo koji drugi literarni oblik, izvan konteksta nastanka i upotrebe predstavlja otežavajuću okolnost u razumijevanju i tumačenju djela, njegovih uzora, namjera i uloge koju je imao u vrijeme svoga nastanka i recepcije. Dijalog u Šiloboda-Bolšića kao forma poduke svakako raspravu ,čini pedagoški zanimljivom“, no kao metoda ne predstavlja specifičnost u odnosu na praksu svoga vremena.

O učestalosti i omiljenosti dijaloga u renesansi i njegovim specifičnostima u odnosu na antičke uzore temeljnu je studiju ponudio Peter Burke ${ }^{395}$, no dijalog je ostao uobičajena i poželjna forma u 17. i 18. stoljeću, koja se često koristila kao metoda poduke i rasprave. Njezin je procvat u renesansi potaknut značajnom ulogom koju je imala u tada iznimno utjecajnih antičkih filozofa, osobito Platona te Cicerona čiji su se govori obilno citirali i oponašali: ,(D)ivljene ovim autorima prošireno je i na njihove dijaloge i ti su dijalozi promatrani kao izazov za kreativno oponašanje.“ ${ }^{396}$ Renesansni dijalozi pisani pod utjecajem

\footnotetext{
${ }^{394}$ Koprek, Katarina. Glazbeni priručnik Fundamentum cantus gregoriani seu choralis Mihaela Šiloboda. // Šilobod, Mihael. Fundamentum cantus gregoriani seu choralis. Sveta Nedjelja: Ogranak MH u Svetoj Nedjelji, 2016. Str. $17-32$.

395 usp. Burke, Peter. The Renaissance dialogue. // Renaissance Studies, 3(1),1989. Str. 1-12.

396 „The admiration for these writers did extend to their dialogues and these dialogues were treated as a challenge to creative imitation. “ Burke na početku teksta upozorava na nedostatnu pozornost usmjerenu prema žanru tipičnom za renesansu, ali i za razdoblja koja joj prethode. „The trouble is that the Renaissance dialogue is rarely studied as a whole. As a period phenomenon it is still somewhat undervalued, even if specific examples of the genre are admired and taken seriously. In Latin, there is a long series from Petrarch (who even presented the results of his introspection by means of a discussion between the personae 'Franciscus' and 'Augustinus'), through Leonardo Bruni, Lorenzo Valla, Giovanni Pontano and Erasmus, to Lipsius on constancy and Bodin on 'the secrets of the sublime'.... There had of course been a considerable medieval literature of debate. In the Middle Ages, the dialogues of Gregory the Great were frequently copied and they were translated into a variety
} 
antičkih uzora, posebice Cicerona, u obliku rasprave učenih članova društva, utjecali su i na oblikovanje vjerske propedeutike i to u oba vjerska tabora - luteranskom i katoličkom. I jedni i drugi upravo su dijalog odabrali kao najpoželjniji oblik vjerske poduke stanovništva čija je pismenost u velikom postotku bila na vrlo niskoj razini. ${ }^{397}$

„Dijaloški oblici bili su vjerojatno najkarakterističniji u ranom modernom razdoblju. ... Tipični oblik katekizma pitanje - odgovor učinio ga je žanrom dostupnim mnogim vrstama čitatelja, ne samo onima koji su uživali mogućnost naprednog školovanja, već $i$ novoopismenjenima ili jedva pismenima. Doista, često je, uz Bibliju, katekizam bio jedina knjiga koju su posjedovali čitatelji u ranom modernom razdoblju. No dijaloški oblici bili su isto tako tipični i za komunikaciju između intelektualaca ... Dijalog je također bio središnji (oblik komunikacije) u salonima 17. i 18. stoljeća ... “398

Peter Burke u svojoj je utjecajnoj studiji „The Renaissance Dialogue“ ponudio klasifikaciju renesansne literature pisane u dijaloškoj formi razvrstavajući je na četiri temeljna tipa dijaloga: katekizam, dramu, učenu raspravu (disputatio) i razgovor. Dijalog u glazbenoj teoriji u renesansnim i baroknim traktatima ugleda se na Ciceronove dijaloge kao na opći uzor te na katekizam koji uz Bibliju postaje najrasprostranjeniji tiskani tekst kasne renesanse i baroka. Usprkos nizu utjecajnih dijaloških rasprava o glazbi, njihov je oblik u istraživanjima ostao

of languages ...“. Usp. Burke, Peter. Op. cit. Str. 2. Dijalog kao žanr nastavlja živjeti i u 17. i 18. stoljeću, no češće u kontekstu pedagogije, a manje kao učena rasprava o odabranoj temi.

\footnotetext{
${ }^{397}$ Više o dijalogu u renesansi usp. Brooks, Jeanice. The Art of Civil Conversation: Courtly Neo-Platonism and the Dialogue Air. / uredili Jeanice Brooks; Philipp Ford; Gillian Jondorf. Poetry and Music in the French Renaissance. Cambridge: Cambridge French Colloquia. Str. 159-184. The Renaissance Culture of Dialogue. uredili Dorothea Heitsch; Jean-François Vallée. Toronto: University of Toronto Press, 2004.
}

${ }^{398}$ Geerdink, Nina; Montoya, Alicia S. Early Modern Period. Introduction. De Pourcq, Maarten; Levie, Sofie. European Literary History: An Introduction. NY: Routledge. 2018. s. p. : „Dialogue genres* were perhaps most characteristic of the early modern period. The prominence of theatre is only one aspect of this dominance. Among the books used in the cause of religious (re)education in the Reformation and Counter-Reformation: the catechism, used first by protestant leaders such as Martin Luther, whose Large Catechism dates from 1529 and imitated by Catholic authors. The typical question-and-answer format of the catechism made it a genre accessible to many kinds of readers, not only those who had enjoyed advanced schooling, but also newly or barely literate readers. Often, indeed, the Catechims was - alongside the Bible - the only - the only book owned by early modern readers. But dialogue forms were just as typical of communication amnog intellectuals ... Dialogue* was also central to seventeenth and eighteenth centuries salons ..." Ekstenzivnu analizu dijaloga kao pedagoške forme u francuskom prosvjetiteljstvu ponudila je Chiron, Jeanne. Le dialogue éducatif des Lumières : innovations, permanences et fantasmes (1754-1804). Education. Université Paris-Est, 2016. URL:

https://tel.archives-ouvertes.fr/tel-01629825 (08.11.2018.) 
zanemaren, čak i za razdoblje renesanse u kojem predstavljaju najčešći način posredovanja znanja. $^{399}$

Ono što odluku Šiloboda-Bolšića da priručnik napiše u dijaloškoj formi (koja je uistinu napisana živim jezikom kojem ne nedostaje poticaja na razgovor oba sudionika) čini ne „trivijalnom i arhaičkom“, već iznimno suvremenom i aktualnom, jest sve veća usmjerenost obrazovanih ljudi sredinom 18. stoljeća prema mladeži i njima primjerenu obrazovanju što je, u konačnici, i važan sastavni dio službene politike Habsburške Monarhije. Opsežna disertacija Jeanne Chiron ${ }^{400}$ o dijalogu kao dominantnom edukativnom obliku druge polovice 18. stoljeća u Francuskoj i općenito procvatu pedagogije koja obiluje pomno razrađenim analizama, kao i mnoge recentne studije dijaloga u glazbenoteorijskim traktatima kroz povijest $^{401}$ dopuštaju smjelost usporedbe lokalnog zagrebačkog priručnika za glazbenu teoriju sa širim europskim pokretom prosvjetiteljstva. Šilobod-Bolšić, prisjetimo se, školovao se u Beču i Bologni što je značilo dostupniju literaturu i izravan pristup uvidu u prosvjetiteljska nastojanja katoličke obnove u odnosu na klerike školovane isključivo u hrvatskim zemljama. Također, vrlo je vjerojatno svjedočio promjenama u obrazovanju koje su inicirala prosvjetiteljska nastojanja Habsburške monarhije te načinima njihova provođenja u praksu.

Pitanje koje se postavlja jest uloga dijaloga kao žanra u regulaciji predstavljanja znanja, odnosno mijenja li forma dijaloga način učenja glazbene teorije potrebne za svladavanje vještine pjevanja gregorijanskoga pjevanja. Budući da dijalog pretpostavlja razgovorom omeđeno trajanje u vremenu, ali i prostor u kojem se rasprava odvija, indicirana temporalnost i spacijalnost prenošenja znanja upućuje na razlike u odnosu na prozni tekst koji redom izlaže definicije i njihove primjere.

Fundamentum je dijalog između imaginarnog učitelja (magister) i učenika (discipulus). Učenik nije ravnopravan sudionik razgovora, već je u podređenom položaju u odnosu na učitelja što potencira isticanjem vlastite nedostatnosti i straha od teškoga gradiva:

\footnotetext{
${ }^{399}$ Usp. Collins Judd, Cristle. Music in Dialogue. // Journal of Music Theory 52:1, 2008. Str. 41 - 74. URL: https://www.jstor.org/stable/40607029, pristup 26.07.2016.: „Nonetheless, music and musical writings have barely figured in the study of dialogue writ large, and there has been little attempt to gauge the extent and nature of musical encounter with dialogue (and of dialogue with music) in the Renaissance.“

${ }^{400}$ Chironne, Jeanne. Le dialogue éducatif des Lumières: innovations, permanences et fantasmes (1754-1804). Education. Université Paris-Est, 2016.

${ }^{401}$ Usp. Collins Judd, Cristle. Op. cit.; Eadem. Reading Renaissance Music Theory: Hearing with the Eyes. Cambridge; Cambridge University Press. 2000.; Harrán, Don. „Towards a Definition of the Early Secular Dialogue." Music and Letters 51, str. 37-50.
} 
„Magister: Ad musices artem, artium liberalium antiquissimam, iuxta de nobilissimam peramanter te invito amantissime discipule.

Discipulus: Ad ardua me invitas erudite magister; nisi enim natus sit poeta, \& musicus, ei docendi labor frustra impenditur.

M: Nihil arduum abhorreas ingenue iuvenis; laboris enim ardui praemium virtus est, natura vero arte perficitur.

D: Saltem per asperam, ac spinosam viam non duca discipulum tuum suavissime magister.

M: Neque hoc metuas boni animi iuvenis: antequam enim pronimiam hanc tractandam suscepissem. Scribentem, sapienter admonuit Horatius: Quid quid praecipies, esto brevis, facilis, \& clarus, ut dicta percipiant animi docilis. ${ }^{\text {“402 }}$

„Učitelj: Glazbenoj umjetnosti, najstarijoj od slobodnih umijeća i tik do najplemenitijeg, ljubazno te pozivam, najdraži učeniče!

Učenik: Na strminu me pozivaš, obrazovani učitelju! Naime, ako nisam rođeni pjesnik i glazbenik uzalud ulažemo napor u ovo učenje.

Učitelj: Ničeg se teškog ne boj, plemeniti mladiću. Jer, vrlina je borba kroz teški rad: priroda se usavršava pravom umjetnošću.

Učenik: Najdraži učitelju, nemoj barem voditi svoga učenika kroz trnje i bodljikavim putem!

Učitelj: Niti toga se ne boj, mladiću dobre duše, jer prije no što sam prešao u ovu provinciju, a mudro me pišući poučio Horacije, odlučio sam sljedeće: što god poučavaš, budi kratak, jednostavan i jasan da rečeno shvate duše koje poučavaš. ““403

Ovaj se odlomak nalazi na samome početku Prvog dijaloga i definira nekoliko elemenata važnih za razumijevanje teksta i ulogu koju je glazba imala u očima pisca priručnika:

1. poduka o glazbi uključuje napor i težak rad, no ne podrazumijeva istaknuti prirodni dar učenika za poeziju i/ili glazbu;

2. umjetnost je sredstvo usavršavanja prirodnih darova koje imamo;

\footnotetext{
${ }^{402}$ Horacije. Ars Poetica, 335-336. URL: https://www.loebclassics.com/view/horacears_poetica/1926/pb_LCL194.459.xml (17.10.2019.) U originalu glasi: „Quicquid praecipies, esto breuis, ut cito dicta / percipiant animi dociles teneantque fideles.“

${ }^{403}$ Šilobod-Bolšić, Mihael. Op. cit. str. 42.
} 
3. put usmjeren prema usavršavanju umijeća i prirode ne mora biti trnovit, budući da je još rimski liričar Horacije postavio temelje valjane i svrhovite poduke koje je učitelj prigrlio.

Oslanjanjem na Horacijevu uputu učitelj definira način poduke koji će biti kratak, jasan i jednostavan, dok model provedbe toga načina pokazuju sljedeća poglavlja. Prvi dijalog na vrlo sažet način, odgovarajući na pitanja učenika, prikazuje nastanak glazbe, prenošenje njezina znanja, svrhu i vrste na koje se dijeli. Kao što smo pokazali u prethodnom poglavlju, Prvi dijalog gotovo u cijelosti parafrazira Samberov tekst iz Prva četiri poglavlja njegova djela Elucidatio musicae choralis (premda isti nije pisan u dijaloškoj formi!).

Iako su pitanja dodijeljena Učeniku oblikovana na način da Učitelj što elegantnije vodi poduku, Učenik u ovome dijalogu nije puki postavljač pitanja, već i poticatelj rasprave i pojašnjenja, postavljajući logična pitanja. Kratki ulomak iz Prvog poglavlja u kojem Učitelj podučava Učenika o porijeklu glazbe lijepo pokazuje aktivnu zadaću koja je namijenjena Učeniku:

„Učenik: O, milosti! O, glazbo, dare dragog Boga! Dušu je obuzela želja za znanjem: koje joj je porijeklo?

Učitelj: Neki kažu da potječe od same prirode, drugi kažu da potječe od šuma rijeka, neki vele od udaranja lonaca, a neki od pjeva ptica. No neka oni govore po svojemu što žele. Ja, pak ne govorim toliko po svojemu, koliko na temelju Svetog Pisma: glazba potječe od osmog čovjeka poslije Adama, Jubala. On je naime bio otac onih koji sviraju citaru i orgulje (Postanak, 4:21), tako da jednoglasnom zboru anđela koji pjevaju na nebesima odgovara $u$ suglasju oktava na zemlji.

Učenik: Teško je suglasje za čovjeka, učitelju. Kako je onda Jubal mogao skladati suglasje?

Učitelj: Itekako je mogao jer je imao brata Tukehaima koji je (nav. dj. gl. 4.) radio s čekićem i bio kovačem svih predmeta od mjedi i željeza. Dakle, njegov brat Jubal skladao je različita suglasja od raznolikih zvukova nejednakih čekića. Tako je, preko jednostavne glazbe, božanskom providnošću stigao do harmonije te je predao potomstvu.

Učenik: Potičeš me na novo pitanje, učitelju. Zar nisu gotovo svi Adamovi potomci zajedno sa svojim umijećima uništeni potopom? Kako je, dakle, Jubal mogao prenijeti glazbu u budućnost? 
Učitelj: Mogao je providnošću. Naime, prije no što je Bog kaznio grešni svijet Jubal je u duhu predvidio kaznu vodom ili ognjem. Da ne bi stoga s lošim svijetom iščeznula i dobra glazba, Jubal se, kao navjerniji čuvar umijeća koje je sam izumio, pobrinuo da podigne dva stupa: jedan mramorni, a drugi od opeke, i jedan i drugi ispisani glazbenim pravilima zato da, ako se mramorni uništi ognjem, stup od opeke ostaje, odnosno ako voda uništi onaj od opeke, da mramorni ostane sačuvan. Vode potopa poplavile su zemlju, uništen je i raznesen stup od opeke, a samo je mramorni stup s urezanimm glazbenim pravilima čitavog pronašao Noa. Taj se stup (kako kaže Samber u Prikazu koralne glazbe) i dan danas za vječan spomen brižljivo čuva u Siriji kao najvrednije blago.“404

Ne radi se, dakle, o automatiziranom modelu dijaloga kakav susrećemo primjerice kod najranijeg primjera takve poduke iz 9. stoljeća u Scolica Enchiriadis. Ondje je također Učenik taj koji postavlja pitanja Učitelju, no ne uključuje se u raspravu poput Šilobodovog. On služi više kao podsjetnik Učitelju i čitatelju na sve što prvi treba podučiti, a potonji usvojiti, kao uređivač teksta, onaj čija ga pitanja čine čitkijim i preglednijim. ${ }^{405}$ Šilobod je dovoljno vješt

\footnotetext{
404 Šilobod-Bolšić, Mihael. Op. cit. str. 50-53.

${ }^{405}$ Scolica enchiriadis de arte musica. URL: https://chmtl.indiana.edu/tml/9th-11th/SCENCH (26.12.2019.) [D]: Tonus quid est? [M]: Legitimum acuminis vel gravitatis spacium inter sonum ac sonum veluti inter cordam et cordam. [D]: Quid vero semitonium? [M]: Semitonia vel limmata dicimus non plena sonorum spacia. Quae tamen suo loco posita et suam sonis proprietatem tribuunt et in concordiae suavitate cantilenam continent. Non suo autem loco posita, dissentire faciunt mela. Nam sciendum, in sonorum serie tunc naturalem ordinari qualitatem, dum naturali ad invicem spacio metiuntur. At si falso metiatur sonus a sono, in aliam mox qualitatem migrat coeptumque transvertit ordinem, et haec ex supradictis duobus vitiis prior dissonantia est. [D]: Lucida, rogo, exemplificatione aperias, qualiter huiusmodi sese absonia habeat. [M]: Temptabo, prout possum, tu adtentus adsis. Sonus [signum] deuterus cum semper intervallo semitonii subiungatur trito [signum], tritus vero a
} 
pisac sposoban unijeti elemente teatralnosti u tekst i omogućiti učeniku ulogu poticatelja rasprave i dodatnih objašnjenja. Učitelj je pak onaj koji svoj autoritet temelji na znanjima stečenim od uglednih pisaca prošlosti. Insistira na kratkoj i jasnoj definiciji no svjestan je važnosti glazbenih primjera kao nezaobilaznih elemenata razumijevanja glazbe koje nudi uz svako verbalno pojašnjenje. Utoliko se priklanja utjecaju Banchierija i njegova djela Cartella musicale koja donosi brojna znanja o svim vrstama glazbe, a u tekst umeće ne samo glazbene primjere teorije, već i cijele skladbe kao glazbenu ilustraciju poduke.

U odnosu na Virginiju Cox koja u studiji o renesansnom dijalogu ${ }^{406}$ insistira na glazbenim primjerima kao elementu koji dijalog čini tipografskim predmetom (knjigom), a ne iskazom,

superiore sui parte habeat [signum] tetrardum, [66] [signum] deuterus vero ab inferiore parte sui habeat [signum] VMKIII:62

VMKIII:66,1

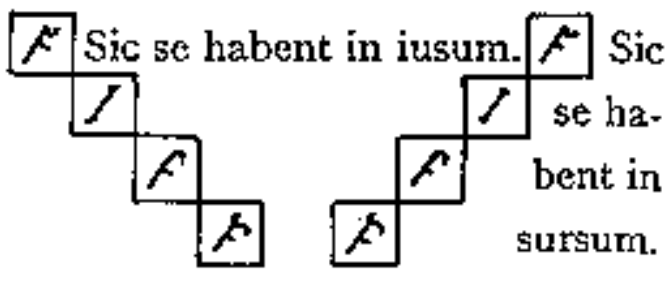

VMKIII:63

VMKIII 64,1

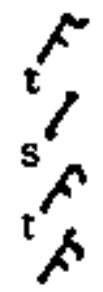

VMKIII:66,2

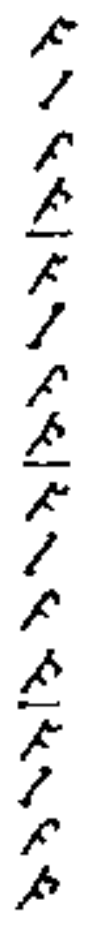

protum, ita:
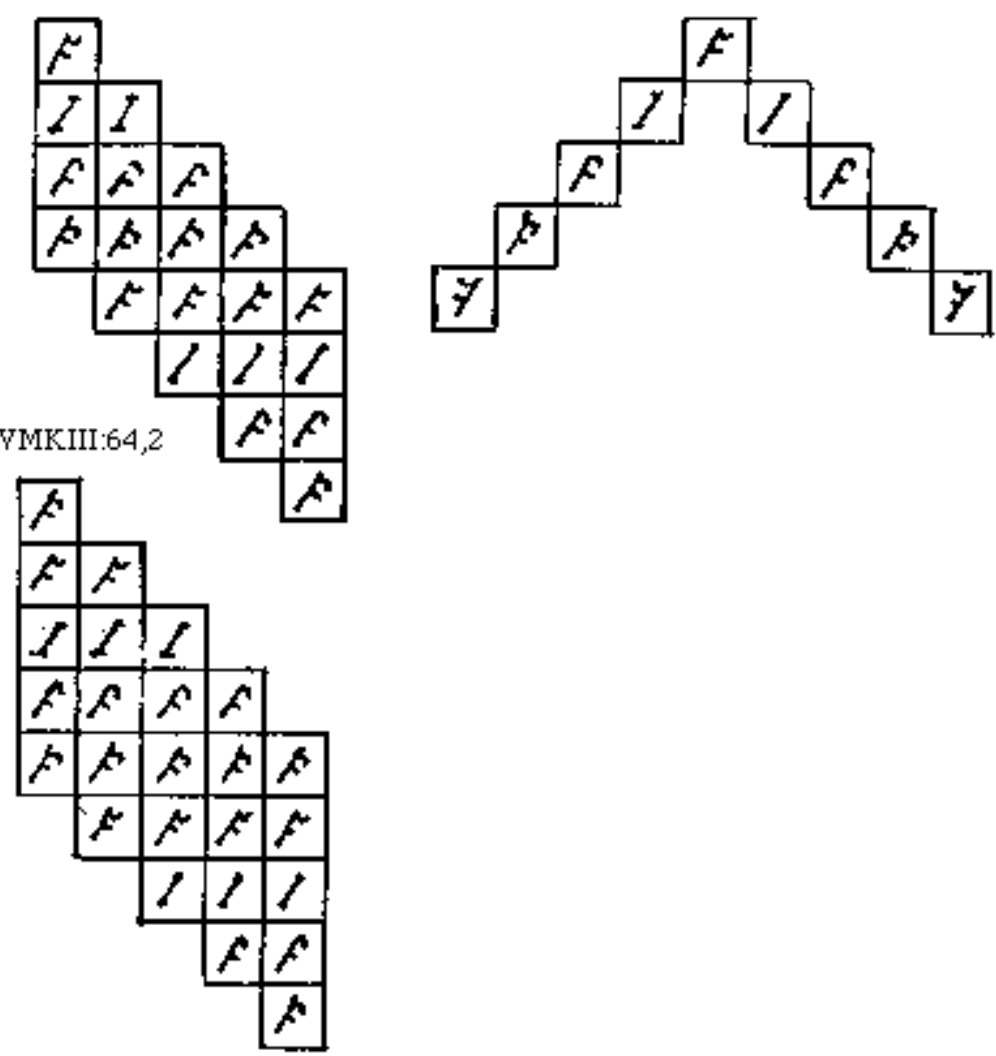

${ }^{406}$ Cox, Virginia. The Renaissance Dialogue: Literary Dialogue in Its Social and Political Contexts, Castiglione to Galileo. Cambridge: Cambridge University Press, 1992. 
smatramo da su upravo glazbeni primjeri ti koji dijalog o teoriji čine živim tekstom, tekstom koji čitatelja poziva na čitanje, ali i pjevanje i sudjelovanje u dijalogu što sugerira i Koprek ${ }^{407}$. Budući da je Fundamentum priručnik za gregorijansko pjevanje (a ne za primjerice sviranje lutnje ili skladanje) i primjeri su ograničeni na one vezane uz jednoglasno pjevanje, uz iznimku skladbe pridodane na samom kraju knjige. Radi se o četveroglasnoj skladbi Te Deum raspisanoj u maniri onoga vremena po glasovima koji stoje okupljeni zajedno za jednim visokim stolom i pjevaju svatko svoju dionicu.

\subsection{Tablice i stihovi}

Narativni oblik teksta poput onog koji nalazimo u Brevis cantus gregoriani notitia, Compendiosa i franjevačkim priručnicima, kao i dijalog kakav promiče Fundamentum cantus gregoriani, usprkos razlici u formi dijele načine predstavljanja znanja. Slijed tumačenja je gotovo uvijek isti: imenovanje pojma koji se objašnjava - definicija često potkrijepljena citatom ili parafrazom uglednog prethodnika - notni primjer koji zorno dočarava izrečeno. Usporedba je i dalje temeljni način razumijevanja i interpretacije: usporedba po sličnosti, kao analogija ili ona koja uspoređuje suprotnosti da bi ih opet svela na barem neki tip srodnosti. Odmak od srednjovjekovnih traktata najuočljiviji je upravo u vizualnom, u slikovnom prikazu tumačenih pojmova i postupaka. Dok je srednji vijek precrtavao dlan s Guidovim sustavom solmizacije i heksakorda, renesansa i barok dodaju tablice, proširuju zalihu mnemotehničkih stihova i nude obilje glazbenih primjera. Mišljenje o glazbi kao praksi funkcionira proizvodeći niz pravila koja se prikazuju najprije kao temeljni model koji se potom multiplicira seleći se crtovljem, tablicom ili redajući promjene u stihovima zamišljenima kao menmotehnička pomagala. Nizanje pojmova prema utvrđenom redu pritom je najčešći tip prenošenja znanja.

\footnotetext{
${ }^{407}$ Koprek piše: „Oblik dijaloga u ovoj raspravi ostaje sve do dramatike napeti razgovor učitelja i učenika, koji potiče na refleksiju i otvara prostor učenju. Tako rasprava ostaje otvorena, tj. ona stvara prostor da se i mi kao treći dijaloški partner (!) nađemo u razgovoru. Forma, dakle, a ne jezik, čuva životnost ove rasprave i tamo gdje se ona današnjem čitatelju čini nerazumljivom, suhom, arhaičnom. Jedan od temeljnih potencijala duhovne moći glazbe ostaje i otvorenost za komunikaciju, za dijalog. Glazba je, ne samo po svom zvukovnom izrazu, već i u svojim semantičkim postavkama i teoretskim raspravama, ,zov“ na komunikaciju i dijalog.“ Koprek, Katarina. op.cit. str. 21
} 
Kao primjer poduke koja redom daje definiciju pojma, potom ga razlaže na više potpojmova, daje povijesni pregled upotrebe, usporedbu načina upotrebe pojma u raznim okolnostima i u konačnici notni primjer, neka posluži objašnjenje pojma ključ (clavis) Mihaela ŠilobodaBolšića: nifeftas?

D. De Clavibus loqueris Mage, \& quam feram aperiant, non ma-

M. Manifestabo equidern tibi, quòd Claves aperiant fyllabas : five voces quibus notze exprimi debeànt, ưt cogniofcas quax nota fic " ut, re, $m i$, \&c॰ Hoc eft Claves funt vocis formandx indices five Generales fuerine, five Particulares.

D. Duplices ergo Claves Generales, \& Patticulares docebis Mage. M.: Docebo omninò, dicámque illas Claves effe Generales, qua in exordio Cantûs, \& capice cujusque fcalx, exprefsè fignantur: Particulares verò qux vel expreffè non fignantur, vel fi fignentur, vim Generalis Clavis non obcinent, ut accidit in cantu bimolli.

D. Dic ergo Magr, quot funt Claves fignabiles?

M. Si de numero quxris? Grạci quoties s. lineis urebancur, fem: per duabus Clavibus Cantum prenotabant: nempe ad primam lineam r. id eft G. \& ad quartam B. vel F. \& C. vel verd G. \& C. Uii vi: des bia.

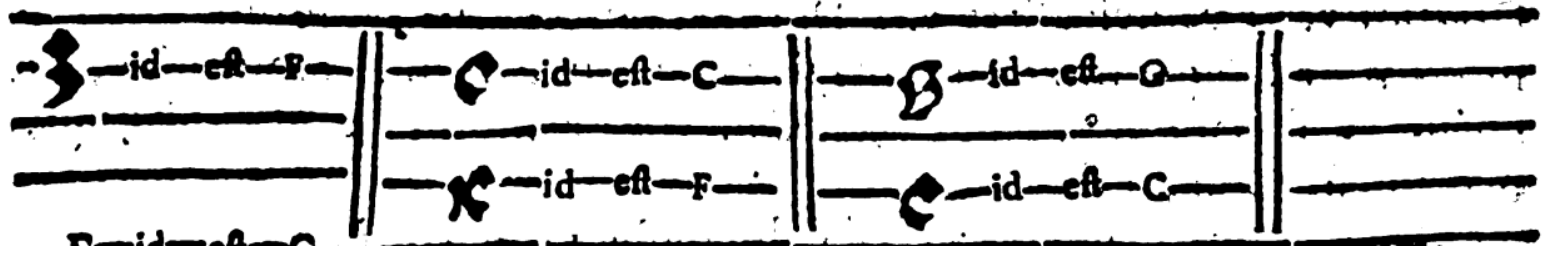




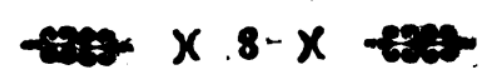

Recentiores tamen, qui 4. lineis utuntur, unicam tantùm Clarem fignare folene. Sic nempe.

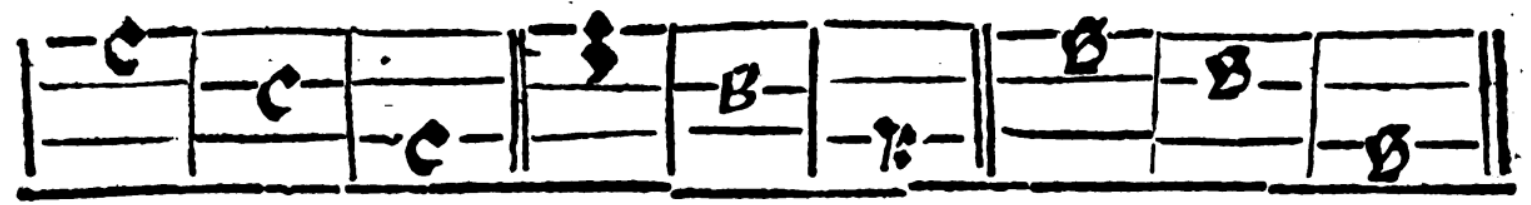

\section{Obferva Magifter in Canou chorali 3. Claves fignabiles, quibus cantus pranotari debet.}

M. Bene obfervas in Cancu Duro. In Cantu tamen b-molli Clavibus C. F. G. adjungi Accidéntalem b. Eft enim unus Cantus durus, b. mollis alter.

D. Quare clavem b. vocas Accidentalem?

M. Quia hac femper affociantur Clavi C. fignata, vel non figpats five accidat in linea, five in fpatio, ut vides bic.

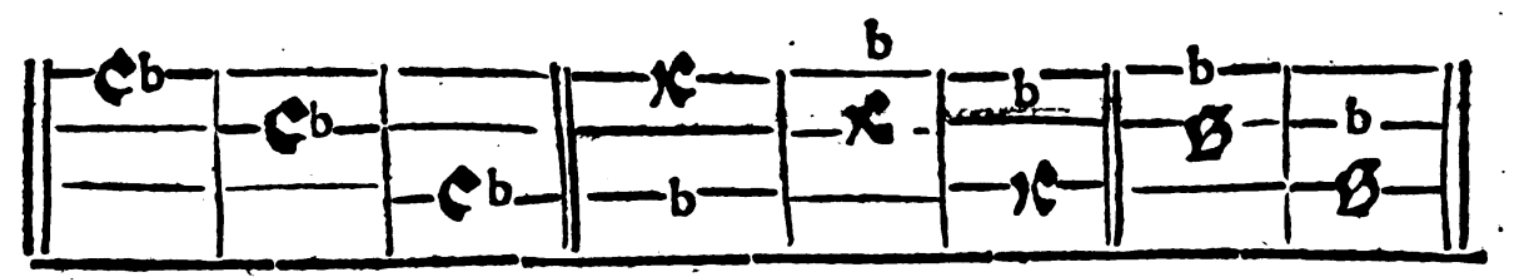

Sl. 5 Šilobod-Bolšić, Mihael. Fundamentum cantus gregoriani seu choralis. Zagreb. 1760.

Str. 7-8.

Objašnjenje ključeva nastavlja se dalje sve dok učenik nije propitao sve moguće opcije upotrebe ključeva. Slično ključeve objašnjavaju i glavni izvori Šiloboda-Bolšića, Banchieri i Samber, ali i franjevački pisci čiji se udžbenici koriste u samostanima diljem Hrvatske.

Tettamanzi se odlučuje za vrlo kratko izlaganje o ključevima pozivajući se na suvremene autore (libri moderni) koje prikazuje kratkim notnim primjerima umetnutim u tekst i usredotočuje se na „proprietà“, vlastitost odnosno mjesto tonova u nizu od dubokih do visokih. S obzirom na lošu vidljivost digitaliziranog teksta, prepisujemo ga:

„Delle chiavi, e cognizione di esse, Cap. II

Le chiavi altro non sono, che un segno sotto al quale si regge, e governa il Canto Fermo, abbenche al parer di alcuoi, vuogliono, che il detto Canto sii getto da piu segni, ma io per quanto ho osservato, tanto ne' libri antichi, quanto moderni, non ho mai trovato altro che due segni, uno de' quali si chiama Chiave di proprieta di natura grave nella posizione di F. fa. ut al 
numero 7. della Mano, e questa e composta di tre note, comme dalla presente figura appare. Or, sequita la seconda chiave, laquale vien chiamata della proprieta di quadro acuto nella posizione di C. sol. fa. ut di numero 8. della mano e questa e composta di due note, comme dalla presente figura appare. ${ }^{\text {“408 }}$

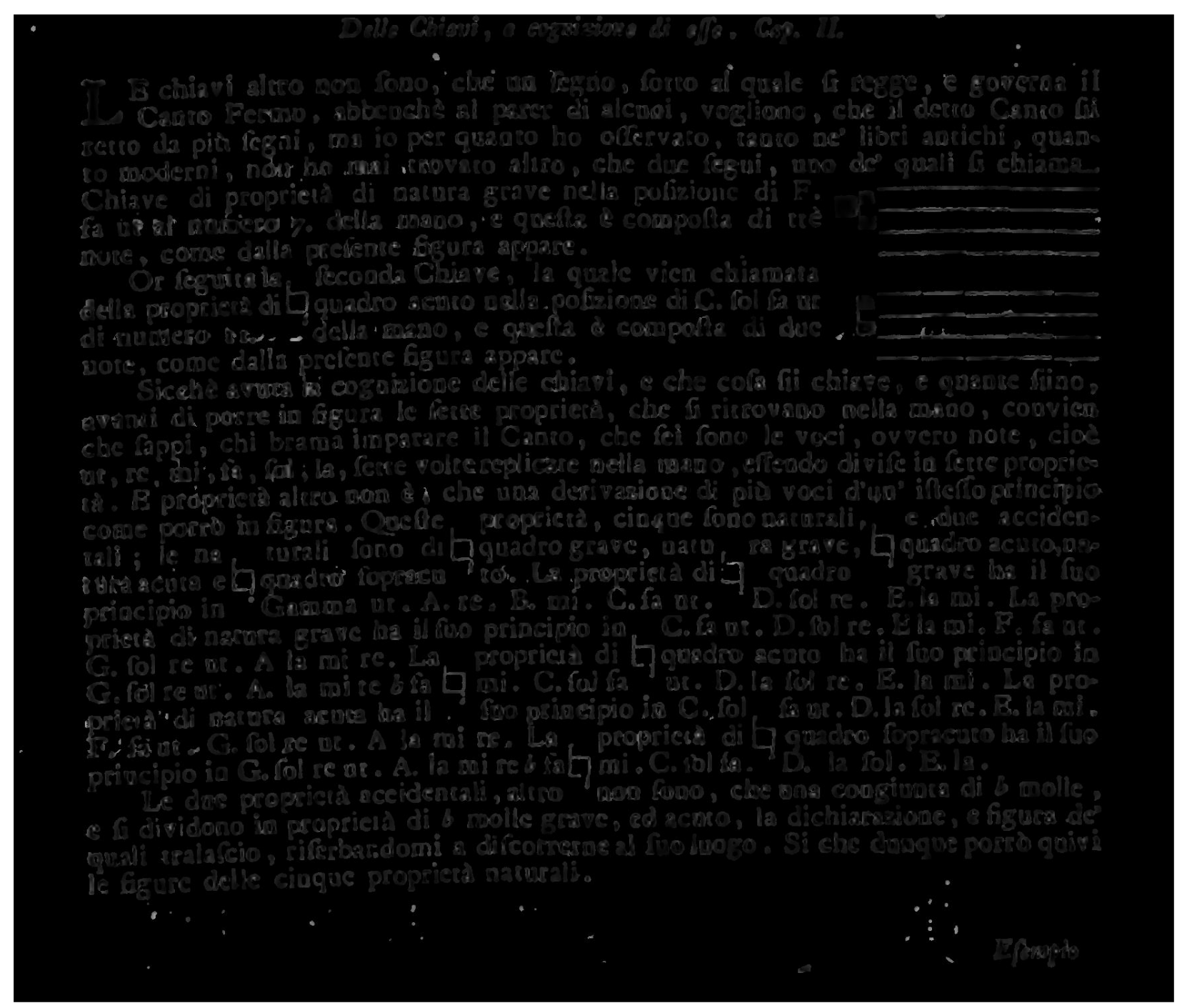

Sl. 6 Tettamanzi, Fabrizio. Breve metodo per apprendere fondatamente e con facilità il canto fermo. Milano: 1756.

Najuočljivija razlika u odnosu na starije prikaze glazbene teorije, koja tekstove samo donekle približava idealu reda i mjere, funkcionalnosti i jasnoće, jest opseg teksta i odabir prikazanih tema. Većina pisaca glazbenoteorijskih priručnika u 17., a osobito u 18. stoljeću više se ne libi ograničiti tekst isključivo na konkretna glazbena znanja ne prežući izostaviti niti uvodne, ne tako davno obavezne teme njezina porijekla, važnosti i uloge. Odmicanje od opširno

\footnotetext{
${ }^{408}$ Tettamanzi, Fabrizio. Op. cit. str. 8.
} 
razrađenih spomenutih tema u odnosu na deskripitivne i preskriptivne tekstove iz srednjega vijeka koji su mahom čuvali barem krhotine spekulativne tradicije, najvidljivija je razlika.

Pietro Aaron u prvoj knjizi Libri tres de institutione harmonica De cantu plano iz 1516. 409 sadržaj dijeli na trideset pet poglavlja izostavljajući uvodne napomene o postanku glazbe, porijeklu njezina imena i ulozi u životu pojedinca i društva. Sadržaj i raspored građe velikim dijelom preuzet će Fabrizio Tettamanzi u svome priručniku. Toma Kovačević, koji na nekoliko mjesta navodi Aarona kao uzor, reducirat će njegovo izlaganje na četrnaest poglavlja izostavljajući opsežniju analizu intervala.

$\mathrm{Na}$ isti način strukturirana je i Compendiosa in cantum gregorianum seu choralem pridodana Psalteriju-Antifonalu, a slično su koncipirani i priručnici franjevaca Fabrizija Tettamanzija i Giuseppea Frezza Dalle Grotte.

Kovačevićevo je djelo, dakle, podijeljeno na četrnaest kratkih poglavlja od kojih svako razmatra jedno područje. Prepisana verzija Kovačevićeva djela koja je jedina bila dostupna nema predgovora (Praefatio) što ne znači da u tiskanom obliku nije postojao. Prvo poglavlje „O različitim imenima tog pjevanja i o njegovu začetniku“ površno prelijeće preko porijekla naziva pjevanja (gregorianus prema Grguru Velikom, planus zbog lakoće učenja u odnosu na figuralis, firmus ,radi stalnosti nota i trajanja“) i njegova začetnika (Tubalkajin, Amfion, Orfej, Pitagora). ${ }^{410}$ Već u drugom odlomku nabraja slova glazbene abecede, a potom nastavlja s izumom solmizacije. Radi se, dakle, o tipičnom postupku ,in medias res“. Drugo poglavlje nešto je opsežnije, donosi prikaz Guidove ruke i uz to njezino opširno tumačenje. Ruka je temelj solfeggia, ,neodoljiv i neprevarljiv putokaz, provodič do skale, do prvog crtovlja, prvog notnog stana, prve 4 koralne crte, kojima se i danas služimo u bilježenju koralnih nota“4411. Sljedeća slika s deset linija, po mišljenju Martina Mihokovića, zapravo je „današnje moderno crtovlje protegnuto od velikog $\mathrm{G}$ u F bas-ključ preko $\mathrm{C}$ crte do $\mathrm{E}^{2 \text { “، }}$ i nalazimo ih $\mathrm{u}$ gotovo svim traktatima o glazbenoj teoriji. ${ }^{412}$

\footnotetext{
${ }^{409}$ Usp. Aaron, Petrus. Libri tres de institutione harmonica, liber primus (izvor: Libri tres de institutione harmonica editi a Petro Aaron Florentino (Bononiae, In aedibus Benedicti Hectoris Bibliopolae Bononiensis, 1516; reprint ed. New York: Broude Bros. 1978.). URL: http://www.chmtl.indiana.edu/tml/16th/AARIH1 (10.08.2019.)

${ }^{410}$ Mihoković, Martin. Op. cit. str. 5.

${ }^{411} \mathrm{Ibid}$. Str. 12.

${ }^{412}$ Ibid. str. 20.
} 


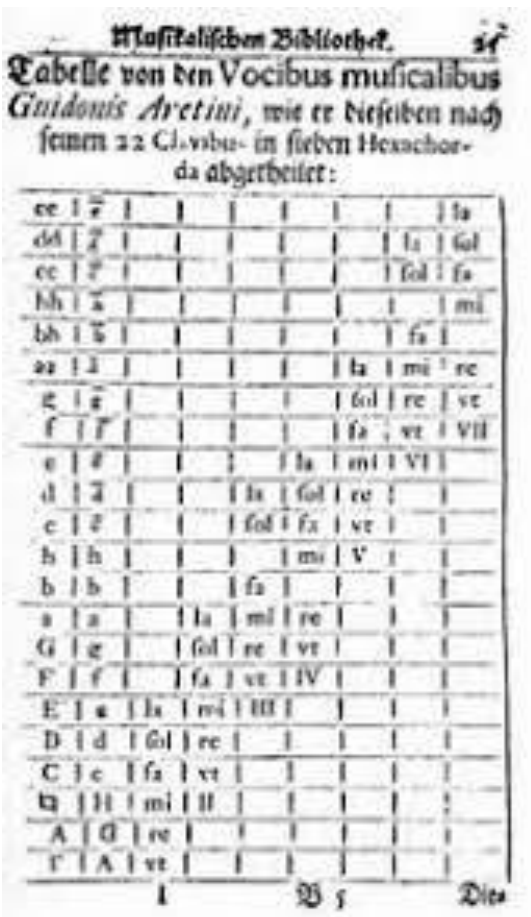

sl. 7 „Tabelle von den Vocibus musicalibus Guidonis Aretini“, Anon. 17. st.

Potom se nastavlja prikaz glazbenoteorijskih tema: solmizacijski nazivi tonova, razlika između tona i polutona koji dijeli na veći i manji, rodovi u gregorijanskom pjevanju, intervali nanizani redom s grčkim imenima (tonus, ditonus, diatexeron, tritonus, diapens, semidiapens, exachordon, etta chordon i diapason), ključevi, mutacije, tonusi, potom podjela načina na savršene, nesavršene i mješavinu jednih i drugih, tonusi psalama, tonusi responzorija i versa, tonusi introita i stari načini (koji se imenuju grčkim nazivima za redne brojeve - protus, deuterus, tritus i tetrardus). U odnosu na izvore koje navodi sam Kovačević, njegov je tekst kratak (brevis), sadržaj reduciran na osnove, no dispozicija građe ugleda se na tekstove Aarona, Gaffurija i Banchierija koji su neosporni uglednici glazbenoteorijske misli. Aaron i Gaffurio svoje su tekstove objavili krajem 15. stoljeća, a Banchieri početkom 17. stoljeća. U tih stotinu godina jedva da se izmijenio način izlaganja znanja o temeljima glazbene teorije: kao što su u 15. stoljeću neosporni autoriteti i dalje bili oni srednjovjekovni, tako su pisci 17. i 18. stoljeća njihova znanja preuzimali iz kompendija autora 15. i 16. stoljeća čime se s jedne strane zadržavao kontinuitet, a s druge implementirala estetika posttridentskog razdoblja koja je u elementarno znanje o gregorijanskom pjevanju uključivala i metričku diobu dobe, koju koralni napjevi ranog srednjeg vijeka nisu poznavali. 
Formalno vješto oblikovan kao razgovor učitelja i učenika, premda jezično katkada nespretno sročen, Mihael Šilobod-Bolšić nudi iste teme u šest poglavlja - dijaloga uz neznatne varijacije. Za razliku od ostalih u Hrvatskim knjižnicama sačuvanih priručnika, Fundamentum cantus gregoriani ne odustaje od tema porijekla i nastanka glazbe te njezina utjecaja na čovjekov karakter. Premda sažeto i skromno, ipak pretendira na cjelovitost prikaza teme razlažući je jasno od izvora i načina postanka, preko vještine pisanja i čitanja nota, do intervala i sustava tonusa te načina intoniranja. Svaki pojam pisac nastoji jasno odrediti (definitio), a pošto ga je temeljito objasnio (explicatio) nudi i glazbeni primjer (exemplum) za svako postojeće objašnjenje ugledajući se na postojeću praksu. Naslovi poglavlja - dijaloga (dialogus) navedeni redom kako se pojavljuju u Fundamentum (poslije Approbatio censoris i Praefatio ad lectorem) ocrtavaju taksonomiju glazbenoteorijskog znanja u 18. stoljeću: I. De authore musices, sive cantus; II. De lineis, notis et clavibus; III. De solmizatione; IV. De intervallis, sive consonantiis; V. De perfectione, \& imperfectione tonorum; VI. De intonationibus.

U potpunosti izbjegavši razmatranje o porijeklu i postanku glazbe i koralnog pjevanja, njegovom imenu i ulozi koju ima, Compendiosa in cantum gregorianum, seu choralem introductio (Compendium cantus choralis kako stoji slabije otisnuto povrh naslova), kao i Kovačevićevo djelo, donosi glazbenoteorijski sadržaj „,in medias res“ podijeljen na sedam poglavlja (capita): 1. De lineis, earumque spatiis, ac clavibus; 2.: De litteris, vocibus, ac notulis; 3. De proprietatibus cantus; 4. De fa ficto, seu accidentali et tritono; 5. De mutationibus in cantu faciendis; 6. De cognitione et varietate tonorum; 7. (caput ultimum) De intonatione et lectura mixta.

Usporedba ovih naslova s naslovima Šilobodovih šest dijaloga ukazuje na prilično ujednačen stav o temeljima znanja koja budući pjevač valja steći. Ona također ukazuje na značajnu razinu terminološke neusklađenosti koja otvara iznimno zanimljivu i opsežnu temu koja izlazi iz okvira ovog istraživanja, a to je mijenjanje sadržaja pojma kroz vrijeme u istom glazbenom, gregorijanskom kontekstu. I jedan i drugi tekst u te temelje uvrštava:

a) pisanu oznaku za notu čiji naziv preuzima iz lingvistike: littera što označava nomen svakoga tona (A, B, C, itd.).

b) crtovlje što obuhvaća crte (lineae) i praznine (spatia) i ključeve (claves)

c) grafičku oznaku za tonove na crtovlju koje Fundamentum naziva nota, a Compendiosa koristi deminutiv notula 
d) solmizaciju koju Fundamentum naziva solmizatio, a Compendiosa koristi stariji termin vox što označava i solmizacijski naziv i zvuk koji se čuje kad se nota označena određenim vox izvodi

e) cantus o kojem Fundamentum piše kao o istoznačnici za glazbu objašnjavajući ukratko nastanak i povijest te potom definirajući njegove različite osobine, odnosno vlastitosti koje Kovačević u Brevis cantus gregoriani notitia i pisac Compendiosa nazivaju proprietas cantus

f) tonus kao oznaku za ono što se danas najčešće naziva modus, odnosno starockrvena ljestvica

g) intonatio što danas označava tonski ispravno izvođenje zapisanog tona, dok u glazbenoj teoriji crkvene glazbe označava odabir ispravnog tonusa prikladnog određenom napjevu

h) intervallum Šilobod-Bolšić izjednačava s pojmom consonantia i objašnjava redom od najmanjeg do najvećeg razmaka među tonovima odnosno glasovima (vox), odnosno od sekunde do septime, kako se podučavaju i danas. Kovačević i autor Compendiosa intervale spominju samo u kontekstu tritonusa, odnosno njegova izbjegavanja

Važnost koju pridaju određenim pojmovima kao što su primjerice mutatio, proprietas, perfectio i imperfectio tonorum ukazuje na postojanje diskrepancije u postojećoj glazbenoj teoriji, u nesuglasju značenjskoga polja koja pokrivaju određeni pojmovi kod različitih pisaca te u važnosti koja se, u svrhu poduke pjevanja, pridaje određenim temama. Čini se, ipak, da je spomenuta diskrepancija prije odraz priklanjanja pojedinog autora (ne)suvremenoj viziji „autentičnosti“" gregorijanskoga pjevanja, nego suštinskih razlika u poimanju temeljnih glazbenih znanja. Dijakronijsko i sinkronijsko istraživanje terminoloških mijena u postojećim priručnicima za glazbenu teoriju, osobito onih koji su svojom važnošću utjecali na velik broj pisaca (npr. Tinctorisov Terminorum musicae diffinitorium, Banchierijeva Cartella musicale, Gaffurijeve Theorica musicae i Practica musicae) izranja kao jedna od mogućih zanimljivih tema koje je otvorio rad na ovoj disertaciji budući da bi, vrlo vjerojatno, razjasnilo brojne do danas postojeće nedoumice vezane uz srednjovjekovnu i renesansnu teoriju glazbe te omogućilo bolje razumijevanje onodobne glazbe.

Postojanost u odabiru temeljnog glazbenoteorijskog sadržaja, također potkrijepljenog obiljem primjera, potvrđuju i priručnici koje su objavljivali pripadnici franjevačkog reda, mahom u Italiji, od kojih su Tettamanzijev i Frezza Dalle Grotteov dijelom inventara mnogih hrvatskih 
franjevačkih samostanskih knjižnica. Uz iznimku kratkog objašnjenja porijekla naziva gregorijanskoga pjevanja, i oni se odlučuju za pristup ,in medias res“ na samom početku prikazujući Guidovu ruku koja je polazište za sva daljnja objašnjenja.

Giuseppe Tettamanzi ${ }^{413}$ se odlučuje za niz kratkih poglavlja u kojima se poslije gotovo svake definicije nudi notni primjer, a cjelokupno znanje je podijeljeno u čak četrdeset poglavlja gotovo istim redoslijedom kao i u tekstovima Šiloboda-Bolšića, Kovačevića, Sambera i Banchierija: objašnjenje Guidove ruke nalazi se na samom početku teksta, a potom slijedi obrazloženje ključeva, mutacija, nota, intervala, tonusa i pravilnog intoniranja, odnosno prepoznavanja tonusa ovisno o mjestu napjeva u liturgiji te vrsti svetkovine kojoj pripadaju određeni napjevi. Naslovi poglavlja svjedoče rascjepkanost prikaza, ali i veću posvećenost detaljima: 1. Comme si devono intendere i nomi fraposti nella Mano; 2. Delle chiavi, e cognizione di esse; 3. Delle mutazioni delle note, ... 4. Della proprieta di b molle, e che cosa si; 5. Delle mutazioni della congiunta di b molle; 6 . Che cosa e tono e della sua divisione; 7 . Del Semitono minore, e maggiore; 8. Del Ditono, ovvero terza maggiore; 9. Del Semiditono, ovvero terza minore; 10. Della quarta minore, ovvero Diatesseron; 11. Che cosa sia Tritono, ovvero quarta maggiore ... 17. Che cosa sia tono; 18. Della composizione del primo tono ...; 26. Della perfezione, ed imperfezione del primo tono; 29. Delle modo di conoscere i toni per le quatro corde communi ...; Delli toni misti, Delli toni irregolari; 33. Che cosa significa EVOVAE; 34. Modo di conoscere li toni con intonazione delli Salim festivi e feriali... Do poglavlja 40. slijede upute za prepoznavanje tonusa responzorija, introita, graduala, Aleluje i poslijepričesnog napjeva (postcommunio). Tekst je isprekidan obilje primjera, baš kao i onaj Šiloboda-Bolšića, a ostatak priručnika, kako smo već spomenuli, posvećen je isključivo primjerima za molitve brevijara (vesperae, matutinum, laudes, prima, tertia ... itd.).

Prezentacija glazbenoteorijskoga znanja Marchetta iz Padove, Johannesa Tinctorisa, Pietra Aarona, Franchina Gaffurija, Adriana Banchierija i Tome Kovačevića mogla bi se nazvati nizom, izlaganjem znanja na način da se podaci predstavljaju po načelu: 1. definicija; 2. opširnije objašnjenje eventualnih nejasnih mjesta; 3. notni primjeri i/ili tablice. To je znanje poredano tako da se izlažu teme po odavno utvrđenom redu kako bi se postupno stjecala vještina čitanja i izvođenja notnih zapisa. U tom smislu, glazbena teorija kao uputa za praksu,

413413 Usp. Tettamanzi, Fabrizio. Breve metodo per apprendere fondatamente e con facilità il canto fermo. Milano: 1756. URL: 
a ne teorija muzike kao metafizičke, spekulativne discipline, poznaje reprezentaciju kao taksonomiju već od prvih velikih pedagoških priručnika 14. i 15. stoljeća - Lucidarium Marchetta da Padove, De inventione et usu musice Johannesa Tinctorisa, De musica plana Pietra Aarona ili anonimni traktat Compendium musices (1499.). Red i klasifikacija glazbenoteorijskog znanja u opširnim prikazima od kraja 16. pa sve do kraja 18. stoljeća dodatno su se, čini se, nadahnjivale velikim shematskim prikazima antičke teorije glazbe, iznova otkrivenim i prevedenim u Italiji u 16. stoljeću. Pritom je, nakon stoljećâ dominacije Boetija kao temeljnog antičkog izvora, Kvintilijanova raskošna glazbenoteorijska shema postala najutjecajnijom (Kasiodorovi spisi i oni Marcijana Kapele bili su kudikamo rjeđe prepisivani i distribuirani). ${ }^{414}$ No takve, opsežno konstruirane klasifikacije bile su rijetke i redovito vezane uz spekulativnu raspravu o glazbenom mathesisu, odnosno brojevima mjerljivoj glazbi - intervalima i ritamskim formulama. ${ }^{415}$

Glazbenoteorijski traktati pisani s pedagoškom namjerom, poput onih koje nalazimo u Hrvatskoj, oslanjaju se na skromnije i svrsishodnije klasifikacije kojima trag možemo pratiti sve do više puta spominjanih karolinških spisa Scolica Enchiriadis i Musica Enchiriadis. Nizovi poredani po određenom redoslijedu tema, dakle klasificirani, vidljivi su, u konačnici, već u Guidovoj ruci koja nudi sistematski, kružni prikaz pravilnog intoniranja (v. sl. 1). Ti su tematski nizovi stoljećima isti, katkada mijenjaju mjesta u redoslijedu, već prema važnosti koju suvremenici pridaju temi. Obuhvaćaju imena tonova, glazbenih ključeva, vrsta tonusa, heksakorda, načina mutacije pri prelasku iz jednog heksakorda u drugi, a od Johannesa de Murisa i notna trajanja, dok je zaključni dio najčešće rezerviran za primjenu naučene teorije

\footnotetext{
${ }^{414}$ Bergua Cavero, Jorge. Invention and Imitation: an overview of musical settings of Classical poetry and the rediscovery of Ancient music, from the Middle Ages to the Renaissance. // Anabases. Traditions et réceptions de l'Antiquité. 8/2013, str. 61-69. URL: http://journals.openedition.org/anabases/4347 (09.04.2020.): ,During the fifteenth and sixteen centuries Italy, and subsequently the rest of Europe, witnessed the process of rediscovery, translation, edition and commentary of the surviving Greek documents concerned with music (Ptolemy, Aristides Quintilianus, Pseudo-Plutarch, etc.). This was a long process which, because of its complexity and itsvery nature, midway between the history of philology and historical musicology, has perhaps never received the attention it deserved."

${ }^{415}$ Ovom modelu prezentacije znanja koji pretendira na sveobuhvatnost i temeljitost prikaza pripadaju u 17. i 18. st. npr. Musurgia universalis sive ars magna consoni et dissoni, Rim: 1650. Athanasiusa Kirchera, Harmonie universelle, contenant la théorie et la pratique de la musique, Paris: 1636. Marina Mersennea. Njima se može pribrojiti i konceptualno usmjeren prema vrsti glazbe trosveščani prikaz svih poznatih glazbenih praksi Michaela Praetoriusa Syntagma Musicum (sv. 1 Musicae Artis Analecta, 1614., sv. 2 De Organographia 1618., sv. 3. Termini Musicali te dodatak drugom svesku Theatrum Instrumentorum seu Sciagraphia, 1620.) koja je objavljena između 1614. i 1620. u Wittenbergu i Wolffenbuttelu. U 18. stoljeću najpoznatiji su prikazi teorije glazbe Johanna Josepha Fuxa Gradus ad Parnassum (lat. 1725., prijevod na njemački 1742.) koji je najpoznatiji kao udžbenik iz kontrapunkta, no prvi je dio traktata posvećen musica speculativa i tako je i naslovljen, potom Der volkommene Kapellmeister Johannesa Matthesona koji spominjemo radi tendencije k enciklopedijskom, sveobuhvatnom prikazu znanja premda je danas najpoznatiji po dijelu teksta koji se odnosi na retoričke figure primijenjene na glazbu, itd.
} 
na praksu liturgijskog pjevanja. Posljednja poglavlja gotovo svih traktata - i domaćih neolatinista i uglednih teoretičara od kojih su učili i koje su obilno citirali i parafrazirali, uvijek se odnose na intoniranje najvažnijih dijelova obreda koji se pjevaju: psalama, versa, responzorija, introita. Uz spomenutu klasifikaciju sadržaja prema važnosti i nizu kao temeljnom načinu prikaza tog sadržaja, važnu ulogu imaju i tabelarni prikazi koji se vrlo često koriste u primjerima za notne visine, vrijednosti trajanja, sustava tonusa, mjesta mutacija iz heksakorda u heksakord.

Uvidom u spomenute traktate od Guida iz Arezza do početka 18. stoljeća, čini se da su upravo tabelarni prikazi te obilje glazbenih primjera glavna razlika između traktata nastalih do kraja 15. stoljeća i onih od 16. do 18. stoljeća. Njihov sadržaj ostaje vrlo sličan onima iz prošlih stoljeća, gotovo da se ne mijenja. No, taj je sadržaj do kraja 15. stoljeća predstavljen gotovo isključivo gustom naracijom koja teče bez prekida i u koju su tek mjestimice uklopljeni glazbeni primjeri na crtovlju.

\section{Stihovi}

Najčešća mnemotehnička sredstva glazbenoteorijskih priručnika 17. i 18. stoljeća su tablice, no vrlo često nalazimo i stihove. Takvim pjesmicama - podsjetnicima služi se i ŠilobodBolšić. Uz pomoć pjesmice, ali i notnog prikaza učeniku valja zapamtiti autentične i plagalne tonuse:

„Fines cunctorum, cantor, dignosce tonorum.

Nam finem primi D continet, atque secundi.

Tertius E regitur, \& quarti finis habetur.

Quintus in F finem, sextus quoque ponit eundem.

Septimus, octavusque tonus cognoscitur ex G.“

„Kantore, razlikuj note finalis svih tonusa.

Naime, nota finalis prvog i drugog nalazi se na D.

Treći kraljuje na E, a tamo notu finalis ima i četvrti. 
Petom je na F, a i šesti je ondje stavlja.

Sedmi i osmi tonus raspoznaju se po noti G. “416

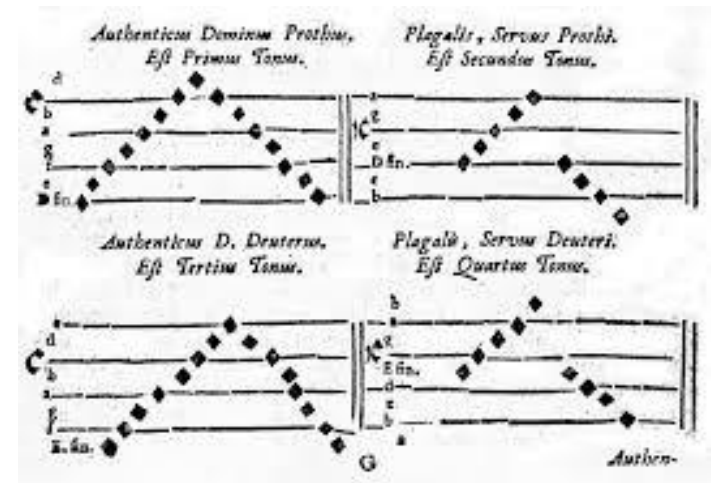

sl. 8 prikaz autentičnih i plagalnih tonusa iz priručnika Šiloboda-Bolšića Fundamentum cantus gregoriani seu choralis. Zagreb: L\&G, 2009. str. 122-123.

Sljedeća pjesmica služi kao mnemotehničko sredstvo za određivanje pripadnosti psalama tonusu:

,Re, la primus habet, $r e, f a$ datur inde secundo.

Tertius ad sextum $m i, f a$, at $m i, l a$ quartus habebit.

$F a, f a$ fert quintus; $f a, l a$ concedito sexto.

Septimus est $u t$, sol; $u t, f a$ capit inde supremus.“

„Re - la ima prvi, re - fa nalazi se potom u drugom.

Treći je u seksti mi - fa, a mi - la će imati četvrti.

fa - fa čini peti, a fa - la je ustupljeno šestom.

Sedmi je ut - sol, a ut - fa preuzima potom zadnji. “417

Potom nudi još jednu koja definira intoniranje psalama na dane velikih svečanosti:

416 Šilobod-Bolšić, Mihael. Op. cit. str. 120-121.

${ }^{417}$ Ibid. Str. 130-131. 
„Primus tonus habet $f a$, sol, la, sextus et idem.

$U t, r e, f a$, octavus, sic tertius atque secundus.

$L a$, sol, la, quartum dant, $u t, m i$, sol, tibi quintum.

Septimus at tonus $f a, m i, f a$, sol, tibi monstrat.“

„Prvi tonus ima fa - sol - la, a tako ima i šesti.

ut - re - fa ima osmi te treći i drugi

la - sol - la daju četvrti, ut - mi - sol daju ti peti

A sedmi ti tonus pokazuje fa $-\mathrm{mi}-\mathrm{fa}-\mathrm{sol}$. ${ }^{6418}$

Takvih je pjesmica u svrhu pamćenja brojnih glazbenoteorijskih pravila napisano stotine. Još u posljednjoj četvrtini 18. stoljeća, točnije 1776. Sir John Hawkins navodi ih kao nezaobilazno sredstvo poduke gregorijanskoga pjevanja:

„Kako bi se olakšalo pamćenje formula za svaki od tonusa, a osobito kako bi se u dječje umove utisnule note finalis i dominante koje ih karakteriziraju, sklapali su se stihovipodsjetnici, kakvih slijedi primjer:

'Primus habet tonus F, SOL et LA, sextus et idem:

UT, RE, FA octavus: sit tertius, atque secundus:

LA, SOL, LA quartus: dant UT, MI, SOL tibi quintum:

Septimus at tonus FA, MI, FA, SOL tibi monstrat. ...'،4119

\footnotetext{
${ }^{418}$ Ibid. str. 132-133.

${ }^{419}$ Hawkins, John. A General History of the Science and Practice of Music. London, 1776. vol. 1, str. 368. URL: https://imslp.simssa.ca/files/imglnks/usimg/9/9c/IMSLP337339-PMLP544570-generalhistoryof01byuhawk.pdf, (20.10.2020.): „To facilitate the remembrance of the formula of each of the tones, and particularly to impress upon the minds of children the finals and dominants that characterize them, memorial verses have been composed, of which the following are the specimen." Uz to, Hawkins, koji u prvom svesku potanko navodi povijest muzike kao matematičke discipline te teoriju i povijest gregorijanskoga pjevanja, itekako je svjestan njegove statičnosti i zahtjeva za očuvanjem izvornoga, čistoga oblika: „By the foregoing deduction of the nature of the Cantus Gregorianus, nothing more is intended than to explain its original form, for it will be observed that none of the authors above-cited presume to make any additions to, or amendements of it, on the contrary they labour to represent it in its purity, and to preserve it from corruption."
} 
U 17. i 18. stoljeću svjedočimo bujanju primjera poredanih u nizove ili u tablice, kako bi bili lakše shvatljivi i pregledniji, kako bi ih se jednostavnije uspoređivalo i pamtilo: „Vide iam omnes, \& singulas in exemplo“, veli Šilobod-Bolšić, neprestano podsjećajući učenika na njihovu važnost: „Sed nulla sine exemplis.“ Riječi moraju biti jasne, označavati jednoznačno ono što se objašnjava, a primjeri još jasniji: „Clare verbis, \& praeclare exemplis doces magistre“, sretan je učenik. ${ }^{420}$ Utjecaj razvoja opće gramatike i njezina prikaza jezika očit je. Valja napomenuti da su tablice prikaza glazbenoteorijske građe (primjerice podjele mjernih vrijednosti ili vrsta tonusa, nizovi intervala, itd.) postojale i ranije, no bile su rijetke. ŠilobodBolšić ih koristi uz obilje primjera, baš kao i franjevački autori Tettamanzi i Frezza Dalle Grotte. Primjeri postaju toliko važni da Tettamanzijev priručnik sastavljen od tri povezane knjige (tre libri), u prvoj i najkraćoj na četrdesetak stranica, podijeljeno u četrdeset poglavlja nudi svo teorijsko znanje obilno potkrijepljeno primjerima potrebno za uspješno učenje pjevanja, dok su druga i treća knjiga u cijelosti posvećene glazbenim primjerima slijedeći raspored brevijara i liturgijskih svetkovina. ${ }^{421}$ Giuseppe Frezza Dalle Grotte također na prvih pedesetak stranica donosi teoriju, a potom ostatak teksta (koji ukupno broji 183 stranice) posvećuje raznim tipovima intoniranja prilikom svetkovina, pjevanja brevijara i slično.

\footnotetext{
${ }^{420}$ Usp. Šilobod-Bolšić, Mihael. Op. cit. Str. 98-99.

${ }^{421}$ Usp. Tettamanzi, Fabrizio. Op. cit. v. bilj. 26.
} 


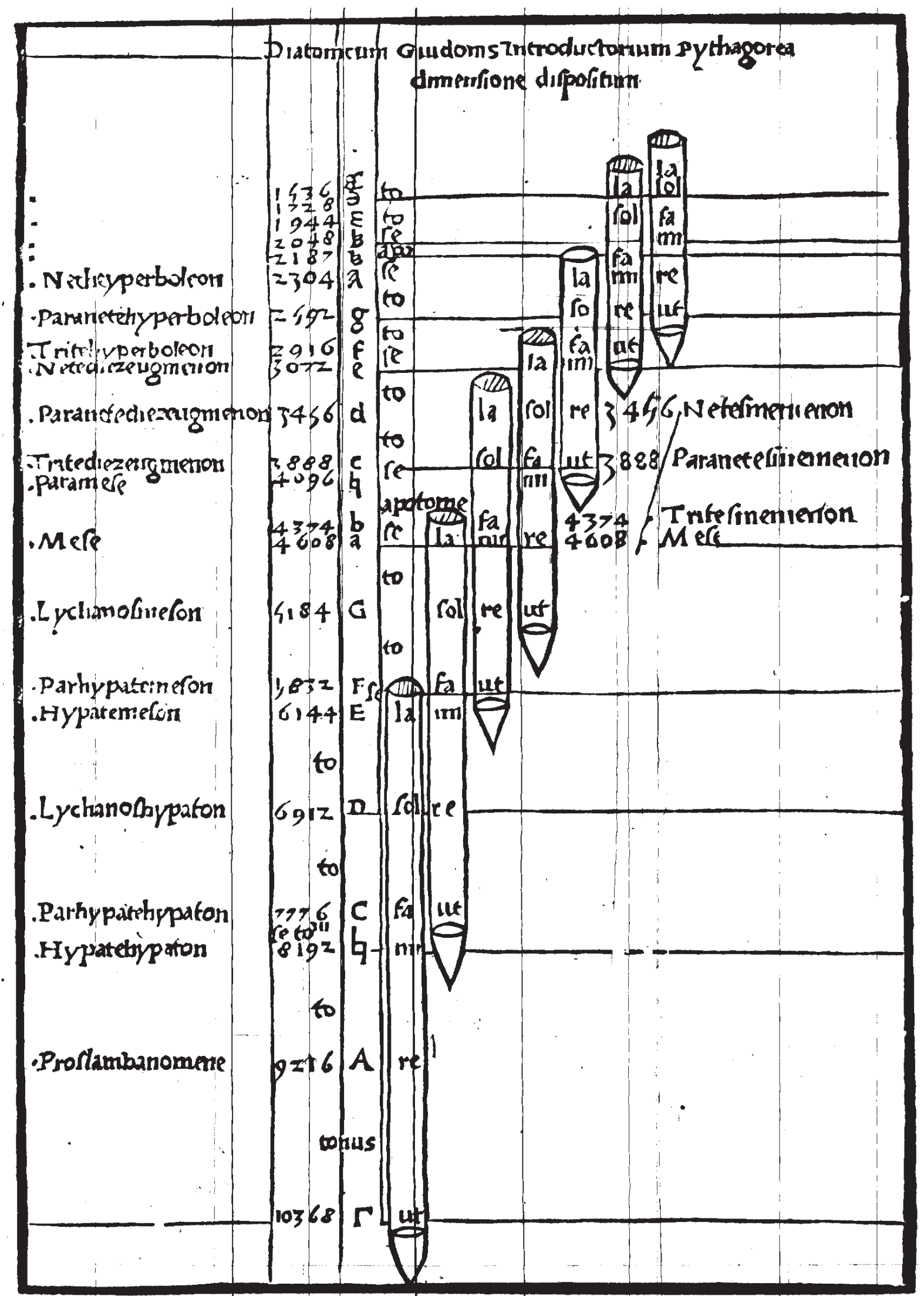

S1. 9 Prikaz niza tonova prema Pitagorinom nauku. S lijeve strane su nazivi intervala prema grčkim nazivima, a s desne nizovi heksakorda. 


\begin{tabular}{|c|c|c|c|c|c|}
\hline \multicolumn{6}{|c|}{ Symbolum Tonorum } \\
\hline \multirow[t]{2}{*}{ D Finalis } & $\mathrm{Re}$ & $\mathrm{La}$ & \multirow{4}{*}{ Initialis } & Per 5 tam & Tonus I. \\
\hline & $\mathrm{Re}$ & $\mathrm{Fa}$ & & Per 3tiam & Tonus II. \\
\hline \multirow[t]{2}{*}{ E anti } & $\mathrm{Mi}$ & $\mathrm{Fa}$ & & Per 6tam & Tonus III. \\
\hline & $\mathrm{Mi}$ & $\mathrm{La}$ & & Per 4tam & Tonus IV. \\
\hline \multirow[t]{2}{*}{$\mathrm{F}$ phonae } & $\mathrm{Fa}$ & $\mathrm{Fa}$ & \multirow[t]{4}{*}{ EUOUAE } & Per 5tam & Tonus V. \\
\hline & $\mathrm{Fa}$ & $\mathrm{La}$ & & Per 3tiam & Tonus VI. \\
\hline \multirow[t]{2}{*}{$\mathrm{G}$} & $\mathrm{Ut}$ & sol & & Per 5tam & Tonus VII. \\
\hline & $\mathrm{Ut}$ & $\mathrm{Fa}$ & & Per 4tam & Tonus VIII. \\
\hline
\end{tabular}

sl. 10 transkripcija tablice simbola tonusa objavljene u Fundamentum cantus gregoriani seu choralis Mihaela Šiloboda-Bolšića. Vidljivo je da u ovoj tablici tonus ima značenje ljestvičnog niza. Antifone i psalmi glazbeno se definiraju i uče prema pripadnosti određenom tonusu.

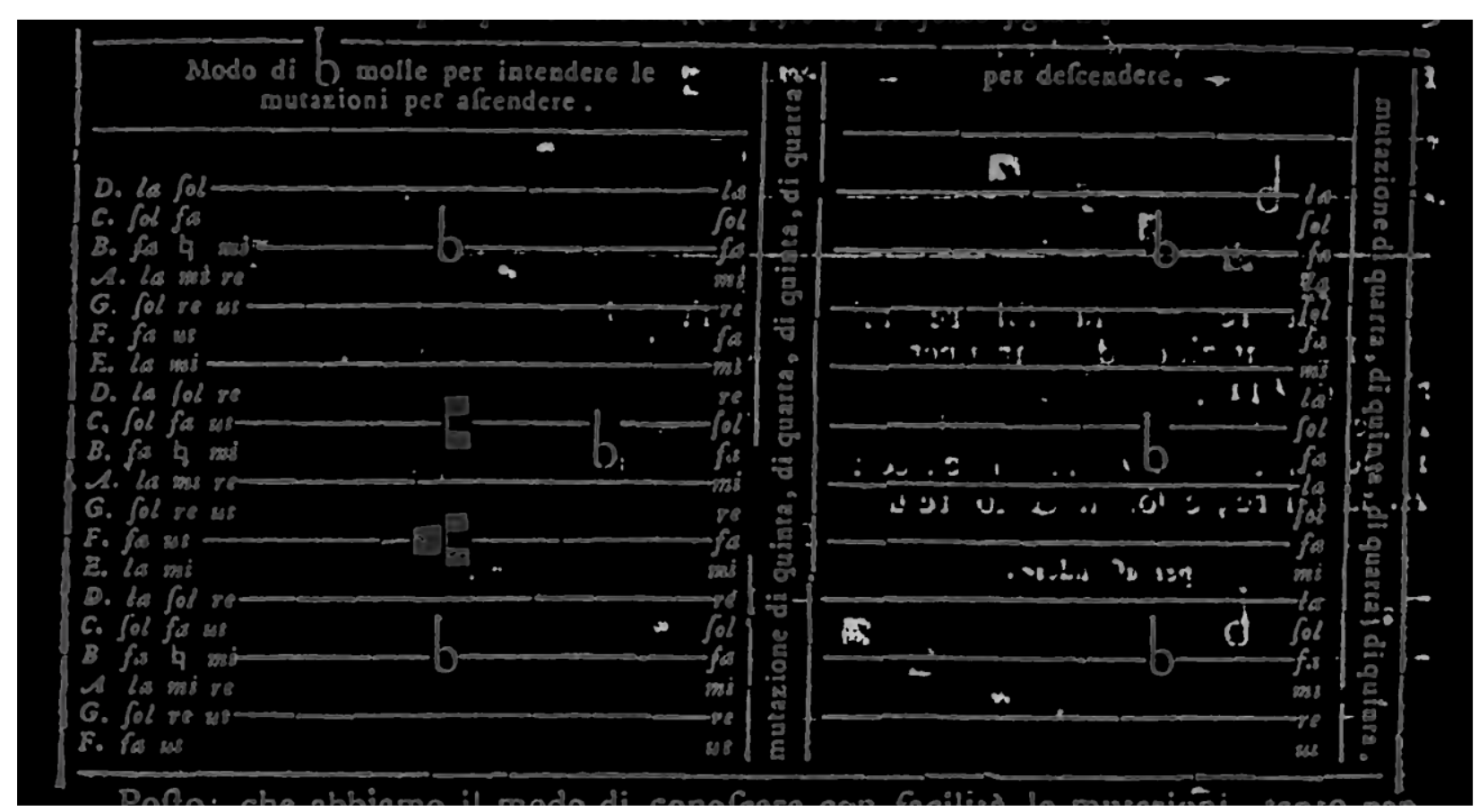

sl. 11 Tettamanzi, Fabrizio. Breve metodo per apprendere fondatamente e con facilità il canto fermo. Milano: 1756. str. 16. 


\section{Il Cantoré Ecclefiaftico b. n. b.}

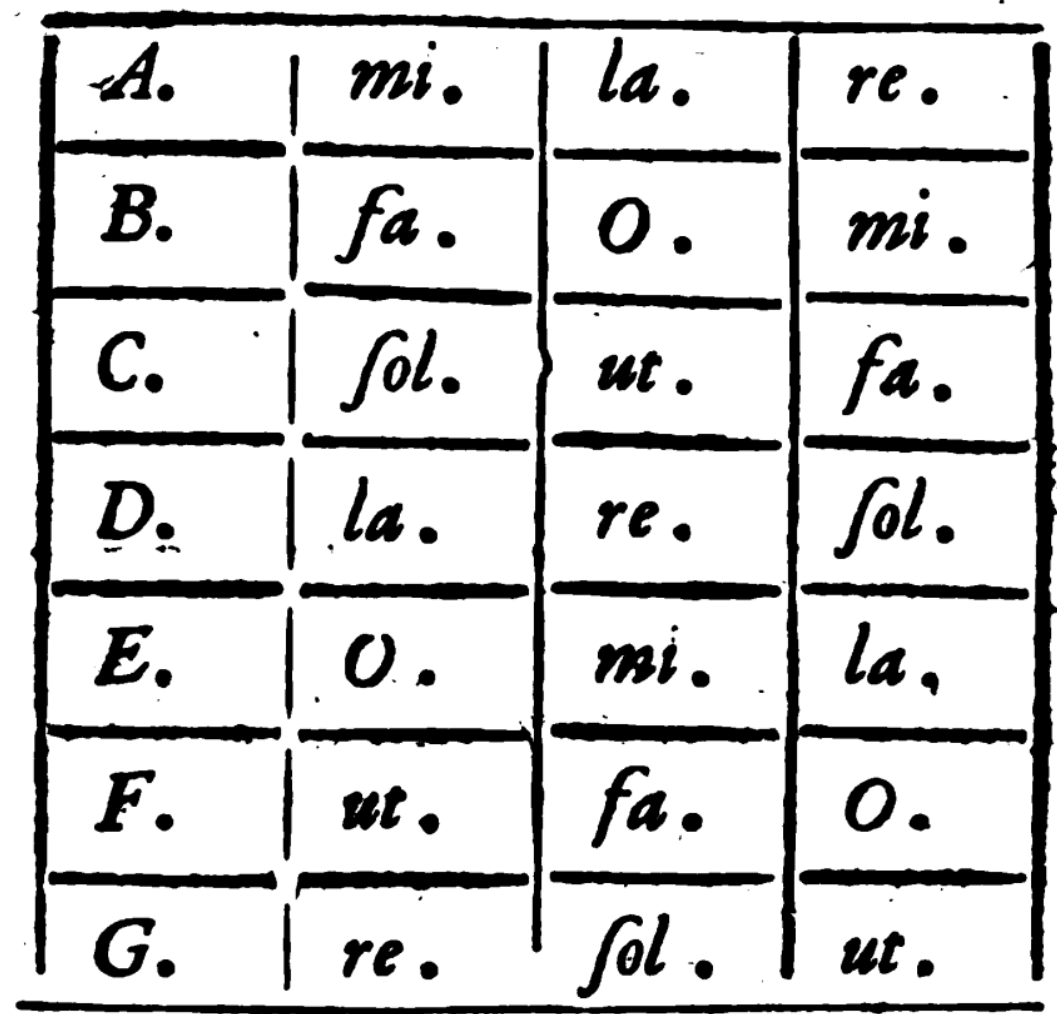

sl. 12 usporedna tablica naziva tonova prema grčkim slovima i Guidovim solmizacijskim slogovima iz priručnika Il Cantore Ecclesiastico Giuseppea Frezza Dalle Grotte. Padova,1733. str. 30.

Na temelju prikazanog niza obrađivanih glazbenoteorijskih tema te načina prikaza znanja koje se zahtijeva od kantora, ali i od korskoga pjevača, uočljivo je da se izbor tema u odnosu na starije tekstove o gregorijanskom pjevanju ne mijenja. Taj je izbor, dakako, reduciran u usporedbi s općim glazbenoteorijskim traktatima tipa Gaffurijevog koji pretendiraju predstaviti svo znanje o glazbi. Redukcijom sadržaja na ono što se piscu čini bitnim prenijeti budućim kapelnicima i pjevačima otkriva se ne samo osobni pogled na elementarnost glazbene poduke već i na ulogu koju glazba ima u kulturnom kontekstu u kojem pisac živi. Stoga je redukcija tim veća što je raspon vrsta izvođene glazbe manji. Insistiranje na velikom broju stranica posvećenih intoniranju psalama prema rasporedu brevijara u franjevačkih 
autora čini temeljnu razliku između franjevačkih i redovničkih glazbenoteorijskih djela te onih čiji su autori svjetovni svećenici ili pak kakav isusovac koji, kao što nam je poznato „nec cantat nec ieiunat“. Ono što se mijenja u 17. stoljeću i vidljivo je već u CM Banchierija, a osobito u kratkim, pedagoški usmjerenim tekstovima objavljivanima diljem Europe za osnovnu glazbenu poduku kantorima, jest spomenuta funkcionalnost prikaza te obilje primjera. Dok u velikim renesansnim traktatima, pa i u raskošnom baroknom Kircherovom djelu Musurgia universalis svjedočimo fascinantnim mješavinama spekulativnog promišljanja glazbe i njezinih praktičnih aspekata te istovremenom promicanju musica plana i musica mensurabilis, priručnici 17. i osobito 18. stoljeća koji se bave gregorijanskim pjevanje priklanjaju se odlukama Tridentskoga koncila i izostavljaju, barem eksplicitno, teme vezane uz polifonu glazbu. Riječ je, s jedne strane, o svjesnoj redukciji sadržaja koja nije uvjetovana isključivo ekonomskim i društvenim prilikama okoline u kojoj autor djeluje. Zapravo, riječ je o onome što Blasius naziva metateorijskom i disciplinskom funkcijom teksta: „Osobito od sredine 17. stoljeća eksplicitna mapiranja teorije stekla su metateorijsku i disciplinsku funkciju, često djelujući kao pokušaju da se stabilizira diskurs za koji se smatralo da je na samome rubu raspada. “422 Dakle, discipliniranjem diskursa nastojalo se disciplinirati praksu koja je posvuda izmicala kontroli. S druge strane, ta svjesna redukcija prikazanih tema izriče apologiju gregorijanskom pjevanju podsjećajući na njegovo vrhovno mjesto u hijerarhiji svih poznatih glazbenih praksi, dok istovremeno diskretno i zamaskirano pripušta u diskurs o gregorijanici teme načelno vezane uz skladanje i izvođenje polifone glazbe. Jedna od njih, primjerice, jest sustav menzuralne notacije koji ne postoji u tradicionalnom koralnom pjevanju, a koje se upravo zbog načelnog izbjegavanja preciznog ritmičkog određenja melodije naziva i musica plana.

Sličan disciplinski efekt, bliži taksonomiji o kojoj govori Foucault ${ }^{423}$, imali su tekstovi poput Šilobod-Bolšićevog.

\footnotetext{
${ }^{422}$ Blasius, Leslie. Op. cit. Str. 27: „Particularly after the middle of the seventeenth century, explicit mappings of theory come to have metatheoretical and disciplinary function, often seeming to be attempts to stabilize a discourse percieved as being on the verge of fragmentation."

${ }^{423}$ Michel Foucault definira je kao „opću znanost mjere i reda“: ,,Science universelle de la mesure et de l'ordre“ Foucault, Michel. Op. cit. Str.70, no dalje veli: ,... le rapport de toute connaissance à la mathesis se donne comme la possibilité d'établir entre les choses, même non mesurables, une succession ordonnée. En ce sens l'analyse va prendre très vite valeur de méthode universelle (...). Mais d'autre part ce rapport à la mathesis comme science générale de l'ordre ne signifie pas une absorption du savoir dans les mathématiques, ni le fondement en elles de toute connaissance possible; au contraire, en corrélation avec la recherche d'une mathesis, on voit apparaître un certain nombre de domaines empiriques qui jusqu'à présent n'avaient été ni formés ni définis (...). Ainsi sont apparues la grammaire générale, l'histoire naturelle, l'analyse des richesses, sciences de
} 
U ovom radu analizirani traktati, kao i oni koje smo konzultirali kao komparativnu građu, prikazuju sadržaj prema praksom utvrđenom redoslijedu, nižući pravila i podatke vezujući usporedbom koja katkad ističe vezu sličnosti, katkada vezu suprotnosti. Osim usporedbom, oni su predstavljeni nizovima i tablicama kako bi srodnosti i razlike bile lakše uočljive i pamtljive.

Taj red, međutim, nije red na kojem počivaju prirodne znanosti. To je, čini se, red kako ga definira sveti Augustin u De Civitate Dei koji je opći red, red koji uzrokuje mir (pax) i smirenost (tranquilitas) duše i tijela i ne dopušta nikakvo uznemiravanje (preturbatio), a primjenjiv je na svo ljudsko djelovanje:

„Ordo est pariumque dispariumque rerum sua cuique loca tribuens dispositio.“

„Red je raspored kojim se jednake i različite stvari postavljaju na svoja mjesta.“424

S obzirom da red kao stavljanje stvari na prikladno mjesto i taksonomiju u smislu nizanja srodnih primjera nalazimo već u renesansi, čini se da je ona u glazbi posljedica mathesisa u značenju koje ima u antici, a na koje referiraju Decartes i Leibniz, kao procesa učenja i modela koji omogućuje obuhvat sveukupnoga znanja nekog predmeta: „Klasična pozicija koju sustavno podržavaju Platon, Aristotel, Descartes i Leibniz jest ona cjeline znanja i modela koji dopuštaju supsumiranje ukupnoga znanja u povezanosti i zajedničkom jeziku. “425

Naime, kao što smo više puta spomenuli, muziku (a ne glazbu!) kao matematičku disciplinu definira broj. Objašnjenje njezina nastanka i ozvučenja, a posljedično i sva pravila koja se vezuju uz praksu temelje se na brojčanim odnosima, kako u melodici - intervali kao iskazivi

l'ordre dans le domaine des mots, des êtres et des besoins..." M. Foucault, Les Mots et les choses, Paris, Gallimard,1966. Str. 71.

${ }^{424}$ Sancti Augustini De civitate Dei 19.13.1. PL. 41. col 640. URL: http://patristica.net/latina/\#t041 (18.10.2019.) Cijeli ulomak glasi: „Pax itaque corporis est ordinata temperatura partium, pax animae inrationalis ordinata requies appetitionum, pax animae rationalis ordinata cognitionis actionisque consensio, pax corporis et animae ordinata uita et salus animantis, pax hominis mortalis et Dei ordinata in fide sub aeterna lege oboedientia, pax hominum ordinata concordia, pax domus ordinata imperandi atque oboediendi concordia cohabitantium, pax ciuitatis ordinata imperandi atque oboediendi concordia ciuium, pax caelestis ciuitatis ordinatissima et concordissima societas fruendi Deo et inuicem in Deo, pax omnium rerum tranquillitas ordinis. Ordo est parium dispariumque rerum sua cuique loca tribuens dispositio. Proinde miseri, quia, in quantum miseri sunt, utique in pace non sunt, tranquillitate quidem ordinis carent, ubi perturbatio nulla est; Verum tamen quia merito iusteque sunt miseri, in ea quoque ipsa miseria sua praeter ordinem esse non possunt; non quidem coniuncti beatis, sed ab eis tamen ordinis lege seiuncti. Qui cum sine perturbatione sunt, rebus, in quibus sunt, quantacumque congruentia coaptantur; ac per hoc inest eis ordinis nonnulla tranquillitas, inest ergo nonnulla pax.“

${ }^{425}$ Usp. Desanti, Jean-Toussaint. Réflexion sur le concept du mathesis. // Figures de la Psychanalyse. 2/12, 2005. Str. 103-137. URL: https://doi.org/10.3917/fp.012.0103 (18.10.2019.): „La position classique soutenue successivement par Platon, Aristote, Descartes et Leibniz, est celle d'une unité du savoir et d'un modèle qui permettent de subsumer l'ensemble des savoirs, dans une cohérence et une langue commune.“ 
brojevni omjeri -, tako i u ritmici, kao notne vrijednosti i mjere. I premda je, kao što ćemo pokazati u sljedećem poglavlju, njezina uloga u osobnom životu svakog čovjeka i društva kao zamišljene cjeline sve do kraja 18. stoljeća objašnjavana vezama sličnosti, taksonomija kao posljedica razumijevanja muzike kao matematičke znanosti prati je od nama poznatih prvih sustavnih prikaza iz antike. Opsesija vezom sličnosti kao temeljnim načinom objašnjavanja polako nestaje, a volja za što jasnijim prikazom pravila i iznimaka stvara sve veći broj traktata posvećenih praksi. No, valja imati na umu da ustrajavanje na srednjovjekovnim autoritetima nije osobitost isključivo udaljenijih i siromašnijih dijelova Europe, izloženih neprestanim ratovima s Turcima poput sjevernih hrvatskih zemalja. Srednjovjekovni pisci o glazbi predstavljaju normu u svim školama zapadne Europe u 16. stoljeću, a Boetije je i dalje obavezna literatura za studente sveučilišta. U tekstu o glazbenoj teoriji poslije 1450. piše:

„Ove nove ideje (sc. adaptacija modalnog sustava u polifonu praksu, odnosi konsonance i disonance, racionalizacija smanjenih i povećanih intervala, harmonija kao tehnički koncept skladanja, itd., op. J. K. C.) razvile su se u sklopu tradicije koja jedva da se promijenila tijekom stoljeća. Pjevači početnici morali su naučiti čitati note, prepoznavati intervale, znati gdje se nalazi polustepen, voditi melodije mutirajući u nove heksakorde, razumjeti moduse i znati razlike između psalamskih tonusa. Sudeći prema brojnim petnaestostoljetnim kopijama Guidovih traktata, traktata Dialogus nekoć pripisanog Odu ${ }^{426}$ i mnogobrojnim verzijama Ars cantus mensurabilis Franka iz Kölna, prošlost je bila vrlo prisutna među glazbenicima petnaestoga stoljeća: ovo su bili temeljni, još uvijek relevantni tekstovi. Boetije je bio obavezna literatura za studente na sveučilištu, a spekulativnu tradiciju predstavljalo je više suvremenih pisaca, od kojih je najutjecajniji bio Johannes de Muris.“427 Ta je prošlost bila predstavljena na način koji je omogućavao brže i lakše učenje osnova potrebnih za sudjelovanje u liturgiji i s njom povezanim svečanostima. Praktična primjena znanja

\footnotetext{
${ }^{426}$ Radi se o Odu iz Clunyja (oko 879.-942.), francuskom redovniku, opatu samostana u Clunyju i autoru brojnih biblijskih komentara, propovijedi, triju himana i niza antifona za oficij sv. Martina. Njemu se donedavno pripisivalo autorstvo glazbenoteorijskog traktata Dialogus de musica, poznat i pod imenom Enchiridion musices, što medievisti u posljednje vrijeme osporavaju. Usp. Huglo, Michel. L'auteur de „Dialogue sur la Musique“ attribué a Odon. // Revue de Musicologie, 55/2, 1969. Str. 119-171. URL: https://doi.org/10.2307/927822 (11.11.2019.)

${ }^{427}$ Blackburn, Bonnie J. Music Theory and Musical Thinking after 1450. Blackburn, Bonnie J. \& Strohm, Reinhard (ed.). Music as Concept and Practice in the Late Middle Ages. str. 301-345.: ,These new ideas were developed within a tradition that changed a little over the centuries. Beginning singers had to be taught to read music, to recognize intervals, to know where the semitone fell, to navigate melodies by mutating to new hexachords, to understand the modes, and to know the psalm-tone differences. To judge by the many fifteenthcentury copies of treatises by Guido, the Dialogus once ascribed to Oddo, and multiple versions of Franco of Cologne's Ars cantus mensurabilis, the past was very much with fifteenth-century musicians: these were basic texts, still relevant. Boethius was required reading for university students, and the speculative tradition continued to be represented by more modern writers, of whome Johannes de Muris was the most influential.“ (str. 302).
} 
regulirana je prema Horacijevom zahtjevu na kratak i jednostavan način, lišena opsežnih spekulativnih rasprava kao uvoda u umijeće glazbe. Glazbena teorija kao spekulativna rasprava o porijeklu, ulozi i matematičkim aspektima glazbe više nije predstavljala metafizički temelj prakse. Ona je opstala kao opravdanje za praksu, ali ne i njezin uvjet. Praktično usmjerena pedagogija u 18. stoljeću dominirala je traktatima o glazbi. U smislu imenovanja stvari što je jedan od temeljnih zadataka klasičnoga diskursa kako ga vidi Michel Foucault, musica practica - teorija zvučeće glazbe, a ne musica theorica - teorija filozofije muzike, poznaje nomenklaturu i taksonomiju kao conditio sine qua non još od traktata Musica Enchiriadis i Scolica Enchiriadis. Međutim, nomenklatura kao imenovanje pojmova u slučaju musica practica ne pretendira na imenovanje njihove biti. Ona pomaže klasifikaciji i taksonomiji, pojednostavljuje opis i razumijevanje, ali ne nastoji biti ontologija koja je, prema Foucaultu, temelj zapadnoga diskursa 17. i 18. stoljeća. ${ }^{428}$ Iznalaženje biti glazbe za kršćanstvo pripada teologiji: njezina uloga - makar implicitna, neiskazana u svakom od postojećih priručnika za praksu - jest uloga poveznice između Boga i čovjeka, ovozemaljskog i svemira, između fizičkog i metafizičkog, između broja i zvuka. Uloga koju joj je namijenio još Platon, a prigrlilo kršćanstvo kroz razmatranja Svetog Augustina i koja je iznova i iznova, bez obzira na svu raznolikost njezina zvučanja, potvrđivana brojnim crkvenim dokumentima i stotinama tekstova koji su joj posvećeni.

Ipak, suživot ostataka spekulativne tradicije koja se, u velikoj mjeri lišena ozbiljnih matematičkih rasprava o broju kao temelju glazbe (tu će raspravu opet pokrenuti francuski teoretičari, osobito Jean Philippe Rameau), zadovoljava lamentacijama o glazbi kao poveznici između zemaljskog i nebeskog, metafizičkog i fizičkog, o glazbi kao spasonosnom Božjem daru, omogućit će opstanak tumačenja glazbe putem veza sličnosti (similitudo). Tu sličnost, međutim, neće argumentirati na način prirodnih znanosti koje je traže i pronalaze u vizualnoj podudarnosti srodnih stvari, već kao doživljaj koji se stoljećima prenosi na isti način pri čemu se ne propitkuje srodnost glazbenih djela koji ga uzrokuju. Povezanost neba i zemlje putem glazbe koje se očituje olakšanjem od nelagode, brige, srdžbe, tuge i usmjeravanjem prema

\footnotetext{
${ }^{428}$ Usp. Foucault, Michel.Oop. cit. Str. 136.: „La tâche fondamentale du „discours“ classique, c'est d'attribuer un nom aux choses, et en ce nom de nommer leur être. Pendant deux siècles, le discours occidental fut le lieu de l'ontologie. Quand il nommait l'être de toute représentation en general, il était philosophie: théorie de la connaisance et analyse des idées. Quand il attribuait à chaque chose représentée le nom qui convenait et que, sur tout le champ de la représentation, il disposait le réseau d'une langue bien faite, il était science - nomenclature et taxinomie.“
} 
„,sretnim nebeskim otocima“, kako nas podučava uvodnik prvome izdanju CO, jednako se očituje u glazbi koju čuje Amfion ili Orfej, kralj David i vjernici u Zagrebačkoj katedrali u 18. stoljeću. Kakva je ta glazba uistinu, pisce o njoj ne zanima. Oni pišu o glazbi koju slušaju i čuju, koju žele prenijeti mladima i učvrstiti kao zajedničku glazbenu baštinu što većeg broja ljudi. To je glazba katoličke liturgije gdjekad lokalno obojena, ali u svakom slučaju prihvatljiva kleru i svima koji brinu o katoličkoj obnovi i na glazbenom planu. Katolicizam je čini univerzalnom i stoga o njoj, ma kako u stvarnosti uistinu zvučala, podjednako mogu pisati austrijski, talijanski i hrvatski kapelnik. 


\section{PETO POGLAVLJE: DISKURS III SIMILITUDO MATER VERITATIS}

„Similitudo autem in contrariis, et ex paribus, in eis rebus quae sub eandem rationem cadunt maxime spectatur.“

„Omne autem (ut certas quasdam in partes tribuamus) probabile quod sumitur ad argumentationem aut signum est aut credibile aut iudicatum aut comparabile.“

Ciceron, De Inventione, XXX, 46-48 429

S obzirom na široko postavljenu definiciju teorije glazbe do kraja 18. stoljeća koja obuhvaća raznolike tipove diskursa o glazbi uključujući, uz normativni, i onaj o musica theorica kao disciplini kvadrivija te etičko-estetički koji raspreda o njezinoj ulozi i svrsi, predgovore zbornicima Cithara octochorda također smo uvrstili u ovo istraživanje. Ti predgovori, kao i drugi slični tekstovi objavljeni u zbornicima diljem Europe, apologetski oblikovanim diskursom brane i promiču crkvenu vokalnu glazbu zagovarajući mnogobrojnim primjerima iz mitologije, Starog i Novog zavjeta njezin opstanak. Budući lišeni obaveze prenošenja normativnog znanja, strukturirani su drugačije od tekstova koji objašnjavaju teoriju u priručnicima za gregorijansko pjevanje. Osnovni njihov cilj jest zahvala meceni koji je omogućio objavljivanje djela, eventualni opis procesa njegova nastanka te objašnjenje svrhe sadržaja koji slijedi, u ovom slučaju uloge liturgijske glazbe. Tekst predgovora priručniku Fundamentum cantus gregoriani seu choralis Šiloboda-Bolšića donekle je srodan predgovorima CO, no znatno je kraći. Compendiosa in cantum gregorianum seu choralem koja se, pridodana Psalteriju-Antifonalu iz 1742., u zagrebačkoj prvostolnici vrlo vjerojatno koristila kao priručnik za učenje pjevanja, ima vrlo kratak uvod (Introductio) u kojem je izložena namjera olakšavanja korištenja $P A$ kratkom temeljnom podukom. Spomenute predgovore zbornicima $\mathrm{CO}$, s obzirom da se u mnogim analizama toga zbornika kao jedan od

\footnotetext{
${ }^{429}$ Cicero. De Inventione. LCL: 386, 86-87. URL: https://www.loebclassics.com/view/marcus_tullius_cicerode_inventione/1949/pb_LCL386.87.xml (04.11.2020.),_Sličnost se pronalazi ponajviše u suprotnostima, u analogijama i u stvarima koje podliježu istom principu.“; „A sve vjerojatno (da ga podijelimo na određene dijelove) što se koristi u argumentu je ili znak ili vjerojatnost ili ono na temelju čega se može prosuditi ili ono što se može usporediti.“
} 
mogućih uzora u sastavljanju zbornika navodi Lyra Coelestis objavljena u Trnavi $1695 .{ }^{430}$, usporedit ćemo s Uvodom (Proemium) i Predgovorom pjevaču ili čitatelju (Praefatio ad Cantorem seu Lectorem) toga izdanja. Ono što je zajedničko ovoj vrsti diskursa jest argumentacija utemeljena na sličnosti (similitudo) koju Foucault pripisuje renesansnoj epistemi. No, sličnost je temelj na kojem počiva objašnjenje svijeta i svih pojava u njemu još u srednjemu vijeku. Similitudo uistinu jest, ne samo za 16. stoljeće, već i za srednji vijek, ali i kasnu antiku način razumijevanja svega svijeta i majka istine - mater veritatis. Usporedba na temelju sličnosti afirmira se kao ključni tip argumentacije u sastavljanju govora, a cilj je kreiranje argumentacije po principu analogije. ${ }^{431}$ Afirmirao ju je Platon, a za patristiku i srednjovjekovne komentatore od posebne su važnosti rimski retoričari Ciceron i Kvintilijan.

Ciceron o pojmu sličnosti (similitudo) govori na mnogo mjesta u retoričkim spisima, mladenačkom djelu De Inventione i kasnijem De Oratore čiji je utjecaj tijekom srednjega vijeka i renesanse teško precijeniti. Oba su, uz Pseudo-Ciceronovu Rethorica ad Herennium, Boetijev tekst De topicis differentiis i Aristotelovu Retoriku u prijevodu Hermana Alemana s arapskog i Wilhelma von Moerbekea s grčkog, zauzimala važno mjesto u skolastičkom obrazovnom sustavu, inicirala bezbrojne komentare srednjovjekovnih i renesansnih učenjaka te postala temeljem ne samo za promišljanje sličnosti kao veze među pojmovima $i$ stvarima. ${ }^{432}$ De Inventione uz definiranje pojma sličnosti i onoga što se može uspoređivati (comparabile), presudan je i za definiranje podjednako važnog pojma u teoriji retorike, ali i

\footnotetext{
${ }^{430}$ Usp. npr. Špralja, Izak. Povijesna situiranost gregorijanskoga pjevanja. // Cithara octochorda. Komentari $i$ studije. / uredili Moguš, Milan; Županović, Lovro. Zagreb: HAZU; Institut za crkvenu glazbu „Albe Vidaković“ KBF; HDCG. 1998. str. 221-250. Kniewald u studiji „Himnodija zagrebačke stolne crkve“ objavljenoj u zborniku Kulturno povijesni zbornik zagrebačke nadbiskupije I. Zagreb. 1944. str. 339-408. kao mogući izvor uz Lyra coelestis navodi i raniji trnavski zbornik Cantus Catholici objavljen u četiri izdanja 1651., 1674., 1675. i 1700. Minucioznom usporedbom napjeva CO i CC koje je proveo Izak Špralja, utvrđeno je, međutim, kako spomenuti zbornici nisu dominantni izvor za napjeve objavljene u CO. Usp. Županović. op. cit. str. 210. CC u verziji iz 1674. koju omogućuje digitalizirani arhiv Mađarske nacionalne sveučilišne knjižnice Hungariana nema predgovora već zbornik počinje adventskim napjevima na latinskom i mađarskom jeziku. Usp. Cantus catholici. Kassa 1674. - RMK I. 1159 - EOK R 244. URL:

https://library.hungaricana.hu/en/view/EvangelikusMuzealisKonyvek_EOK_R_0244/?pg=0\&layout=s (29.12.2019.)

${ }^{431}$ Paul Bartha u enciklopedijskom članku o analogiji veli: „An analogy is a comparison between two objects, or systems of objects, that highlights respects in which they are thought to be similar. Analogical reasoning is any type of thinking that relies upon an analogy. An analogical argument is an explicit representation of a form of analogical reasoning that cites accepted similarities between two systems to support the conclusion that some further similarity exists. In general (but not always), such arguments belong in the category of ampliative reasoning, since their conclusions do not follow with certainty but are only supported with varying degrees of strength." Usp. Bartha, Paul. Analogy and Analogical Reasoning. // The Stanford Encyclopedia of Philosophy (Spring 2019 Edition) / uredio Edward N. Zalta. URL: https://plato.stanford.edu/archives/spr2019/entries/reasoning-analogy/ (17.11.2019.)

${ }^{432}$ Usp. Fredborg, Karin Margareta. The Scholastic Teaching of Rhetoric in the Middle Ages. // Cahiers de l'institut du Moyen Âge grec et latin. Université de Copenhague, vol. 55 (1987). Str. 85-105. URL:

http://opac.regesta-imperii.de/lang_de/anzeige.php?pk=459433 (03.12.2020.)
} 
teorije književnosti općenito: pojma općeg mjesta (locus communis) koji omogućava uspostavljanje veze između brojnih tekstova nudeći uvid u zajednički obrazovni i kulturološki temelj kršćanske Europe. 433

O uočavanju sličnosti u prvoj rečenici gornjega citata Ciceron veli: „No sličnost je ponajviše vidljiva u stvarima koje su suprotne jedna drugoj, ili su jednake jedna drugoj, u stvarima koje podliježu istom principu.“

„No, (kako bismo ovo mogli podijeliti na određeni način) ${ }^{434}$ sve vjerojatno što se koristi u argumentaciji je ili znak, ili nešto vjerodostojno, ili nešto na temelju čega se donosi sud ili nešto što se može usporediti s nečim drugim.“

U spisu De Inventione definicija sličnosti je općenita i ukazuje na odnos sličnosti. Odnos sličnosti uočava se procesom usporedbe (comparatio), a usporedivost (comparabile) je „quod in rebus diversis similem aliquam rationem continet" - ono što u različitim stvarima čuva nekakav sličan odnos. ${ }^{435}$ Usporedba koja proizlazi iz mogućnosti uspoređivanja jest način na koji vezu sličnosti uspostavljaju i predgovori CO, predgovor priručniku Fundamentum, kao i ostali tekstovi utvrđeni kao njihov izvor u dijelovima u kojima govore o svrsi glazbe.

\section{Upućujući na Platona kao izvor, sveti Augustin u tekstu Contra academicos uspostavlja} neraskidivu vezu između istine, koja je besmrtna i stanuje u svijetu koji spoznajemo razumom te svijeta sličnog spoznajnome svijetu, koji spoznajemo vidom i dodirom i koji je sličan onom

\footnotetext{
${ }^{433}$ Rubinelli, Sara. Ars Topica: The Classical Technique of Constructing Arguments from Aristotle to Cicero. Springer, 2009. Str. 94.: ,When Cicero was still a young student, he began an ambitious rhetorical treatise which has been transmitted as De Inventione. He never completed the treatise and he himself in a later work speaks of it as a book of his adolescence. Yet, rudimentary as it may have been, during the Middle Ages and Renaissance De Inventione was considered Cicero's main work on rhetoric, and it still nowadays offers an intelligent overview of the standard rhetorical theory of Cicero's time.“
}

${ }^{434}$ Ciceron misli na argumentaciju koja slijedi definiciju sličnosti i prethodi ovoj rečenici. Usp. Cicero. Op. cit.: „In contrariis, hoc modo: "Nam si iis, qui inprudentes laeserunt, ignosci convenit, iis, qui necessario profuerunt, haberi gratiam non oportet." Ex pari, sic: "Nam ut locus sine portu navibus esse non potest tutus, sic animus sine fide stabilis amicis non potest esse." In iis rebus, quae sub eandem rationem cadunt, hoc modo probabile consideratur: "Nam si Rhodiis turpe non est portorium locare, ne Hermocreonti quidem turpe est conducere." Haec tum vera sunt, hoc pacto: "Quoniam cicatrix est, fuit vulnus"; tum veri similia, hoc modo: "Si multus erat in calceis pulvis, ex itinere eum venire oportebat."

${ }^{435}$ Usp. Berteau, Rolande. Similitudo. // L'antiquité classique. Tome 48, fasc. 1, 1979. Str. 154-160. URL: https://www.persee.fr/doc/antiq_0770-2817_1979_num_48_1_1936 (11.09.2020.): „Si similitudo exprime le rapport de ressemblance, comparabile semble bien signifier l'expression globale des domaines rapprochés et de leur point commun. Dans le De oratore, similitudo est le terme de comparaison le plus employé et sa polyvalence sémantique est remarquable : il désigne soit la relation de ressemblance, soit le lieu commun basé sur cette dernière soit la comparaison rhétorique." 
istinitom (verisimile). ${ }^{436}$ Sličnost je, dakle, temeljna veza dvaju svjetova, onoga koji pokušavamo dokučiti razumom i ovoga koji vidimo i osjećamo, nevidljivog i vidljivog. Stoga rasprava o similitudo često odjekuje u filozofskim raspravama srednjega vijeka. „Kao prvo, povezana je ontološki s hijerarhijom bića u razlikovanju spoznajnog i osjetilnog svijeta. Kao drugo, izravno je dovedena u odnos s pitanjem spoznaje Boga i spoznaje sebe. “437 Odnos koji je, oslanjajući se na Platona, uspostavio sveti Augustin postao je temeljem argumentacije u filozofiji općenito, ali i u glazbi. Glazba je čujni odraz nečujnoga, veza s nebeskim zborom anđela, izravni put do Boga.

Pošto smo u trećem poglavlju analizirali cognitio auctorum, a u četvrtom načine regulacije i klasifikacije predstavljenoga znanja, u ovom ćemo poglavlju pažnju usmjeriti na načine razumijevanja i objašnjavanja važnosti glazbe, njezine uloge i svrhe u ljudskom životu istražujući, kao i u prethodnim poglavljima, uzore za postojeći diskurs. Tekstovi predgovora, pritom, budući dijelom iznimno popularnog zbornika liturgijske glazbe, primjer su mišljenja o glazbi kao o praktičnom fenomenu, ali i zalihe pripovijesti koje se smatraju relevantnima i stoljećima opstaju kao važan dio književnog i muzičkog naslijeđa.

Budući da njihov cilj nije prenošenje konkretnoga znanja, već promicanje važnosti vokalne glazbe, odnosno privlačenje pažnje čitatelja/pjevača/slušatelja na sadržaj koji mu slijedi, cjelina teksta pažljivo je oblikovana poštujući onodobna retorička pravila. Poštujući važnost retorike u crkvenom obrazovanju te, posljedično i u oblikovanju ovih tekstova, istraživanje smo usmjerili u četiri glavna smjera: analizu predgovora (praefatio) kao žanra tipičnog za renesansnu i baroknu literaturu, njegovo oblikovanje koje reflektira snažan utjecaj antičkog, odnosno skolastičkog retoričkog naslijeđa. To se naslijeđe uočava i u korištenju općih mjesta

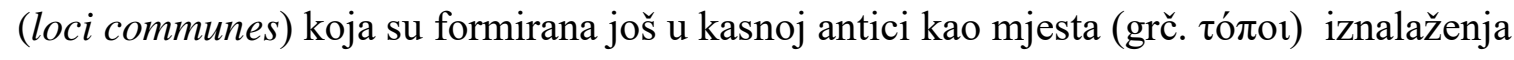
argumenata u retorici, ali i u dijalektici. Potom se analizira svrha tako napisanih tekstova koja se može obuhvatiti pojmom korisnosti (utilitas) i na koncu model argumentacije koji počiva na sličnosti (similitudo).

\footnotetext{
${ }^{436}$ Augustini Contra Academicos 6. III, 17, 37. URL: https://www.documentacatholicaomnia.eu/04z/z_03540430_Augustinus_Contra_Academicos_Libri_Tres__MLT.pdf.html (11.09.2020.): « Sat est enim ad id quod uolo, Platonem sensisse duos esse mundos: unum intelligibilem, in quo ipsa ueritas habitaret; istum autem sensibilem, qui manifestum est nos uisu tactuque sentire. Itaque illum uerum, hunc ueri similem et ad illius imaginem factum."

${ }^{437}$ Doucet, Dominique. Similitudo mater veritatis, dissimilitudo mater falsitatis. // Archives de Philosophie, 61/2, 1998. Str. 269-291. URL: http://www.jstor.org/stable/43037672 (16.09.2018.): „Elle se trouve liée premièrement ontologique de la hiérarchie des êtres dans la distinction monde intelligible et le monde sensible. Deuxièmement, elle est directement mise en rapport avec la question de la connaissance de Dieu et de la connaissance de soi ..."
} 
Predgovor je tipičan žanr renesanse i baroka koji u našem slučaju nadilazi puku uvodničarsku zahvalu pisca mecenama i/ili skicu djela kojemu prethodi te promovira obnoviteljska nastojanja Katoličke crkve. Osim toga, koristi se i kao poligon za opomenu ili pohvalu uglednih članova društva, obračun s neistomišljenicima ili izlaganje mišljenja o temama kojima nije mjesto u glavnom tekstu.

Opća mjesta (loci communes ili topoi) reflektiraju oslanjanje pisca na tradiciju pisanja predgovora oblikovanu još u kasnoj antici ${ }^{438}$ te ustrajavanje mitoloških i religijskih pripovijesti (o glazbi) što s formalne i sadržajne strane ukazuje na očuvanje srednjovjekovnog modela mišljenja.

Korisnost (utilitas) kao temeljna odrednica velikog dijela literature objavljene u zemljama Habsburške monarhije tijekom 18. stoljeća proizlazi iz rastuće političke svijesti o potrebi za obrazovanjem što većeg broja stanovništva kroz prizmu katoličke obnove i uspostavom čvršćeg, centraliziranog sustava upravljanja kakav priželjkuje Bečki dvor. Ona se iskazuje dvojako: kao društvena korisnost - obrazovanje novih pjevača i sudjelovanje širih slojeva društva u obredima čime se u konačnici podržava crkveni i politički sustav u kojem pisac djeluje - i kao osobna korisnost - glazba i umjetnost općenito kao put prema postizanju moralnih odlika koje će pojedincu omogućiti primjereniji i ugodniji život i, najvažnije, spas duše, odnosno jedinstvo s Bogom.

Sličnost (similitudo) kao veza između stvari i analogija kao argumentacija na temelju sličnosti kojom se objašnjava i razumijeva svijet, pa onda i glazba u njemu, opstaje kao dominantni tip argumentacije u mnogim tekstovima sve do kraja 18. stoljeća. U glazbenoj teoriji koja je snažno vezana uz kršćansku ideologiju, budući da je Katolička crkva najrasprostranjeniji poslodavac glazbenicima, a crkveni obredi najsigurnije mjesto za stjecanje glazbenog iskustva - slušalačkog i izvodilačkog, ovaj tip argumentacije opstaje i kad u drugim područjima znanja počinje dominirati argumentacija temeljena na dedukciji. Pritom se sličnost iskazuje kao temeljni način tumačenja u dva osnovna modela naslijeđena iz srednjovjekovnog sustava razumijevanja svijeta: metafizičke pansemioze i univerzalnog alegorizma. ${ }^{439}$

\footnotetext{
${ }^{438}$ Usp. Janson, Tore. Latin Prose Prefaces. Studies in Literary Conventions. Stockholm, Göteborg, Uppsala: Almqvist \& Wiksell, 1964.

${ }^{439}$ Metafička pansemioza i univerzalni alegorizam pojmovi su koje koristi Umberto Eco u knjizi Umjetnost $i$ ljepota u srednjovjekovnoj estetici. Metafizička pansemioza ili metafizički simbolizam označava razvoj predodžbe „o simbolu kao pojavi ili izrazu koji nas upućuje nekoj mračnoj, riječima (a još manje pojmovima) neiskazivoj stvarnosti“ od antike do renesanse. Ta se metafizička semioza ,pretače u teoriju analogia entis, i prema tome razrješava se u semiotičkoj viziji univerzuma u kojemu je svaka posljedica znak vlastita uzroka.“
} 


\subsection{Praefatio libri}

Predgovor djelu (praefatio) tipična je literarna forma renesanse i baroka, govor iz kojega možemo puno toga doznati o autoru, ali i o sadržaju koji ga slijedi. ${ }^{440}$ Praefatio je, veli Gérard Genette, jedan od pragova teksta. Duži uvodni tekst koji prethodi glavnom u slučaju latinskih predgovora proznim djelima najčešće nosi naziv praefatio libri, katkada i proemium, razlikujući se od cenzorovog odobrenja (approbatio censoris) ili posvete (dedicatio). ${ }^{441}$ Praefatio se u teoriji književnosti tretira kao zaseban žanr s obzirom na svrhu, zakonitosti formuliranja i obilnu upotrebu konvencija. U pozitivistički usmjerenim istraživanjima važan je i kao izvor podataka o autoru teksta. Gérard Genette ga uz posvete, marginalije, naslove, podnaslove i epigrafe, svrstava u paratekst kao jedan od pragova (fr. seuil, lat. limen) interpretacije glavnoga teksta koji obavijestima o djelu i autoru određuje izvjesna očekivanja čitatelja. ${ }^{442}$ Tvori ga „raznorodna skupina praksi i diskursa svih oblika“, a određenu stabilnost u formi i sadržaju, smatra Genette, pokazuje od sredine 16. stoljeća:

„poslije (vrlo duge) faze pretpovijesti o kojoj ću nešto malo reći, većina tema i postupaka u pisanju predgovora postoje već od sredine 16. stoljeća, a kasnije varijacije ne otkrivaju istinsku evoluciju, već prije niz raznovrsnih izbora u repertoaru koji je mnogo stabilniji no što bi se a priori moglo povjerovati, ...“443

\footnotetext{
Univerzalni alegorizam, veli Eco, utemeljen je pak na alegorizmu Svetog pisma i enciklopedijskom alegorizmu te kao takav omogućuje čitanje svijeta kao skupa simbola koristeći jezik po uzoru na Sveto pismo. Usp. Eco, Umberto. Umjetnost i ljepota u srednjovjekovnoj estetici (prev. Željka Čorak). Zagreb: IPU, 2007. str. 68-79. ${ }^{440}$ U kontekstu hrvatske književne historiografije Rafo Bogišić o posvetama i predgovorima veli: „Posvete i predgovori, odnosno uvodni napisi u književnim djelima, neobično zanimljiv i dragocjen instruktivan fenomen u pojavi i objašnjenju književnog postupka već u vremenima renesanse, u 18. će stoljeću umnogome proširiti i produbiti dimenzije autorova različita odnosa prema svom poslu. Posvete i predgovori u autora 18. stoljeća višestruko su značajni. ...", Bogišić, Rafo. Hrvatska književna historiografija 18. stoljeća. // Dani hvarskog kazališta. Hrvatska književnost uoči preporoda. Split: Književni krug, 1997. Str. 5-18. v. str. 6 i dalje.

${ }^{441}$ Introductio se nikada ne rabi za označavanje uvodnoga teksta koji ima funkciju predgovora. U srednjovjekovnim i novovjekovnim tekstovima na latinskom taj se izraz koristi najčešce u naslovima djela koja čitatelja uvode u određenu problematiku, npr. Ottonis Gibeli Introductio musicae theoreticae didactam. Bremae, 1660.; Christiani Tomasii introductio ad philosophiam aulicam ... . Halae Magdeburgicae, 1702.

${ }^{442}$ usp. Genette, Gérard. Seuils. Paris: Éditions du Seuil, 1987. Genette razlikuje tri tipa predgovora: originalni autorski predgovor, alografski i fikcionalni predgovor. Razlikuje, također, uvod (l'introduction) od predgovora (la préface) citirajući Jacquesa Derridau koji se pak poziva na Hegela diferencirajući ih prema razini veze s glavnim tekstom pri čemu je uvod manje historičan i manje upućuje na okolnosti nastanka djela, prikazujući arhitektonske, opće i suštinske probleme djela. Usp. Genette, Gérard. Op. cit. str. 150-151.

${ }^{443} \mathrm{Ibid}$. str. 152: „... apres une (très longue) phase de préhistoire dont je vais dire un mot, la plupart des thèmes et des procédés de la préface sont en place dès le milieu du XVIe siècle, et les variations ulterieures ne relèvent pas d'une véritable évolution, mais plutôt d'une serie de choix divers dans un répértoire beaucoup plus stable qu'on ne le croirait à priori, ... “Fazu pretpovijesti Genette vremenski smješta između Homera i Rabelaisa.
} 
Ipak, valja biti na oprezu. Kako će pokazati analiza općih mjesta u predgovorima hrvatskih pisaca, većina tema i postupaka u 18. stoljeću baština je ne samo 16. stoljeća, već se usporednice mogu pratiti sve do kasne antike. Osim toga, valja se podsjetiti da Genette prije svega analizira umjetničku književnost, dok se u našem slučaju radi o predgovorima glazbenim zbornicima i priručnicima. Uz to, bavi se književnošću na vernakularu što nerijetko utječe ne samo na izbor tema koje predgovor izlaže, već i na formulaičnost koja mu je inherentna. Genetteova definicija originalnog predgovora i njegove uloge u svakom nam slučaju pomaže:

„Autorski predgovor za koji se pretpostavlja da je originalan, naziv kojeg ćemo skratiti na originalni predgovor, kao glavnu funkciju ima osigurati tekstu dobru čitljivost.“4444

Na primjeru predgovora zborniku napjeva Cithara octochorda pokazat ćemo što za njegova pisca znači dobra čitljivost odnosno što se čitatelju/korisniku nudi, a što od njega očekuje. Predgovor je u našem slučaju prag na kojem otvaramo vrata prema glavnome sadržaju napjevima - i predvorje u kojem dobivamo uvid u etički, estetički i društveni okvir glazbene prakse. Budući da ne prethodi književnome tekstu, niti samo tekstu, već prije svega glazbi, postaje zanimljiv kao poseban tip diskursa o glazbenoj praksi, odnosno o napjevima katkada zapisanima i notama i tekstom, katkada samo tekstom uz napomenu na koju se melodiju pjevaju (ad notam).

Predgovor prvom izdanju CO nudi nam vrlo konkretan opis nastanka djela te zahvalu Ivanu Zniki koji se, doduše, ne navodi imenom i prezimenom, ali se zato vrlo precizno popisuju njegove zasluge za uređenje zagrebačkih crkava, širokogrudnost u podupiranju umjetnosti, kao i upućenost u aktualne umjetničke prakse:

„Quantum non tibi ab hinc Coelitum debebunt Basilicae! Quas, posteaquam tot sumptuosis ornasti decoribus $^{445}$; nunc etiam in Numinis, Superumque laudem vocales efficies.“

„... quam, etsi iam alias mole sua Coelo admotam, adhuc sublimius liberali tua dextera extollere non definis: dum, sui structura mirabilem, maiorem insuper iubes a novis operibus ciere admirationem."

\footnotetext{
${ }^{444}$ Ibid.: „La préface auctoriale assomptive originale, que nous abregerons donc en préface originale, a pour fonction cardinale d'assurer au texte une bonne lecture.“

${ }^{445}$ Cit. prema Šourek, Danko. Donatorska i naručiteljska djelatnost zagrebačkoga kanonika Ivana Znike. //

Tkalčić. Godišnjak Društva za povjesnicu Zagrebačke nadbiskupije, 9, 2005. Str. 327 - 410.
} 
„Humilitatem iam suam exuit ignoti fere hactenus nominis Pagus Urabche Caput quae supra totam viciniam attolit: postquam in medio illius, honori triumphalis Virginis \& Martyris Barbarae, magnificam ex fundamentis, praedivite Ara superbam \& figuratis laquearibus arcuatam aere proprio erexisti Basilicam.“

„Koliko li će Ti zbog toga dugovati bazilike nebesnika? Pošto si ih već uresio s toliko skupocjenih ukrasa, sada još i okupljaš glasove na hvalu Boga i Nebesnika.“

„Premda je već svojom veličinom blizu Nebu, Ti je svojom darežljivom desnicom ne prestaješ još više izdizati, dok zapovijedaš da, divna u svom zdanju, novim djelima izaziva još veće divljenje.“

„Svoje neznatnosti lišava se već i selo Vrapče, do sada gotovo nepoznatog imena, kao glava koja se izdiže iznad svega susjedstva, pošto si u njegovom središtu vlastitim novcem iz temelja podignuo veličanstvenu baziliku u čast slavne Djevice i Mučenice Barbare, koja se diči prebogatim oltarom i oslikanim kasetiranim svodom.“

Uređenje katedralne oltarne pregrade parskim mramorom, dotad neviđenim u Zagrebu, još je jedna od novina koje je Znika donio u Zagreb: „On će se, uvezen iz stranih zemalja za veliku svotu, izdići u obliku ograde izrađene kao prizor borbe grimiza sa snijegom."446

Predgovor drugom i trećem izdanju također daje precizne podatke o nastanku i namjeni zbornika za Zagrebačku biskupiju koja ,,[G]onjena [tom] revnošću i gorljivošću za predobivanje duša, [ona] često podnosi nemale žrtve (quo animarum lucrandarum zelo \& fervore mota, non leves duntaxat assumpsit saepe expensas). ${ }^{\text {‘447 }}$

„Sed nec hic suam sistit gloriam Divi Stephani Regis Basilica Zagrabiensis, dum eam videlicet tot praeclara sumptibus ejusdem erecta facinora laudibus exollunt, depraedicant tot ingeniosi labores ad avertendas culpas \& defectus, quos in DEI, Divorumque negligenti servitio comisere populi; ejus etenim munificam liberalitatem non parum honorabit opusculum hoc Citharae octochordae, quo dilectum suum populum DEO efficacius, \& intimius copulari desiderat, cujus aures, \& animus laudum Divinarum sono demulcitus, violam dein submissae reverentiae colligat, rosam amoris \& fiducia in DEUM odoret, lilia multiplicis obsequii Divini, \& integrae devotionis carpat.“

${ }^{446}$ CO I. Usp. Prilog 1. Prijepis predgovora prema primjerku CO I iz 1701. koji se čuva u Zbirci rijetkosti NSK pod signaturom RIID-8 ${ }^{\circ}-191$.

${ }^{447}$ Usp. Prilog 2. 
„Dobrotvornu darežljivost, na ime Zagrebačke crkve neće samo malo proslaviti ovo djelce Osmožične citare, kojim namjerava svoj mili narod djelotvornije i nježnije povezati s Bogom: uši će se i duh naroda raznježiti zvukom božanskih pohvala, a potom će brati ljubicu poniznoga štovanja i mirisati ružicom ljubavi i pouzdanja u Boga i trgati ljiljane raznovrsna bogoslužja i potpune pobožnosti.“

Uz hvalospjeve Zagrebačkoj biskupiji kao metafori njezinih uglednika što su prepoznali važnost objavljivanja zbornika crkvenih napjeva, sva tri izdanja (prvo nešto manje od preostala dva, ali podjednako eksplicitno) glazbu ističu kao vrijedan alat u procesu obraćenja ili pak jačanja pobožnosti čime se potvrđuje njezina bitna uloga u pastoralnom radu obnoviteljskog katolicizma.

Predgovor prvom izdanju, hvaleći nemale zasluge mecene Ivana Znike koji je, uz opsežan graditeljski rad u zagrebačkim crkvama, podupro i izdavanje $\mathrm{CO}$, obrazlaže njegovo mecenatstvo nastojanjem da „sva ljudska srca dođu u njegov kraljevski dvor“, budući da se ,[J]oš [se] više uzdiže zasluga svetog pjevanja, jer oduševljenje što ga ono stvara sjedinjuje ljudske duhove sa samim Bogom, kako je tvrdio Strabon“. 448

Predgovor drugom i trećem izdanju još je eksplicitniji jasno ističući zasluge Zagrebačke katedrale, pobožne i gorljive majke u poticanju na vrline, u čupanju mana, sprečavanju širenja krivovjerničke pokvarenosti, učvršćivanju i širenju bogoštovlja i katoličke vjere: „ea sit potius sollicida \& provida Mater, cujus zelo commendatur virtus, extirpatur vitium, cujus fervor non patitur haereticae pravitatis propaginem, cujus studio Divini cultus, \& Catholicae Religionis Sanctitas pro viribus firmatur, $\&$ amplificatur“، ${ }^{449}$

To čini, dakako, uz pomoć prigodnih propovijedi, ali i vokalne glazbe. Stoga će njezinu darežljivost u potpori izdavanju CO proslaviti narod koji će se uz pomoć glazbe „djelotvornije i nježnije povezati s Bogom: uši će se i duh naroda raznježiti zvukom božanskih pohvala“:

\footnotetext{
${ }^{448}$ Usp. Prilog 1. „Parum dixi; altius assurgit sacrae hymnodiae meritum: cuius voluntate cum ipso Deo coniungi animos, Strabo asseruit.Cor tuum, Reverendissime Domine, iam captum teneo. Dum Musici concentus praerogativa Divina humanis uniri dixi. Nam, quemadmodum Cor Tuum sibi totum Deus vindicat. Sic universorum cupis pectora in illius abire Regiam.“

${ }^{449}$ Usp. Prilog 2.
} 
„,ejus etenim munificam liberalitatem non parum honorabit opusculum hoc Citharae octochordae, quo dilectum suum populum DEO efficacius, \& intimius copulari desiderat, cujus aures, \& animus laudum Divinarum sono demulcitus ... “450

Njezina je moć, dokazuje brojnim primjerima pisac, čudesna u privlačenju ljudi Bogu, stoga je i uspjeh CO zajamčen, ,jer kad Anđeli zborno pjevaju, Bog se silno naslađuje. On svoje predrage službenike običava preko anđeoskog pjevanja izvanredno pozivati k nebeskim radostima“.

„Quare si miram plane, \& deliciosam musica vocalis habet virtutem, quantam quaeso non est adeptura efficaciam, haec nostra Cithara octochorda, trahendi ad DEUM hominum Corda? Utpote qua musica; Angelorum videlicet concentibus, DEUS ipse mirifice delectatur, \& suos Charissimos servos ordinarie per Angelorum cantum ad Coelestia gaudia eliminaliter solet evocare ..." ${ }^{\text {451 }}$

Pritom, s obzirom na sadržaj zbornika koji donosi napjeve, a ne instrumentalne skladbe sukladno uputama Tridentskoga koncila, vokalna glazba, odnosno gregorijansko pjevanje kakav se izvodio u 18. stoljeću te nabožni narodni napjevi, predstavljaju ideal muziciranja u sklopu liturgije: upućuju na pjev anđela. Pisac predgovora, međutim, ne govori potanko o glazbi kakvu zbornik donosi i kakvu valja izvoditi kako bi vjernici valjanije sudjelovali u liturgiji te povećali izglede za vječni spas. Jedino što doznajemo jest da je riječ o napjevu (cantus), odnosno o vokalnoj glazbi (musica vocalis). No, u nizanju primjera koje navodi kako bi čitatelja upoznao s nizom sjajnih efekata koje je glazba imala na čovjeka, cantus postaje musica općenito, a pisac se ne libi navoditi niti pripovijesti u kojima je ključnu ulogu odigrala instrumentalna glazba:

„Quid obsecro Elisaeum requisitum a Regibus futuri belli exitum pronuntiare fecit, nonne dulce Psaltis modulamen? Elisaeus enim jussit sibi Psaltem adduci teste Biblia Sacra, quo psallente facta est super eum manus Domini statimque Divinum Prophetiae Spiritum recepit. Quae virtus a Rege Saul malignum spiritum propulsavit, nonne Cithara Davidica dulci harmonia pulsata?“

„Što je, molim, navelo proroka Elizeja da se, na traženje kraljeva, izjasni o ishodu budućega rata? Slatko sviranje svirača, zar ne? Elizej je, naime, kako svjedoči Biblija, zatražio da mu se

\footnotetext{
${ }^{450}$ Ibid.
}

${ }^{451}$ Ibid. 
dovede svirač te, dok je ovaj udarao u glazbalo, siđe ruka Gospodnja nad njega te je odmah primio Svetoga Duha Proroštva. Kojom je snagom od kralja Šaula protjeran zloduh? Zar ne Davidovom citarom koju je on milozvučnim skladom prebirao?“

Takav postupak ukazuje na ignoriranje distinkcije između vokalne, vokalno-instrumentalne ili instrumentalne glazbe bilo stoga što svu glazbu smatra jednako sposobnom pružiti utjehu i mir te povećati pobožnost, bilo stoga što argumentaciju u prilog izvođenju glazbe nalazi u zalihi pripovijesti koje kultura 18. stoljeća baštini iz skolastičkog sustava obrazovanja koji uz Bibliju favorizira, kroz filter kršćanstva propuštenu antičku mitologiju i književnost. Snaga skolastičkim autoritetima potvrđene argumentacije ne propitkuje se u pojedinostima, već postaje opće mjesto govora o glazbi.

Sadržaj predgovora CO, kao i njegova dispozicija, jedva da imaju dodirnih točaka s glazbenoteorijskim traktatima koji nude znanje nužno za praktično muziciranje, no cilj im je isti: afirmacija gregorijanskoga pjevanja. I u analiziranim predgovorima kompilacija je metoda kojom pisci potvrđuju vlastitu načitanost, no, s obzirom da je riječ o tekstu koncipiranom prema retoričkim principima sklapanja govora, navođenje autora od kojih su pripovijesti preuzete nije nužno. Te pripovijesti tvore zalihu, usudili bismo se reći, popularnog govora o glazbi koji joj u društvu osigurava važno mjesto. Kompilacija ovdje nije u službi prezentacije znanja, već snaženja poticaja na muziciranje u svrhu jačanja pobožnosti.

\subsubsection{Retorika katoličke obnove}

Nadalje, valja razjasniti mjesto koje zauzimaju predgovori kojima se bavimo u suvremenoj distribuciji znanja, odnosno aktualnoj podjeli humanističkih znanosti. Unatoč mnogim definicijama koje književnost definiraju kao sve napisano u određenom kulturnom krugu, smatramo da je pojam književnost bolje izbjeći kada se govori o tekstovima kojima se bavimo u disertaciji, bez obzira na njihove umjetničke (ne)kvalitete. Ponajprije stoga što glazbenoteorijski tekstovi nisu zamišljeni kao umjetničke tvorevine, (premda je željeni cilj umijeće pjevanja!), već kao prosvjetiteljska i pedagoška djela. Za predgovore $\mathrm{CO}$, među kojima je tekst objavljen u drugom (1723.) i trećem izdanju (1757.) primjer dosta uspjelog retoričkog umijeća, ipak je, čini se, presudna njihova društvena, politička i teološka uloga parateksta zborniku liturgijskih i paraliturgijskih napjeva. Uz to, pojam književnosti je za prvu polovicu 18. stoljeća anakron u smislu u kojem se profilira u 19. stoljeću, budući da literatura 
u 18. stoljeću obuhvaća i retoriku, gramatiku, pravo, historiografiju, geografiju pa onda i muzičkofilozofske i glazbenoteorijske rasprave, kao i enciklopedije i rječnike. ${ }^{452}$

Predgovore CO i predgovor priručniku Šiloboda-Bolšića moguće je opisati kao (na)govore adhortativnog karaktera kojima je, uz zahvalu zaslužnima za moralnu i financijsku potporu djelu, svrha prije svega potaknuti i ohrabriti na korištenje sadržaja koji u knjizi slijedi. Retorički jasno strukturirani prema naslijeđenom antičkom, a u renesansi iznimno omiljenom modelu čiji su temelj Ciceronovi govori, predstavljaju zanimljiv primjer onoga što Benoît Timmermans naziva protureformacijskom baroknom retorikom koju u kontekstu sjeverne Hrvatske u prvoj polovici 18. stoljeća možemo nazvati retorikom katoličke obnove. ${ }^{453}$ Ona se koleba u sukobu ciceronovaca kao promicatelja patosa i anticiceronovaca koji su od govornika zahtijevali moral, odmjerenost, vjerodostojnost $\mathrm{i}$ istinu, odnosno etos kao polazište i svrhu govora. ${ }^{454}$ Naime, ,[V]rednovanje propovjedništva, sumnja u osobnu meditaciju; protureformacija, dakle, posvuda daje pravo glasa retorici kao militantnom sredstvu okupljanja stada, ponovnog osvajanja izgubljenih duša. No to ne znači da je ona posve jedinstvena ili jednolična fronta. ... Među reprezentativnim protureformacijskim retorikama pojedine će biti vjernije ciceronskoj struji jer su zaokupljene učinkovitošću ... “455 Pri analizi predgovora koji glazbu vrednuju na temelju pripovijesti iz antičke mitologije, starozavjetnih priča i svetačkih legendi, na prvi je pogled vrlo teško suditi o iskazanome moralu, odmjerenosti, vjerodostojnosti i istinitosti govornika, odnosno pisca kako bi se procijenila

\footnotetext{
${ }^{452}$ Nebrojeni su autori definirali pojam književnosti oslanjajući se redovito na umjetničko kao temeljni atribut književnih tekstova. Rene Wellek u knjizi Theory of Literature književnost suprotstavlja znanosti o književnosti, a ne literaturi te je definira kao kreativnu aktivnost i umjetnost (usp. Wellek, Rene; Warren, Austin. Theory of Literature. NY: Harcourt, Brace and Company, 1948. Str. 3.). Milivoj Solar u priručniku Teorija književnosti piše: „Najčešće se tako riječ 'književnost' i u svagdašnjem govoru i u znanosti upotrebljava u užem smislu: misli se na one jezične tvorevine koje se razlikuju i od svagdašnjeg, običnog govora i od govora u svim onim ljudskim djelatnostima koje nemaju osobitu umjetničku svrhu i funkciju.“, Solar, Milivoj. Teorija književnosti. ŠK: Zagreb. 2005 20. Str. 9. Drugi su pak, na što upućuje i prva definicija u Hrvatskoj enciklopediji, književnost određivali sveukupnošću napisanoga u nekoj kulturi: „Sveukupnost pisanih djela, dokumenata, spomenika jednoga kulturnoga kruga.“, usp. Književnost. Hrvatska enciklopedija, mrežno izdanje. URL: https://www.enciklopedija.hr/Natuknica.aspx?ID=32128 (5.09.2019.) Ovakvu definiciju nudi većina općih enciklopedija, a široko je razumije i suvremeni filozof i teoretičar Peter Lamarque smatrajući da bi se sva pisana djela bez obzira na vrstu ako su dobro napisana, lijepo izrađena i krasi ih rječitost mogla imenovati kao književnost. Usp. Lamarque, Peter. Philosophy of Literature. Oxford: Blackweill Publishing. 2008. str. 29. ${ }^{453}$ O problemu imenovanja razdoblja v. „Prvo poglavlje: zemljopisno i povijesno situiranje“, str. 7-9.

${ }^{454} \mathrm{O}$ apsurdnoj situaciji u kojoj se našla renesansna, a potom i barokna retorika zbog zamjene teza u kojoj se originalni Ciceronov zahtjev za etosom nauštrb patosa izvrće te se ciceronovcima nazivaju oni koji plediraju za svrhovitost govora/teksta koji će ganuti (movere) duše, a anticiceronovcima oni koji izvještačenost i pretjeranu stilizaciju govora smatraju zlom koje narušava nužnu moralnost i istinitost teza govornika, usp. Meyer, Michel; Carrilho, Manuel Maria; Timmermans, Benoît. Povijest retorike od Grka do naših dana (prev. Vanda Mikšić). Zagreb: Disput, 2008. Str. 87-103. Općenito o retorici, njezinoj povijesti, ključnim tekstovima, mjestu u obrazovanju, itd. usp. A Companion to Rhetoric and Rhetorical Criticism / uredili Walter Jost; Wendy Olmsted. s. 1.: Blackwell Publishing. 2004.

455 Ibid. Str. 103 - 104.
} 
njegova retorička pozicija. No, poznato je da su Stari i Novi zavjet, ali i antička mitologija i pripovijesti o svecima, većini ljudi u prvoj polovici 18. stoljeća predstavljali često jedine, a samim tim i neupitno istinite izvore za razumijevanje i objašnjavanje svijeta u kojem su živjeli. U tom smislu, citati i parafraze iz spomenute baštine svojevrsna su garancija vjerodostojnosti pisca, ali i učinkovitosti govora. Važno je, također, u analizi dominantnog retoričkog modela u objavljenim tekstovima, uzeti u obzir utjecaj isusovačkog obrazovnog modela koji je u hrvatskim zemljama (ali i u ostalim zemljama Habsburške monarhije!) bio vrlo snažan. Isusovački je Ratio studiorum, podsjeća Timmermans, označio ,povratak humanističkim studijima nauštrb znanosti, povratak poetici i retorici nauštrb logike i filozofije. “456 Niz objavljenih priručnika iz retorike od početka 17. pa sve do sredine 18. stoljeća potvrđuje kontinuitet u sadržaju predmeta čija je glavna misija „očuvati interese pape i monarhija koje ju podržavaju“457. Ta je misija ispunjena pošto je ispunjen zahtjev za objavljivanjem, u okviru spomenutih interesa, korisnih djela. Bez sumnje, zahtjev Katoličke crkve za revitalizacijom pastorala i unifikacijom obreda kao važnog načina očuvanja jedinstva Crkve, a time i papinskog utjecaja svakako se dijelom ispunjava i putem poduke u liturgijskom pjevanju i širenjem nabožnih pjesama u narodu.

S obzirom na činjenicu da su poetika i retorika ponovno zauzele važno mjesto u obrazovanju domaćih klerika obrazovanih u Zagrebu, ali i ilirskim kolegijima u Beču i Bologni, nesumnjivo su utjecale i na način govora o glazbi u kojem nalazimo poetiziranje izričaja, odnosno Timmermansovim riječima, prevagu patosa nad etosom. Predgovor prvom izdanju CO kraći je i siromašniji primjerima o spasonosnim učincima glazbe na čovjekovu dušu. On je prije svega hvalospjev Ivanu Zniki i njegovu mecenatskom djelovanju, a tek potom, $\mathrm{u}$ kontekstu Znikinih neizmjernih obnoviteljskih i graditeljskih zasluga, pohvala glazbi kao spasiteljici duše. No i taj je predgovor odraz isusovačke retoričke poduke koja efektno osmišljenim rečenicama, obiljem metafora i alegorija potvrđuje njezinu važnost $u$ obrazovanju pisaca 17. i 18. stoljeća. O meceninim sjajnim pothvatima propovjedaonica Katedrale govori vlastitom ljepotom i stidi se prvog umjetnika koji ju je izradio, mramor se znoji pod dlijetom i čekićem, a njegov sjaj sličniji je ogledalu no kamenu:

„In hac beneficentiam tuam, tacente quamquam Ecclesiaste, non muta declamabit Exedra: in cuius elegantiorem fabricam, peregrinam a remotioribus Oris, cum Pario, Lybicoque marmore evocasti Architectonicam. Pudet iam suae artis Protogenem: visoque tam ordinato in saxea

\footnotetext{
456 Ibid.

${ }^{457}$ Ibid.
} 
hac mole colorum certamine, victum indignabunda manu prope excussit penicillum. Sudant actu sub lima, \& malleo Sacrario additura decus marmora: quae ab Exteris, grandi aere, advehenda plagis, non modo ad arcendum a penitioribus Divarum adytis profanum Vulgus in Cancellos assurgent, muricis cum nive amulationem in spectaculum daturos; sed \& sacris Antistitum pedibus illimia, non tam Saxa, quam specula substernent.“

„Premda o Tvome dobročinstvu šuti Crkovnjak, propovijedaonica neće ostati nijema: za njezinu si profinjeniju izradu iz dalekih zemalja, zajedno s parskim i libijskim mramorom, doveo neobičnu arhitektoniku. Ona se već stidi svog prvotnog umjetnika koji, kada gleda na ovoj kamenoj masi tako skladnu igru boja, kao da ljutitom rukom odbacuje pobijeđeni kist. Već se pod dlijetom i čekićem znoji mramor koji će svetištu dodati poseban čar. On će se, uvezen iz stranih zemalja za veliku svotu, izdići u obliku pregrade izrađene kao prizor borbe grimiza sa snijegom, ne samo zato da odbije svjetinu od unutrašnjosti Svetišta, nego i da svetim biskupskim nogama podloži ne toliko blistavo kamenje koliko ogledala!“ 458

Predgovor drugom i trećem izdanju CO svojim raskošno pisanim predgovorom koji obiluje sugestivnim opisima nevjerojatnih i čudesnih učinaka što ih glazba ima na ljudski život, ne dopušta, kao uostalom ni uvod u zbornik Lyra Coelestis, ni zrno sumnje u dokaze što ih nudi.

Ne samo da je Elizeja pomoću glazbe dotaknuo Sveti Duh Proroštva, a iz Šaula ista ta glazba izgnala demone, već su se i brojni sveci Katoličke crkve, bivajući grešnima na put svetosti obratili upravo uz pomoć glazbe:

„Quis demum Albertum monachum a via lubrica abstraxit, \& tanta dein sanctitate clarescere fecit, nonne dulcis musicalis notae gratia?! Quia cum adhuc saecularis esset, audiens a parvulo quodam Juvene vitam, \& conversionem Sancti Theobaldi suaviter decantari, tanta repente gratia Divinitas compunctus est, ut inde coeperit vitam vivere Sanctam;““

„Što je napokon monaha Alberta odvratilo od zavodljivoga puta, a onda učinilo da on poslije stane tolikom svetošću svijetliti ako ne milost slatke pjesme?! Jer dok je on još bio svjetovnjak, čuvši nekog mladića kako miloglasno opjeva život i obraćenje svetog Teobalda, iznenada se skrušio tolikom milinom Božanstva da je otada stao živjeti svetim životom.“459

Osobito je pak opsežan prikaz utjecaja glazbe na Aleksandra Velikog, kralja čija povijesna veličina (on je celeberrimus magnus Alexander) u kršćanskom svijetu nije zasjenjena

\footnotetext{
${ }^{458}$ Usp. Prilog 1.

${ }^{459}$ Usp. Prilog 2.
} 
činjenicom da je bio poganin. Taj je prikaz sjajan primjer vještog interpoliranja pisca u antički izvor: prema riječima autora, Timotej ${ }^{460}$, sviranjem osmožične citare (cithara octochorda) smiruje kraljev bijes. Premda CO ne donosi instrumentalne skladbe, čitaču se sugerira moć glazbe koja je u njoj donesena. Govoreći o Aleksandru Velikom, pisac citira Himerija (vjerojatno prema Fociju) koji potanko iznosi sve promjene Aleksandrova raspoloženja, ovisno o tome kakvu bi mu glazbu svirao Timotej koji ga je s lakoćom odvraćao od ma kojeg neugodnog duševnog stanja (i u ovom je primjeru riječ o vokalnoinstrumentalnoj, a ne samo o vokalnoj glazbi!): kad bi kralju duh klonuo zbog neke mučne i odvratne predodžbe, milozvučno bi mu Timotejevo pjevanje odmah uzdiglo duh:

„Timotheus musicalis notae peritissimus omnes Alexandri affectus in quacunque partem volebat, facile flectebat, vidisses forte rem insipidam \& fastidiosam oculis objectam, Regis animum deprimere? Eum ocyus Timothei dulci Cantu ad Coelum usque elevari suspexisses. Vidisses aliquando Regem immoderate furore ardere? Arte \& industria Timothei praesentis Citharam octochordam blande pulsantis, seu amoena voce modulantis, ejus animum statim domari obstupuisses. “461

Jednako je efikasna glazba bila i u rješavanju tjeskobe, tuge ili grešne požude:

„Vidisses Regem moerore angi, aut tristia turbari? Protinus a Timotheo ridentem ostendi admiratus fuisses. Vidisses Regem vitiosis irretitum voluptatibus? Illico suavi Timothei carmine castissimum habuisses. Et ut omnia dicam, talem tibi videre Alexandrum licuisset, qualem tibi eum Timotheus reddidisset.“

„Jeste li vidjeli kako kralja tjeskoba duše ili tuga smućuje? Začudili biste se kako se smjesta, i to zahvaljujući Timoteju, stao smijati! Vidjeli ste, možda, kako Aleksandra sapinju grešne požude? Odmah biste ga, zbog Timotejeve milopojke, imali kao najčistijeg čovjeka! Pa da sve sažmem, Aleksandra ste mogli vidjeti onakvim kakvim bi vam ga načinio Timotej.“

Nižući primjer za primjerom, pisac gradira patos navodeći sve strašnije i čudesnije događaje. Od obraćenja svetaca milozvučnim napjevima, do reguliranja Aleksandrovih raspoloženja što

\footnotetext{
${ }^{460}$ Pripovijest o Timotejevom umijeću bila je dobro poznata u renesansi. Spominje je kratko i Galileo Galilei u znamenitom Dialogo della musica anticha e moderna. Usp. Galilei, Galileo. Dialogo della musica anticha e moredna. URL: http://ks.petruccimusiclibrary.org/files/imglnks/usimg/7/7a/IMSLP91211-PMLP187468Galilei_-_Dialogo_della_musica.pdf (19.09.2019. ) Str. 97.

${ }^{461}$ Ibid.
} 
instrumentalnom glazbom, što laganim pjevom, pisac dolazi do zastrašujućih primjera u kojima je glazba spriječila ubojstvo, pa čak i zaustavila rat:

„Testis est Empedocles, cujus hospitem, dum quidam furibundus juvenis gladio invaderet, is suo canendi modo juvenis iram repressit.“

„O tome svjedoči Empedoklo čijeg je gosta sumanuti mladić upravo namjeravao probosti mačem, kad li Empedoklo svojim načinom pjevanja savlada mladićev bijes!‘462

Najhrabriji ratnički narod antičke Grčke, Lakedemonjani, razdirani građanskim ratovima, pošto su čuli Metimnejca Terpandra kako pjeva, ne samo da su se izmirili, već su se stali i obostrano cjelivati:

„Testes sunt Lacedaemones, qui cum olim bellis civilibus affligerentur, oraculum illis redditum fuit. Si Terpandrum Methymnaeum Cithara canentem audirent, protinus conciliandos esse; quod \& factum est: nam ejsu cantu commoti, lacrymantes sese invicem osculabantur.“

„Svjedoče i Lakedemonjani, kojima je, dok su patili od građanskih ratova, stiglo ovakvo proroštvo: Ako čuju kako uz citaru pjeva Metimnejac Terpandar, smjesta će se pomiriti. A to se i dogodilo, jer ganuti njegovim pjevanjem, u suzama se stadoše obostrano cjelivati.“463 U njezine zasluge ubraja se i čuvanje ćudorednog ponašanja. Sjajan dokaz je pripovijest o Agamemnonu koji je, polazeći u Trojanski rat, i, kasnije će se pokazati s pravom, sumnjajući u odanost supruge Klitemnestre, ostavio pjevača koji ju je svojim glazbeničkim umijećem kojim je iznosio svijetle primjere čestitih žena, trebao držati dalje od udvarača. Koliko je ovaj bio uspješan, govori nam podatak da ga je Egist morao ubiti kako bi zaveo Klitemnestru: „Fecit hoc Agamemnon, qui peregre profecturus uxorem Clytemnestram Cantori reliquit custodiendam, ut ab improbis cogitationibus mentem ejus averteret illustrium foeminarum exempla pudicis modis decantando; nec prius Aegystus illi vitium inferre potuit, quam Cantorem interemisset.“

„To je učinio Agamemnon koji je, polazeći na daleko putovanje, svoju ženu ostavio pjevaču da je čuva kako bi joj duh odvraćao od grešnih misli i to opjevajući čiste primjere slavnih

\footnotetext{
462 Ibid.

${ }^{463}$ Ibid.
} 
žena. A nju Egist nije mogao natjerati u nevjeru prije no što je ubio pjevača!‘464

Agamemnonu u susprezanju žudnje očito nisu pomogli pjevači koji su pratili grčku vojsku pod zidine Troje, budući da se kući vratio s ljubavnicom Kasandrom, Prijamovom kćeri i ubrzo potom skončao od vlastite žene. No, taj dio pripovijesti ne zanima Šiloboda-Bolšića.

Niz se nastavlja pohvalama vokalnoj glazbi koja je „ona prva Gospodarica okrijepljenih duša“ „Haec prima recreandorum animorum Domina vocalis musica“, „mlijeko duše koje na blagi način obnavlja duh“ - „lac animae dulciter animum refoventis asseruit“, zanosi ne samo ljude, već i životinje: „nebeske ptice i morske ribe blago obuhvaća, jer ne skupljaju li i marne pčelice med pjevušeći?“. I velike se životinje potčinjavaju njezinim moćima: „Plutarh piše da se jeleni tetoše pjevanjem, a isto o slonovima tvrdi Strabon“ - „Cervos cantu demulceri scribit Plutarchus. Idem de Elephantis asserit Strabo.“465

Tijekom nizanja primjera, pisac svako malo umeće retoričko pitanje kojim provjerava efikasnost izrečenoga kod dobronamjernoga čitatelja i prijatelja kantora:

„Quis inquam dubitat cantu animos hominum non moveri?““

„Tko, velim, sumnja u to da su od pjevanja ganute ljudske duše?“

„Plura ne spectare cupis de admiranda cantus, seu musicae vocalis Virtute o benevole Lector seu amice Cantor?“

„Želiš li iscrpnije promatrati divnu snagu pjevanja ili vokalne glazbe, dobri čitatelju ili prijatelju pjevaču? ${ }^{\text {‘466 }}$

S obzirom na sve navedene primjere iz kojih je očito „da pjevanje ili vokalna glazba vlada nad svim moćima mikrokozma, tko bi, molim, mogao biti toliko lijen, a da zanemari ovu Osmožičnu citaru i ovu ugodnu uspješnost, koja svojom milom vladavinom upravlja srcima smrtnika, tko onda ne bi svom vjernom puku nju pjevao ili ne bi nastojao da se pjeva?“467, pita se autor, uvjeren da je svojom argumentacijom osigurao uspjeh djelu kojemu piše predgovor.

Ipak, uz podršku mecene, dobronamjernog čitatelja i prijatelja kantora, potrebna mu je i potpora najuglednijih članova društva koji izbjegavaju svoje vjerske obaveze izvršiti na

\footnotetext{
${ }^{464}$ Ibid.

465 Ibid.

466 Ibid.

${ }^{467}$ Ibid.
} 
prihvatljiv način. Na samom kraju predgovora pisac se ljuti na one koji bi, po njegovu mišljenju, morali biti saveznici Crkve u promicanju ispravnog načina bogoštovlja te izravno p(r)oziva plemićke obitelji zbog privatiziranja liturgijskog slavlja na vlastitim imanjima čime pružaju loš primjer ostalim građanima.

„\& Tu Nobilis Familia ita erubescis Abavorum, Avorum \& Patrum tuorum in similibus vestigia sequi atque laudabilia facinora (ipsi DEO valde chara) imitari? Oh pudor! Oh dedecus intollerabile! Et quod plus est, tam turpis acedia, tam vitiosa authoritas invaluit apud te o Nobilis Familia, quod nec ad Ecclesaim Parochialem Diebus Festis venire velis, sed cum scandalo aliorum domi tuae incurie delitescis, non profecto Antenati tui diebus Festis domi suae velut vespertiliones in speluncis delitescebant, non privator Mystas ex monasteriis educebant, non putrida illa \& inutilia Status Ecclesiastici membra colligebant, in privatis suis Curiis servabant, \& ad sacrificium privatim habendum adhibebant, nec adhibuisse unquam observati sunt, nisi speciali \& valde, gravi coacti fuissent causa \& necessitate, \& hoc pro pauco tempore ..."

„Pa zar da se ti, plemenita i Bogu premila obitelji, toliko stidiš u istome svjedočenju slijediti primjere svojih pradjedova, djedova i otaca i njihovih hvalevrijednih (i Bogu vrlo milih) djela?! O, sramote! O, nepodnosiva rugla! I što je gore, kod tebe je, plemenita obitelji, prevladao tako ružan nemar, tako poročan ugled da ne želiš ni na blagdane ići u župnu crkvu, nego se, na sablazan drugih, bezbrižno kriješ kod kuće. Tvoji se preci nipošto nisu na blagdan skrivali kod svoje kuće kao šišmiši u spiljama: nisu privatne misnike dovodili iz samostana, niti su okupljali one lijene i nekorisne članove crkvenog staleža u privatnim svojim kurijama, čuvali i koristili se njima za privatno služenje mise. Nikada se takvo što nije radilo, osim kad bi na to bili prisiljeni posebnim i teškim razlogom i nuždom, i to samo na kratko vrijeme.““68

Kako bi izbjegli pravedni Božji gnjev, valjalo bi im odmah prioniuti na primjereno izvršavanje vjerskih dužnosti i tako poslužiti kao primjer „,manje nadarenom i manje obrazovanom puku“.

„Quamobrem age quaeso Tu illustrissimi \& Nobilissimi stemmatis Propago, ad evitandam justissimi Vindicis iram \& copiam meritorum in Coelis comoparandam; age inquam tuoque laudabili exemplo per diligentem nimirum accessum tuum ad Ecclesiam Parochialem, incultioris genii \& ingenii Populum ad laudes Dei excitare non desiste ...“

${ }^{468}$ Ibid. 
„Stoga, daj, učini (nešto), molim Tebe, mladicu najsjajnijeg i najplemenitijeg roda, da izbjegneš srdžbu najpravednijeg Osvetnika i da postigneš na Nebu obilje zasluga! Daj, velim, svojim hvalevrijednim primjerom i marnim svojim pohađanjem župne crkve, neprestance potiči manje nadareni i manje obrazovani puk na štovanje Boga،“469

Predgovor Bolšićevom tekstu kudikamo je koncizniji. Njime dominira ideja korisnosti samog priručnika u okolnostima u kojima, po mišljenju autora, nedostaje sažeto i jasno predstavljanje glazbene teorije. Lakoća i jednostavnost, reći će Učitelj u Prvome dijalogu, zahtjevi su koje je pred učitelje postavio još Horacije i koje u bilo kojoj vrsti poduke valja slijediti. ${ }^{470}$

„Attamen vidi ego tyrones iuvenes, nobilissimae huius artis amantes, qualis ego olim fueram, ita inter se disceptare, ut uter ab altero discere debeat, ex adverso audiens haud discernere valebat. Nequaquam ideo: quod deessent aut auctores, aut magistri, qui eorum nodos solvere possent, aut vellent; sed quod deesset facilitas, \& claritas rudi, ac inerti iuvenum ingenio accommoda. Quamobrem operae pretium haud mediocre, ut spero, me facturum putabam, si Fundamenta cantus choralis ex variis probatisque auctoribus, quasi ex viridario flores in unum fasciculum methodo dialogica, utpote suaviori, ac magis pervia, qua totius rei summa in animos iuvenum facilius, ac fructuosius influere posset, colligerem.“

„Ipak sam vidio mlade početnike, ljubitelje ove najplemenitije umjetnosti, kakav sam i sam nekoć bio, kako međusobno raspravljaju tako da onaj koji sluša sa strane nije mogao razlučiti koji od kojega treba učiti. Nije to nipošto stoga što ne bi postojali pisci ili učitelji koji njihove poteškoće mogu ili žele riješiti, nego stoga što je nedostajala lakoća i jednostavnost prikladna nevještom i tromom duhu mladih. Stoga sam smatrao da ću učiniti, kako se nadam, prilično korisno djelo, budem li sakupio Osnove koralnog pjevanja iz djela raznih i vrsnih autora kao cvijeće iz vrta u jedan svezak i to metodom dijaloga، “471

Svrha učenja pjevanja za Šiloboda-Bolšića nije upitna. Očigledna je potreba za ovakvim priručnikom pa je donekle izlišna i argumentacija u korist same glazbe. Dovoljno je da je imenuje najplemenitijom od svih umjetnosti (nobilissima ars) i uzrokom Platonove sreće na zemlji i Davidove na nebu istakne glazbu, te isto zajamči i svojim čitateljima:

\footnotetext{
${ }^{469}$ Ibid.

${ }^{470}$ Usp. Šilobod-Bolšić, Mihael. Op. cit. Str. 48-49. Parafraza Horacijeva distiha iz Ars Poetica, 335-336. U originalu glasi: Quicquid praecipies, esto breuis, ut cito dicta / percipiant animi dociles teneantque fideles.

471 Šilobod-Bolšić, Mihael. Op. cit. Str. 45.
} 
„... si enim (quemadmodum Dialogo I. dicturi sumus) reliquis artibus praestantior haec ars, felicem in terris Platonem, ac beatum in coelis fecit Davidem; minime vos inopes relinquet orphanos.“

„Ako je, naime (kako ćemo pokazati u Prvom dijalogu), ova umjetnost izvrsnija od ostalih umjetnosti, učinila Platona sretnim na zemlji, a blaženog Davida na nebu, ni vas nipošto neće ostaviti kao siromašnu nahočad.“472

I on, poput kolege pisca teksta u $\mathrm{CO}$, koristi predgovor za svođenje računa s neistomišljenicima. Pritom mu problem ne predstavlja blazirano plemstvo koje zazire od zajedničkih obreda s narodom, već zlonamjerni kritičari koji neargumentirano, prije no što su i pročitali djelo, pišu i govore protiv njega: „longe plures esse, qui iis carpendis linguas suas intentent; aliosque censurare, cavillare, iudicare audeant, praesumant; etsi fors nec opus auctoris viderint ${ }^{\star 473}$. No, ti ga kritičari, usprkos početnom kolebanju, nisu odvratili od nauma, što zahvaljujući podršci mecene, što piščevoj želji da ispuni svoje poslanje: „eiusmodi Zoilos ${ }^{474}$, ego quoque, licet minimus, ut evitarem, scripturus, suspensam identidem tenui manum, atque etiam calamum abieci, abiectum tamen, suffragio gratiosi Moecenatis, ac patroni mei resumpsi ...“

Tko su bili ti Zoili, kako ih prema znamenitom Homerovom kritičaru naziva Šilobod-Bolšić, i jesu li uistinu postojali, ili je riječ o upotrebi općeg mjesta kako bi se pojačao učinak hvale meceni i odvažnosti samoga pisca da, usprkos kritikama, ne odbaci pisaljku, možemo samo nagađati. $^{475}$

Predgovori dvama franjevačkim priručnicima koji su najprisutniji u franjevačkim samostanima diljem Hrvatske posve su drugačije koncipirani. Fabrizio Tettamanzi svom djelu Breve metodo per apprendere il canto fermo piše kratak predgovor na jednoj stranici u kojem uopće nema govora o glazbi kao umijeću niti o njezinoj ulozi ili svrsi. Sažeti tekst upućuje

\footnotetext{
472 Ibid. Str. 44-45.

${ }^{473}$ Ibid. Str. 44-45.

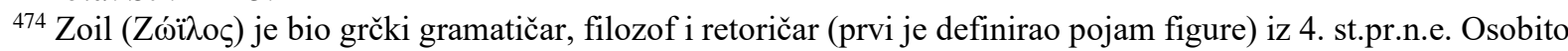
je bio poznat kao sastavljač spisa protiv Platona te po kritikama Homerovog opusa. U antici stečena reputacija

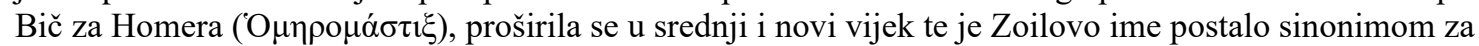
nesmiljeni kriticizam, ironiju i često neutemeljen apriorni negativni sud o nekom djelu. Usp. Leksikon antičkih autora / priredio Dubravko Škiljan. Zagreb: Latina \& Graeca: Matica hrvatska, 1996. Str. 612-613.

${ }^{475} \mathrm{~S}$ obzirom na vrlo složene odnose crkvenih velikodostojnika u Zagrebačkoj biskupiji i, općenito plemića u hrvatskim zemljama sredinom 18. stoljeća o čemu svjedoče tekstovi Adama Baltazara Krčelića, lako je moguće pretpostaviti da su, u kontekstu sukoba određenih struja, pripadnici jedne strane unaprijed kritizirali svaki, pa i najmanji pothvat one druge. Sudeći po obrani vlastitoga djela Fabrizija Tettamanzija (usp. sljedeću bilješku), kritike na račun pisaca glazbenopraktičnih priručnika očito su bile redovita pojava.
} 
samo na činjenicu korisnosti (utilitas), budući da ovakvih priručnika nedostaje te odbija kritike malicioznih jezika obračunavajući se s onima koji mu odriču znanje u području glazbe. ${ }^{476}$ Svjestan je da nudi temelj glazbenog obrazovanja i objašnjava trodijelnu strukturu djela: „Ukoliko sam, dakle, to napravio za učenike, ne polažem pravo da steknem slavu među najuglednijima u ovom umijeću. Podijelio sam djelo u tri knjige od kojih prva služi samo onima koji se žele usavršiti u pjevanju, a druga i treća služe za dodatno vježbanje stručnjaka, kojima nedostaju druge knjige za uporabu na koru. “4777

\subsection{Loci communes}

U novovjekovnom latinitetu prozni predgovori, baš kao i njihovi antički uzori, obiluju općim mjestima (topoi, loci communes). U većini slučajeva radi se o posveti meceni, obrani teme knjige od mogućih napada, isticanju vlastite skromnosti, jednoj od metafora prikupljanja materijala (vrlo često onoj vezano uz pčelinje prikupljanje meda) i skiciranju sadržaja kao uputnice potencijalnim čitateljima. Tore Janson u radu o proznim predgovorima na latinskom upozorava da se velik broj formula definirao do 500. godine n.e. čime se Ernestu Curtiusu i ostalim autorima koji su se bavili predgovorima kao posebnim žanrom u predmodernoj književnosti i literaturi općenito, otvorilo golemo polje istraživanja srednjovjekovnih formula prenošenih i kasnije sve do druge polovice 18. stoljeća. ${ }^{478}$ Toreova sinteza toposa u kasnoj antici temeljila se na uvidu u djela kršćanskih pisaca koja je svrstao u dva velika bloka: onaj koji se bavi teologijom i onaj koji se bavi biografskim i historiografskim tekstovima. ${ }^{479}$

\footnotetext{
${ }^{476}$ Usp. Tettamanzi, Fabrizio. Op. cit. str. 2.: „Se nel pubblicare Opere alle Stampe, alcuno meritò già mai rimproveri di temerità, quello son'io que gli giustifico anche nelle lingue de' più maligni.“

477 Tettamanzi, Fabrizio. Op. cit. Str. 2.: „Se adunque ciò feci per li Scolari, non pretesi acquistarmi fama da' più rinomati in quest'arte. Ho diviso questo in tre libri, il primo de' quali serve solo per chi desidera approfittarsi nel Canto, il secondo ed il terzo serve per esercizio ancora de' Periti, mancandogli altri Libri per uso del Coro.“ ${ }^{478}$ Usp. Janson, Tore. Latin Prose Prefaces. Studies in Literary Conventions. Stockholm, Göteborg, Uppsala: Almqvist \& Wiksell, 1964.; Curtius, Ernest. Latinska književnost i europsko srednjovjekovlje. Zagreb: Naprijed, 1998. Predgovore hrvatskih pisaca u 18. stoljeću proučavao je Rafo Bogišić, no usmjerio se pretežno na književna djela, usp. Bogišić, Rafo. Posvete i predgovori hrvatskih pisaca 18. st. Dani hvarskog kazališta. Hrvatska književnost 18. stoljeća: tematski i žanrovski aspekti. Split: Književni krug Split, 1995. str. 5-29.
}

${ }^{479}$ Usp. Janson, Tore. Op. cit. Str. 116.: „Latin literature during the fourth and fifth centuries was dominated by the works of Christian authors. I $t$ is around these that the remaining part of this study will centre. They comprise a very large group, the number of such works with a preface being around two hundred. The majority of writers concerned have obviously been inspired by their religion. Their works can be roughly divided by content into two groups. The first comprises theological works of different kinds, the other historical and biographical studies. In the former we can distinguish between a variety of sub-groups, including apologetics, protreptics, theological textbooks and theological pamphlets. The second main group consists of certain works in which general history is presented from the Christian outlook, of paraphrases of biblical history and of the lives of saints and martyrs." 
Činjenica da većinu navedenih toposa nalazimo u svim analiziranim predgovorima, ali u određenoj mjeri i u kratkim, funkcionalnim tekstovima franjevačkih pisaca koji se stilom znatno odmiču od predgovora LC, CO i Fundamentum, jasno je da je antičkom retorikom nadahnuto kršćanstvo ključni pojam za razumijevanje izvora kojima se bavimo. Uz to, uvidom u Toreova i Curtiusova istraživanja, vidljivo je da su predgovori objavljenim knjigama koje se bave tradicionalnim skolastičkim temama u 17. i 18. stoljeću, kojima teorija muzike kao matematičke discipline, ali i praktična teorija glazbe pripadaju, po upotrebljavanim formulama koje iznose i retoričkoj dispoziciji teksta usporedivi ne samo s renesansnim i srednjovjekovnim modelima - uzorima, već i onim (kasno)antičkima što se može razumjeti kao još jedna potvrda Le Goffove teze o dugom srednjem vijeku.

Analiza općih mjesta u predgovorima otkriva nam ne samo način upotrebe formula i toposa kojima barata govor o glazbi u prvoj polovici 18. stoljeća, već donekle i kontekst u kojem se odvijalo pisanje i izdavanje knjiga o glazbi.

Brojne predgovore najraznovrsnijim pjesničkim i proznim djelima, moguće je podijeliti na dvije glavne vrste: epistolarni tip predgovora i retorički tip predgovora. Svi hrvatski izvori pripadaju potonjem nudeći bujan retorički stil sklon patosu u predgovorima $\mathrm{CO} i$ funkcionalan, odrešit, jasan i koncizan stil u predgovoru Fundamentum. I jedni i drugi, međutim, obiluju općim mjestima kakvi krase predgovore „dugog srednjeg vijeka“. Ta su opća mjesta u našem slučaju posveta meceni, afektirana skromnost i ono što Curtius naziva „teološka teorija““480. Uz to, opće mjesto koje ćemo pomnije razraditi jest korisnost (utilitas) kao temeljna svrha svih tekstova.

\subsubsection{Posveta (Dedicatio)}

Posvete u predgovorima svim trima izdanjima CO uklopljene su u predgovore, premda $\mathrm{u}$ onodobnim priručnicima vrlo često bivaju izdvojenima u poseban tekst. Prvo izdanje CO posvećeno je meceni koji je omogućio izdavanje zbornika, a to je kanonik Ivan Znika. Cijeli je predgovor, u stvari, oblikovan kao pohvala Znikinoj mecenatskoj djelatnosti, čak više onoj graditeljskoj po kojoj je do danas ostao zapamćen u povijesti umjetnosti kao jedan od najagilnijih donatora i promicatelja suvremenih kretanja u arhitekturi i plastici.

\footnotetext{
${ }^{480}$ Usp. Curtius, Ernest. Op. cit. Str. 611-612.
} 
Predgovor prvom izdanju CO posveta je i hvalospjev meceni ,ad reverendissimum dominum: dominum Moecenatum“ Ivanu Zniki ${ }^{481}$, njegovoj brizi i dobročinstvu čije zrake tjeraju tamu:

„Vix cunas ingressus, perieram: nisi iam inde a principio Orphanum, Tibi derelictum, suscipiens, benigno confovisses affectu. Solem vix videram, cum me repetundarum damnabant tenebrae: quas nin beneficentiae tuae radiis eliseras; in ipso lucis confinio ad latebras retractus ${ }^{1}$, intempestum Ortui meo copulassem Occasum.“

„Tek što se nađoh u kolijevci, bila bih propala da nisi od samog početka prihvatio Tebi ostavljeno siroče i dobronamjerno ga potpomogao. Jedva sam ugledala Sunce, kad me stade osuđivati tama otplate duga, a da je Ti nisi protjerao zrakama svojih dobročinstava, ja bih, u sam osvit odvučena natrag u zapećak, svome izlasku prerano pridružila zalazak!،‘482

Ne samo da je uredio oltare i crkve, već je i, sve u svrhu veće hvale Boga i Nebesnika potpomogao izdavanje $\mathrm{CO}$ :

„Quantum non tibi ab hinc Coelitum debebunt Basilicae! Quas, posteaquam tot sumptuosis ornasti decoribus; nunc etiam in Numinis, Superumque laudem vocales efficies.“

„Koliko li će Ti zbog toga dugovati bazilike nebesnika? Pošto si ih već uresio s toliko skupocjenih ukrasa, sada još i okupljaš glasove na hvalu Boga i Nebesnika. “483

Predgovor drugom i trećem izdanju, međutim, nije posvećen pojedincu, već zagrebačkoj katedrali čiji je biskup, vjerojatno, podupro izdavanje CO. U prvom je izdanju CO cijeli predgovor alegorizam koji se manifestira u antropomorfizmu samoga zbornika: zbornik poprima ljudske osobine, on je siroče koje bi propalo da nije bilo Znikine intervencije. U predgovoru drugom i trećem izdanju pisac u trećem licu antropomorfizam primjenjuje na zagrebačku katedralu kao instituciju koja brine, gorljivo radi na dobrobit svojih vjernika i potiče dodatne oblike pobožnosti izdavanjem zbornika napjeva.

\footnotetext{
${ }^{481}$ Ivan Znika (1629. - 1706.) bio je zagrebački kanonik od 1669. do svoje smrti i jedan od najaktivnijih podupiratelja umjetnosti. Podigao je, uredio i uresio brojne crkve i kurije, dovodio strane umjetnike koji su uveli brojne aktualne novīne od kojih je najpoznatija korištenje mramora u izradi kipova. Osim toga, podržavao je i književnike te je tako, primjerice, 1696. financirao izdavanje djela Kronika aliti szpomen szvega svieta vikov Pavla Rittera Vitezovića. O potpori izdavanju CO, Klaić piše: „Trebalo je štampom objelodaniti veliku zbirku hrvatskih crkvenih pjesama s kajdama i potpunim hrvatskim tekstom, poznatu pod naslovom: „Cithara octochorda“. Ali kako nije bilo novaca pokucalo se je na vrata kanonika čuvara. I tako je njegovom darežljivošću 1701. god. u Beču štampano znamenito djelo ... “ usp. Klaić, Vjekoslav. Kanonik Ivan Znika, mecen hrvatske umjetnosti i književnosti, (1609. - 1706). // Bogoslovska smotra, sv.13, br. 2. Zagreb: 1925. Str. 356-370. ${ }^{482}$ Usp. Prilog 1.

${ }^{483}$ Ibid.
} 
„Zagrebačka crkva Svetog Kralja Stjepana, dobra i gorljiva majka koja revnuje gorljivo za Gospoda Boga vojskâ““-Benigna, \& zelosa Mater Divi Stephani Regis Basilica Zagrabiensis, zelo zelata pro Domino DEO exercituum“. Premda je pisac ne želi „uzdizati veličanstvenim pohvalama: nju, kojoj slava i veličina ne cvate samo u domovini nego joj po gotovo cijeloj Europi vječan napreduje ugled, a ime joj hvale i diče“ ipak spominje njezinu brigu, ne samo o izvanjskome sjaju, već i o dušama o kojima dodatno brine darežljivo objavljujući zbornik napjeva: Dobrotvornu darežljivost, na ime Zagrebačke crkve neće samo malo proslaviti ovo djelce Osmožične citare, kojim namjerava svoj mili narod djelotvornije i nježnije povezati s Bogom. “484

Mihael Šilobod-Bolšić ne imenuje svoga mecenu, no spominje ga kao onoga koji ga je potaknuo da, usprkos svojoj neznatnosti i kritikama dežurnih Zoila, ne odustane od pisanja priručnika, ugledajući se u Platonovu uputu prema parafrazi u Ciceronovu spisu De oficiis: „... ego quoque, licet minimus, ut evitarem, scripturus, suspensam identidem tenui manum, atque etiam calamum abieci, abiectum tamen, suffragio gratiosi Moecenatis, ac patroni mei resumpsi, qui ex Platone monitum me esse volebat: Nos nobis natos non esse; sed ortus nostri partem patria, partem parentes, partem amici, partem denique posteri sibi vendicent.“

„Ipak, odbačenu sam je ponovno uzeo uz podršku ljubaznog Mecene i mog pokrovitelja koji me želio opomenuti prema Platonu: Nismo rođeni sami za sebe, nego u našem postojanju sudjeluju dijelom domovina, dijelom roditelji, dijelom prijatelji i napokon dijelom potomci. ${ }^{\text {‘485 }}$

\subsubsection{Afektirana skromnost}

Afektirana skromnost još je jedna od retoričkih formula naslijeđenih iz kasne antike. Nedostojnost (indignitas), neznatnost (parvitas), poniznost (humilitas) u srednjem je vijeku, a

\footnotetext{
${ }^{484}$ Usp. Prilog 2. Cijeli odlomak glasi: „Sed nec hic suam sistit gloriam Divi Stephani Regis Basilica Zagrabiensis, dum eam videlicet tot praeclara sumptibus ejusdem erecta facinora laudibus exollunt, depraedicant tot ingeniosi labores ad avertendas culpas \& defectus, quos in DEI, Divorumque negligenti servitio comisere populi; ejus etenim munificam liberalitatem non parum honorabit opusculum hoc Citharae octochordae, quo dilectum suum populum DEO efficacius, \& intimius copulari desiderat, cujus aures, \& animus laudum Divinarum sono demulcitus, violam dein submissae reverentiae colligat, rosam amoris \& fiducia in DEUM odoret, lilia multiplicis obsequii Divini, \& integrae devotionis carpat.“

${ }^{485}$ Usp. Treće poglavlje, bilj. 309 i 310.
} 
i kasnije, najčešće u vezi s idejom da je onaj tko piše za to sposoban isključivo po milosti Božjoj. ${ }^{486}$ Snažno je uz topos afektirane skromnosti vezan i onaj što ga Curtius u kontekstu španjolske književnosti 17. stoljeća naziva „teološkom teorijom“. Naime, sve nama vidljivo i razumljivo Božji je dar, donum Dei. Iz tog je razloga, kao nekoć u Homera u kojega iz pisca progovaraju Muze, pisac sposoban valjano obaviti svoj posao samo uz Božju pomoć. Njegova nedostatnost, nesposobnost i neznatnost pomognute su Božjom intervencijom. Ta je afektirana skromnost na različite načine iskazana u analiziranim predgovorima.

Predgovor prvom izdanju CO u cjelini funkcionira kao alegorija: knjiga postaje osobom, djetetom koje je izgubilo oca i govori u vlastito ime. Mecena je imenovan, ali ne i pisac. On je knjiga sama. Identificirana s nejakim stvorenjem, istovremeno iskazuje vlastitu poniznost $\mathrm{i}$ potrebu za zaštitom.

„Amisso, in mei enixu, Patre; mira faventis Sortis providentia, in Te, reverendissime Domine, protinus Tutorem accepi. Vix cunas ingressus, perieram: nisi iam inde a principio Orphanum, Tibi derelictum, suscipiens, benigno confovisses affectu.“

„Izgubivši pri svojem rođenju oca, čudesnom sam brigom sklone mi Sudbine u Tebi, prečasni Gospodine, odmah dobila zaštitnika. Tek što se nađoh u kolijevci, bila bih propala da nisi od samog početka prihvatio Tebi ostavljeno siroče i dobronamjerno ga potpomogao.“487

Nesrazmjer njezinih sposobnosti i slave s onima mecene neupitan je, ona odzvanja neznatnijim žicama no što se nada da može u slavu mecene: ,[V]erum quia humilioribus in Tui praeconia Cithara mea insonat chordis; quam ut insignia tua decora sibi fidat, pro dignitate, depangere“. Ipak, nedorasla u slavi (imparis gloriae), „stvara epilog svojoj pjesmi sa zajedničkim željama svih valjanih ljudi: neka te na boljitak Crkvi i dušama Višnji što dulje čuva na zemlji“: ,imparis, gloriae tuae, cantici sui epilogum communibus duntaxat proborum omnium votis conficit: ut, in ecclesiarum, animorumque proventus Te Superi quam diutissime Terris indulgeant; “488

Topos afektirane skromnosti ne nalazimo u predgovoru drugom i trećem izdanju CO. On je primjer pohvalnice Zagrebačkoj katedrali kao mjestu intenzivnog promicanja pobožnosti i gorljive apologije vokalne glazbe.

\footnotetext{
${ }^{486}$ Usp. Curtius, Ernest. Op. cit. str. 437-443.

${ }^{487}$ Usp. Prilog 1.

${ }^{488}$ Ibid.
} 
Mihael Šilobod-Bolšić, pak, u svome predgovoru ističe korisnost kao glavnu ideju djela. Posao je izvršio „trudom i zalaganjem“ kako nas obavještava već u naslovu teksta ne propuštajući istaknuti vlastite nemale zasluge u izradi djela. Takav je priručnik nedostajao u okruženju, ne stoga što ne bi postojali stručnjaci da ga napišu, već ,,stoga što je nedostajala lakoća i jednostavnost prikladna nevještom i tromom duhu mladih“. Iz tog je razloga on odlučio sadržaj predstaviti „,metodom dijaloga, budući da je dražesnija i pristupačnija te da se njome bit cijele stvari može lakše i plodnosnije uliti u duše mladih“. Uz to je sadržaj prikazao na način da „lakoći ne nedostaje ljupkosti niti ljupkosti lakoće“. ${ }^{489}$ Ipak, da se čitatelju samohvala ne učini pretjeranom, na nekoliko mjesta interpolira izraze afektirane skromnosti u smislu prepuštanja procjene uspjeha njegova rada nekom drugom (čitatelju i cenzoru).

Šilobod ne tvrdi da je „trudom i zalaganjem“ učinio korisno djelo, već se samo skromno nada da je u tome uspio: „Quamobrem operae pretium haud mediocre, ut spero, me facturum putabam".

Štoviše, procjena uspjeha ovakvog načina pisanja je na mudrome cenzoru: „Quo in scriptionis genere quantum profecerim, intelligentis censoris fuerat iudicare“, čime se čitatelja stavlja u poziciju prihvaćanja cenzorova mišljenja koje je, dakako, povoljno za pisca.

Premda neznatan, želio je izbjeći nesmiljene kritike dežurnih Zoila te je, odbacujući pisaljku, odustajao od pisanja: „eiusmodi Zoilos, ego quoque, licet minimus, ut evitarem, scripturus, suspensam identidem tenui manum, atque etiam calamum abieci“, no uz podršku mecene „suffragio gratiosi Moecenatis“ - knjigu je ipak dovršio.

\subsubsection{Utilitas}

„Parum dixi; altius assurgit sacrae hymnodiae meritum: cuius voluntate cum ipso Deo coniungi animos, Strabo asseruit. “490 (CO I, Praefatio libri)

\footnotetext{
489 Šilobod-Bolšić, Mihael. Op. cit. str. 44-45. Cijeli odlomak u originalu glasi: Nequaquam ideo: quod deessent aut auctores, aut magistri, qui eorum nodos solvere possent, aut vellent; sed quod deesset facilitas, \& claritas rudi, ac inerti iuvenum ingenio accommoda. Quamobrem operae pretium haud mediocre, ut spero, me facturum putabam, si Fundamenta cantus choralis ex variis probatisque auctoribus, quasi ex viridario flores in unum fasciculum methodo dialogica, utpote suaviori, ac magis pervia, qua totius rei summa in animos iuvenum facilius, ac fructuosius influere posset, colligerem: collectaque, ratione quasi amico foedere ita copularem, ut nec claritati suavitas; nec suavitati deesset claritas.“

${ }^{490}$ Strabon $(\Sigma \tau \rho \alpha ́ \beta \omega v)$ je grčki geograf iz prvog stoljeća pr. Kr. i uz Klaudija Ptolemeja najvažniji izvor za antičku geografiju. Gotovo je u cijelosti sačuvano njegovo djelo Geografija ( $\Gamma \varepsilon \omega \gamma \rho \alpha \varphi \iota x \alpha ́)$ u sedamnaest knjiga u
} 
U sklopu literature shvaćene kao sve ono što je napisano tekstovi koji impliciraju ars kao umijeće, vještinu ili znanje, oni koji nisu pisani niti čitani u okvirima kantovskog bezinteresnog sviđanja (anakronom, dakako, u našem slučaju) nazivaju se utilitarnima. Bez obzira na njihovu brojnost $\mathrm{i}$ važnost $\mathrm{u}$ određenim povijesnim razdobljima, kao i nemalu geografsku raširenost, rjeđe se analiziraju upravo zbog nedostatka estetskog elementa koji bi ih u očima istraživača učinio vrijednima napora. U 17. i 18. stoljeću, međutim, utilitarni se tekstovi ne samo stilom približavaju takozvanoj lijepoj književnosti, već zauzimaju i veći dio ukupne literarne produkcije.

Nesumnjivo, predgovori CO, a naročito onaj objavljen u drugom i trećem izdanju koji je urešen brojnim primjerima iz europskog mitološkog i kršćanskog naslijeđa, zajedno s pedagoškim priručnicima o kojima smo raspravljali u kontekstu diskursa kao kompilacije, pripadaju korpusu utilitarne barokne literature sjevernih hrvatskih zemalja koja se čita tijekom gotovo cijelog 18. stoljeća, budući da njihova upotreba seže sve do Vrhovčeva ukinuća zagrebačkog obreda na izmaku stoljeća. Baroknost izričaja spomenutih predgovora književnostilistička je tematika kojom se ne možemo baviti u ovome radu. No, istražujući model oblikovanja teksta kojim dominira usporedba kao similitudo i imago, barokni klišeji shvaćeni kao „potonulo kulturno dobro“491 prispjelo na „dno“ s površine elitne kulture i tropološka alegoreza, važna su poveznica srednjovjekovnih temelja argumentacije koja se oslanja na usporedbu po sličnosti i suvremenog afiniteta za nizanjem raskošnih i stimulativnih slika koje su, također, usporedive po sličnosti.

„Utilitarni tekstovi urešeni baroknim figuralnim klišejima javljaju se nakon 1600. u svim evropskim sredinama, u nekima kao subliterarni proizvodi, u drugima kao evolutivno najviša dostignuća književne djelatnosti. I vremenski su okviri potonuloga baroka impozantne širine. Dok je u višim katovima evropske kulture barok nailazio na otpore još u doba svoje najveće

kojima uz zemljopisne podatke navodi i pojedinosti iz povijesti, kulture i mitologije nekog naroda. Strabona su parafrazirali brojni pisci od srednjega vijeka do 18. stoljeća, pa tako i uvodnik (Proemium) Lyra Coelestis iz kojeg je, vrlo vjerojatno, pisac CO preuzeo tvrdnju. Ondje se citira 10. knjiga u kojoj Strabon navodi da je sve što je od glazbe djelo Boga, a sami glazbenici ne samo da su službenici Božji, već se na neki način smatraju bogovima: ,dum Strabo libro 10. Geographiae dicit, omne id, quod musicum est, opus DEI esse, ipsosque Musicos non solum Ministros DEI, sed DEOS quodam modo existimandos.“ Usp. Lyra coelestis : svavi concordia divinas laudes personans elaborata, et juxta musicales notas in harmoniam adaptara nuncque primo typis edita. / Opera et studio ... Georgy Naray, Archidiaconi Zoliensis, Ecclesiae Metropolitanae Strigoniensis Canonici, Seminarii S. Stephani Regis Ungariae p. t. Praefecti. / Superiorum permissu. / Tyrnaviae Typis Academicis per Joannem An-/ dream Hormann. Anno. M. DC. XCV. s. p.

URL: https://library.hungaricana.hu/hu/view/RMK_I_1479/?pg=0\&layout=s (07.10.2019.)

${ }^{491}$ Usp. Kravar, Zoran. Barok kao potonulo kulturno dobro. // Croatica XVIII, 1987. str. 169-187. 
popularnosti, a oko sredine seičenta počeo već i pomalo zastarijevati, u utilitarnoj je književnosti živio kroz čitavo 17. stoljeće, pa i dulje, održavši se u nekim književnostima s evropske periferije sve do pred početak 19. stoljeća.“492

Glazbenoteorijski, pedagoški intonirani tekstovi Kovačevića, Šiloboda-Bolšića i anonimnog autora priručnika Compendiosa in cantum gregorianium seu choralem kao i oba predgovora zbornicima CO, pripadaju literaturi čija je društvena funkcija i za pisca i za čitatelja važnija od jezične razine djela. Štoviše, premda u okvirima svojih vještina paze i na izričaj, korisnost i svrhovitost djela poželjno je jasno istaknuti kao osobitost koja djelu daje dodatnu vrijednost. U izraženoj svijesti pisca o važnosti djela kao priručnika (bilo kao udžbenika, bilo kao zbornika s popijevkama) te o njegovoj prosvjetiteljskoj ulozi, moguće je iščitati revnost katoličke obnove koja je osobito nastojala oko privlačenja stada pastiru ne samo retoričkim, već i glazbenim sredstvima.

Korist neizmjernih darova kojima zagrebački kanonik Znika znamenit po neumornoj i izdašnoj potpori umjetnosti i obrazovanju u zagrebačkim crkvama, nije materijalnog, već duhovnog oblika:

„Zelus Domus Dei dum te comedit; ne religioso convivio desit potus, aureos substantiae tuae latices sufit. Sugit? Immo pleno bibit ore: te utpote cuncta Latifundia tua, meliore aeternitatis lucro, in Aras profundente.“

„Dok te revnost za Dom Božji izjeda, kako Tvojoj duhovnoj gozbi ne bi ponestalo pića, ona siše zlatne sokove Tvojeg imetka. Siše? Čak pije punim ustima dok Ti sve svoje veleposjede rasipaš na oltare no s boljim dobitkom u vječnosti.“493

A svrha CO jest upućivanje ljudskih čežnji i želja prema nebesima, umjesto prema zemaljskim dobrima:

„Ex quo \& illud emolumenti in tuorum censum meritorum profluet: quod, cum venefica Sirenum carmina passim pudorem plurimorum in Syrtes illidant; ne suavi hoc toxico decepta incantentur animae, substituta Sacrorum hymnorum dulcedine, hominum affectus \& desideria sis ad fortunatas Coelorum insulas, elusa charybdi, pellecturus.“

\footnotetext{
492 Ibid., str. 173.

493 Prilog 1.
} 
„Odatle će u račun Tvojih zasluga doteći i ova korist: budući da otrovne sirenske pjesme stidljivost mnogih posvuda zavode u Sirtu, kako duše ne bi bile začarane ovim slatkim otrovom, a pošto si im u zamjenu ponudio slast svetih himana, upućivat ćeš ljudske čežnje i želje, izbjegavši Haribdu, prema sretnim nebeskim otocima.“494

Još je jasnije svrhovitost iskazana u drugom i trećem izdanju CO u kojima je kao predgovor objavljen identičan tekst. Ondje je kudikamo opširnije iznesena namjera i svrha priručnika nižući primjer za primjerom blagodati koje muzika pruža čovjeku, njegovu psihičkom i fizičkom zdravlju te zdravlju duše. Niz događaja poznatih iz antičke mitologije i povijesti podjednako su uvjerljivi dokazi njezine vrijednosti, kao i prispodobe iz Starog i Novog zavjeta. Orfej i Amfion stoje uz Aleksandra Velikog i Timoteja, David i Šaul uz sv. Ivana Zlatoustog i Halkedonija, Elizej, Egist, Empedoklo, Terpandar, Teofrast, Plutarh dokazuju njezinu veličinu baš kao i sveti Martin, Nikola Tolentinski, sveta Margareta ili Ognjena Marija te premudri Židov Filon. Gotovo da nije ispuštena niti jedna poznatija pripovijest vezana uz moć glazbe!

Gorljivost zagrebačkog kaptola u spašavanju duša svojih vjernika istaknuta je već prvom rečenicom uvoda, a odnos crkve i vjernika prikazan dvjema metaforama: odnosom majke i kćeri te pastira i stada, ovaca i ovčinjaka:

„Benigna, \& zelosa Mater Divi Stephani Regis Basilica Zagrabiensis, zelo zelata pro Domino DEO exercituum Filias suas esurientes pabulo verbi Divini implet, ut fidelis populus illo enutritus aeternam adipiscatur salutem ..."

„Zagrebačka crkva Svetoga Kralja Stjepana, dobra i gorljiva majka revnuje gorljivo za Gospodina Boga vojskâ te hranom Riječi Božje napunja svoje gladne kćeri kako bi vjerni puk, njome nahranjen, postigao vječno spasenje. “495

No, čini se, ipak, da to nije dovoljno. Usprkos „,̌estim navještajima Božje riječi“, valja prionuti i uz glazbu koja još učinkovitije postiže svrhu privlačenja Majci Crkvi, te će uz njezinu pomoć pastiri lakše privlačiti Kristove ovce u ovčinjak:

\footnotetext{
494 Ibid.

${ }^{495}$ Ibid.
} 
„Ast Zelosa Mater Divi Stephani Regis Basilica Zagrabiensis, Zelum vestro etiamnum constanti Zelo confirmari cupit o Pastores ovium Christianarum! Ut renovato utilissimo hoc opusculo, seu Cithara octochorda per secuturas annorum illiades, oves Christi ad ovile insatiabilis voluptatis, laudes DEI \& Divorum dulci modulamine personando allicere tota mentis vestrae industria non intermittatis in hymnis nempe \& canticis; ut ait Doctor gentium, Spiritialibus cantantes \& psallentes Domino.“

„Ali gorljiva majka - zagrebačka bazilika Svetog Stjepana Kralja - i sada želi svoju predanost povećati i vašim žarom, Pastiri kršćanskog stada! Po novom izdanju ovog vrlo korisnog djelca, tj. Osmožične Citare, kroz sljedeće tisućljeće ne zanemarujte Kristove ovce svom dušom i svim nastojanjima privlačiti u ovčinjak neizrecive slasti i to himnima i popijevkama duhovnim, kako veli Učitelj naroda, pjevajući i psalmujući Gospodu. “496 Jer, ne smijemo zaboraviti da ,,ipak pjevanje ili vokalna glazba koja se izvodi kod žrtava, svetih pokopa i kod drugih oblika štovanja Vrhovnoga Bića, ima divnu snagu da privlači duše, da se Bogu

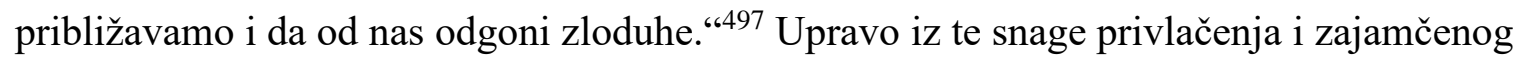
tjerana zloduha proizlazi nepobitna korisnost ovoga zbornika. Tko bi, pita se pisac nižući sjajne primjere iz prošlosti, posumnjao u njezinu moć da preoblikuje duše naroda na bolje, da blaži bogove (sic!) i tako osigurava vječni spas svakome tko je sluša i izvodi. „dobrohotnom čitaču ili prijatelju pjevaču“ obraća se pisac navodeći brojne primjere koje ćemo pomnije analizirati u odjeljku o usporedbi i sličnosti kao načinu objašnjavanja i razumijevanja svijeta. Opsežan primjer Timotejeva utjecaja na Aleksandra Velikog naveli smo u odlomku o retoričkim postupcima. On, dakako, predstavlja i sjajan primjer raznih koristi koje možemo steći slušajući glazbu. No, takvih je primjera napretek.

Mihael Šilobod-Bolšić u predgovoru Fundamentum iskazuje svijest o važnosti i korisnosti djela, ali i o načinu izlaganja sadržaja. Budući da smo o tome pisali u kontekstu afektirane skromnosti, ističemo samo kraj teksta u kojem se ističe osobna korist ispravnoga pjevanja, ali i mogućnost privlačenja drugih vjernika, sasvim u skladu s idejama katoličke obnove. Ono će, naime, isprositi uslišanje molbi i tako potaknuti i druge na pobožnost:

\footnotetext{
${ }^{496}$ Ibid.

${ }^{497}$ Ibid. cijeli odlomak glasi: „Cantus tamen, seu musica vocalis in sacrificiis, in Sacris mausolaeis, atque in alio supremi Numinis cultu adhibita, admirabilem sane fidelium animos trahendi, DEUM nobis appropinquandi, \& malignos spiritus a nobis fugandi virtutem habet.“
} 
„Accedite ergo nobilissimis praeceptis meis imbuendi, ut horum facilitate $\&$ recte canere sciatis; \& quod canetis, a Deo optimo impetretis; atque alios etiam ad pares devotionis affectus excitetis.“

„Pristupite, dakle, vi koji trebate upiti moje najplemenitije pouke, da zbog njihove lakoće naučite pravilno pjevati te da ono što pjevate postignete od jedinoga Boga, pa da i druge potaknete na jednake osjećaje pobožnosti.“498

\subsubsection{Pietas}

Pobožnost (pietas) je, nesumnjivo, jedna od najvažnijih vrlina koju katolička obnova nastoji ojačati tijekom desetljeća koja slijede Tridentski koncil. Postiže se snažnijim poticanjem vjernika na sudjelovanje u liturgiji, ali i boljim razumijevanjem obrednih tekstova i molitava. Pobožnost je jedna od važnijih odlika koju ističu i sami Habsburgovci: „Temelj za barokni katolicizam koji će za mnogo godina oblikovati habsburške teritorije, bio je odlučno postavljen kroz promociju pobožnih zaklada, hodočašća i štovanje marijanski kult, ali također i kroz provođenje beskompromisne i neumorne religijske politike. ${ }^{\text {“499 }} \mathrm{U}$ tekstovima 18. stoljeća, pa čak i onima objavljivanima u razvijenijim i bogatijim sredinama od sjeverne Hrvatske, moguće ju je objasniti izrazitim utjecajem posttridentske obnoviteljske politike koja se nije iscrpila u 16. i 17. stoljeću, već je, osobito putem isusovačkog sustava obrazovanja Ratio studiorum, opstala sve do pred kraj 18. stoljeća. ${ }^{500}$ Ona se, dakako, isprepliće s utilitas, koja je osnovni uvjet produkcije teksta, i educatio koja je osobito važna u krajevima s velikim brojem slabo ili nikako obrazovanih ljudi što i jesu dominantne ideje prosvjetiteljstva kakvo promiče Habsburški dvor. ${ }^{501}$ Educatio kao nužnost za stvaranje činovničkog kadra najšireg

\footnotetext{
498 Šilobod-Bolšić, Mihael. Op. cit. Str. 46-47.

${ }^{499}$ Usp. Binder, Dieter A. Pietas Austriaca? The Imperial Legacy in Interwar and Postwar Austria. // Religions, 2017, 8/171. Str. 1-10. URL: https://www.researchgate.net/publication/319347003_Pietas_Austriaca_The_Imperial_Legacy_in_Interwar_and _Postwar_Austria/link/59a60640aca272895c145d50/download (21.11.2020.) „The foundation for a baroque Catholicism that would for many years shape the Habsburg territories was decisively laid by promoting pious endowments, pilgrimages and Marian veneration, but also by pursuing an intransigent and relentless religious policy." O konceptu austrijske pobožnosti u razdoblju baroka vidi studiju Coreth, Anna. Pietas Austriaca. s. 1. Purdue University Press, 2001.

${ }^{500}$ Primjerice, cijela prva knjiga Gradus ad Parnassum Johanna Josepha Fuxa, objavljena u Beču 1725. na latinskom, a 1742. na njemačkom jeziku, posvećena je spekulativnoj teoriji glazbe i kao glavni tip argumentacije koristi analogiju prema sličnosti. Glazbena teorija objašnjava se mahom pojmovima aequalitas - inaequalitas, proportio, numerus, itd. Usp. Fux, Johann Joseph. Gradus ad Parnassum. Beč, 1725. URL: https://imslp.org/wiki/Gradus_ad_Parnassum_(Fux\%2C_Johann_Joseph) (23.12.2020.)

${ }^{501}$ Usp. Beales, Derek. Op. cit.
} 
tipa i utilitas kao njegova posljedica pogodovali su kulturi pisanja priručnika kakvi se pišu u svim područjima koja se smatraju temeljnima za obrazovanje (latinski, matematika $\left.{ }^{502} \ldots\right){ }^{503}$

Ulogu liturgijske glazbe u hrvatskom društvu 18. stoljeća teško je precijeniti, budući da se radi o često jedinom tipu muziciranja koje redovito ima prilike slušati većina stanovništva. Sasvim izgledno, književnost baroka u sjevernim hrvatskim zemljama, kao i crkvena glazba koja predstavlja dominantni oblik muziciranja sve do pred sam kraj 18. stoljeća, velikim su dijelom nastali kao alati pastorala ${ }^{504}$ što ga provodi katolička crkva po uputama Tridentskih odluka, alati kojima je zadaća poticati pietas.

FCG je alat u rukama predanih promicatelja katoličke obnove, tim više što je glazba dar i milost svemogućega Boga, „singulare donum, \& gratia omnipotentis Dei“. Ne samo da je valja prakticirati, već i druge treba poticati na isto, veli Šilobod-Bolšić i poziva učenike da se koriste knjigom kako bi naučili ,,pravilno pjevati te da ono što pjevate postignete od jedinoga Boga, pa da i druge potaknete na jednake osjećaje pobožnosti.“ Ne samo što će podučeni pjevači pjevanjem isprositi uslišanje svojih molbi, već im valja i širiti ove „umjetnosti izvrsnije od ostalih““ - ,reliquis artibus praestantior haec ars“. ${ }^{505}$

Pisac predgovora prvoga izdanja CO I ${ }^{506}$ također ističe pobožnost kao vjerojatni razlog za meceninu potporu zborniku:

\footnotetext{
502 Šilobod-Bolšić je, osim priručnika za učenje glazbe, napisao i udžbenik iz aritmetike na kajkavskom Aritmetika Horvacka. Zagreb: 1758. za poduku u osnovnim školama.

${ }^{503}$ Slična je situacija i u suvremenoj produkciji knjiga. Rastući broj priručnika za gotovo sva područja ljudskog interesa potaknuo je i znanstveno istraživanje o pisanju priručnika za pisanje književnosti. Usp. Writing Manuals for the Masses. The Rise of the Literary Advice Industry from Quill to Keyboard / uredili Anneleen Masschelein; Dirk de Geest. Leuven: University of Leuven, 2021.
}

504 Philippe Chevallier u članku „Le christianisme est-il un pouvoir comme un autre?“ raspravljajući o religiji kao temi u opusu Michela Foucaulta, upozorava na njegovo viđenje modela kršćanskog pastorala kao prethodnice i uzora oblikovanja svjetovne vlasti u 17. i 18. stoljeću te poseban uspjeh koji je kršćanstvo polučilo u smislu kontinuiranog, povijesno sljedivog modela upravljanja ljudima u njihovoj svakodnevici: „Cette pratique politique qui va s'imposer dans plusieurs pays d'Europe à compter des XVII ${ }^{\mathrm{e}}$-XVIII ${ }^{\mathrm{e}}$ siècles, a un „modèle“ ou encore une „matrice“ fameuse : le modèle chrétien du pastorat [Foucault 2004, p. 151]. Selon Foucault, le christianisme est la première religion à avoir développé et généralisé avec le plus de constance et de succès historique le gouvernement des hommes „dans leur vie quotidienne“, „,dans leur vie réelle“. ... Mais dans le christianisme seul, le pastorat va devenir la relation fondamentale englobant toutes les autres relations entre le peuple et ceux qui en ont la responsabilité. Cette relation fondamentale s'applique en effet à tous les niveaux de la hiérarchie ecclésiale, du plus local (le curé) au plus universel (l'évêque), en passant par l'abbé, berger de son monastère, et bien sûr le Christ, berger de l'humanité. Le pouvoir pastoral permet une véritable coupe longitudinale des rapports de pouvoir au sein de l'Église.“ usp. Chevallier, Philippe. Le christianisme est-il un pouvoir comme un autre ? // ThéoRèmes [En ligne]. Philosophie, mis en ligne le 11 juin 2016. URL: http://journals.openedition.org/theoremes/769 (12.09.2020.)

\footnotetext{
${ }^{505}$ Usp. bilj. 474.

${ }^{506}$ Za sve citate iz Predgovora CO I v. dalje Prilog 1.
} 
„Quippe placuit Tibi in me, per Ecclesiasticae Symphoniae modulos distincta, pietas ...“

„Zasigurno Ti se kod mene svidjela iznimna pobožnost urešena melodijama crkvene pjesme ..."

Ona se, međutim, ne potiče samo pjesmom, već i obilnim darivanjem crkvi i ukrašavanjem hramova po čemu je Znika poznat već u svoje vrijeme:

„Quis est, qui nesciat tuae non mediocria in Deum, Divosque pietatis monumenta; in quorum Phana aureum de munificentiae tuae fonte Pactolum derivas?“

„Postoji li čovjek koji ne zna za spomenike Tvoje velike pobožnosti prema Bogu i Svecima u čije hramove iz izvora svoje darežljivosti slijevaš zlatonosnu rijeku Paktol?“‘

Potporom CO ,pietatis augendae studio, a te desiderari videbatur“ - čini se da želi povećati pobožnost. Štoviše, „citra Amphionis fabulam, Thebis potiores Christianae pietatis conditurus es Arces, easque non hominibus duntaxat, sed \& coelestibus Geniis incolendas“, „poput Amfiona u Tebi ćeš podići čvršće kule kršćanske pobožnosti i nastaniti ih ne samo ljudima nego i nebeskim duhovima.“

A promatranje kako se pobožnost prelijeva na nove naraštaje bit će Znikina najveća nagrada: „transfusam in seros Nepotes pietatem cernens“.

\subsection{Similitudo mater veritatis}

Sličnost kao veza između pojava koje nas okružuju i događaja kojima svjedočimo ili o kojima doznajemo te, naposlijetku, kao veza između pojmova koje koristimo u jeziku temeljni je koncept na kojem počiva razumijevanje i objašnjavanje svijeta kršćanskih pisaca tijekom dugog srednjeg vijeka. Usprkos novínama koje je u proučavanju jezika i prirode donio epistemološki obrat koji je Michel Foucault imenovao klasicističkim, u kojem je temeljni koncept obrazlaganja red, sličnost se sve do kraja 18. stoljeća zadržala u brojnim tekstovima posvećenima tumačenju glazbe, osobito onima posvećenima rasvjetljavanju njezine veze sa svemirom i svijetom, makrokozmosom i mikrokozmosom. Osobito je važna u tekstovima koji tumače važnost i svrhu glazbe, njezin utjecaj na čovjeka, njegov karakter i djelovanje iz čega proizlazi ne samo željeni spas duše pojedinca, već i osobine društva u cjelini. Trag prema Platonovoj ideji o dobroj glazbi koja generira valjanog pojedinca i posljedično sretno i dobro 
usklađeno društveno uređenje, također izvedenoj prema konceptu sličnosti kao analogije, moguće je pratiti tijekom cijele povijesti glazbene teorije ponajviše zahvaljujući Augustinovoj interpretaciji Platona koja je imala snažan utjecaj na kršćanstvo u cjelini. Ta je ideja snažno prisutna u predgovorima svim izdanjima $\mathrm{CO}$, ali i u predgovoru FCG.

U članku u kojem detaljno razlaže povijest definiranja i redefiniranja usporedbe i sličnosti, pokušavši objasniti zabludu u koju su zbog pogrešne interpretacije Kvintilijana upali retoričari srednjega vijeka izjednačivši comparatio i similitudo ${ }^{507}$, Arpad Vigh upozorava da Ciceron u svome djelu Topika razlikuje dvije vrste veze prema sličnosti: similitudo per conlationem $\mathrm{i}$ similitudo per comparationem. ${ }^{508}$ Od Kvintilijana, pak, potječe definicija odnosa sličnosti (similitudo) s primjerom (exemplum) što je i temeljni model uspostavljanja veze u izvorima analiziranima u disertaciji.

„...za njega (sc. Kvintilijana, op. J. K. C.) su primjer (exemplum) i sličnost (similitudo) neovisni dokazi jedan za drugoga. Prvi se, odgovarajući aristotelovskoj $\pi \alpha \rho \alpha ́ \delta \varepsilon \imath \gamma \mu \alpha$, sastoji od supostavljanja sličnih stvari (in omni similium adpositione) i podijeljen je na dva glavna područja: primjere preuzete iz povijesnih činjenica koje mogu biti slične, različite ili suprotne od stvari koju treba dokazati te od izmišljenih primjera koji su preuzeti ili iz pjesničke tradicije, ..., ili iz basni poput onih Ezopovih ... ${ }^{6509}$ Sličnost kao dokaz posjeduje snagu sličnu onoj primjera i također se dijeli na dva osnovna tipa: prvi je sličnost stvari koje se

\footnotetext{
${ }^{507}$ Nöth, Winifried. Handbook of Semiotics. Bloomington: Indiana University Press, 1990. Str. 132: „While comparatio concerns the quantitative relations of 'larger/smaller than' or 'just as large as', similitudo involves a qualitative judgment about two similar properties. Only the latter type of comparison is relevant for metaphor." ${ }^{508}$ Usp. M. Tulli Ciceronis Topica. LCL, 386. URL: https://www.loebclassics.com/view/marcus_tullius_cicerotopica/1949/pb_LCL386.383.xml (04.11.2020.) [41] Similitudo sequitur, quae late patet, sed oratoribus et philosophis magis quam vobis. Etsi enim omnes loci sunt omnium disputationum ad argumenta suppeditanda, tamen aliis disputationibus abundantius occurrunt aliis angustius. Itaque genera tibi nota sint; ubi autem eis utare, quaestiones ipsae te admonebunt. [42] Sunt enim similitudines quae ex pluribus collationibus perveniunt quo volunt hoc modo: Si tutor fidem praestare debet, si socius, si cui mandaris, si qui fiduciam acceperit, debet etiam procurator. Haec ex pluribus perveniens quo vult appellatur inductio, quae Graece §pagvgó nominatur, qua plurimum est usus in sermonibus Socrates. [43] Alterum similitudinis genus collatione sumitur, cum una res uni, par pari comparatur hoc modo: Quem ad modum, si in urbe de finibus controversia est, quia fines magis agrorum videntur esse quam urbis, finibus regendis adigere arbitrum non possis, sic, si aqua pluvia in urbe nocet, quoniam res tota magis agrorum est, aquae pluviae arcendae adigere arbitrum non possis.“

509 Vigh, Árpád. Comparaison et Similitude. // Neohelicon 5 (1977), str. 191-218. URL:

https://doi.org/10.1007/BF02093139 (10.09.2020.): , ... pour lui, l'exemple (exemplum) et la similitude (similitudo) sont des preuves indépendantes l'une de l'autre. La première, correspondant au aristotélicien, consiste en une juxtaposition de choses semblables (in omni similium adpositione), et se voit divisée en deux espèces principales: les exemples tirés des faits historiques qui, à leur tour, peuvent être semblables, dissemblables ou contraires à la chose à prouver, et les exemples inventés, tirés soit de la tradition poétique ..., soit de fables comme celles d'Esope. La similitude qui, comme preuve, a une force proche de celle de l'exemple (proximas exemplo vires habet similitudo), connait egalement deux espèces principales: l'une que l'on tire des choses à peu près semblables (ex rebus paene paribus) à celles qu'on veut éclairer, est plus directe que l'autre, la parabole qui est tirée de plus loin (longius res), non seulement des actions humaines, mais aussi des animaux, ou des objets inanimés, et que Cicéron appelait conlatio.“
} 
uspoređuju, a drugi je parabola kao pripovijest o sličnim događajima. U slučaju kršćanskih autora primjeri često proizlaze iz antičke pjesničke i mitološke tradicije. Njihovo pogansko porijeklo ne smeta kršćanskom piscu, jer, kako na primjeru mnogo davnijeg teksta (povjesnice) veli Nenad Ivić, „Riječi pjesnika neznabožaca skrivaju nevidljivi poticaj; povjesnik pak zna da je Bog vječan, da je i u davnini, neznabošcima usprkos, djelovao.“510

Podjednako su važni, dakako, oni preuzeti iz Svetoga pisma i od crkvenih naučitelja (auctoritates) te pripovijesti o svecima. Primjeri i sličnost koja ih povezuje jamac su istinitosti izrečenoga, jer dolaze od autoriteta koji su protumačili izvjesnost svijeta.

Ta izvjesnost funkcioniranja sličnosti i potpuno povjerenje u davna exempla, prisutno je u prvom izdanju CO, no pisac ne smatra da ju je potrebno posebno dokazivati. Ona se podrazumijeva sama po sebi. Dovoljno mu je podsjetiti na nekolicinu slavnih i čudesnih događaja, a pritom bira grčku mitologiju. Podsjeća na pripovijest o Argonautima kao na primjer negativnog djelovanja jedne vrste glazbe: „cum venefica Sirenum carmina passim pudorem plurimorum in Syrtes illidant", sirenske su pjesme brod Argonauta nagnale u Sidranski zaljev, i spasonosnog djelovanja slatkoće svetih himana „sacrorum hymnorum dulcedine“ koji će spriječiti takav nemili događaj, štoviše, pomoći će da pjevač poput Odisejeve družine izbjegne Haribdu ,elusa charybdi, pellecturus“ i krene putem sretnih nebeskih otoka.

Pripovijest o Amfionu dokazuje jedva zamislivu snagu koju glazba posjeduje: ta on je, utvrđujući Tebu s bratom Zetom, sviranjem na liri natjerao kamenje da se samo od sebe slaže. „Thebis potiores Christianae pietatis conditurus es Arces“, Čvrsta i sigurna poput Tebanske utvrde, bit će pobožnost mecene koji podupire glazbu. Treći primjer, baš kao i prethodni, ističe sličnost efekta koji glazba ima na čovjeka (u slučaju Amfiona i na stvari), kako u davnoj prošlosti, tako i danas. Aludira na jednu je od najznamenitijih prispodoba vezanih uz glazbu iz Staroga zavjeta. To je priča o kralju Šaulu iz kojega je David sviranjem citre (sic!) istjerao demone. ${ }^{511}$ Uz pomoć citre, (sc. CO) još pobjedonosnije od Davida, mecena će istjerivati demone:

\footnotetext{
${ }^{510}$ Ivić, Nenad. Domišljanje prošlosti: kako je trinaeststoljetni splitski arhiđakon Toma napravio svoju salonitansku historiju. Zageb: Zavod za znanost o književnosti Filozofskoga fakulteta u Zagrebu, 1992. Str. 61. 511 Jeruzalemska Biblija. Zagreb: KS, 2007. Samuel I, 16:23: „I kad god bi Božji duh napao Šaula, David bi uzeo harfu i svirao; tada bi Šaulu odlanulo i bilo bi mu bolje, a zao bi duh odlazio od njega.“
} 
„Musicum vel in senio non te dedecet instrumentum: quo praesertim \& psalte regio victoriosius e non unius Saulis sinu Daemonium excuties.“

Pripovijesti o Amfionu, Davidu i Šaulu, sirenama i njihovim pjesmama koje su zavodile mornare i tjerale ih u nevolju zajednička su baština europske kulture 18. stoljeća, poznata svima koji su imali priliku školovati se. Spominje ih Petar Aaron u traktatu Thoscanello in musica, Adriano Banchieri u Cartella musicale, Johann Baptist Samber u Elucidatio musicae choralis. Navodi ih i mogući izvor za CO, slovačka Lyra coelestis. Njoj je,ipak, s obzirom na dugačak tekst predgovora u koji je uključila brojne zgode vezane uz glazbu, sličniji predgovor drugom i trećem izdanju CO.

Taj je tekst kudikamo raskošniji u prikazivanju svih mogućih učinaka glazbe. Je li riječ o piscu boljeg obrazovanja ili veće sklonosti kićenom baroknom izrazu? Ili je riječ o kvalitetnijoj pripremi drugog i trećeg izdanja pri kojoj je pisac predgovora imao vremena i prostora dati si oduška i nanizati najčudesnije pripovijesti kojima dokazuje glazbinu izvanrednu moć?

U svakom slučaju, tekst je, uz formalno jasan retorički koncept katoličko obnoviteljskog tipa, riznica argumenata koji su se koristili pri raspravi o glazbi ili obrani iste od eventualnih napada onih koji joj nisu bili skloni.

Drugo i treće izdanje, premda navodi i niz primjera iz antičke baštine, pravi je kompendij svjedočanstava o čudesnim učincima pjevanja i sviranja na biblijske ličnosti i svece Katoličke crkve. Pritom, glazba uvijek ima presudnu i pozitivnu ulogu na sve spomenute velikane, bilo da ih je nagnala na donošenje ispravne odluke, utješila, ohrabrila ili naprosto odvratila od zloga. Osim toga, budući da Stari zavjet kudikamo češće pripovijeda o glazbi od Novoga, upravo se on nudi kao glavni izvor za dokaze o njezinu božanskom porijeklu. Usporedbom s predgovorom Lyra coelestis, vidljivo da je ona bila vrlo vjerojatan izvor za predgovor CO II i CO III.

Prorok Elizej prva je spomenuta biblijska ličnost koja je pod utjecajem glazbe primila Božju poruku i spasila Izraelce od Moaba. Ciklus pripovijesti o Elizeju nalazi se na kraju Druge knjige o Kraljevima. Znamenit kao Ilijin nasljednik od kojega je primio proročku karizmu, Elizej je prepoznat kao čudotvorac. Gerhard von Rad, njemački teolog, u vezi s pripovijestima o Elizeju tvrdi: »Nigdje u Starom zavjetu nisu na manjem prostoru ispričana tolika čudesa i nigdje se više ne nalazi takva bezazlena radost za čudesima, čisto naslađivanje u stalno novom 
i iznenađujućem pokazivanju proročke karizme. “512 Njegovo čudotvorstvo očituje se u prirodnim pojavama, povijesno-političkim događajima i u djelovanju na ljude. Pripovijest u kojoj glazba postaje medij između Boga i proroka govori o pobuni moapskoga kralja protiv Jorama, kralja Izraela. Ovaj s kraljevima Judeje i Edoma kao saveznicima odlazi preko Edomske pustinje, no sedam dana ne nalaze vodu. Potom Jošafat, kralj judejski predlaže da za savjet pitaju Elizeja koji pak traži da mu dovedu svirača.

„Sad mi dovedite svirača“. I dok je glazbenik svirao, siđe ruka Jahvina nada nj. I on reče: „Ovako veli Jahve: 'Iskopajte u ovoj dolini mnogo jama. Jer ovako veli Jahve: nećete osjetiti vjetra niti ćete vidjeti dažda, a ova će se dolina napuniti vodom. I pit ćete vi, vaša marva i vaša stoka. “513

Veza s glazbom snažna je: Bog šalje poruku proroku Elizeju dok ovaj sluša glazbu. CO veli: „Quid obsecro Elisaeum requisitum a Regibus futuri belli exitum pronuntiare fecit, nonne dulce Psaltis modulamen? Elisaeus enim jussit sibi Psaltem adduci teste Biblia Sacra, quo psallente facta est super eum manus Domini statimque Divinum Prophetiae Spiritum recepit.“

„Što je, molim, navelo proroka Elizeja da se, na traženje kraljeva, izjasni o ishodu budućega rata? Slatko sviranje svirača, zar ne? Elizej je, naime, kako svjedoči Biblija, zatražio da mu se dovede svirač te, dok je ovaj udarao u glazbalo, siđe ruka Gospodnja nad njega te je odmah primio Svetoga Duha Proroštva." ${ }^{\text {"514 }}$

Monah Albert, redovnik dominikanac koji je poslije postao blaženik, potom i svetac i crkveni naučitelj, doctor universalis Albert Veliki, obratio se također slušajući u glazbu prenesenu pripovijest o svetom Teobaldu. Pripovijest o njima važna je kao dokaz da su se velikani Katoličke crkve preobratili upravo uz pomoć glazbe, baš kao i ,multi alii ex auditu musicae vocalis“ - „mnogi drugi slušajući vokalnu glazbu“. Jer, što je, pita se pisac, ,nonne dulcis notae gratia“, ako ne milost slatke pjesme odvratilo redovnika Alberta od zavodljivoga puta „a via lubrica“ 515

\footnotetext{
${ }^{512}$ von Rad, Gerhard. Theologie des Alten Testaments II. Die Theologie der prophetisch en Überlieferungen Israels. München, 1987. ${ }^{9}$ Str. 36-37. (prema Lujić, Božo. Čudotvorna i iscjeliteljska djelatnost proroka Elizeja. // Bogoslovska smotra, 82 (2012), 2. Str. 245-262.)

${ }^{513}$ Jeruzalemska Biblija. Zagreb: KS, 2007. Druga knjiga o Kraljevima, 3:15-17.

${ }^{514}$ V. Prilog 2.

${ }^{515}$ Ibid. Cijeli odlomak glasi: Quis demum Albertum monachum a via lubrica abstraxit, \& tanta dein sanctitate clarescere fecit, nonne dulcis musicalis notae gratia? Quia cum adhuc saecularis esset, audiens a parvulo quodam Juvene vitam, \& conversionem Sancti Theobaldi suaviter decantari, tanta repente gratia Divinitas compunctus est, ut inde coeperit vitam vivere Sanctam; \& multi alii ex auditu musicae vocalis singulariter ad DEUM conversi sunt.
} 
O tome nam, vrlo sličnim riječima, svjedoči i predgovor LC:

„Ita factum legitur cum sancto Alberto Monacho, qui cum adhuc saecularis esset, audiens minimum quendam, vitam \& conversionem sancti Theobaldi, musicem decantantem, tanta repente gratia divinitus, compunctus est, ut inde coeperit in magna vivere sanctitate. Et multi alii ex audite Musicae tam instrumentalis, quam vocalis, singulariter ad DEUM conversi sunt.“

Sličnost je prisutna i u ideji prirođenosti (ingenuus) glazbe ljudskom biću. Ona je prirođena ljudskoj naravi, a veliki muževi Platon i Ivan Zlatousti potvrđuju da ne možemo bez nje. Ona je toliko utkana u čovjeka da se dojenčad njome uspavljuje, a svi drugi njome tješe, bilo u sretnim, bilo u teškim trenucima: „aliique Viri Praestantissimi testantur ita nobis cantum seu musicam vocalem ingenitam esse, ut ea nullo modo carere possimus, \& quodnatura nostra usque adeo delectetur Canicis, tantamque cum eis habeat necessitudinem, ut vel infantes ab uberibus pendentes si fleant $\&$ afflictentur, ea ratione sopiantur. Alii quoque non solum in laetis $\&$ prosperis, sed in quacunque etiam duriori \& molestiori opera, Canticis sese consolantur;“"516

LC spominje Ivana Zlatoustog i Psalam 41 (koji u suvremenoj redakciji Biblije nosi broj 42), no ne zaustavlja se na uspavljivanju dojenčadi. Baš kao i kod malene djece, glazba je na sličan način učinkovita i u tješenju jarma na dugom putu, a isto tako i kod ljudi najrazličitijih zanimanja: pastira, ratara, mehaničara, mornara i vojnika: „Saepe quoque viatores meridie agentes, jugalia animalia de itineris molestia canticis consolantur.“ Kao dokaz njezinoj svevremenosti i sveobuhvatnosti citira Ovidijevu elegiju iz Četvrte knjige Tristia:

„hoc est cur cantet vinctus quoque compede fossor,

indocili numero cum grave mollit opus.

cantat et innitens limosae pronus harenae,

adverso tardam qui trahit amne ratem;

quique refert pariter lentos ad pectora remos,

in numerum pulsa brachia iactat aqua.

„Što je napokon monaha Alberta odvratilo od zavodljivoga puta, a onda učinilo da on poslije stane tolikom svetošću svijetliti ako ne milost slatke pjesme?! Jer dok je on još bio svjetovnjak, čuvši nekog mladića kako miloglasno opjeva život i obraćenje svetog Teobalda, iznenada se skrušio tolikom milinom Božanstva da je odsele stao živjeti svetim životom. A tako su se i mnogi drugi slušanjem vokalne glazbe neobično obratili Bogu!"،

${ }^{516}$ Ibid. 
fessus ubi incubuit baculo saxove resedit

pastor, harundineo carmine mulcet oves.

cantantis pariter, pariter data pensa trahentis,

fallitur ancillae decipiturque labor.“517

Vokalnu je glazbu, uza sve spomenuto, moguće primijeniti ne samo u raznim životnim situacijama. Ona prati i neminovan, ali za istinskog vjernika radostan trenutak smrti koja je, za vjerne ujedno i prelazak u nebo. Kao što je uza zvuke vokalne glazbe, pripovijeda pisac predgovora CO, Djevica Marija prenesena u nebo, „to se dogodilo i u smrtnoj borbi Svetog Martina, Nikole Tolentinskog, Blažene Marije Ogniacensis i premnogih drugih svetaca kad su se selili iz ovoga života. O divne li sile pjevanja! O velike li uzvišenosti vokalne glazbe!“ Sveprisutna je i moćna, „quod Cantus seu musica vocalis in omnes Microcosmi potentias dominetur", vlada nad svim silama mikrokozmosa. A taj je mikrokozmos sastavljen i od životinja, a ne samo od ljudi. Stoga se usporedba njezine djelotvornosti seli s djelovanja na ljudska bića na utjecaj koji ima na životinje. Ovdje u pomoć priskaču Marcijal, Plutarh i Strabon:

„Ast dulce melos non tantum hominum rapit animos, verum ipsa animantia terra, volucres Coeli, \& pisces maris, virtutis suae gratia amoene amplexatur; etenim apicula parvae nonne cantillando mella colligunt? Ab avium suavi modulamine, nonne illico ab ipso crepusculo matutino totus resonat aether? unde sicut fistulis aves alliciuntur: ita serpentes cantu disrumpi comprobatum est, inquit Martialis. Cervos cantu demulceri scribit Plutarchus. Idem de Elephantis asserit Strabo. Delphinios, aliosque quodam pisces, musica tam instrumentalis quam etiam vocali plurimum delectari, certissima experientia compertum est.“

„No ugodno pjevanje ne zanosi samo ljudske duše nego i same zemaljske životinje, nebeske ptice i morske ribe blago obuhvaća, jer ne skupljaju li i marne pčelice med pjevušeći? Zar milim cvrkutanjem ptica već od ranog jutra ne odzvanja zrak? ... Otuda je dokazano, veli Marcijal da, kako se frulicama ptičice mame, tako se zbog glazbe raspuknu zmije. Plutarh piše da se jeleni tetoše pjevanjem, a isto o slonovima tvrdi Strabon. Posve sigurno iskustvo vodi

\footnotetext{
${ }^{517}$ Ovidi Nasoni Tristium Liber quartus. I, 5-14. URL: https://www.loebclassics.com/view/ovidtristia/1924/pb_LCL151.159.xml (10.12.2020.) Usp. Lyra coelestis ... Trnava, 1695. „Proemium“. s. p. URL: https://library.hungaricana.hu/hu/view/RMK_I_1479/?pg=0\&layout=s (07.10.2019.)
} 
nas do spoznaje da dupini i neke druge ribe uživaju kako uz instrumentalnu, tako i uz vokalnu glazbu. ${ }^{\text {"518 }}$

Sve životinje uživaju u glazbi, osim zmija. Zmije su simbol đavla i zla. Stoga na njih vokalna glazba ne može djelovati kao na ostale životinje. One se razderu, raspuknu od pjesme (cantu disrumpi). ${ }^{519}$

LC donosi malo drugačiji tekst. Opet je na djelu usporedba sa sličnosti. Glazba se iz svih navedenih razloga sviđa posvema (omnino), i ljudima i bogovima ,placetque musica hominesque deosque“. Glazba se, dakle, sviđa i životinjama „cum musicalis Harmonya omnibus quoquo modo insit rebus“ jer se glazbena harmonija na neki način nalazi u svim stvarima i „Mundo Coeloque communis sit“ - "zajednička je svijetu i nebu““. ${ }^{520}$ Spominje se i Plutarh i Strabon, ali i Orfejeva lira koja je krotila i tigrove i lavove: cuius dulcedo non solum Tygres lenire possuit, rapidosque leones ${ }^{6521}$.

Retoričkim pitanjima zatvara se krug sličnosti. Ako, dakle, glazba, posjeduje tolike silne moći, ako je zajednička svijetu i nebu, ako se njezina harmonija nalazi u svemu što nas okružuje, ali i u nama samima, tko onda ne bi želio biti izložen njezinu smirujućem i tješiteljskom utjecaju? Tko se ne bi želio pomoću nje približiti samome Bogu i ,s anđelima tvoriti jedan zbor"?

Sličnost djelovanja glazbe koja, osim u primjeru sa zmijama koje su utjelovljene Zloga, uvijek donosi olakšanje i rješenje problema, ostatak je ne samo epistemologije koja sve objašnjava analogijom, već i njezina filozofijskoga promišljanja što je pripadalo kvadriviju pod imenom musica theorica. Odjeci Platonovih misli o njezinoj funkcionalnosti u društvu pretvoreni su $\mathrm{u}$ apologiju vokalnoj glazbi koja je ovdje izjednačena s gregorijanskim pjevanjem. Vokalna glazba je dar Božji, vladarica nad silama mikrokozmosa, tješiteljica, milostiva pratiteljica

\footnotetext{
518 V. Prilog 2.

${ }^{519}$ U Knjizi postanka 3,14 Jahve proklinje zmiju: Nato Jahve, Bog, reče zmiji:

»Kad si to učinila, / prokleta bila među svim životinjama / i svom zvjeradi divljom! / Po trbuhu svome puzat ćeš i zemlju jesti sveg života svog!“‘. Nenad Ivić u knjizi Domišljanje prošlosti veli: „Zmija je u Apokalipsi izjednačena s đavlom i sotonom: "Bijaše zbačen veliki Zmaj, stara 'Zmija' koja se zove 'đavao' - 'sotona', zavodnik cijeloga svijeta - bijaše zbačen na zemlju i bijahu zbačeni s njime njegovi anđeli." ... Sveti Augustin pak u svojim Ennarrationes in psalmos govori o zmiji ili zmaju kao đavolskom znaku. "Usp. Ivić, Nenad. $O p$. cit. Str. 26.

${ }^{520}$ Usp. Rankin, Susan. Naturalis concordia vocum cum planetis. Conceptualizing the Harmony of the Spheres in the Early Middle Ages // Citation and Authority in Medieval and Renaissance Musical Culture: Learning from the Learned / uredile Suzannah Clarke; Elizabeth Eva Leach. Woodbridge: Boydell Press, 2005. Str. 3-19.

${ }^{521}$ Lyra coelestis. Trnava, 1695. „Proemium“, s. p. URL:

https://library.hungaricana.hu/hu/view/RMK_I_1479/?pg=0\&layout=s (07.10.2019.)
} 
smrti. Ove ćemo odjeke analizirati u posljednjem poglavlju disertacije u kojem ćemo prikazati odnos ostataka spekulativne teorije glazbe s onom praktičnom.

Provedena analiza primjera ukazala je da su uz spomenutu utilitarnost, koja je dominantni idejni koncept velikog dijela barokne književnosti, pa tako i predgovora $C O$ te sličnost kao epistemološki koncept, značajna još dva obilježja teksta. Prvo je oslanjanje na (protureformacijska) retorička pravila o čemu smo govorili u odlomku o retorici katoličke obnove, a drugo uključuje raskoš jezičnog izraza, gomilanje figura i slika kojima je zadaća potaknuti pobožnost čime potvrđuje baroknu suvremenost piščeva izričaja. Baroknim bi se obilježjem mogla nazvati i očigledna fascinacija antičkom mitologijom te eksplicitno izražena svijest o prolaznosti ovozemaljskog života koja potiče snažnu usredotočenost na metafizičko, odnosno spas duše, zbog čega se glavnina upotrijebljenih parabola preuzima iz Starog i Novog Zavjeta. Većina slika koje nam uvodnici $C O$ opisuju služe promicanju glazbe kao sigurnoga puta prema vječnome spasu.

Uvodnik prvog izdanja CO zahvala je meceni, kanoniku Ivanu Zniki, a koristi alegoriju kao temeljnu figuru teksta. Sam tekst prikazan je kao nejako dijete, odbačeno od prvih izdavača i prihvaćeno i potpomognuto darežljivošću mecene. Tekst je primjer barokne kićenosti, prepun općih mjesta i metafora fokusiran na isticanje zasluga mecene koji je omogućio tisak zbornika čiju je važnost slutio pisac posvete, a potvrdila tri izdanja u razmaku od pedeset i šest godina te golem utjecaj koji su napjevi imali na oblikovanje osjećaja pripadnosti crkvi i ilirskom narodu. Taj se utjecaj ne može precijeniti s obzirom da i danas deseci napjeva koje baštinimo iz zbornika CO tvore opće mjesto u liturgijskoj i paraliturgijskoj glazbenoj praksi u Hrvatskoj. U ovom predgovoru, kao ni u sljedeća dva izdanja ne nalazimo pozivanje na autoritete $\mathrm{u}$ području glazbene teorije na način na koji ih spominju Kovačević i Šilobod-Bolšić. Njihovo je ime i ovdje istaknuto kao jamac istine i pouzdanosti izrečenoga. No, fokus nije na odnosu pisac - podatak, već na svojevrsnoj personifikaciji glazbe čije se blagotvorno djelovanje iznova i iznova potvrđuje primjerima čija je jedina poveznica glazba. Ovi su tekstovi posljednji tragovi razumijevanja glazbe kao spekulativne discipline (premda pisani da obrane praksu!) kojoj je osnovni cilj povezivanje transcendentalnog s fizičkim, odnosno glazbe kao medija koji jedini dokazano i uspješno posreduje između metafizičkog i fizičkog ostvarujući kroz ideju smirenosti i radosti u Bogu vrhunac koji čovjek treba i može postići.

Predgovor drugom i trećem izdanju raskošno nam prikazuje kako su razumijevali glazbu domaći klerici sredinom 18. stoljeća. Analiza uzora i izvora provedena u Trećem poglavlju 
upozorila je na veliku vjerojatnost preuzimanja teksta iz starijeg trnavskog zbornika LC čiji je predgovor nešto opširniji od predgovora $\mathrm{CO}$, no u hrvatskom zborniku gotovo da nema primjera koji ne nalazimo u CO. Similitudo funkcionira na dvije razine. Prva je opća i očito se oslanja na analognu argumentaciju kao temelj svakog obrazovanja u Hrvatskoj toga vremena. Nizanjem raznovrsnih, ali uvijek veličanstvenih i efektnih primjera postavlja se retoričko pitanje na koje je, da je potreban, moguć samo jedan jedini odgovor. Ako deseci primjera dokazuju glazba snažno i pozitivno djeluje na velikane antičke mitologije, ako je obratila niz katoličkih svetaca, ako se izvodila pri prijenosu tijela Djevice Marije u nebo, ako dakle slično, ali uvijek jednako uvjerljivo donosi dobrobit u najrazličitijim situacijama, neće li onda i suvremenom pjevaču 18. stoljeća donijeti iste dobrobiti? Druga razina povezanosti jest ona sa glazbenim, odnosno pjesničkim sadržajem koji slijedi u zborniku. Naime, tematika i motivika tekstova popijevki u CO usko su vezane uz blagdane ili liturgijsko vrijeme kroz godinu za koje su namijenjene. Iz toga proizlazi da niti sadržajno, niti motivički ne mogu ponuditi veliku raznolikost. Oblikuju se oko biblijskih parabola, važnih osoba i događaja. I dok je retorički stil predgovora bujan i insistira na efektnosti, glazbeni stil napjeva prilagođen je „dobrohotnom čitatelju“ koji češće oskudijeva i u temeljnom glazbenom obrazovanju, no što ga krase iznimne glazbene vještine. Stoga je i ovdje korisnost na djelu. Napjevi prilagođeni gotovo svakome svojom melodijskom jednostavnošću, a pjesnički izričaj motivički prilagođen općim mjestima suvremene kulture - antičkoj mitologiji i povijesti kako je prenosi sustav skolastičkog obrazovanja te Svetom pismu kao temeljnom izvoru svega znanja. Analiza sadržaja primjera (exempla) koji su vezani sličnošću, pokazala je da većina potječe iz dva temeljna izvora znanja: antičke mitologije i povijesti s jedne i Svetog pisma te svetačkih legendi s druge strane. Koliko god ovi izvori činili temelj i srednjovjekovnim tekstovima o glazbi, jezično efektno prepričane pripovijesti nanizane jedna uz drugu od kojih svaka za sebe svjedoči nevjerojatnu moć glazbe, karakteristike su baroknog diskursa o glazbi. Utoliko, premda donose apologiju ,anakronoj“ praksi gregorijanskoga pjevanja koja je, nota bene, također udešena po ukusu vremena, ukazuju na svijest o suvremenim uzusima pripovijedanja. Usprkos običaju liturgijskih glazbenih i književnih oblika da „okamene“ svoj oblik te ga na taj način njeguju stoljećima, u njih se ipak utiskuju određene suvremene prakse. U glazbenom smislu uočljivo je to u jednostavnosti melodije i njezinom prilagođavanju stihu, kako latinskom, tako i kajkavskom. U literarnom smislu suvremenost izričaja najvidljivija je u već spomenutom gomilanju epiteta i gotovo potpunoj zaodjevenosti teksta u baroknu metaforiku te korištenje posttridentskih toposa prolaznosti života, potrebe za povećanom pobožnosti i snažnog nastojanja oko postizanja vječnog života. 


\section{ŠESTO POGLAVLJE: MUSICA THEORICA - MUSICA PRACTICA}

\subsection{Teorija glazbe: historija kao definicija}

Izvori kojima se bavi ova disertacija, ma koliko se međusobno razlikuju, pripadaju najšire shvaćenoj teoriji glazbe. Jedni više pristaju suvremenim idejama o teoriji kao o korpusu znanja koje valja steći, kao o uputi za izvedbu ili za pothvat skladanja. Drugi glazbu objašnjavaju iz aspekta njezine uloge u ljudskom životu, oblikovanju karaktera ili pak spasu od zloga zbog čega bi ih suvremena teorija teško pripustila u svoje okrilje, no namjera im je ista kao i prethodnima: da potaknu praksu. Ovo će poglavlje nastojati pružiti teorijske okvire u kojem su se kretali hrvatski pisci u kontekstu pluralnosti epistemologija što je jedno od osnovnih obilježja teorije u 17. i 18. stoljeću.

Mihael Šilobod Bolšić i Toma Kovačević napisali su priručnike za učenje koralnoga pjevanja koje iz suvremene pozicije možemo nazvati osamnaestostoljetnim elementarijem solfeggia. Sličan njihovom je priručnik Compendiosa in cantum gregorianum seu choralem interpoliran u Psalterij-Antifonal iz 1742. što se čuva u Riznici Zagrebačke katedrale. Detaljniji po pitanju izložene teorije i osobito opširni u uputama za intoniranje psalama su priručnici talijanskih franjevaca Tettamanzija i Frezza Dalle Grotte koji se nalaze u brojnim hrvatskim samostanskim knjižnicama. Potonji detaljno prikazuju teoriju, ali zato ništa ne govore o porijeklu i nastanku glazbe, niti o njezinoj svrsi. CO kao kapitalni svjedok liturgijskog muziciranja u 18. stoljeću u sva tri izdanja primjerima pomno objašnjava sva čuda koja od glazbe možemo očekivati, ali ne govori ništa o teoriji koja je nužna da se zapisane primjere može valjano otpjevati. Svi spomenuti tekstovi, kao i niz izvora na temelju kojih su nastali, ali i oni koje su zaobišli, ma koliko disparatni bili po formi i sadržaju danas su dio golemog i iznimno heterogenog arhiva tekstova koji se naziva teorijom glazbe.

O problematici obuhvaćanja vrlo raznovrsnih spisa o glazbi nastalih tijekom dva i pol tisućljeća jednim te istim pojmom, usprkos tome što se jedni bave filozofijom, drugi matematikom i fizikom, treći glazbenom propedeutikom, a četvrti uputama za skladanje ili glazbenu analizu, kao i činjenici da se pojam teorija u većini slučajeva ne spominje u naslovu, 
a vrlo često niti u tekstu, pisali su mnogi koji su se bavili njezinom poviješću. ${ }^{522}$ Kratak pregled ove problematike prikazali smo u Uvodu disertaciji.

Svi traktati koji se bave matematičkim proporcijama intervala, modusima, solmizacijom, notacijom, akustikom, konsonantnim i disonantnim intervalima, potom harmonijom - od transcendentalne harmonije sfera do praktičnih uputa za usklađivanje akordskih sklopova -, polifonijom, etičkim, estetičkim i historijskim aspektom glazbe te uputama za skladanje, svrstavaju se, sve do pojave prvih općih povijesti glazbe u 18. stoljeću ${ }^{523}$, u glazbenu teoriju. Slijedom toga, svi novovjekovni latinstički izvori koji pišu o glazbi na bilo koji način također su glazbenoteorijski tekstovi koji, kao i brojni drugi nastali do kraja 18. stoljeća, teoriju kao pojam vrlo često uopće ne spominju. Ipak, njihov sadržaj nudi uvid u načine na koje se o glazbi razmišljalo i govorilo u to doba te u vrstu i opseg utjecaja prethodećih i suvremenih glazbenoteorijskih autora i drugih izvora i pisaca koji nisu nužno bili glazbeni teoretičari, ali su uživali opći autoritet. Ti se oblici račvaju u dva glavna smjera: prvi donosi etički intoniran narativ utemeljen na neoplatonizmu renesanse, dok je drugi dio sve raširenijeg propedeutičkog diskursa koji i u području glazbe reflektira naputke katoličke obnove i, nešto kasnije, prosvijećenog apsolutizma Habsburške monarhije.

Teorija se, u stvari, promatrana kroz linearnost vremenskoga tijeka koji potiče na izučavanje njezine povijesti, raznovrsnošću tema koje obrađuje kontinuirano opire sabiranju i sabijanju pod vlastiti zajednički nazivnik. Uguravanje velikog broja različitih tema u područje nazvano teorijom glazbe rezultiralo je, ne samo u pokušajima njezina historiografskoga prikaza, već i u njoj samoj, iznimnom sadržajnom heterogenošću koja se prostire kroz gotovo sve humanističke discipline, ali i matematiku i fiziku. Utoliko ju je, baš kao i estetiku glazbe, vrlo teško jednoznačno definirati: svaka njezina definicija snažno je historijski uvjetovana.

Pišući o estetici glazbe, Carl Dahlhaus je napisao kako je njezin predmet zapravo njezina povijest. Ista bi se tvrdnja, čini se, mogla izreći i o teoriji glazbe, a donekle je ponavlja i sam Dahlhaus u svojoj studiji „Was heißt Geschichte der Musiktheorie?“524. Opiranje glazbene

\footnotetext{
${ }^{522}$ Usp. Dahlhaus, Carl. Was heißt „Geschichte der Musiktheorie“?. // Ideen zu einer Geschichte der Musiktheorie, Friederich Zaminer (ur.). Darmstadt: Wissenschaftliche Buchgesellschaft, 1985. The Cambridge History of Western Music Theory / uredio Thomas Christensen. Cambridge: Cambridge University Press, 2008. Raznovrsnost tema koje je moguće istraživati u kontekstu povijesti teorije glazbe dobro je predstavljena u priručniku Music Theory and the Exploration of the Past / uredili Christopher Hatch; David W. Bernstein. Chicago: Univeristy of Chicago Press, 1993.

${ }^{523}$ Temu filozofije povijesti glazbe pregledno je obradio Warren Dwight Allen u vrlo korisnom priručniku Philosophies of Music History: A Study of General Histories of Music 1600-1960. Dover: Dover Publications, 1962. Tom se temom posljednjih šest desetljeća nakon njega nitko nije sustavno bavio.

${ }^{524}$ Usp. Dahlhaus, Carl. Op. cit. (1985)
} 
teorije vlastitoj razvojno zamišljenoj povijesti zapravo nije drugo do opiranje ideji da pojam ostaje sadržajno statičan tijekom vremena te da njegova povijest treba biti koherentna $u$ smislu sadržajnog jedinstva i razvoja usmjerenog od jednostavnijeg ka složenijem i vice versa. Teorija glazbe opire se željenoj povjesničarskoj koherentnosti brojnim „fundamentalnim ontologijskim promjenama značenja“c525 i posljedično, sadržajnom mnogolikošću koja nas tjera da unutar znanstvenih koncepata koji su oblikovani tijekom 19. i 20. stoljeća, teme kojima se bavi odlažemo po strani, odnosno predajemo na izučavanje matematici, fizici, filozofiji i teologiji. Ta je mnogolikost, usto, ne samo dijakronijska u razdoblju koje stilovima definirana povijest glazbe naziva barokom, već i sinkronijska, što je jasno i naročito dobro vidljivo u 18. stoljeću. U razmaku od nekoliko desetljeća objavljeni su traktati koji svojim sadržajem jedva da mogu biti različitiji, a glazbena teorija shvaćena kao matematička disciplina (musica theorica ili scientia musicae) još uvijek postoji, no sve više uzmiče pred tekstovima o glazbenoj praksi (musica practica, musica instrumentalis). Thomas Salmon 1705. raspravlja o proporcijama na način antičkih teoretičara u svome djelu The Theory of Musick Reduced to Arithmetical and Geometric Proportions, Johann Mattheson obraća se otmjenome čovjeku (Galant Homme) u djelu Das neu-eröffnete Orchestre ${ }^{526}$ iz 1713. nudeći uvid u izvođenje glazbe, njezine tehničke termine i oblikovanje ukusa čime se stječe meritornost za sudjelovanje u raspravi o njoj. Johann Joseph Fux objavio je desetljećima nezaobilazni priručnik za kontrapunkt Gradus ad Parnassum 1725. (potom izlazi prijevod s latinskoga na njemački 1742.). Za razliku od većine njemačkih kolega, francuski enciklopedist Jean Philippe Rameau u prvim desetljećima 18. stoljeća bavi se akustikom i tradicionalnim sadržajem musica theorica: objašnjava glazbene proporcije uz pomoć tradicionalne pitagorejske raspodjele žice u Traité de l'harmonie objavljenom 1722., a usprkos tome što četiri godine kasnije u Nouveau système de musique theorique uvodi novi termin corps sonore kao akustički princip, ostaje snažno vezan uz glazbenoteorijsku tradiciju 17. stoljeća. David Kellner objavljuje njemački bestseller za glazbenu poduku šifriranog basa Treulicher Unterricht zum Generalbass 1737., a Johann Mattheson svoje kapitalno djelo namijenjeno kantorima Der vollkommene Kapellmeister koje se nadovezuje na bogatu srednjovjekovnu i ranonovjekovnu tradiciju propedeutičkih glazbenoteorijskih spisa tiska

\footnotetext{
${ }^{525}$ Christensen, Thomas. Op. cit. Str. 13

${ }^{526}$ Puni naziv djela u diplomatičkom prijepisu glasi Das neu-eröffnete Orchestre, oder Universelle und gründliche Anleitung wie ein Galant Homme einen vollkommenen Begriff von der Hoheit und Würde der edlen Music erlangen / seinen Gout darnach formiren / die Terminos technicos verstehen und geschicklich von dieser vortrefflichen Wissenschafft raisonniren möge. durch J. Mattheson, Secr. mit beygefügten Anmerkungen Herrn Capell-Meister Keisers
} 
1739. Spomenuti su tekstovi, dakako, samo djelić bogate glazbenoteorijske baštine 18 . stoljeća što jasno ukazuje da je ,,povijest teorije glazbe ostvariva tek ako napustimo svaku čvrstu definiciju teorije i umjesto toga dopustimo fleksibilnu mrežu značenja“‘527. Čini se da se najkorisnijim pokazuje Dahlhausova sugestija o teoriji kao o jednom mogućem obliku (ujedno i svim mogućim teorijskim, odnosno diskurzivnim oblicima) uvida u glazbeni sadržaj (eine Form der Einsicht in musikalische Sachverhalte), čime dopuštamo i uviđamo njezine mijene

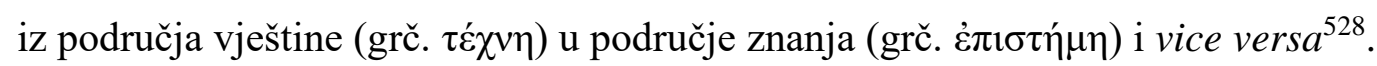

Valja nam, prije no što definiramo teorijske okvire hrvatskih neolatinističkih izvora spomenuti još jednu terminološku zamku: izjednačavanje pojma musica theorica i pojma teorija glazbe. Musica theorica pojam je koji se odnosi na filozofijsko i matematičko promišljanje glazbe i kao takav rabi se opisujući traktate koji se dominantno bave spekulativnim promišljanjem glazbe i njezinih elemenata. ${ }^{529} \mathrm{U}$ ranom srednjem vijeku, češće se umjesto theoria koristi pojam scientia ili disciplina, a u kasnijim stoljećima speculatio kao latinska inačica grčkoga pojma: „Theoria enim graece, speculatio est latine“, upozorava nas ugledni flamanski teoretičar iz 14. stoljeća, Jakob iz Liègea u svome traktatu Compendium de musica. ${ }^{530}$ Spekulativnim traktatima o glazbi pripada veći dio produkcije antike te mnogi glazbenoteorijski radovi nastali do 17 . stoljeća ${ }^{531}$. Musica practica kao uputa (praecepta) ili

\footnotetext{
${ }^{527}$ Christensen, Thomas. Introduction. // The Cambridge History of Western Music Theory / uredio Thomas Christensen. Cambridge: Cambridge University Press, 2002. Str. 13.: „Such a history of music theory is only conceivable, then, if we abandon any fixed definition of theory and allow instead for a flexible network of meanings."

${ }^{528}$ Dahlhaus, Carl. Op. cit. Str. 12.: „Läßt man sich, um ein Stück Boden zu gewinnen, von der Trivialität leiten, daß Theorie der Musik, was immer sie sonst sein mag, jedenfalls eine Form der Einsicht in musikalische Sachverhalte ist, so kann man - nach aristotelischem Muster - zu zeigen versuchen, wodurch sie sich von anderen Formen der Einsicht unterscheidet. Und angesichts des antiken Ursprungs der Musiktheorie - oder dessen, was in der europäischen Tradition Musiktheorie heißt - ist es nicht überflüssig, an die aristotelische Gegenüberstellung von Erfahrung, technē (Kunstfertigkeit) und epistēmē (Wissenschaft) zu erinnern.“

${ }^{529} \mathrm{O}$ (ne)korištenju pojma theoria za ono što mi danas nazivamo teorijom Thomas Christensen kaže: „With the spread of Aristotelian thought in the thirteenth century, however, a number of scholastically trained musical writers did start to employ the Latin cognates theoria and practica in their writings, including the likes of Franco of Cologne, Jehan des Murs, Walter of Odington, and Johannes Grocheo. But as Jacques of Liege noted, there was already a perfectly good Latin translation for the Greek word theoria: speculum (Compendium de musica 1.1; Speculum musicae 5.13). Hence, whereas earlier medieval writers would refer to the scientia of music with regard to its philosophical study, later medieval writers employed the term speculatio (as in Jacques's eponymous summa of musical knowledge). It was only in the later fifteenth century that some Italian humanists (above all,Franchino Gaffurio) explicitly entitled their musical writings 'theoria'.", Christensen, Thomas. Op. cit. Str. 5.

${ }^{530}$ v. Jacobus Leodensis. Compendium de musica, 1:1. URL: http://www.chmtl.indiana.edu/tml/14th/JACCDM

${ }^{531} \mathrm{Na}$ ovoj činjenici, čini se, temelji se odluka Lesliusa Blasiusa o periodizaciji u prikazivanju mapiranja glavnih glazbenoteorijskih pravaca, o čemu smo pisali u Četvrtom poglavlju. Uistinu, bez obzira na očit pomak prema didaktici i praksi još od karolinške renesanse, formalni obrazovni sustav glazbu stavlja u kontekst sedam slobodnih umijeća, a time i u kontekst matematičkih i fizikalnih nauka, sve do 17. stoljeća. Osobito je upečatljiv povratak interesa prema filozofiji glazbe stasao tijekom talijanske renesanse kad se događa prava eksplozija glazbenoteorijskih spisa koji gotovo da u potpunosti ignoriraju konkretnu glazbenoizvođačku praksu.
} 
praktični uvod (grč. $\varepsilon i \sigma \alpha \gamma \omega \gamma \eta \dot{\eta}$ u sr. vijeku compendium ili summula) pojam je koji obuhvaća konkretno znanje potrebno da bi se glazba izvodila i/ili skladala. U antici je glazba i pisanje o njoj uz matematički i filozofski aspekt, uključivalo i vrlo konkretnu glazbenu teoriju koja se vezuje uz praksu koja je podjednako važna, štoviše neodvojiva od njezina ethosa ${ }^{532}$

Spekulativna glazbena teorija, pojam kojem se utječemo iz današnje perspektive u kojoj teorija, barem u historiografskom smislu, obuhvaća svu silu najrazličitijih mogućih pisanja o glazbi, još je jedan pojam proizišao iz naše potrebe za razjašnjavanjem sadržajnog obilja i povijesne perspektive. Spekulativna glazbena teorija, upozorava Christensen, u kasnom bi srednjem vijeku, a vjerojatno i renesansi smatrana redundantnim pojmom. Ta, Musica je bila sama po sebi spekulativna matematička znanost kvadrivija i nitko je drugačije nije doživljavao. Ona je, kako tvrdi Albert Reithmüller, kao znanost kvadrivija u sebi uključivala i speculatio i theoria. ${ }^{533}$

U ranom srednjem vijeku utjecaj Boetijeva koncepta glazbe kao spekulativne znanosti koji zapravo ignorira zvučnu konkretizaciju brojčanih odnosa toliki je da priručnici za praksu gotovo da i ne postoje, ili barem nisu sačuvani. Pojavi interesa za pisanje praktičnih manuala za izvođenje glazbe pogodovalo je nastojanje Karolinške države da obnovom „odozgo“ reafirmacijom latinskog jezika i kulture kao kohezivnog faktora, pokuša unificirati litrugijski obred prema onom rimskom. Nepostojanje dovoljnog broja obrazovanih koji bi ga mogli primjereno glazbeno opsluživati potaknulo je pisanje manuala. Iz tog razdoblja potječu prvi priručnici s glazbenoteorijskim sadržajem koji se tiče glazbene prakse, odnosno izvedbe: Musica enchiriadis i Scholica enchiriadis. ${ }^{534} \mathrm{Od}$ razdoblja karolinške renesanse do spisa

\footnotetext{
${ }^{532} \mathrm{O}$ iznimnoj važnosti praktične glazbe u odgoju Grka te o njezinoj velikoj ulozi u sinkretičkim umjetničkim formama koje zapravo jedine primjereno konkretiziraju sadržaj pojma mousikē, v. Barbarić, Damir. Mousikē i ethos u Grka. // Treći program Hrvatskog radija (0353-94743) 80 (2012), str.135-143. URL: http://eprints.ifzg.hr/702/1/Mousike\%20i\%20ethos\%20u\%20Grka.pdf (27.02.2019.)

${ }^{533}$ Usp. Christensen, Thomas. Op. cit. Str. 5.: No late medieval writer would call such philosophical writings on music "speculative theory," since it was understood that any properly "theoretical" discussion of music was "speculative" in the original, Platonic sense of the word. Albrecht Riethmuller has thus made the amusing point that the modern locution "speculative music theory" would have been doubly redundant for a medieval writer, since the original concept of musica as a quadrivial science already entailed the concepts of both speculatio and theoria."
}

${ }^{534}$ Aurelijanov tekst Musica disciplina potječe iz sredine 9. stoljeća i najstariji je danas poznati glazbenoteorijski tekst koji uključuje aspekt spekulativnog razmatranja muzike kao matematičke discipline, za što je glavni izvor Boetijev spis De institutione musica, i elemente konkretne glazbene poduke. Ono što ga čini temeljem za daljnji razvoj teorije usmjerene na zvučeću glazbu jest jasno iskazana svijest o dihotomiji musicus i cantor koja se proteže sve do 18. stoljeća i neosviješteno ponavlja usprkos promjeni percepcije važnosti jednog i drugog. Promjena se doima neznatnom no uistinu je velika: musica se od tada jasno vezuje uz praksu kantora u crkvama i stoga musicus nije više samo aritmetičar i filozof koji se upušta isključivo u raspravu o rationes. Naprotiv, 
Micrologus Guida iz Arezza u 11. stoljeću mali je broj sačuvanih priručnika s uputama za kantora $^{535}$, no već od 12. stoljeća nadalje snažno raste broj priručnika s uputama za izvođenje jednoglasne crkvene glazbe i polifonije, kao i za skladanje te postupno do 16. stoljeća - u kojem ponovno cvatu spekulativni traktati - postaje dominantnim tipom diskursa o glazbi.

Mnoge spomenute elemente zrcale i hrvatski izvori. Priručnici Tome Kovačevića i Mihaela Šiloboda-Bolšića donose uputu za praksu - musica practica i slijede trend sve većeg broja manuala namijenjenih glazbenicima izvođačima koji se objavljuju u velikoj mjeri tijekom 17. i 18. stoljeća u mnogim europskim zemljama.

Renesansnu fascinaciju antikom koja se u baroku nastavlja oslanjanjem na teme iz mitologije ne samo u glazbenim, već i u književnim i likovnim djelima te utjecaj katoličke obnove koja potiče vjersko obrazovanje što je vidljivo čestim citiranjem biblijskih prispodoba svjedoče predgovori CO koji više ili manje izravnom refleksijom o harmoniji kao skladu duše i tijela, svemira iz svijeta te etičkim glazbinim djelovanjem pripadaju korpusu musica theorica.

\footnotetext{
musicus u 9. stoljeću mora znati sve o konkretnim glazbenim pojavama, kao i o vrstama napjeva, ali i o pjesništvu: „Is est enim musicus, cui secundum speculationem propositamve rationem ac musicam convenientiam, de modis ac rithmis, deque cantilenarum generibus ac permixtionibus, sed et de poetarum carminibus adest facultas sine errore iudicandi.“ Ibid., [f. 63v] IIII Quot habeat humana musica partis; I stoga je njihov odnos usporediv s onim učitelja gramatike i običnog čitača, tjelesne vještine i razuma, i na koncu kao učitelja i učenika: „Tantum inter musicum distat et cantorem quantum inter grammaticum et simplicem lectorem et quantum inter corporale artificium et rationem. Etenim artificium corporale quasi serviens famulatur; [f. 68v] ratio vero quasi domina imperat: quia nisi a ratione vegetetur opus, manus operantis inaniter laborant. Nam omnis ars atque disciplina honorabiliorem naturaliter habet rationem quam artificium quod manu opereque expletur. Multo enim est maius scire quod quisque faciat quam illud facere quod sciat. ...,Etenim in tantum distare videntur inter se musicus et cantor quantum magister et disciplus.“ Ibid., VII Quid sit inter musicum et cantorem, V68 - F62v - GS38b - R132. Nešto mlađi tekstovi koji danas u medievističkoj muzikologiji uživaju kultni status, Musica Enchiriadis i Scholica Enchiriadis potječu iz kasnog 9. stoljeća i uz razmatranja pitagorejskih brojčanih odnosa (ratio) kako ih prenosi Boetije, daju upute za notaciju, klasificiranje gregorijanskih napjeva i pjevanje korala i organuma. Rasprava o organumu kao najstarijem poznatom obliku polifonije, formiranje četiri osnovna tona (protus, deuterus, tritus, tetrardus - po ugledu na starogrčki glazbenoteorijski sustav) kao temelja crkvenog modusa te stavljanje liturgijskog napjeva u središte pozornosti rasprave osiguralo im je mjesto u svim historiografskim i leksikografskim priručnicima za glazbu.
}

${ }^{535}$ Uz već spomenute Musica disciplina, Musica Enchiriadis i Scholica Enchiriadis, važan je i tekst monaha po imenu Regino Prumiensis Epistola de harmonica institutione u SEMS. URL:

http://www.chmtl.indiana.edu/tml/9th-11th/REGHAR (21.11.2020.) 
Teorija glazbe u današnjim historiografskim prikazima obuhvaća i jednu i drugu vrstu diskursa o glazbi, baš kao što joj pripadaju i svi kasniji oblici teoretiziranja i analiziranja glazbe. ${ }^{536}$

Ona je, dakle, područje koje obiljem raznovrsnih koncepata te pluralnošću epistemologija koje su ga određivale tijekom prošlosti, kao i složenošću odnosa s drugim humanističkim disciplinama, zahtijeva iscrpnije, historijski osviješteno određenje te otvorenost prema drugim znanostima koje su stoljećima participirale u teoriji glazbe i ne može se izjednačiti s predmodernom musica theorica koja implicira filozofijski aspekt muzike.

\subsection{Odjeci antike - musica theorica ili musica speculativa}

Toma Kovačević i Mihael Šilobod - Bolšić u svojim priručnicima na prvi pogled uopće ne spominju klasičnu, spekulativnu teoriju glazbe. S obzirom da se radi o tekstovima vrlo jasne pedagoške namjene koji smjeraju biti priručnicima lokalnim kantorima u crkvama u procesu poduke budućih koralista takva se odluka čini posve logičnom. Franjevački priručnici talijanskih pisaca Frezza Dalle Grotte i Tettamanzija, pisani s istom namjerom, također izostavljaju raspravu o metafizičkom aspektu glazbe. Ipak, premda je rasprava o brojčanim odnosima koji stvaraju određene harmonije (intervale) koje reflektiraju kozmičko kretanje planeta oko zemlje napuštena, postoje sačuvani odjeci ideja iz područja musica theorica.

U 18. stoljeću musica mundana postaje theorica ili speculativa i znači, kao i njezin antički uzor, proces spoznaje glazbenih zakona. Musica humana, kao internalizacija glazbe u ljudskome tijelu koja u čovjeku odražava zakone musica mundana i povezuje fizičko s dušom prisutna je u ideji musica vocalis ispreplićući s njom polje djelovanja. Upravo to ispreplitanje vidljivo je u prispodobama o utjecaju glazbe kao posljedica analoškog odnosa makrokozmosa i mikrokozmosa, svemira i svijeta, duše i glazbene harmonije sačuvanima u predgovorima zborniku Cithara octochorda, dok je etički aspekt glazbe opstao u Kovačevićevom i Šilobodovom manualu u poglavlju o tonusima.

\footnotetext{
${ }^{536} \mathrm{O}$ tome opsežnije vidi kod Christensen, Thomas. Op. cit. U ovom tekstu Christensen pojam Musica theorica rabi ravnopravno s engleskim nazivom Music Theory, razlikujući navodnicima spekulativnu od opće glazbene teorije.
} 
Šilobod-Bolšić, čiji je tekst kudikamo opsežniji, ali i bolje strukturiran od Kovačevićevog, na nekoliko mjesta aludira na poznavanje temelja spekulativne teorije kako ju je prenosio srednji vijek. U Trećem smo poglavlju u analizi korištenih izvora pri kompilaciji djela istaknuli učestalo spominjanje Platona koji je postavio temelje etičkog poimanja glazbe za kršćansku civilizaciju. Njezina se odgojno-obrazovna uloga oslanja na važnost stjecanja same vještine razumijevanja glazbe, a potom i muziciranja i stavlja je čak i ispred tjelovježbe. Ona pak proizlazi iz ideje o glazbi kao odrazu harmonije sfera, fizičkoj manifestaciji metafizičkog, svjetovnom zrcalu transcendentalnog. ${ }^{537}$ Platonova je ideja opstala u podjeli glazbe koju je definirao Boetije i u kojoj musica mundana predstavlja savršenu glazbu svemira koju je moguće pojmiti isključivo putem matematičkih izračuna. Druga je, dakako, povezana s prvom i u kršćanstvu našla plodno tlo u tekstovima koji su razmatrali dobrobit glazbe za dušu u odnosu na njezinu sirensku zavodljivost koja odvraća od prave pobožnosti i tjera prema fizičkim užicima. Platon, međutim, u Šiloboda-Bolšića nijednom nije citiran u bilo kojem od oba spomenuta smisla. ${ }^{538}$ Boetiju je, pogrešnim čitanjem Sambera, pripisao definiciju dobroga pjevanja koje ovaj nije autor. ${ }^{539} \mathrm{Ni}$ podjela glazbe nije ona Boetijeva, već suvremenija, preuzeta iz Samberova djela Elucidatio musicae choralis. Šilobod glazbu dijeli na pet vrsta:

„Ita est, unicum dico, sed quintuplex intelligo. Musica enim prima est theorica, seu speculativa, quae in sola contemplatione, \& coginitione regularum versatur, cuius finis est scire; ut si quis sciat quidem artem, eius tamen specimen non exhibeat. Secunda est practica, quae in ipsum opus, seu exercitium prodit; cuius finis est agere, nullo post actum relicto opere; ut si quis solum doceat musicam. Tertia est poetica, quae praeter cognitionem, \& exercitium post laborem aliquid operis relinquit; veluti poëta carmen post mortem. Quarta est

\footnotetext{
${ }^{537}$ Usp. Bower, Calvin W. The transmission of ancient music theory into the Middle Ages. // The Cambridge History of Western Music Theory / uredio Thomas Christensen. Cambridge: Cambridge University Press, 2008. Str. 136-167. Str. 147: „The goal of learning musica is to ascend to the level of reason. The fundamental principle motivating Platonic music theory is knowing, the acquisition of pure knowledge, and Boethius's threefold division of music and three classes of musicians resonate consistently with that principle. Every legitimate facet of musica was subject to quantification by Boethius: every function in the collection of pitches was calculated with a point on the ruler, was assigned a discrete number, and was noted with a geometric symbol (a letter); even basic elements in the theory of ancient tonality (the tonoi and the harmonia) were reduced to expositions of species of fourth, fifth, and octave - quantitative reductions that reveal little of musical function or effect. The beauty of this theoretical system - if one may so speak - lies in its internal consistency and its congruence with Platonic ontology and epistemology.“

${ }^{538}$ Usp. Treće poglavlje.

${ }^{539}$ Usp. Treće poglavlje, bilj. 315.
} 
instrumentalis, quae sine voce, \& textu solis instrumentis paragitur. Quinta vocalis, quae voce fit.“

„Da, kažem da je jedna, ali je pojmim peterostruko. Prva je, naime, musica theoreica ili speculativa koja se bavi samim promišljanjem i spoznajom pravila. Njoj je cilj znanje. A ako netko i poznaje umjetnost ne mora nužno biti predstavnik ove vrste. Druga je musica practica koja se odnosi na sviranje i vježbanje. Njezina je svrha izvedba, a nakon izvedbe više nema djela, kao na primjer kada netko samo poučava glazbu. Treća je musica poetica koja osim spoznaje i izvođenja, nakon uloženog truda ostavlja neko djelo, kao što i pjesnik ostavlja pjesmu poslije smrti. Četvrta je musica instrumentalis koja se bez glasa i teksta izvodi samo na instrumentima. Peta je musica vocalis koja se bavi glasom. “540

Boetijeva slavna podjela dijeli muziku na tri dijela:

„Sunt autem tria. Et prima quidem mundana est; secunda vero humana; tertia quae in quibusdam constituta est instrumentis, ut in cithara vel in tibiis, caeterisque quae cantilenae famulantur.“

„Postoje tri. A prva je dakako mundana; druga humana; treća je ona koja je sastavljena od nekih instrumenata, kao od citare ili tibije i drugih kojima se služe napjevi.“

U Šiloboda se vidi pomak u sadržaju pojma musica u dva smjera. Prvi je svijest o skladanju i skladatelju (musica poetica) i uočavanje razlike između izvedbe kao nečeg nestalnog i prolaznog (musica practica) i skladbe iza koje ostaje (zapisano) djelo (aliquid operis). Drugi je podjela musica practica na dvije vrste, vokalnu i instrumentalnu što nam potvrđuje svijest o važnosti instrumentalne glazbe kao različite i odvojene od one vokalne. Neosviješteno ponavljanje Boetijeve podjele, integriralo je, naime, u značenjsko polje musica instrumentalis i vokalnu i instrumentalnu glazbu i više nije pristajalo praksi 18. stoljeća.

Cijela ideja o glazbi čije poznavanje osigurava spoznaju počinje s Pitagorinim naukom i njegovim poimanjem muzike kao matematičke znanosti, što joj poslije osigurava mjesto u kvadriviju unutar sedam slobodnih umijeća: „Svemir je bio shvaćen kao uređena cjelina, sustav čije je dijelove objedinjavao obrazac božanske „harmonije“ ili koordinacije. Ključ toga reda leži u broju ... ${ }^{541}$ Postojana legenda koja se do danas ponavlja u povijesti glazbe Pitagori

\footnotetext{
540 Šilobod-Bolšić, Mihael. Op. cit. Str. 54-55.

${ }^{541}$ Greek Musical Writings, vol. II: Harmonic and Acoustic Theory / uredio Andrew Barker. Cambridge: Cambridge University Press, 2004. Str. 28: „The universe was concieved as an ordered unity, a system whose parts were held together in a pattern of divine „harmony“ or coordination. The key to the nature of this order lay
} 
pripisuje otkriće da se interval oktave, koji se od 5. stoljeća naziva i harmonija ( $\dot{\alpha} \rho \mu$ ovía), u brojevima može izraziti kao 2:1, interval kvinte kao 3:2, kvarte kao 4:3, itd. Muzika shvaćena kao matematička disciplina odredila je i značenje pojma musicus (koji se danas vrlo često pogrešno prevodi pojmom glazbenik) kao onoga koji poznaje i razumije matematička pravila nastanka intervala i njihovih međusobnih odnosa. „Muzika, dakle, postaje sredstvo za postizanje višega cilja, instrument pomoću kojega se može (pokušati) spoznati savršenstvo. “" ${ }^{6542}$

Zagrebački kanonik Kovačević legendu je očito poznavao, no Pitagorin izum intervala povezao je u istome odlomku s latinskim nazivima tonova ljestvice te ona ostaje tek krnje prisjećanje na velikog matematičara.

Naime, pripovijest o Pitagori pronašla je svoje mjesto kao crtica o začetnicima pjevanja u Tominoj Brevis cantus gregoriani notitia na samom početku priručnika koji, kako nalažu retorička pravila, izlaže uvod u temu. Prvo poglavlje nosi, prema prijevodu Martina Mihokovića naslov „O različitim imenima tog pjevanja i o njegovu začetniku“, a drugi odlomak toga poglavlja kaže:

„Zatim, da se označi začetnik pjevanja, svejedno ili gregorijanskoga ili kićenoga, jedni misle jedno, drugi drugo. Jednima je začetnik Tubalkajin, drugima Amfion, a trećima Orfej. A vrlo mnogi uzimaju, da je poslije Potopa grčki filozof Pitagora počeo pjevanje, kada je nekom prilikom u nekoj kovačnici razabrao da različni čekići izdaju različite glasove. ${ }^{543}$ Otuda su onda, po izračunanom razmjeru, nastala šestora slova koja označuju ova naša: g, a, b, c, d, e.

in number ... I dalje: „A persistent tradition held that the Pythagoreans' interest in number and their deployment of numerical conceptions in cosmological contexts began from Pythagoras'discovery that certain fundamental musical relations can be expressed as ratios of numbers.“ (,... postojana tradicija smatrala je da je Pitagorino zanimanje za brojeve i njihovu implementaciju u numeričke koncepcije u kozmološkome kontkestu, počela od Pitagorina otkrića da određeni temeljni glazbeni odnosi mogu biti izraženi kao odnos brojeva.“)

${ }^{542}$ Ibid. Str. 14: „Finally, in the majority of 'Pythagorean' writers, the study of harmonics is part of a much larger enterprise, designed to show how the same principles govern ' harmonious' relations between the elements of all significant structures in the cosmos. The universe and its parts are all subject to the same perfect patterns of intelligible mathematical order.“ „Naposlijetku, kod većine pitagorejskih pisaca, studij harmonije dio je mnogo većeg pothvata, osmišljenog kako bi se pokazalo na koji način isti principi upravljaju harmoničnim odnosima između elemenata svih značajnih struktura kozmosa. Svemir i svi njegovi dijelovi podložni su istim savršenim obrascima inteligibilnog matematičkog reda“.

${ }^{543}$ Postavši topos u kvadrivijskoj disciplini musica, spomenuta legenda u kojoj Pitagora udaranjem čekića o žicu „otkriva“ matematičke proporcije intervala svoje mjesto pronalazi u mnogim glazbenoteorijskim spisima. Pripovijest ide ovako: Pitagora je, prolazeći uz kovačnicu čuo različite visine tonova koje su proizvodili udarci čekića o nakovanj. Potom je odlučio izmjeriti duljinu žice te uočio da dvostruko kraća žica daje ton za oktavu viši od prvog tona te je taj odnos označio omjerom 2:1. Nadalje, dijelovi žice u omjeru 3:2 daju kvintu, a u omjeru 4:3 kvartu. 
Grci su ih pjevali na mjesto onih šestorih slogova, kojima se mi sada služimo: ut, re, mi, fa, sol, la. “544

Kovačević preskače cijeli dio o intervalima (koje, usput rečeno, u cijelom priručniku uopće ne definira) i prelazi na grčke nazive tonova što, dakako, nema izravne veze s Pitagorinim izračunima. Iz ovih su, kao što znamo, nastali intervali oktava, kvinta i kvarta koji su zbog omjera cijelih brojeva kojima su mogli biti prikazani, nazvani harmonia. Oktava je nastala iz omjera 2:1, kvinta iz omjera 3:2, a kvarta iz omjera 4:3.

Šilobod-Bolšić pak, miješa legendu o Pitagori s onom iz Knjige postanka koja pripovijeda o braći Jubalu i Tubal-Kajinu od kojih je prvi praotac svirača, a drugi onih što kuju željezo. ${ }^{545}$ Premda na početku ispravno navodi Jubala kao začetnika orguljanja i citaranja (,Ipse enim (Gen. C. 4. V. 21.) fuit Pater canentium cithara, \& organo"), netom poslije pripisuje mu zasluge grčkoga filozofa.

„D: Operosa est homini consonantia magister! Quomodo ergo eam componere poterat Iubal?

M: Poterat sane, quia habuit fratrem Tubalcain, qui (citato cap. 4) fuit malleator, \& faber in cuncta opera aeris, \& ferri. ${ }^{546}$ Frater ergo eius Iubal, ex diverso inaequalium malleorum sono, diversas consonantias composuit: atque ita per musicam simplicem, divina providentia ad harmonicam pervenit, eamque posteritati tradidit.“

„Učenik: Teško je suglasje za čovjeka, učitelju. Kako je onda Jubal mogao skladati suglasje?

Učitelj: Itekako je mogao jer je imao brata Tukehaima koji je (nav. dj. gl. 4.) radio s čekićem i bio kovačem svih predmeta od mjedi i željeza. Dakle, njegov brat Jubal skladao je različita suglasja od raznolikih zvukova nejednakih čekića. Tako je, preko jednostavne glazbe, božanskom providnošću stigao do harmonije te je predao potomstvu. "“547

Brkanje pojmova i osoba, olako prenošenje Pitagorinih zasluga starozavjetnom ocu sviranja na citri i orguljama kako bi osigurao božansku intervenciju u pronalasku „harmonije“ te posljedično izostavljanje pripovijesti o matematičaru čije je pronalaske tradicija smatrala presudnima u stvaranju muzike kao znanosti, pokazuje usredotočenost na praktično znanje

\footnotetext{
${ }^{544}$ Cit. prema Mihoković, Martin. Op. cit. Str. 5.

545 Jeruzalemska Biblija. Zagreb: KS, 2008. Knjiga postanka, 4, 21-22: „Bratu mu bijaše ime Jubal. On je praotac svih koji sviraju na liru i sviralu. Sila rodi Tubal-Kajina, praoca onih koji kuju bakar i željezo.“

${ }^{546}$ Jeruzalemska Bibilja. Zagreb: KS, 2020. ${ }^{8}$ Knjiga postanka, 4: 22-23.

${ }^{547}$ Šilobod-Bolšić, Mihael. Op. cit. str. 50-51.
} 
kojem izvor nastanka intervala nije od velike koristi. Onaj tko treba znati pjevati na koru ne mora ništa znati o teoriji: on je cantor, a ne musicus. No, Šilobod-Bolšić ipak je uložio određeni trud u konzistentan prikaz nastanka muzike kao prakse i pravila. Za razliku od Kovačevića koji odmah nudi imena tonova i nastavlja dalje sa solmizacijom, ključevima i notnim trajanjem, Šilobod-Bolšić odlučuje učeniku prepričati njezino porijeklo, ali pritom bira verziju koja zaslužnima čini starozavjetne ličnosti, a ne grčke filozofe. Pritom ne govori napamet, već na temelju Svetog pisma. Prikazuje njezin put koji ju je vodio od izumitelja Jubala koji je, ne doznajemo na koji način budući da je bio otac citaranja i orguljanja, o čemu svjedoči četvrto poglavlje Knjige postanka, izumio zemaljsku glazbu kao odraz unisonog anđeoskog pjeva, ali u konsonantnom intervalu oktave.

„Ego vero non tam ex me, quam ex sacris litteris dicam: musicam originem habere ab octavo post Adam homine Iubal. Ipse enim (Gen. C. 4. V. 21.) fuit Pater canentium cithara, \& $\operatorname{organo}^{548}$, ut unisono canentium Angelorum choro in coelis, corresponderet in consonantia suae octava in terris.“

„Ja, pak ne govorim toliko napamet, koliko na temelju Svetog pisma: glazba potječe od osmog čovjeka poslije Adama, Jubala. On je naime bio otac citaranja i orguljanja (Postanak, Gl. 4, st. 21.), tako da jednoglasnom zboru anđela koji pjevaju na nebesima odgovara $u$ suglasju oktava na zemlji. “549

Jubal je, pripovijeda dalje Šilobod, priredio dva stupa s glazbenim pravilima: jedan mramorni, a drugi od opeke. Ako mramorni bude uništen ognjem, sačuvat će se onaj od opeke. U slučaju potopa, nestat će stup od opeke, a mramorni će ostati postojan. Upravo se to i dogodilo u strašnom biblijskom potopu koji je od ljudskoga roda jedini preživio Noa. Tako je Noa, uz sve vrste životinja koje je poveo sa sobom u korablju, spasio i glazbenu teoriju.

\footnotetext{
${ }^{548}$ Jeruzalemska Bibilja. Zagreb: KS, 2020. ${ }^{8}$ Knjiga postanka, 4:21.
}

549 Šilobod-Bolšić, Mihael. Ibid. 


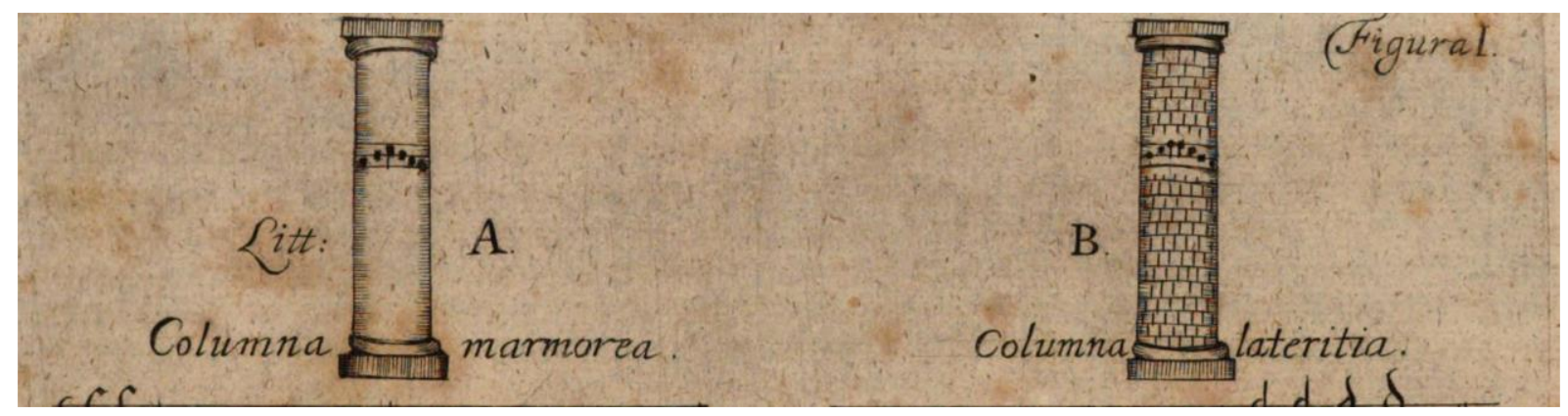

S1. 13 Mramorni stup i stup od opeke s urezanim pravilima glazbene teorije. Samber, Johann Baptist. Elucidatio musicae choralis. Salzburg, 1710. Str. 15.

Samberov tekst kao izvor i uzor Šilobodu daje odgovor na ovu zavrzlamu i nama danas nerazumljivo pripisivanje Pitagorina izuma Jubalu, o kojem Biblija izvještava vrlo oskudno, dok je legenda o Pitagori stoljećima opće mjesto govora o glazbi. Pripovijest o Pitagori topos je glazbene teorije od Boetija koji ju je prenio iz antike. Odricanje zasluga velikanu kojeg spominju gotovo svi utjecajni teorijski traktati čini se neobičnim. No, ako se prisjetimo da su tekstovi pisani u jeku katoličke obnove i nastojanja da crkvena vokalna glazba postane sva Glazba (o čemu svjedoče i brojni primjeri navođenja antičkih primjera sviranja u korist crkvene vokalne glazbe, što smo pokazali u Petom poglavlju disertacije), ovaj postupak ne treba nas previše iznenaditi. Uz to, valja se podsjetiti na sve izrazitiju dominaciju pedagoškog diskursa o glazbi koji je, bez obzira na eksploziju spekulativnih traktata u 16. stoljeću u Italiji, u 17. i 18. stoljeću nesumnjivo činio veći dio glazbene teorije. ${ }^{550} \mathrm{Na}$ temelju čega je, dakle, palo na pamet Samberu da poveže Jubala i udaranje čekića o nakovanj te posljedični pronalazak intervala? Stih iz Knjige postanka koji prethodi onome o Jubalu donosi ključnu informaciju. Njegov je brat Tubal-Kajin bio otac sviju onih što kuju mjed i željezo, veli Biblija. Živeći uz brata, Jubal je mogao čuti zvukove različitih čekića kako udaraju o nakovanj i proizvode „harmonije“. Samber, za razliku od Šiloboda, na taj način i vodi argumentaciju u četvrtom poglavlju svoga djela:

\footnotetext{
${ }^{550}$ Za pregled stanja u području glazbene teorije u 17. stoljeću usp. članke objavljene u sklopu Symposium on Seventeenth- Century Theory: Cohen, Albert. Symposium on Seventeenth-Century Music Theory: France. // Journal of Music Theory 16/1-2, 1972. Str. 16-35. Buelow, George. Symposium on Seventeenth-Century Music Theory: Germany. // Journal of Music Theory 16/1-2, 1972. Str. 36-49. Horsley, Imogene. Symposium on Seventeenth-Century Music Theory: Italy. // Journal of Music Theory 16/1-2, 1972. Str. 50-61. Također i Blasius, Leslie. Op. cit.; Wason, Robert W. Musica practica: music theory as pedagogy. // The Cambridge History of Western Music Theory / uredio Thomas Christensen. Cambridge: Cambridge University Press, 2008. Str. 46-77.
} 
„Wie dann zu lesen ist Genesis Cap. 4 allwo er gennenet wird Pater Canentium Cythara, \& Organo: Jubal hat nicht allein Musicam simplicem, sondern auch Harmonicam durch die Klang unterschidlicher Hämmern seinse Brudern Tubal (welcher ein Schmid war) erfunden: Wie dann auch Jubal solche Hammer gewogen/ und gefunden/ dass der schweriste Hammer zwölf Pfund/ der ander neun / der dritte acht/ und der kleiniste sechs Pfund gehabt habe: ... “

„Kako se može pročitati u Postanku, gl. 4 posvuda je poznato da je otac sviranja na citri i orguljama Jubal (koji) nije pronašao samo jednoglasnu glazbu, nego i višeglasnu kroz zvukove različitih čekića svoga brata Tubala (koji je bio kovač): potom je Jubal takve čekiće izvagao i otkrio da najteži čekić ima dvanaest funti ${ }^{551}$, drugi devet, treći osam i najmanji šest: ..."

Zato neki vele da je višeglasna glazba, veli Samber dalje, potekla od pečenog kamenja, odnosno cigli.

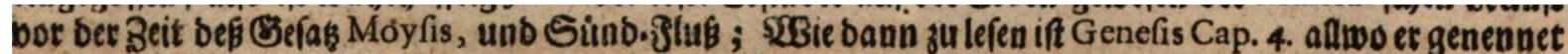
witb Pater Canentium Cythara, \& Organo : Jubal bat nicbt allein Muficam fimplicem, ronbern aucb

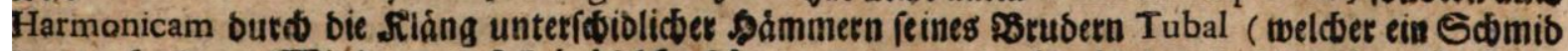

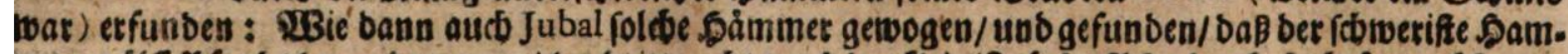

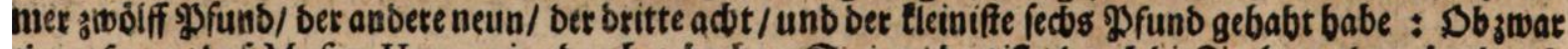

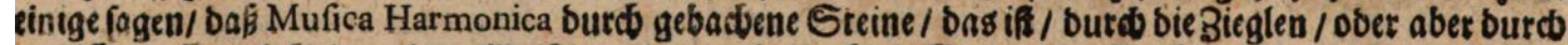
getwiffe groff- unb tleine erbene Be efdirz/ als man barauf mit Berten ober Oxutben icbluge/ wobutd allerley Siangen geboiret wutben / berbot fommen feve/ tbut abet foldbed Petrus Comeftorus in feinet Schola-

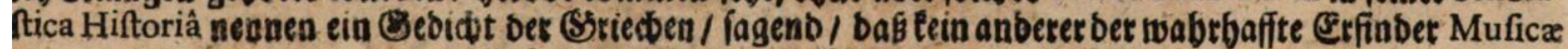

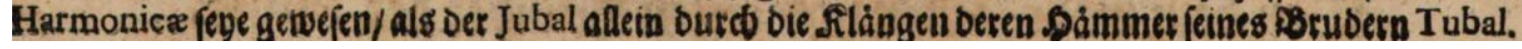

Sl. 14 Ulomak iz četvrtog poglavlja o porijeklu glazbe iz Samber, Johann Baptist. Elucidatio musicae choralis. Salzburg, 1710. Str. 4.

Od utjecajnih glazbenoteorijskih tekstova čiji su se ulomci nalazili u prosječnoj liber textualis za poduku u muzici, Guidov Micrologus donosi pripovijest o Pitagori, doduše skraćenu, dok Jubala ne spominje. Johannes de Muris kojeg u kontekstu podjele notne vrijednosti spominju i

\footnotetext{
${ }^{551}$ Pfund (stnjem.) je stara njemačka mjera za težinu nastala prema latinskom pondus. Funta je težila 454 grama.
} 
Kovačević i Bolšić u djelu Musica practica ne navodi legendu o Pitagori, ali je zato opširno razrađuje u Musica speculativa. ${ }^{552}$

Izvor za zamjenu uloga Jubala i Pitagore donosi nam sam Samber. Riječ je o vrlo utjecajnom spisu iz 12. stoljeća Scholastica Historia Petrusa Comestorusa. ${ }^{553}$

Spekulativnom glazbenom teorijom naši učitelji pjevanja, dakle, jedva da se bave. No, to je također tipično za razdoblje u kojem djeluju, jer je većina traktata već u kasnom srednjem vijeku „odbacivala bilo kakve ozbiljne rasprave o harmoniji sfera (ili bi je barem ublažavala zdravom dozom Aristotelovskog skepticizma). Umjesto toga, pisci ovih traktata ... uzeli su mnoge od naslijeđenih kvantitativnih tema ... - tetrakord, oblici oktave, izračuni intervala, itd. - i prilagodili ih s različitim stupnjevima uspjeha problemima suvremene glazbene prakse." ${ }^{\text {554 }}$

\footnotetext{
${ }^{552}$ Falkenroth, Christoph. Die Musica speculativa des Johannes de Muris. Beihefte zum Archiv für Musikwissenschaft, vol. 34. Stuttgart, Steiner, 1992. URL: https://chmtl.indiana.edu/tml/14th/MURISAPP. (13.09.2020.), ,[292] Pythagoram artem nobis tradidisse sonorum.Hic Pythagoras antiquus princeps numerorum et proportionum magister, cui a toto tempore vitae numerus obedivit, sic ut vi numerorum scire singula intueretur, in anxietate diu manens, quomodo ad artem de melodiis rationem inveniret, quadam vice divino nutu fabrorum officinas praeteriens hanc cognitionem mentaliter circumvolvens, quosdam malleos super incudem cedentes mirabilem harmoniam emittentes audivit. Ad quos conversus fervens veritatis inquisitor iussit inter se permutatim malleos <singulos> permutari, dubitans ne ex viribus hominum tanta proveniret melodia. Quibus alternatis rediit eadem symphonia sicut prius. Unde conclusit, non in lacertis virorum, sed in natura malleorum tales concordantias contineri, tam numeri, quam mensurae, quam ponderis ratione. Quintus tamen foras eiiciebatur, quoniam <inutilis> cuilibet aliorum comparatus dissonabat, consideratisque ponderibus aliorum in dupla, sesquialtera et sesquitertia reperta sunt proportionibus. Et in quibuscumque aliis rebus, tympanis, tintinnabulis et ceteris has proportiones continentibus easdem reperiri harmonias. Unde in hac experientia requievit per tertiam. Ex quibus experimentis rationis musicae deducta fuerunt principia per quartam. Propter symphoniam subiungere vim numerorum Pythagoras sonorum consonantias per proportiones ponderum reperit. Et eaedem proportiones in numeris his reperiuntur 1298 6.Iam tres harmonias perfectas esse sonantes. Quod non sint pauciores tribus, experientia <docuit>. Sed si sint plures quam natura voluit [293] revelare, Deus novit. Perfectiores tamen usque ad nos his tribus nemo umquam repertus est. Et sunt hae: diapason, qui es 12 ad 6; diapente, 12 ad 8 vel 9 ad 6; diatesseron, ut 12 ad 9 aut 8 ad 6 . Tonus vero, qui est ut 9 ad 8 , non est consonantia, sed pars eius. Has tres melodias numeros dare tonantes. “
}

${ }^{553}$ Usp. Petrus Comestor. Historia Scholastica: Historia Libri Genesis, Caput 28: De generationibus Cain. URL: https://babel.hathitrust.org/cgi/pt?id=ucm.5316856714\&view=1up\&seq=3. (12.11.2020.)

${ }^{554}$ Christensen, Thomas. Op. cit. Str. 6.: „Most treatises of “speculative” music theory in the late Middle Ages had dropped any serious discussion of celestial harmony (or at least, tempered it by a healthy dose of Aristotelian skepticism). Instead, the authors of these treatises ... took many of the received quantitative topics of classical harmonics - the tetrachord, octave species, calculations of interval ratios, etc. - and adapted them with various degrees of success to issues of contemporary musical practice. Problems of pitch material (scales, intervals, mode, and solfege) were grouped under the rubric of musica plana; that of rhythm and mensural theory (really a kind of advanced counterpoint) under the rubric of musica mensurabilis.“ 
Trend spajanja jedne i druge teorije ostao je prisutan i u 16., 17. i 18. stoljeću kada su najveći spekulativni traktati - oni Zarlina, Salinasa, Ceronea, Mersennea i Rameaua ${ }^{555}$ - „svi bili objavljeni u paru s komplementarnim traktatima musica practica, svi, štoviše povezani unutar korica jednog te istog sveska. ${ }^{\text {(556 }}$

Krhotine spekulativne teorije u priručnicima Kovačevića i Šiloboda-Bolšića vidljive su i u opisivanju etičkih odlika pojedinih tonusa. Kovačević je pritom vrlo koncizan i ne upušta se u raspravu o osobinama pojedinog tonusa. On ih jednostavno dijeli na autentične i plagalne ne opisujući svaki posebno, ali im pridaje grčka imena: Protus, Deuterus, Tritus i Tetrardus. Pritom su ,prvi autentični živi i veseli, jer im se napjev penje /cum terminis ascendentibus/, a drugi, plagalni su afektuozni i žalobni, napjev se izvodi spuštanjem glasa /cum terminis descendentibus/." 557

Šilobod-Bolšić i na ovom je mjestu elokventniji u prikazu i, osim što svih osam tonusa naziva imenima koja im i mi danas pripisujemo, svakome pridaje i karakter.

Nazivi prva četiri autentična tonusa koje koristi i Šilobod-Bolšić (dorski, frigijski, lidijski, miksolidijski) potječu od Aristotela, tvrdi Boetije u De Institutione musica. On im je dodao prefiks hypo te tako dao naziv plagalnim oblicima tonusa. O tome nas obavještava Monachus Carthusiensis u Tractatus de musica plana iz 15.st.:

„Ad supradicta quatuor nomina, scilicet Dorius, Frigius, Lydius, et Mixolydius que ponit Aristotiles "octo politicorum", Boetius superaddit istam dictionem "Hypo", et inde veniunt quatuor toni plagales ultra ipsos quatuor tonos principales. Unde versus:

Dorius et Frigius, Lydius, Mixolydiusque

Cuivis des Hypo, collateralis erit.

\footnotetext{
${ }^{555}$ Radi se o sljedećim traktatima: Zarlino, Gioseffo. Le Istitutioni harmoniche. Venecija, 1558.; Salinas, Francisco de. De musica libri septem. Salamanca: Mathias Gastius, 1577.; Cerone, Pietro. El melopeo y maestro: tractado de música theorica y pratica; en que se pone por extenso; lo que uno para hazerse perfecto musico ha menester saber. Napulj, 1613. Ceroneov gigantski spis sastojao se od 1160 stranica podijeljenih u 22 sveska!: Mersenne, Marin. Harmonie universelle. Paris: 1636-1637.; Rameau, Jean-Philippe. Traité de l'harmonie. Paris, 1722.

${ }^{556}$ Bower, Calvin M. Op. cit. Str. 152.: ,It is worth noting that of the most important treatises of speculative music theory that would be penned over the following centuries by Zarlino, Salinas, Cerone, Mersenne, and Rameau, all were paired with complementing treatises of musica practica - all indeedboundwithin the covers of the same volume."
}

${ }^{557}$ Usp. Mihoković, Martin. Op. cit. str. 21. Ovu definiciju nalazimo i kod Sambera. Usp. Samber, Johann Baptist. Op. Cit. 
Secundum Boetium sic vocantur octavi toni:

Dorius dicitur primus tonus

Hypodorius dicitur secundus tonus

Frigius dicitur tertius tonus

Hypofrigius dicitur quartus tonus

Lydius dicitur quintus tonus

Hypolydius dicitur sextus tonus

Mixolydius dicitur septimus tonus

Hypomixolydius dicitur octavus tonus. “558

Od šesnaestog stoljeća poznata je i vrlo raširena Zarlinova i Glareanova teorija tonusa koja ih broji dvanaest (dodani su eolski i jonski) razvrstavajući ih prema poziciji tritonusa. No, suprotno historiografima, ona ne svjedoči prvi spomen durskog i molskog sustava, već nastoji upotpuniti postojeći modalni sustav. ${ }^{559}$ Šilobod-Bolšić navodeći tonuse pristaje uz teoriju poteklu od Boetija koja ih broji osam. Raspored tonova u svakom od njih definira određene osobine i stvara poseban ugođaj. Budući da se radi o gregorijanskome pjevanju u kojem su tekst i melodija nerazdruživi, osobine tonusa definiraju i sadržaj teksta koji im je primjeren i obratno. Pobjednička i radosna tema ne može se pjevati u frigijskom tonusu koji je „oštar i tvrd i zahtijeva teme vrijedne ljutnje“, dok melodija u njegovoj plagalnoj verziji, hipofrigijskom ,plačljivom laskavcu“ ne odgovara „dostojanstvenom i misaonom“ tekstu koji se, opet, najbolje združuje s dorskim modusom. A teme napjevi koji govore o postizanju milosti od Boga ili Djevice Marije čak imaju vlastiti modus - onaj miksolidijski.

\footnotetext{
${ }^{558}$ URL: http://boethius.music.indiana.edu/tml/15th/CARTRA. (24.06.2019.)

${ }^{559}$ Usp. Lester, Joel. Major-Minor Concepts and Modal Theory in Germany, 1592-1680. // Journal of the American Musicological Society, 30/2 (1977). Str. 208-253.
} 
„Minime gentium frustra decantantur. Sed ex diversitate materiae, atque rerum, diversos quoque \& varios convenit esse tonos. Primus enim tonus Dorius dictus partim tristis, partim iucundus: convenit ergo, ut contineat materias graves, \& sententiosas. Secundus Hipodorius est flebilis, \& gravis: appropriabit ergo sibi res tristes, \& lamentabiles. Tertius Frigius, est asper, \& durus, requiret ergo materias iracundas. Quartus Hipofrigius, est adulator flebilis, adeoque vult habere materis tractantes de tranquilitate animi, \& rerum. Quintus Lidius, est suavis, \& delectabilis: \& petit materias iucundas, vel victoriosas. Sic in festo Corporis Christi quinta ad laudes antiphona: Vincenti dabo manna. Est quinti toni. Sextus Hipolidius, est gravis ac devotus, vultque habere materias devotas, vel funebres \& calamitosas. Septimus Mistolidius, est melancholicus, continetque materias tristes, ac conturbatas. Octavus Hipermistolidius, est plenus suavitate, ac iucunditate; habetque materias mansuetas \& graves; continentes res speculativas, \& divinas, de impetranda gratia a Deo, eiusque Beata Virgine.“

„Ni za što na svijetu ne pjevaju se bez razloga, nego zbog različitosti građe i tema odgovara da tonusi budu različiti i raznoliki. Naime, za prvi, dorski tonus kaže se da je dijelom tužan, a dijelom ugodan. Odgovara mu, dakle, da sadrži dostojanstvenu i misaonu građu. Drugi, hipodorski jest žalostan i uzvišen. Odgovarat će mu, dakle, tužne teme i one bliske jadikovci.

Treći, frigijski je oštar i tvrd te stoga zahtijeva teme vrijedne ljutnje. Četvrti, hipofrigijski je plačljivi laskavac i stoga nastoji posjedovati građu koja govori o miru duše i prirode. Peti, lidijski je ugodan i zabavan te traži ugodnu ili pobjedničku građu. Tako je na blagdan Tijelova peta antifona u laudama Vincenti dabo manna u petom tonusu. Šesti, hipolidijski je dostojanstven i pobožan te zahtijeva vjernički ili pogrebni i nesretan karakter. Sedmi, miksolidijski je melankoličan i sadrži tužne i uznemirujuće osobine. Osmi, hipomiksolidijski je pun ljupkosti i ugode te ima blage i dostojanstvene osobine jer sadrži spekulativne i božanske teme o postizanju milosti od Boga i Blažene Djevice. “560

Imenujući tonuse antičkim nazivima i nudeći uvid u njihov karakter, Šilobod-Bolšić donekle predstavlja iznimku kad Fundamentum usporedimo s priručnicima iste teme i namjene i sličnoga opsega. Toma Kovačević, Fabrizio Tettamanzi i Frezza Dalle Grotte, Mihael Keinspeck (ili Reinspeck kako ga navodi Samber) i Johann Baptist Samber, da nabrojimo samo one najbliže po pitanju teme, vremena i mjesta izdavanja, ali niti Adriano Banchieri u Cartella musicale ${ }^{561}$ koju kao izvor navode gotovo svi nabrojani autori, ne spominju više

\footnotetext{
560 Šilobod-Bolšić, Mihael. Op. cit. Str. 142-143.

${ }^{561}$ Banchieri, Adriano. Cartella musicale nel canto figurato, fermo e contrapunto. Venezia, 1614. Str. 68-69. URL: https://imslp.org/wiki/Cartella_musicale_(Banchieri\%2C_Adriano). (14.01.2020.)
} 
Boetijevu terminologiju, kao ni ugođaj koji stvara svaki pojedini tonus. Tonusi su, u svih navedenih autora, kao u priloženoj slici iz Samberova Elucidatio, imenovani rednim brojem, a ekstenzivno tumačenje svakog pojedinog odnosi se na njihovo korištenje u psalmima i antifonama.

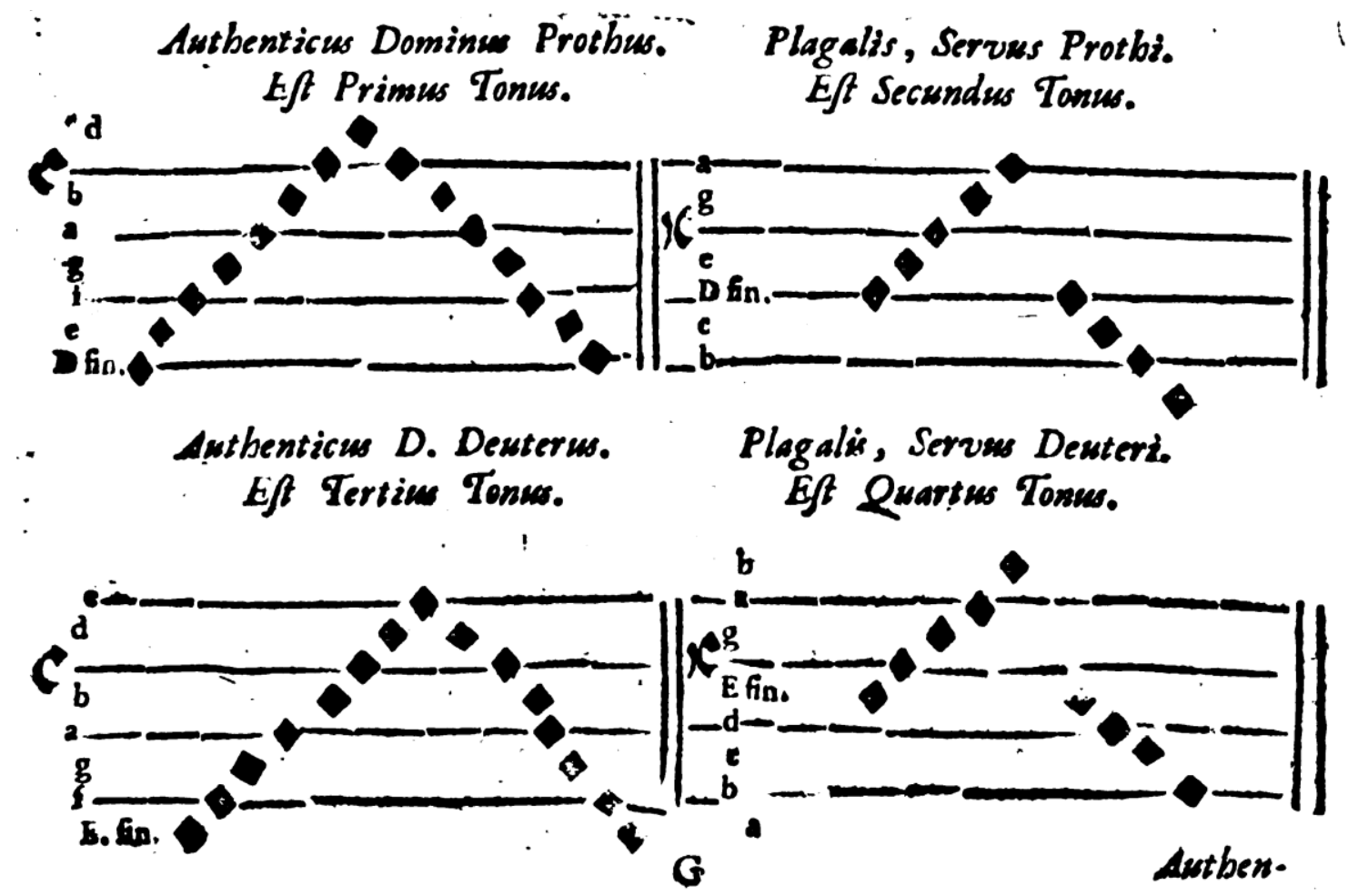

S1. 15 Šilobod-Bolšić, Mihael. Fundamentum cantus gregoriani seu choralis ... Str. 122. Prikaz prva četiri tonusa nazvana prema grčkim rednim brojevima. Tek u posljednjem poglavlju (O intonacijama) pisac im pridaje tradicionalna imena i definira osobine svakog pojedinog.

Platonovo učenje o harmoniji temelj je na kojem je kršćanstvo stvorilo vlastitu ideju o muzici kao o matematičkoj znanosti koja čini dio kvadrivija. Pošto je, uz teoriju brojeva, geometriju, stereometriju i astronomiju, o glazbi kao praksi koja čini neizostavni dio kurikuluma filozofavladara raspravljao u Državi ${ }^{562}$, Platon se u Timeju ${ }^{563}$ opsežno bavi harmonijom sfera i ulogom glazbe u rezoniranju harmonije makrokozmosa i mikrokozmosa. Platonizam, odnosno neoplatonizam kakav je propagirao najsustavniji tumač Platonovih djela Plotin (uvodnik $C O$

\footnotetext{
${ }^{562}$ Usp. knj. VII Platon. Država (prev. Martin Kuzmić). Zagreb: Naklada Jurčić, 2009. ${ }^{6}$

${ }^{563}$ Usp. Timej, 34b - 36d. Cit. prema Barbarić, Damir. Skladba svijeta. Zagreb: MH, 2017.
} 
III ga naziva „Platonicae sapientiae Antistite“ - vrhovnikom platonske mudrosti), temeljno je odredio kršćansku teologiju i filozofiju u cjelini, pa tako i filozofiju i teoriju glazbe. Ideja snažnog i nezamjenjivog utjecaja glazbe na čovjekovu dušu i shvaćanje duše kao medija transcendentalnog prilagođavana je kršćanskoj teologiji ${ }^{564}$, no opstala je kao temelj svakog filozofskog promišljanja glazbe.

Tri su glavna Platonova doprinosa misli o glazbi u kršćanstvu koja su se, posredstvom Plotina, a potom Augustina i Boetija, zadržala sve do kraja 18. stoljeća.

1. harmonija (grč. $\dot{\alpha} \rho \mu o v i ́ \alpha)$

Pitagori pripisana teorija o nastanku i odnosu intervala na temelju brojevnih odnosa nazvana je harmonijom, što je u najstarijim antičkim glazbenoteorijskim spisima bio sinonim za interval. Na temelju činjenice da je interval odnosno harmonija u stvari brojevni odnos, musica je kao spekulativna matematička znanost uz aritmetiku, geometriju (i stereometriju) te astronomiju uvrštena u kvadrivij sedam slobodnih umijeća. Pritom musica kao dio kvadrivija nije mousikē, harmonični suodnos umijeća sviranja, pjevanja i plesa koja je bila zamišljena i ostvarena kao idealni sinkretični oblik neprestano prisutan u svim javnim prigodama. ${ }^{565}$

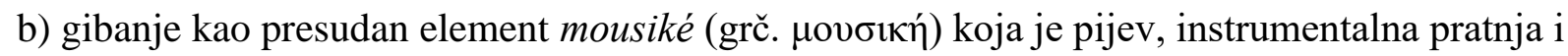
ples u jednome te gibanje kao temeljna odlika duše koja je i sama gibanje, stoga i najpodložnija utjecaju glazbe. Budući da s njome dijeli isti temeljni princip s njome je i usporediva.

c) princip ethosa (grč. ๕̌ 9 o $)^{566}$ koji proizlazi iz prethodnoga, a odnosi se na stanje duše koje je promjenjivo i na koje je stoga glazbom moguće utjecati. Principi etičkog djelovanja glazbe na

\footnotetext{
${ }^{564}$ Nepregledan je niz znanstvenih članaka posvećenih Platonovoj misli o glazbi. Za temeljiti uvid usp. Moutsopoulos, Evanghelos. La Musique dans l'oeuvre de Platon. Paris: Puf, 1989.; Greek Musical Writings. Cambridge Readings in a Literature of Music, sv. I i II / uredio Andrew Barker. Cambridge: Cambridge University Press, 1990.; Pelosi, Francesco. Plato on Music, Soul and Body. Cambridge: Cambridge University Press, 2010. Za odnos platonizma i neoplatonizma v. de Vogel, Cornelia J. On the neoplatonic Character of Platonism and platonic Character of Neoplatonism. // Mind, 62/ 245 (1953), str. 43-64. Oxford: Oxford University Press. URL: https://www.jstor.org/stable/2251287?seq=1\#page_scan_tab_contents ; Eadem. Rethinking Plato and Platonism. Leiden, New York: Københaven: Köln: E. J. Brill, 1986.; Gretić, Goran: Platonizam i temelji neoplatonizma- // Prilozi za istraživanje hrvatske filozofske baštine, 10/ 1-2 (1984), str. 125166.

${ }^{565}$ Usp. Barbarić, Damir. Mousikē i ethos u Grka. // Treći program Hrvatskog radija (0353-94743) 80 (2012), str.135-143. URL: http://eprints.ifzg.hr/702/1/Mousike\%20i\%20ethos\%20u\%20Grka.pdf (27.02.2019.) ${ }^{566}$ Hrvatski jezični portal definira etos kao 1. fil. osobine, sustav vrijednosti i ponašanja specifičnih za određen narod ili kulturu; ćudoređe, moral, običaj i 2. starogrčki nauk o moralu, ćudoređu, o običajima. Ethos se ovdje razumijeva historijski kao naziv za vjerovanje u antičkoj grčkoj kulturi prema kojem su glazba i čovjekova duša povezane posredstvom harmonije kao zajedničke biti, a koja je uz to i temeljna odlika svemira. Glazba stoga ima
} 
čovjeka najčešće su i najbrojnije neizravne reference na (neo)platonizam, a argumentacija se oslanja podjednako na pripovijesti iz grčke mitologije i iz Staroga Zavjeta.

Kršćanska interpretacija platonizma kroz spise svetog Augustina definirala je korpus znanja koji danas nazivamo spekulativna teorija i koji počiva na broju kao temelju definicije glazbe. ${ }^{567}$

Augustinovo viđenje nebeske harmonije kao ideala savršenstva ne samo po sebi, već i za ljudska bića koja joj moraju težiti, što će postići putem glazbe, iznjedrila je dva srodna koncepta koji se posredno oslanjaju i na Platonovu ideju odgoja ( $\pi \alpha \iota \delta \varepsilon i \alpha)$ kroz glazbu. Prvi se odnosi na glazbu kao tješiteljicu, a drugi na glazbu kao poticateljicu pobožnosti i izravnu vezu s Bogom i anđelima. S vremenom, sve je manje rasprava posvećeno numeričkim izračunima glazbenih elemenata i usporedbama nebeskih harmonija s onim zemaljskima, a naglasak prelazi na etičku i soteriološku ulogu glazbe. I jedna i druga nalaze uporište u Svetom pismu, osobito u Starom zavjetu koji u odnosu na Novi zavjet kudikamo češće spominje glazbu. ${ }^{568}$ Predgovori Cithara octochorda ističu važnost glazbe u jačanju pobožnosti i u neoplatonističkoj maniri povezuje harmoniju glazbe s harmonijom ljudskih duša, kao što smo već pokazali na primjerima njezina čudesnog djelovanja u Petom poglavlju. Upravo u tim dijelovima teksta otkrivaju se neoplatonistički stavovi baštinjeni od kasne antike: u smislu isticanja glazbe kao Božjega dara i njezine moći da uputi čovjeka ,prema sretnim nebeskim

moć pozitivnog i negativnog utjecaja na oblikovanje čovjekova karaktera i mijenu stanja duše. Ovaj stav zagovaraju i Platon (Država, III) i Aristotel (Politika, VIII).

${ }^{567}$ Usp. Brennan, Brian. Augustine's De Musica. // Vigiliae Christianae, 42/3 (Sep. 1988), str. 267-281. URL: https://www.jstor.org/stable/1584121 (16.04.2020.), ,There is a hierarchy of number from the One Himself down through the numeri. All music, good or bad, contains in some way the divine patterning. God has created all things and rules through all, ut etiam peccatrix et aerumnosa anima numeris agatur, et numeros agat usque ad intimam carnis corruptionem: qui certe numeri minus minusque pulchri esse possunt, penitus vero carere pulchritudine non possunt (De Mus. 6.17.). Such an aesthetic formula provided Augustine with a justifica- tion of the attraction that music had for him." Cijeli spis De Musica raspravlja o broju i njegovim manifestacijama u metru i zvuku. Spis De musica libri sex ${ }^{567}$ tek je prvi dio planiranoga traktata posvećenoga glazbi koji se trebao nastaviti raspravom o melodici. ${ }^{567}$ Pritom prvih pet knjiga raspravlja o ritmu i metru dok je šesta knjiga poslije prerađena te je posjedujemo u obliku u kojem je kao emendatio poslana Memoriusu: „Sextum sane librum, quem emendatum repperi, ubi est omnis fructus ceterorum, non distuli mittere caritati tuae; fortassis ipse tuam non

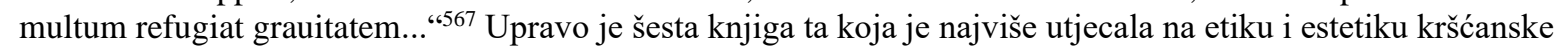
glazbe u kasnoj antici i tijekom cijelog srednjega vijeka. U njoj se, s jasnim uporištem u neoplatonizmu, insistira na broju kao temelju jednakosti, sličnosti, suglasja i reda: moć i ljepotu glazbe kao puta (Anagoge) prema spoznaji nosi aequalitas numerosa. Čak i površnim čitanjem De Musica, a osobito uvidom u brojnu filološku i muzikološku literaturu o tom spisu, jasno je da ona nije bila niti uzor niti izvor Šilobodu-Bolšiću, kako tvrdi Koprek u svom članku.

${ }^{568}$ Usp. Mitchell, J. C. The Music of the Old Testament Reconsidered. // Palestine Exploration Quarterly, 124/2, str. 124-143. URL: https://www.tandfonline.com/doi/abs/10.1179/peq.1992.124.2.124 (15.12.2020.) 
otocima“, kako veli prvo izdanje CO,, ovi su predgovori bliži Augustinovoj ideji glazbe od priručnika Šiloboda-Bolšića i Kovačevića.

Samome predgovoru prvoga izdanja prethode dva znamenita citata iz Biblije. Prvi je iz poslanice Efežanima 5, 18-19:

„Implemini Spiritu Sancto, loquentes vobismetipsis in Psalmis \& hymnis \& canticis Spiritualibus, cantantes \& psallentes in Cordibus vestris Domino, gratias agentes semper pro omnibus in nomine Domini nostri Iesu Christi.“ Ephes. Cap. 5, vers. 18.

„I ne opijajte se vinom u kojem je razuzdanost, nego - punite se Duhom! ${ }^{19}$ Razgovarajte među sobom psalmima, hvalospjevima i duhovnim pjesmama! Pjevajte i slavite Gospodina u svom srcu! ${ }^{20}$ Svagda i za sve zahvaljujte Bogu i Ocu u imenu Gospodina našega Isusa Krista! ${ }^{6569}$

Efež., 5.18-19

Drugi citat potječe iz Staroga Zavjeta, iz Psalma koji se naziva Molitvom starca:

„Repleatur os meum laude, ut cantem gloriam tuam, tota die magnitudinem tuam.“

Psal. 70. Vers. 8.

"Usta mi bijahu puna tvoje hvale, slaviše te svaki dan!"6570

Psalmus, hymnum i canticus spiritualis - psalam, himan i duhovna pjesma izvode se pjevajući i psalmirajući - cantare i psallere. To će pjevanje ,zemaljskim pjevačima“ omogućiti ne samo sjedinjenje s anđelima „kojima je pravi užitak tvoriti jedan zbor s onima koji pjevaju psalme“, nego će doprijeti i do samoga Boga, budući da „oduševljenje što ga ono stvara sjedinjuje ljudske duhove sa samim Bogom. “571

\footnotetext{
${ }^{569}$ Cijeli tekst u Vulgati glasi: „(18)et nolite inebriari vino in quo est luxuria sed implemini Spiritu (19) loquentes vobismet ipsis in psalmis et hymnis et canticis spiritalibus cantantes et psallentes in cordibus vestris Domino (20) gratias agentes semper pro omnibus in nomine Domini nostri Iesu Christi Deo et Patri." URL: https://www.biblestudytools.com/vul/ephesians/5.html (15.05.2019.)

${ }^{570}$ U suvremenom izdanju Biblije numeracija je nešto drugačija pa se ovaj Psalam vodi kao Ps 71 (70), 8

${ }^{571}$ Usp. Prilog 1.
} 
Predgovor drugom i trećem izdanju, budući kudikamo bogatiji primjerima djelovanja glazbe, češće spominje i njihovu svrhu. Kristova je crkva, „ovčinjak neizrecive slasti“ u koji ovce Kristove valja privući ne samo propovijedima, nego i ,in hymnis nempe \& canticis; ut ait Doctor gentium, Spiritialibus cantantes \& psallentes Domino“, „,himnima i popijevkama duhovnim, kako veli Učitelj naroda, pjevajući i psalmujući Gospodu. “572

One imaju dvostruko djelovanje: izgone demone i istovremeno nas približavaju Bogu:

„Cantus tamen, seu musica vocalis in sacrificiis, in Sacris mausolaeis, atque in alio supremi Numinis cultu adhibita, admirabilem sane fidelium animos trahendi, DEUM nobis appropinquandi, \& malignos spiritus a nobis fugandi virtutem habet.“

„Jer, ipak pjevanje ili vokalna glazba koja se izvodi kod žrtava, svetih pokopa i kod drugih oblika štovanja Vrhovnoga Bića, ima divnu snagu da privlači duše, da se Bogu približavamo i da od nas odgoni zloduhe.“

„... sed pura suavitate ita hominum animos permeat, ut in iisdem summum Regimen exerceat. “ 573 Štoviše, u ljudske duše čistom slašću uvodi svoju vrhovnu vlast.

Pojmu musica, dakle, kako ga definira sv. Augustin prema Varonu: musica est scientia bene modulandi, kao znanosti moduliranja u smislu određivanja mjere i reda ${ }^{574}$, u hrvatskim izvorima nema mjesta. Niti na jednome mjestu u hrvatskim izvorima musica se ne spominje kao disciplina koja se oslanja na broj i brojevne odnose (ako izuzmemo poglavlja o intervalima koja govore samo o broju stupnjeva koji se prelaze u određenom intervalu od tona do tona). Nepostojanje referenci na broj kao temelj harmonije, etičkoga djelovanja glazbe i njezinih estetičkih kvaliteta, ne smije nas, međutim, zavarati. Predgovori zbornicima napjeva nisu mjesto na kojem se razglaba o matematičkim izračunima, no u isticanju važnosti glazbe pri pokušaju dosezanja metafizičkog i izvantjelesnog, upravo božanskog, premda neiskazana, kao temelj počiva ideja sklada corporea i incorporea razumljiva jedino kroz brojevne odnose.

\footnotetext{
572 Usp. Prilog 2.

573 Ibid.

${ }^{574}$ Usp. McInnis, John. Augustine's De Musica in the 21st Century Music Classroom. Religions, 6 (2015), str. 211-220. URL: https://www.researchgate.net/publication/276839678_Augustine\%27s_De_Musica_in_the_21st_Century_Music _Classroom (11.07.2019.): „Modulor, in this context, may signify an application of measure to musical quantity, as in rhythm, and not simply musical singing or playing.“
} 
„I tko, molim, u to sumnja, da se jednako i po ovoj našoj Osmožičnoj citari ne mijenjaju (na bolje) duše naroda, po Citari koja silno razveseljuje srce čovjeka, a samoga Boga ublažuje i koja (kao nešto premilo onim besmrtnim „bozima“, koji se sastoje od božanske duše) jest stvorena zato da blaži „,bogove“, pa kad ne bi bila sama za to stvorena, ne bi se po crkvama ni upotrebljavala. Tko, velim, sumnja u to da se pjevanjem ljudske duše ne ganjuju?“

Augustinov affectum pietatis kao posljedica slušanja i izvođenja glazbe pjevanjem cantare/canere/psallere - nastaje kao posljedica njezina sklada (symphonia i harmonia) $\mathrm{s}$ nebom (coelum).

haec enim est pulcherrima in dissonio Consonantia diversorumque Concordia, quae omnibus suo modo inest rebus, ac Mundo, Coeloque communis est, dum universae res creatae diversis in unum finem tendentiis in ipsamet discordia pulcherrime concordant, \& naturalem quandam seu perjucundam Harmoniam exercent. Haec molestas curas reliquasque cogitationum distractiones de secreto naturae veluti regina sensuum procedens, per dulcissimas musicalis notae voluptates expellit.

„Vokalna glazba jest onaj najljepši sklad u neskladu i sloga različitih stvari koja se na svoj način, nalazi u svim stvarima. Zajednička je i Svijetu i Nebu, jer stvorene se stvari raznolikim težnjama prema jednome cilju prekrasno slažu u samoj različitosti, ostvarujući tako neki prirodni i vrlo ugodni sklad. Ona, izlazeći iz dubine prirode kao kraljice osjetila, izgoni mučne brige i ostale umne rastresenosti i to preko najugodnijih užitaka glazbe.“575

\subsection{Estetika kao dio musica theorica?}

„Daje joj se za pravo tek kada se shvati i dopusti da ona nije zatvorena disciplina sa čvrsto određenim predmetom, nego prije neodređen i široko obuhvatan zbroj problema i gledišta za koje prije osamnaestog stoljeća možda nitko nije slutio da će jednom srasti u jedan sklop s vlastitim imenom, te čije prepletanje i uzajamno djelovanje ostaje čudnim i kasnije. ... Sustav estetike je njezina povijest: povijest u kojoj se prožimaju misli i iskustva raznovrsnog podrijetla. ${ }^{\text {(576 }}$

Carl Dahlhaus

\footnotetext{
575 Usp. Prilog 2.

${ }^{576}$ Dahlhaus, Carl. Estetika glazbe. Zagreb: AGM, 2003. Str. 9-10.
} 
Situacija u analizi estetike koju promiču glazbenoteorijski spisi koji se odnose na gregorijansko pjevanje donekle je usporediva sa situacijom u kojoj se nalazimo kada iste svrstavamo u glazbenu teoriju i tražimo u njima elemente usporedive s teorijom glazbe kakva je definirana u 19. stoljeću. Ako se složimo s Dahlhausom da ,[E]stetika, teorija umjetničkog djela u modernom, emfatičnom smislu, raskida ne samo s tehnološkim, nego i sa spekulativnim ili moralnim razmatranjem glazbe “577, postaje jasno da je nametanje atributa estetički u smislu novovjekovne estetike dominantno metafizički usmjerenim teorijama Platona i neoplatoničara, ako ne pogrešno, onda barem nepotpuno.

O suštinskoj razlici u razumijevanju latinskog pojma ars i suvremenog pojma umjetnosti (engl. art, njem. Kunst, tal. arte) napisani su mnogi radovi. ${ }^{578}$ Ta je razlika vrlo važna za historijsko propitivanje područja koje danas prisvaja estetika, koja se i tijekom 18. stoljeća pod drugim imenom bavila metafizičkim pitanjima: svrhom i ulogom umijeća (artes), odnosno trima vrijednostima koje se nalaze ili ne nalaze u njima, a često se zajedno navode još od Platona: dobrim (bonum), lijepim (pulchrum) i istinitim (verum). Nerijetko se ovim pojmovima pribrajao i četvrti pojam: korisno $(\text { utile })^{579}$.

Valorizacija konteksta, odnosno prihvaćanje historijske uvjetovanosti glazbenog djela (ili skupine djela, stila i slično) automatski isključuje mogućnost definiranja univerzalnih glazbenih kategorija primjenjivih na svaku vrstu glazbe ${ }^{580}$. Upravo iz razloga nametanja klasicističke estetike, ono što je u srednjem vijeku većim dijelom pripadalo metafizici pokušalo se u raznim povijestima estetike, katkada vrlo nekritički, premjestiti u estetiku koju definiraju „teorijska razmišljanja o statusu glazbe kao umjetnosti i (o statusu glazbe kao, op. J.

\footnotetext{
${ }^{577}$ Ibid. Str. 25.

${ }^{578}$ Navodimo nekoliko najvažnijih pregleda vezanih (i) uz estetiku glazbe: Tatarkjevič, Vladislav. Historija šest pojmova (prev. Petar Vujičić). Beograd: Nolit, 1980.; Dahlhaus, Carl. Estetika glazbe. Zagreb: AGM, 2003. (prijevod djela Musikästhetik. Laaber: Laaber-Verlag, 1986.; Fubini, Enrico. History of Music Aesthetics. Macmillan: 1990.; Lippman, Edward A. A History of Western Musical Aesthetics. University of Nebraska Press: 1992.; Supičić, Ivan. Estetika europske glazbe: Povijesni i tematski aspekti. Zagreb: ŠK, 2006; Edström, KarlOlof. A Different Story. Aesthetics and the History of Western Music. Pendragon Press: 2008.; i dr.

${ }^{579}$ Wladyslaw Tatarkiewicz upozorava da su se ove tri najviše vrste vrijednosti pojavljivale u srednjem vijeku „sa nešto drugačijom klasifikacijiom, ne kao tri vrednosti, nego kao transcendentalia, odnosno tri najviše vrste predikata.“ Usp. Tatarkjevič, Vladislav. Op. cit. Str. 11.

${ }^{580}$ Padilla, Alfonso. Les universeaux en musique et la definition de la musique. // Les Universeaux en musique: Actes du 4e Congrès international sur la signification musicale / Costin Miereanu, Xavier Hascher. Paris: Publications de la Sorbonne, 1994. Str. 219-231.: „Selon Marcia Herndon et Jean-Jacques Nattiez, on doit chercher la définition de la musique (ou la différenciation entre un phénomène musicale et un phénomène qui ne l'est pas), non seulement dans les concepts, mais aussi bien dans les attitudes envers ces phénomènes. Herndon souligne que plutôt que de se poser des questions sur le „quoi“ de la musique, on doit s'interroger sur le „quand“ du phénomène musical: c'est le contexte qui est décisif.“
} 
K. C.) obliku suvislog ustrojstva“"581. Analizirajući pomnije 18. stoljeće, estetiku se pokušava izjednačiti s učenjem o afektima, a njega opet s teorijom ethosa nastojeći na taj način uspostaviti kontinuitet u njezinu razvoju. Međutim, kad Edgar de Bruyne ${ }^{582}$ piše o srednjovjekovnim estetičkim teorijama, valja imati na umu da se ne radi o estetici kao filozofskoj disciplini koja se bavi umjetničkim objektom. Gotovo do samog kraja 18. stoljeća usko je vezana uz moralno djelovanje, čak toliko da je etičko vladanje argument za estetičko djelovanje i vice versa, prispodobivo podjednako kroz biblijske pripovijesti, grčku mitologiju i rimsku poeziju. To je jasno vidljivo i u predgovorima CO. Admirabilis virtus i pura suavitas odlike su musica vocalis veli pisac. No, one nisu samo moralne odrednice vokalne glazbe, već i estetičke. Divljenja vrijedna vrlina koja potiče čistu slast pojmovi su koji povezuju osjetilni svijet onih koji je slušaju i pjevaju s nebeskim. Sve do klasicističkog oblikovanja estetike kao filozofije lijepog u umjetnosti, proučavanje lijepog pripada metafizici i retorici, odnosno raspravama o moralnoteološkim problemima i, zatim od renesanse, pokušaju primjene retoričkih postulata na glazbu koja reflektira verbalni jezik. Osobito je opasno, stoga, nekritički primijeniti postulate novovjekovne estetike na djela crkvene umjetnosti, na što je prije gotovo stotinu godina upozorio Jacques Maritain: „Stoga valja najprije zapitati antičke mislioce što oni misle o Lijepom u svojoj metafizici a potom se treba zaputiti prema Umijeću te vidjeti u kojoj su vezi ta dva naziva. Premda će nas takav postupak zbuniti, on će nam barem pružiti korisnu pouku te ćemo prepoznati zabludu „Estetike“ novovjekovnih filozofa. Držeći da umjetnosti pripadaju samo lijepa umijeća i raspravljajući o lijepom samo u vezi s umjetnošću, ta se estetika izlaže opasnosti da izobliči pojam Umijeća i pojam Lijepoga. “583

Slična je situacija i u određivanju osobina tonusa kakvu nalazimo u Šiloboda-Bolšića. Etičnost svakog pojedinog određuju i njegovu estetičnost te stoga u procjeni odabira pojedinog tonusa za tekst antifone, valja, uz njegove muzičke osobine, imati na umu i one

\footnotetext{
${ }^{581}$ Goehr, Lydia ... [et al.]. Philosophy of Music. // NGROVED ${ }^{2}$, sv. 19. Str. 611-612.: „The theoretical reflections on the status of music as an art and as a form of meaningful articulation, ..."

${ }^{582}$ Usp. De Bruyne, Edgar. Etudes d'Esthétique Medievale. Paris: Editions Albin Michel, 1998. kojoj je u ponovljenom francuskom izdanju dodan tekst L'Esthétique du Moyen Age zamišljen kao opsežna sinteza prethodećih mu Etudes.

583 Maritain, Jacques. Art et Scolastique. Paris: Editions Saint Paul, 1986. (Umjetnost i skolastika / prev. Marko Kovačević. Zagreb: Nakladni zavod Globus, 2001.). Str. 7. „C'est à la Métaphysique des Anciens qu'il faut aller demander ce qu'ils pensaient du Beau, pour de là s'avancer à la rencontre de l'Art, et voir ce qu'il advient de la jonction de ces deux termes. Un tel procédé, s'il nous déconcerte, nous apporte du moins un utile enseignement, en nous rendant sensible l'erreur de 1' « Esthétique » des philosophes modernes, qui considérant dans l'art les seuls beaux-arts, et ne traitant du beau qu'au sujet de l'art, s'expose à vicier à la fois la notion de l'Art et celle du Beau."
} 
metafizičke koje su s prvima, dakako, nerazdruživo povezane. ${ }^{584}$ FCG nam donosi još jednu informaciju koja potvrđuje uvjetovanost estetike napjeva zahtjevima koje postavlja tekst, ali i apliciranjem od Tridentskoga koncila zahtijevanih metričkih pravila koja deklamaciju prema uzoru na antiku promiču kao ideal čime se gregorijansko pjevanje odmiče od kvaliteta koje se pridaju njegovoj izvornoj inačici. No, niti rasprava o podmetanju teksta pod melodiju ne prolazi bez isticanja potrebe za čuvanjem sklada:

„D: Postremum est, quod te rogo, dic mihi magistre quare supra aliquam syllabam textus, plures notae farciuntur?

M: Ratio petenda est ex ipsis verbis textus. Quae enim verba maioris sunt contemplationis, in iis syllaba aut in longius canitur, aut in altius elevatur: servata nihilominus semper, \& ubique tam toni, quam harmoniae proportione.“

„Učenik: Reci mi učitelju, to je posljednje što te pitam, zašto je iznad nekog sloga teksta nagomilano više nota?

Učitelj: Razlog treba tražiti u samim riječima teksta. Naime, u riječima koje su dostojne dubljeg razmatranja pjevaju se duži slogovi ili se dižu naviše. Svakako, uvijek i posvuda treba čuvati skladan odnos tonusa i harmonije. “585

Etički utjecaj glazbe zajedno s njezinom snažnom, nerazdruživom vezom s dušom svijeta daju joj značaj kakav nije imalo niti jedno drugo umijeće. Oslanjajući se na snagu Platonovih argumenata svi kasniji teoretičari glazbe promišljaju pojmove lijepog i dobrog kao međusobno uvjetovanog, ali i kao nužno vezanog uz metafizičko. Opsežna uputa koja daje stroge smjernice o povezanosti određenog tonusa s antifonom ili psalmom, a koju u posljednjem poglavlju priručnika donosi Šilobod-Bolšić primjer je razumijevanja veze etike i estetike u teoriji gregorijanskoga pjevanja. Važnost tih uputa ne može se precijeniti, budući da svi drugi usporedni priručnici - Samber, Tettamanzi i Frezza Dalle Grotte ${ }^{586}$ - istu problematiku tumače kudikamo opsežnije od našega pisca. One tvore koherentan glazbenotekstovni korpus čija se ekspresivnost $\mathrm{u}$ etičkom i estetičkom smislu potvrđuje neprestanim ponavljanjem. Time su bliske antičkoj teoriji tonusa kada se on „,nalazio utjelovljen

\footnotetext{
${ }^{584}$ Opisi osobina pojedinih tonusa mijenjali su se kroz stoljeća, tim više što su bili udaljeniji od kasnoantičkih izvora. Usp. Meyer, Kathi. The Eight Gregorian Modes on the Cluny Capitals. // The Art Bulletin, 34/2 (1952), str. 75-94. Meyer u članku donosi usporedni pregled modusa i pripisanih im osobina od 8. pa sve do 14. stoljeća što potvrđuje nestalnost u povezivanju glazbenih kvaliteta neke ljestvice sa sadržajem uglazbljenog teksta. 585 Šilobod-Bolšić. Op. cit. Str. 150-151.

${ }^{586}$ Usp. Samber, Johann Baptist. Op. cit. Str. 61-85.; Tettamanzi, Fabrizio. Op. cit. Secondo libro i Terzo libro; Frezza Dalle Grotte, Giuseppe. Op. cit. Seconda parte i Terza parte.
} 
određenom broju tipičnih djela povezanih istim stilom, istom moralnom vrijednošću i često istom društvenom primjenom ili namjenom “587. Istovremeno, koliko god se teorija afekata u realizaciji činila udaljenom od gregorijanike 18. stoljeća, obje dijele čvrsto oslanjanje na retoriku u smislu neizravne, ,intelektualne i pikturalne“ reprezentacije svijeta. Baš kao što su tonusi i njima primjereni biblijski stihovi bili strogo povezani primjerenošću međusobnih odnosa kako bi se postigla željena ekspresivnost, tako su u baroku „osjećaji [su] bili klasificirani i stereotipizirani u zbir takozvanih afekata, od kojih je svaki predstavljao mentalno stanje koje je u sebi bilo statično. Posao skladatelja bio je u tome da afekti glazbe odgovaraju onima riječi. “588

U cijelom dugom srednjem vijeku dobra glazba ujedno je i lijepa i vice versa: glazbina ljepota potiče dobrotu. Ovakav stav u estetičkom promišljanju glazbe proteže se u raspravama o glazbi sve do druge polovice 18. stoljeća, dok za crkvenu glazbu vrijedi i danas. Funkcija uhu ugodne (suavitas) crkvene glazbe ima ulogu pojačavanja molitve i ljubavi prema $\mathrm{Bogu}^{589}$ te osnaživanja odnosa Boga s čovjekom tijekom liturgije. Ona podjednako raduje Boga i anđele na nebesima, kao i čovjeka na zemlji; glazba izgoni zloduha i odgoni malodušnost; glazba ukrašava molitvu i razveseljava dušu, kako nam veli i predgovor CO. Gregorijansko pjevanje, pa i u obliku u kojem ga nalazimo u 18. stoljeću (a koji medievisti u većini historiografija i danas nazivaju dekadentnim), može se promatrati i kao estetički objekt istovremeno imajući na umu uvjetovanost estetičkog etičkim. Ta uvjetovanost nije, međutim, samo glazbena već postoji isključivo u sinergiji s tekstom te kao integralni dio svečanosti liturgije i časoslova. Autonomnost i nesvrhovitost što definiraju djelo od njegove afirmacije krajem 18. stoljeća, ne postoji u misaonom sustavu dio kojega je gregorijansko pjevanje. Glazba kojoj riječi i kontekst izvedbe daju smisao i svrhu i koja je skladana kako bi prenosila tekstualne poruke koje određuju njezin oblik, estetički se proučava uz hermeneutiku teksta u sinergiji s kojim ostvaruje namijenjenu joj ulogu. Uzimajući u obzir da je tekst gregorijanskoga pjevanja tekst sv. Pisma, njegova je uloga soteriološka per se. Intelektualno promišljanje dobrote i ljepote kao međuovisnih vrlina (grč. kalokagathia, lat. bonitas i pulchritudo) i empirijsko djelovanje koje rezultira lijepim i dobrim izgledom i djelovanjem filozofijski su koncepti koji glazbu

\footnotetext{
${ }^{587}$ Bukofzer, Manfred F. Music in the Baroque Era. New York: Norton, 1947. Str. 4-5. Cit. prema Supičić, Ivan. Op. cit. Str. 111.

${ }^{588}$ Ibid.

${ }^{589}$ Izreka je potekla iz komentara sv. Augustina na Psalam 74, 1: Qui enim cantat laudem, non solum laudat, sed etiam hilariter laudat. qui cantat laudem, non solum cantat, sed et amat eum quem cantat. In laude confitentis est praedicatio, in cantico amantis affectio...Usp. Sanctus Augustinus. Enarratio in Psalmum 72, 1. CCL 39, 986 (PL 36, 914).
} 
promišljaju izvanglazbeno, kao mentalni i fizički put prema postizanju ovih osobina. Njome se, potvrđuju hrvatski autori, uspinjemo prema Bogu i otvaramo prema pravom bitku: za njih je umjetničko i ljudsko odraz božanskog, ali i sredstvo nadilaženja ovozemaljskog na putu prema nebeskom.

\subsection{Musica practica}

Budući da su izvori iz kojih su hrvatski pisci Kovačević i Šilobod-Bolšić kompilirali svoje priručnike istraženi u Trećem poglavlju, ovdje nam preostaje definirati teorijski okvir njihovih tekstova u odnosu na njima suvremene glazbenoteorijske priručnike.

Proces postupne afirmacije glazbe kao prakse vidljiv je u teorijskim tekstovima koji, usprkos renesansnoj tendenciji povratka prema antičkoj filozofiji i književnosti, postaju prije svega uputa za kantora. ${ }^{590}$ Osim toga, „tijekom tri stoljeća koja su uslijedila po završetku Tridentskog koncila 1563., cvala je aktivnost na polju katoličkog liturgijskog pjevanja.“591 Ovakav razvoj uvjetovan je željenom demokratizacijom liturgije koja prestaje biti posvećeni obred namijenjen prije svega redovnicima i klericima, već se otvara i običnom narodu.

Ona je uključivala prilagodbu postojećih koralnih napjeva novim glazbenoteorijskim i tekstualnim preferencama. U stvarnosti, to je značilo unificiranje melodijskog kretanja i opsega prema sustavu crkvenih ljestvica - tonusa. Napetosti između teorije i prakse bile su odgovorne za ponavljane zahtjeve za revizijom koralnih napjeva, od kojih su zahtjevi postavljeni na Tridentskom koncilu, zbog njegova šireg društvenog značenja i dugoročnog utjecaja što ga je imao na osnaživanje katoličke vjere i stabiliziranje liturgije, najpoznatiji. Uz probleme glazbenoteorijske prirode - pokušaja prilagođavanja prakse teoriji - 15. i 16. stoljeće svjedoči humanističkoj usredotočenosti na tekst, njegov oblik, jasnoću izraza i razumljivost te ispravnu akcentuaciju. To je, dakako, uvjetovalo promjene koje će zauvijek izmijeniti izgled, zvuk i percepciju gregorijanskoga pjevanja i u sljedećim stoljećima. „Obrazovani ljudi onoga doba toliko su bili prožeti ovim idejama da su ih smatrali bezvremenima i univerzalnima. Ako

\footnotetext{
${ }^{590}$ Usp. npr. popis inkunabula i objavljenih faksimila traktata o gregorijanskom pjevanju na URL: https://www.omifacsimiles.com/mgencatalogs.html (10.12.2020.)

591 „During the three centuries following the conclusion of the Council of Trent in 1563, there was a remarkable flowering of activity in the realm of Catholic liturgical chant, ..." $\mathrm{u}$ : Karp, Theodore, An Introduction to the Post-Tridentine Mass Proper. Middleton, Wisconsin: American Institute of Musicology, 2005. Sv. 1, str. 1.
} 
gregorijansko pjevanje nije slijedilo ove propise, onda je ono bilo pogrešno. “592 U tom je smislu Tridentski koncil, deklariravši potrebu za pogledom unatrag prema ,izvornom“ gregorijanskom pjevanju, u stvari afirmirao suvremenu estetiku renesanse ističući deklamatorni princip kao temelj autentičnosti napjeva. ${ }^{593}$

\subsubsection{Tonus, modus, vox}

Prenošenje glazbenoteorijskih postulata iz 16. i 17. stoljeća vidljivo je u analizi izvora (probati auctores) iz čijih su tekstova Šilobod-Bolšić i Kovačević kompilirali, no podjednako su važni i srednjovjekovni izvori, osobito Guido iz Arezza od kojeg preuzimaju sustav heksakorda. Vidljivo je to i iz Samberova teksta za koji smo na više mjesta pokazali da je vrlo vjerojatno predstavljao temelj za FCG. Samber najčešće spominje Adriana Banchierija te Michalea Reinspecka (Keinspecka) kao autoritete od kojih je učio o glazbi, ali na prvome mjestu, baš kao i naši pisci, navodi Guida i manus guidonica. Tema - cantus gregorianus presudno određuje vrstu građe koju pisci prenose, ali i način njezine upotrebe.

Terminologija se, međutim, prenosi nekonzistentno. Guido naziv modus koristi za šest nizova tonova, heksakorde raspoređene u tri oktave - gravis, acuta i superacuta, dok tonus koristi za razmak od cijelog stepena između dva tona, a semitonus za polustepen. Modus, a ne tonus u Guidovom tekstu Micrologus naziv je za ljestvice koje se i danas nazivaju crkvenim modusima:

„Dispositis itaque vocibus inter vocem et vocem alias maius spatium cernitur, ut inter [Gamma]. et A. et inter A. et B. alias minus, ut inter B. et C. Et maius quidem spatium tonus dicitur: minus vero semitonium, semis videlicet, id est, non plenus tonus.“

\footnotetext{
${ }^{592}$ Karp, Theodore. Op. cit. Str. 2.: „Educated people of the time were so deeply imbued with these ideas that they thought of them as timeless and universal. If chant did not follow these dictates then it was chant that was faulty."

${ }^{593}$ Usp. bilj. 146 i 160.
} 
„Stoga u raspoređenim glasovima između glasa i glasa vidi se čas veći razmak, kao između G i A, i između A i B, čas manji kao između B i C. A ovaj veći razmak naziva se ton, manji pak poluton, polu očito zato što nije puni tonus. “"594

„Cum ergo dicatur autentus protus et plagis proti, similiter de reliquis, qui naturaliter in vocibus erant quatuor divisi, in cantibus facti sunt octo. Abusio autem tradidit latinis dicere pro autento proto et plagis proti primus et secundus, pro autento deutero et plagis deuteri tertius et quartus, pro autento triti et plagis triti quintus et sextus, pro autento tetrardo et plagis tetrardi septimus et octavus.“

„Kada bi se, dakle, reklo autentični prvi i plagalni od prvoga, na isti način bi se reklo i o ostalima koji bijahu prirodno podijeljeni u tonovima na četiri, a u napjevima su podijeljeni $u$ osam. A nepravilnom upotrebom u latinskom se prenijelo za prvi autentični i plagalni od prvoga prvi i drugi, za drugi autentični i njegov plagalni treći i četvrti, za treći autentični i njegov plagalni peti i šesti, za četvrti autentični i njegov plagalni sedmi i osmi.“595

Vox je kod njega naziv za ton označen imenom (A, B, C, D ...). Tako i kod Šiloboda koji uz termin vox vezuje jednom solmizacijske nazive, a drugi puta glas kao zvučnu realizaciju napisane note bez obzira na nazive tonova:

„... quia in loco illo, ubi est solum $u t$, non potest alia vox dici, quam $u t . “$

„... jer na onome mjestu gdje je samo ut, ne može se izgovoriti drugi slog osim ut.“

„Si est caudata; tunc erit longa, \& vox infra illam diutius protrahetur.“

„Ako ima rep, tad će biti duga i glas se ispod nje duže zadrži.“"596

Toma Kovačević pak cijeli stepen naziva spatium perfectum, a polustepen spatium imperfectum. ${ }^{597}$

\footnotetext{
${ }^{594}$ D'Arezzo, Guido. Micrologus. // Scriptores ecclesiastici de musica sacra potissimum, 3 vols. / Martin Gerbert (ur.). St. Blaise: Typis San-Blasianis, 1784; reprint Hildesheim: Olms, 1963. Caput IV. Quibus sex modis sibi invicem voces iungantur. i Caput XII.divisione quatuor modorum in octo. URL: https://chmtl.indiana.edu/tml/9th-11th/GUIMIC (15.02.2020.).

${ }^{595}$ Ibid. Ovdje smo radi veće jasnoće u hrvatskom jeziku grčke nazive za redne brojeve kojima su u teoriji do 18. stoljeća označavani tonusi (protus, deuterus, tritus, tetrardus) prevodili na hrvatski, kao i latinske (primus, secundus, tertius, quartus, itd.).

596 Šilobod-Bolšić, Mihael. Op. cit. Str. 84-85 i 64-65.

${ }^{597}$ Usp. Mihoković, Martin. Op. cit. Str. 14.
} 
Od 16. stoljeća uvedena je teorija tonusa koja umjesto dotadašnjih osam uvodi njih dvanaest dodajući dorskom, frigijskom, lidijskom i miksolidijskom i „,njihovim plagalnim slugama“ eolski i jonski. Uz to, terminologija traktata koji se odnose i na cantus figuratus i instrumentalnu glazbu, sve češće koristi termin modus umjesto tonus. (I Šilobod veli „Tonus je nekoć u Grka predstavljao glazbeno pravilo, a zatim su ga glazbenici preimenovali u modus ${ }^{598}$ ) Ta se teorija, potekla od Gioseffea Zarlina, premda je Samber kao važan Šilobodov uzor poznaje, nije odrazila u priručnicima naših pisaca. Razlog je upravo činjenica da oni pišu samo o gregorijanskom pjevanju koje načelno ne podliježe ritmizaciji, o cantus planus, a ne o cantus figuratus. Temelj za pisanje o tonusu ostaju definicije koje nude Guido iz Arezza i Franchino Gaffurio prema Guidu (za Kovačevića). Adriano Banchieri u Cartella musicale koju kao izvor spominju i Šilobod i Kovačević i Samber, objašnjava Zarlinovu odluku da tradicionalnim tonusima doda eolski i jonski njihovom čestom upotrebom u instrumentalnoj i polifonoj glazbi, jer omogućavaju kudikamo veći opseg melodije u oba smjera te zaključuje: „Si conclude adunque che, gl'otto Tuoni possino servire alle Messe, Salmi, Himni, Cantici, e l'altre musice alternanti al Canto Fermo, \& gli duodeci Modi per compuonere Concerti, Franceze, Toccate, Madrigali, \& in somma ogni Cantilena discrepante al Canto Fermo;“

„Zaključuje se dakle da osam tonusa može služiti za mise, psalme, himne, popijevke i drugu muziku srodnu gregorijanskome pjevanju, a dvanaest modusa za skladanje koncerata, francuskih skladbi, tokata, madrigala i općenito svakog napjeva koji se razlikuje od gregorijanskoga pjevanja. “" ${ }^{\text {599 }}$

\subsubsection{Nota}

I dok heksakordalni sustav i podjela na osam tonusa/modusa pokazuje snažnu vezanost uz srednjovjekovni glazbenoteorijski sustav, uvođenje bilježenja različitih znakova za trajanje pojedine note, kao i ligatura, pokazuje priklanjanje renesansnoj teoriji ne samo u grafiji, već i u oblikovanju napjeva. Otklon od tradicionalnog bilježenja koralnih napjeva jednovrsnim znakom notnoga trajanja - notom longa navodi Bolšić, kao i Compendiosa te pristaju uz de Murisovu podjelu trajanja notnoga znaka. Za gregorijansko pjevanje navode tri vrste znaka:

\footnotetext{
598 Šilobod-Bolšić, Mihael. Op. cit. Str. 117.

${ }^{599}$ Banchieri, Adriano. Op. cit. Str. 88.
} 
nota longa, nota brevis koja ima polovicu vrijednosti trajanja od note brevis te semibrevis koja je pak upola kraća od note brevis.

„Si est caudata; tunc erit longa, \& vox infra illam diutius protrahetur. Si est sine dependente cauda, tunc erit brevis, \& vox nonnihil citius canetur. Si vero ets angularis, tunc erit semibrevis, \& vox infra illam citissime absolvi debebit.“

„Ako ima rep tada će biti longa i glas se ispod nje duže zadrži. Ako je bez ovješenog repa tada se zove brevis i glas pjeva nešto hitrije. A ako je zaobljena tada će biti semibrevis i glas će se pod njom morati najbrže maknuti. “600

Pisac Compendiosa veli vrlo slično:

„Inter quas hoc solum discrimen (loquendo de cantu Chorali) intercedit, ut longa tractius brevi, et haec semibrevi in cantu decurratur.“

„Među njima (govoreći o koralnome pjevanju) samo je ova razlika, da je longa izdržanija od brevis, a ova od semibrevis.“601

I koliko god relevantno ostalo po pitanju heksakorda i naziva tonova, Guidovo izlaganje o metru više nije prikladno za gregorijansko pjevanje u 18. stoljeću. On je u to vrijeme, naime, čvrsto vezan uz latinsku prozodiju i „,nemala je sličnost između metrike i napjeva“. 602

Zanimljiva je, međutim, grafija Šiloboda-Bolšića i zbornika CO. Premda je, sudeći po kasnijim transkripcijama napjeva ${ }^{603}$, ritam napjeva slijedio naglaske u riječima, a ne formalnu versifikaciju, niti Šilobod, niti CO ne bilježe napjeve različitim notama, već u svim zapisima koriste isključivo nota brevis (CO I i CO II) i semibrevis (FCG i CO III). Budući da LC napjeve zapisuje notama različita trajanja, kao i PA, čini se da zagrebački izvori svjesno

600 Šilobod-Bolšić, Mihael. Op. cit. Str. 64-65.

${ }^{601}$ Usp. Compendiosa in Cantum Gregorianum seu Choralem introductio. // Psalterio-Antiphonale. Beč, 1742. Str. 133.

${ }^{602}$ Usp. D'Arezzo, Guido. Op. cit. Caput XV. De commoda componenta modulatione: „Non autem parva similitudo est metris et cantibus, cum et neumae loco sint pedum, et distinctiones loco versuum, utpote ista neuma dactylico, illa vero spondaico, illa iambico metro decurreret, et distinctionem nunc tetrametram nunc pentametram, alias quasi hexametram cernes, et multa alia, ut elevatio et positio tum ipsa sibi, tum altera alteri similis vel dissimilis praeponatur, supponatur, apponatur, interponatur, alias coniunctim, alias divise, alias commixtim, ad hunc modum. Item ut in unum terminentur partes et distinctiones neumarum atque verborum, nec [17] tenor longus in quibusdam brevibus syllabis, aut brevis in longis sit, quia obscoenitatem parit, quod tamen raro opus erit curare.“

${ }^{603}$ Usp. Cithara octochorda. Zagreb, 1757. Komentari i studije, sv. 2. Zagreb: HAZU: Institut za crkvenu glazbu „Albe Vidaković“ KBF Sveučilišta u Zagrebu: Hrvatsko društvo crkvenih glazbenika, 1998. 
zadržavaju tradicionalni način zapisa koralnih napjeva zbog kojih je ovaj i nazvan cantus planus.

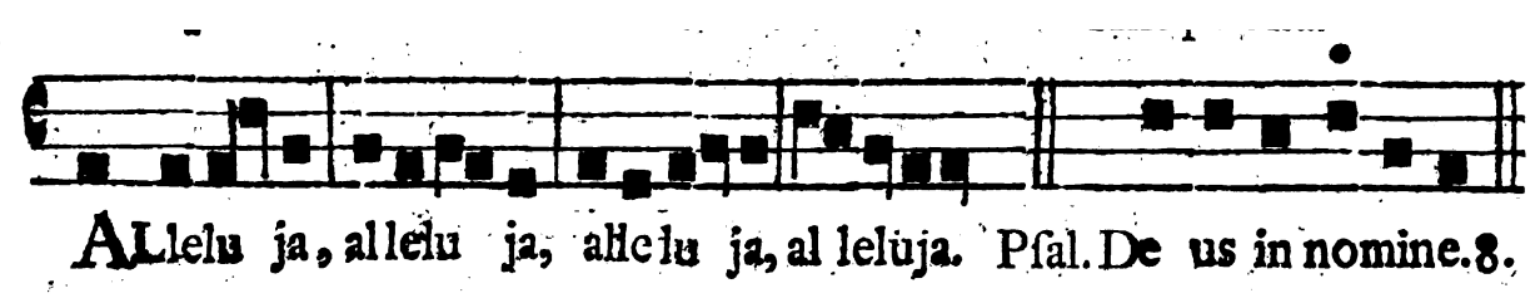

Sl. 15 Notni primjer Uskrsne antifone iz Psalterija-Antifonala, Beč, 1742. Str. 2.

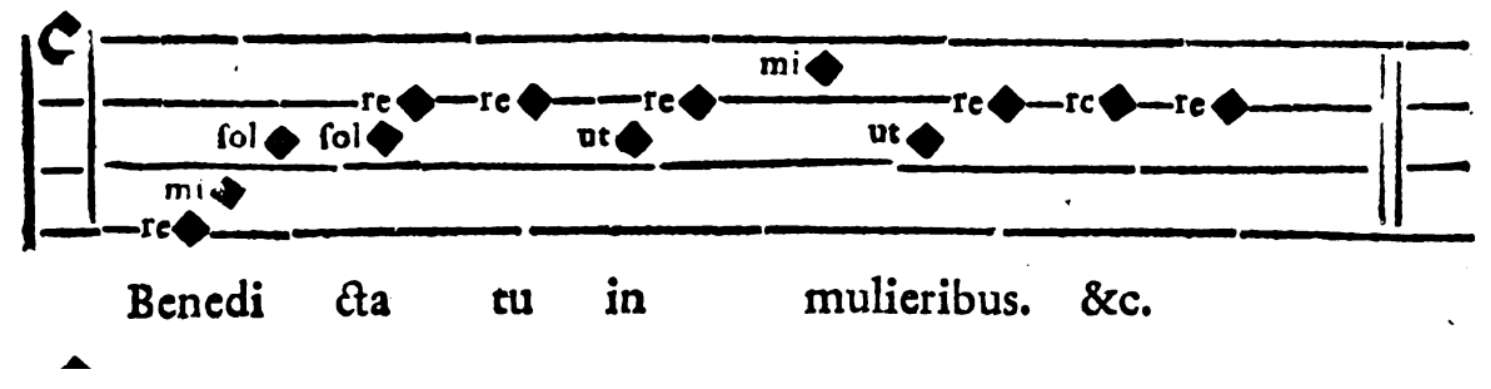

S1. 17 Notni primjer iz Šilobod-Bolšić, Mihael. Fundamentum cantus gregoriani seu choralis ... Zagreb, 1760. Str. 13.

U tom smislu, upozorava fra Izak Špralja, usprkos aktualnoj ritmizaciji gregorijanskoga pjevanja diljem Europe još od 16. stoljeća, zagrebački izvori notnom grafijom sugeriraju i zapis i izvođenje koje se pripisuje tradicionalnoj, izvornoj izvodilačkoj praksi:

„U tumačenju gregorijanskih napjeva s obzirom na trajanje pojedine note u razdoblju tzv. dekadencije gregorijanskoga korala postojala su različita gledišta. Moguće je da je Zagrebačka (prvostolna) crkva, svjesna svojega vlastitog obreda i liturgijsko-glazbene baštine, pomno čuvala i način tumačenja te gregorijanske baštine, pa da su se zbog toga priređivači triju izdanja CO opredijelili za ovakvu grafičku sliku notnog teksta.“604

Diskurs o glazbi pisan i objavljivan u Zagrebu (i za Zagreb) u prvih šezdeset godina 18. stoljeća obuhvaća teme muzike kao moćne iscjeliteljice duše i tijela i osnažiteljice vjerskih osjećaja, koja vodi one koji joj se prepuste anđelima i Bogu. Takav govor o glazbi pripada u svojoj biti spekulativnim raspravama o muzici (musica theorica) kao fizičkoj emanaciji harmonije sfera $\mathrm{i}$, objavljen u predgovorima $\mathrm{CO}$ usmjeren je prema afirmaciji aktualne liturgijske glazbe čije primjere donose sami priručnici. Opsežniji, ali vrlo sličan tekst

604 Špralja, Izak. Op. cit. str. 224-225. 
objavljen je u trnavskom zborniku LC, a vrlo vjerojatno i u drugim zbornicima objavljivanima u Europi, čime se potvrđuje aktualnost takvoga diskursa, barem u kontekstu jednoglasne crkvene glazbe.

Musica practica kakvu učenicima nude priručnici hrvatskih pisaca, s obzirom na aktualne instrumentalne i vokalno-instrumentalne žanrove koje nalazimo u baroknoj glazbi, ne može se nazvati aktualnom. Međutim, ako je promatramo u kontekstu edukativne glazbene teorije, tog nemalog dijela glazbenoteorijskih tekstova objavljivanih u prvoj polovici 18. stoljeća, nipošto je se ne može odbaciti kao anakronu ili neprimjerenu vremenu u kojem je nastala. U 18. stoljeću su se, naime, i to ne samo u perifernim, siromašnim i kulturno zabačenim dijelovima Europe, objavljivali slični priručnici u velikom broju kako bi se zadovoljile potrebe rastuće svijesti o važnosti obrazovanja što većeg broja ljudi, ali i nastojanja Katoličke crkve da putem istog tog obrazovanja ojača vlastiti, reformacijom ugroženi položaj najvažnijeg i najutjecajnijeg saveznika svjetovnih vladara. Pritom je njezina epistemologija u sebi dvojaka i objedinjuje ono što Blasius naziva racionalističkom sintezom i empirizmom. Prvi je u teoriji gregorijanskoga pjevanja vidljiv u organizaciji materijala u obliku teorema, dok se drugi otkriva kroz sve veći broj priloženih primjera uz definicije. ${ }^{605}$ Ta se, ,„više prema praksi orijentirana tradicija, osobito utjecajna tijekom sedamnaestog i osamnaestog stoljeća, prije svega zanima kodifikacijom i klasifikacijom, kulminirajući u velikim semiotičkim projektima prosvjetiteljstva."606

\footnotetext{
${ }^{605}$ Usp. Blasius, Leslie. Op. cit. Str. 37: „Implicit in Mersenne’s topography are the two dominant epistemologies of the seventeenth and eighteenth centuries, rationalism and empiricism. The first posits a synthesis, in which simple primitives are subsumed in a calculus or mechanics whose product is a complex (and usually phenomenal) whole. (In some ways, it may be seen as a rigorous successor to the mos geometricus - the organization of material in terms of propositions and theorems - which is characteristic of the sixteenth-century musical treatise.) Musically, this rationalism reaches its apogee in the harmonic calculus found in Leonhard Euler's Tentamen novae theoriae musicae (1739), yet it is in a different guise to be found in the various reconstructions of the origin of music popular in the later eighteenth century. The second (empirical) epistemology abstracts criteria by which a range of distinct and commensurable areas can be ordered taxonomically on some sort of series through decomposition or analysis."

${ }^{606}$ Cook, Nicholas. Epistemologies of music theory. // The Cambridge History of Western Music Theory / uredio Thomas Christensen. Cambridge: Cambridge University Press, 2008. Str. 80.: „The second and more practically oriented tradition, particularly influential during theseventeenth and eighteenth centuries, is concerned primarily with codification andclassification, culminating in the grand semiotic projects of the Enlightenment;"“
} 


\section{ZAKLJUČAK}

Gregorijansko pjevanje je živa, prisutna i neprekidna glazbena praksa koja je u velikom dijelu glazbene historiografije od pojave razvijene polifonije pa sve do cistercitske reforme svrstana pod nekoliko šturih informacija o dekadentnom razdoblju nekad slavne prakse koja čeka povratak izvorima. Šutnja općih povijesti glazbe o opstanku gregorijanskoga pjevanja od 16. pa sve do 19. stoljeća, ali i temeljnih monografskih studija koje ovo razdoblje podjednako ignoriraju, mogla bi značiti da je ono i u percepciji ondašnjih glazbenika predstavljao sporednu praksu na koju su, kako sugeriraju hrvatske povijesti glazbe, morali pristati samo oni koji su imali nesreću živjeti u rubnim dijelovima Europe.

Budući da sjeverne hrvatske zemlje u 18. stoljeću, sve do pred sam njegov kraj, od glazbenih izvora ne nude gotovo ništa osim kantuala, procesionala, pasionala i priručnika o gregorijanskom pjevanju te znamenitih zbornika napjeva Cithara octochorda, analizom dostupnih izvora željeli smo istražiti u kojoj je mjeri govor o glazbi i praksa koju zagovara uistinu rubna i anakrona.

Stoga smo u radu pokušali rekonstruirati mišljenje o glazbi u 18. stoljeću na tragu ideje o koherentnoj zagrebačkoj glazbenoliturgijskoj praksi koju je u svome radu o zborniku CO naznačio Izak Špralja. Temeljna ideja bila je propitati načine govora o glazbi u dvama priručnicima objavljenima u razmaku od 60 godina: Brevis cantus gregoriani notitia Tome Kovačevića iz 1701. (od kojeg su, nažalost, danas dostupne samo loše čitljive fotokopije i diplomski rad Martina Mihokovića) te Fundamentum cantus gregoriani seu choralis Mihaela Šiloboda-Bolšića iz 1760. Uz njih, izvori su bili predgovori svim trima izdanjima CO (objavljenima od 1701. do 1757.) koji nude vrlo opsežan, živ i zanimljiv diskurs o glazbi koji sadržajno zadire u antičku povijest i mitologiju i, dakako, Sveto pismo, iako u mnogo manjoj mjeri. Svi su spomenuti tekstovi objavljeni u Zagrebu ili Zagrebačku crkvu spominju kao naručitelja. Iznimka je Toma Kovačević čiji tekst ne spominje zagrebačku katedralu izravno kao mecenu, no Kovačević je bio ugledni zagrebački kanonik, a tekst koji podučava pjevanje gregorijanskoga pjevanja na nekoliko mjesta izričito spominje specifičnosti zagrebačkog obreda, zbog čega možemo zaključiti da je namijenjen (i) zagrebačkoj prvostolnici.

Spomenuti izvori nagnali su nas na traženje dodatnih usporednih tekstova koji su se u isto vrijeme objavljivali i/ili koristili u sjevernim hrvatskim zemljama, kako bismo stekli uvid u stupanj aktualnosti, odnosno anakronosti analiziranog diskursa o glazbi. Pri tome smo se vodili nekolicinom načela koja su omogućila otvaranje ovih tekstova i bolje razumijevanje 
njihova značenja za vrijeme u kojem su nastali i za koje su namijenjeni. Prvo je načelo odbacivanja apriorne teze o „,nepostojanju“ gregorijanike kao redovite glazbene prakse, što sugerira glazbena historiografija. Drugo se načelo odnosi na pomno istraživanje sekundarnih izvora koji katkada nisu izravno spomenuti, ili su pak kao izvori spomenuti oni autori koje je autor upoznao isključivo putem tuđih kompilacija, prerada i parafraza. Time smo mogli bolje rekonstruirati glazbenoteorijski arhiv iz kojeg su crpili zagrebački kanonik školovan u Beču i Bologni na samom početku 18. stoljeća te svetonedjeljski župnik koji je, očito, bio marljiv učenik gdje god da se školovao, ali i pisci predgovora CO. Treće se načelo odnosi na često ignoriranu činjenicu da je u svim službenim dokumentima Katoličke crkve upravo gregorijansko pjevanje kao jednoglasna liturgijska glazba istican kao jedini izvorni, pravi i poželjni način muziciranja te da je, isključivo zbog ideje prikazivanja razvoja u glazbi i očuvanja stilske koherentnosti pojedinih razdoblja ignoriran u prikazima razdoblja od sredine 16. stoljeća pa do velike reforme u Solèsmesu. Četvrto načelo tiče se potpunog povjerenja u vjerodostojnost argumenata istraživanih pisaca: nastojali smo ne diskriminirati izvore koje pisci navode, ali ni načine na koje ih upotrebljavaju. Njihova argumentacija njima je samima, a vrlo vjerojatno i njihovim čitateljima, bila apsolutno vjerodostojna.

Tekstove smo podijelili na dvije grupe koje, premda povezane gregorijanskim pjevanjem kao žanrom koji podučavaju i/ili zastupaju kao jedini poželjan i ispravan, „dignior et antiquior“ dostojniji i stariji, nude posve različiti tip govora o glazbi.

Prvi je odjek kasnoantičke i srednjovjekovne musica theorica koja muziku promatra kao matematičku znanost i razumije je samo kao odraz harmonije sfera. Iz te ideje razvijena ideja o njezinim etičkim odlikama u Platona, a prenesena preko spisa svetog Augustina i Boetija u kršćanski skolastički sustav postupno je formirala ideju o muzici kao posrednici u spasu duše i poveznici između Boga i čovjeka. Takav diskurs nude i obilno obrazlažu predgovori drugom i trećem izdanju CO.

Drugi je usmjeren na obrazovanje mladih pjevača i nastoji sažeto prikazati sva znanja potrebna za vješto izvođenje gregorijanskih napjeva. Takav je tip govora svoj put započeo još u karolinškoj renesansi, a afirmirao ga je i u 18. stoljeću nezaobilazni Guido iz Arezza. U 17. i 18. stoljeću priručnici za poduku u pjevanju (ali i sviranju, no time se nismo bavili u ovome radu), postali su najčešće objavljivani tekstovi o glazbi. Njihovu popularnost dodatno su potaknula tri događaja: reformacija, katolička obnova i, najšire shvaćeno, prosvjetiteljstvo. 
Posljednjih tridesetak godina u Europi i Sjedinjenim američkim državama, u kontekstu pokušaja prevladavanja linearne pozitivističke glazbene historiografije, upravo je ovo razdoblje postalo zanimljivo istraživačima, o čemu svjedoče disertacije i knjige koje se bave glazbom i, općenito, kulturom katoličke obnove.

Uz pokušaj definiranja korpusa glazbenoteorijskoga znanja u prvoj polovici 18. stoljeća u sjevernim hrvatskim zemljama, na temelju istraživanja dominantnih epistemologija 17. i 18. stoljeća (Dahlhaus, Foucault, Cook, Blasius), željeli smo ispitati postoje li u hrvatskim izvorima elementi, iz suvremene znanstvene perspektive, aktualnih načina organizacije i prikaza znanja.

Analizirajući načine sastavljanja svih izvora, zaključili smo da je srednjovjekovni način oblikovanja teksta, kompilacija, osnova na kojoj počivaju i svi hrvatski tekstovi, kako priručnici, tako i predgovori CO.

Uspoređujući priručnike musica practica s drugim priručnicima iz spomenutog razdoblja, pokazali smo da je kompilacija metoda sastavljanja teksta i u razvijenijim sredinama od zagrebačke (npr. Samberov Elucidatio objavljen u Salzburgu, 1710.) te da supostoje dva osnovna tipa prikaza znanja. Prvi je sažet i jasan, pomalo monoton prikaz glazbene teorije koji se ne zamara odviše navođenjem izvora, a osobito ne „obranom“ teme. Takav su model priručnika odabrali franjevački pisci Fabrizio Tettamanzi u Breve metodo per apprendere ... il canto fermo iz 1756. i Giuseppe Frezza Dalle Grotte u tekstu Il Cantore ecclesiastico iz 1733. te anonimni pisac Compendiosa ..., priručnika opsegom slična Kovačevićevom, pridodanom Psalteriju-Antifonalu iz Beča (1742.). Pritom su veći opseg djela i obilje primjera koji se nude temeljna razlika između franjevačkih tekstova i upute iz PA. Šilobod-Bolšić ponudio je formalno najbolje strukturiran priručnik koji živim dijalogom između Učitelja i Učenika kudikamo više od prethodno spomenutih, zadržava pažnju čitatelja na građi koju nudi. Uz to, insistira na primjerima koje vješto uklapa u definicije. Način prikaza građe otkriva nastojanje da je se prikaže pregledno i jasno, poštujući u prošlosti uspostavljeni red u redoslijedu prikazanih tema. Način klasifikacije građe pritom se odmiče od renesansnog modela opisivanja i traženja sličnosti i priklanja se modelu tablica, grafičkih prikaza i mnemotehničkih alata kao što su stihovi.

Kao i hrvatski izvori, tako se i komparativna građa (Samber, Tettamanzi, Frezza Dalle Grotte, Compendiosa ...) bavi isključivo gregorijanskim pjevanjem, ili je ovaj dijelom nekog šireg traktata (kao u Cartella musicale Adriana Banchierija). Zbog toga je i glazbena teorija reducirana na znanja koja su potrebna kantoru i pjevaču, a ne skladatelju ili instrumentalistu. 
Musica theorica prisutna je kao odjek nekad ekstenzivnih matematičko-filozofskih elaborata, čuvajući uspomenu na čudesna djela koja muzika postiže. Imajući posvemašnju moć nad ljudskim dušama, ona ih obraća na put dobra, dok one zle (zmije kao metafore zla) tjera da se raspadnu. Ovakav tip argumentacije u korist glazbe također se nalazi, ne samo u spekulativnim traktatima, već i u suvremenim zbornicima objavljenima u Habsburškoj monarhiji, kao što je Lyra colestis koja je, očito, bila uzorom piscu CO, barem za tekst predgovora, ako već ne za izbor napjeva. ${ }^{607}$ Kao što pedagoški traktati referiraju na teoriju od Guida iz Arezza pa sve do suvremenog im Sambera, dokazujući upućenost u suvremenu glazbenoteorijsku produkciju, dakako u okvirima zadane teme, tako CO reflektira način objašnjavanja svijeta utemeljen u (neo)platonizmu. Takav način kojem je temelj spoznaje usporedba po sličnosti (comparatio ad similitudinem), nije, međutim, napušten u 17. i 18. stoljeću razvojem prirodnih znanosti i postupnom afirmacijom taksonomije. U teoriji glazbe nalazimo ga još sredinom 18. stoljeća u traktatima čija je važnost za povijest teorije glazbe neosporna, a gotovo uvijek se odnosi upravo na etičko djelovanje glazbe.

Supostojanje musica theorica i musica practica, zadiranje u prošlost sve do Guida iz Arezza u praktičnoj poduci, a do Amfiona i Orfeja u objašnjavanju njezinih metafizičkih osobina, legitimno svrstava domaće izvore u europski glazbenoteorijski diskurs, opsežan po broju objavljenih tekstova i iznimno heterogen po sadržaju i načinu njegova prikaza. Shvaćanje glazbe kao Božjega dara i nadnaravne pojave nad čijim moćima čovjek nema utjecaja, ali i svijest o važnosti jačanja pobožnosti tipične za katoličku obnovu sve do kraja 18. stoljeća odražava suvremenu im stvarnost ispunjenu neprekidnim nastojanjem da se Istina donese što većem broju ljudi. Latinski jezik kojim su pisani, uz to što piscima omogućava elegantnije posezanje za potrebnim argumentima, čini ih dostupnima i čitateljima izvan sjevernohrvatskih zemalja, a takvu mogućnost naznačuju primjerci Šilobodova priručnika u Bologni i

Bressanoneu.

${ }^{607}$ O LC kao uzoru za glazbeni dio zbornika CO usp. Špralja, Izak. Op. cit. 


\section{BIBLIOGRAFIJA}

\section{Izvori}

Cithara octochorda seu cantus sacri Latino-Sclavonici quos in octo partes ... Viennae Austriae Typis Leopoldi Voigt, universitatis typ., MDCCI.

Cithara octochorda. Zagreb, 1757. sv. 1. Zagreb: HAZU: Institut za crkvenu glazbu „Albe Vidaković“ KBF Sveučilišta u Zagrebu: Hrvatsko društvo crkvenih glazbenika, 1998.

Compendiosa in cantum gregorianum seu choralem introductio. // Psalterio-Antiphonale. Beč, 1742.

Frezza dalle Grotte, Giuseppe. Il Cantore ecclesiastico per istruzione de' Religiosi Minori Conventuali, e benefizio comune di tutti gli Ecclesiastici. Padova: Nella stamperia del seminario Giovanni Manfrè, 1733.

Fundamentum cantus gregoriani, seu choralis pro captu tyronis discipuli, ex probatis authoribus collectum, et brevi, ac facili dialogica methodo in lucem expositum opera, ac studio. A. R. D. Michaelis Sillobod, parochi in Martinszka Vesz. Zagrabiae, Typis Cajetani Francisci Härl, Inclyti Regni Croatiae Typographi, 1760.

Lyra coelestis : svavi concordia divinas laudes personans elaborata, et juxta musicales notas in harmoniam adaptara nuncque primo typis edita. / Opera et studio ... Georgy Naray, Archidiaconi Zoliensis, Ecclesiae Metropolitanae Strigoniensis Canonici, Seminarii S. Stephani Regis Ungariae p. t. Praefecti. / Superiorum permissu. / Tyrnaviae Typis Academicis per Joannem An- / dream Hormann. Anno. M. DC. XCV. URL:

https://library.hungaricana.hu/hu/view/RMK_I_1479/?pg=0\&layout=s (07.10.2019.) Tettamanzi, Fabrizio. Breve metodo per apprendere fondatamente e con facilità il canto fermo. Milano, Agnelli, 1756. URL:

https://books.google.hr/books/download/Breve_Metodo_per_apprendere_fondatamente.pdf\% 3Fid\%3DJBIDAAAAcAAJ\%26hl\%3Dhr\%26output\%3Dpdf (17.08.2018.)

\section{Sekundarni izvori}

Aaron, Petrus. Libri tres de institutione harmonica, liber primus (izvor: Libri tres de institutione harmonica editi a Petro Aaron Florentino (Bononiae, In aedibus Benedicti 
Hectoris Bibliopolae Bononiensis, 1516; reprint ed. New York: Broude Bros. 1978.). URL: http://www.chmtl.indiana.edu/tml/16th/AARIH1 (10.08.2019.)

Antiquae musicae auctores septem. Graece et latine. Marcus Meibomius restituit ac notis explicavit, Amstelodami: Ludovicum Elzevirum, 1652. URL:

https://books.google.be/books?vid=GENT900000090383\&printsec=frontcover\&hl=nl\#v=one page \&q\&f=false, $(28.07 .2020$.)

Athanasii Kircheri Fuldensis Soc. Iesu Presbyteri Musurgia Universalis sive Ars Magna consoni et dissoni in x libros digesta. ... Romae, Ex Typographia Haeredum Francisci Corbelletti. Anno Iubilaei. MDCL. URL:

https://books.google.hr/books?id=Fr1CAAAAcAAJ\&printsec=frontcover\&redir_esc=y\#v=on epage\&q\&f=false $(17.04 .2018$.)

Banchieri, Adriano. Cartella musicale del canto figurato, fermo \& contrapunto... Venetiis, 1614. URL: https://imslp.org/wiki/Cartella_musicale_(Banchieri\%2C_Adriano) (21.08.2019.)

Cantus catholici. Kassa 1674. - RMK I. 1159 - EOK R 244. URL:

https://library.hungaricana.hu/en/view/EvangelikusMuzealisKonyvek_EOK_R_0244/?pg=0\& layout $=\mathrm{s}(29.12 .2019$.)

Chiodino, Giovanni Battista. Arte pratica latina et volgare di far contrapunto a mente, \& a penna, divisa in diece libretti, brevissimi, ordinatissimi et facilissimi. In Venetia, Appresso Ricciardo Amadino, 1610. URL: https://download.digitalesammlungen.de/pdf/15985259857282bsb10527103.pdf (12.04.2020.)

Chiodino, Giovanni Battista. Praxis sphaerica clarissima. De motibus, \& proprietatibus celorum, \& planetarum, tribus libris disposita, cum questionibus ad sententiam Scoti, ad libros metheorum Aristotelis. Cum duplo indice capitum, \& sententiarum. Per mag. Ioan. Baptistam Chiodinum minor. conuentual. .... - Venetiis : apud Ambrosium \& Bartholomeum Dei, fratres, 1615. URL: https://bibdig.museogalileo.it/Teca/Viewer?an=958438 (12.04.2020.)

Cicero. De Officiis, 1:22. URL: https://www.thelatinlibrary.com/cicero/off1.shtml (23.04.2020.)

Cicero. M. Tulli Ciceronis Rhetorica, Tomus II. A. S. Wilkins. Oxonii. e Typographeo Clarendoniano. 1911. Scriptorum Classicorum Bibliotheca Oxoniensis. URL: 
http://www.perseus.tufts.edu/hopper/text?doc=Cic.\%20Brut.\%2051.191\&lang=original (13.2.2019.)

Ciconia, Johannes. Nova musica and De proportionibus. / kritičko izdanje i prijevod Oliver B. Ellsworth. Lincoln: London: University of Nebraska Press, 1993.

Declarationes Illust. Sac. Rom. Cardinalium Congregationis. Ipsis Sacrosancti / Oecumenici Concilii Tridentini canonibus et decretis insertas. Coloniae Agrippinae, 1619.: Sessio XVII, 18. jan. 1562. i Sessio XXIII, 15. jul 1563., Doctrina de Sacramento Ordinis, canon XII. URL: https://books.google.hr/books/about/Declarationes_Illust_Sac_Rom_Cardinalium.html?id=M 1GK0PKtMoAC\&redir_esc=y (24.07.2019.)

De Martinis, Joannes Baptist. Clavis cantus ecclesiastici seu modus intonandi et cantandi. Roma: Nicolo Angelo Tinassi, 1661.

Der vollkommene Capellmeister, Das ist Gründliche Anzeige aller derjenigen Sachen, die einer wissen, können, und vollkommen inne haben muß, der einer Capelle mit Ehren und Nutzen vorstehen will: Zum Versuch entworffen von Mattheson. Hamburg; Christian Herold, 1739. URL: https://archive.org/details/bub_gb_gMlCAAAAcAAJ/page/n11/mode/2up (16.03.2019.)

Gaffurio, Franchino. Practica musicae. (digit. prema Practica musice Franchini Gafori Laudensis (Milan: Ioannes Petrus de Lomatio, 1496; reprint ed., New York: Broude Bros., 1979.) URL: http://www.chmtl.indiana.edu/tml/15th/GAFPM1 (13.07.2019.)

Gaffurio, Franchino. Theorica musice, liber primus. (digit. prema Theorica musice Franchini Gafuri Laudensis. Milan: Ioannes Petrus de Lomatio, 1492; reprint ed., New York: Broude Bros., 1967. URL: http://www.chmtl.indiana.edu/tml/15th/GAFPM1 (13.07.2019.) Guidonis Aretini. Regulae rhythmicae. // Divitiae musicae artis A/IV / uredili Joseph Smits van Waesberghe; Eduard Vetter. Buren: Knuf, 1985. Str. 92-133. URL: http://www.chmtl.indiana.edu/tml/9th-11th/GUIRR (02.10.2018.) Guidonis Monachi Aretini Micrologus ad praestantiores codices mss. exactus cura et studio Ambrosii M. Amelli o. s. b. Romae: Desclée, Lefebvre et S. Edit. Pont.,1904. URL: https://www.scribd.com/doc/316059199/Guido-D-Arezzo-Micrologus-pdf (24.03.2019.) Musica enchiriadis. URL: https://chmtl.indiana.edu/tml/9th-11th/MUSENCI (11.03.2019.) 
Samber, Johann Baptist, Elucidatio musicae choralis; Das ist, Gründlich und wahre Erläuterung oder Unterweisung, wie die edle und uralte Choral-Music fundamentaliter nach denen wolgegründten Reglen mit leichter Mühe möge erlehrnt werden ... Salzburg, 1710.

Sancti Bonaventurae Commentaria in quatuor libros Sententiarum magistri Petri Lombardi, Proemium in librum primum sententiarum, quaestio IV, sv. I. Firenze: Quaracchi,1882. URL: https://archive.org/details/doctorisseraphic11bona (14.10.2019.)

Scholica enchiriadis de arte musica. URL: https://chmtl.indiana.edu/tml/9th-11th/SCHEN (11.03.2019.).

Scriptores ecclesiastici de musica sacra potissimum, 3 sv. // uredio Martin Gerbert. St. Blaise: Typis San-Blasianis, 1784; pretisak Hildesheim: Olms, 1963., 1:152-73. URL:

https://books.google.de/books?id=VdtWAAAAcAAJ\&printsec $=$ frontcover\&hl=de\&source=g bs_atb\#v=onepage \&q\&f=false $(17.04 .2018$.

Summa Doctrinae Christianae ex postrema cognitione doctoris Petri Canisii ... Antverpiae 1587. URL: https://books.google.hr/books?id=bvwTAAAAYAAJ\&redir_esc=y (13.05.2020.) 


\section{Bibliografija}

A Companion to Boethius in the Middle Ages. // uredili, Noel Harold Kaylor; Edward Phillip Phillips, Leiden: Brill, 2012.

A Companion to Rhetoric and Rhetorical Criticism. uredili Walter Jost; Wendy Olmsted. s. 1.: Blackwell Publishing. 2004.

Adler, Guido. Umfang, Methode und Ziel der Musikwissenschaft. // Vierteljahrschrift für Musikwissenschaft, 1 (1885) 1. Str. 5-20.

Allen, Warren Dwight. Philosophies of Music History: A Study of General Histories of Music 1600-1960, Dover Publications: 1962.

Althusser, Louis; Balibar, Etienne. Kako čitati Kapital. Zagreb: Centar za kulturnu djelatnost SSO, 1975.

Andreis, Josip. Povijest glazbe. Povijest hrvatske glazbe, knj. 4. Zagreb: Liber Mladost. 1974. Andreis, Josip. Albertijev „Dijalog“. O 350-godišnjici objavljivanja. // Arti musices, 1 (1969), str. 91-104.

Anić, Vladimir. Veliki rječnik hrvatskoga jezika. Zagreb: Novi liber, 2003.

Atkinson, Charles M. The Critical Nexus, Tone-System, Mode and Notation in Early Medieval Music. Oxford: Oxford University Press, 2008.

Augustini Contra Academicos 6. III, 17, 37. URL:

https://www.documentacatholicaomnia.eu/04z/z_0354-

0430_Augustinus_Contra_Academicos_Libri_Tres_MLT.pdf.html (11.09.2020.)

Banchieri, Adriano. Cartella musicale nel canto figurato, fermo e contrapunto. Venezia, 1614. Str. 68-69. URL: https://imslp.org/wiki/Cartella_musicale_(Banchieri\%2C_Adriano). (14.01.2020.)

Barbarić, Damir. Mousikē i ethos u Grka. // Treći program Hrvatskog radija (0353-94743) 80 (2012), str.135-143. URL:

http://eprints.ifzg.hr/702/1/Mousike\%20i\%20ethos\%20u\%20Grka.pdf (27.02.2019.) 
Bartha, Paul. Analogy and Analogical Reasoning. // The Stanford Encyclopedia of Philosophy (Spring 2019 Edition) / uredio Edward N. Zalta. URL:

https://plato.stanford.edu/archives/spr2019/entries/reasoning-analogy/ (17.11.2019.)

Bedouelle, Guy. Povijest crkve. Zagreb: KS, 2004.

Beales, Derek. Enlightenment and Reform in Eighteenth-century Europe. London: New York: I. B. Tauris, 2005.

Benyovsky Latin, Irena; Vitek, Darko. Gradovi // U potrazi za mirom i blagostanjem.Hrvatske zemlje u 18. stoljeću/ uredila Lovorka Čoralić. MH: Zagreb. 2013.

Bergua Cavero, Jorge. Invention and Imitation: an overview of musical settings of Classical poetry and the rediscovery of Ancient music, from the Middle Ages to the Renaissance. // Anabases. Traditions et réceptions de l'Antiquité. 8/2013, str. 61-69. URL: http://journals.openedition.org/anabases/4347 (09.04.2020.)

Bernhard, Michael. Rezeption der Institutio Musica des Boethius im frühen Mittelalter. Boèce ou la chaîne des savoirs. Actes du Colloque International de la Fondation Signer-Polignac, Paris, 1999. // uredio Alain Galonnier. Louvain - Paris: Peeters, 2003. Str. 601-612.

Berteau, Rolande. Similitudo. // L'antiquité classique. Tome 48, fasc. 1, 1979. Str. 154-160. URL: https://www.persee.fr/doc/antiq_0770-2817_1979_num_48_1_1936 (11.09.2020.)

Biblia Sacra Vulgata. Zagreb: Kršćanska sadašnjost, 2013.

Bilić, Franjo. Paraliturgijska glazba sjevernohrvatskog baroka - spona između pučkog i umjetničkog izraza. // Glazbena baština naroda i narodnosti Jugoslavije od 16. do 19. stoljeća I / uredio Srećko Lipovčan. Zagreb - Varaždin: MIC, 1980. Str. 15-22.

Binder, Dieter A. Pietas Austriaca? The Imperial Legacy in Interwar and Postwar Austria. // Religions, 2017, 8/171. Str. 1-10. URL:

https://www.researchgate.net/publication/319347003_Pietas_Austriaca_The_Imperial_Legac y_in_Interwar_and_Postwar_Austria/link/59a60640aca272895c145d50/download (21.11.2020.)

Bisaro, Xavier. Par-delà des monts: Les traités de „,canto fermo“. URL: https://www.cantusscholarum.univ-tours.fr/publications/essais-et-notes-de-travail/canto-fermo/ (20.06.2020.)

Blackburn, Bonnie J. Gaffurius Francinus. Grove Music Online. URL: https://doi.org/10.1093/gmo/9781561592630.article.10477 (13.07.2019.) 
Blasius, Leslie. Mapping the Terrain. // The Cambridge History of Western Music Theory/, uredio Thomas Christensen. Cambridge: Cambridge University Press, 2008. Str. 27-45.

Blažeković, Zdravko. Bilješke o glazbenicima na zagrebačkom Griču u 18. stoljeću. // Glazbeni barok u Hrvatskoj / uredio Ennio Stipčević. Osor: Osorske glazbene večeri, 1989. Str. $114-129$.

Blažević, Zrinka. Vitezovićeva Hrvatska između stvarnosti i utopije. Ideološka koncepcija u djelima postkarlovačkog ciklusa Pavla Rittera Vitezovića (1652.-1713.). Zagreb: Barbat, 2002.

Boèce ou la chaîne des savoirs. Actes du Colloque International de la Fondation SignerPolignac, Paris, 1999. // uredio Alain Galonnier. Louvain - Paris: Peeters, 2003.

Bogišić, Rafo. Hrvatska književna historiografija 18. stoljeća. // Dani hvarskog kazališta. Hrvatska književnost uoči preporoda. Split: Književni krug, 1997. Str. 5-18.

Bogišić, Rafo. Posvete i predgovori hrvatskih pisaca 18. st. Dani hvarskog kazališta. Hrvatska književnost 18. stoljeća: tematski i žanrovski aspekti. Split: Književni krug Split, 1995. str. 5-29.

Bogišić, Rafo. Književnost prosvjetiteljstva. // Od renesanse do prosvjetiteljstva, Povijest hrvatske književnosti 3 / uredili Marin Franičević; Franjo Švelec; Rafo Bogišić. Zagreb: Liber Mladost, 1974. Str. 293-376.

Bohlman, Philip V. Ontologies of Music. // Rethinking Music / uredili Nicholas Cook i Mark Everist. Oxford: Oxford University Press, $2010 .^{3}$ Str. 17-34.

Boisits, Barbara. Cäcilianismus. // Oesterreischisches Musiklexikon online. URL: //www.musiklexikon.ac.at/ml/musik_C/Caecilianismus.xml

Bowler, Calvin M. The transmission of ancient music theory into the Middle Ages. The Cambridge History of Western Music Theory. // uredio Thomas Christensen. Cambridge: Cambridge University Press, 2008. Str. 136-167.

Bratulić, Josip. Pavao Ritter Vitezović, utemeljitelj Hrvatske zemaljske tiskare u Zagrebu. // Senjski zbornik, 22 (1995), Str.179-186.

Brennan, Brian. Augustine's De Musica. // Vigiliae Christianae, 42/3 (Sep. 1988), str. 267281. URL: https://www.jstor.org/stable/1584121 (16.04.2020.) 
Brooks, Jeanice. The Art of Civil Conversation: Courtly Neo-Platonism and the Dialogue Air. // Poetry and Music in the French Renaissance / uredili Jeanice Brooks; Philipp Ford; Gillian Jondorf. Cambridge: Cambridge French Colloquia. Str. 159-184.

Buelow, George J. A History of Baroque Music. Bloomington \& Indianapolis: Indiana University Press, 2004.

Burke, Peter. The Renaissance dialogue. // Renaissance Studies, 3(1),1989. Str. 1-12.

Canfora, Luciano. Le copiste comme auteur (prev. Laurent Calvié i Gisle Cocco). Toulouse: Anacharsis, 2012.

Carr, Edward Callet. Što je povijest?. Zagreb: Srednja Europa, 2004.

Chailley, Jacques. Povijest glazbe srednjeg vijeka (prev. Jelena Knešaurek Carić). Zagreb: HMD. 2006.

Chevallier, Philippe. Le christianisme est-il un pouvoir comme un autre ? // ThéoRèmes [En ligne]. Philosophie, mis en ligne le 11 juin 2016. URL:

http://journals.openedition.org/theoremes/769 (12.09.2020.)

Chiron, Jeanne. Le dialogue éducatif des Lumières : innovations, permanences et fantasmes (1754-1804). Education. Université Paris-Est, 2016. URL: https://tel.archives-ouvertes.fr/tel$01629825(08.11 .2018$.

Christensen, Thomas. Music Theory in Clio's Mirror. // Giger, Andreas i Mathiesen, Thomas J. (ur.). Music in the Mirror: Reflections on the History of Music Theory and Literature for the Twenty-First Century. Lincoln \& London: University of Nebraska Press, 2002. Str. 1-20. Christensen, Thomas. Introduction. // The Cambridge History of Western Music Theory / uredio Thomas Christensen. Cambridge: Cambridge University Press, 2002. Str. 1-23. Ciceron, Marko Tulije. De Inventione. LCL: 386, 86-87. URL: https://www.loebclassics.com/view/marcus_tullius_cicerode_inventione/1949/pb_LCL386.87.xml (04.11.2020.)

Ciceron, Marko Tulije. Topica. LCL, 386. URL: https://www.loebclassics.com/view/marcus_tullius_cicero-topica/1949/pb_LCL386.383.xml (04.11.2020.)

Citation and Authority in Medieval and Renaissance Musical Culture. Learning from the Learned / uredile Suzannah Clarke; Elizabeth Eva Leach. Woodbridge: The Boydell Press, 2005. 
Cohen, David E. Notes, Scales and Modes in the Earlier Middle Ages. // The Cambridge History of Western Music Theory. / uredio Thomas Christensen. Cambridge: Cambridge University Press, 2008. Str. 307-363.

Collins Judd, Cristle. Music in Dialogue. // Journal of Music Theory 52:1, 2008. Str. 41-74.

URL: https://www.jstor.org/stable/40607029 (26.07.2016.)

Collins Judd, Cristle. Reading Renaissance Music Theory: Hearing with the Eyes. Cambridge; Cambridge University Press. 2000.

Combe, Dom Pierre. Histoire de la restauration du chant grégorien d'après des documents inédits. Abbaye Saint Pierre Solèsmes, 1968.

Constitutiones Societatis Jesus, p. VI, c. III, n. 4. URL:

https://archive.org/details/constitutionesso00jesuuoft (05.01.2020.)

Coreth, Anna. Pietas Austriaca. s. 1. Purdue University Press, 2001.

Crnčević, Ante. Concilium Tridentinum i liturgijska reforma. Prijekoncilska liturgijska nastojanja i recepcija poslijekoncilske obove. // Tridentska baština: katolička obnova $i$ konfesionalizacija u hrvatskim zemljama. / uredile_Zrinka Blažević; Lahorka Plejić Poje. MH: KBF: FFDI: Zagreb, 2016. str. 31-41.

Curtius, Ernest. Europska književnost i latinsko srednjovjekovlje. Zagreb: Naprijed, 1998.

Cvekan, Paškal. Franjevačko zakonodavstvo o pjevanju i orguljama u 17. i 18. stoljeću. Glazbeni barok u Hrvatskoj. Zbornik radova sa simpozija održanog u Osoru 1986. godinel uredio Ennio Stipčević. Osor: Osorske glazbene večeri, 1989. Str. 145-154.

Dahlhaus, Carl. The Eighteenth Century as a Music-Historical Epoch (prev. Ernest Harriss). // College Music Symposium, 26/1986, Str. 1-6.

Dahlhaus, Carl. Was heisst „Geschichte der Musiktheorie?“. // Ideen zu einer Geschichte der Musiktheorie GMth 1 / uredio Frieder Zaminer. Darmstadt: WBG, 1985. Str. 8 - 39.

Dahlhaus, Carl. Die Musiktheorie im 18. und 19. Jahrhundert: I. Grundzüge einer Systematik. Darmstadt: Wissenschaftliche Buchgesellschaft. 1984.

Dammann, Rolf. Zur Musiklehre des Andreas Werckmeister. // Archiv für Musikwissenschaft, 11/3 (1954). Str. 206-237.

Dammschroder, David; Williams, David Russel. Music Theory from Zarlino to Schenker. A Bibliography and guide. New York: Pendragon Press, 1990. 
Dani hvarskog kazališta. Hrvatska književnost 18. stoljeća: tematski i žanrovski aspekti. // uredio Nikola Batušić et al. Zagreb: Split: HAZU: Književni krug Split, 1995.

Dauphant, Clotilde. La mise en recueil : diffusion \& réception des textes médiévaux. // Acta fabula, sv. 12, br. 3. Poétiques médiévales : lire, inventer, composer, 2011. URL :

http://www.fabula.org/acta/document6229.php1 (8.09.2017.)

Davison, J. A. The Homeric Question. // Companion to Homer / uredili A. J. B. Wace; F. H. Stubbings. London: Macmillan \& co. 1963.

Deleuze, Gilles. Foucault. Minneapolis, London: The University of Minnesota Press, 1988.

Desanti, Jean-Toussaint. Réflexion sur le concept du mathesis. // Figures de la Psychanalyse. 2/12, 2005. Str. 103-137. URL: https://doi.org/10.3917/fp.012.0103 (18.10.2019.)

de Vogel, Cornelia J. On the neoplatonic Character of Platonism and platonic Character of Neoplatonism. // Mind, 62/ 245 (1953), str. 43-64. Oxford: Oxford University Press. URL: https://www.jstor.org/stable/2251287?seq=1\#page_scan_tab_contents (14.07.2019.)

de Vogel, Cornelia. Rethinking Plato and Platonism. Leiden, New York: Københaven: Köln: E. J. Brill, 1986.

Diskurs. // Struna. Hrvatsko strukovno nazivlje. URL: http://struna.ihjj.hr/naziv/diskurs/25343/ (01.04.2018.)

Disticha Catonis. URL: https://www.thelatinlibrary.com/cato.dis.html (23.01.2020.)

Doucet, Dominique. Similitudo mater veritatis, dissimilitudo mater falsitatis. // Archives de Philosophie, 61/2, 1998. Str. 269-291. URL: http://www.jstor.org/stable/43037672 (16.09.2018.)

Dugan, Franjo. O našem glazbenom prilogu s. Crisiense Majus, vulgo S. Joannis dictum. // Sv. Cecilija, 1917. Str. 9-20.

Eco, Umberto. Umjetnost i ljepota u srednjovjekovnoj estetici (prev. Željka Čorak). Zagreb: IPU, 2007.

Edge, Dexter. Viennese Music Copyists and the Transmission of Music. // Revue de Musicologie 84/2, 1998. Str. 298-304.

Ewans, J. R. W.; Thomas, T. V. (ur.). Crown, Church and Estates. Central European Politics in the Sixteenth and Seventeenth Centuries. New York: St Martin's Press, 1991.

Evans, Robert J.W. Das Werden der Habsburger Monarchie 1550-1700. Gesellschaft, Kultur, Institutionen. Forschungen zur Geschichte des Donauraumes 6. Wien: Böhlau Verlag, 1986. 
Falkenroth, Christoph. Die Musica speculativa des Johannes de Muris. Beihefte zum Archiv für Musikwissenschaft, vol. 34. Stuttgart, Steiner, 1992. URL:

https://chmtl.indiana.edu/tml/14th/MURISAPP. (13.09.2020.)

Fellerer, K. G. \& Hadad, Moses. Church Music and the Council of Trent. The Musical Quarterly, 39:4, 1953. Str. 576-594. URL: http://ww.jstor.org/stable/739857 (26.03.2016.)

Foucault, Michel. Qu'est-ce que les Lumières?. Dits et Ecrits, tome IV. Paris: Gallimard, 1994. str. 562-578. URL: https://monoskop.org/File:Foucault_Michel_Dits_et_ecrits_4_19801988.pdf (02.02.2021.);

Foucault, Michel. Les mot set les choses. Une archéologie des sciences humaines. Paris: Editions Gallimard, 1966. (Riječi i stvari. Arheologija humanističkih znanosti. prev. Srđan Rahelić. Zagreb: Golden marketing, 2002.)

Francescantonio Vallotti nel Il centenario della morte (1780-1980): Biografia, catalogo tematico delle opere e contributi critici / uredio Giulio Cattin. Padova: Messaggero, 1981.

Frangeš, Ivo. Povijest hrvatske književnosti. Zagreb: NZMH; Ljubljana: Cankarjeva založba, 1987.

Franzen, August. Pregled povijesti crkve. Zagreb: KS, 1996.

Fredborg, Karin Margareta. The Scholastic Teaching of Rhetoric in the Middle Ages. //

Cahiers de l'institut du Moyen Âge grec et latin. Université de Copenhague, vol. 55 (1987).

Str. 85-105. URL: http://opac.regesta-imperii.de/lang_de/anzeige.php?pk=459433

(03.12.2020.)

Fuller, Sarah. Interpreting Hucbald on Mode. // Journal of Music Theory (52:1), 2008. Str. 1340.

Fux, Johann Joseph. Gradus ad Parnassum. Beč, 1725. URL:

https://imslp.org/wiki/Gradus_ad_Parnassum_(Fux\%2C_Johann_Joseph) (23.12.2020.)

Galilei, Galileo. Dialogo della musica anticha e moredna. URL:

http://ks.petruccimusiclibrary.org/files/imglnks/usimg/7/7a/IMSLP91211-PMLP187468-

Galilei_-_Dialogo_della_musica.pdf (19.09.2019.)

Geerdink, Nina; Montoya, Alicia S. Early Modern Period. Introduction. De Pourcq, Maarten;

Levie, Sofie. European Literary History: An Introduction. NY: Routledge. 2018.

Genette, Gérard. Seuils. Paris: Éditions du Seuil, 1987. 
Geschichte der Musiktheorie / Uredio Frieder Zaminer, 15 sv. Darmstadt: Wissenschaftliche Buchgesellschaft, 1990.

Gibson, Sophie. Aristoxenus of Tarentum and the Birth of Musicology. NY \& London:

Routledge, 2005.

Gilson, Étienne. La philosophie au moyen âge. Paris, 1944. Str. 268.

Gjerdingen, Robert. An Experimental Music Theory? // Rethinking Music / uredili Nicholas Cook i Mark Everist. Cambridge: Cambridge University Press 2010. ${ }^{3}$ Str. 161-170.

Goehr, Lydia ... [et al.]. Philosophy of Music. // NGROVED², sv. 19.

Goehr, Lydia. Writing Music History. // History and Theory, 31 (1992), str. 182-199. URL: https://www.jstor.org/stable/2505596 (14.11.2018.).

Greek Musical Writings, vol. II: Harmonic and Acoustic Theory / uredio Andrew Barker. Cambridge: Cambridge University Press, 2004.

Gretić, Goran: Platonizam i temelji neoplatonizma- // Prilozi za istraživanje hrvatske filozofske baštine, 10/ 1-2 (1984), str. 125-166.

Grout, Donald Jay; Burkholder, J. Peter; Palisca, Claude V. A History of Western Music. NY: W. W. Norton \& Co. 2006.7

Habermas, Jürgen. Filozofski diskurs moderne. Dvanaest predavanja. Zagreb: Globus, 1988. Hankins, James, Plato in the Italian Renaissance, Leiden, NY, København, Köln: E. J. Brill, 1990.

Hankins, James. Plato in the Middle Ages. // Dictionary of the Middle Ages / uredio Joseph Reese Strayer. sv. IX, str. 694-704. New York: 1987. URL:

https://www.scribd.com/doc/7878958/Hankins-Plato-in-the-Middle-Ages (14.11.2019.)

Hawkins, John. A General History of the Science and Practice of Music. London, 1776. vol. 1, str. 368. URL: https://imslp.simssa.ca/files/imglnks/usimg/9/9c/IMSLP337339PMLP544570-generalhistoryof01byuhawk.pdf, (20.10.2020.)

Hayburn, Robert F.. Papal Legislation on Sacred Music, 95 A. D. to 1977 A. D. s. 1.: Liturgical Press, 1979. 
Hermann, Ursula. Andreas Werckmeister (1645-1706). Doktorska disertacija. Sveučilište u Halleu, 1950.

Hiley, David. Western Plainchant. A Handbook. Oxford: Clarendon Press, 1993.

Honorius Augostodunensis Gemma animae 1.16 „De cantoribus“. PL 172: 549 B-C. URL: https://www.documentacatholicaomnia.eu/04z/z_1080-

1137_Honorius_Augustodunensis_Gemma_Animae_MLT.pdf.html (26.05.2019.).

Horbec, Ivana; Matasović, Maja; Švoger, Vlasta. Od protomodernizacije do modernizacije školstva u Hrvatskoj: zakonodavni okvir. Zagreb: Hrvatski institut za povijest, 2017.

Horvat, Rudolf. Prošlost grada Zagreba. Zagreb: AC, 1992.

Hoško, Emanuel Franjo. Franjevačke visoke škole u kontinentalnoj Hrvatskoj, Zagreb: KS, 2002.

Hoško, Franjo Emanuel. Franjevci i poslanje Crkve u kontinentalnoj Hrvatskoj. Zagreb: Kršćanska sadašnjost, 2001.

Horacije. Ars Poetica, 335-336. URL: https://www.loebclassics.com/view/horacears_poetica/1926/pb_LCL194.459.xml (17.10.2019.)

Huglo, Michel. L'auteur de „Dialogue sur la Musique“ attribué a Odon. // Revue de Musicologie, 55/2, 1969. Str. 119-171. URL: https://doi.org/10.2307/927822 (11.11.2019.) Humphrey, Illo. Bibliography. URL: https://u-bordeaux3.academia.edu/IlloHumphrey (03.08.2019.)

Hunt, Lynn. Nova kulturna historija. Zagreb: Naklada Ljevak, 2001.

Hobsbawm, Eric. Nations and Nationalism Since 1780: programme - Myth-Reality. Oxford: Oyford University Press, $1992^{2}$. (Nacije i nacionalizam - program, mit, stvarnost. prev. Nata Čengić. Zagreb: Novi Liber, 1993.)

Ivić, Nenad. Domišljanje prošlosti: kako je trinaeststoljetni splitski arhiđakon Toma napravio svoju salonitansku historiju. Zageb: Zavod za znanost o književnosti Filozofskoga fakulteta u Zagrebu, 1992.

Jacobus Leodensis. Compendium de musica, 1:1. URL:

http://www.chmtl.indiana.edu/tml/14th/JACCDM

Janson, Tore. Latin Prose Prefaces. Studies in Literary Conventions. Stockholm; Göteborg; Uppsala: Almquist \& Wiksell, 1963. 
Jedin, Hubert. Velika povijest crkve, sv. IV (prev. Ivica Tomljenović). Zagreb: KS, 2004.

Jedin, Hubert. Velika povijest crkve, sv. V: Crkva u doba apsolutizma i prosvjetiteljstva. Zagreb: KS, 1978.

Jelčić, Dubravko. Povijest hrvatske književnosti: tisućljeće od Baščanske ploče do postmoderne. Zagreb: Naklada P.I.P. Pavičić 2004. ${ }^{2}$

Jeruzalemska Biblija. Zagreb: KS, $2020^{8}$.

Ježić, Slavko. Hrvatska književnost od početaka do danas 1100.-1941. Zagreb, 1944.

Judson, Pieter M. Povijest Habsburškog carstva. Zagreb: Sandorf, 2018.

Karp, Theodore. An Introduction to the Post-Tridentine Mass-Proper. Middleton, Wisconsin: American Institute of Musicology, 2005.

Katalinić, Vjera. Pregled izvora o glazbenoj kulturi baroknog razdoblja na tlu SR Hrvatske. // Glazbeni barok u Hrvatskoj / uredio Ennio Stipčević. Osor: Osorske glazbene večeri, 1989. Str. 20-47.

Katušić, Maja. Pregled političkih zbivanja. // U potrazi za mirom i blagostanjem. Hrvatske zemlje u 18. stoljeću / uredila Lovorka Čoralić. Zagreb: MH, 2013. Str. 3-26.

Klaić, Vjekoslav. Kanonik Ivan Znika, mecen hrvatske umjetnosti i književnosti, (1609. 1706). // Bogoslovska smotra, sv.13, br. 2. Zagreb: 1925. Str. 356-370.

Klaić, Vjekoslav. Toma Kovačević, povjesničar hrvatski (1664.-1724.). // Bogoslovska smotra. Zagreb, 13/1925. br. 1, str. 69-91.

Klaić, Vjekoslav. Obrana Pavla Rittera Vitezovića od god. 1710. // Građa za povijest književnosti Hrvatske, Zagreb: 1915. Str. 375-394.

Klaić, Vjekoslav. Život i djela Pavla Rittera Vitezovića. Zagreb: MH, 1914.

Kniewald, Dragutin. Himnodija zagrebačke stolne crkve. Zagreb, 1944. Kulturno povijesni zbornik zagrebačke nadbiskupije I. Zagreb. 1944. str. 339-408.

Kniewald, Dragutin. Obred i obredne knjige zagrebačke stolne crkve 1094-1788. Zagreb, 1940.

Književnost. Hrvatska enciklopedija, mrežno izdanje. URL: https://www.enciklopedija.hr/Natuknica.aspx?ID=32128 (5.09.2019.)

Koprek, Katarina. Gregorijanski manual Fundamentum cantus gregoriani seu choralis (1760.) Mihajla Šiloboda - Bolšića. // Povijesni prilozi 33, 2007. Str. 311-330. 
Koprek, Katarina. Glazbeni priručnik Fundamentum cantus gregoriani seu choralis Mihaela Šiloboda. // Šilobod, Mihael. Fundamentum cantus gregoriani seu choralis. Sveta Nedjelja: Ogranak MH u Svetoj Nedjelji, 2016. Str. 17 - 32.

Korsyn, Kevin. Decentering music. Oxford: Oxford University Press, 2005.

Kravar, Zoran. Barok kao potonulo kulturno dobro. // Croatica XVIII, 1987. str. 169-187.

Kuhn, Thomas. Struktura znanstvenih revolucija (prev. Mirna Zelić). Zagreb: Jesenski \& Turk, 2013.

Lamarque, Peter. Philosophy of Literature. Oxford: Blackweill Publishing. 2008.

Le Bihan, Anne. Discours et lien social. URL:

http://www.champlacanienfrance.net/IMG/pdf/Le_Bihan.pdf (05.06.2013.)

Le Goff, Jacques. Un long Moyen Âge. Paris: Pluriel, 2010.

Leksikon antičkih autora. Priredio Dubravko Škiljan. Zagreb: Latina \& Graeca: Matica hrvatska, 1996.

Lester, Joel. Major-Minor Concepts and Modal Theory in Germany, 1592-1680. // Journal of the American Musicological Society, 30/2, 1977. Str. 208-253.

Lewis, Charlton T.; Short, Charles. A Latin Dictionary. URL:

http://www.perseus.tufts.edu/hopper/text?doc=notitia\&fromdoc=Perseus\%3Atext\%3A1999.0 4.0059 (08.09.2019.)

Lisac, Josip. Pavao Ritter Vitezović kao leksikograf. // Prikazi i osvrti. Rasprave Instituta za hrvatski jezik i jezikoslovlje. Knj. 36/2, 2010. str. 385-470.

Livljanić, Katarina. Nepoznati rukopisni procesional u kontekstu procesionalnih obrednih priručnika zagrebačke stolnice s kraja 17. i prve polovice 18. stoljeća. Diplomski rad na Odsjeku za muzikologiju Muzičke akademije Sveučilišta u Zagrebu, sign. DR 1297, 1989. Long, Micol. Autografia e epistolografia tra XI e XIII secolo. Milano: Ledizioni, 2014. str. 175. URL: https://books.openedition.org/ledizioni/409 (23.11.2019.)

Lujić, Božo. Čudotvorna i iscjeliteljska djelatnost proroka Elizeja. // Bogoslovska smotra, 82 (2012), 2. Str. 245-262. 
Lutteken, Laurenz. Konfession und Säkularisation. Zu den Schwierigkeiten der

Musikgeschichtsschreibung mit der Kirchenmusik des 18. Jahrhunderts. // Musik aus Klostern Alpenraums / uredili Peter Lang; Giulio Castellani. Peter Lang AG: 2010.

Manczak, Tomasz. Dieu dans la Consolation de Philosophie // Phares XVIIb-03. Str. 59-73.

URL: https://revuephares.com. (04.02.2021.)

Maingueneau, Dominique. Analyse du discours et archive. // Semen (en ligne), 8/1993, mis en ligne le 12 juin 2007. URL: http://journals.openedition.org/semen/4069. (26.02.2020.)

Mantuani, Josip. Dva glazbena rukopisa iz franjevačkog samostana u Varaždinu. // Sv.

Cecilija, 1924. Str. 1-5.

Marević, Jozo. Latinsko-hrvatski enciklopedijski rječnik. Zagreb: MH, 2000.

Maritain, Jacques. Art et Scolastique. Paris: Editions Saint Paul, 1986. (Umjetnost i skolastika / prev. Marko Kovačević. Zagreb: Nakladni zavod Globus, 2001.)

Mathiesen, Thomas J. Greek music theory. The Cambridge History of Western Music Theory. // uredio Thomas Christensen. Cambridge: Cambridge University Press, 2008. Str. 109-135.

McCreles, Patrick. Music and Rhetoric. // The Cambridge History of Western Music Theory. // uredio Thomas Christensen. Cambridge: Cambridge University Press, 2008. Str. 847-879.

Medieval Grammar and Rhetoric. Language Arts and Literary Theory AD 300-1475. uredile Rita Copland; Ineke Sluiter. Oxford: Oxford University Press, 2012.

Mews, Constant J. Questioning the Music of the Spheres in Thirteenth-Century Paris: Johannes de Grocheio and Jerome de Moravia. // Knowledge, Discipline and Power in the Middle Ages. Essays in Honour of David Luscomb / uredili Joseph Canning, Edmund King i Martial Staub. Leiden: Brill, 2011.

Meyer, Michel; Carrilho, Manuel Maria; Timmermans, Benoît. Povijest retorike od Grka do naših dana (prev. Vanda Mikšić). Zagreb: Disput, 2008.

Mihoković, Martin. Prikaz o djelu Tome Kovačevića „,Kratki nauk o gregorijanskom pjevanju“. Dipl. rad u strojopisu. Zagreb: ICG, 1970.

Mills, Sara. Michel Foucault. London \& New York: Routledge, 2003. 
Mitchell, J. C. The Music of the Old Testament Reconsidered. // Palestine Exploration Quarterly, 124/2, str. 124-143. URL:

https://www.tandfonline.com/doi/abs/10.1179/peq.1992.124.2.124 (15.12.2020.)

M. l'abbé Drioux. La somme theologique de Saint-Thomas, latin-français en regard. Paris:

EB, 1853. URL:

https://books.google.com.bz/books?id=7RoVAAAAQAAJ\&printsec=frontcover\#v=onepage $\& q \& \mathrm{f}=$ false, $(12.04 .2020$.$) .$

Monumenta Ignatiana. Fontes narrativi II. Romae, 1951.

Moutsopoulos, Evanghelos. La Musique dans l'oeuvre de Platon. Paris: Puf, 1989.

Morin, Edgar. La méthode, 1 - La nature de la nature. Paris: Point seuils Essais, 123, 1977.

Musa, Ivica. Tridentski sabor - koncil nad koncilima?. // Tridentska baština. Katolička obnova i konfesionalizacija u hrvatskim zemljama. MH-KBF-FFDI, Zagreb 2016. Str. 17-30.

Music Theory and the Exploration of the Past / uredili Christopher Hatch; David W.

Bernstein. Chicago: Univeristy of Chicago Press, 1993.

Nacionalna i sveučilišna knjižnica. http://www.nsk.hr/obljetnica-rodenja-pavla-ritteravitezovica/ (17.04.2019.)

Nattiez, Jean-Jacques. Le discours sur la musique entre science et littérature. Allocution de remerciements prononcée lors de la remise de la médaille 2009 de l'Académie des lettres du Quebec. Montréal: 2009. str. 8. URL:

http://www.academiedeslettresduquebec.ca/system/ckeditor_assets/attachments/140/nattiez_ medaille.pdf?1408383286 (14.03.2018.)

Nöth, Winifried. Handbook of Semiotics. Bloomington: Indiana University Press, 1990. Str. 132.

Nowacki, Edward. Greek and Latin Music Theory. Principles and Challenges. University of Rochester Press: 2020.

Novak, Slobodan Prosperov. Povijest hrvatske književnosti od Bašćanske ploče do danas. Zagreb: Golden marketing, 2003.

Novak, Zrinka. Crkva i vjerske prilike. // U potrazi za mirom i blagostanjem. Hrvatske zemlje u 18. stoljeću / uredila Lovorka Čoralić. Zagreb: MH, 2013. Str. 169-194. 
Novaković, Darko (prir.). Hrvatski latinisti. Razdoblje humanizma. Zagreb: Erasmus, 1997.

O' Malley, John W. Was Ignatius Loyola a church reformer? How to look at Early Modern Catholicism. // The Catholic Historical Review 77(1991), str. 71-87.

Ovidi Nasoni Tristium Liber quartus. I, 5-14. URL: https://www.loebclassics.com/view/ovidtristia/1924/pb_LCL151.159.xml (10.12.2020.)

Palisca, Claude V.. Baroque as a Music-Critical Term, // French Musical Thought 1600-1800 / uredile Georgia Cowart i Ann Arbor. Michigan: UMI Research Press, 1989. Str. 7-21.

Palisca, Claude V.. Humanism in Italian Renaissance Musical Thought. New Haven \& London: Yale University Press, 1985.

Pavlović, Cvijeta. Kako rasplesti klupko hrvatske književnosti XVIII. stoljeća. // Dani Hvarskoga kazališta. Četiri desetljeća Hvarskoga kazališta - dosezi i propusti u istraživanju hrvatske književnosti i hrvatskog kazališta, Zagreb: Split: HAZU: Književni krug Split, 2014. Str. $152-179$.

Pelosi, Francesco. Plato on Music, Body and Soul. Cambridge: Cambridge University Press, 2010.

Pesce, Dolores. Guido d'Arezzo's Regule rithmice, Prologus in antiphonarium, and Epistola ad michaelem: a critical text and translation, with an introduction, annotations, indices, and new manuscript inventories. Musicological Studies, sv. LXXIII. Ottawa, Canada: The Institute of Mediaeval Music, 1999.

Petrić, Hrvoje. O katoličkoj obnovi i obrazovanju na prostorima Senjske, Modruške i Zagrebačke biskupije u 17. stoljeću. // Podravina, 4/8 (2005), str. 147-166.

Petrus Comestor. Historia Scholastica: Historia Libri Genesis, Caput 28: De generationibus Cain. URL: https://babel.hathitrust.org/cgi/pt?id=ucm.5316856714\&view=1up\&seq=3. (12.11.2020.)

Picone, Philippe. La question musicale au concile du Trente. // Le Jardin de Musique, V:2, 2008. Str. 49-60. URL:

https://www.academia.edu/6981419/_La_question_musicale_au_Concile_de_Trente_in_actes _du_colloque_Musiques_et_r\%C3\%A9formes_religieuses_aux_XVIIe_et_XVIIIe_si\%C3\% A8cles_statuts_fonctions_pratiques_Le_Jardin_de_Musique_Paris_Universit\%C3\%A9 (30.09.2019.)

Platon. Država (prev. Martin Kuzmić). Zagreb: Naklada Jurčić, 2009. ${ }^{6}$ 
Platonis Opera. // uredio John Burnet. Oxford University Press, 1903. Plato, Laws. URL: http://www.perseus.tufts.edu/hopper/text?doc=Perseus\%3atext\%3a1999.01.0165 (14.11.2019.) Plato, Republic. URL:

http://www.perseus.tufts.edu/hopper/collection?collection=Perseus\%3Acorpus\%3Aperseus\% 2Cwork\%2CPlato\%2C\%20Republic (14.11.2019.)

Povijest hrvatske književnosti u sedam knjiga. Goldstein, Slavko (ur.). Zagreb: Liber:

Mladost, 1974-1978. sv. 3.

Powell, J. G. F. Dialogues and Treatises. A Companion to Latin Literature. str. 223-240.

URL: https://doi.org/10.1002/9780470996683.ch17 (17.04.2020.)

Powers, Harold S. Tonal Types and Modal Categories in Renaissance Polyphony. // Journal of the American Musicological Society. 34/3, 1981, str. 428-470./ URL:

http://links.jstor.org/sici?sici=0003-

0139\%28198123\%2934\%3A3\%3C428\%3ATTAMCI\%3E2.0.CO\%3B2-T

Rankin, Susan. Naturalis concordia vocum cum planetis. Conceptualizing the Harmony of the Spheres in the Early Middle Ages // Citation and Authority in Medieval and Renaissance Musical Culture: Learning from the Learned / uredile Suzannah Clarke; Elizabeth Eva Leach. Woodbridge: Boydell Press, 2005. Str. 3-19.

Rausch, Alexander. Samber, Johann Baptist. // Oesterreichisches Musiklexikon online. URL: https://www.musiklexikon.ac.at/ml/musik_S/Samber_Johann.xml, (07.08.2020.)

Regino Prumiensis Epistola de harmonica institutione u SEMS. URL:

http://www.chmtl.indiana.edu/tml/9th-11th/REGHAR (21.11.2020.)

Reiseinwiever, Ana J. Gudio of Arezzo and his Influence on Music Learning. // Musical Offerings, 3/1, čl. 4, 2012. URL:

https://digitalcommons.cedarville.edu/musicalofferings/vol3/iss1/4 (20.08.2019.).

Religijske teme u glazbi // uredio Marijan Steiner. Zagreb: FTIDI, 2003.

Riemann, Hugo. Geschichte der Musiktheorie im 9.-19. Jahrhundert. Hildesheim - Zurich New York: Georg Olms Verlag, 1990.

Rubinelli, Sara. Ars Topica: The Classical Technique of Constructing Arguments from Aristotle to Cicero. Springer, 2009. 
Sancti Augustini De civitate Dei 19.13.1. PL. 41. col 640. URL:

http://patristica.net/latina/\#t041 (18.10.2019.)

Schopenhaur, Arthur, Die Kunst recht zu behalten, Megaphon eBooks 2008. URL:

http://www.wendelberger.com/downloads/Schopenhauer_DE.pdf (20.04.2020.)

Shek, Brnardić, Teodora. Svijet Baltazara Adama Krčelića : obrazovanje na razmeđu tridentskoga katolicizma i katoličkoga prosvjetiteljstva. Zagreb: Hrvatski institut za povijest, 2009.

Solar, Milivoj. Teorija književnosti. ŠK: Zagreb. $2005^{20}$.

Soldo, Josip Ante. Glazbena ostavština 17. i 18. stoljeća u franjevačkim samostanima Splitske provincije. Glazbeni barok u Hrvatskoj. Zbornik radova sa simpozija održanog u Osoru 1986. godine/ uredio Ennio Stipčević. Osor: Osorske glazbene večeri, 1989. Str. 130-144.

Stahl, William H.; Johnson, Richard; Burge, Evan Laurie. Martianus Capella and the Seven Liberal Arts. sv. I: The Quadrivium of Martianus Capella. Columbia University Press: 1991. (reprint izdanja iz 1971.)

Stahl, William H. To a better Understanding of Martianus Capella // Speculum: 40/1, University of Chicago Press, 1965. Str. 102-115. URL:

https://www.jstor.org/stable/2856467?seq=1 (28.07.2020.)

Steiner, Marijan; Županović, Lovro. The Jesuit Contribution to Croatian Musical Culture, with Particular Emphasis on the 17th and 18th Centuries. // Jesuits Among the Croats. / uredio Valentin Pozaić. Zagreb: Filozofski i teološki institut, S. J.; Beč: Hrvatski povijesni institut, 2000. Str. 457-479.

Stipčević, Ennio. Andreisova glazbena historiografija o „renesansi“ i „baroku“ u hrvatskoj glazbi. // Arti musices 40/1-2 (2009), str. 89-98.

Stipčević, Ennio. „Pisni duhovne“: o narodnim nabožnim popijevkama 18. stoljeća. // Glazba, tekst, kontekst Zagreb: Meandar, 2006.

Stipčević, Ennio. Glazba i glazbenici XVII. stoljeća. // Hrvatska i Europa, kultura, znanost $i$ umjetnost, sv. III. Barok i prosvjetiteljstvo (XVII-XVIII. stoljeće). / uredili Ivan Golub; Ivan Supičić. Zagreb: Školska knjiga, 2003. Str. 717-725. 
Stipčević, Ennio: Hrvatska glazba, Povijest hrvatske glazbe do 20. stoljeća, Zagreb: Školska knjiga, 1997.

Stipčević, Ennio. Counter-Reformation, Jesuits and Music Culture in Croatia of the 17th and 17th Centuries / Protureformacija, isusovci i glazbena kultura 17. i 18. stoljeća. // The Musical Baroque, Western Slavs, and the Spirit ot the European Cultural Communion / Glazbeni barok $i$ zapadni Slaveni u kontekstu europskog kulturnog zajedništva. / uredio Stanislav Tuksar. Zagreb: HMD-HAZU, 1993. Str. 85-90 i str. 235-240.

Stipčević, Ennio. Hrvatska glazbena kultura 17. stoljeća. Split: Književni krug Split. 1992.

Stipčević, Ennio. Glazbeni barok u Hrvatskoj, uvodna razmatranja. // Glazbeni barok u Hrvatskoj. / uredio Ennio Stipčević. Osor: Osorske glazbene večeri, 1989. Str. 7-19.

Šaban, Ladislav. Glazba u franjevačkom samostanu u Varaždinu. // Varaždinski zbornik 11811981. / uredio Andre Mohorovičić. Varaždin: JAZU, 1983. Str. 323-329.

Šaško, Ivan. „Liturgijski identitet Sakramentara iz Zagreba. Istraživanje na temelju molitava korizmenoga vremena“. CCP, 55 (2005), str. 7-41.

Šaško, Ivan. Biskup Kažotić, promicatelj knjige u Hrvata s posebnim naznakama iz povijesti liturgije. Croatica Christiana Periodica (CCP) 49 (2002), str. 59-68.

Šebelić, Ivan Leopold. Hrvatska enciklopedija, mrežno izdanje. Leksikografski zavod Miroslav Krleža, 2020. URL: http://www.enciklopedija.hr/Natuknica.aspx?ID=59402 (26.01.2020.)

Šilobod - Bolšić, Mihael. Fundamentum cantus gregoriani seu choralis. prir. i prev. Jelena Knešaurek Carić. Zagreb: L\&G, 2009.

Širola, Božidar. Crkvena glazba u Hrvatskoj. // Croatia sacra, 11-12 (1943). Str. 296-339.

Šourek, Danko. Donatorska i naručiteljska djelatnost zagrebačkoga kanonika Ivana Znike. // Tkalčić. Godišnjak Društva za povjesnicu Zagrebačke nadbiskupije, 9, 2005. Str. 327 - 410. Špralja, Izak. Pitanje urednika/priređivača glazbenog zbornika Cithara octochorda (CO). // Glazba i baština: zbornik u čast Lovri Županoviću. / uredio Ennio Stipčević. Šibenik: Gradska knjižnica „Juraj Šižgorić“”, 2002. Str. 259-270.

Špralja, Izak. Povijesna situiranost gregorijanskoga pjevanja u vrijeme pojave Citharae octochordae i njegova primjena posebice u trećem izdanju toga zbornika. // Cithara octochorda: Komentari i studije / uredili Milan Moguš i Lovro Županović. Zagreb: HAZU: 
Institut za crkvenu glazbu Albe Vidakovićc KBF Sveučilišta u Zagrebu: Hrvatsko društvo crkvenih glazbenika, 1998. Str. 221-250.

Špralja, Izak. Cithara Octochorda. Glazbeni zbornik Zagrebačke crkve iz 18. stoljeća (Beč 1701. i 1723.; Zagreb 1757.) s posebnim osvrtom na glazbene oblike pokazatelje glazbenih razdoblja. Zagreb: Hrvatsko društvo crkvenih glazbenika, 1998.

The Cambridge History of Eighteenth-Century Music / uredio Simon P. Keefe. Cambridge: Cambridge University Press, 2011.

The New Oxford History of Music. V. sv. Opera and Church Music / uredili Nigel Fortune; Lewis, Anthony. London: Oxford University Press, 1975.

The Oxford History of Western Music. Sv. II, The Seventeenth and Eighteenth Centuries I uredio Richard Taruskin. Oxford: New York: 2005.

The Renaissance Culture of Dialogue. uredili Dorothea Heitsch; Jean-François Vallée. Toronto: University of Toronto Press, 2004.

Tokić, Marko. Platon i Plotin o glazbi. // Filozofska istraživanja, 142/36, 2016. sv. 1, str. 193202. URL: https://hrcak.srce.hr/173350 (27.02.2019.)

Trattati italiani di canto fermo. URL: http://canto-fermo.univ-tours.fr/collections/show/3 (20.06.2020.)

Treitler, Leo. The Historiography of Music: Issues of Past and Present. // Rethinking Music / uredili Nicholas Cook; Mark Everist. Oxford: Oxford University Press, 1999. Str. 356-377.

Tridentska baština. Katolička obnova i konfesionalizacija u hrvatskim zemljama. / uredila Zrinka Blažević; Lahorka Plejić Poje. Zagreb: FFDI: KBF: MH, 2016.

Tuksar, Stanislav. „Quid agat musica in tarantis \& in aliis morbis“ - Ideas on Music Therapy in Dissertatio VI (1695) by Giorgio Baglivi.// Music Migration in the Early Modern Age: Centres and Peripheries - People, Works, Styles, Paths of Dissemination and Influence /uredile Jolanta Guzy-Pasiak i Aneta Markuszewska. Varšava: Liber Pro Arte, 2016. Str. 281297.

Tuksar, Stanislav. Misao o glazbi u autora podrijetlom iz hrvatskih povijesnih zemalja u tiskom objavljenim djelima 16. i 17. stoljeća. // Filozofska istraživanja, 142/36, 2016. Str. 273-286.

Tuksar, Stanislav. Hrvatska i Europa // 3. sv. Barok i prosvjetiteljstvo / uredio Ivan Supičić. Zagreb: S̆K, 2003. Str. 735-742.

Tuksar, Stanislav. Kratka povijest hrvatske glazbe. Zagreb: MH, 2000. 
Tuksar, Stanislav. Hrvatska glazbena terminologija u razdoblju baroka. Nazivlje glazbala $i$ instrumentalne glazbe u tiskanim rječnicima od 1649. do 1742. godine. Zagreb: HMD: MIC KDZ, 1992.

Tuksar, Stanislav. Hrvatski renesansni teoretičari glazbe. Zagreb: JAZU, 1978.

Užarević, Josip. 1995. Znanost o književnosti i teorija interpretacije. // Trag i razlika. Čitanja suvremene književne teorije / uredili Nenad Ivić, Vladimir Biti i Josip Užarević. Zagreb:

Naklada MD /HUGHZ. Str. 13-37.

Vanino, Miroslav. Povijest kazališta isusovačke gimnazije u Zagrebu. // Hrvatska prosvjeta, III (1916.) Str. 132-140.

Vanino, Miroslav. Isusovci i hrvatski narod. sv. I. Zagreb: GZH, 1969.

Vigh, Árpád. Comparaison et Similitude. // Neohelicon 5 (1977), str. 191-218. URL:

https://doi.org/10.1007/BF02093139 (10.09.2020.)

von Rad, Gerhard. Theologie des Alten Testaments II. Die Theologie der prophetisch en Überlieferungen Israels. München, $1987 .{ }^{9}$

Vulgata. URL: https://www.biblestudytools.com/vul/ephesians/5.html (15.05.2019.)

Wagner, Peter. Un piccolo trattato sul canto ecclesiastico. // Rassegna Gregoriana 3 (1904), Str. 481-484.

Wellek René. Concepts of Criticism. New Haven, Conn.: Yale University Press, 1963.

Wellek, Rene; Warren, Austin. Theory of Literature. NY: Harcourt, Brace and Company, 1948.

Winkelbauer, Thomas. Ständefreiheit und Fürstenmacht. Länder und Untertanen des Hauses Habsburg im konfessionellen Zeitalter (2 sv.). Wien: Ueberreuter, 2003.

Woodley, Robert. Renaissance music theory as literature: on reading the Proportionale Musices of Iohannes Tinctoris. // Renaissance Studies, 1/2 (1987.), str. 209-220.

Wright, Anthony David. Early Modern Papacy: From the Council of Trent to the French Revolution 1564 - 1789. London: Harlow: Essex: Longman, 2000.

Zagorac, Vladimir. Povijesno-liturgijski aspekt Pavlinskog zbornika. // Pavlinski zbornik 1644. II. Transkripcija i komentari / priredili i popratne studije napisali Koraljka Kos, Antun Šojat i Vladimir Zagorac. Zagreb: HAZU - Nakladni zavod Globus, 1991.

Zagrebački biskupi i nadbiskupi / uredio Juraj Batelja ... [et al.] Zagreb: ŠK, 1995.

Županović, Lovro. Hrvatski glazbeni zbornik Cithara octochorda iz XVIII. stoljeća i njegovo značenje za (domaću) glazbenu kulturu onoga doba i danas. // Cithara octochorda. Zagreb 1757. Komentari i studije / uredili Milan Moguš i Lovro Županović. Zagreb: HAZU, Insititut 
za crkvenu glazbu „Albe Vidaković“ KBF Sveučilišta u Zagrebu, Društvo hrvatskih crkvenih glazbenika, 1998. Str. 203-219.

Županović, Lovro. Stoljeća hrvatske glazbe. Zagreb: Školska knjiga, 1980.

Županović, Lovro. Spomenici hrvatske glazbene prošlosti: Varaždinski skladateljski krug s kraja XVIII stoljeća. Zagreb: DHS (danas HDS). 1973. 


\section{PRILOG 1}

Prijepis i prijevod predgovora prvom izdanju zbornika Cithara octochorda, Beč, 1701. 
CITHARA OCTOCHORDA SEU CANTUS SACRI LATINO-SCLAVONICI, quos in Octo Partes, pro diversis Anni temporibus, distributos;

Ut in Sclavoniae Populis Erga DEUM, Divosque AnIMos aCCenDat ${ }^{608}$ : Pia sua munificentia in lucem prodire jussit, REVERENDISSIMUS DOMINUS, DOMINUS JOANNES ZNIKA $^{609}$, Almae \& Vetustissimae Cathedralis Ecclesiae Zagrabiensis Custos, \& Canonicus Senior; nec non Abbas Ecclesiae SS. Trinitatis de Petrovaradino.

VIENNAE AUSTRIAE, Typis LEOPOLDI VOIGT, Universitatis Typ.

${ }^{608} \mathrm{~S}$ obzirom da je nastarije izdanje Cithara octochorda ujedno i jedino koje na naslovnici nema označenu godinu tiskanja, svi koji su se bavili ovom temom navodili su kao vjerodostojan podatak Janka Barléa koji je početkom dvadesetoga stoljeća, bez navođenja izvora na temelju kojih je donio zaključak, odlučno tvrdio da je djelo tiskano 1701. godine. Dvojbu oko vjerodostojnosti Barléovih zaključaka razriješio je fra Izak Špralja uočivši XXXX (godina) da je tiskar ili autor djela pronašao zgodan, ali tada nimalo neuobičajen način navođenja datuma. AnIMos aCCenDat premetanjem slova daje nam godinu (A) 1701. pisanu rimski brojkama (MDCCI). Usp. Županović, Lovro. Hrvatski glazbeni zbornik Cithara octochorda iz XVIII. stoljeća i njegovo značenje za (domaću) glazbenu kulturu onoga doba i danas. Cithara octochorda Zagreb 1757³: Komentari $i$ studije. Zagreb: HAZU: Institut za crkvenu glazbu „Albe Vidaković“ KBF Sveučilišta u Zagrebu: Hrvatsko društvo crkvenih glazbenika, 1998. Str. 203-204.

${ }^{609}$ Usp. Ibid. i Ivančan, Ljudevit. Podatci o zagrebačkim kanonicima od godine 1193. do 1924. I-III, strojopis u Arhivu HAZU. Sign. 243/1. O Zniki piše u II. svesku, str. 615-622.; Vidi i Šourek, Danko. Donatorska i naručiteljska djelatnost zagrebačkoga kanonika Ivana Znike. // Tkalčić. Godišnjak Društva za povjesnicu Zagrebačke nadbiskupije, 9, 2005. Str. 327 - 410. 
Implemini Spiritu Sancto, loquentes vobismetipsis in Psalmis \& hymnis \& canticis Spiritualibus, cantantes \& psallentes in Cordibus vestris Domino, gratias agentes semper pro omnibus in nomine Domini nostri Iesu Christi.

Ephes. Cap. 5, vers. 18.

Repleatur os meum laude, ut cantem gloriam tuam, tota die magnitudinem tuam.

Psal. 70. Vers. 8. 


\section{PRAEFATIO LIBRI}

Ad Reverendissimum D: D. Moecenatem.

Amisso, in mei enixu, Patre; mira faventis Sortis providentia, in Te, reverendissime Domine, protinus Tutorem accepi ${ }^{610}$. Vix cunas ingressus, perieram: nisi iam inde a principio

Orphanum, Tibi derelictum, suscipiens, benigno confovisses affectu. Solem vix videram, cum me repetundarum damnabant tenebrae: quas nin beneficentiae tuae radiis eliseras; in ipso lucis confinio ad latebras retractus ${ }^{611}$, intempestum Ortui meo copulassem Occasum. Quippe placuit Tibi in me, per Ecclesiasticae Symphoniae modulos distincta, pietas: quae, ut melodis olim Sacras Aedes impleret vocibus; natales meos a prompto iam funere vindicasti. Quantum non tibi ab hinc Coelitum debebunt Basilicae! Quas, posteaquam tot sumptuosis ornasti decoribus; nunc etiam in Numinis, Superumque laudem vocales efficies. Quis est, qui nesciat tuae non mediocria in Deum, Divosque pietatis monumenta; in quorum Phana ${ }^{612}$ aureum de munificentiae tuae fonte Pactolum ${ }^{613}$ derivas? Quot non Arae de tui aerarii vena, quo ubertim collucent, hausere splendorem? Atque ut minores caeterae curiosarum laudum indaginem subterfugiant; Nequit sane vel inhebetes non impingere oculos Princeps totius Sclavoniae D. Stephani Regis Basilica; quam, etsi iam alias mole sua Coelo admotam, adhuc sublimius liberali tua dextera extollere non definis: dum, sui structura mirabilem, maiorem insuper iubes a novis operibus ciere admirationem. In hac beneficentiam tuam, tacente quamquam Ecclesiaste, non muta declamabit Exedra ${ }^{614}$ : in cuius elegantiorem fabricam, peregrinam a

\footnotetext{
${ }^{610}$ Cijeli predgovor piše „Cithara“ sama. Pisac predgovora svoje riječi stavlja u usta zborniku čiji je mecena već spomenuti Ivan Znika.

${ }^{611}$ Dio "in ipso lucis confinio ad latebras retractus" nije preveden u prijevodu objavljenom u pretisku 3. izdanja Cithare, HAZU, 1998. U originalnom tekstu predgovora 1. izdanju, ujedno i jedinom dostupnom u Hrvatskoj (NSK, Zagreb RII-8o-191, sig. vet. R 1.792) taj se dio nalazi, stoga nije jasno zašto ga je prevoditelj izostavio. ${ }^{612}$ Pisac pogrešno piše riječ fanum, i, n. što znači hram, mjesto posvećeno nekom božanstvu.

${ }^{613}$ Paktol, rijeka u Lidiji koja je sobom nosila zlatni pijesak.

${ }^{614}$ Propovjedaonica u zagrebačkoj katedrali čiju je izradu financirao Ivan Znika izrađena u dvobojnom mramoru. Usp. Marković, Vladimir. Anđeo iz zagrebačke katedrale. // Peristil, 49/2006. Str. 99-106.: Ugovor je 1695. godine Mihael Cussa iz Ljubljane, "vajar i graditelj zemaljske pokrajine Kranjske" sklopio sa zagrebačkim biskupom Stjepanom Seliščevićem, obvezavši se da će propovjedaonicu izgraditi od bijelog i crnog mramora s reljefima Krista i četiri evanđelista te velikim anđelom koji će na ramenima i rukama nositi njezin balkon. Cussa je propovjedaonicu postavio sljedeće godine, o čemu svjedoči natpis uklesan u ogradu njezina balkona u vrhu pristupnih stepenica: 16 DEO 96. BEATO REGI STEPHANO IOANNES ZNIKA ABBAS PETROVARADINENSIS. CVSTOS ET CANONICVS ECCLESIAE HVIVIS FIERICVRAVIT. Iznad natpisa
} 
remotioribus Oris, cum Pario, Lybicoque marmore evocasti Architectonicam. Pudet iam suae artis Protogenem: visoque tam ordinato in saxea hac mole colorum certamine, victum indignabunda manu prope excussit penicillum. Sudant actu sub lima, \& malleo Sacrario additura decus marmora: quae ab Exteris, grandi aere, advehenda plagis, non modo ad arcendum a penitioribus Divarum adytis profanum Vulgus in Cancellos assurgent, muricis cum nive amulationem in spectaculum daturos; sed \& sacris Antistitum pedibus illimia, non tam Saxa, quam specula substernent. Humilitatem iam suam exuit ignoti fere hactenus nominis Pagus Urabche Caput quae supra totam viciniam attolit: postquam in medio illius, honori triumphalis Virginis \& Martyris Barbarae, magnificam ex fundamentis, praedivite Ara superbam \& figuratis laquearibus arcuatam aere proprio erexisti Basilicam ${ }^{615}$ : quae ad caeterarum invidiam, ipso sui principio, magnetis instar, dissitos etiam Populos ad devotionem, nec munerum de tholis suspendendorum vacuos, trahit. Quid plura? Zelus Domus Dei dum te comedit; ne religioso convivio desit potus, aureos substantiae tuae latices sufit. Sugit? Immo pleno bibit ore: te utpote cuncta Latifundia tua, meliore aeternitatis lucro, in Aras profundente. Porro cum tot illustres in Ecclesiarum decorem beneficentiae scenas instruis: illud, pietatis augendae studio, a te desiderari videbatur; ut postquam Templis maiestatem, ad excitandam in populus erga Divina reverantiam \& affectum, addidisti; linguas etiam in Conditoris laudem, Coelitumque praeconia laxares. Nimirum sic Nominis tui, quod a Verbi Incarnati seu Voce seu Praecursore mutuasti, implebis mensuram: dum non Zachariae duntaxat, ast multorum Illyrici populorum mutas veluti hactenus ad Divum encomia linguas in Coeleste resolves Canticum. Ex quo \& illud emolumenti in tuorum censum meritorum profluet: quod, cum venefica Sirenum carmina passim pudorem plurimorum in Syrtes illidant; ne suavi hoc toxico decepta incantentur animae, substituta Sacrorum hymnorum dulcedine, hominum affectus \& desideria sis ad fortunatas Coelorum insulas, elusa charybdi, pellecturus. At Citharam, quam fronte, nomineque gero, venerandae tuae abnuet quis convenire senectae: immo qui Canis, sincerique candore pectoris Olor es; Musicum vel in senio non te dedecet instrumentum: quo praesertim \& psalte regio victoriosius e non unius Saulis sinu Daemonium excuties; \&, citra Amphionis fabulam, Thebis potiores Christianae pietatis conditurus es Arces, easque non hominibus duntaxat, sed \& coelestibus Geniis incolendas. Reipublicae siquidem laudes Dei canentium confoederati sese associant Angeli: queis, Ephramo teste, in

koji kronogramom ponavlja 1696. godinu i spominje zagrebačkog kanonika i kustosa katedrale Ivana Zniku, na istoj mramornoj ploči ograde, u plitkom i obojenom reljefu prikazan je i njegov grb. Znikin udio u izgradnji propovjedaonice točnije objašnjava nekoliko rečenica dopisanih njegovom rukom na poleđini ugovora, kojima se obvezuje da će troškove izrade propovjedaonice platiti vlastitim novcem."

${ }^{615}$ Usp. Šourek, Danko. Op. cit. 
deliciis est, eundem cum psallentibus Chorum instruere. Parum dixi; altius assurgit sacrae hymnodiae meritum: cuius voluntate cum ipso Deo coniungi animos, Strabo asseruit.

Cor tuum, Reverendissime Domine, iam captum teneo. Dum Musici concentus praerogativa Divina humanis uniri dixi. Nam, quemadmodum Cor Tuum sibi totum Deus vindicat. Sic universorum cupis pectora in illius abire Regiam. Ut ideo nulla iam me ab Aedibus Tuis repulsa ferendae pulset suspicio: ubi quidquid pietatem erga Superos spirat, patulas fores invenit; nec ad conclave modo, quin \& ad ipsa Tua praecordia admittitur. In eo siquidem praecipue Ingenii tui vertuntur curae: ut nihil, quod ad Divini cultus facit incrementum, praetermittas, aut despicias incurius; eo substantias tuas vel sentiens, vel reputans crescere; qui tui prodigus, in animis aeque, ac Templis Religionem, Virtutum Principem, propagas. Nempe in fidam Posterorum memoriam itura est Petrovaradinensis Insulae felicitas ${ }^{616}$ : ut quae nn tam emeritum coronarit verticem; quam ipsa a tantis Virtutum Tuarum decoribus redimita triumphaverit; illustriorem a meritis tuis referens, quam tibi affundens splendorem. Verum quia humilioribus in Tui praeconia Cithara mea insonat chordis; quam ut insignia tua decora sibi fidat, pro dignitate, depangere: imparis, gloriae tuae, cantici sui epilogum communibus duntaxat proborum omnium votis conficit: ut, in ecclesiarum, animorumque proventus Te Superi quam diutissime Terris indulgeant; quoad nempe, tua erga me munificentia, transfusam in seros Nepotes pietatem cernens, cum grandaevo dierum Simeone, ultro ceu Olor invites dulci Tua funera Cantu: Nunc dimittis Servum Tuum Domine, secundum Verbum Tuum in pace.

\footnotetext{
${ }^{616}$ Znika je bio i petrovaradinski biskup.
} 


\section{PREDGOVOR KNJIZI}

\section{Prečasnom G. G. Meceni}

Izgubivši pri svojem rođenju oca, čudesnom sam providnošću sklone mi Sudbine u Tebi, prečasni Gospodine, odmah dobila zaštitnika. Tek što se nađoh u kolijevci, bila bih propala da nisi od samoga početka prihvatio Tebi ostavljeno siroče i dobronamjerno ga potpomogao. Tek što ugledah Sunce, stane me osuđivati tama otplate duga. Da je Ti nisi protjerao zrakama svojih dobročinstava, ja bih, u sam osvit odvučena natrag u zapećak, svome izlasku prerano pridružila zalazak! Zasigurno Ti se kod mene svidjela iznimna pobožnost urešena melodijama crkvene pjesme koja bi trebala ugodnim glasovima ispuniti nekoć svete hramove pa si moje rođenje obranio od već pripremljenog pokopa, ne bi li jednom milozvučnim glasovima ispunjavala svete hramove.

Koliko li će Ti zbog toga dugovati bazilike Nebesnika? Pošto si ih već uresio s toliko skupocjenih ukrasa, sad ćeš oblikovati glasove na hvalu Boga i Nebeskih stanara.

Postoji li čovjek koji ne zna za spomenike Tvoje velike pobožnosti prema Bogu i Svecima u čije hramove iz izvora svoje darežljivosti slijevaš zlatonosnu rijeku Paktol? Nisu li toliki oltari iz žile Tvoga rudnika crpli sjaj kojim raskošno blistaju? Pa zar da neke manje od najfinijih pohvala iznevjere očekivanje? Baziliku svetog Stjepana Kralja, prvu u cijeloj Slavoniji, moraju uočiti i najslabije oči. Premda se već svojim zdanjem primaknula Nebu, Ti je svojom darežljivom desnicom ne prestaješ još više izdizati, dok zapovijedaš da, divna u svom zdanju, novim djelima izaziva još veće divljenje. Premda o Tvome dobročinstvu šuti Crkovnjak, propovjedaonica neće ostati nijema: za njezinu si profinjeniju izradu iz dalekih zemalja, zajedno s parskim i libijskim mramorom, doveo neobičnu arhitektoniku. Ona se već stidi svog prvotnog umjetnika koji, kada gleda na ovoj kamenoj masi tako skladnu igru boja, kao da ljutitom rukom odbacuje pobijeđeni kist. Već se pod dlijetom i čekićem znoji mramor koji će svetištu dodati poseban čar. On će se, uvezen iz stranih zemalja za veliku svotu, izdići u obliku ograde izrađene kao prizor borbe grimiza sa snijegom, ne samo zato da odbije svjetinu od unutrašnjosti Svetišta, nego i da svetim biskupskim nogama podloži ne toliko blistavo kamenje koliko ogledala!

Svoje neznatnosti lišava se već i selo Vrapče, do sada gotovo nepoznatog imena, kao glava koja se izdiže iznad svega susjedstva, pošto si u njegovom središtu vlastitim novcem iz temelja podignuo veličanstvenu baziliku u čast slavne Djevice i Mučenice Barbare, koja se 
diči prebogatim oltarom i oslikanim kasetiranim svodom. Ona, na zavist ostalih, već od samog početka poput magneta na pobožnost privlači čak i udaljeni puk.

Što još da kažem? Dok te revnost za Dom Božji izjeda, kako Tvojoj duhovnoj gozbi ne bi ponestalo pića, ona siše zlatne sokove Tvojeg imetka. Siše? Čak pije punim ustima dok Ti sve svoje veleposjede rasipaš na oltare, no s boljim dobitkom u vječnosti.

Nadalje, budući da podižeš toliko slavnih i dobrotvornih prizora za ukras crkvama, čini se da želiš povećati pobožnost, pošto si učinio sve za veličanstvenost hramova i za poticanje naroda na bogoštovlje naroda i odanosti, a još si i jezike odriješio da slave Stvoritelja i diče nebesnike. Tako ćeš, kada odriješiš ne samo Zaharijina, nego i za slavljenje Boga dosada nijema usta mnogih ilirskih naroda za nebeski pjev, ispuniti smisao svojeg imena koje si posudio od Utjelovljene Riječi ili Glasa, ili Preteče! Odatle će u račun Tvojih zasluga doteći i ova korist: budući da otrovne sirenske pjesme stidljivost mnogih posvuda zavode u Sirtu, kako duše ne bi bile začarane ovim slatkim otrovom, a pošto si im u zamjenu ponudio slast svetih himana, upućivat ćeš ljudske čežnje i želje, izbjegavši Haribdu, prema sretnim nebeskim otocima.

No možda će tko reći da Tvojoj časnoj starosti ne priliči Citara koju nosim na naslovnici i u imenu? Baš naprotiv, Tebi koji si sjedinom i iskrenom bjelinom grudi Labud, čak i u starosti pristaje glazbeni instrument kojim ćeš još pobjedonosnije od onoga kraljevskoga pjevača psalama istjerivati mnoge demone iz Šaulova krila. Tako ćeš, prema Amfionovoj priči, u Tebi sebi podići čvršće kule kršćanske pobožnosti i nastaniti ih ne samo ljudima nego i nebeskim duhovima. Zemaljskim će se pjevačima pohvalnica Bogu pridružiti anđeli kojima je, prema Efremovu svjedočanstvu, pravi užitak tvoriti jedan zbor s onima koji pjevaju psalme. Premalo sam rekla. Još se više uzdiže zasluga svetog pjevanja, jer oduševljenje što ga ono stvara sjedinjuje ljudske duhove sa samim Bogom, kako je tvrdio Strabon. Tvoje sam srce, prečasni gospodine, već zarobila kada sam rekla da se snagom glazbenoga sklada Božansko sjedinjuje s ljudskim. Jer, kao što Bog za sebe traži čitavo Tvoje srce, tako opet Ti želiš da sva ljudska srca dođu u njegov kraljevski dvor.

Stoga me više ne muči nikakva slutnja da bih mogla biti odbijena od Tvoje palače na kojoj, svatko tko diše odanošću prema Uzvišenima nalazi otvorena vrata te biva primljen ne tek $\mathrm{u}$ odaje, već i u samo Tvoje srce. A tvoj duh se osobito brine da ne propustiš ništa što uzvisuje bogoštovlje, niti da išta prezreš zbog nemara. U tu svrhu ili nastojiš ili zamišljaš da ti imetak raste, kako bi darežljivošću u dušama jednako kao i po hramovima, promicao religiju, prvu od 
svih vrlina. Sigurno će se u vjernom spomenu novih naraštaja nalaziti sreća petrovaradinske mitre, jer ona nije toliko okrunila vrhunac zasluga koliko je sama, okićena tolikim ukrasima Tvojih vrlina, trijumfirala više pripovijedajući o blistavijem sjaju Tvojih zasluga nego dajući ga. No, budući da moja Citara Tebi na slavu odzvanja neznatnijim žicama no što se uzda da može prema dostojanstvu utvrditi Tvoje časne odlike, zbog nedoraslosti njezine slave Tvojoj, ona samo stvara epilog svojoj pjesmi sa željama sviju valjanih ljudi: neka te na boljitak Crkvi i dušama Višnji što dulje čuva na zemlji. Stoga ćeš, zbog svoje darežljivosti prema meni, dokle god budeš gledao kako se pobožna odanost prelijeva na buduće potomke, s dugovjekim Simeonom kao labud dozivati slatkom pjesmom: Sad otpuštaš slugu svoga, Gospodaru, po riječi svojoj u miru. 
PRILOG 2

Prijepis i prijevod predgovora drugom i trećem izdanju Cithara octochorda 
CITHARA OCTOCHORDA, SEU CANTUS SACRI LATINO-CROATICI, QUOS IN OCTO PARTES PRO DIVERSIS ANNI TEMPORIBUS distributos, AC CHORALI METHODO adornatos, PIA SUA MUNIFICENTIA IN LUCEM PRODIRE JUSSIT ALMA, ET VETUSTISSIMA CATHEDRALIS ECCLESIA ZAGRABIENSIS. ZAGRABIAE, Typis ANTONII REINER, Inclyti Regni Croatiae Typographi Privilegiati, Anno 1757. 
PRAEFATIO AD PASTOREM ET POPULUM.

Implemini Spiritu Sancto loquentes vobis metipsis in psalmis \& hymnis \& canticis Spiritualibus cantantes \& psallentes in cordibus vestris Domino, gratias agentes semper pro omnibus in nomine Domini nostri JESU Christi.

Ephes. 5. Cap. 18.

Benigna, \& zelosa Mater Divi Stephani Regis Basilica Zagrabiensis, zelo zelata pro Domino DEO exercituum ${ }^{617}$ Filias suas esurientes pabulo verbi Divini implet, ut fidelis populus illo enutritus aeternam adipiscatur salutem, quo animarum lucrandarum zelo \& fervore mota, non leves duntaxat assumpsit saepe expensas, licet multorum saeculorum dies numerando, novercantis fortunae mores sustulerit, toties Marte oppugnata, Vulcani voragine destructa; Inimicorum persecutionibus inique delusa, atque omni ferme auro, \& thesauro exspoliata; semper ad asperitatem stetit gloriosa, semper publici boni ergo, liberalis perseveravit.

Hic tamen nolim ego eam magnificis exaltare encomiis, cui non tantum sua domi adolescit magnitudo \& gloria, sed etiam in tota prope Europa perennis amplificata fama, \& nomen laudabile celebratur. Nolim cuiquam persuadere ejusdem praerogaticas $\&$ virtutes, qua merito totum gloriatur Regnum, clarificatur Patria, \& perenniter natio Croatica floret; ea sit potius sollicida \& provida Mater, cujus zelo commendatur virtus, extirpatur vitium, cujus fervor non patitur haereticae pravitatis propaginem, cujus studio Divini cultus, \& Catholicae Religionis Sanctitas pro viribus firmatur, \& amplificatur; sit merito hortus ex quo flores \& fructus honestissimae vitae decerpuntur in odorem suavitatis Divinae, nominetur illa Cor Patriae unice aestuans omnia sua membra in salutarem supremi Numinis amorem intendi.

Sed nec hic suam sistit gloriam Divi Stephani Regis Basilica Zagrabiensis, dum eam videlicet tot praeclara sumptibus ejusdem erecta facinora laudibus exollunt, depraedicant tot ingeniosi labores ad avertendas culpas \& defectus, quos in DEI, Divorumque negligenti servitio comisere populi; ejus etenim munificam liberalitatem non parum honorabit opusculum hoc Citharae octochordae, quo dilectum suum populum DEO efficacius, \& intimius copulari

${ }^{617}$ Biblia Sacra Vulgata. Zagreb: Kršćanska sadašnjost, 2013. Prva Knjiga o kraljevima 19:14-16: „Zelo zelatus sum pro Domino Deo exercituum, quia dereliquerunt pactum tuum filii Israel: altaria tua destruxerunt, prophetas tuos occiderunt gladio, derelictus sum ego solus, et quaerunt animam meam ut auferant eam.“ 
desiderat, cujus aures, \& animus laudum Divinarum sono demulcitus, violam dein submissae reverentiae colligat, rosam amoris \& fiducia in DEUM odoret, lilia multiplicis obsequii Divini, \& integrae devotionis carpat.

Ast Zelosa Mater Divi Stephani Regis Basilica Zagrabiensis, Zelum vestro etiamnum constanti Zelo confirmari cupit o Pastores ovium Christianarum! Ut renovato utilissimo hoc opusculo, seu Cithara octochorda per secuturas annorum illiades, oves Christi ad ovile insatiabilis voluptatis, laudes DEI \& Divorum dulci modulamine personando allicere tota mentis vestrae industria non intermittatis in hymnis nempe \& canticis; ut ait Doctor gentium, Spiritialibus cantantes \& psallentes Domino. ${ }^{618}$

Et licet Populus vester doctrina fide, \& morum sit instructus per frequentes (ut opinari licet) verbi Divini praedicationes, quibus ejus animum ad obsequium DEI trahere conamini: Cantus tamen, seu musica vocalis in sacrificiis, in Sacris mausolaeis, atque in alio supremi Numinis cultu adhibita, admirabilem sane fidelium animos trahendi, DEUM nobis appropinquandi, \& malignos spiritus a nobis fugandi virtutem habet. Quid obsecro Elisaeum requisitum a Regibus futuri belli exitum pronuntiare fecit, nonne dulce Psaltis modulamen? Elisaeus enim jussit sibi Psaltem adduci teste Biblia Sacra, quo psallente facta est super eum manus Domini statimque Divinum Prophetiae Spiritum recepit. Quae virtus a Rege Saul malignum spiritum propulsavit, nonne Cithara Davidica dulci harmonia pulsata? Sicut enim serpentes a Cantu disrumpuntur praesertim satanici teste Martiale: ita cum Cantu maligni spiritus fugantur, referente id Plotino Platonicae sapientiae Antistite. Quis demum Albertum monachum a via lubrica abstraxit, \& tanta dein sanctitate clarescere fecit, nonne dulcis musicalis notae gratia? Quia cum adhuc saecularis esset, audiens a parvulo quodam Juvene vitam, \& conversionem Sancti Theobaldi suaviter decantari, tanta repente gratia Divinitas compunctus est, ut inde coeperit vitam vivere Sanctam; \& multi alii ex auditu musicae vocalis singulariter ad DEUM conversi sunt.

Verum si intimius adhuc suavissimae hujus Harmoniae virtutem \& efficaciam intueri cupis o benevole Lector seu amice Cantor, eam profecto in omnes humanos affectus mirabiliter diffusam reperies, siquidem ea non imperiose, sed pura suavitate ita hominum animos permeat, ut in iisdem summum Regimen exerceat; celeberrimum magni Alexandri id comprobat exemplum scribente Himerio: Timotheus musicalis notae peritissimus omnes

${ }^{618}$ Biblia Sacra Vulgata. Zagreb: Kršćanska sadašnjost, 2013. Poslanica Efežanima 5:19: „loquentes vobismetipsis in psalmis, et hymnis, et canticis spiritualibus, cantantes et psallentes in cordibus vestris Domino“ 
Alexandri affectus in quacunque partem volebat, facile flectebat, vidisses forte rem insipidam $\&$ fastidiosam oculis objectam, Regis animum deprimere? Eum ocyus Timothei dulci Cantu ad Coelum usque elevari suspexisses. Vidisses aliquando Regem immoderate furore ardere? Arte \& industria Timothei praesentis Citharam octochordam blande pulsantis, seu amoena voce modulantis, ejus animum statim domari obstupuisses. Vidisses Regem moerore angi, aut tristia turbari? Protinus a Timotheo ridentem ostendi admiratus fuisses. Vidisses Regem vitiosis irretitum voluptatibus? Illico suavi Timothei carmine castissimum habuisses. Et ut omnia dicam, talem tibi videre Alexandrum licuisset, qualem tibi eum Timotheus reddidisset. Quis jam amabo dubitat pari affectu non flecti hac nostra Cithara octochorda animos Populi, quae non leviter laetificat cor hominis \& DEUM ipsum placat, utpote quae (quia Immortalibus DIis qui ex anima constant Divina, gratissima est), placandorum Deorum causa instituta est, \& nisi in hunc finem instituta fuisset, in sacris aedibus nec adhiberetur. Quis inquam dubitat cantu animos hominum non moveri? Si Calcedonius, Plato, Aristoteles, Divus Chrysostomus, aliique Viri Praestantissimi testantur ita nobis cantum seu musicam vocalem ingenitam esse, ut ea nullo modo carere possimus, \& quodnatura nostra usque adeo delectetur Canicis, tantamque cum eis habeat necessitudinem, ut vel infantes ab uberibus pendentes si fleant \& afflictentur, ea ratione sopiantur. Alii quoque non solum in laetis \& prosperis, sed in quacunque etiam duriori \& molestiori opera, Canticis sese consolantur; ubique locum habet musica vocalis, ubique in levamen quodpiam usurpari solet; haec enim est pulcherrima in dissonio Consonantia diversorumque Concordia, quae omnibus suo modo inest rebus, ac Mundo, Coeloque communis est, dum universae res creatae diversis in unum finem tendentiis in ipsamet discordia pulcherrime concordant, \& naturalem quandam seu perjucundam Harmoniam exercent. Haec molestas curas reliquasque cogitationum distractiones de secreto naturae veluti regina sensuum procedens, per dulcissimas musicalis notae voluptates expellit. Haec animi passiones, tumidosque attenuat, \& extinguit furores, Testis est Empedocles, cujus hospitem, dum quidam furibundus juvenis gladio invaderet, is suo canendi modo juvenis iram repressit. Testes sunt Lacedaemones, qui cum olim bellis civilibus affligerentur, oraculum illis redditum fuit. Si Terpandrum Methymnaeum Cithara canentem audirent, protinus conciliandos esse; quod \& factum est: nam ejsu cantu commoti, lacrymantes sese invicem osculabantur. Haec prima recreandorum animorum Domina vocalis musica, morbis quoque corporis \& animi medetur testante id saluberrimae Medicinae principe Theophrasto: vocum enim concentus ex anima in corpus influere solet, \& occulto quodam tramite sese insinuat, ac eos praesertim morbos levat, qui animum vehementer exagitare solent. 
Plura ne spectare cupis de admiranda cantus, seu musicae vocalis Virtute o benevole Lector seu amice Cantor? En \& intuere ipsos quoque Gentiles, qui ut a vitiis abstinerent, cantum seu musicam vocalem adhibebant. Fecit hoc Agamemnon, qui peregre profecturus uxorem Clytemnestram Cantori reliquit custodiendam, ut ab improbis cogitationibus mentem ejus averteret illustrium foeminarum exempla pudicis modis decantando; nec prius Aegystus illi vitium inferre potuit, quam Cantorem interemisset.

Ast dulce melos non tantum hominum rapit animos, verum ipsa animantia terra, volucres Coeli, \& pisces maris, virtutis suae gratia amoene amplexatur; etenim apicula parvae nonne cantillando mella colligunt? Ab avium suavi modulamine, nonne illico ab ipso crepusculo matutino totus resonat aether? Quae usque adeo deliniuntur cantu, ut exinde non raro capturam sui, atque necem ipsam incurrant juxta illud: fistula dulce Canit volucrem dum decipit auceps ${ }^{619}$; unde sicut fistulis aves alliciuntur: ita serpentes cantu disrumpi comprobatum est, inquit Martialis. Cervos cantu demulceri scribit Plutarchus. Idem de Elephantis asserit Strabo. Delphinos, aliosque quodam pisces, musica tam instrumentalis quam etiam vocali plurimum delectari, certissima experientia compertum est.

Quare si miram plane, \& deliciosam musica vocalis habet virtutem, quantam quaeso non est adeptura efficaciam, haec nostra Cithara octochorda, trahendi ad DEUM hominum Corda? Utpote qua musica; Angelorum videlicet concentibus, DEUS ipse mirifice delectatur, \& suos Charissimos servos ordinarie per Angelorum cantum ad Coelestia gaudia eliminaliter solet evocare; id contigit in extrema vitae lucta sancti Martini: Nicolai Tolentini: beatae Mariae Ogniacensis, \& plurimorum aliorum sanctorum in ex hac vita emigratione. O miram Cantus efficaciam! O magnam musicae vocalis excellentiam! Quam olim sapientissimus hebraeorum Philo lac animae dulciter animum refoventis asseruit, qua nullum praestantius melancholiae remedium Xenocrates judicavit: quam Centorinus Divinitatem plane, ad permovenda hominum corda appellavit.

Ergo cum ita sit, quod Cantus seu musica vocalis in omnes Microcosmi potentias dominetur, quis quaeso tantae reperietur pigritiae? Qui Citharam hanc octochordam \& suavem efficaciam dulci Tyrrannide in mortalium corda dominantem populo suo fideli aut non decantet, aut non

\footnotetext{
${ }^{619}$ Disticha Catonis. Liber I, 27: „Noli homines blando nimium sermone probare; Fistula dulce canit, volucrem dum decipit auceps.“ URL: https://www.thelatinlibrary.com/cato.dis.html (23.01.2020.)
} 
curet decantari. Agite proinde, agite o benigni animarum Curatores; $\&$ populum vestrum laudes DEI \& Divorum cantu personando commovere non desistite. Agite, \& Citharam hanc octochordam pulsando ${ }^{620}$, inquinatam peccatis mentem populi excitate. Agite, \& hac Cithara Infernalium spirituum insidias a populo vobis subjecto arcete; cum ea saepe citius ad evitanda $\&$ detestanda crimina, quam multorum verbi Divini Praeconum praerogativa, animos homnum soleat excitare. Has laudum Divinarum primitias ad augendam supremi Numinis gloriam in promptuarium Ecclesiae dedicandas duxit, Zelosa Mater Divi Stephani Regis Basilica Zagrabiensis, ut habito hoc pio opusculo in psalmis, \& hymnis, \& Canticis spiritualibus cantantes \& psallentes in nomine Domini nostri JESU Christi ${ }^{621}$ Divinarum unanimiter collaudare valeant Bonitatem, quae congruenter profecto hac Cithara octochorda laudari poterit, si Populus conabitur procurare peritum decantandi hanc Citharam, aut etiam ipsi litterarum gnari Parochiani eandem saepe decantarint, hic etenim totius populi os $\&$ animus unitus magnam vitae \& morum bonitatem in Ecclesia DEI hauriet $\&$ assequetur juxta axioma Philosophorum diserte asserentium: omne tantum habet bonitatis, quantum habet unitatis.

Quoniam vero, Tu quoque claro de Stemmate oriunda Propago, Parochianis certae Ecclesiae subjectis adnumeraris, non erubesce quaeso publice in Ecclesia DEI hanc Citharam octochordam, amoena qua vales voce resonare, testatur enim Salvator mundi minando quod: qui eum erubescit coram hominibus, pariter erubescere velit coram Patre suo ${ }^{622}$. Considera obsecro paulisper praeclaram tuorum Antenatorum vitam \& mores, qui licet tanta Nobilitate, tanta dignitate \& Authoritate conspicui fuissent, ad Ecclesiam tamen Parochialem, non tantum diebus Festis diligentissime comparuere, verum quovis ferme die Festo suave DEI \& Divorum melos decantare in Templis non erubuere: \& Tu Nobilis Familia ita erubescis Abavorum, Avorum \& Patrum tuorum in similibus vestigia sequi atque laudabilia facinora (ipsi DEO valde chara) imitari? Oh pudor! Oh dedecus intollerabile!

Et quod plus est, tam turpis acedia, tam vitiosa authoritas invaluit apud te o Nobilis Familia, quod nec ad Ecclesaim Parochialem Diebus Festis venire velis, sed cum scandalo aliorum domi tuae incurie delitescis, non profecto Antenati tui diebus Festis domi suae velut vespertiliones in speluncis delitescebant, non privator Mystas ex monasteriis educebant, non

\footnotetext{
${ }^{620}$ Biblia Sacra Vulgata. Zagreb: Kršćanska sadašnjost, 2013. Psalam 92 (91) 1:4: „, Bonum est confiteri Domino et psallere nomini tuo Altissime/ ad anuntiandam mane misericordiam tuam et fidem tuam in nocte/ in decacordo et in psalterio in cantico in cithara" 621 V. bilj. 606.

${ }^{622}$ Vjerojatno parafraza Druge poslanice Korinćanima VIII, 21: „Providemus, inquit, bona, non solum coram Deo, verum etiam coram hominibus“"
} 
putrida illa \& inutilia Status Ecclesiastici membra colligebant, in privatis suis Curiis servabant, \& ad sacrificium privatim habendum adhibebant, nec adhibuisse unquam observati sunt, nisi speciali \& valde, gravi coacti fuissent causa $\&$ necessitate, $\&$ hoc pro pauco tempore: Verum \& urente sole, \& turbide tempestatem aut large aquam pluente Coelo ad templum Parochiale accelerarunt, suoque exemplo diligenti videlicet sua frequentatione ad Ecclesiam, ac laudabili facinore amoeno nempe saepius de rebus Divinis Cantu fidelem Populum ad Ecclesiam DEI allexerunt: \& tu tam delicate tuam foves naturam, atque die specialiter DEI \& Divorum cultui dicato, ab Ecclesia Parochiali te absentem reddere praesumis nobilis Familia? O facinus execrabile! Merito Divino furore reprehendendum.

Quamobrem age quaeso Tu illustrissimi \& Nobilissimi stemmatis Propago, ad evitandam justissimi Vindicis iram \& copiam meritorum in Coelis comoparandam; age inquam tuoque laaudabili exemplo per diligentem nimirum accessum tuum ad Ecclesiam Parochialem, incultioris genii \& ingenii Populum ad laudes Dei excitare non desiste, Te ipsam testor o Nobilis Propago nonne copiosior Populus accurrit ad praedicationem verbi Divini \& ad sacrificium Missae die Festo audiendum, sii suum Dominum ad Ecclesaim Parochialem venire, saepiusque etiam musicam vocalem publice decantare intelligit? Ah age quaeso, ut de te una cum populo \& Pastore illud Sacrae Bibliae effatum dici queat: multitudinis autem credentium erat cor unum \& anima una in servitio nempe \& Laudibus DEI.

Verum ad vos denuo me converto \& singulariter alloquor o Vigiles Ecclesiae Pastores, qui cepistis Vineam DEI procurare, cavete ne steriles, \& inanes sitis, sed attolite corda vestra, \& providete ne Laudes DEI \& Divorum per defectum Cantus in Templis debilicentur: \& introibit Rex Gloriae ${ }^{623}$. Attolite animos \& satagite sub magni Sacrificii cultu, Cantu personare, ut una cum Populo habeatis desiderabilia super aurum \& lapidem pretiosum multum \& dulciora super mel \& favum ${ }^{624}$. Attolite voces \& cantate Domino hoc Canticum novum $^{625}$ annuntiantes de die in diem Salutare ejus; sicque pascite (ita petente Apostolorum Principe) qui in vobis est, Gregem DEI, providentes non coacte sed spontanee secundum DEUM, neque turpis lucri gratia sed voluntarie, neque ut dominantes in Cleris sed forma

\footnotetext{
${ }^{623}$ Biblia Sacra Vulgata. Zagreb: Kršćanska sadašnjost, 2013. Psalam 24:7: „Adtollite portas principes vestras et elevamini portae aeternales et introibit rex gloriae.“

${ }^{624}$ Ibid. Psalam 18, 10:11: „Timor Domini sanctus, permanens in saeculum saeculi; judicia Domini vera, justificata in semetips desiderabilia super aurum et lapidem pretiosum multum, et dulciora super mel et favum."

${ }^{625}$ Ibid. Psalam 97, 1.
} 
facti Gregis ex animo, \& cum apparuerit Princeps Pastorum percipietis immarcescibilem Gloriae Coronam, AMEN. ${ }^{626}$

${ }^{626}$ Biblia Sacra Vulgata. Zagreb: Kršćanska sadašnjost, 2013. Prva Petrova poslanica 5, 2:4: ,pascite qui in vobis est gregem Dei, providentes non coacte, sed spontanee secundum Deum: neque turpis lucri gratia, sed voluntarie:/ neque ut dominantes in cleris, sed forma facti gregis ex animo./ Et cum apparuerit princeps pastorum, percipietis immarcescibilem gloriae coronam.“ 


\section{PREDGOVOR}

Pastiru i puku

Napunite se Duhom Svetim, razgovarajte međusobno psalmima i himnima i duhovnim popijevkama, pjevajući i psalmujući u svojim srcima Gospodu, zahvaljujući vazda za sve - u ime Gospoda našega Isusa Krista. Ef 5, 18.

Zagrebačka crkva Svetoga Kralja Stjepana, dobra i gorljiva majka revnuje gorljivo za Gospodina Boga vojskâ te hranom Riječi Božje napunja svoje gladne kćeri kako bi vjerni puk, njome nahranjen, postigao vječno spasenje. Gonjena tom revnošću i gorljivošću za predobivanje duša, ona često podnosi nemale žrtve: iako broji mnogostoljetne dane, podnijela je ćudljivost maćehinske sudbine, toliko ju je puta napadao Mart, toliko ju je puta razaralo vulkansko ždrijelo, neprijateljski progoni krajnje ponižavali te joj pljačkali gotovo sve zlato i blago. A ipak bi ona uvijek ustajala kao pobjednica, uvijek bi nasuprot grubosti ustajala slavna i uvijek bi, prema tome, ustrajala u svojoj darežljivosti za opće dobro!

Ja je ovdje ipak ne želim uzdizati veličanstvenim pohvalama: nju, kojoj slava i veličina ne cvate samo u domovini nego joj po gotovo cijeloj Europi vječan napreduje ugled, a ime joj hvale i diče. Ne bih htio nikoga uvjeravati o njezinim povlasticama i vrlinama, čime se $\mathrm{s}$ pravom ponosi cijelo Kraljevstvo, slavi Domovina i vječito cvate hrvatska nacija: ona je prije svega brižna i skrbna Majka čijom se krepošću potiče vrlina, čupa mana, čija gorljivost ne dopušta da se širi krivovjernička pokvarenost, a čijim se nastojanjem što je moguće više učvršćuje i povećava svetost bogoštovlja i katoličke vjere. Ona s pravom postaje vrtom u kojem se beru cvijeće i plodovi najčasnijeg života kao miris slatkoće Gospodnje. Nju zovu srcem domovine koje samo raspaljuje sve svoje udove na spasonosnu ljubav prema višnjem Bogu.

Ali ni time ne svršava slava zagrebačke bazilike Svetog Stjepana Kralja. Dok je, naime, tolika sjajna djela podignuta o njenom trošku uzdižu svojim pohvalama, diče je i mnogi duševni napori oko odvraćanja od grijeha i pogrešaka što ih narod čini nemarnim služenjem i štovanjem Boga i svetaca. Dobrotvornu darežljivost na ime Zagrebačke crkve itekako će proslaviti ovo djelce Osmožična citara, kojim namjerava svoj mili narod djelotvornije i nježnije povezati s Bogom: uši će se i duh naroda raznježiti zvukom božanskih pohvala, a 
potom će brati ljubicu poniznoga štovanja i mirisati ružicom ljubavi i pouzdanja u Boga i trgati ljiljane raznovrsna bogoslužja i potpune pobožnosti.

No gorljiva majka, zagrebačka bazilika Svetog Stjepana Kralja, sada želi svoju predanost povećati i vašim žarom, Pastiri kršćanskog stada! Po novom izdanju ovog vrlo korisnog djelca, tj. Osmožične Citare, kroz sljedeće tisućljeće ne zanemarujte Kristove ovce svom dušom i svim nastojanjima privlačiti u ovčinjak neizrecive slasti i to himnima i popijevkama duhovnim, kako veli Učitelj naroda, pjevajući i psalmujući Gospodu.

I premda je vaš puk u vjerskoj pouci i ćudoređu poučen čestim (kako se možemo nadati) navještajima riječi Božje, s pomoću kojih pokušavate privesti njegov duh k bogoštovlju, ipak pjevanje ili vokalna glazba koja se izvodi kod žrtava, svetih pokopa i kod drugih oblika štovanja Vrhovnoga Bića, ima divnu snagu da privlači duše, da se Bogu približavamo i da od nas odgoni zloduhe. Što je, molim, navelo proroka Elizeja da se, na traženje kraljeva, izjasni o ishodu budućega rata? Slatko sviranje svirača, zar ne? Elizej je, naime, kako svjedoči Biblija, zatražio da mu se dovede svirač te, dok je ovaj udarao u glazbalo, siđe ruka Gospodnja nad njega te je odmah primio Svetoga Duha Proroštva. Kojom je snagom od kralja Šaula protjeran zloduh? Zar ne Davidovom citarom po kojoj je on prebirao milozvučnim skladom? Pa kao što zmije, osobito one sotonske, pucaju zbog pjevanja, kako svjedoči Marcijal, tako pjevanje goni u bijeg zle duhove, kako o tome izvješćuje Plotin, vrhovnik platonske misli. Što je napokon monaha Alberta odvratilo od zavodljivoga puta, a onda učinilo da on poslije stane tolikom svetošću svijetliti ako ne milost slatke pjesme?! Jer dok je on još bio svjetovnjak, čuvši nekog mladića kako miloglasno opjeva život i obraćenje svetog Teobalda, iznenada se skrušio tolikom milinom Božanstva da je otada stao živjeti svetim životom. A tako su se i mnogi drugi slušanjem vokalne glazbe neobično obratili Bogu!

Nego, dobrohotni čitaču ili prijatelju pjevaču, ako još srdačnije želiš motriti snagu i učinkovitost ovog premilog sklada, onda ćeš sigurno uočiti kako je glazba divno razlivena u sve ljudsko čuvstvo: ona, naime, prožima ljudske duše ne silovito nego svojom čistom slašću, tako da u njih uvodi svoju vrhovnu vlast. To potvrđuje onaj glasoviti primjer Aleksandra Velikoga, kako to piše Himerije: „Glazbeni virtuoz Timotej lako je mogao Aleksandrove osjećaje usmjeravati na koju je god stranu htio. Kad biste vidjeli kako je kraljev duh klonuo, pošto bi mu se pred očima ukazalo nešto odvratno i mučno, vidjeli biste također kao mu se odmah uzdiže duh milozvučnim Timotejevim pjevanjem. Jeste li ikada vidjeli kako se kralj preko svake mjere razbjesnio? Kad bi svojom vještinom i marom prisutni Timotej stao lago 
udarati u Osmožičnu citaru ili nježnim glasom pjevati, odmah biste se zadivili kako mu se duša kroti. Jeste li vidjeli kako kralja smućuje tjeskoba duše ili tuga? Začudili biste se kako se smjesta, i to zahvaljujući Timoteju, stao smijati! Vidjeli ste, možda, kako Aleksandra sapinju grešne požude? Odmah biste ga, zbog Timotejeva umilnoga pjeva, imali kao najčistijega čovjeka! Pa da ukratko kažem, mogli ste Aleksandra vidjeti onakvim kakvim bi Vam ga načinio Timotej.“

I tko, molim, u to sumnja, da se jednako i po ovoj našoj Osmožičnoj citari ne mijenjaju (na bolje) duše naroda, po Citari koja silno razveseljuje srce čovjeka, a samoga Boga ublažuje i koja (kao nešto premilo onim besmrtnim „bozima“, koji se sastoje od božanske duše) jest stvorena zato da blaži „,bogove“, pa kad ne bi bila sama za to stvorena, ne bi se po crkvama ni upotrebljavala. Tko, velim, sumnja u to da su pjevanjem ganute ljudske duše? Ako Halkedonij, Platon, Sveti Ivan Zlatousti i drugi najugledniji muževi svjedoče da nam je pjevanje ili vokalna glazba toliko prirođena da bez nje nikako ne možemo i da naša narav toliko uživa u pjesmama i da je toliko povezana s njima, tako da čak i dojenčad kad plaču i kad ih što boli, na taj se način uspavljuju. I drugi se, ne samo u veselju i u sreći nego i u bilo kojem pa i težem i mučnijem poslu, pjesama tješe. Posvuda se ori vokalna glazba, svagdje se njome koriste kao olakšanjem. Vokalna glazba jest onaj najljepši sklad u neskladu i sloga različitih stvari koja se na svoj način, nalazi u svim stvarima. Zajednička je i Svijetu i Nebu, jer stvorene se stvari raznolikim težnjama prema jednome cilju prekrasno slažu u samoj različitosti, ostvarujući tako neki prirodni i vrlo ugodni sklad. Ona, izlazeći iz dubine prirode kao kraljice osjetila, izgoni mučne brige i ostale umne rastresenosti i to preko najugodnijih užitaka glazbe. Harmonija slabi strasti duše i oholosti te smiruje bijes. O tome svjedoči Empedoklo čijeg je gosta sumanuti mladić upravo namjeravao probosti mačem, a on je potom svojim načinom pjevanja suzbio mladićev bijes! Svjedoče i Lakedemonjani, kojima je, dok su patili od građanskih ratova, stiglo ovakvo proroštvo: Ako čuju kako uz citaru pjeva Metimnejac Terpandar, smjesta će se pomiriti. A to se i dogodilo, jer, ganuti njegovim pjevanjem, u suzama se stadoše međusobno cjelivati. Vokalna je glazba ona prva Gospodarica okrijepljenih duša: ona liječi bolesti i tijela i duše, kako to svjedoči prvak najuspješnije medicine Teofrast: naime, vokalno koncertiranje obično preko duše djeluje na tijelo. Nekim se tajanstvenim putem glazba uvlači te olakšava posebno one bolesti koje ponajčešće znaju snažno uznemirivati dušu. 
Želiš li iscrpnije promatrati divnu snagu pjevanja ili vokalne glazbe, dobri čitatelju ili prijatelju pjevaču? Evo, pogledaj i sam neznabožačke narode koji su se pjevanjem ili vokalnom glazbom koristili kako bi se oslobodili mana. To je učinio Agamemnon koji je, polazeći na daleko putovanje, svoju ženu ostavio pjevaču da je čuva kako bi joj duh odvraćao od grešnih misli i to opijevajući čiste primjere slavnih žena. A nju Egist nije mogao natjerati u nevjeru prije no što je ubio pjevača!

No ugodno pjevanje ne zanosi samo ljudske duše nego i same zemaljske životinje, obuhvaća nebeske ptice i morske ribe blago, jer ne skupljaju li i marne pčelice med pjevušeći? Zar ne odzvanja zrak milim cvrkutanjem ptica već od ranog jutra? Ptice su toliko očarane pjevanjem da zbog toga nerijetko podliježu vlastitom zarobljavanju, prema onoj: Frulicom nježno svira dok pticu ne prevari lovac. Otuda je, veli Marcijal, dokazano da, kako se frulicama mame ptičice, tako se zbog glazbe raspuknu zmije. Plutarh piše da se jeleni tetoše pjevanjem, a isto o slonovima tvrdi Strabon. Posve sigurno iskustvo vodi nas do spoznaje da dupini i neke druge ribe uživaju kako uz instrumentalnu, tako i uz vokalnu glazbu.

Stoga, ako vokalna glazba ima posve čudesnu i ugodnu moć, koliko li, molim, neće polučiti uspjeha ova naša Osmožična citara, da k Bogu privlači ljudska srca i to baš kao glazba, jer kad Anđeli zborno pjevaju, Bog se silno naslađuje. On svoje predrage službenike običava anđeoskim pjevanjem izvanredno pozivati k nebeskim radostima. To se i dogodilo kod preminuća Velike Gospe neba i zemlje Djevice Marije, to se dogodilo u smrtnoj borbi Svetog Martina, Nikole Tolentinskog, Blažene Marije Ognjene i premnogih drugih svetaca kad su se selili iz ovoga života. O divne li sile pjevanja! O velike li uzvišenosti vokalne glazbe! Za takvu je glazbu nekoć premudri Židov Filon tvrdio da je mlijeko duše koje na blagi način obnavlja duh. O njoj je Ksenokrat sudio da od nje nema boljega lijeka melankoliji. Nju je Centorin nazvao čak božanstvom koje pokreće ljudska srca.

Pa kad je, dakle, tako da pjevanje ili vokalna glazba vlada nad svim moćima mikrokozma, tko bi, molim, mogao biti toliko lijen, a da zanemari ovu Osmožičnu citaru i ovu ugodnu uspješnost, koja svojom milom vladavinom upravlja srcima smrtnika, tko onda ne bi svom vjernom puku nju pjevao ili ne bi nastojao da se pjeva? Dajte zato, dajte, dobri dušobrižnici, ne prestajte poticati svoj puk da pjevanjem slavi Boga i Svece. Hajde, i udarajući u ovu Osmožičnu citaru, podbadajte narodnu dušu koju onečistiše grijesi. Hajde, ovom Citarom odbijajte od svoga naroda zasjede paklenskih zloduha; budući da ona, često brže od svih prednosti navjestitelja Riječi Božje običava pobuđivati ljudske duše. Gorljiva majka 
zagrebačka, Bazilika Svetog Stjepana Kralja, prinijela je ove prve plodove sve na veću slavu Vrhovnoga Božanstva i na korist Crkve, kako bi ljudi, služeći se njima kod psalama i himana i duhovnih popijevaka u ime Gospoda našega Isusa Krista, mogli jednodušno hvaliti Dobrotu koja će se dolično ubuduće hvaliti ovom Osmožičnom citarom, pa će čak i nepismeni župljani iz nje moći često pjevati. Ovdje će, naime, u crkvi Božjoj ujedinjeni, usta cijeloga puka i njegov duh - crpsti i postizati veliku dobrotu života i ćudoređa prema onom aksiomu filozofa koji jasno tvrde: svako biće ima samo onoliko dobrote koliko ima jedinstva!

Budući da se i Ti, potomče slavnih predaka, ubrajaš među župljane određene Crkve, molim te nemoj se stidjeti da javno u Božjemu hramu ovoj Osmožičnoj citari miloglasno odjekuješ, jer Spasitelj svijeta svjedoči: Tko se njega zastidi pred ljudima, toga će se i On stidjeti pred svojim Ocem. Promotri malo, molim te, slavan život i vladanje svojih predaka, koji su, premda su bili ugledni tolikim plemstvom, tolikim dostojanstvom i ugledom, ipak najmarnije polazili u župnu crkvu ne samo na blagdane nego se gotovo na svaku svetkovinu nisu stidjeli od srca pjevati pjesmu Bogu i Svecima. Pa zar da se ti, plemenita i Bogu premila obitelji, toliko stidiš u istome svjedočenju slijediti primjere svojih pradjedova, djedova i otaca $i$ njihovih hvalevrijednih (i Bogu vrlo milih) djela?! O sramote! O nepodnosiva rugla!

I što je gore, kod tebe je, plemenita obitelji, prevladao tako ružan nemar, tako poročan „ugled“ da ne želiš ni za blagdane ići u župnu crkvu, nego se na sablazan drugih bezbrižno kriješ kod kuće. Tvoji se pretci nipošto nisu na blagdan skrivali kod svoje kuće kao šišmiši u spiljama: niti su privatne misnike dovodili iz samostana, niti su okupljali one lijene i nekorisne članove crkvenog staleža u privatnim svojim kurijama, čuvali ih i koristili za privatno služenje mise. Nikada nisu bili viđeni da se time služe, osim kad bi na to bili prisiljeni posebnim i teškim razlogom i nuždom, i to samo na kratko vrijeme. Napokon, oni su i kad je žeglo sunce i kad je bilo tmurno vrijeme, a kiša lijevala kao iz kabla, hitjeli u župnu crkvu i svojim su primjerom - pohađanjem župne crkve i pohvalnim činom, ugodnim pjevanjem o božanskim djelima - privlačili vjerni puk u crkvu Božju: a Ti tako razmaženo tetošiš svoju narav da, na onaj dan koji je posebno posvećen štovanju Boga i Svetaca, drsko od župne crkve izbivaš, Ti plemenita obitelji! O prokleta li zločina što ga Božji gnjev s pravom mora pokarati!

Stoga, daj, učini nešto, molim Tebe, mladicu najsjajnijeg i najplemenitijeg roda, da izbjegneš srdžbu najpravednijeg Osvetnika i da postigneš na Nebu obilje zasluga! Daj, velim, svojim hvalevrijednim primjerom i marnim pohađanjem župne crkve, neprestance potiči manje 
nadareni i manje obrazovani puk na štovanje Boga. Zaklinjem Te, plemenita mladico: zar neće narod u većem broju nagrnuti na propovijedanje Riječi Božje i na služenje misne Žrtve nedjeljom kada shvati da i njegov gospodin dolazi u župnu crkvu, a češće i javno [sudjeluje u izvođenju] vokalne glazbe?! Ah, molim Te, učini to kako bi se o Tebi, zajedno s narodom i pastirom, mogla reći ona riječ Sv. Pisma: u mnoštvu je onih koji uzvjerovaše bilo jedno srce $i$ jedna duša - naime, u služenju i hvaljenju Boga.

No sad se ponovno obraćam Vama i Vama posebice govorim, o budni pastiri Crkve koji ste se počeli brinuti za Božji vinograd: pazite da ne budete neplodni i isprazni sinovi, nego uzdignite svoja srca i zauzmite se da slavljenje Boga i Svetaca kroz crkveno pjevanje ne oslabi: $i$ unići će Kralj slave. Uzdignite duhove i izvršavajte svoju dužnost da u vrijeme velikoga žrtvenoga bogoštovlja zvonko pjevate, pa da zajedno s narodom postignete ono vrednije od zlata $i$ dragocjenoga kamenja i slađe od meda i saća.

Dignite glasove i pjevajte Gospodu ovи pjesmu novu, navješćujući iz dana u dan spasenje njegovo; i tako pasite (kako to moli Apostolski prvak) povjereno vam stado Božje, nadgledajte ga - ne prisilno, nego dragovoljno, po Božjem; ne radi prljava dobitka, nego oduševljeno; i ne kao gospodari Baštine nego kao uzori stada. Pa kad se pojavi Nadpastir, primit ćete neuveli vijenac slave. AMEN. 


\section{BIOGRAFIJA AUTORICE}

Jelena Knešaurek Carić rođena je 1977. u Zagrebu gdje je završila Klasičnu gimnaziju i Srednju glazbenu školu „Vatroslava Lisinskog“. Studij muzikologije na Muzičkoj akademiji u Zagrebu završila je 2000, a poslijediplomski znanstveni studij pohađala je od 2005.-2007. Studirala je klasičnu filologiju na Filozofskom fakultetu Sveučilišta u Zagrebu. Doktorski studij Književnosti, izvedbenih umjetnosti i filma na Filozofskom fakultetu upisala je 2010. godine. Tijekom studija sudjelovala je u znanstvenom projektu HAZU br. 213001 HAZU (1992.-2009.) Od 1999. do danas stalna je suradnica Trećeg programa Hrvatskog radija na kojem je objavila više stotina stručnih muzikoloških tekstova. Od 1999. do 2005. bila je stalna suradnica - scenaristica i voditeljica Redakcije za ozbiljnu glazbu HRT-a. Od 2002. do 2016. radila je kao voditeljica produkcije Koncertne dvorane Vatroslava Lisinskog gdje je osmislila i realizirala više stotina koncerata u mnogim ciklusima te ostvarila brojne bilateralne kulturne suradnje s veleposlanstvima Francuske, Italije, Njemačke, Austrije i Velike Britanije. Od 2016. do danas vodi Ured Hrvatskog društva glazbenih umjetnika. Autorica više desetaka tekstova za koncertne programe u dvorani Lisinski te za časopise Vijenac, Gordogan, Hrvatska revija i Cantus.

Govori engleski, francuski i njemački jezik, a služi se talijanskim.

\section{Znanstveni skupovi:}

Music. Discourse. Power. University of Minho, Braga, Portugal Braga 2011.

"Public discourse through professional music critics: two simultanous and diverse standpoints on key issues of transitional society."

14th International Biennial Conference on Baroque Music, Belfast 2010. "Music "worth mentioning": a reassessment of the anonymous Northern Croatian baroque music sources"

\section{Objavljeni radovi:}

Knešaurek Carić, Jelena. Mihael Šilobod Bolšić: Fundamentum cantus gregoriani seu choralis. L\&G: Zagreb, 2009. (transkripcija, komentar, prijevod originala i znanstvena studija). ISBN: 978-953-6565-04-7

Knešaurek Carić, Jelena. Ispravljanje nepravde // Gordogan, 19-22, VIII (XXVII), 2010., str. 244-248

Knešaurek Carić, Jelena. Glazba za slušanje, glazba za gledanje, glazba za druženje. // Hrvatska revija. MH: Zagreb, 1, 2014. 
Knešaurek Carić, Jelena. Juraj (Giorgio) Alberti: Dialogo per imparare con brevità à Cantar Canto figurato. Venetia 1619. / Dialogue How to Learn Fast to Sing Canto figurato, Venice 1619. // Companion to Ivan Lukačić. Épitome musical / uredili Vito Balić, Vincent Besson, Ennio Stipčević. Brepols: 2021. (u tisku)

\section{Objavljeni prijevodi:}

Delannoi, Gil: Mozart ili genij suzdržanosti, Naklada Stih, Zagreb, 2007.

Chailley, Jacques: Povijest glazbe srednjega vijeka, HMD, Zagreb, 2006. 